U.S. Department of the Interior

U.S. Geological Survey

\title{
Data for Quaternary faults, liquefaction features, and possible tectonic features in the Central and Eastern United States, east of the Rocky Mountain front
}

By

Anthony J. Crone and Russell L. Wheeler

Open-File Report 00-260

This report is preliminary and has not been reviewed for conformity with U.S. Geological Survey editorial standards nor with the North American Stratigraphic Code. Any use of trade names in this publication is for descriptive purposes only and does not imply endorsement by the U.S. Government.

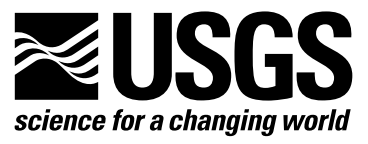




\section{Contents}

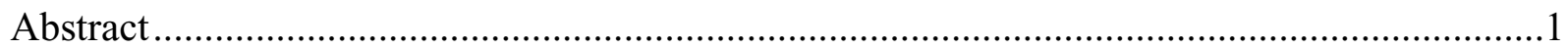

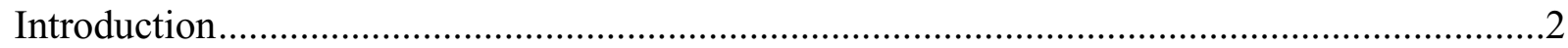

Strategy for Quaternary fault map and database .......................................................... 10

Synopsis of Quaternary faulting and liquefaction features in the Central and Eastern United

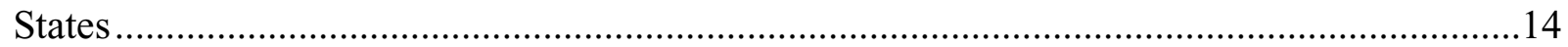

Overview of Quaternary faults and liquefaction features...............................................14

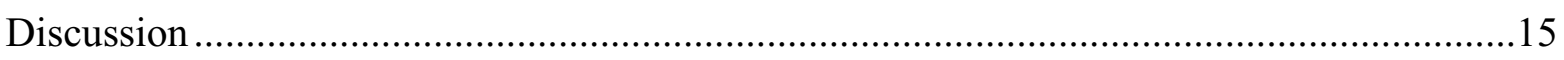

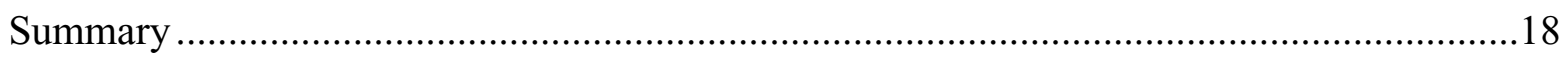

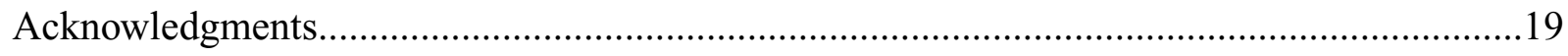

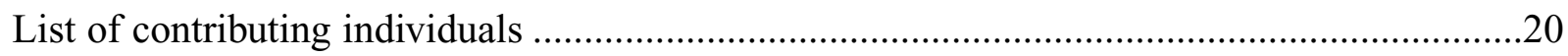

Definition of database field names and selected geological terms ....................................21

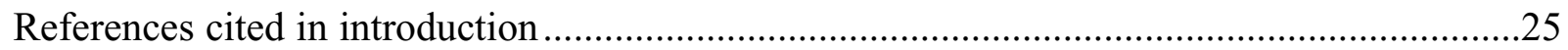

Fault and liquefaction features database.....................................................................27

\section{Class A Features:}

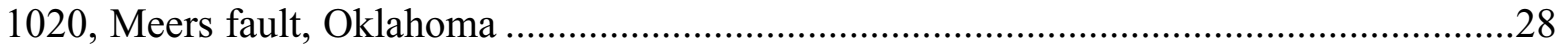

$1020 a$, Unnamed (northwest) section ..........................................................................29

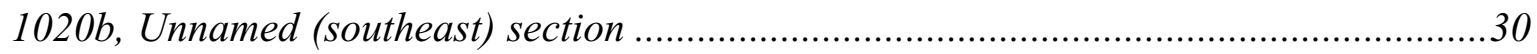

1023, Reelfoot scarp and New Madrid seismic zone, Missouri-Arkansas-Tennessee............37

Historical surface deformation, the New Madrid earthquakes.......................................50

1024, Wabash Valley liquefaction features, Indiana-Illinois ...........................................53

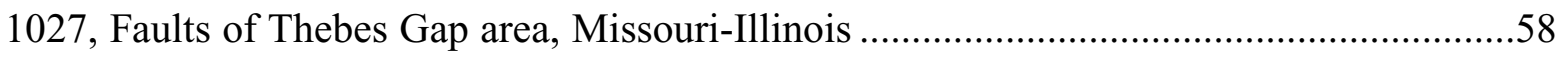

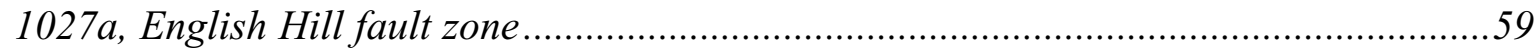

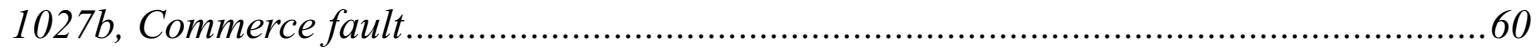

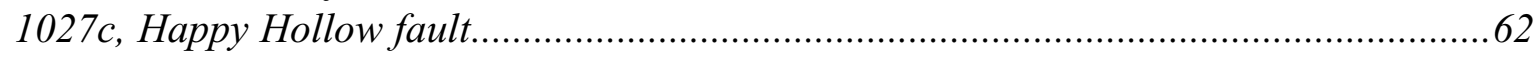

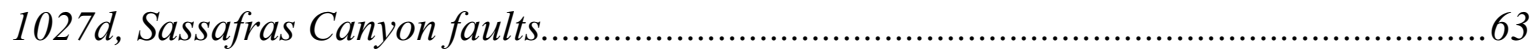

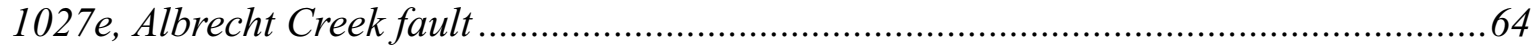

1027f, Lambert trench at intersection of English Hill and Albrecht Creek faults .............65

1028, Fluorspar Area fault complex, Illinois-Kentucky ...................................................68

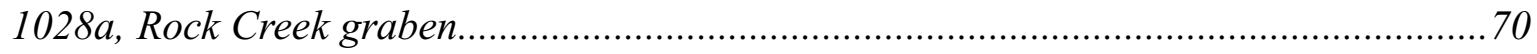

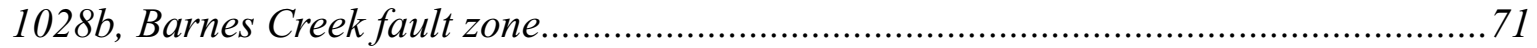

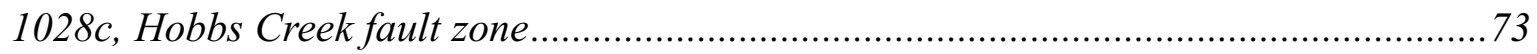

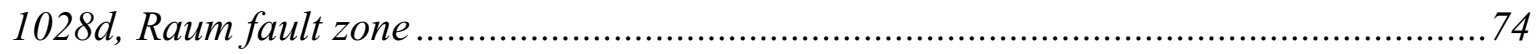

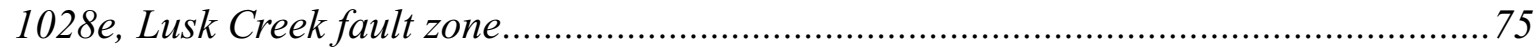

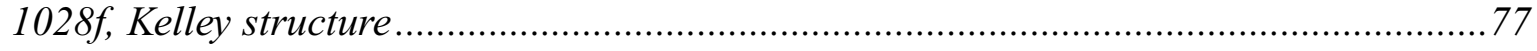


1029, Western Lowlands liquefaction features, Missouri-Arkansas .....................................80

1030, St. Louis-Cape Girardeau liquefaction features, Missouri-Illinois...............................86

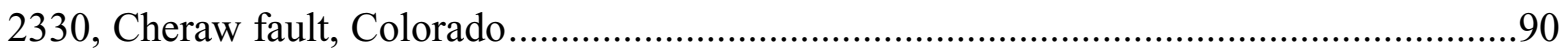

2651, Newbury liquefaction features, Massachusetts.........................................................95

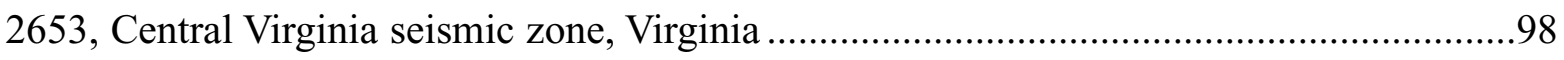

2657, Charleston liquefaction features, South Carolina ....................................................102

2658, Bluffton liquefaction features, South Carolina.........................................................

2659, Georgetown liquefaction features, South Carolina-North Carolina ............................113

\section{Class B Features:}

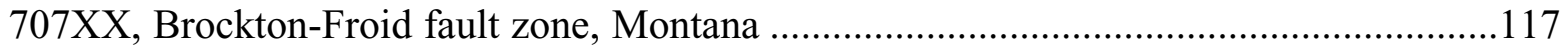

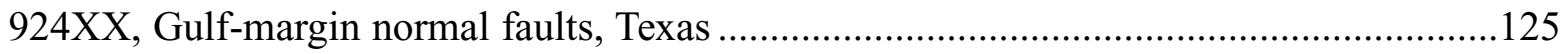

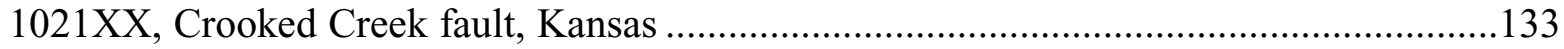

1022XX, Gulf-margin normal faults, Louisiana-Arkansas ...................................................137

2654XX, Gulf-margin normal faults, Alabama-Florida …….............................................143

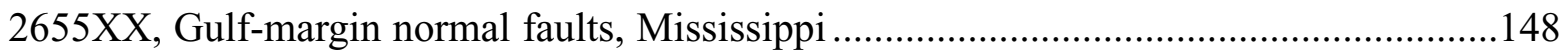

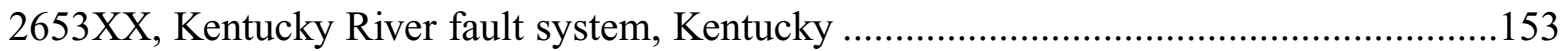

1025XX, Monroe uplift, Arkansas-Louisiana-Mississippi ...................................................156

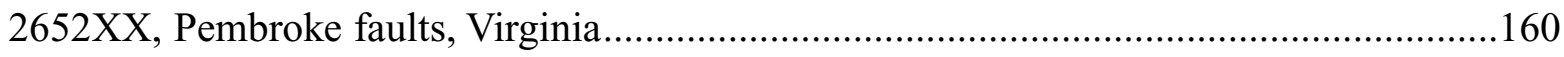

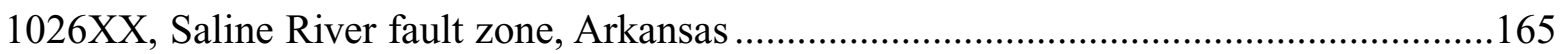

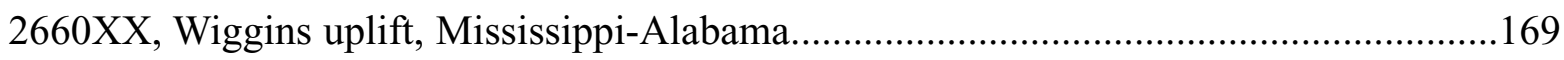

\section{Class C Features:}

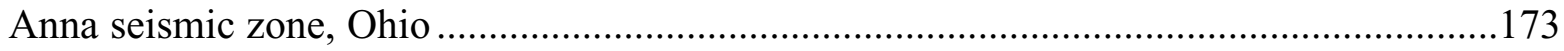

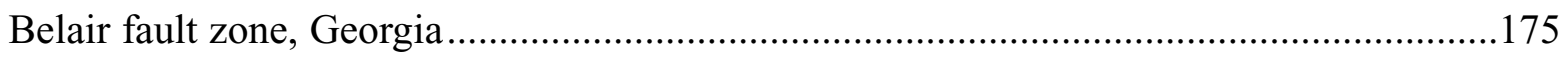

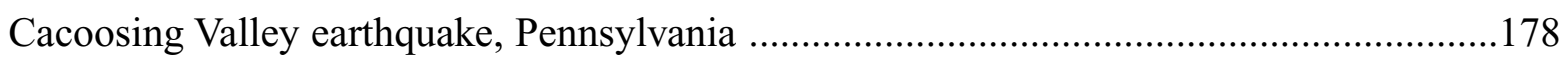

Cape Fear arch, North Carolina-South Carolina ……...................................................181

Catlin Lake-Goodnow Pond lineament, New York .........................................................184

Champlain lowlands normal faults, New York-Vermont ....................................................186

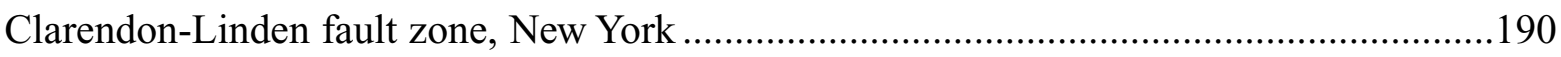

Cooke fault, South Carolina ……………………….................................................194

Cornwall-Massena earthquake, New York-Ontario ………………………….................196

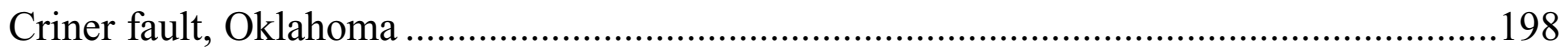

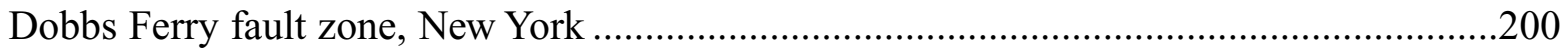

Everona fault-Mountain Run fault zone, Virginia ………................................................203

Hares Crossroads fault, North Carolina...........................................................................207 
Helena Banks fault zone, offshore South Carolina ...........................................................209

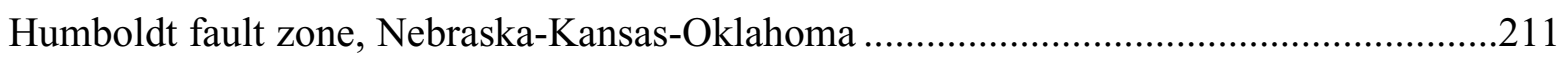

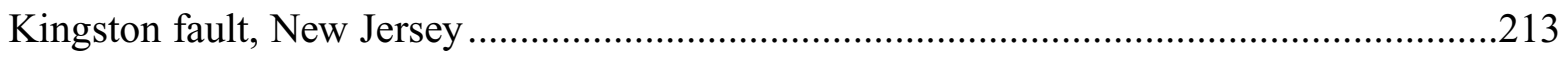

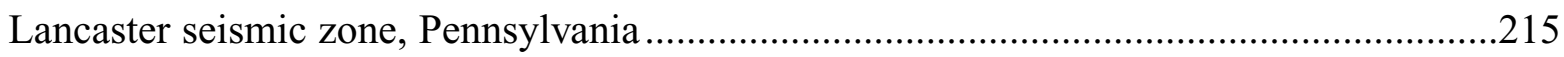

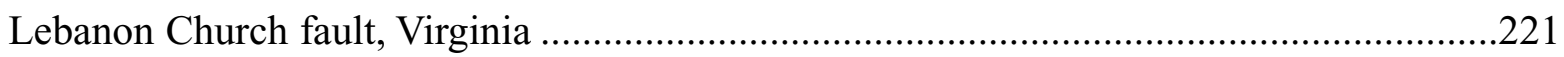

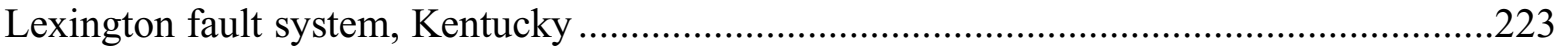

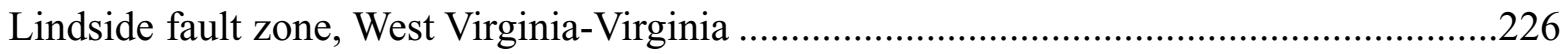

Louisiana wrench faults, Louisiana-Arkansas-Mississippi ................................................228

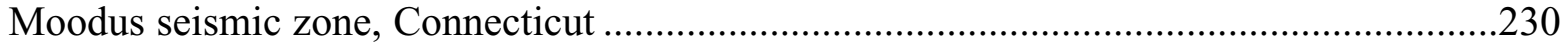

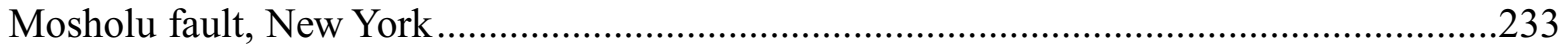

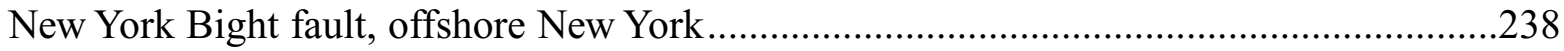

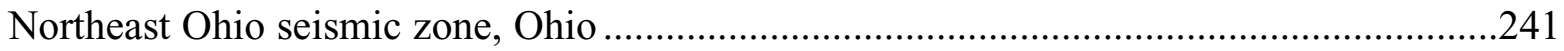

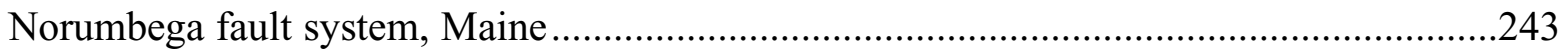

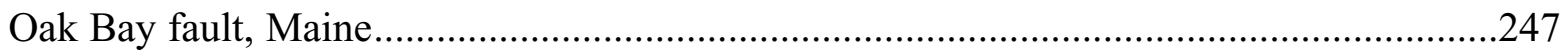

Offset glaciated surfaces, Maine-Massachusetts-New Hampshire-New York-Vermont ......249

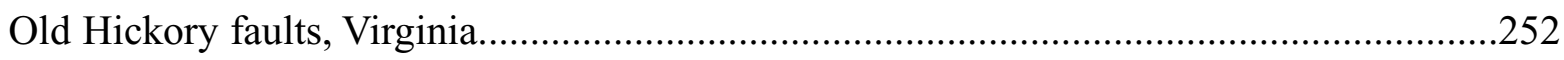

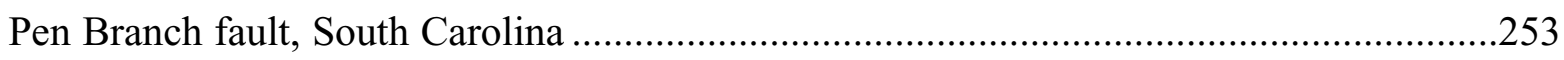

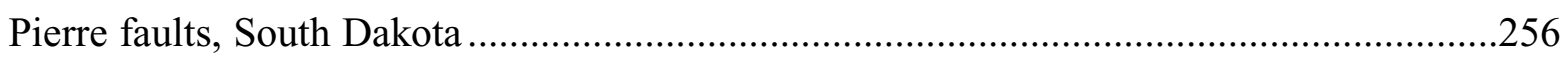

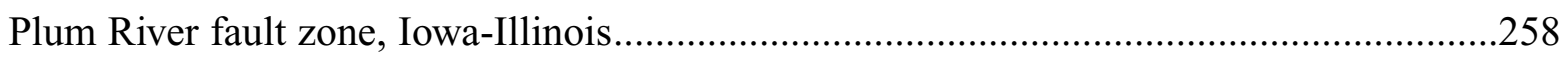

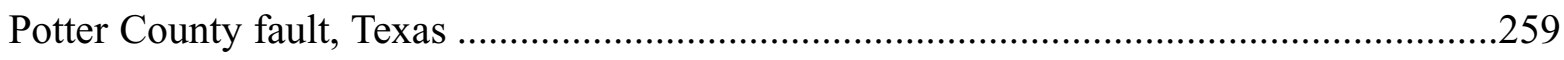

Ramapo fault system, New Jersey-New York ……………..........................................260

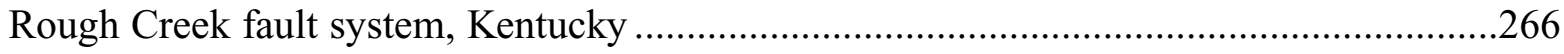

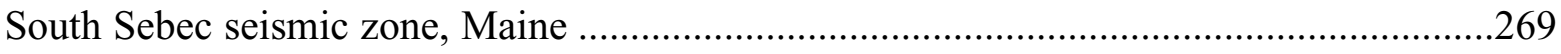

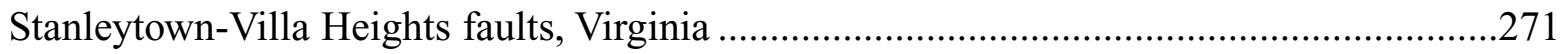

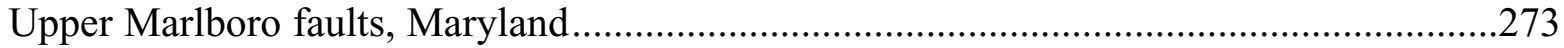

Washita Valley fault, Oklahoma...........................................................................................22

\section{Class D Features:}

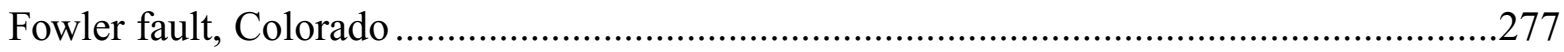

Grossman's Hammock rock reef fault, Florida ……………….......................................28

Hain Quarry fissures, Connecticut.........................................................................28

Harlan County fault, Nebraska ..................................................................................28

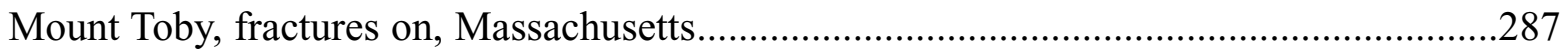

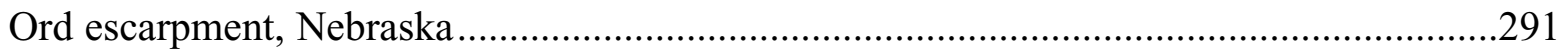

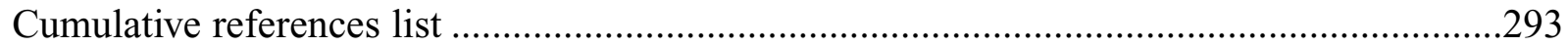




\section{List of Features by State:}

\section{Alabama}

Gulf-margin normal faults 2654XX (Class B)

Wiggins uplift 2660XX (Class B)

\section{Arkansas}

Gulf-margin normal faults 1022XX (Class B) .............................................................137

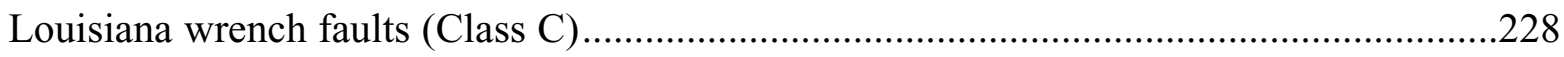

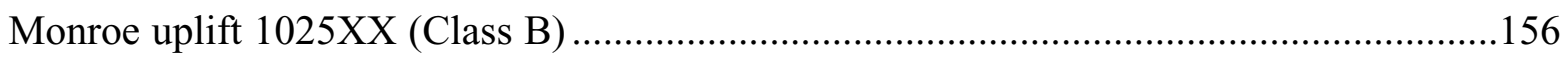

Reelfoot scarp and New Madrid seismic zone 1023 (Class A) ........................................37

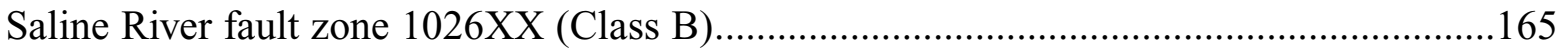

Western Lowlands liquefaction features 1029 (Class A)...............................................8

\section{Colorado}

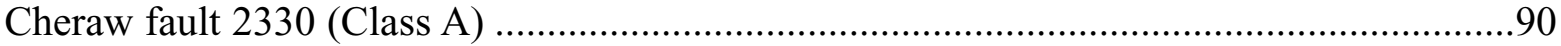

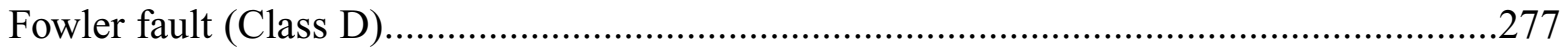

\section{Connecticut}

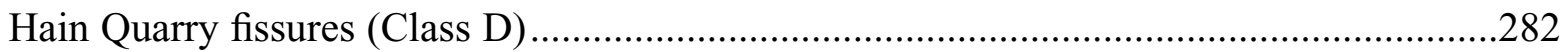

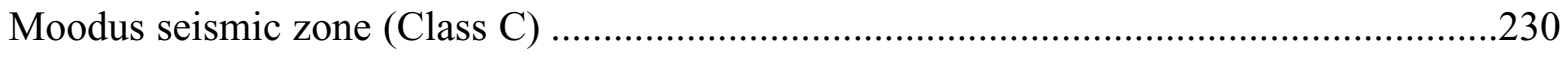

\section{Florida}

Gulf-margin normal faults 2654XX (Class B) ......................................................... 143

Grossman's Hammock rock reef fault (Class D)........................................................280

\section{Georgia}

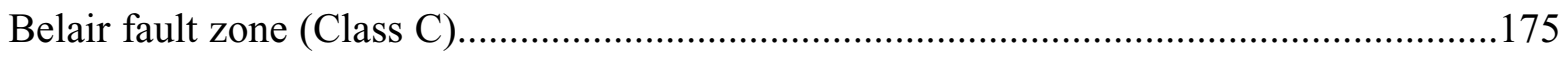

\section{Illinois}

Albrecht Creek fault 1027e (Class A) ............................................................................64

Barnes Creek fault zone 1028b (Class A) ..................................................................... 71

Commerce fault 1027b (Class A) ..............................................................................60

English Hill fault zone 1027a (Class A) ...................................................................59

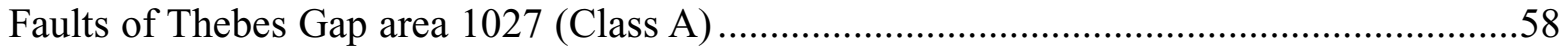

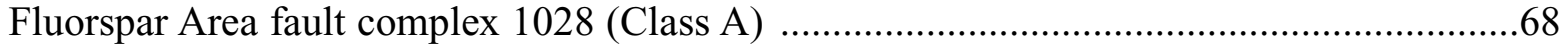

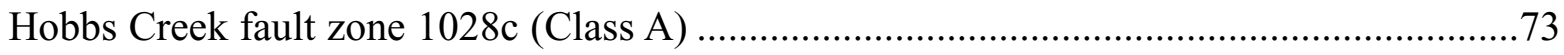

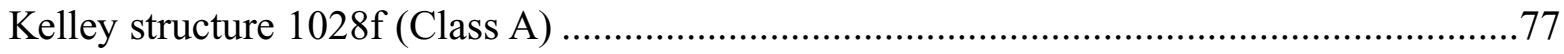


Lambert trench at intersection of English Hill and Albrecht Creek faults 1027f (Class A) .65

Lusk Creek fault zone 1028e (Class A) ................................................................... 75

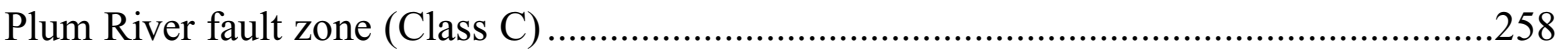

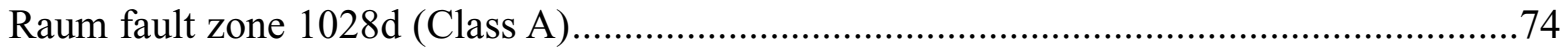

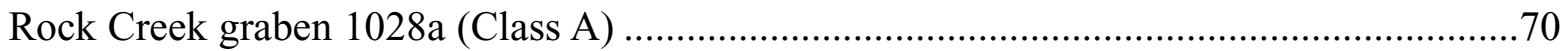

St. Louis-Cape Girardeau liquefaction features 1030 (Class A) ......................................86

Wabash Valley liquefaction feature 1024 (Class A) .......................................................53

\section{Indiana}

Wabash Valley liquefaction feature 1024 (Class A) .....................................................53

\section{Iowa}

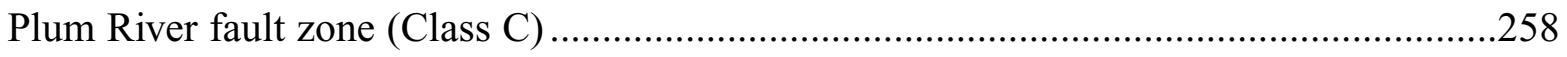

\section{Kansas}

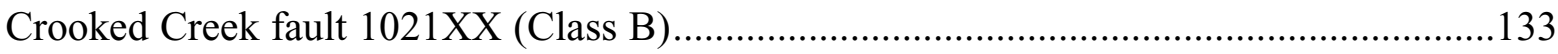

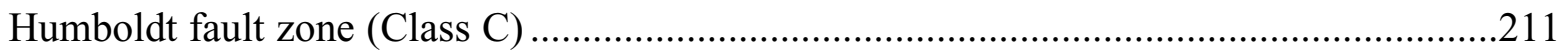

\section{Kentucky}

Barnes Creek fault zone 1028b (Class A) .................................................................... 71

Fluorspar Area fault complex 1028 (Class A) ....................................................................68

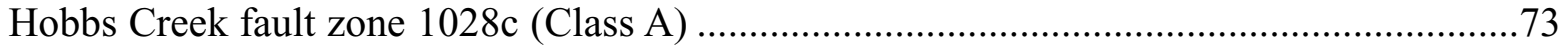

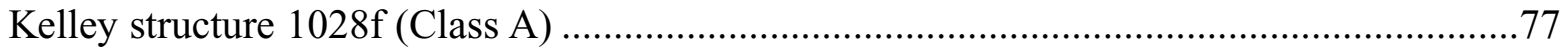

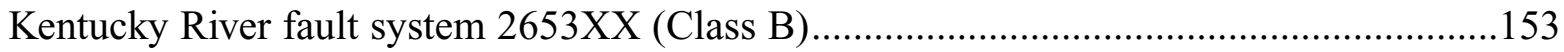

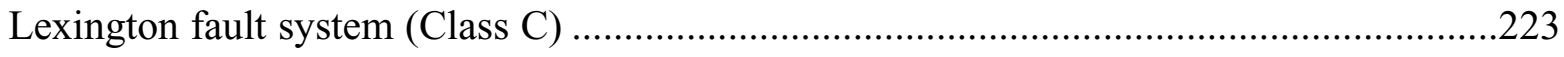

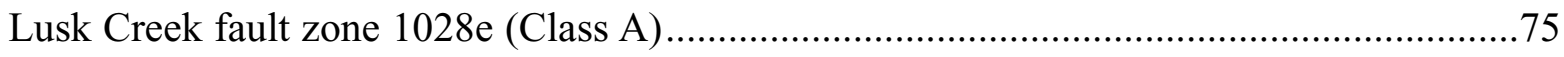

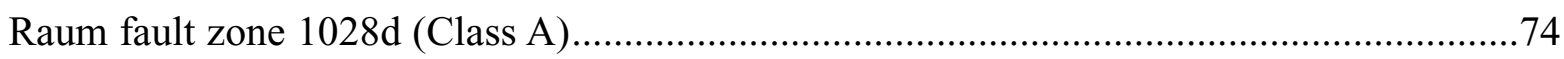

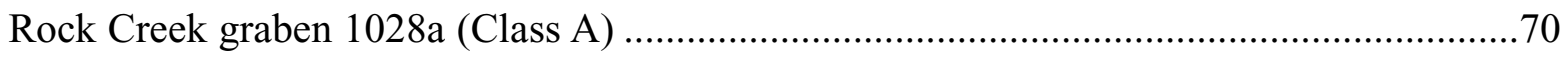

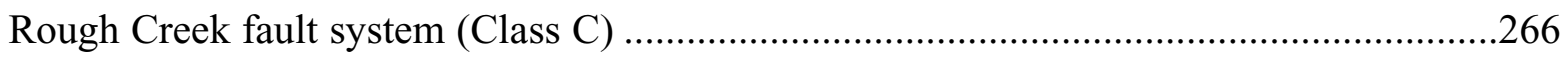

\section{Louisiana}

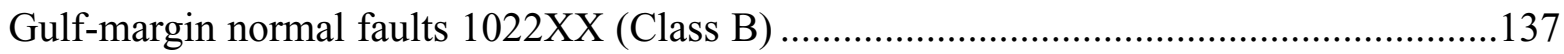

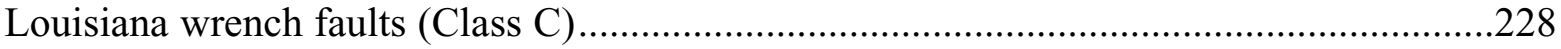

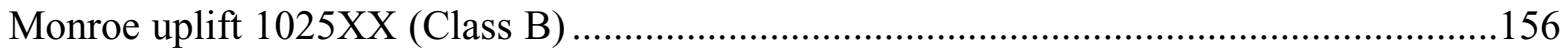

\section{Maine}

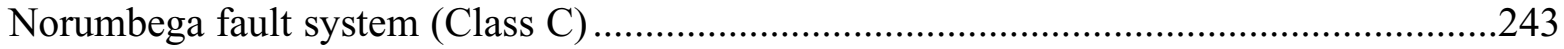

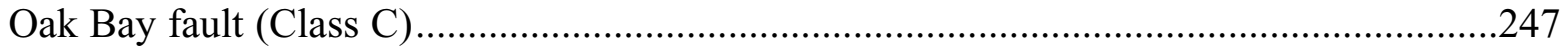




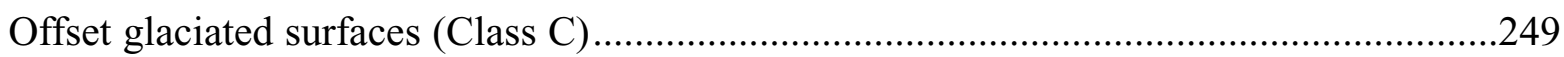

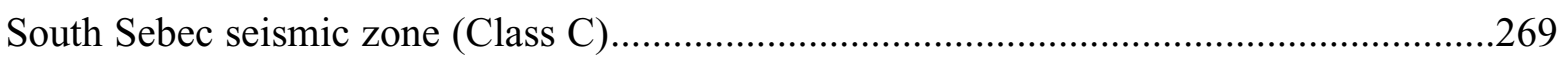

\section{Maryland}

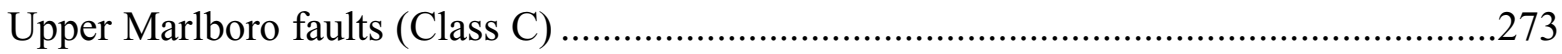

\section{Massachusetts}

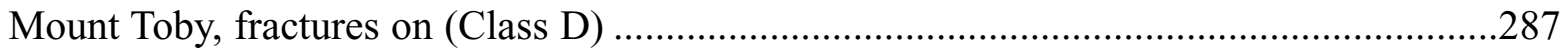

Newbury liquefaction features 2651 (Class A) ..............................................................95

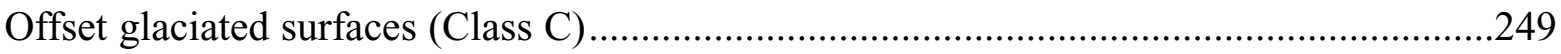

\section{Mississippi}

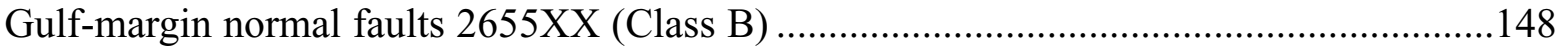

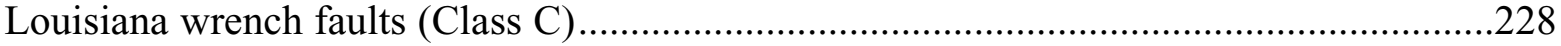

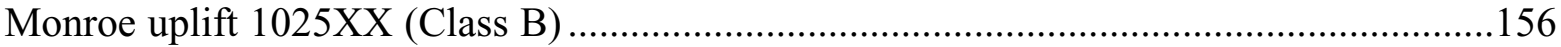

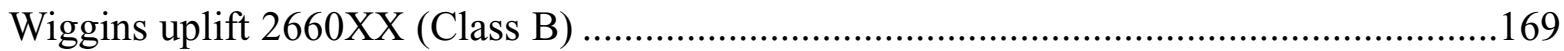

\section{Missouri}

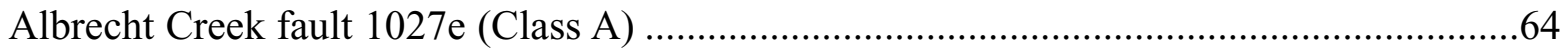

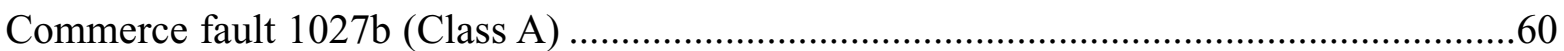

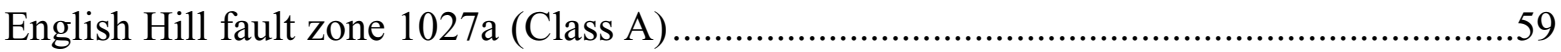

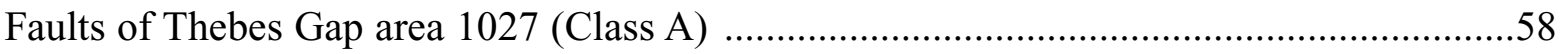

Happy Hollow fault 1027c (Class A) ...........................................................................62

Reelfoot scarp and New Madrid seismic zone 1023 (Class A) .........................................37

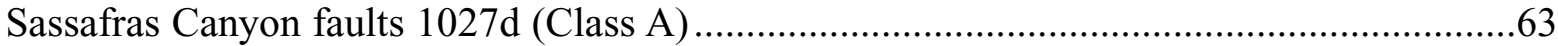

St. Louis-Cape Girardeau liquefaction features 1030 (Class A) ......................................86

Western Lowlands liquefaction features 1029 (Class A)................................................80

\section{Montana}

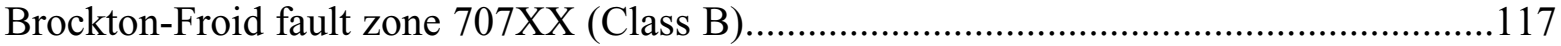

\section{Nebraska}

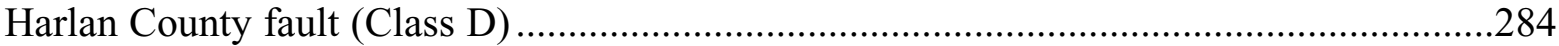

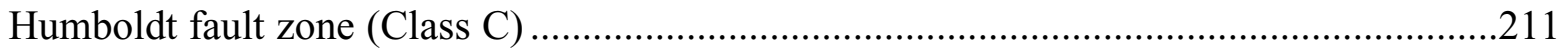

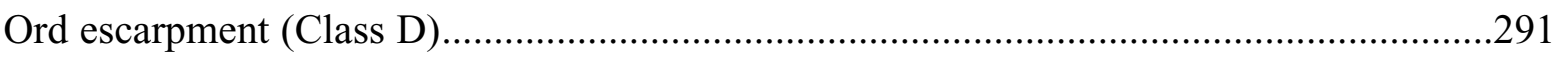

\section{New Hampshire}

Offset glaciated surfaces (Class C) 


\section{New Jersey}

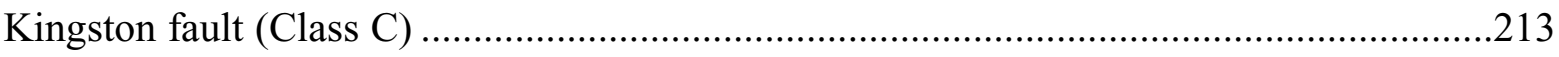

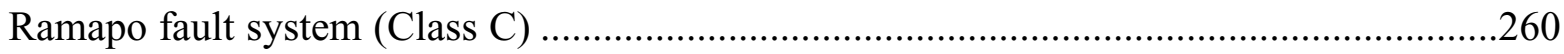

\section{New York}

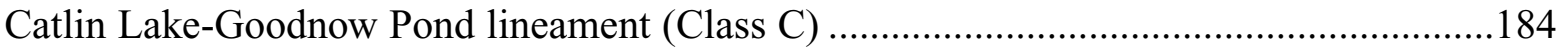

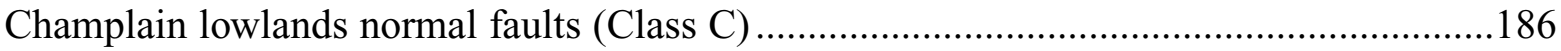

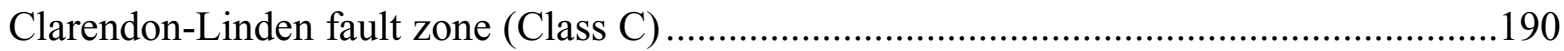

Cornwall-Massena earthquake (Class C)......................................................................196

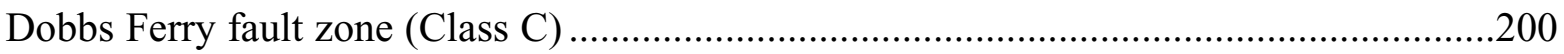

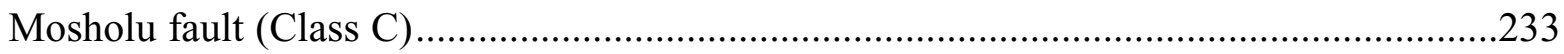

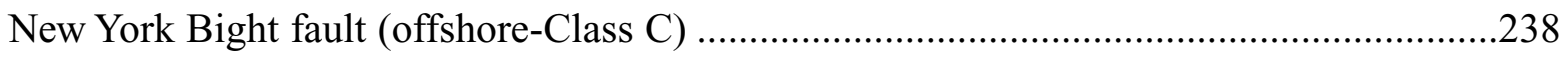

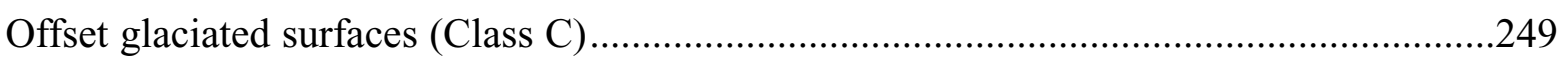

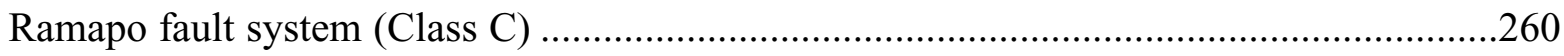

\section{North Carolina}

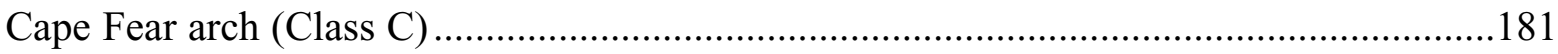

Georgetown liquefaction features 2659(Class A) ........................................................113

Hares Crossroads fault (Class C)....................................................................................20

\section{Ohio}

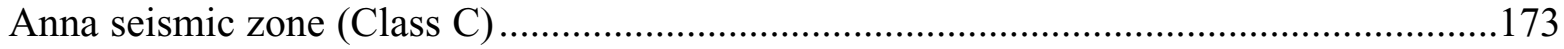

Northeast Ohio seismic zone (Class C) .......................................................................241

\section{Oklahoma}

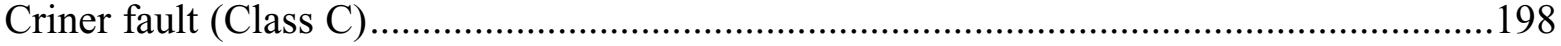

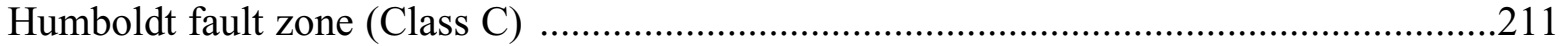

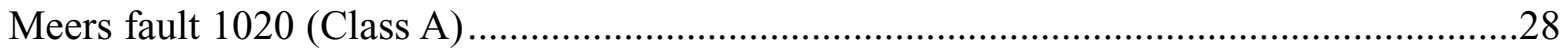

Unnamed (northwest) section of Meers fault 1020a (Class A) ...............................................29

Unnamed (southeast) section of Meers fault 1020b (Class A).................................................30

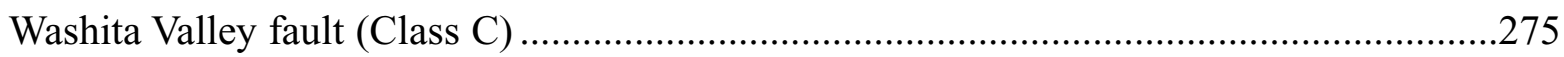

\section{Pennsylvania}

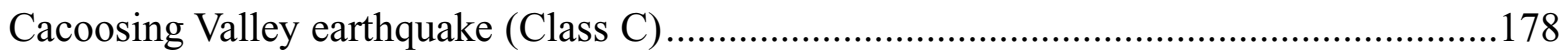

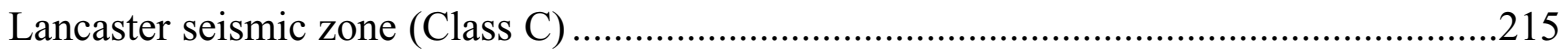

\section{South Carolina}

Bluffton liquefaction features (Class A) 2658, 109 


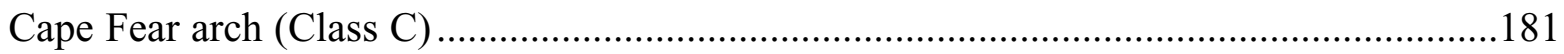

Charleston liquefaction features (Class A) 2657, .........................................................102

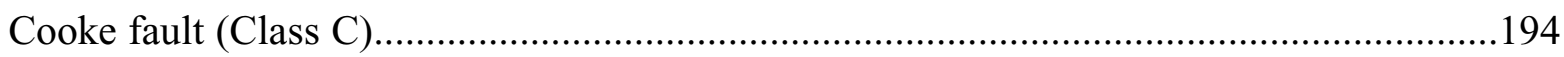

Georgetown liquefaction features (Class A) 2659 .......................................................113

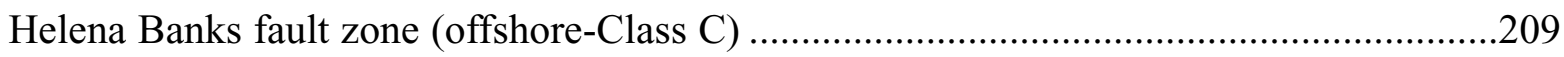

Pen Branch fault (Class C) ………………………………........................................25

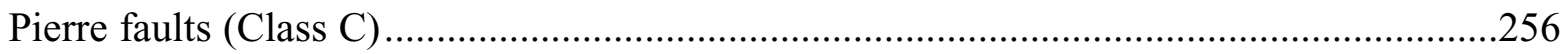

\section{Tennessee}

Reelfoot scarp and New Madrid seismic zone 1023 (Class A).............................................37

\section{Texas}

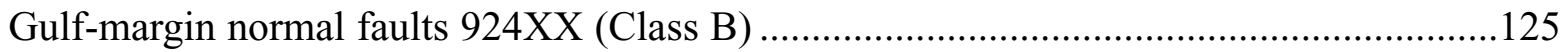

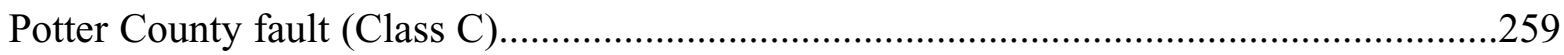

Vermont

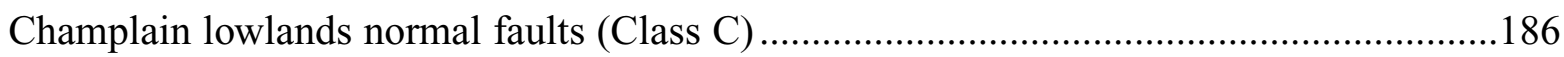

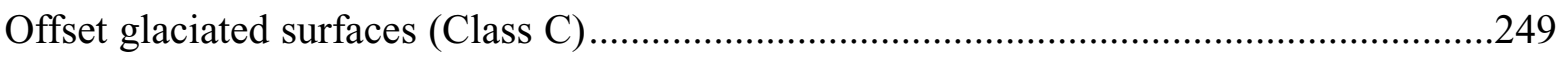

\section{Virginia}

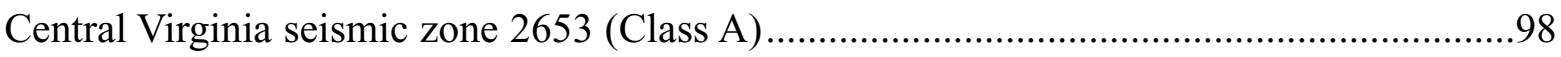

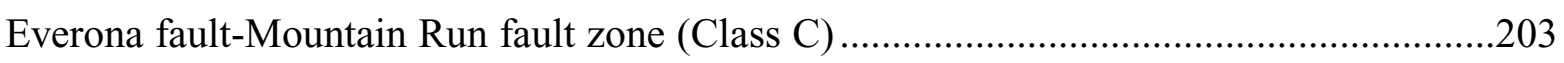

Lebanon Church fault (Class C) ..................................................................................22

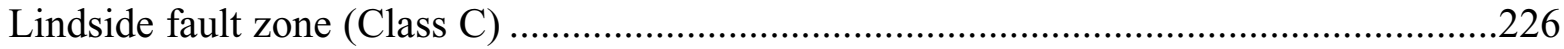

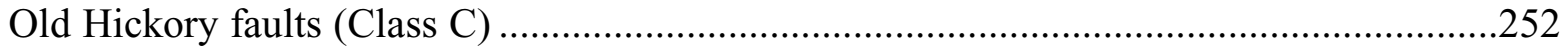

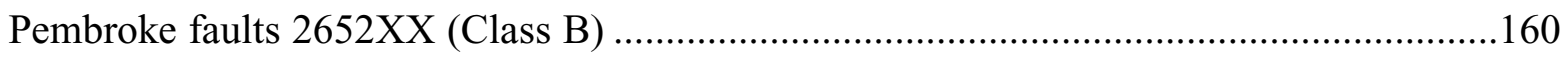

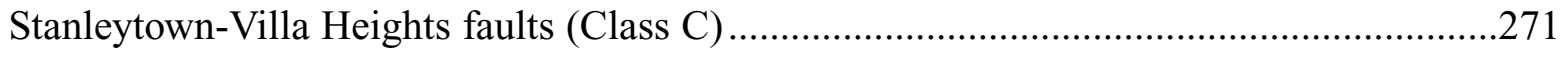

\section{West Virginia}

Lindside fault zone (Class C)

\section{Figures}

Figure 1. Map of historical seismicity and location of 13 Quaternary faults and liquefaction features in the Central and Eastern United States

Figure 2. Map of historical seismicity and location of 11 Class B features in the Central and Eastern United States

Figure 3. Map of historical seismicity and location of 45 Class C \& D features in the Central and Eastern United States 
Figure 4. Map and oblique aerial view of the Meers fault, southeastern Oklahoma..............12

Figure 5. Map and photograph of liquefaction features in the New Madrid seismic zone, central Mississippi River Valley, Arkansas, Missouri, and Tennessee

Figure 6. Map and photograph of Cheraw fault, southeastern Colorado.............................16

Figure 7. Map of the Charleston-Georgetown-Bluffton area, South Carolina, and photograph of damage from the August 31, 1886, earthquake.

Figure 8. Map of selected sites along the eastern section of the Meers fault scarp. 36

Figure 9. Map of Reelfoot scarp and selected features in the area of the New Madrid seismic zone...... .49

\section{Tables}

Table 1. Definitions of classes used in the compilation of Quaternary faults, liquefaction features, and deformation in the Central and Eastern United States.....

Table 2. Summary of Quaternary faults, liquefaction features, and deformation in the Central and Eastern United States. 


\title{
Data for Quaternary faults, liquefaction features, and possible tectonic features in the Central and Eastern United States, east of the Rocky Mountain Front
}

\author{
by \\ Anthony J. Crone and Russell L. Wheeler \\ United States Geological Survey \\ Geologic Hazards Team \\ Mail Stop 966, Box 25046 \\ Denver, CO 80225-0046 \\ Prepared as part of the U.S. Geological Survey's \\ National Earthquake Hazard Reduction Program (NEHRP) project on \\ UNITED STATES MAP OF QUATERNARY FAULTS AND FOLDS \\ In cooperation with the International Lithosphere Program's \\ Task Group II-2, World Map of Major Active Faults \\ Michael N. Machette, Co-chairman
}

\begin{abstract}
The USGS is currently leading an effort to compile published geological information on Quaternary faults, folds, and earthquake-induced liquefaction in order to develop an internally consistent database on the locations, ages, and activity rates of major earthquake-related features throughout the United States. This report is the compilation for such features in the Central and Eastern United States (CEUS), which for the purposes of the compilation, is defined as the region extending from the Rocky Mountain Front eastward to the Atlantic seaboard. A key objective of this national compilation is to provide a comprehensive database of Quaternary features that might generate strong ground motion and therefore, should be considered in assessing the seismic hazard throughout the country. In addition to printed versions of regional and individual state compilations, the database will be available on the World-Wide Web, where it will be readily available to everyone. The primary purpose of these compilations and the derivative database is to provide a comprehensive, uniform source of geological information that can by used to complement the other types of data that are used in seismic-hazard assessments.
\end{abstract}

Within our CEUS study area, which encompasses more than 60 percent of the continuous U.S., we summarize the geological information on 69 features that are categorized into four classes (Class A, B, C, and D) based on what is known about the feature's Quaternary activity. The 
CEUS contains only 13 features of tectonic origin for which there is convincing evidence of Quaternary activity (Class A features). Of the remaining 56 features, 11 require further study in order to confidently define their potential as possible sources of earthquake-induced ground motion (Class B), whereas the remaining features either lack convincing geologic evidence of Quaternary tectonic faulting or have been studied carefully enough to determine that they do not pose a significant seismic hazard (Classes $\mathrm{C}$ and $\mathrm{D}$ ).

The correlation between historical seismicity and Quaternary faults and liquefaction features in the CEUS is generally poor, which probably reflects the long return times between successive movements on individual structures. Some Quaternary faults and liquefaction features are located in aseismic areas or where historical seismicity is sparse. These relations indicate that the record of historical seismicity does not identify all potential seismic sources in the CEUS. Furthermore, geological studies of some currently aseismic faults have shown that the faults have generated strong earthquakes in the geologically recent past. Thus, the combination of geological information and seismological data can provide better insight into potential earthquake sources and thereby, contribute to better, more comprehensive seismic-hazard assessments.

\section{Introduction}

The "World Map of Major Active Faults" Task Group is compiling published fault data, developing a digital database of the fault data, and preparing a series of maps for the United States and other countries in the Western Hemisphere that show the locations, ages, and activity rates of major earthquake-related features such as faults, liquefaction features, and fault-related folds. This report presents the data that was compiled for the Central and Eastern United States (CEUS). (Data compiled for the Active Faults project also includes information on Quaternary folds, but no active folds are known or reported in the CEUS, so we do not include folds in this report.) These data compilations, the digital database, and the companion map summarize the published information on these known tectonic features and present the information in an internally consistent format. The Western Hemisphere effort is sponsored by International Lithosphere Program (ILP) Task Group II-2; the data compilation, database, and map for the United States is funded largely by the National Earthquake Hazard Reduction Program (NEHRP) through the U.S. Geological Survey. Work in the Western Hemisphere is being coordinated by Michael N. Machette, the digital database is being designed and managed by Kathleen M. Haller, and map data are being digitized and manipulated by Richard L. Dart. Collectively, these efforts represent a key contribution to the new Global Seismic Hazards Assessment Program (ILP Task Group II-0) for the International Decade for Natural Disaster Reduction.

This report is the fourth in a series of state and regional data compilations that will ultimately constitute a Quaternary fold and fault database for the entire United States. Previously released compilations include U.S. Geological Survey Open-File Report 96-002 for West Texas (Collins and others, 1996 \#993), Open-File Report 98-521 for New Mexico (Machette and others, 1998), Colorado State Geological Survey Open-File Report 98-8 for Colorado (Widmann and others, 1998), and a report for western Montana, which will be released as a Montana Bureau of Mines and Geology publication (Haller and others, \#1750).

This compilation of information for the Central and Eastern U.S. is presented in two forms: (1) this Open-File Report, which provides a printed catalog of the data and (2) a digital database that is currently being assembled and will be available on the World-Wide Web in the near future. State and regional compilations are being merged into a national digital database, which 
contains referenced values for a variety of geographic, geologic, and paleoseismologic parameters for the features described here, as well as the written descriptions included in this report.

This report and the companion digital database summarize the published evidence of known Quaternary surface faulting, liquefaction features, and suspect tectonic features in the CEUS, which is that part of the country east of the Rocky Mountain Front. This large region, which encompasses more than 60 percent of the area of the contiguous United States, is generally regarded as being tectonically stable region. With the notable exception of the New Madrid seismic zone in the central Mississippi Valley, the CEUS has few earthquakes compared to seismically active regions of the country such as the Intermountain West and the plate-margin settings of California, the Pacific Northwest, and Alaska. Furthermore, the rates of deformation on features in the CEUS is generally low compared to the rate at which surficial geological processes modify the landscape. As a result, the geologic and geomorphic expression of most tectonic deformation in the CEUS is commonly subtle to obscure, and is generally difficult to detect confidently. These low rates of deformation in the CEUS present special challenges for seismic-hazard assessments and mitigation because damaging earthquakes are infrequent and, as a result, the population and infrastructure are generally not well prepared to endure strong ground motion. This general lack of preparedness can result in substantial damage and loss from even moderate-magnitude events.

This compilation summarizes evidence of tectonic deformation that has occurred in Quaternary time. The time span encompassed by Quaternary period has been subject to numerous revisions and on-going discussion over the years. A review of the opinions concerning the age of the Quaternary-Tertiary boundary is beyond the scope of this report, but for the purposes of this compilation and the project, the Quaternary period is considered to begin at 1.6 Ma.

Features described in this compilation are classified into one of four categories: Class A, Class B, Class C, and Class D (Table 1) on the basis of geological evidence of Quaternary faulting or deformation. The primary types of geological evidence summarized in this report include paleoseismological, stratigraphic, geomorphic, structural, and sedimentological information.

Historical earthquakes are direct evidence of Quaternary faulting, but historical earthquakes are seismological evidence, which we consider as distinct and separate from geological evidence, for the purposes of this report. Thus, we do not use this seismological evidence in this classification scheme.

Features categorized in Class A (fig. 1; tables 1 and 2) have good geological evidence of tectonic origin and are potentially seismogenic. For these features, detailed evidence of Quaternary deformation or strong ground motion (for example, the Wabash Valley liquefaction features) has been described and is well documented in the scientific literature. The publishedgeologic evidence describing these features compellingly demonstrates evidence of Quaternary activity. Each Class A feature is labeled by a four-digit integer (table 2) that corresponds to the feature's number listed in the digital database.

In the CEUS, liquefaction features are a key type of evidence used in many areas to identify strong ground shaking, and by inference, strong earthquakes, seismic faulting, and Quaternary deformation. Thus the occurrence of widespread liquefaction features is taken as evidence that a significant seismogenic fault is located nearby, even though the causative fault may not have been identified. We recognize that liquefaction features can be caused by non-tectonic processes, including artesian groundwater and landslides, but generally, these non-tectonic liquefaction features tend to be localized and to occur in recognizable geomorphic settings. In contrast, the liquefaction features used to identify Class A features have been generally discovered over a significant area and in settings that are not conductive to artesian flow or landslides. 


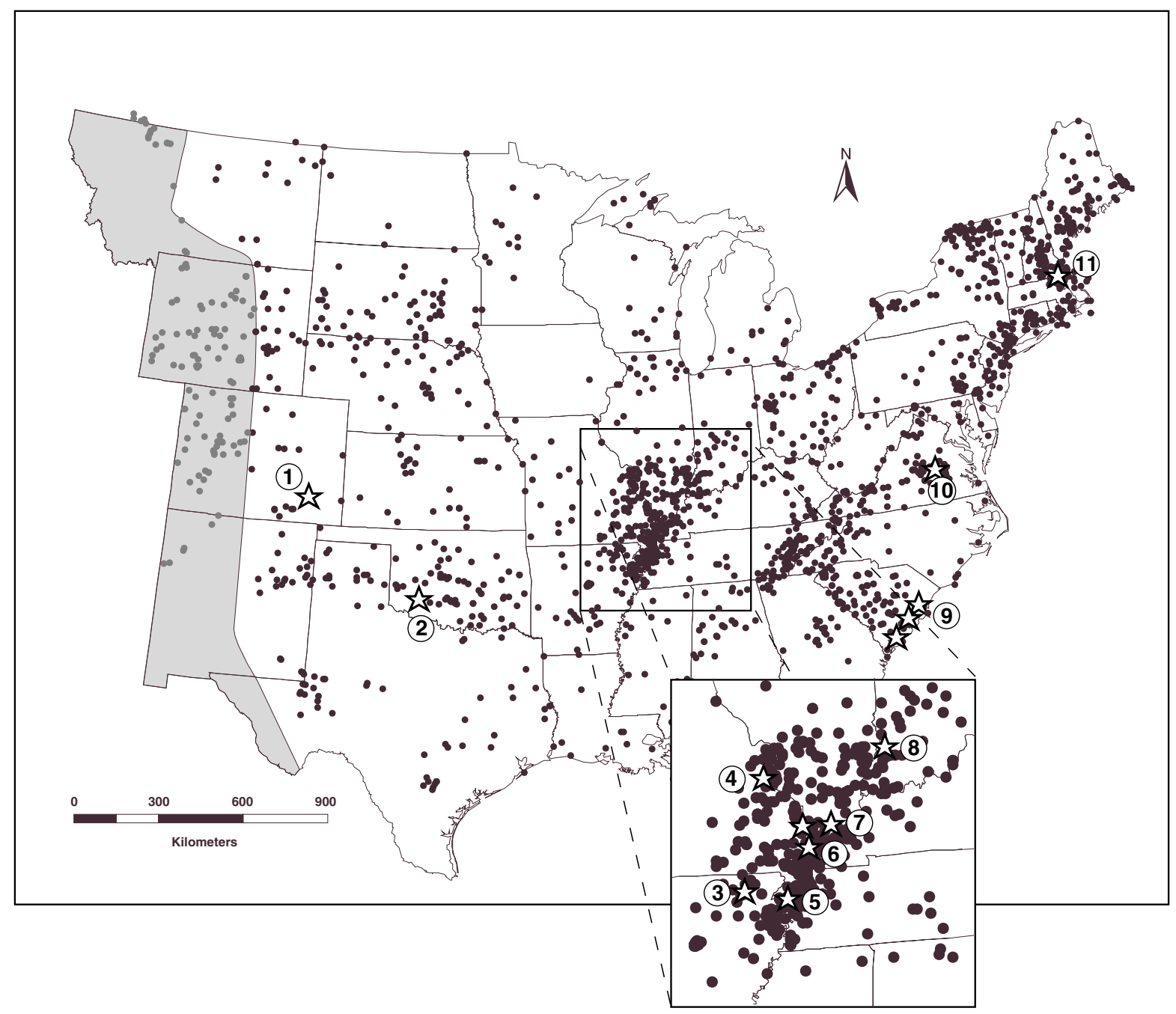

Figure 1. Map of historical seismicity of the Central and Eastern United States and the location of 13 Quaternary faults and singular or groups of liquefaction features; see discussions of individual features for details. Study area extends from the Atlantic Coast to the eastern edge of the shaded area on the map. Quaternary faults and liquefaction features (Class A) are labeled by circled numbers and stars: 1, Cheraw fault, Colorado; 2, Meers fault, Oklahoma; 3, Western Lowlands liquefaction features, MissouriArkansas; 4, St. Louis-Cape Girardeau liquefaction features, Missouri-Illinois; 5, Reelfoot scarp and New Madrid seismic zone, Missouri-Arkansas-Tennessee; 6, Thebes Gap area, Missouri; 7, Fluorspar Area fault complex, Illinois-Kentucky; 8, Wabash Valley liquefaction features, Indiana-Illinois; 9, CharlestonBluffton-Georgetown liquefaction features, South Carolina-North Carolina; 10, Central Virginia seismic zone; 11, Newbury liquefaction features, Massachusetts. See text for explanation of classes. Solid dots are historical earthquakes of $m_{b} 3.0$ or greater; seismicity catalog provided by C. Mueller, USGS. 
Table 1. Definitions of classes used in the compilation of Quaternary faults, liquefaction features, and deformation in the Central and Eastern United States.

[This report follow the standard usage in the earthquake-hazards community by distinguishing between seismological evidence and geological evidence. We use geological evidence to assign possible Quaternary faults and features to one of the four classed described below. The main types of geological evidence summarized in this report are paleoseismological, stratigraphic, sedimentological, structural, and geomorphological information. Historical earthquakes are direct evidence of Quaternary tectonic faulting, but historical earthquakes are seismological evidence, and we do not use them in this classification]

\begin{tabular}{|c|l|}
\hline Class Category & \multicolumn{1}{|c|}{ Definition } \\
\hline Class A & $\begin{array}{l}\text { Geologic evidence demonstrates the existence of a Quaternary fault of tectonic origin, } \\
\text { whether the fault is exposed for mapping or inferred from liquefaction or other } \\
\text { deformational features. }\end{array}$ \\
\hline Class B & $\begin{array}{l}\text { Geologic evidence demonstrates the existence of a fault or suggests Quaternary } \\
\text { deformation, but either (1) the fault might not extend deeply enough to be a potential } \\
\text { source of significant earthquakes, or (2) the currently available geologic evidence is too } \\
\text { strong to confidently assign the feature to Class C but not strong enough to assign it to } \\
\text { Class A. }\end{array}$ \\
\hline Class C & $\begin{array}{l}\text { Geologic evidence is insufficient to demonstrate (1) the existence of tectonic fault, or (2) } \\
\text { Quaternary slip or deformation associated with the feature. }\end{array}$ \\
\hline Class D & $\begin{array}{l}\text { Geologic evidence demonstrates that the feature is not a tectonic fault or feature; this } \\
\text { category includes features such as demonstrated joints or joint zones, landslides, } \\
\text { erosional or fluvial scarps, or landforms resembling fault scarps, but of demonstrable } \\
\text { non-tectonic origin. }\end{array}$ \\
\hline
\end{tabular}

Table 2. Summary of Quaternary faults, liquefaction features, and deformation in the Central and Eastern United States.

[ID Number refers to the number assigned to the structure in the fault compilation and the digital database. "Time of MRE" is time of most recent paleoevent; see the definition of terms in this report for explanation of the time of most recent event and the slip-rate category. For liquefaction features, the slip-rate category is described as "unknown" because the faults that generated earthquakes at these sites have not been identified or characterized, and therefore it is impossible to determine a slip rate. General locations of features are shown in figure 1.]

\begin{tabular}{|l|l|c|l|l|l|}
\hline $\begin{array}{c}\text { Structure Name } \\
\text { (listed alphabetically) }\end{array}$ & \multicolumn{1}{|c|}{ Location } & $\begin{array}{c}\text { ID } \\
\text { No. }\end{array}$ & $\begin{array}{c}\text { Time of } \\
\text { MRE }\end{array}$ & $\begin{array}{l}\text { Slip-Rate } \\
\text { Category }\end{array}$ & \multicolumn{1}{|c|}{ Comments } \\
\hline $\begin{array}{l}\text { Bluffton liquefaction } \\
\text { features }\end{array}$ & South Carolina & 2658 & $\begin{array}{l}\text { Latest } \\
\text { Quaternary }\end{array}$ & unknown & $\begin{array}{l}\text { Prehistoric liquefaction } \\
\text { features southwest of the } \\
\text { liquefaction from the 1886 } \\
\text { Charleston, South Carolina, } \\
\text { earthquake. }\end{array}$ \\
\hline $\begin{array}{l}\text { Central Virginia } \\
\text { seismic zone }\end{array}$ & Virginia & 2653 & $\begin{array}{l}\text { Latest } \\
\text { Quaternary }\end{array}$ & unknown & $\begin{array}{l}\text { Few small late Holocene sand } \\
\text { dikes reported in area of } \\
\text { modern seismicity. }\end{array}$ \\
\hline $\begin{array}{l}\text { Charleston liquefaction } \\
\text { features }\end{array}$ & South Carolina & 2657 & Historical & unknown & $\begin{array}{l}\text { 1886 earthquake caused } \\
\text { impressive liquefaction; } \\
\text { paleoseismic studies indicate } \\
\text { multiple prehistoric events. }\end{array}$ \\
\hline
\end{tabular}


Table 2. (continued).

\begin{tabular}{|c|c|c|c|c|c|}
\hline $\begin{array}{c}\text { Structure Name } \\
\text { (listed alphabetically) }\end{array}$ & Location & $\begin{array}{l}\text { ID } \\
\text { No. }\end{array}$ & $\begin{array}{l}\text { Time of } \\
\text { MRE }\end{array}$ & $\begin{array}{l}\text { Slip-Rate } \\
\text { Category }\end{array}$ & Comments \\
\hline Cheraw fault & Colorado & 2330 & $\begin{array}{l}\text { Latest } \\
\text { Quaternary }\end{array}$ & $<0.2 \mathrm{~mm} / \mathrm{yr}$ & $\begin{array}{l}\text { In currently aseismic region; } \\
\text { three events in the past } \sim 25 \mathrm{ka} \text {. }\end{array}$ \\
\hline $\begin{array}{l}\text { Georgetown } \\
\text { liquefaction features }\end{array}$ & $\begin{array}{l}\text { South } \\
\text { Carolina, } \\
\text { North Carolina }\end{array}$ & 2659 & $\begin{array}{l}\text { Latest } \\
\text { Quaternary }\end{array}$ & unknown & $\begin{array}{l}\text { Prehistoric sand blows } \\
\text { northeast of Charleston, South } \\
\text { Carolina that have an age of } \\
\text { about } 1.64 \mathrm{ka} \text {. }\end{array}$ \\
\hline $\begin{array}{l}\text { Fluorspar area fault } \\
\text { complex }\end{array}$ & $\begin{array}{l}\text { Illinois, } \\
\text { Kentucky }\end{array}$ & 1028 & Late Quaternary & $<0.2 \mathrm{~mm} / \mathrm{yr}$ & $\begin{array}{l}\text { Contains several fault zones } \\
\text { and structures in the fluorspar } \\
\text { mining district of southern } \\
\text { Illinois and western Kentucky. }\end{array}$ \\
\hline Meers fault & Oklahoma & 1020 & $\begin{array}{l}\text { Latest } \\
\text { Quaternary }\end{array}$ & $\begin{array}{l}0.2-<1 \\
\mathrm{~mm} / \mathrm{yr}\end{array}$ & $\begin{array}{l}\text { In currently aseismic region; } \\
\text { two late Holocene events on } \\
\text { SE section; poor information } \\
\text { on NW section. }\end{array}$ \\
\hline $\begin{array}{l}\text { Newbury liquefaction } \\
\text { features }\end{array}$ & Massachusetts & 2651 & $\begin{array}{l}\text { Latest } \\
\text { Quaternary }\end{array}$ & unknown & $\begin{array}{l}\text { Sand dikes injected into } \\
\text { glaciomarine sand; possibly } \\
\text { two events with younger event } \\
\text { occurring in } 1727 \text { earthquake. }\end{array}$ \\
\hline $\begin{array}{l}\text { Reelfoot scarp and } \\
\text { New Madrid seismic } \\
\text { zone }\end{array}$ & $\begin{array}{l}\text { Missouri, } \\
\text { Arkansas, } \\
\text { Tennessee }\end{array}$ & 1023 & Historical & unknown & $\begin{array}{l}\text { Three M 8 events in 1811- } \\
\text { 1812; little known about } \\
\text { causative faults that are buried } \\
\text { beneath thick Mississippi } \\
\text { embayment sediments. } \\
\text { Reelfoot scarp is the only } \\
\text { confirmed Quaternary tectonic } \\
\text { fault scarp in the region. }\end{array}$ \\
\hline $\begin{array}{l}\text { St. Louis-Cape } \\
\text { Girardeau liquefaction } \\
\text { features }\end{array}$ & $\begin{array}{l}\text { Missouri, } \\
\text { Illinois }\end{array}$ & 1030 & $\begin{array}{l}\text { Latest } \\
\text { Quaternary }\end{array}$ & unknown & $\begin{array}{l}\text { Exposures in stream cuts in SE } \\
\text { Missouri and adjacent SW } \\
\text { Illinois revealed sand blows, } \\
\text { sand dikes or sand sills at } 48 \\
\text { sites }\end{array}$ \\
\hline Thebes Gap faults & $\begin{array}{l}\text { Missouri, } \\
\text { Illinois }\end{array}$ & 1027 & Late Quaternary & unknown & $\begin{array}{l}\text { Detailed geologic mapping } \\
\text { identified several faults; } \\
\text { trenching has documented } \\
\text { multiple events on several } \\
\text { faults. }\end{array}$ \\
\hline $\begin{array}{l}\text { Wabash Valley } \\
\text { liquefaction features }\end{array}$ & $\begin{array}{l}\text { Illinois, } \\
\text { Indiana }\end{array}$ & 1024 & $\begin{array}{l}\text { Latest } \\
\text { Quaternary }\end{array}$ & unknown & $\begin{array}{l}\text { Clastic dikes exposed in river } \\
\text { banks define large area of } \\
\text { prehistoric strong shaking. }\end{array}$ \\
\hline $\begin{array}{l}\text { Western Lowlands } \\
\text { liquefaction features }\end{array}$ & $\begin{array}{l}\text { Missouri, } \\
\text { Arkansas }\end{array}$ & 1029 & $\begin{array}{l}\text { Latest } \\
\text { Quaternary }\end{array}$ & unknown & $\begin{array}{l}\text { Prehistoric liquefaction } \\
\text { features in the area west of } \\
\text { Crowleys Ridge adjacent to } \\
\text { the New Madrid seismic zone } \\
\text { indicate strong ground shaking } \\
\text { from earthquake sources other } \\
\text { than those that generated the } \\
\text { New Madrid earthquakes. }\end{array}$ \\
\hline
\end{tabular}


In several locales, detailed studies have shown that liquefaction has occurred multiple times in the past.

The second category in this compilation is Class B features (table 1; fig. 2), which are also assigned a four-digit integer in the digital database. As treated in this report, the geologic evidence of Quaternary tectonic activity on Class B features is far less compelling than for Class A features. In some cases, Class B features may show clear evidence of Quaternary offset or deformation, but it is uncertain if these surface structures extend to sufficient depths to generate strong earthquakes and therefore produce strong ground motion. An example of these kind of structures might be surficial faults in young volcanic terrains or faults in areas of known modern subsidence (Gulf Coastal Plain), which are probably not true seismogenic structures even though they displace Quaternary-age deposits or rocks. The second basis for assigning a feature to Class B is because, in our judgement, the geologic and/or geomorphic evidence of Quaternary deformation is equivocal. The evidence reported in the geological literature may be incomplete or inconclusive, but it is tantalizing enough that we cannot dismiss the feature as probably non-seismogenic. Quaternary activity on these kinds of features is still a possibility; but considerable uncertainty remains about the feature's future seismogenic potential. Future studies of Class B features may yield evidence that permits them to be reclassified with greater confidence, but given the present state of knowledge, we cannot conclusively determine if they belong in the Class A "known Quaternary feature" category or in the Class C category. Class B features are assigned a four-digit number followed by "XX", which allows Class B features to be easily distinguished from Class A features in the database.

Faults and features assigned to Class $\mathrm{C}$ do not have demonstrated Quaternary activity and are not considered to be potential earthquake sources (table 1; fig. 3). Generally, Class C features are not known to have Quaternary slip. In some cases, detailed studies have revealed evidence showing that specific features actually have a non-tectonic origin. These non-tectonic features are assigned to a separate class, Class D, and include features such as solution collapses, features related to subsidence, landslides, and erosional scarps. Class $\mathrm{C}$ and $\mathrm{D}$ features are included in this compilation and in the database because their inclusion provides a complete record of all features that have been examined.

This report is not a guide to seismic hazard. It is important to emphasize the distinction between the seismic hazard of an area and the proximity of Class $\mathrm{C}$ features, which lack geologic evidence of Quaternary faulting. It is critical to understand that this compilation is based only on a collection of reported geological evidence of Quaternary faulting; it does not focus on information about historical seismicity. This compilation was prepared to support efforts to update the USGS national seismic-hazard mapping efforts, and other hazard assessments.

Earthquake information is incorporated into hazard maps and assessments separately from geological information. Seismic-hazard assessments in the CEUS generally rely heavily on historical seismicity to quantify the hazard, and they use geological information secondarily. This compilation summarizes geological information. Earthquakes occur on faults, so the occurrence of earthquakes in a region is seismological proof that movement is occurring on faults, therefore, Quaternary tectonic faulting is occurring. However, the evidence of this on-going Quaternary faulting may or may not be expressed geologically at the surface. Thus, when we designate a fault as a Class $\mathrm{C}$ feature, we base this assignment only on geological evidence. This assignment largely ignores the fact that historically significant earthquakes may have occurred in the surrounding area, and the presence of this seismicity indicates the potential for future significant earthquakes. 


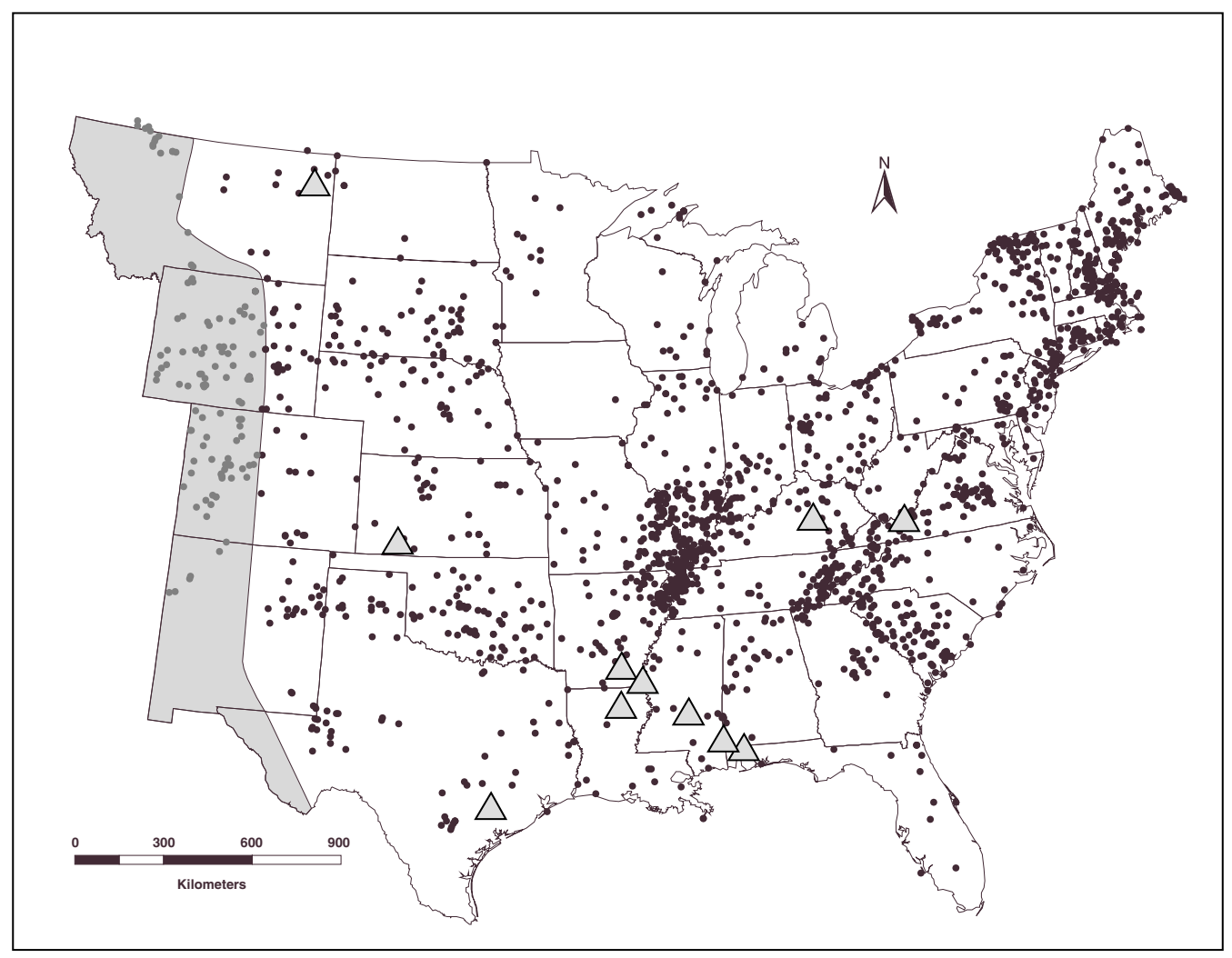

Figure 2. Index map showing historical seismicity of the Central and Eastern United States and the location of 11 Class B features. See text for explanation of classes. Study area extends from the Atlantic Coast to the eastern boundary of the shaded area. Shaded triangles show general locations of Class B features; see text for details and description of features. Solid dots are historical earthquakes of $m_{b} 3.0$ or greater; seismicity catalog provided by C. Mueller, USGS. 


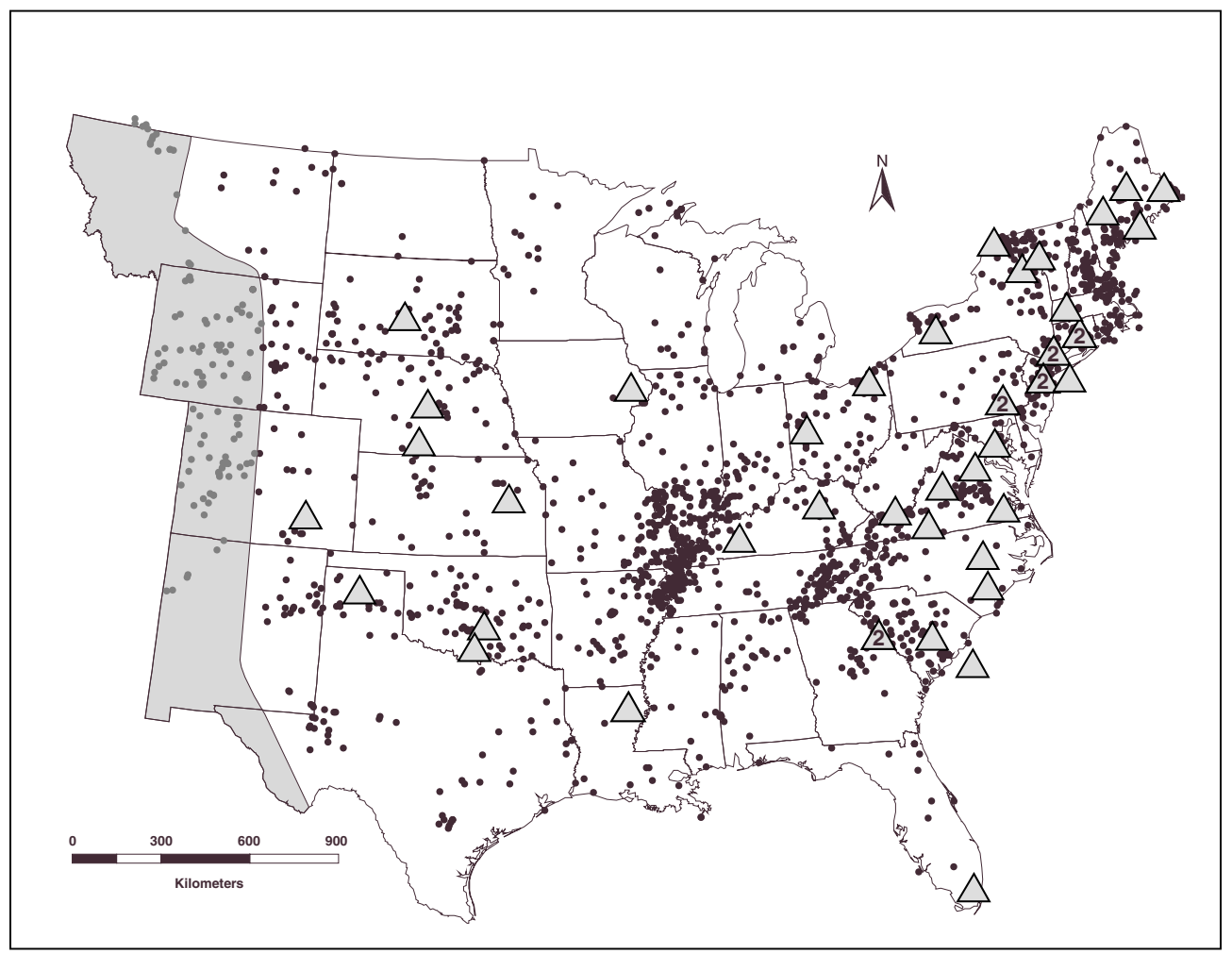

Figure 3. Map of historical seismicity of the Central and Eastern United States and location of 45 Class $C \& D$ features. See text for explanation of classes. The study area extends from the Atlantic Coast to the eastern boundary of the shaded area. Shaded triangles show locations of Class $C$ \& $D$ features; triangles containing a number indicate the number of closely spaced features near this location. See text for additional details. Solid dots are historical earthquakes of $m_{b} 3.0$ or greater; seismicity catalog provided by C. Mueller, USGS. 


\section{Strategy for Quaternary Fault Map and Database}

A primary objective of this national and global compilation of Quaternary faults and folds is to develop an internally consistent database of geological information that can be used in seismichazard assessments. In regions of low to moderate seismicity, such as the CEUS, geological data on Quaternary faults or liquefaction features provide valuable information that complements the record of historical seismicity. In many parts of the United States, especially in lowseismicity regions, the 200- to 300-year-long historical record is very short compared to the long recurrence times between significant earthquakes and the generally slow rates of deformation. As a result, the distribution of 200-300 years of historical earthquakes may not highlight all potential seismic sources and, therefore, not accurately reflect the full seismic hazard. Paleoseismic studies commonly document a record of surface faulting or deformation that typically spans thousands to tens of thousands of years. Therefore, these paleoseismic studies provide a longer-term perspective of hazards that augments the comparatively short historical record. Thus, developing a more complete inventory of Quaternary seismogenic faults can be a useful contribution to improved seismic-hazard assessments in regions of low to moderate historic seismicity (Crone and others, 1997a; Wheeler and Frankel, 2000). Unfortunately, the inventory in the CEUS is likely incomplete because the region has not been uniformly and systematically examined for evidence in the field of Quaternary faulting; such a systematic examination would be a worthy goal for future workers.

The data in this Open-File Report are being entered into the digital database, which is the source of information for the United States Map of Quaternary Folds and Faults. The database has been designed to accommodate data for a variety of faults, folds, and neotectonic features that span a wide spectrum in terms of data quality and abundance. For example, the paleoseismic history of many faults in California is known in considerable detail because of they have been the subject of numerous studies. In contrast, most features elsewhere in the country, including the CEUS, are poorly studied. As a result, the database of these less-studied features contains many empty fields, giving an appearance of being incomplete (i.e., unnamed faults, fields having no data, or limited descriptions). Despite this incomplete appearance, the database fields will present a uniform, systematic analysis of structures that can be assessed as potential seismic sources. The presence of incomplete fields in the database shows where future studies can add new information and increase our knowledge of specific features. Thus, the database is dynamic and will be updated through time. The information in this Open-File Report (and the database) is the first iteration of data for faults and structures in the CEUS; as significant new information becomes available, it will be used to update the digital database. Collectively, when the information from the CEUS is merged with similar data from other parts of the country, the database will a valuable source of geological information that will be readily accessible to everyone.

To accommodate these large differences in the level of study, the fault compilation and digital database have two major subsets of fault descriptions: (1) simple faults or features or (2) sectioned faults or features. Sectioned faults are generally well studied, and the geological data suggests that the age, slip rate, or recurrence interval for surface faulting changes along the strike of the feature. This information implies that surface-rupturing earthquakes have occurred on different parts of the fault at different times in the past. On the basis of this kind of geological information, the fault can be logically subdivided into separate structural (or possibly seismogenic) entities (segments) that may rupture independently during surface-faulting 
earthquakes. The Meers fault in southwestern Oklahoma (fig. 4) is the only sectioned fault described in this report. By the project's standards (and definitions), a fault is subdivided into sections on the basis of geomorphologic and geologic data (scarp morphology, stratigraphic control on times of faulting, geologic structures that may control physical segmentation, etc.). In some cases, such as the Meers fault, pronounced contrasts in the geomorphic expression of faulting along strike combined with paleoseismic studies that define the chronology of the youngest events on the fault are sufficient to subdivide the structure into sections.

In comparison, simple faults have limited detailed geological information and few or no paleoseismologic studies. In the absence of this type of detailed information, it is not possible to subdivide these features into sections. With the exception of the Meers fault, all of the features in the CEUS described in this report are simple features, according to the standards established for this project.

The term "segment" is popular and commonly used in the earthquake-geology community, but the term has many ambiguous meanings because different kinds of segments are described in the scientific literature (dePolo and others, 1991). To avoid confusion, the term "segments" has been dropped for this project in favor of the general term "sections", which is defined above.

Fourteen numbered features discussed in this report have documented evidence of Quaternary tectonic faulting or evidence of liquefaction (table 2). Fault traces or areas of liquefaction were taken from original sources and were digitized at an appropriate scale for use in Arc/Info*Geographic Information System (GIS) software that permits rescaling, output in a wide variety of projections, and assigning attributes to the geographic data (colors, line weights, and symbols for various maps). The information fields in the database and in this Open-File Report provide a comprehensive summary of information that is known about these features. Published or publicly available data are referenced extensively, and cited in standard USGS format, with the exception that we include a database reference number (e.g., Haller and others, 1993 \#655).

No faults in the CEUS are known to have had surface-rupturing earthquakes in historic time, although the series of major earthquakes that struck the New Madrid seismic zone (fig. 5) in 1811-1812 did produce considerable surface deformation (Russ, 1982). The most prominent expression of this deformation occurred as warping along the Reelfoot scarp, where recent paleoseismic studies have documented multiple deformation events in late Quaternary time.

Structures having pre-Quaternary movement are not included in this compilation unless there is sufficient geological evidence of substantial Quaternary movement. Thus the CEUS faults and liquefaction features included in this report and in the database are defensible potential sources of future ground rupturing or strong shaking based on geologic evidence from the Quaternary period (1.6 million years). The occurrence of seismicity associated with or aligned along preQuaternary faults, buried faults, or folds is not compelling enough evidence (by itself) to include these pre-Quaternary structures in the compilation and database. This database focuses on geological evidence only, so although seismicity is suggestive of Quaternary activity, it does not alone qualify a feature to be included in this geological database.

The digital database contains an extensive listing of information and parameters for each Class A and B structure such as fault length and dip direction, as well as descriptive geologic, geomorphic and paleoseismologic information. Because the project is integrating data from the

\footnotetext{
*Use of trade or brand names, such as Arc/Info, are for descriptive purposes only and do not constitute endorsement by the U.S. Geological Survey or the Department of Interior.
} 

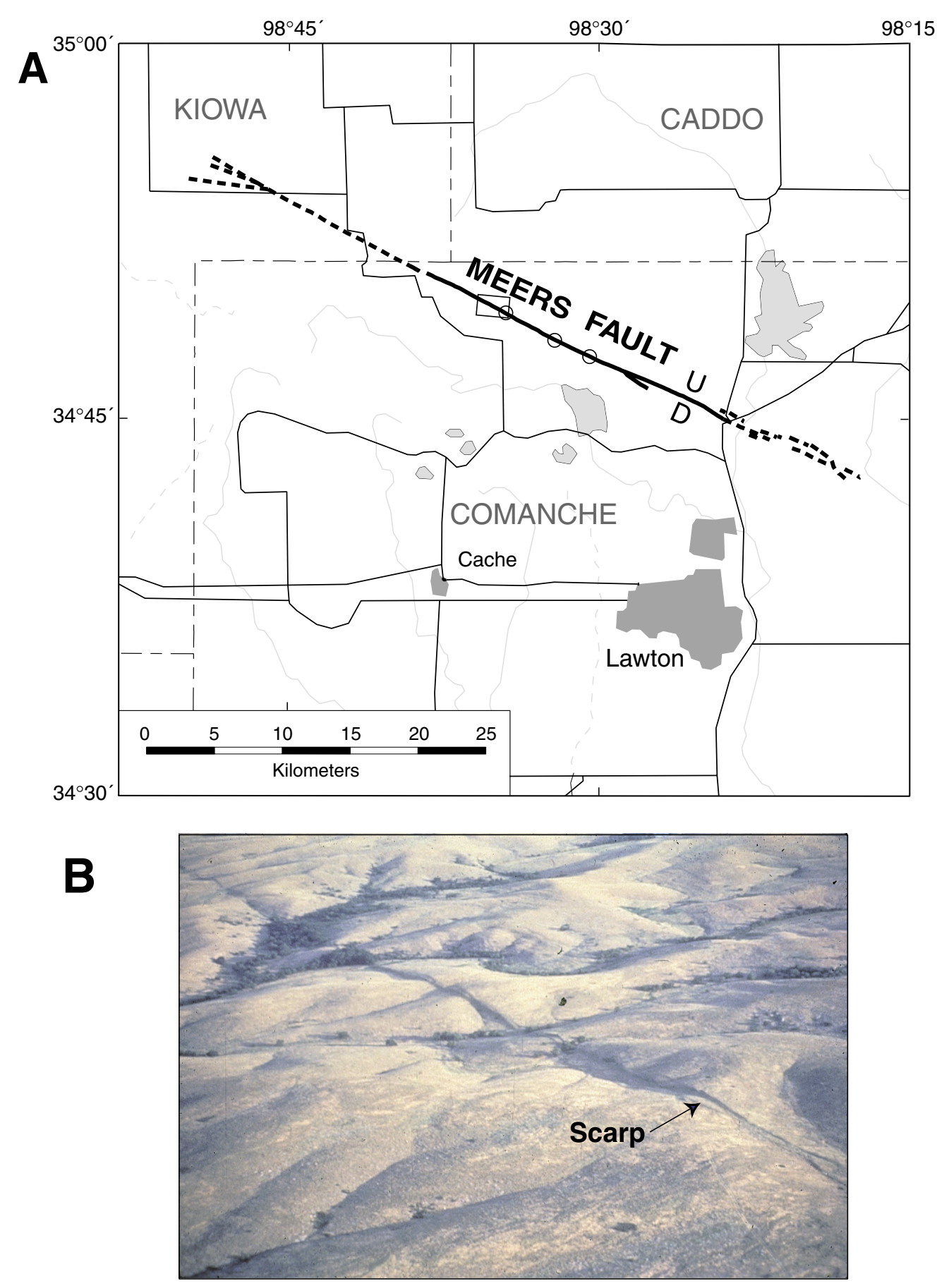

Figure 4. Location map (A) and oblique aerial view (B) of the Meers fault, southeastern Oklahoma. Fault is shown by solid bold line; dashed where scarp is less prominent. Upthrown and downthrown sides of scarp are designated by $U$ and $D$, respectively. Open box shows approximate location of the oblique aerial view shown in (B). Open circles show approximate locations of sites where trenches were excavated. The fault is located in an aseismic part of the Central U.S., but paleoseismic studies have documented two surface-rupturing earthquakes on the Meers fault during the past 3,000 years. The most recent event occurred about 1,200 yr B.P. Aerial photograph provided by Kenneth V. Luza, Oklahoma Geological Suvey. 


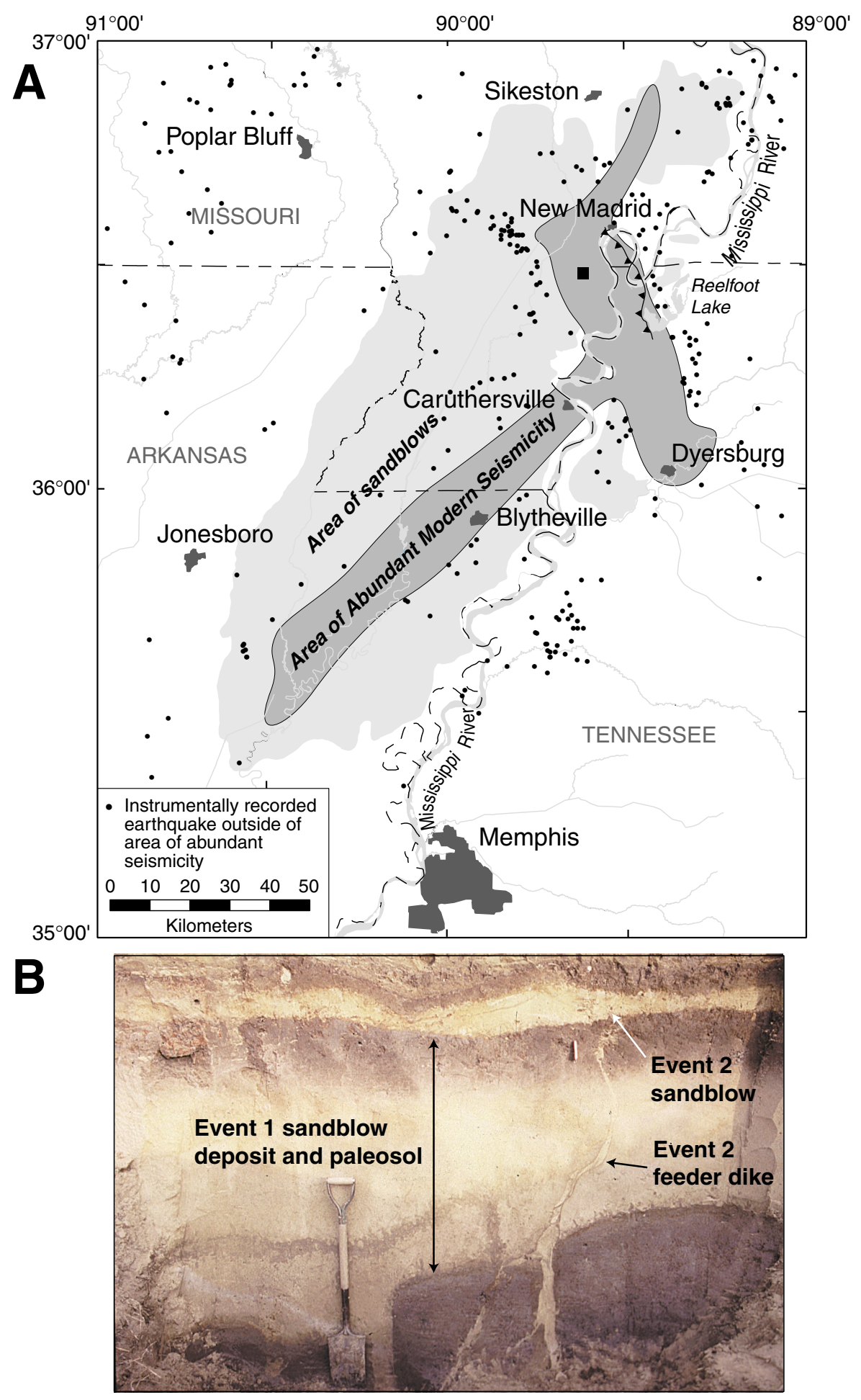

Figure 5. Location map (A) and photograph (B) of liquefaction features in the New Madrid seismic zone, central Mississippi River Valley, Arkansas, Missouri, and Tennessee. A series of magnitude 7-8 earthquakes struck the New Madrid region in the winter of 1811-1812. Reelfoot scarp, shown by solid line with triangles on the upthrown side, is located along the western side of Reelfoot Lake. Paleoseismic studies have documented the occurrence of several Holocene events that produced wide-spread liquefaction. Photograph courtesy of E.S. Schweig, III, USGS. 
entire United States, each Class A and B structure has a unique number. Structure names are determined from the literature and from common usage, and although some structures in different regions have the same name or a similar name, no attempt was made to avoid such duplications. Geologic data fields include narratives describing the geologic setting, geomorphic expression, and age of faulted deposits. Additional paleoseismologic data include descriptions of paleoseismological studies (i.e., trenching) and estimates of recurrence intervals. Field names are shown in bold and are defined below in "Definition of Database Terms" (see also, general guidelines of Haller and others, 1993 \#655). When the computer database of this report is implemented, the user will be able to search for data in a specific field or a combination of fields. Nonsearchable fields, such as "Comments", document the source of data and any pertinent details that the compiler deems worthy to explain further.

We have made an effort to include all pertinent data on a structure, especially where conflicting interpretations may be apparent. Where multiple interpretations exist in the literature, we use a hierarchy that defines what data will be presented in the primary database fields in order to achieve some level of consistency. We give highest priority to fault-related studies, particularly those addressing the Quaternary history of a fault, such as paleoseismic investigations, over general geologic studies, such as, bedrock mapping. In most cases, more recent studies are given priority, although some older studies are helpful and authoritative. Investigations based on detailed mapping (for example, 1:24,000 scale) or similar examinations are given priority over less detailed mapping (for example, 1:250,000 scale) or regional studies. Thus, even though we give the most weight to recent paleoseismological studies of Quaternary faulting, alternative interpretations based on other types of studies are provided in the appropriate "Comments" field.

\section{Synopsis of Quaternary Faulting and Liquefaction Features in the Central and Eastern United States}

The only previous compilations of Quaternary (and Neogene) faults and structures in the CEUS were regional studies by Howard and others (1978 \#312) and Prowell (1983 \#1951) Both compilations were traditional map products that showed the locations and additional information. Since these landmark efforts, additional Quaternary or potentially Quaternary faults have been recognized in the region, and several detailed studies have been conducted to better constrain various paleoseismologic characteristics for selected faults. As mentioned above, detailed studies have also discounted some suggested Quaternary faults, either by showing them to be older than Quaternary or by demonstrating that they are non-tectonic features.

\section{Overview of Quaternary faults and liquefaction features}

In this compilation, we classify 14 features in the CEUS as having demonstrable Quaternary tectonic faulting or deformation (Class A) (fig. 1, table 2). Of these features, five are faults, nine are hidden faults inferred from evidence of Quaternary liquefaction. In addition, we classify 11 features as Class B features, and, we assign a total of 39 other features to Class C because they lack geological evidence of Quaternary tectonic deformation. Lastly, we include six features in Class D because they have been determined not to be tectonic faults.

The 14 Quaternary faults and liquefaction features (or groups of features) in the CEUS are widely distributed across the region (fig. 1). In most cases, the features remained unnoticed for many years or are difficult to study because of their poor surficial expression. The small number of confirmed Quaternary features in such a large part of the country is first-order evi- 
dence of the general tectonic stability of the CEUS. However, based on the relatively recent recognition of Quaternary activity on faults that were initially mapped decades ago, Meers fault (fig. 4) and Cheraw fault (fig. 6), it is probable that our inventory of potential seismic sources in the CEUS is incomplete and other seismogenic features might be identified in the future.

Much of the evidence of paleoearthquakes in the region is derived from evidence of liquefaction, which is secondary evidence of strong ground motion inferred to result from large magnitude earthquakes (Obermeier and Pond, 1999). Local and regional mapping and dating of Quaternary deposits associated with the liquefaction features permit estimates of paleoearthquake magnitudes and ages, but this type of secondary evidence does not identify nor provide detailed information on causative faults. Nevertheless, documenting paleoliquefaction events provides valuable information that contributes to improved seismic-hazard assessments.

It is worth emphasizing that only selected parts of the CEUS have been carefully and systematically examined in the field for evidence of Quaternary faulting. Many parts of the CEUS have never been critically evaluated for field evidence of Quaternary deformation, and therefore, it is very likely that the inventory presented in this report is incomplete. We suspect that a more comprehensive, systematic field examination of the entire CEUS would discover other features that would be classified as Class A or Class B features.

\section{Discussion}

The 13 confirmed Quaternary faults and liquefaction features in the CEUS are widely distributed over an area that covers more than half of the contiguous 48 states. The number of significant historical earthquakes in the CEUS is meager compared to the smaller area west of the Rocky Mountain Front, and no historical CEUS earthquakes have produced documented surface ruptures. The generally low level of seismicity is testimony to the relative stability of the region and the low rates of deformation. Despite the evidence of low deformation rates, this part of the United States is not devoid of seismic hazard nor is it immune to damaging and potentially devastating earthquakes. In fact, moderate-magnitude events (M 4-6) can cause significant damage because many buildings and the infrastructure in the CEUS are relatively old and are not designed to withstand even a modest amount of strong ground motion.

The correlation between the distribution of historical seismicity in the CEUS and the confirmed Quaternary faults and liquefaction features is highly variable (fig. 1). In some cases, such as the New Madrid seismic zone and the Charleston, South Carolina region (fig. 7), the correlation is strong because historical earthquakes have generated many of the geological features described in this report. Elsewhere, the correlation is weak or non-existent. Some confirmed Quaternary faults and liquefaction features are located in areas that are aseismic or where the sparse seismicity is widely distributed. This variable correlation indicates that, in plate-interior settings, the historical seismicity may not identify all of the potential seismic source zones (Crone and others, 1997a).

Recurrence intervals of most features described here are poorly known, but based on evidence from other analogous plate-interior settings, the average recurrence time for significant earthquakes on isolated individual faults could be tens of thousand of years or longer (Crone and others, 1993, 1997a; Machette and others, 1994). Paleoseismic studies of the Meers fault, Oklahoma (Crone and Luza, 1990; fig. 4), and the Cheraw fault, Colorado (Crone and others, 1997b; fig. 6), indicate that surface-rupturing earthquakes on these faults occur in temporal clusters, in which short periods of activity are separated by relatively long quiescent intervals. 

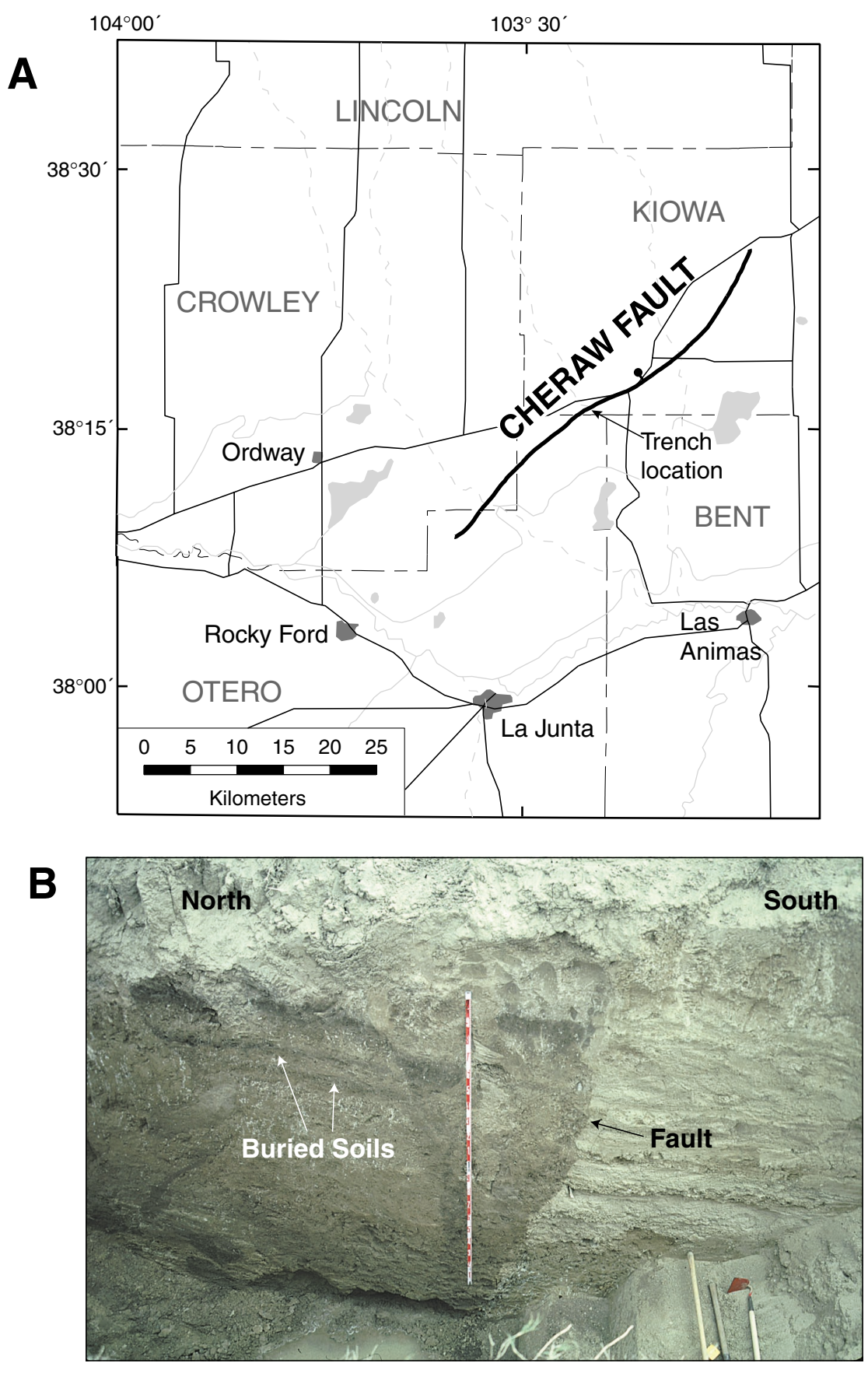

Figure 6. Location map (A) and photograph (B) of Cheraw fault, southeastern Colorado. The combination of little historical seismicity in the region and the subdued expression of the 44-km-long fault scarp suggested that the Cheraw fault did not pose a notable seismic hazard. However, paleoseismic studies show that the most recent surface-faulting event occurred about 8 k.y. ago and that three events have produced surface rupture in the past approximately $25 \mathrm{k} . \mathrm{y}$. 

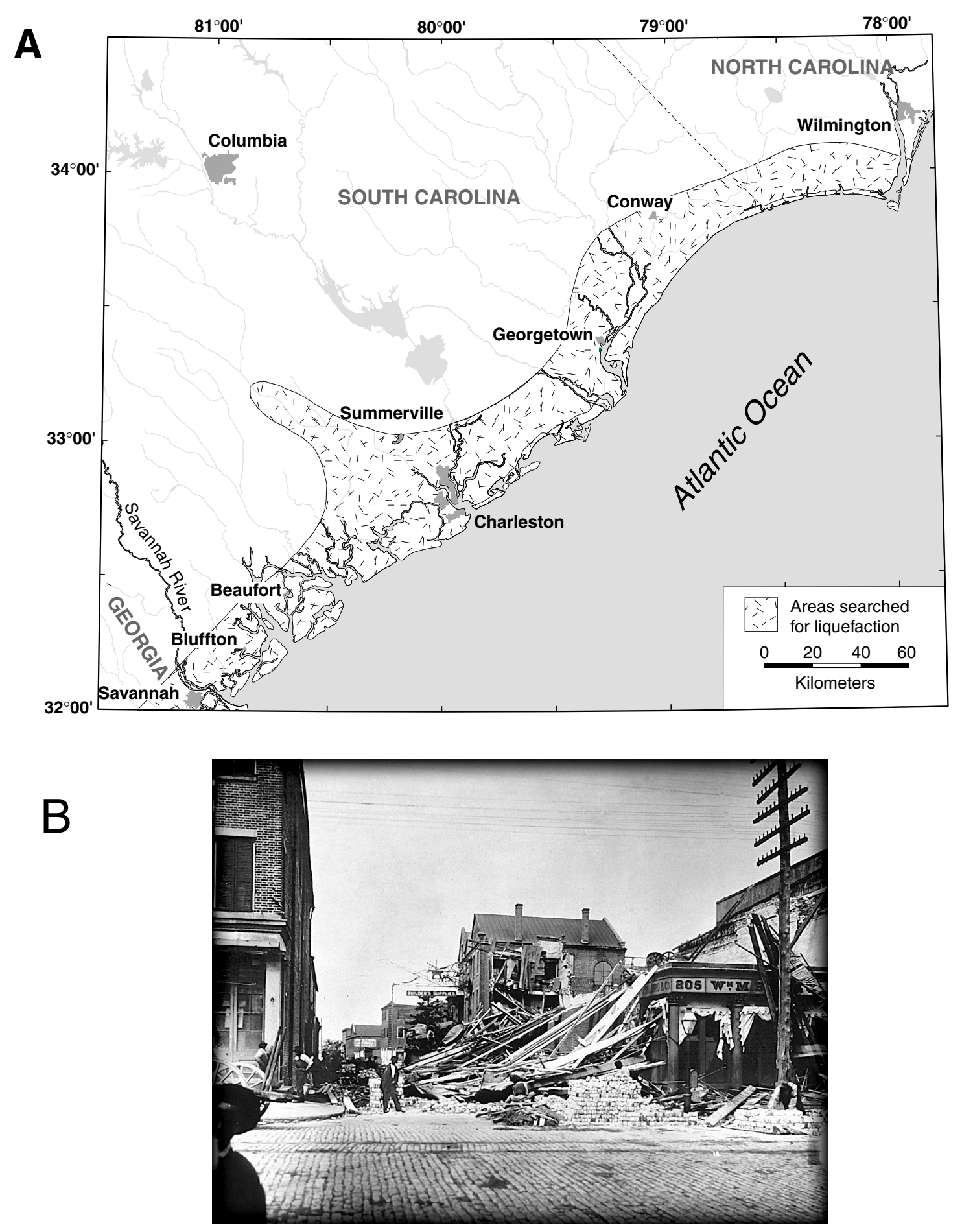

Figure 7. Location map (A) of the Charleston-Georgetown-Bluffton area in South Carolina and photograph (B) of damage from the August 31, 1886, earthquake. The 1886 earthquake produced significant liquefaction. Studies of paleoliquefaction features along the Coastal Plain of South Carolina and North Carolina have found evidence of multiple episodes of strong ground shaking during the past 3,000-5,000 years, but the faults that generated the earthquakes remain unidentified. 
During active periods, the recurrence time between events is on the order of a few to several thousand years, whereas quiescent intervals commonly span several tens of thousands of years or longer. Because of the large variability in inter-event times, it is difficult, and perhaps inappropriate, to characterize these faults by a single recurrence interval.

The New Madrid seismic zone (fig. 4) and Charleston, South Carolina, (fig. 7) region are the most active seismic zones in the CEUS and the sites of the most significant historical earthquakes in the region. In both zones, the geological expression of the seismic activity is best expressed by widespread liquefaction features; little or nothing is known about the causative faults. However, recent and on-going paleoseismic studies of liquefaction features have greatly improved our knowledge of recurrence of large earthquakes in these seismically active regions. These studies suggest that, during the late Holocene, earthquakes large enough to cause liquefaction have occurred in these zones at time intervals of several hundred to a few thousand years (for details, see discussions of these specific features). However, subsurface structural studies show that the rates of late Holocene deformation cannot have been sustained throughout the Quaternary because the underlying bedrock is not extensively deformed (Coppersmith, 1988; Schweig and Ellis, 1994; Pratt, 1994). This contrast between the high rates of modern seismicity versus the geologic evidence of lower, long-term rates indicates that either the deformation has only began in the very recent geologic past, or that the temporal pattern of deformation is very episodic on geological time scales.

We have noted the value of including a list of non-Quaternary or possibly non-tectonic (Class C) and demonstrated non-tectonic (Class D) features in this compilation because their inclusion provides a comprehensive list of all features that we've evaluated to date. An additional benefit is that we provide a brief summary of what is currently known about these features. These summaries could furnish the starting point for future, more comprehensive studies that reexamine these features.

In some cases, reexamination of previously dismissed features has revealed evidence of Quaternary activity. One example is the Meers fault, in southeastern Oklahoma (fig. 4). The Meers fault is one of a series of faults that define the southwestern margin of the Anadarko basin, a major, long-lived petroleum province in Oklahoma. A prominent scarp along the fault is present in resistant Paleozoic bedrock and was originally mapped in the 1930's. The scarp was explained as an exhumed scarp. However, nearly five decades later in the 1980's, the evidence of Quaternary activity became apparent when field geologists first recognized scarps on latest Quaternary fluvial deposits; subsequent paleoseismological studies have documented the occurrence of multiple late Holocene surface ruptures on the fault. This example demonstrates the merit of reevaluating features that are now discounted as potential seismic sources.

\section{Summary}

A systematic evaluation of published information on 69 features in the Central and Eastern U.S. has led to classifying 13 features as Quaternary tectonic faults or liquefaction features (Class A), 11 features as Class B features, and 45 features as either pre-Quaternary or non-tectonic (Class C \& D) features. The information from this evaluation is part of a national compilation of Quaternary faults and folds being led by the USGS. The parameters used to classify features into the above-cited classes are part of the standards for the national compilation. Information for the compilation is being assembled and incorporated into a digital database that will be available on the World Wide Web. 
In the CEUS, few Quaternary faults have conspicuous surface expression, and much of the evidence of Quaternary deformation and earthquakes is derived from historical and ancient liquefaction features. Although valuable as evidence of past strong ground shaking, liquefaction features do not identify a specific causative fault. Without identifying a specific fault, it is difficult to fully characterize the seismic source for hazard analyses. Nevertheless, liquefaction features provide invaluable information about the areas affected by strong ground shaking and the frequency of past earthquakes. In the absence of information about the causative fault, this type of information can contribute to better hazard evaluations.

The correlation between the distribution of historical seismicity in the CEUS and the confirmed Quaternary faults and liquefaction features is highly variable, which substantiates the observation that historical seismicity is an imperfect indicator of potential sources of strong earthquakes in some tectonic settings. Furthermore, geological studies of aseismic faults such as the Meers fault show that currently aseismic faults have generated strong earthquakes in the recent geological past. Thus, a comprehensive inventory of potentially seismogenic structures in the CEUS must be derived from both seismological and geological information.

This compilation provides a starting point for future systematic investigations of potentially seismogenic features in the CEUS. By assembling, summarizing, and classifying information in the published literature on Quaternary tectonic features, we are providing a resource that will permit geoscientists to efficiently review the status of knowledge for specific geological features. We acknowledge that the CEUS has not been systematically or uniformly examined for field evidence of Quaternary faulting, which suggests that evidence of Quaternary deformation on some features may yet remain undiscovered. It follows from this observation that our report is likely incomplete. Nevertheless, this report serves as a starting point to identify selected features that warrant additional detailed study in order to corroborate, better characterize, or refine the evidence of Quaternary deformation. As a result, this report will ultimately contribute to an improved understanding of the seismic hazards in the Central and Eastern United States.

\section{Acknowledgments}

The authors appreciate the support of the National Earthquake Hazards Reduction Program (NEHRP), which has funded the compilation effort and much of the work cited in this report. We thank the numerous colleagues who either reviewed portions of the report or supplied information for the report. In particular, we are grateful to our colleagues who contributed to this compilation by providing descriptions of features that they have studied or for which they have extensive knowledge; they are listed in the List of Contributors. We also thank Michael N. Machette and Kathleen M. Haller for their guidance in how to best resolve compilation problems that were unique to CEUS features and Richard Dart for his assistance in preparing digital location maps for many of the CEUS features. We appreciate the diligent efforts of Ms.

Philadelphia Morrow for entering much of the information into the digital database. The advice and input from many of our colleagues and collaborators in assembling this collection of information was invaluable, but we accept responsibility for errors or omissions. Kathleen Haller carefully reviewed this report and provided numerous helpful comments and recommendations. We have also benefited from comments and recommendations provided by the State Geologists and their staffs from many of the states encompassed in this study area. 


\section{List of Contributing Individuals}

Richard W. Harrison

U.S. Geological Survey

Mail Stop 926A, National Center

12201 Sunrise Valley Drive

Reston, Virginia 20192

phone: (703) 648-6928

e-mail: rharrison@usgs.gov

Paul V. Heinrich

Louisiana Geological Survey

Louisiana State University

P.O. Box G, University Station

Baton Rouge, Louisiana 70893

phone: (504) 388-4398

email: heinrich@intersurf.com

W. John Nelson

Illinois State Geological Survey

615 E. Peabody Drive

Champaign, Illinois 61820

Phone: (214) 244-2428

e-mail: jnelson@isgs.uiuc.edu

Wayne L. Newell

U.S. Geological Survey

12201 Sunrise Valley Drive, MS 926A

Reston, Virginia 20192

phone: (703) 648-6991

email: wnewell@usgs.gov

David C. Prowell

U.S. Geological Survey

3039 Amwiler Rd.

Atlanta, Georgia 30360

phone: (770) 903-9185

email: dprowell@usgs.gov
Stephen F. Obermeier

U.S. Geological Survey

Mail Stop 955, National Center

12201 Sunrise Valley Drive

Reston, Virginia 20192

phone: (703) 648-6791

e-mail: sobermei@usgs.gov

Charles K. Scharnberger

Dept. of Earth Sciences

Millersville University

Millersville, Pennsylvania 17551

phone: (717) 872-3289

email: cscharnb@marauder.millersv.edu

Eugene S. Schweig, III

U.S. Geological Survey \& Center for

Earthquake Research and Information (CERI)

Campus Box 526590

University of Memphis

Memphis, Tennessee 38152-6590

phone: (901) 678-4974

e-mail: schweig@ceri.memphis.edu

Scott D. Stanford

New Jersey Geological Survey

P.O. Box 427

Trenton, New Jersey 08625

phone: (609) 292-1185

email: scotts@njgs.dep.state.nj.us

Martitia P. Tuttle

M. Tuttle and Associates

HC 33, Box 48

Bay Point Road

Georgetown, Maine 04548

phone: (207) 371-2796

email: mptuttle@erols.com 


\section{Definition of Database Field Names and Selected Geological Terms}

Specialized fields (shown below in bold letters) provide abstracted data, many of which will be in searchable fields when the digital database is released. In addition to the searchable fields, more detailed information is provided in the "Comments" sections that follow selected fields. If no pertinent information was found in the published literature for a field, then we show "none" or "not reported". The following description provides definitions of fields (in alphabetical order) and indicates where various information, if known, can be found. In addition, selected definitions of geological terms are included to assist the reader in understanding the guidelines used to compile this report and the database.

Parts of the descriptions in the following definitions are taken from standardized definitions for the entire digital database, and therefore, not all aspects of the definitions may necessarily apply to CEUS features discussed in this report.

Age of faulted deposits This field includes the ages of faulted deposits at the surface. In general, these data are from surficial geologic mapping, but in some cases they may be from descriptions in referenced work. In some cases, the age of faulted deposits may not agree with the time of the most recent paleoevent. This inconsistency may arise because of the manner in which particular studies are given preferable citation based on recency and scope of the study.

Average strike The average strike of the trace of the structure in degrees is computed from GIS software and is recorded for faults and fold axes. The strike bearings are confined to the northwest and northeast quadrants of the compass and are reported as $-90^{\circ}$ to $90^{\circ}$ values, respectively).

Compiler and affiliation The name and affiliation of the person(s) primarily responsible for compilation or revision of data presented for a structure. Full names and addresses of these compilers are shown in the list of contributors.

County If the structure is in more than one county, the county containing the majority of the structure is listed first, followed by county name(s) for the remainder of the structure. In cases where the features encompass numerous counties, the counties are listed alphabetically by state.

Date of compilation This field shows when data were compiled (or revised) for this project (e.g., 03/13/98; month/day/year).

Dip Measured dip or range of dip values. In many cases, these data are near-surface measurements at specific locations. Additional data, such as approximate location and the type of material in which the fault is exposed, are included in "Comments".

Dip direction General down-dip direction(s) of the structure defined by compass octants: north $(\mathrm{N})$, west $(\mathrm{W})$, south $(\mathrm{S})$, east $(\mathrm{E})$, northwest $(\mathrm{NW})$, northeast $(\mathrm{NE})$, southwest $(\mathrm{SW})$, southeast (SE), or vertical (V). If separate faults dip in different directions, multiple directions may be listed.

Fault A fracture or zone of fractures along which there has been differential movement. Three major categories of faults are widely recognized: normal faults, reverse or thrust faults, and strike-slip faults. Descriptions of these fault types are common in the geological literature. 
Footwall The underlying side of a fault beneath an inclined fault plane. That is, the part of the fault you would be standing on if you were in a tunnel that was excavated through a fault.

Geologic setting This description provides a generalized perspective of the fault in terms of its regional geologic setting, amount of total offset, and general age of offset strata.

Geomorphic expression General description of the structure's geomorphic expression including the presence or absence of fault scarps, offset streams, monoclines, shutter ridges, associated landslides, etc.

Hanging wall The overlying side of a fault above an inclined fault plane. That is, the part of the fault you would be over your head if you were in a tunnel that was excavated through a fault.

Historical Surface Faulting This field (and associated fields) describe surface faulting from historical earthquakes. The New Madrid seismic zone in the central Mississippi River Valley is the only location in the CEUS where tectonically induced surface deformation has occurred in historical time.

Holocene The epoch of the Quaternary period that begins at the end of the Pleistocene and extends to the present. The time interval encompassed by the Holocene has been the subject of various definitions. For the purposes of this report, the Holocene is considered to begin about 10,000 years ago.

Length This field specifies two types of length data. The first is the end-to-end length of the Quaternary-age fault or fold axes as measured from the most distal ends of the digital data. In cases where numerous faults are collected under one description, this length is shown as "not applicable". The second type of length is the trace length. This length is the sum of lengths of the actual map traces. Faults or fault zones with multiple (overlapping) strands typically have cumulative trace lengths that exceed the end-to-end length by a factor of 1.5 or more.

Lineament A linear topographic feature or alignment of topography that may be controlled by the underlying crustal structure. Some lineaments are associated with faults.

Name (Structure name or Section name) The earliest referenced name for a fault, fold, liquefaction feature, or fault section (where appropriate) generally is given preference, except in cases where a more commonly accepted name is widely used in the recent literature. "Comments" also contains other names and references in which they are used, the geographic limits of the structure, north to south or west to east, as shown in this compilation; various geographic limits that are different in other studies are also included. Minor changes in original name may have been made for reasons of clarity or consistency where appropriate.

\section{Number}

Structure number The structure (fault, fold, or liquefaction feature) is assigned a number within the predetermined limits for the region. All fault numbers cited in the text are bounded by brackets (i.e., [2015]. References to the same structure shown in other compilations are included in "Comments". Only features assigned to Class A and Class B are assigned structure numbers.; the structure numbers for Class B features are appended with "XX" to easily identify Class B features.

Section number A lower-case alpha character is assigned to the northernmost or westernmost section of a fault (e.g., fault 207 has three sections: 207a, 207b, 207c). 
Number of sections (only used for faults with sections) Numerical value for number of sections (e.g., 4) defined in this compilation. "Comments" include reference in which sections are discussed; if the term "segment" is used in the literature, an explanation of why "section" is used in the database is provided.

Normal fault A fault in which the hanging wall appears to have moved down relative to the footwall. The footwall is the one that you would stand one if the fault plane is exposed.

$1^{\circ} \times 2^{\circ}$ sheet If the structure is mapped in more than one $1^{\circ} \times 2^{\circ}$ quadrangle, the name of the quadrangle in which the majority of the structure is located is listed first, followed by quadrangle name(s) for the remainder of the structure.

Quaternary period The time interval in the Cenozoic era between the Tertiary and the present. It includes the Pleistocene epoch and the Holocene. The time interval encompassed by the Quaternary has been the subject of various definitions. For the purposes of this report, the Quaternary is considered to begin about 1.6 million years ago (Ma).

Paleoseismological Studies This field includes a synopsis of detailed site-specific studies, typically those involving exploratory trenching. Sites of morphologic studies or detailed mapping (without trenching) are not described herein. Study sites are numbered sequentially from north to south or west to east in the format of fault number, section letter, and site number (e.g., 601c-3)

Pleistocene The epoch in the Quaternary period that preceded the Holocene. For the purposes of this compilation, the Quaternary period is considered to begin about 1.6 million years ago and end at the beginning of the Holocene epoch, about 10,000 years ago.

Province Field contains physiographic province names defined by Fenneman and Johnson (1946 \#461).

Recurrence interval Time interval in years (based on historical data, calendric or calibrated radiocarbon dates), in ${ }^{14} \mathrm{C}$ yr (based on uncalibrated radiocarbon dates), in k.y. (kiloyears) (based on less precise dating methods, stratigraphy, or geomorphology), or not reported. Also includes the time interval (in parentheses) for which this recurrence interval is valid. (e.g., 10-130 k.y.) Alternative published recurrence intervals, starting with that which applies to the most recent time interval, are included in "Comments".

References Complete bibliographic citations for all references are included for each structure, and collectively for all structures in the cumulative reference list. In-text citations of references are presented in a standard USGS format with the exception of the addition of a reference-specific number at the end. This reference number eliminates the need for the traditional alpha character for authors having multiple publications in the same year (e.g., 1988a, b).

Reliability of location Reliability of location (Good or Poor) is related to the scale of the source map for the trace of the structure and to the method by which the trace of the structure was mapped. To qualify for a "Good" location, the trace of the structure must have been published on a topographic base map at a scale of 1:250,000 or more detailed and have been accurately located on the original map using photogrammetry or similar methods, or the trace of the structure was published on a topographic base map at a scale of 1:100,000 or more detailed, but transferred without photogrammetric methods. Traces that do not 
meet the above standards (less detailed scale, planimetric base, transfer by inspection, etc.) constitute a "Poor" location. Judgments of reliability may not directly relate to line symbols (solid, dashed, dotted) that are used; however, all concealed or inferred faults are considered poorly located.

Reverse fault A fault in which the hanging wall appears to have moved up relative to the footwall. The footwall is the one that you would stand one if the fault plane is exposed.

Section name (see Name)

\section{Section number (see Number)}

Sense of movement Includes thrust faulting (motion on a fault having a dip of less than $45^{\circ}$ dip); reverse faulting, (on a fault having a dip greater than $45^{\circ}$ dip); dextral slip (right lateral); sinistral slip (left lateral); or normal slip. For oblique slip, principle sense of movement is followed by secondary sense (e.g., dextral $>$ normal). Ratios of the slip components are included, where known, in order to better characterize sense of movement (e.g., dextral/normal 3:1).

Slip-rate category The primary field shows one of four slip-rate categories: less than $0.2 \mathrm{~mm} / \mathrm{yr}, 0.2$ to less than $1 \mathrm{~mm} / \mathrm{yr}, 1$ to $5 \mathrm{~mm} / \mathrm{yr}$, greater than $5 \mathrm{~mm} / \mathrm{yr}$. In the CEUS, the only rates that apply are the less than $0.2 \mathrm{~mm} / \mathrm{yr}$ and 0.2 to less than $1 \mathrm{~mm} / \mathrm{yr}$ categories. "Unknown" precedes the most likely slip-rate category if no published slip rate is known. "Comments" include a brief description of published slip rates and pertinent documentation. Generally, two types of slip rates are reported. The first type is termed a "geologic slip rate" and is typically derived from the age and amount of offset of surficial geologic deposits. These rates are not precise, but do place broad limits on possible slip rates, and hence characterize the fault in one of the above-mentioned categories. The second type of slip rate is termed a "paleoseismic slip rate" and is derived from times of faulting events and amounts of offset of geologic datums or piercing points. This type of slip rate is more precise, but is rare owing to the need for detailed studies of the fault (i.e., paleoseismologic investigations involving trenching and numeric dating). For structures in the CEUS, information on slip rates is rare because few discrete faults are known, and there is limited information on those faults. Furthermore, the temporal clustering of surface-rupturing events on these faults makes it difficult to define a single slip-rate value.

State If the structure is located in more than one state, then the state in which the majority of the structure is located is listed first, followed by state name(s) for the remainder of the structure.

Strike-slip fault A fault in which the dominant sense of motion on the fault is parallel to the fault's trace along the ground surface. Also known as a lateral-slip fault. Motion is commonly described as left-lateral (sinistral) or right-lateral (dextral) strike slip.

\section{Structure name (see Name)}

\section{Structure number (see Number)}

Synopsis This field contains a short summary of information on the structure that follows in the database. 
Tertiary period The first period in the Cenozoic era of the geological time scale. The Tertiary era begins at the end of the Cretaceous period (about 65 million years ago) and ends at the beginning of the Quaternary period (about 1.5-2 million years ago).

Time of most prehistoric faulting (faulting, folding, or liquefaction event) The primary field shows one of the four prehistoric time categories: latest Quaternary (Holocene and latest Pleistocene, $<15 \mathrm{ka}$ ), late Quaternary (Holocene and late Pleistocene, $<130 \mathrm{ka}$ ), middle and late Quaternary $(<750 \mathrm{ka})$, or Quaternary $(<1.6 \mathrm{Ma})$. This field only documents prehistoric surface faulting. If there is historical surface faulting or folding, it would be documented under "Historical Surface Faulting".

\section{References Cited in Introduction}

Coppersmith, K.J., 1988, Temporal and spatial clustering of earthquake activity in the Central and Eastern United States: Seismological Research Letters, v. 59, no. 4, p. 299-304.

Crone, A.J., and Luza, K.V., 1990, Style and timing of Holocene surface faulting on the Meers fault, southwestern Oklahoma: Geological Society of America Bulletin, v. 102, p. 117.

Crone, A.J., Machette, M.N., and Bowman, J.R., 1993, Geologic investigations of the 1988 Tennant Creek, Australia, earthquakes-Implications for paleoseismicity in stable continental regions: U.S. Geological Survey Bulletin, 2032-A. 51p.

Crone, A.J., Machette, M.N., and Bowman, J.R., 1997a, Episodic nature of earthquake activity in stable continental regions revealed by palaeoseismicity studies of Australian and North American Quaternary faults: Australian Journal of Earth Science, v. 44, no., 2, p. 203-214.

Crone, A.J., Machette, M.N., Bradley, L.-A., and Mahan, S.A., 1997b, Late Quaternary surface faulting on the Cheraw fault, southeastern Colorado: U.S. Geological Survey Geologic Investigations Map I-2591, 1 oversize pl., 7 p. pamphlet.

dePolo, C.M., Clark, D.G., Slemmons, D.B., Ramelli, A.R., 1991, Historical surface faulting in the Basin and Range province, western North America-implications for fault segmentation: Journal of Structural Geology, v. 13, no. 2, p. 123-136.

Fenneman, N.M., and Johnson, D.W., 1946, Physical divisions of the United States: U.S. Geological Survey, scale 1:7,000,000.

Haller, K.M., Machette, M.N., and Dart, R.L., 1993, Maps of major active faults, western hemisphere, International Lithosphere program (ILP) project II-2, Guidelines for U.S. database and map, June 1993: U.S. Geological Survey Open-File Report 93-338, 45 p.

Howard, K.A., Aaron, J. M., and 11 others, 1978, Preliminary map of young faults in the United States as a guide to possible fault activity: U.S. Geological Survey Miscellaneous Field Investigations Map MF-916, scales 1:5,000,000 and 1:7,500,000, 2 oversize sheets.

Machette, M.N., Personius, S.F., Kelson, K.I., Haller, K.M., and Dart, R.L., 1998, Map and database of Quaternary faults and folds in New Mexico: U.S. Geological Survey Open-File Report 98-521, 443 p., 1 plate (1:750,000 scale). 
Machette, M.N., Crone, A.J., and Bowman, J.R., 1994, Geologic investigations of the 1986 Marryat Creek, Australia, earthquake-Implications for paleoseismicity in stable continental regions: U.S. Geological Survey Bulletin, 2032-B. 29p.

Obermeier, S.F. and Pond, E.C., 1999, Issues in using liquefaction features for paleoseismic analysis: Seismological Research Letters, v. 70, p. 34-58.

Pratt, T.L., 1994, How old is the New Madrid seismic zone?: Seismological Research Letters, v. 65 , no. 2., p. $172-179$.

Prowell, D.C., 1983, Index of faults of Cretaceous and Cenozoic age in the Eastern United States: U.S. Geological Survey Miscellaneous Field Studies Map MF-1269, scale $1: 2,500,000,2$ oversize sheets.

Russ, D.P., 1982, Style and significance of surface deformation in the vicinity of New Madrid, Missouri: U.S. Geological Survey Professional Paper 1236-H, p. 95-114.

Schweig, E.S., and Ellis, M.A., 1994, Reconciling short recurrence intervals with minor deformation in the New Madrid seismic zone: Science, v. 264 , p. 1308-1311.

Wheeler, R.L., and Frankel, A., Geology in the 1996 USGS seismic-hazard maps, Central and Eastern United States: Seismological Research Letters, v. 71, no. 2, p. 273-282.

Widmann, B.L., Kirkham, R.M., and Rogers, W.P., 1998, Preliminary Quaternary fault and fold map and database of Colorado: Colorado Geological Survey Open-File Report 98-8, 331p., 1 plate, scale 1:500,000. 


\section{Fault and Liquefaction Features Database}

The following discussion of Quaternary faults and folds in the Central and Eastern United States east of the Rocky Mountain Front are presented in ascending numerical order by the structure's number and alphabetically for unnumbered features. 


\section{0, Meers fault (Class A)}

Structure Number 1020

Structure Name Meers fault (Class A)

Comments: Originally named the "Thomas fault" by Harlton (1951 \#670). It was renamed the Meers Valley fault on the 1954 version of the Oklahoma Geologic map (Harlton, 1963 \#667), but subsequent common usage has shortened the name to the Meers fault. The sections of the fault discussed here extend from near Sugar Creek on the northwest to near Beef Creek (tributary of East Cache Creek) on the southeast.

Synopsis: Fault originally mapped in about the late 1930's, and scarp was considered to be an erosionally exhumed fault-line scarp. The scarp, formed on late Quaternary deposits, was first recognized by M. Charles Gilbert in the early 1980's during field studies of the igneous rocks exposed in the nearby Wichita Mountains. Paleoseismic studies of the fault indicate a temporal clustering of events in the late Quaternary. These studies have established the occurrence of two well-dated, late Holocene events, and a preceding event that occurred middle Pleistocene time or earlier.

Date of compilation $03 / 03 / 94$

Compiler and affiliation Anthony J. Crone, U.S. Geological Survey

State Oklahoma

County Comanche; Kiowa

$1^{\circ} \times 2^{\circ}$ sheet Lawton

Province Central Lowland

Geologic setting The fault is one of at least four west- to northwest-trending faults that form the Frontal Wichita fault system (Harlton, 1951 \#670; 1963 \#667; 1972 \#666), which is the boundary between the Paleozoic sedimentary rocks in the Anadarko basin to the northeast and the Cambrian intrusive and extrusive igneous rocks that comprise the Wichita Mountains to the southwest. Faults in the frontal fault system have a cumulative down-to-the-northeast throw of as much as $10 \mathrm{~km}$. In contrast, the Quaternary scarp indicates a down-to-the-southwest sense of throw on the fault. Uncertain amounts of lateral slip have probably occurred on many faults in the frontal fault system; estimates range from a few kilometers to as much as $120 \mathrm{~km}$. The location and trend of the fault system were probably controlled by zones of crustal weakness that developed during formation of the Southern Oklahoma aulacogen in latest Precambrian to Early Cambrian time.

\section{Number of sections 2}

Comments: The two sections described here are based on the distinctly different surficial expression of the fault along each section. A conspicuous, continuous Holocene scarp is present along a 26-km-long section of the fault, but low-sun angle photography suggests that the Holocene rupture along this section may be as much as $37 \mathrm{~km}$ long (Ramelli and others, 1987 \#668; Ramelli and Slemmons, 1990 \#665). This 26- or possibly 37-km-long section is considered as section " $\mathrm{b}$ " in this compilation. A poorly studied section is located northwest of 
section "b", and is referred to as section "a" in this compilation. Knowledge and information on this northwesterly section based solely on work by Cetin (1990 \#658; 1992 \#674). The actual length and details of the subsurface extent of the Meers fault are not well known, but subsurface (Harlton, 1951 \#670; 1963 \#667) and magnetic (Jones-Cecil and Crone, 1989 \#663; Jones-Cecil, in press \#673) data show that the fault extends for tens of kilometers to the northwest and southeast of the Quaternary scarp (section b). Other sections of the fault may exist at depth that are not expressed in Quaternary deposits.

Length End to end $(\mathrm{km})$ : $\quad 54.16$

Cumulative trace $(\mathrm{km}): \quad 72.85$

Comments: This end-to-end length includes the poorly known and poorly mapped northwestern section of the fault. Cumulative length is the collective length of all strands.

Average strike $-26.1^{\circ}$

\section{0a, Unnamed (northwest) section}

\section{Section number $1020 \mathrm{a}$}

Section name Unnamed (northwest) section

Comments: Cetin (1990 \#658; 1992 \#674) discusses this section of the fault, but does not give it a name. This section is confined to Kiowa County and extends from near Sugar Creek on the northwest to the Comanche County line on the southeast.

\section{Quality of location Poor}

Comments: Location based on 1:100,000-scale sketch map in Cetin (1992 \#674). Cetin (1990 \#658) contends that evidence exists that indicates Holocene surface deformation extends about $30 \mathrm{~km}$ northwest of the northwestern end of the continuous scarp (1020b).

Sense of movement Sinistral reverse

Comments: Exposures in stream cuts reveal down-to-the-southwest vertical offset. Lateral slip is inferred to be the same as that for the adjacent section of the fault to the southeast (1020b).

\section{Dip $30-40^{\circ}$}

Comments: Drill-hole and seismic-reflection data indicate that the faults in the frontal fault system dip at moderate angles (approximately $30-40^{\circ}$ ) to the southwest at depth. The assigned dip value assumes that this section of the fault has a dip at depth that is similar to other major faults in the frontal fault system. In the exposures discussed by Cetin (1992 \#674), the fault's dip is probably near vertical based on his schematic maps, which show steep dips ranging from about $80^{\circ} \mathrm{NE}$ to about $60^{\circ} \mathrm{SW}$.

\section{Main dip direction $\mathrm{SW}$}

Geomorphic expression none

Age of faulted deposits at the surface late Holocene?? (Cetin, 1990 \#658). 
Paleoseismological studies Cetin (1992 \#674) examined natural exposures along the banks of Saddle Mountain Creek, Longhorn Mountain Creek, and Sugar Creek and their tributaries for evidence of deformation and possible faulting. He mapped seven exposures in detail, but in the 1992 report, he only discussed three exposures, all of which are in Kiowa County: 1) a site on a branch of Saddle Mountain Creek (NE, SW, Sec. 30, T. 5 N., R. 14 W.), 2) on Longhorn Creek (NW, NE, Sec. 23, T. 5 N., R. 14 W.), and 3) on Sugar Creek (SW, NW, Sec 16, T. 5 N., R. 14 W.). At these sites he reports folding in Paleozoic rocks that are commonly undeformed elsewhere, cracks in the rocks that are filled with Quaternary sediments, and overthickened A horizons on the downthrown side of the fault.

Timing of most recent paleoevent latest Quaternary $(<15 \mathrm{ka})$

Comments: The only studies of this section of the fault are those of Cetin (1990 \#658; 1992 \#674) in which he cites buried organic soil horizons, displaced terrace deposits, deflected stream alignments, and buried fragments of soil A horizons in colluvium on the downthrown side of the fault as evidence of Holocene fault movement in this area. He indicates that the faulting is late Holocene in age because of radiocarbon ages of $1090 \mathrm{yr}$ B.P. and $706 \mathrm{yr}$ B.P. (apparently uncalibrated ages) on soil organics in stream exposures. It is difficult to confidently determine the stratigraphic relations between the dated samples and the inferred faulting. The absence of a conspicuous scarp along this section of the fault seems to be contrary to the inference of late Holocene faulting. Without further study, the evidence of late Holocene rupture on this section is suspect because relations between dated samples and stratigraphic units that are inferred to indicate faulting are unclear.

\section{Recurrence interval Not reported}

Slip-rate category unknown; probably $<0.2 \mathrm{~mm} / \mathrm{yr}$

Comments: Little is known about the surface-faulting events on this section, but long-term slip rate is probably much less that $1 \mathrm{~mm} / \mathrm{yr}$ due to poor surface expression of fault. The subdued geomorphic expression of the fault along this section argues that the late Quaternary slip rate on this section is lower than the rate on the southeastern section (1020b).

Length $(\mathrm{km})$ End to end: 18.35

Cumulative: 27.74

Comment: This section is poorly studied and poorly mapped, so the significance of these length values is uncertain.

Average strike (azimuth) $-23.3^{\circ}$

\section{0b, Unnamed (southeast) section}

\section{Section number $1020 \mathrm{~b}$}

Section name Unnamed (southeast) section

Comments: Fault has not been formally divided into sections or segments, although, as described above, only part of the entire fault has a Quaternary scarp. Therefore, in most discussions of the region's Quaternary tectonics, the "Meers fault" usually refers to this section 
of the fault that has a Quaternary scarp, in contrast to the subsurface Meers fault which is much longer than the fault scarp. The part of the fault discussed in this section extends from the northern boundary of Comanche County southeastward to near Beef Creek, which is a tributary of East Cache Creek.

\section{Quality of location Good}

Comments: The northwestern 26-km-long part of this section from the northern boundary of Comanche County to about $1.5 \mathrm{~km}$ southwest of Richards Spur has a prominent scarp that is very obvious, especially on low-sun-angle photography (Ramelli and others, 1987 \#668). Southeastward from the Richards Spur area, discontinuous, more subtle scarps increase the total length of this section to $37 \mathrm{~km}$ (Ramelli and Slemmons, 1990 \#665); these subtle scarps have not been carefully checked in the field because they are in an artillery range of the U.S. Army Fort Sill. The location of the 26-km-long section is based on A.J. Crone's mapping of the scarp using 1: 18,000-scale aerial photographs and transferring its location to 1:50,000scale topographic maps. The location of the subtle scarps is based on a 1:160,000-scale map shown as figure 5 of Ramelli and others (1987 \#668).

\section{Sense of movement: Sinistral reverse}

Comments: Estimates of the ratio of sinistral to vertical displacement vary from approximately 1.3:1 (Kelson and Swan, 1990 \#659) to >5:1 (Crone and Luza, 1990 \#661). A ratio of $2: 1$ is probably a good general estimate. Reverse sense of movement is based on northeasterly dip in shallow subsurface, however, at depth, the fault probably dips to the southwest. The very linear trace of the fault suggests that it has a near-vertical dip in the shallow subsurface.

\section{Dip $40^{\circ} \mathrm{SW}-76^{\circ} \mathrm{NE}$}

Comments: Drill-hole and seismic-reflection data indicate that the major faults in the frontal fault system dip at moderate angles to the southwest. At depth, the Meers fault has a moderate dip (about $40^{\circ}$ ) to southwest (McConnell, 1989 \#660)). In the shallow subsurface, nearvertical to northeasterly dips are common (Crone and Luza, 1990 \#661; Miller and others, 1990 \#664). The northeasterly to vertical dips in the shallow subsurface may be the result of steepening and refraction of fault as it approaches the surface.

\section{Main dip direction SW}

Geomorphic expression This section has a prominent, continuous, linear scarp for $26 \mathrm{~km}$ and to the southeast, an additional $9 \mathrm{~km}$ of subtle, discontinuous, arcuate scarps. The linear part of the scarp strikes N. $60^{\circ} \mathrm{W}$. The scarp is formed on two lithologically different Permianage rock types. The northwestern part of the scarp is formed on the Post Oak Conglomerate, which is a well-indurated, resistant limestone-pebble conglomerate in a calcareous matrix. Eastward from about $2 \mathrm{~km}$ west of Canyon Creek, the scarp is formed on the Hennessey Shale, which is much less resistant to erosion. In the Post Oak terrain, the scarp is very prominent and sharp, whereas in the Hennessey terrain, it is more subdued but still obvious on conventional and low-sun-angle aerial photography and on the ground. The 9-km-long subtle scarps at the eastern end of this section are not obvious on conventional aerial photography; their existence was recognized from low-sun-angle photography (Ramelli and others, 1987 \#668). 
Age of faulted deposits at the surface late Holocene (Luza and others, 1987 \#544; 1987 \#669; Ramelli and others, 1987 \#668; Madole, 1988 \#662; Crone and Luza, 1990 \#661; Kelson and Swan, 1990 \#659; Swan and others, written commun. 1993 \#675).

Paleoseismological studies Detailed studies have been conducted at 5 locations along this section. Starting from the northwest, site 1020b-1 is named the "Valley site" of Kelson and Swan (1990 \#659) and Swan and others (written commun. 1993 \#675) where a 1.5-m-high scarp is formed on Holocene alluvium. The vertical displacement from brittle deformation at this site is estimated to be about $1.8 \mathrm{~m}$, and the total vertical deformation from both faulting and folding is estimated to be about $3.6 \mathrm{~m}$. Their best estimate of sinistral displacement is about 9 m. A 21-m-long trench at this site exposed stratigraphic evidence of two late Holocene faulting events; the age of the older event is bracketed between 2000 and 2900 years ago, and the younger event occurred 800-1600 years ago.

At site 1020b-2 "Northwestern Ponded Alluvium" site of Kelson and Swan (1990 \#659) and Swan and others (written commun. 1993 \#675), a small northeastward-flowing drainage has deposited alluvium against an uphill-facing scarp. A network of 7 trenches at this site indicate about $1.8 \mathrm{~m}$ of vertical and $3.1 \mathrm{~m}$ of sinistral displacement in a channel thalweg. The trenches exposed two fault-related colluvial wedges; radiocarbon dating of stratigraphic units in the trenches indicates that the older event occurred sometime before 1700 years ago and the younger event probably occurred about 1050 years ago.

Site 1020b-3 corresponds to the "Ponded Alluvium" sites of Crone and Luza (1990 \#661) and the "Southeastern Ponded-Alluvium" site of Kelson and Swan (1990 \#659) and Swan and others (written commun. 1993 \#675). Here, Holocene movement on the fault has created a 1.1-m-high, uphill-facing scarp on Post Oak Conglomerate that has disrupted the gradient of several small drainages and ponded alluvium against the scarp. Crone and Luza (1990 \#661), Kelson and Swan (1990 \#659) and Swan and others (written commun. 1993 \#675) excavated a network of trenches parallel to and across the scarp. Studies of these trenches yield estimates of vertical displacement that range from $0.7 \mathrm{~m}$ to $2.7 \mathrm{~m}$ and estimates of sinistral displacement that range from 3.4 to $5.0 \mathrm{~m}$. Scarp-derived colluvial wedges indicate two late Holocene faulting events. The older event preceded deposition of a colluvial-wedge deposit that yielded a radiocarbon age of $3400 \mathrm{yr}$ B.P. The most recent event immediately preceded deposition of a younger colluvial wedge that yielded a radiocarbon age of $1050 \mathrm{yr}$ B.P.

Site 1020b-4 is the "Canyon Creek" site of Luza and others (1987 \#544), Luza and others (1987 \#669), Crone and Luza (1990 \#661), Kelson and Swan (1990 \#659) and Swan and others (written commun. 1993 \#675). Two trenches at this site were excavated in Hennessey Shale and Quaternary alluvium. The trenches did not find convincing stratigraphic evidence of multiple Holocene faulting events; the absence of this evidence may be related to the abundant ductile deformation in the shale, which minimized the likelihood of a surface-rupturing earthquake forming a scarp with a discrete free face. Without a free face, faulting-related colluvial wedges never formed to leave a record of multiple rupturing events. Based on the similar size of the scarp here with the measured vertical offsets at sites in the Post Oak Conglomerate terrain (sites 1020b-1, 1020b-2, 1020b-3), the two Holocene events recorded elsewhere along this section likely ruptured the fault at this site. These trenches did yield an estimate of 1100-1300 yr B.P for the age of the most recent event. At this site, scarp profiles 
on Holocene deposits and on middle(?) Pleistocene deposits indicate a similar amount of vertical displacement (5.1-5.4 m) (Kelson and Swan (1990 \#659) and Swan and others, (written commun. 1993 \#675) on both deposits. These data suggest that, prior to the two late Holocene events, no surface ruptures had occurred extending back to at least middle Pleistocene time.

Site 1020b-5 is the "Browns Creek" site of Madole (1988 \#662). Natural exposures along the creek reveal fault-related fan alluvium that is at least $1.4 \mathrm{~m}$ thick adjacent to the fault. Radiocarbon dating brackets the age of the fan alluvium to be less that 1,360 \pm 100 years old and greater than $470 \pm 150$ years old.

Timing of most recent paleoevent latest Quaternary (<15 ka)

Comments: Two late Holocene events are documented--one between 1,100-1,300 yrs ago (Luza and others, 1987 \#669; Luza and others, 1987 \#544; Madole, 1988 \#662; Crone and Luza, 1990 \#661; Kelson and Swan, 1990 \#659), and a preceding event between 2,000-2,900 yrs ago (Kelson and Swan, 1990 \#659; Swan and others, written commun. 1993 \#675). The discontinuous scarps east of the prominent linear scarp are unstudied but are presumed to be Holocene in age.

Recurrence interval $0.6-1.7$ k.y. $(<2.9 \mathrm{ka})$

Comments: The recurrence interval is based on timing of the two documented Holocene events. However, it is difficult to assign a conventional recurrence interval because the available data suggests temporal clustering of events. Stratigraphic evidence of pre-Holocene faulting events is lacking. Topographic profiles of scarps formed on Pleistocene deposits show that the Pleistocene deposits are vertically offset about the same amount as the Holocene deposits (Crone and Luza, 1990 \#661; Kelson and Swan, 1990 \#659). Based on the degree of soil development on these deposits, they are thought to be middle Pleistocene in age (on the order of 130-790 ka) (Madole, 1988 \#662). These relations indicate that the middle Pleistocene deposits have only been deformed by the late Holocene events. Therefore, prior to the two late Holocene events, no surface faulting events have occurred for $100 \mathrm{k} . \mathrm{y}$. or more.

Slip-rate category unknown; probably $0.2 \mathrm{~mm} / \mathrm{yr}$

Comments: There are no known published slip rates for this section of the Meers fault, probably because slip rate is difficult to determine because geologic evidence indicates temporal clustering of events - the two late Holocene events occurred about 700-1,800 years apart and any older events are more than about $130 \mathrm{ky}$. The only geologic constraints on the time of the surface deformation that preceded these two Holocene events is that it occurred more than 100 k.y. earlier and possibly many hundreds of thousands of years earlier.

Based on the time interval between the two late Holocene events, the late Holocene slip rate would be about $0.9-4.9 \mathrm{~mm} / \mathrm{yr}$, but these must be viewed as a maximum values. The time between the late Holocene events is 700-1,800 years based on the estimated ages of these events (1,100-1,300 and 2,000-2,900 yrs ago, respectively). The only slip-per-event data available are the Holocene events are based on measuring the total slip for the two late Holocene events and dividing the value by 2, which yields slip-per-event estimates as small as $1.6 \mathrm{~m}$ and as large as $3.4 \mathrm{~m}$ (Kelson and Swan, 1990 \#659; Swan and others, written commun. 1993 \#675). The 3.4-m-per-event value was determined at site 1020b-4 where only the ver- 
tical component of slip was measured. These ranges of inter-event times and slip-per-event yield a short-term Holocene slip rate of $0.9-4.9 \mathrm{~mm} / \mathrm{yr}(1.6 \mathrm{~m}$ in $1,800 \mathrm{yr}$ and $3.4 \mathrm{~m}$ in 700 $\mathrm{yr}$ ); however, the values probably have very large uncertainties.

Geological evidence indicates that the short-term, Holocene slip rate is anomalously high compared to the fault's long-term behavior. The cumulative net slip in Quaternary deposits is on the order of 3.9-5.9 m (Kelson and Swan, 1990 \#659; Swan and others, written commun. 1993 \#675). If these total slip values are divided by 100,000 years (the minimum estimated age of the Quaternary deposits), then the maximum long-term slip rates are 0.039-0.059 $\mathrm{mm} / \mathrm{yr}$. If the Quaternary deposits are actually older, then the calculated slip rates decrease accordingly.

The measurements of lateral and vertical displacement along the fault presented by Ramelli and others (1987 \#668) and Ramelli and Slemmons (1990 \#665) permit another estimate of a long-term slip rate. These authors note a location near the center of the scarp where the lateral slip may be about $20 \mathrm{~m}$, and the scarp is slightly less than $5 \mathrm{~m}$ high. These values suggest a net slip of about $20.6 \mathrm{~m}$. The age of the scarp at this location is unknown, but it is formed in the highly resistant Post Oak Conglomerate. Thus, the scarp could be hundreds of thousands of years old. If we use a conservative estimate of 200,000 years for the age of the scarp in resistant bedrock, then the long-term slip rate is $0.1 \mathrm{~mm} / \mathrm{yr}$; if the bedrock scarp is 500,000 years old, then the slip rate is $0.04 \mathrm{~mm} / \mathrm{yr}$. The conclusion is clear- - the long-term slip rate for this section of the Meers fault is very likely a small fraction of a millimeter per year, and the short-term rate, which is computed using the time interval between the two late Holocene events, indicates an anomalously high rate of fault slip. Thus we assign the Meers fault of a slip-rate category of less than $0.2 \mathrm{~mm} / \mathrm{yr}$ because this value probably reflects the long-term rate of displacements on the fault

Length (km) End to end: 35.31

Cumulative: 45.11

Comment: This section is relatively well studied and mapped using low-sun-angle air photography.

Average strike (azimuth) $-27.8^{\circ}$

Endpoints (lat.-long.) $34^{\circ} 50^{\prime} 50.83^{\prime \prime} \mathrm{N}$; $98^{\circ} 38^{\prime} 20.74^{\prime \prime} \mathrm{W}$

$34^{\circ} 42^{\prime} 41.68^{\prime \prime} \mathrm{N} ; 98^{\circ} 17^{\prime} 24.07^{\prime \prime} \mathrm{W}$

\section{References}

\#658 Cetin, H., 1990, The northwest continuation of the Meers fault and its tectonic activity in southwestern Oklahoma: Geological Society of America Abstracts with Programs, v. 22, p. 3.

\#674 Cetin, H., 1992, The northwest extension of the Meers fault in southwestern Oklahoma, in Sharma, S., ed. Proceedings of the 28th symposium on engineering geology and geotechnical engineering: 28th Symposium on Engineering Geology and Geotechnical Engineering, Boise, Idaho, April 1-3, 1992, Proceedings, p. 43-58.

\#661 Crone, A.J., and Luza, K.V., 1990, Style and timing of Holocene surface faulting on the Meers fault, southwestern Oklahoma: Geological Society of America Bulletin, v. 102, p. 1-17. 
\#672 Gilbert, M.C., 1983, The Meers fault of southwestern Oklahoma-Evidence for possible strong Quaternary seismicity in the midcontinent [abs.]: EOS, Transactions of the American Geophysical Union, v. 64, p. 313.

\#671 Gilbert, M.C., 1983, The Meers fault-Unusual aspects and possible tectonic consequences: Geological Society of America Abstracts with Programs, v. 18, p. 1.

\#670 Harlton, B.H., 1951, Faults in sedimentary part of Wichita Mountains of Oklahoma: Bulletin of the American Association of Petroleum Geologists, v. 35, p. 988-999.

\#667 Harlton, B.H., 1963, Frontal Wichita fault system of southwestern Oklahoma: Bulletin of the American Association of Petroleum Geologists, v. 47, p. 1552-1580.

\#666 Harlton, B.H., 1972, Faulted fold belts of southern Anadarko basin adjacent to Frontal Wichitas: Bulletin of the American Association of Petroleum Geologists, v. 56, p. 1544-1551.

\#673 Jones-Cecil, M., in press, Total-field aeromagnetic and derivative maps of the Lawton area, southwestern Oklahoma: U.S. Geological Survey Geophysical Investigations Series Map GP-998-A, 2 sheets, scale 1:100,000.

\#663 Jones-Cecil, M., and Crone, A.J., 1989, Constraints on the Anadarko basin-Wichita uplift boundary interpreted from aeromagnetic data, in Johnson, K.S., ed., Anadarko basin symposium, 1988: Oklahoma Geological Survey Circular 90, p. 228-232.

\#659 Kelson, K.I., and Swan, F.H., 1990, Paleoseismic history of the Meers fault, southwestern Oklahoma, and implications for evaluations of earthquake hazards in the Central and Eastern United States, in Weiss, A.J., ed., Seventeenth water reactor safety information meeting: Proceedings of the U.S. Nuclear Regulatory Commission NUREG/CP-0105, v. 2, p. 341-365.

\#669 Luza, K.V., Madole, R.F., and Crone, A.J., 1987, Investigation of the Meers fault in southwestern Oklahoma: U.S. Nuclear Regulatory Commission NUREG/CR-4937, 53 p., 2 pls.

\#544 Luza, K.V., Madole, R.F., and Crone, A.J., 1987, Investigation of the Meers fault, southwestern Oklahoma: Oklahoma Geological Survey Special Publication 87-1, 75 p., 2 pls.

\#662 Madole, R.F., 1988, Stratigraphic evidence of Holocene faulting in the mid-continentThe Meers fault, southwestern Oklahoma: Geological Society of America Bulletin, v. 100, p. 392-401.

\#660 McConnell, D.A., 1989, Determination of offset across the northern margin of the Wichita uplift, southwest Oklahoma: Geological Society of America Bulletin, v. 101, p. 13171332.

\#664 Miller, R.D., Steeples, D.W., and Myers, P.B., 1990, Shallow seismic reflection survey across the Meers fault, Oklahoma: Geological Society of America Bulletin, v. 102, p. $18-25$.

\#665 Ramelli, A.R., and Slemmons, D.B., 1990, Implications of the Meers fault on seismic potential in the Central United States, in Krinitzsky, E.L., and Slemmons, D.B., eds., 
Neotectonics in earthquake evaluation: Geological Society of America Reviews in Engineering Geology, v. 8, p. 59-75.

\#668 Ramelli, A.R., Slemmons, D.B., and Brocoum, S.J., 1987, The Meers fault-Tectonic activity in southwestern Oklahoma: U.S. Nuclear Regulatory Commission NUREG/CR-4852, 25 p.

\#675 Swan, F.H., Wesling, J.R., Hanson, K.A., Kelson, K.I., and Perman, R.C., written commun. 1993, Draft report-Investigation of the Quaternary structural and tectonic character of the Meers fault (southwestern Oklahoma): Technical report to U.S. Nuclear Regulatory Commission, Washington, D.C., under Contract NRC-04-87-007, July 1993, 104 p., 3 pls.

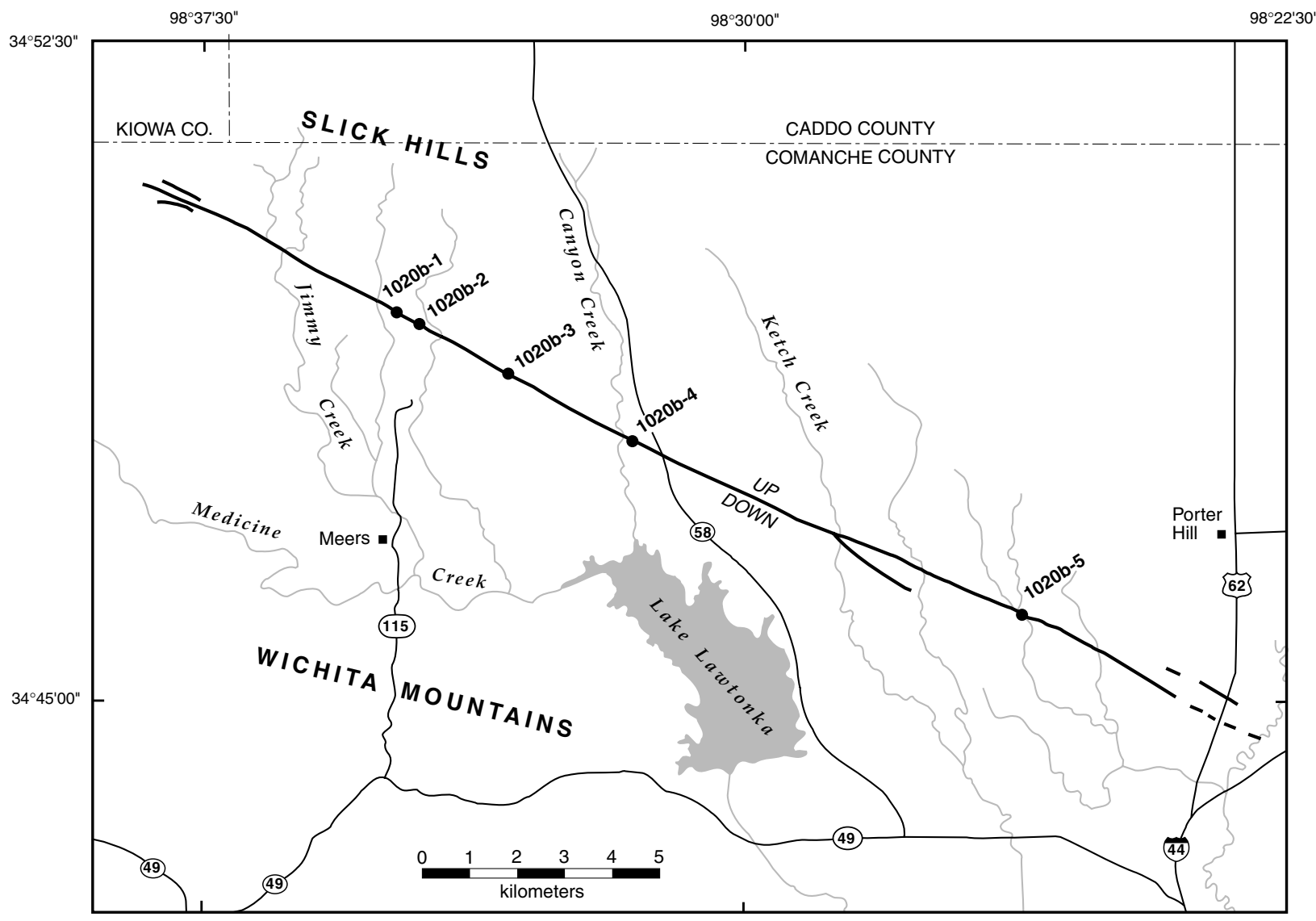

Figure 8. Schematic diagram shows location of selected sites along the eastern section of the Meers fault scarp (1020b), southeastern Oklahoma. Solid dots identify location of sites that are discussed in the text. 


\section{3, Reelfoot scarp and the New Madrid seismic zone (Class A)}

\section{Structure Number 1023}

Structure Name Reelfoot scarp and the New Madrid seismic zone (Class A)

Comments: These features are located in the central part of the Mississippi River Valley. At present, structural and tectonic information about specific seismogenic faults is limited, in part because the seismogenic faults are not expressed or are poorly expressed at the surface.

Furthermore, the entire river valley is covered by latest Quaternary sediments, so only the geologically youngest deformation is expressed at the surface. The Reelfoot scarp is a topographic escarpment that extends south-southeastward from near the town of New Madrid, Missouri, along the western margin of Reelfoot Lake, to a point south of the lake. It is the most prominent geomorphic feature in the entire seismic zone that is clearly known to have a tectonic origin.

Synopsis: In the winter of 1811-1812, at least three major earthquakes occurred in the New Madrid seismic zone, and the area remains the most seismically active area in central and eastern North America. The 1811-1812 earthquakes were among the largest historical earthquakes to occur in North America and were perhaps the largest historical intraplate earthquakes in the world. The earthquakes produced widespread liquefaction throughout the seismic zone and prominent to subtle surface deformation is several areas, but they did not produce any known surface faulting. Other than the pervasive sand blows throughout the seismic zone, the Reelfoot scarp is the most prominent geomorphic feature that has been produced by the modern tectonism. Recent studies of the scarp have provided valuable information on the recurrence of deformation on the scarp, calculated uplift rates, and the history of faulting.

Date of compilation April 12, 1994; revised May, 1999, April, 2000.

Compiler and affiliation Anthony J. Crone and E.S. Schweig, U.S. Geological Survey

State Arkansas, Missouri, Tennessee, Kentucky

County Craighead, Crittenden, Mississippi, Poinsett (Arkansas); Dunklin, Mississippi, New Madrid, Pemiscot (Missouri); Dyer, Lake (Tennessee)

$1^{\circ} \times 2^{\circ}$ sheet Blytheville, Dyersburg, Memphis, Poplar Bluff

\section{Province Coastal Plain}

\section{Quality of location Good}

Comments: Many features shown on maps of the New Madrid seismic zone are not discrete faults; the most notable exception is the Reelfoot scarp, which is located along the western shore of Reelfoot Lake in extreme northwestern Tennessee. The three most commonly noted features associated with the contemporary deformation are: (1) the Lake County uplift and Reelfoot scarp, (2) areas of suspected coseismic subsidence, and (3) areas of abundant liquefaction during the 1811-1812 earthquakes. The locations of these features are derived from the digital data used to generate the suite of seismotectonic maps of the New Madrid, Missouri area (Wheeler and Rhea, 1994 \#754; Rhea and others, 1994 \#3814). 
Geologic setting The modern seismicity in the New Madrid seismic zone is intimately associated with the Reelfoot rift (Ervin and McGinnis, 1975 \#735), a northeasterly-trending, 70-kmwide graben that has as much as $2 \mathrm{~km}$ of structural relief on magnetic basement (Hildenbrand and others, 1982 \#721; Hildenbrand, 1985 \#736). The rift is best defined by magnetic data, which also reveals the presence of major positive magnetic anomalies along the flanks and axis of the rift that are inferred to be mafic plutons (Hildenbrand and others, 1982 \#721; Hildenbrand, 1985 \#736).

The follow sequence of events summarizes the geologic history of the Reelfoot rift and the current tectonic setting of the New Madrid seismic zone. Crustal extension that resulted in development of the Reelfoot rift began in latest Precambrian or Early Paleozoic time. It is likely that the Reelfoot rift is generally contemporaneous with other large-scale late Precambrian-Early Paleozoic, extensional features along the rifted margin of southeastern North America, including the Southern Oklahoma aulacogen, the Rough Creek-Rome graben system, and the Marathon rift (Thomas, 1991 \#678). Active rifting ceased by Late Cambrian time, and the Reelfoot rift was filled with a 1- to 4-km-thick sequence of marine clastic and carbonate sedimentary rocks. During the Late Paleozoic and much of the Mesozoic, the region was uplifted, and several kilometers of sedimentary rocks were eroded from the crest of the Pascola arch. In Permian time, mafic igneous dikes and sills intruded the sedimentary rocks; radiometric dating of a mica-peridotite dike in a drill hole near Reelfoot Lake in northwestern Tennessee yielded an age of $267 \mathrm{Ma}$. Near the end of the Mesozoic, probably beginning in early to middle Cretaceous time, regional subsidence occurred again. Also in early Cretaceous time, a series of igneous intrusions were emplaced along the margins of the rift; the emplacement of these intrusions is cited as evidence of reactivation of the rift, although extensional features are not known. During the late Cretaceous and continuing through the Eocene, subsidence resulted in formation of the Mississippi embayment. The embayment was filled with a southward-thickening wedge of predominantly clastic marine and continental sediments. Oligocene sediments are generally absent in the northern Mississippi embayment. In late Quaternary time and probably in earlier episodes, tremendous volumes of glacial meltwater from much of North America flowed down the Mississippi-Ohio Rivers drainage system and through the northern embayment. Braided streams that transported the meltwater deposited outwash sand and gravel in the embayment that is typically tens of meters thick in the New Madrid region. In early Holocene time, the Mississippi River changed from a braided stream to a meandering regime and began developing the modern meander belt. As a meandering river, fine-grained overbank sediment that was deposited as annual floods spread across wide expanses of the modern river valley.

The contemporary seismicity and current deformation in the New Madrid region is controlled by a regional stress field in which the maximum compressive stress is oriented approximately east-northeast-west-southwest. Within this stress field, ancient faults, most of which originally formed as extensional features during rifting, have been reactivated mainly as strike-slip faults. The modern seismicity is concentrated into three major trends that form a zigzag pattern that has an overall northeasterly trend. The modern seismicity is largely associated with rift-related features. The southwesternmost trend is a narrow, linear, 120-km-long zone of earthquakes in northeastern Arkansas and extreme southeastern Missouri; this zone of earthquakes roughly coincides with the position of an axial fault zone that is commonly present 
along the center of most rifts. Focal mechanisms for earthquakes in this zone indicate mainly dextral slip (Herrmann and Canas, 1978 \#732; Herrmann, 1979 \#733). This zone of seismicity coincides with the Blytheville arch, which is an enigmatic subsurface structure that is only known from seismic-reflection data and is pre-middle Ordovician in age (Herrmann and Canas, 1978 \#732; Crone and others, 1985 \#728). At the northeastern end of this $120-\mathrm{km}-$ long zone, the second seismicity trend extends north-northwestward from extreme northwestern Tennessee to near the town of New Madrid, Missouri. This zone of earthquakes is can be referred to as the "cross-rift" trend of seismicity because is cuts obliquely across the northeasterly trend of the Reelfoot rift. Earthquakes in this trend form a diffuse pattern and have a variety of focal-mechanism solutions including reverse and normal faulting; recent studies suggest that many earthquakes in this cross-rift trend are occurring on southwesterly dipping reverse faults (Chiu and others, 1992 \#730). The third prominent zone of zone of earthquakes is a linear trend that extends northeasterly from the town of New Madrid and is close to the northwestern margin of the rift. Few earthquakes in this trend have yielded good focal mechanisms, but the available data indicates dextral slip on faults in this trend (Herrmann and Canas, 1978 \#732; Herrmann, 1979 \#733). Thus the current seismicity indicates that contemporary deformation in the New Madrid seismic zone is occurring on a two left-stepping, en echelon, dextral slip faults.

\section{Sense of movement dextral reverse}

Comments: The sense of movement on active faults is derived from seismological data, which is summarized in the preceding section. These data indicate that the regional deformation is dominated by dextral slip in the two northeast-trending linear zones of seismicity. The two linear seismicity trends are linked by a zone of northwest-trending seismicity. Accurately located earthquakes in this northwesterly trend highlight the presence of a southwesterly dipping reverse fault (Chiu and others, 1992 \#730). Modeling of deformation and comparison with geomorphic features are consistent with this interpretation.

Based on combined information from seismological, seismic-reflection profiling, geomorphic, and geological studies, Reelfoot scarp is interpreted as an east-dipping moncline which is the surface expression of a fault-propagation fold associated with the underlying blind Reelfoot thrust fault (Van Arsdale and others, 1995 \#3965; Kelson and others, 1996 \#3811; Mueller and others, 1999 \#3963; Van Arsdale, 2000 \#3968). In the shallow subsurface, the scarp is composed of a series of flexures that collectively produce the total topographic relief on the scarp (Mueller and others, 1999 \#3963) .

\section{Dip near-vertical to $31^{\circ}$}

Comments: Focal mechanisms and hypocenter locations indicate near-vertical dips for faults in the linear, northeasterly trending seismicity zones (Herrmann and Canas, 1978 \#732; Herrmann, 1979 \#733; Chiu and others, 1992 \#730; Pujol and others, 1998 \#3793). Hypocenter locations indicate dips of about $31^{\circ}-48^{\circ}$ on faults in the cross-rift trend (Chiu and others, 1992 \#730), which is the down-dip extension of the Reelfoot fault. Thus, at depths of $7-14 \mathrm{~km}$, the microseismicity indicates that the Reelfoot fault has a dip of about $34^{\circ}$ (Chiu and others, 1992 \#730), upward toward Reelfoot scarp, this plane has a dip of about $55^{\circ}$ between depths of 0.5 and $7 \mathrm{~km}$, and at depths of less than $0.5 \mathrm{~km}$, the fault plane probably has a dip of $16^{\circ}$ or less (Mueller and others, 1999 \#3963). 
Main dip direction SW for faults in cross-rift trend, which includes the blind Reelfoot thrust fault.

Geomorphic expression The geomorphology of the New Madrid seismic zone is dominated by the fluvial features of the Mississippi River and the latest Pleistocene braided stream terraces that are primarily composed of outwash sand and gravel. The most prominent geomorphic expression of the contemporary tectonism is the Lake County uplift (feature 1023-1), a teardrop-shaped uplift in extreme northwestern Tennessee that has a maximum length of about $50 \mathrm{~km}$ and maximum width of about $23 \mathrm{~km}$ (Russ, 1982 \#722). Geomorphic studies indicate that recent deformation the uplift has elevated the late Holocene fluvial sediments as much as $9 \mathrm{~m}$.

Part of the eastern margin of the Lake County uplift is defined by Reelfoot scarp (feature 1023-2), which separates the uplift from Reelfoot Lake on the east. The scarp is the only tectonic scarp in the entire seismic zone. A trench across the scarp exposed a group of normal faults at the scarp's base (Russ, 1979 \#753), and seismic-reflection data shows that the scarp coincides with the Reelfoot fault, a near-vertical down-to-the-east fault (Zoback, 1979 \#731). Recent studies have revealed as much as $9 \mathrm{~m}$ of structural relief on the scarp (Mueller and others, 1999 \#3963), which is the result of a monoclinal flexure, with secondary normal faulting across the crest of the flexure (Kelson and others, 1992 \#729; Kelson and others, 1996 \#3811).

The surface expression of Reelfoot scarp is most distinctive along the western margin of Reelfoot Lake, even though the shallow sediments are only tilted to the east at slopes of 5-7 (Mueller and others, 1999 \#3963). Original studies of the scarp traced its length for a distance of only $11 \mathrm{~km}$, but recent work suggests that the scarp extends from west of New Madrid, Missouri, through the Kentucky bend, along the west side of Reelfoot Lake to just south of the lake: a total distance of about $32 \mathrm{~km}$. Farther southeastward, no scarps are known, but on the basis of seismic-reflection and geomorphic data, Van Arsdale and others (1999 \#3967) propose that the subsurface fault may be approximately $70 \mathrm{~km}$ long.

Initial studies of the surficial effects of the 1811-1812 earthquakes suggested possible uplift elsewhere in the New Madrid region (Fuller, 1912 \#723), but geologic and geomorphic studies have yet to confirm the presence of these features. Fuller (1912 \#723) also noted several areas where subsidence probably or possibly occurred during the 1811-1812 earthquakes. One area of probable subsidence is Reelfoot Lake (Van Arsdale and others, 1998 \#3966). Historical accounts and geomorphic evidence indicate that the lake was enlarged as a result of the earthquakes (Russ, $1982 \# 722$ ), but it is unclear if the enlargement was the result of subsidence beneath the lake, uplift of the Lake County uplift, which resulted in damming of drainage through Reelfoot Lake, or a combination of both processes.

Of the many "sunklands" described by Fuller (1912 \#723), only two have been studied in sufficient detail to provide insight into their origin: the Big Lake (feature 1023-3) and the St. Francis (1023-4) "sunklands" in northeastern Arkansas (Guccione and others, 1988 \#3809; Guccione and Hehr, 1991 \#737; Guccione and others, 1994 \#739). Bathymetric and sedimentologic evidence and radiocarbon dating suggest that these areas were drowned in a time frame that is consistent with subsidence induced by the 1811-1812 earthquakes. Other "sunklands", described by Fuller (1912 \#723) and predicted by modeling, appear on old maps, but have not been studied. 
A recently recognized, 135-km-long lineament named the Bootheel lineament (feature 10235) has been speculated to be the surface expression of a coseismic fault related to the 18111812 earthquakes (Schweig and Marple, 1991 \#725; Schweig and others, 1992 \#726). The expression of the lineament varies along strike and is marked by (1) a distinct contrast in the density of sand blows and liquefied sand, (2) shallow linear depressions along the feature, (3) continuous and discontinuous linear sand bodies at the surface, and (4) meander scars that appear to truncate at the lineament (Schweig and Marple, 1991 \#725; Schweig and others, 1992 \#726). In detail, parts of the lineament are composed of individual, en echelon, linear segments. Locally there is as much as $1.0 \mathrm{~m}$ of topographic relief across the feature, but the sense of topographic relief varies, that is, in places the western side is high and elsewhere, the eastern side is high. Eight trenches have been excavated across the feature at four sites. These trenching studies have revealed that the lineament is typically associated with largescale liquefaction features, especially major sand-blow feeder dikes (Schweig and Marple, 1991 \#725; Schweig and others, 1992 \#726; Crone and others, 1995 \#883). The origin of the lineament is still unclear, but Schweig and Marple (1991 \#725) speculate that it may mark the location of a lateral-slip fault even though little of the modern seismicity is spatially associated with it. Johnston and Schweig (1996 \#3810), using historical descriptions of the effects of the 1811-1812 New Madrid earthquakes, suggest that the first large event occurred, in part, on the Bootheel lineament.

The most widespread expression of recent strong earthquakes in the New Madrid region is the abundant liquefaction features (sand blows and sand-filled fissures), which are concentrated in a 40- to 60-km-wide belt from near Charleston, Missouri on the northeast to south of Marked Tree, Arkansas (Obermeier, 1988 \#3813). Geologic conditions in the New Madrid region are near optimum for the development of liquefaction features during strong earthquakes: a thin (2-8 m thick), fine-grained "topstratum" deposit overlies water-saturated, unconsolidated "substratum" sand and gravel. Extensive liquefaction occurred during the 1811-1812 earthquakes; locally the ground surface was buried by more than $1 \mathrm{~m}$ of liquefied sand, and hundreds of square kilometers of the land surface are have been mapped as being more than 25 percent covered by liquefied sand (Obermeier, 1988 \#3813). Haller and Crone (1986 \#718), Obermeier and others (1990 \#717), Rodbell and Schweig (1993 \#716), Wesnousky and Leffler (1992 \#713), and Tuttle and Barstow (1996 \#3815) describe the attributes of selected sand blows and liquefaction features from the 1811-1812 earthquakes.

The 1811-1812 earthquakes caused at least 221 landslides along the bluffs that define the eastern boundary of the Mississippi River alluvial plain (Jibson and Keefer, 1988 \#715). The majority of the landslides are covered by mature vegetation, which indicates that they did not form within the last few decades and field evidence suggests that most of the landslides are approximately the same age (Jibson and Keefer, 1988 \#715). This implies that most of the landslides were triggered by a single event, which is likely to have been the 1811-1812 earthquakes. Dynamic and static slope stability analyses of one landslide revealed that the landslide would be stable under all geologic conditions except those caused by strong earthquake-induced ground motion (Jibson and Keefer, 1992 \#714).

Age of faulted deposits at the surface Late Holocene fluvial sediments are deformed in the Lake County uplift and along Reelfoot scarp; small-displacement reverse faults are associated 
with the scarp but it is not clear if these faults are directly connected to the Reelfoot fault at depth.

Paleoseismological studies The first detailed studies of the 1811-1812 earthquakes and their surficial effects was conducted by M.L. Fuller nearly a century after the shocks (Fuller, 1912 \#723). Since Fuller's pioneering work, numerous studies have examined diverse aspects of the geology, geomorphology, and tectonics of the New Madrid region. Many of those studies are cited in other parts of this discussion.

Detailed studies of the Reelfoot scarp in northwestern Tennessee have documented evidence of three deformation events within the past 2,400 years and characterized the style of nearsurface deformation associated with the scarp (Kelson and others, 1996 \#3811). Late Holocene fluvial deposits are warped into an 8-m-high, east-facing monocline. Borehole data and trenches at three sites characterized the style of near-surface deformation associated with the scarp and constrain the timing of three deformation events on the scarp.

The Crittenden County fault zone (feature 1023-6) in northeastern Arkansas has no known surface expression but extensive seismic-reflection studies suggest that Quaternary sediments are deformed by movement on the fault (Luzietti and others, 1992 \#705). The fault zone, in part, coincides with the southeastern margin of the Reelfoot rift and has sense of vertical offset that is opposite to the net structural relief in the underlying rift (Crone, 1992 \#706). Drill-hole and seismic-reflection data show that the top of Paleozoic rocks are vertically offset about $80 \mathrm{~m}$ across the fault zone and that shallower strata are offset progressively less (Luzietti and others, 1992 \#705; Crone, 1992 \#706) . Deformation associated with the fault zone can be confidently traced through the Tertiary rocks that fill the Mississippi embayment (Luzietti and others, 1992 \#705). Very high-resolution reflection data confirm that late Quaternary deposits are faulted, and a deformed reflector as shallow as 6-7 m could be resolved with these data (Williams and others, 1995 \#3820). The lack of nearby stratigraphic control precluded determining if this reflector represented Holocene strata. An exploratory trench coincident with the very high-resolution reflection profile failed to find any unequivocal evidence of Holocene movement on the fault zone (Crone and others, 1995 \#883).

Timing of most prehistoric deformation latest Quaternary $(<15 \mathrm{ka})$

Comments: Some details of the chronology of prehistoric earthquakes in the New Madrid region are becoming clear after more than two decades of work. Although some earlier studies reported no definitive evidence of pervasive liquefaction similar to that which occurred in 1811-1812 in the region during the Holocene (Wesnousky and Leffler, 1992 \#713; Rodbell and Schweig, 1993 \#716), others, including all recent studies by the same investigators, have demonstrated repeated late Holocene paleoliquefaction on a regional scale. In the northern part of the seismic zone, Russ (1979 \#753) described stratigraphic evidence of two prehistoric earthquakes that postdate the maximum age of 2,250 radiocarbon years for the fluvial sediments exposed in his trench across Reelfoot scarp (feature 1023-2). Subsequent trenching studies (Kelson and others, 1992 \#729; 1996 \#3811) have constrained the timing of the most recent paleoevent on the scarp to have occurred between A.D. 1310 and A.D. 1540 and have yielded equivocal evidence of a preceding event that occurred prior to about A.D. 900 (see below). Saucier (1991 \#711) reported evidence of a strong earthquake north of New Madrid that occurred shortly before A.D. 539 and presents weaker evidence of a younger event about 
A.D. 991. Tuttle and others (1998 \#3817) have found evidence from the central and northern parts of the seismic zone for an earthquake that occurred A.D. 1530 $\pm 130 \mathrm{yr}$.

Tuttle and Schweig (1995 \#3818; 1996 \#3819) and Tuttle and others (1996 \#3816; 1998 \#3817) report widespread evidence throughout the New Madrid seismic zone of a prehistoric event around A.D. 900. They have also found scattered evidence for earlier events that caused less liquefaction. Thus, currently available paleoseismic data in parts of the New Madrid region suggests the occurrence of a penultimate event about 470 years ago, but the evidence is not uniform or widespread. However, evidence for an event at 1,000 years ago is widespread and well dated archeologically and with radiocarbon age determinations.

Deformation on the scarp associated with the 1811-1812 New Madrid earthquake sequence produced extensive liquefaction, folded the fluvial sediments, and caused minor reactivation of small faults that bound an extensional graben in the uplifted (hanging wall) of the Reelfoot scarp (Kelson and others, 1996 \#3811). The penultimate deformation event occurred between A.D. 1260 and 1650 (350-740 yr B.P.), produced about $1.3 \mathrm{~m}$ of throw in the grabenbounding faults, and caused folding and development of the scarp. The oldest documented event associated with the scarp occurred between A.D. 780 and 1000 (1000-1120 yr B.P.), and initially produced the small graben in the hangingwall of the Reelfoot fault.

\section{Recurrence interval unknown}

Comments: Despite considerable efforts, reliable geologic data on the recurrence of strong, potentially damaging earthquakes in the NMSZ has been elusive, and the currently available data are limited, inconclusive and contradictory.

Paleoseismic studies (Russ, 1979 \#753; Saucier, 1991 \#711; Kelson and others, 1992 \#729; 1996 \#3811) have suggested a recurrence interval of about 500-1100 years for earthquakes that are large enough to produce significant surface deformation or liquefaction in various parts of the seismic zone. The most recent studies (Tuttle and Schweig, 1995 \#3818; Tuttle and others, $1996 \# 3816$; $1996 \# 3819$; $1998 \# 3817$ ) suggest that there were about 900 years between the last two New-Madrid-size events (A.D. 900 to A.D. 1811) and that widespread liquefaction occurs every few hundred years. However, the record studied thus far is too short to be used for a long-term recurrence rate.

The detailed investigations of the Reelfoot scarp described above provide information that permitted Kelson and others (1996 \#3811) to estimate a recurrence interval of 150-900 years, with a more likely range of about 400-500 years. It is not clear if these rate estimates reflect the overall behavior of major events for the entire seismic zone or only apply to the Reelfoot scarp. In the absence of better data for the entire seismic zone, we choose to categorize the recurrence interval as unknown.

\section{Slip-rate category unknown}

Comments: In the absence of well-determined data on the timing of paleoevents and the amount of tectonic slip produced by those events, it is impossible to estimate reliable or even meaningful Holocene or late Quaternary slip rates.

Despite the lack of well-constrained slip-rate data for specific faults in the New Madrid region, some general inferences can be made about general deformation rates using structural 
and stratigraphic data (McKeown, 1982 \#709). A wide range of fault slip rates can be calculated in the New Madrid region depending on time intervals and datums that are being considered. Long-term slip rates of 0.001-0.0009 mm/yr result from measuring the amount of vertical displacement of various Paleozoic, Mesozoic and Cenozoic stratigraphic horizons and assigning an age for those horizons (McKeown, 1982 \#709; Van Arsdale, 2000 \#3968).

Estimated short-term slip rates are much higher than these long-term values, and some of the short-term slip rates are comparable the rates of major plate-boundary faults. Based on the amount of Holocene deformation associated with the Lake County uplift (feature 1023-1) and the Reelfoot scarp (1023-2), the calculated rate on the fault is as much as $6.1 \pm 0.7 \mathrm{~mm} / \mathrm{yr}$ (Mueller and others, 1999 \#3963). Based on the geometric relationship between the Reelfoot fault and faults along the main rift-axis zone of seismicity, Mueller and others (1999 \#3963) compute a slip rate of 1.8-2.2 $\mathrm{mmy} / \mathrm{yr}$ on the axial faults.

Geodetic studies in the New Madrid seismic zone have yielded results that imply contrasting slip rates. One geodetic study in part of the New Madrid seismic zone yields a very high contemporary slip rate of 5-7 mm/yr (Liu and others, 1992 \#708), but this high slip rate must be an anomalously high, very short-term rate, considering the lack of regional topography. Also, if sustained, these rates would have produced much more faulting and deformation in Paleozoic and Cretaceous rocks than actually exists. A more recent geodetic study has questioned whether the Liu and others (1992 \#708) results are statistically significant (Newman and others, 1999 \#3964). Geodetic data analyzed by Newman and others (1999 \#3964) indicate virtually no significant deformation is currently occurring, that is, their results show that the measured rate does not differ significantly from zero. The significance of the divergent results from these two studies remains unresolved and is the subject of considerable discussion.

Because various studies yield such diverse slip-rate estimates, we choose to define the slip rate for deformation in the New Madrid seismic zone as unknown.

\section{Length (km) Not applicable}

Comment: The New Madrid seismic zone is defined on the basis of abundant and widespread historical and microseismicity that is concentrated in three prominent trends. These concentrations of microseismicity and the major earthquakes that occurred in 1811-1812 indicate that Quaternary faulting is occurring in the seismic zone, but with the exception of the Reelfoot scarp, discrete faults are not expressed at the surface. Therefore it is difficult to assign a specific length for the entire zone. Overall, the abundant seismicity extends from near Marked Tree, Arkansas, on the southwest to near Charleston, Missouri, on the northeast, which is a distance of about $180 \mathrm{~km}$, but diffuse seismicity extends a greater distance.

Recent studies have shown that the Reelfoot scarp is about $32 \mathrm{~km}$ long and the subjacent Reelfoot fault may be as much as $70 \mathrm{~km}$ long. However, this fault is the only that has conspicuous surface expression and therefore can be studied at the surface. Based on the historical seismicity, there are other significant but unexposed faults in the seismic zone.

Average strike (azimuth) Not applicable

Comment The New Madrid seismic zone is not a single feature but is defined by the region of abundant seismicity in the central Mississippi River Valley. Accordingly, it is not possible 
to define an average strike but most of the seismicity is associated with the Reelfoot rift, which has a northeasterly trend. The Reelfoot scarp is a well-defined feature, but is small in comparison to the general dimensions of the seismic zone. The average azimuth of the Reelfoot scarp is $337^{\circ}$.

\section{References}

\#730 Chiu, J.M., Johnston, A.C., and Yang, Y.T., 1992, Imaging the active faults of the central New Madrid seismic zone using PANDA array data, in Johnston, A.C., Shedlock, K.M., Herrmann, R.B., and Hopper, M.G., eds., New Madrid special issue: Seismological Research Letters, v. 63, p. 375-393.

\#706 Crone, A.J., 1992, Structural relations and earthquake hazards of the Crittenden County fault zone, northeastern Arkansas, in Johnston, A.C., Shedlock, K.M., Herrmann, R.B., and Hopper, M.G., eds., New Madrid special issue: Seismological Research Letters, v. 63, p. 249-262.

\#883 Crone, A.J., Giardino, M., and Schweig, E.S., III, 1995, Paleoseismic studies of the Bootheel lineament, southeastern Missouri, and the Crittenden County fault zone, northeastern Arkansas, New Madrid seismic zone, central United States: U.S. Geological Survey Miscellaneous Field Studies Map MF-2279, 21 p. pamphlet, 1 sheet.

\#728 Crone, A.J., McKeown, F.A., Harding, S.T., Hamilton, R.M., Russ, D.P., and Zoback, M.D., 1985, Structure of the New Madrid seismic source zone in southeastern Missouri and northeastern Arkansas: Geology, v. 13, p. 547-550.

\#735 Ervin, C.P., and McGinnis, L.D., 1975, Reelfoot rift-Reactivated precursor to the Mississippi embayment: Geological Society of America Bulletin, v. 86, p. 1287-1295.

\#723 Fuller, M.L., 1912, The New Madrid earthquake: U.S. Geological Survey Bulletin 494, 119 p., 1 plate.

\#737 Guccione, M.J., and Hehr, L.H., 1991, Origin of the "sunklands" in the new Madrid seismic zone-Tectonic or alluvial drowning? [abs.]: Seismological Research Letters, v. 62 , p. 171-172.

\#739 Guccione, M.J., Miller, J.Q., and VanArsdale, R.B., 1994, Amount and timing of deformation near the St. Francis "sunklands", northeastern Arkansas: Geological Society of America Abstracts with Programs, v. 26, p. 7.

\#3809 Guccione, M.J., Prior, W.L., and Rutledge, E.M., 1988, Crowley’s Ridge, Arkansas, in Hayward, O.T., ed., South-central section: Geological Society of America Centennial Field Guide, v. 4, p. 225-230.

\#718 Haller, K.M., and Crone, A.J., 1986, Log of an exploratory trench in the New Madrid seismic zone near Blytheville, Arkansas: U.S. Geological Survey Miscellaneous Field Studies Map MF-1858, 1 sheet,.

\#733 Herrmann, R.B., 1979, Surface wave focal mechanisms for eastern North American earthquakes with tectonic implications: Journal of Geophysical Research, v. 84, no. B7, p. 3543-3552. 
\#732 Herrmann, R.B., and Canas, J.-A., 1978, Focal mechanism studies in the New Madrid seismic zone: Bulletin of the Seismological Society of America, v. 68, p. 1095-1102.

\#736 Hildenbrand, T.G., 1985, Rift structure of the northern Mississippi embayment from the analysis of gravity and magnetic data: Journal of Geophysical Research, v. 90, no. B14, p. 12,607-12,622.

\#721 Hildenbrand, T.G., Kane, M.F., and Hendricks, J.D., 1982, Magnetic basement in the upper Mississippi embayment region-A preliminary report, in McKeown, F.A., and Pakiser, L.C., eds., Investigations of the New Madrid, Missouri, earthquake region: U.S. Geological Survey Professional Paper 1236, p. 39-53.

\#715 Jibson, R.W., and Keefer, D.K., 1988, Landslides triggered by earthquakes in the central Mississippi Valley, Tennessee and Kentucky, in Russ, D.P., and Crone, A.J., eds., The New Madrid, Missouri, earthquake region-Geological, seismological, and geotechnical studies: U.S. Geological Survey Professional Paper 1336-C, p. C1-C24.

\#714 Jibson, R.W., and Keefer, D.K., 1992, Analysis of the seismic origin of a landslide in the New Madrid seismic zone, in Johnston, A.C., Shedlock, K.M., Herrmann, R.B., and Hopper, M.G., eds., New Madrid special issue: Seismological Research Letters, v. 63, p. 427-437.

\#3810 Johnston, A.C., and Schweig, G.D., 1996, The enigma of the New Madrid earthquakes of 1811-1812: Annual Review of Earth and Planetary Sciences, v. 24, p. 339-384.

\#3811 Kelson, K.I., Simpson, G.D., Van Arsdale, R.B., Harris, J.B., Haraden, C.C., and Lettis, W.R., 1996, Multiple Holocene earthquakes along the Reelfoot fault, central New Madrid seismic zone: Journal of Geophysical Research, v. 101, p. 6151-6170.

\#729 Kelson, K.I., VanArsdale, R.B., Simpson, G.D., and Lettis, W.R., 1992, Assessment of the style and timing of surficial deformation along the central Reelfoot scarp, Lake County, Tennessee, in Johnston, A.C., Shedlock, K.M., Herrmann, R.B., and Hopper, M.G., eds., New Madrid special issue: Seismological Research Letters, v. 63, p. 349356.

\#708 Liu, L., Zoback, M.D., and Segall, P., 1992, Rapid intraplate strain accumulation in the New Madrid seismic zone: Science, v. 257, p. 1666-1669.

\#705 Luzietti, E.A., Kanter, L.R., Schweig, E.S., Shedlock, K.M., and VanArsdale, R.B., 1992, Shallow deformation along the Crittenden County fault zone near the southeastern boundary of the Reelfoot rift, northeast Arkansas, in Johnston, A.C., Shedlock, K.M., Herrmann, R.B., and Hopper, M.G., eds., New Madrid special issue: Seismological Research Letters, v. 63, p. 263-275.

\#709 McKeown, F.A., 1982, Overview and discussion, in McKeown, F.A., and Pakiser, L.C., eds., Investigations of the New Madrid, Missouri, earthquake region: U.S. Geological Survey Professional Paper 1236, p. 1-14.

\#3963 Mueller, K., Champion, J., Guccione, M., and Kelson, K., 1999, Fault slip rates in the modern New Madrid seismic zone: Science, v. 286, p. 1135-1138. 
\#3964 Newman, A., Stein, S., Weber, J., Engeln, J., Mao, A., and Dixon, T., 1999, Slow deformation and lower seismic hazard at the New Madrid seismic zone: Science, v. 284, p. 619-621.

\#3813 Obermeier, S.F., 1988, Liquefaction potential in the central Mississippi Valley: U.S. Geological Survey Bulletin 1832, p. 21.

\#717 Obermeier, S.F., Jacobson, R.B., Smoot, J.P., Weems, R.E., Gohn, G.S., Monroe, J.E., and Powars, D.S., 1990, Earthquake-induced liquefaction features in the coastal setting of South Carolina and in the fluvial setting of the New Madrid seismic zone: U.S. Geological Survey Professional Paper 1504, 44 p., 1 plate.

\#3793 Pujol, J., Herrman, R., Chiu, S.-C., and Chiu, J.-M., 1998, Constrained joint location of New Madrid seismic zone earthquakes: Seismological Research Letters, v. 69, p. 5668.

\#3814 Rhea, S.B., Wheeler, R.L., and Tarr, A.C., 1994, Map showing seismicity and sandblows in the vicinity of New Madrid, Missouri: U.S. Geological Survey Miscellaneous Field Studies Map MF-2264-A, scale 1:250,000.

\#716 Rodbell, D.T., and Schweig, E.S., III, 1993, The record of seismically induced liquefaction on late Quaternary terraces in northwestern Tennessee: Bulletin of the Seismological Society of America, v. 83, p. 269-278.

\#753 Russ, D.P., 1979, Late Holocene faulting and earthquake recurrence in the Reelfoot Lake area, northwest Tennessee: Geological Society of America Bulletin, v. 90, p. 10131018.

\#722 Russ, D.P., 1982, Style and significance of surface deformation in the vicinity of New Madrid, Missouri, in McKeown, F.A., and Pakiser, L.C., eds., Investigations of the New Madrid, Missouri, earthquake region: U.S. Geological Survey Professional Paper 1236-H, p. 95-114.

\#711 Saucier, R.T., 1991, Geoarchaeological evidence of strong prehistoric earthquakes in the New Madrid (Missouri) seismic zone: Geology, v. 19, p. 296-298.

\#725 Schweig, E.S., III, and Marple, R.T., 1991, Bootheel lineament-A possible coseismic fault of the great New Madrid earthquakes: Geology, v. 19, p. 1025-1028.

\#726 Schweig, E.S., III, Marple, R.T., and Li, Y., 1992, An update of studies of the Bootheel lineament in the New Madrid seismic zone, southeastern Missouri and northeastern Arkansas, in Johnston, A.C., Shedlock, K.M., Herrmann, R.B., and Hopper, M.G., eds., New Madrid special issue: Seismological Research Letters, v. 63, p. 277-284.

\#678 Thomas, W.A., 1991, The Appalachian-Ouachita rifted margin of southeastern North America: Geological Society of America Bulletin, v. 103, p. 415-431.

\#3815 Tuttle, M., and Barstow, N., 1996, Liquefaction-related ground failure: A case study in the New Madrid seismic zone, Central United States: Bulletin of the Seismological Society of America, v. 86, p. 636-645.

\#3816 Tuttle, M.P., Lafferty, R.H., III, Guccione, M.J., Schwig, E.S., III, Lopinot, N., Cande, R.F., Dyer-Williams, K., and Haynes, M., 1996, Use of archaeology to date liquefac- 
tion features and seismic events in the New Madrid seismic zone, Central United States: Geoarchaeology, v. 11, p. 451-480.

\#3817 Tuttle, M.P., Lafferty, R.H., III, and Schweig, E.S., III, 1998, Dating of liquefaction in the New Madrid seismic zone and implications for seismic hazard: U.S. Nuclear Regulatory Commission NUREG/CR-0017, 77 p.

\#3818 Tuttle, M.P., and Schweig, E.S., 1995, Archeological and pedological evidence for large prehistoric earthquakes in the New Madrid seismic zone, Central United States: Geology, v. 23, p. 253-256.

\#3819 Tuttle, M.P., and Schweig, E.S., 1996, Recognizing and dating prehistoric liquefaction features: Lessons learned in the New Madrid seismic zone, Central United States: Journal of Geophysical Research, v. 101, p. 6177-6178.

\#3968 Van Arsdale, R.B., 2000, Displacement history and slip rate on the Reelfoot fault of the New Madrid seismic zone: Engineering Geology, v. 55, p. 219-226.

\#3967 Van Arsdale, R.B., Cox, R.T., Johnston, A.C., Stephenson, W.J., and Odurn, J.K., 1999, Southeastern extension of the Reelfoot fault: Seismological Research Letters, v. 70, no. 3 , p. 348-359.

\#3965 Van Arsdale, R.B., Kelson, K.I., and Lurnsden, C.H., 1995, Northern extension of the Tennessee Reelfoot scarp into Kentucky and Missouri: Seismological Research Letters, v. 66, no. 5, p. 57-62.

\#3966 Van Arsdale, R.B., Stahle, D.W., Cleaveland, M.K., and Guccione, M.J., 1998, Earthquake signals in tree-ring data from the New Madrid seismic zone and implications for paleoseismicity: Geology, v. 26, no. 6, p. 515-518.

\#713 Wesnousky, S.G., and Leffler, L.M., 1992, The repeat time of the 1811 and 1812 New Madrid earthquakes - A geological perspective: Bulletin of the Seismological Society of America, v. 82, p. 1756-1785.

\#754 Wheeler, R.L., and Rhea, S., 1994, Map showing surficial and hydrologic features in the vicinity of New Madrid, Missouri: U.S. Geological Survey Miscellaneous Field Studies Map MF-2264-E, 1 sheet, scale 1:250,000.

\#3820 Williams, R.A., Luzietti, E.A., and Carver, D.L., 1995, High-resolution seismic imaging of Quaternary faulting in the Crittenden County fault zone, New Madrid seismic zone, northeastern Arkansas: Seismological Research Letters, v. 66, p. 42-57.

\#731 Zoback, M.D., 1979, Recurrent faulting in the vicinity of Reelfoot Lake, northwestern Tennessee: Geological Society of America Bulletin, v. 90, p. 1019-1024. 


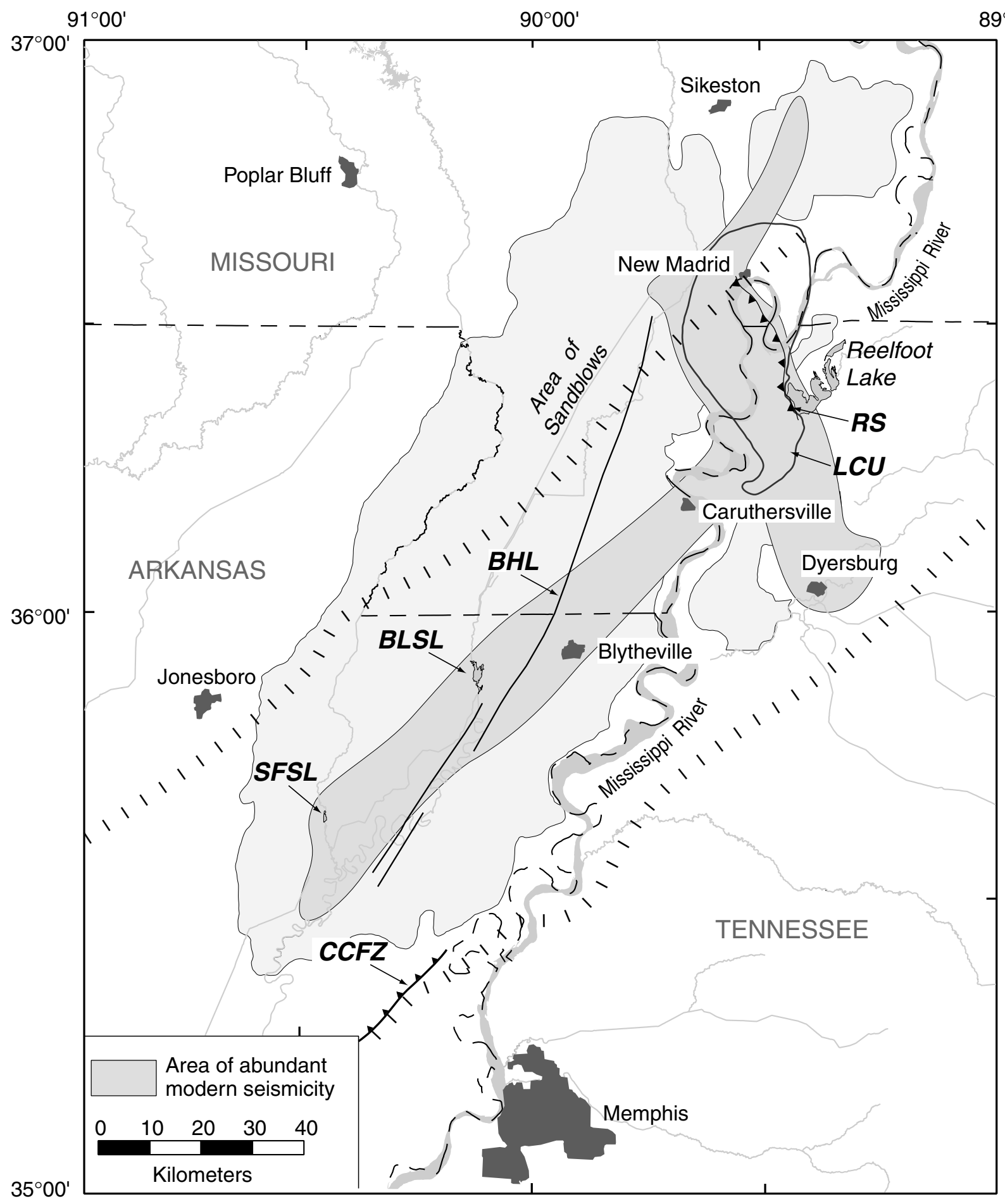

Figure 9. Schematic diagram showing the Reelfoot scarp and selected features in the area of the New Madrid seismic zone. Light shaded area shows location of abundant sand blows and medium shaded area shows location of abundant modern seismicity. Selected features are: LCU, Lake County uplift (1023-1); RS, Reelfoot scarp (1023-2); BLSL, Big Lake sunklands (1023-3); SFSL, St. Frances sunklands (1023-4); BHL, Bootheel lineament (1023-5); CCFZ, Crittenden County fault zone (1023-6). 


\section{Historical surface deformation, the New Madrid earthquakes}

Comments: Consisted of a series of at least 3 and possibly 4 major $(\mathbf{M} \geq 7.5)$ events during a period of 2 months in the winter of 1811 and 1812 (Street and Nuttli, 1984 \#724; Johnston, $1996 \# 1842$ ). Strong aftershocks persisted in the region for at least one year (Street and Nuttli, 1984 \#724). The first major earthquake occurred at 2:15 a.m. (all times are local times) on December 16,1811. It was followed by another major earthquake at 8:15 a.m. the same day that was the smallest of the 4 major events; most reports of the New Madrid earthquakes note three principle events, and this event is commonly not cited as one of the principle earthquakes. The next major event occurred at 9 a.m. on January 23, 1912; historical accounts suggest that this event was intermediate in size between the first and last major shocks. The last and largest earthquake occurred at 3:45 a.m. on February 7, 1812.

\section{Affected Structure(s), Segment(s), or Section Numbers 1023}

Date 04/7/94; updated 5/14/99

Magnitude or intensity maximum MMI $=\mathrm{X}-\mathrm{XII}$; estimated $\mathrm{m}_{\mathrm{b}}=7.01-7.54$

Comments: The New Madrid earthquakes predate modern seismological instruments, therefore all magnitude and moment estimates are based on establishing scaling relations between earthquake intesnsityintensity data and various magnitude scales. Nuttli (1973 \#745) reported the majority of the available intensity data that was obtained from published accounts of the earthquakes. Nuttli $(1979 \# 756)$ reported that the felt areas for the three principleprincipal shocks was were about 5,000,000 $\mathrm{km}^{2}$. Johnston (1996 \#1842) used Stover and Coffman's (1993 \#1986) revised contours to estimate that the felt area for the first December 16, 1811, earthquake was about 4,200,000 $\mathrm{km}^{2}$. Johnston assumed a reduced felt area west of the Mississippi River, as noted in the 1895 Charleston, Missouri, earthquake. Originally Nuttli (1983 \#743) Nuttli $(1973,1979)$ assigned body-wave estimates of 7.1-7.4 for the three principle shocks, but he later revised the estimates slightly upward to 7.2-7.5 (Nuttli and others, 1979). and Estimated ssurface-wave magnitudes for the three principle shocks are 8.0, 7.8, and 8.2 (Nuttli, 1979), he revised these values upward toof 8.5, 8.4, and 8.8 in subsequent reports (Nuttli, 1983). .

Moment magnitude or seismic moment $\mathrm{M}_{\mathrm{O}}=4.01 .8 \times 10^{287}, 2.56 .3 \times 10^{27}, 7.91 .0 \times 10^{287}$ dyne-cm; M 8.1 \pm 0.3, . M 7.8 \pm 0.3, M 8.0 \pm 0.3 .

Comments: Estimates of seismic moment $\left(\mathrm{M}_{\mathrm{O}}\right)$ and moment magnitude $(\mathbf{M})$ are from Nuttli Johnston (1996 \#1842). These estimates are not based on measurements from seismograms, but are based on regression of seismic moment against isoseismal areas for global and eastern North America stable continental regionsscaling relations between intensity data and the moment of recent historical earthquakes. Because these moment magnitude and seismic moment values are estimates, seismologists continue to discuss the accuracy of these estimates.

Location of epicenter $36^{\circ}$ N., $90^{\circ} \mathrm{W}$.; $36.3^{\circ}$ N., $89.6^{\circ} \mathrm{W}$; $36.5^{\circ}$ N., $89.6^{\circ} \mathrm{W}$.

Comments: Epicentral locations are for the three principleprincipal shocks in the series. The locations are very generalized and are based solely on isoseismal maps that were constructed from limited historical accounts of the earthquakes (Nuttli, 1982 \#720). 


\section{Depth of epicenter unknown}

Comments: no data is available to offer insight into the depths of the 1811-1812 earthquakes. However, monitoring of the recent seismicity indicates that the depth of the brittle-ductile transition zone in the crust (that is, the change from brittle faulting in the upper part to ductile deformation below) ranges from about $14 \mathrm{~km}$ deep in the southwestern part of the seismic zone to $16-17 \mathrm{~km}$ in the northwestern part of the seismic zone (Himes and others, 1988 \#742). If the 1811-12 earthquakes were similar to other large intraplate earthquakes in the world and nucleated at the base of the brittle crust, then one can speculate that the depths of the epicenters was in the range of $15 \mathrm{~km}$ deep.Johnston (1996 \#1842) suggests that rupture must have initiated in the brittle zone, which he takes as about $20 \mathrm{~km}$, but could have ruptured downward to $33 \mathrm{~km}$, the depth at which feldspardeformation converts from brittle to ductile processes.

Sense of movement unknown

Comments: Based on focal mechanisms of the current seismicity, it is likely that some of the major events were dextral slip events and others probably had a significant component of reverse slip.

Dip unknown

Comments: Joint hypocentral determination studies by Pujol and others (1998 \#3793) indicate that modern faulting is occurring on nearly vertical faults, with a stepover zone dipping about $31^{\circ}-48^{\circ}$ to the southwest. This stepover zone is located in extreme western Tennessee and adjacent southeastern Missouri in the are approximately between Dyersburg, Tennessee, and New Madrid, Missouri.

\section{Maximum slip at surface unknown}

Comments: Recent studies have suggested that the stream bed of Running Reelfoot Bayou was uplifted perhaps $2 \mathrm{~m}$ probably during the February 7, 1812, earthquake (Van Arsdale and others, 1999 \#3795).

\section{Geophysical average slip unknown}

\section{Length of surface rupture unknown}

Comments: The great historical earthquakes did not produce any discrete surface rupture. They did produce additional uplift of the Lake County uplift, northwestern Tennessee (Russ, 1982 \#722; Stahle and others, 1992 \#3794) and may have caused subsidence in the "sunk lands" in northeastern Arkansas (Guccione and others, 1988 \#738; Guccione and Hehr, 1991 \#737; Guccione and others, 1994 \#739) and southeastern Missouri (Ellis and others, 1995 \#3474).

\section{References}

\#3474 Ellis, M.A., Schweig, E.S., Prejean, S.G., and Johnston, A.C., 1995, Rupture scenario for the 1811-1812 New Madrid earthquakes based on static stress relaxation and change of topography: Eos, Transactions of the American Geophysical Union, v. 76, no. 46, p. F380. 
\#737 Guccione, M.J., and Hehr, L.H., 1991, Origin of the "sunklands" in the new Madrid seismic zone-Tectonic or alluvial drowning? [abs.]: Seismological Research Letters, v. 62, p. 171-172.

\#738 Guccione, M.J., Lafferty, R.H., III, and Cummings, L.S., 1988, Environmental constraints of human settlement in an evolving Holocene alluvial system, the lower Mississippi Valley: Geoarchaeology, v. 3, p. 65-84.

\#739 Guccione, M.J., Miller, J.Q., and VanArsdale, R.B., 1994, Amount and timing of deformation near the St. Francis "sunklands", northeastern Arkansas: Geological Society of America Abstracts with Programs, v. 26, p. 7.

\#742 Himes, L., Stauder, W., and Herrmann, R.B., 1988, Indication of active faults in the New Madrid seismic zone from precise location of hypocenters: Seismological Research Letters, v. 59, p. 123-131.

\#1842 Johnston, A.C., 1996, Seismic moment assessment of earthquakes in stable continental regions-III. New Madrid 1811-1812, Charleston 1886 and Lisbon 1755: Geophysical Journal International, v. 126, p. 314-344.

\#745 Nuttli, O.W., 1973, The Mississippi Valley earthquakes of 1811 and 1812 - Intensities, ground motion and magnitudes: Bulletin of the Seismological Society of America, v. 63, p. 227-248.

\#756 Nuttli, O.W., 1979, Seismicity of the Central United States, in Hatheway, A.W., and McClure, C.R., Jr., eds., Geology in the siting of nuclear power plants: Geological Society of America Reviews in Engineering Geology, v. 4, p. 67-93.

\#720 Nuttli, O.W., 1982, Damaging earthquakes of the central Mississippi Valley, in McKeown, F.A., and Pakiser, L.C., eds., Investigations of the New Madrid, Missouri, earthquake region: U.S. Geological Survey Professional Paper 1236, p. 15-20.

\#743 Nuttli, O.W., 1983, Average seismic source-parameter relations for mid-plate earthquakes: Bulletin of the Seismological Society of America, v. 73, p. 519-535.

\#3793 Pujol, J., Herrman, R., Chiu, S.-C., and Chiu, J.-M., 1998, Constrained joint location of New Madrid seismic zone earthquakes: Seismological Research Letters, v. 69, p. 56-68.

\#722 Russ, D.P., 1982, Style and significance of surface deformation in the vicinity of New Madrid, Missouri, in McKeown, F.A., and Pakiser, L.C., eds., Investigations of the New Madrid, Missouri, earthquake region: U.S. Geological Survey Professional Paper 1236-H, p. 95-114.

\#3794 Stahle, D.W., VanArsdale, R.B., and Cleaveland, M.K., 1992, Tectonic signal in baldcypress trees at Reelfoot Lake, Tennessee: Seismological Research Letters, v. 63, p. 439448.

\#1986 Stover, C.W., and Coffman, J.L., 1993, Seismicity of the United States, 1568-1989 (revised): U.S. Geological Survey Professional Paper 1527, 418 p.

\#724 Street, R., and Nuttli, O., 1984, The central Mississippi Valley earthquakes of 1811-1812, in Gori, P.L., and Hays, W.W., eds., Proceedings of the symposium on "the New Madrid seismic zone": U.S. Geological Survey Open-File Report 84-770, p. 33-63.

\#3795 Van Arsdale, R.B., Cox, R.T., Johnston, A.C., Stephenson, W.J., and Odurn, J.K., 1999, Southeastern estension of the Reelfoot fault: Seismological Research Letters, v. 70, p. 348-359. 


\section{4, Wabash Valley Liquefaction Features (Class A)}

Structure Number 1024

Structure Name Wabash Valley liquefaction features (Class A)

Comments: Includes the southern halves of Indiana and Illinois. There is no known Quaternary surface rupture on faults in the Wabash Valley region. Quaternary faults have recently been reported in southernmost Illinois, near Metropolis (Nelson, 1996 \#2837), but none can be linked with liquefaction features throughout the southern halves of Indiana and Illinois. The following discussion focuses on the presence of paleoliquefaction features throughout the study area. On the basis of the strong evidence that these liquefaction features are late Quaternary in age, they are listed as Class A features in this compilation.

Synopsis: Clastic dikes filled with sand and gravel, interpreted to be the result of earthquakeinduced liquefaction, occur throughout much of southern Indiana and adjacent parts of Illinois. At least seven and probably eight prehistoric earthquakes have been documented during the Holocene, as well as, at least one during the latest Pleistocene. Nearly all of these liquefaction features originated from earthquakes centered in southern Indiana and Illinois, and not further south in the nearby source region of the great 1811-12 New Madrid earthquakes.

The recognition of different earthquakes is based mainly on establishing limits on the timing of liquefaction features in combination with the regional pattern of liquefaction effects, but some earthquakes have been recognized only by geotechnical testing at sites of liquefaction.

Prehistoric magnitudes were probably on the order of moment magnitude M 7.5, which greatly exceeds the largest historical earthquakes of M 5.5 in the region. The strongest prehistoric earthquakes had epicenters in the vicinity of the lower Wabash Valley, where the valley borders both Indiana and Illinois.

Date of compilation 04/15/94; updated 02/27/97, 04/03/00

Compiler and affiliation Steven F. Obermeier \& Anthony J. Crone, U.S. Geological Survey

State Indiana, Illinois

County Southern halves of Indiana-Illinois, and especially the following counties: Clark, Crawford, Jasper, Lawrence, Wabash, White (Illinois); Daviess, Gibson, Know, Pike, Posey, Sullivan, Vigo (Indiana)

$1^{\circ} \times 2^{\circ}$ sheet Evansville, Vincennes, Indianapolis, Paducah, Belleville, Decatur

Province Interior Low Plateaus, Central Lowland

Reliability of location Poor

Comments: Precise location of the structures that produced the strong ground motion, which formed the liquefaction features, is unknown.

Geologic setting The Wabash Valley region in southeastern Illinois and southwestern Indiana has been an area of persistent seismicity (Nuttli, 1979 \#756) and the site of several moderate magnitude ( $M=4.5-5.8)$ historical earthquakes (Taylor and others, 1989 \#699; Langer and Bollinger, 1991 \#700), but little is known about the causative faults. The most prominent net- 
work of faults in the region is the Wabash Valley fault system (Bristol and Treworgy, 1979 \#703), a series of north-northeast-trending normal faults that are mapped at the surface.

Seismic-reflection data show that the faults are rooted in Precambrian basement and define a 40-km-long, 22-km-wide graben named the Grayville graben (Bear and others, 1997 \#2833). Dip-slip displacements on some of the faults are as much as $0.6 \mathrm{~km}$, and laterally offset structural trends suggest 2-4 km of lateral displacement on some faults.

On the basis of gravity and magnetic data, Braile and others, (1982 \#702) proposed that the Wabash Valley fault zone is part of the northeastern arm of a late Precambrian-early Phanerozoic rift complex in the central mid-continent. However subsequent studies indicate that the Wabash Valley faults are the expression of relatively minor tectonic structures and are probably not part of a failed rift arm (Hildenbrand and Ravat, 1997 \#2835). At present, the seismicity in the region cannot be directly associated with any bedrock structures at shallow depth, although a geophysical magnetic and gravity lineament seems to be a good candidate (Hildenbrand and Ravat, 1997 \#2835), and a possible fault zone has been located at depth (McBride and others, 1996 \#2836). The lineament, some $600 \mathrm{~km}$ in length, extends from Arkansas into the Wabash Valley, and terminates in the epicentral region of the strongest paleoearthquakes (M 7.5 and 7.1). Alternatively, McBride and others (1996 \#2836) have identified structural features in the upper crust that might correlate with the location of a M 5.5 earthquake that occurred in the area on November 9, 1968.

Some historical seismicity also persists throughout southern Indiana-Illinois, but the strongest events are concentrated in the vicinity of the Wabash Valley.

Sense of movement unknown

Comments: Earthquake focal mechanisms for events in the Wabash Valley region indicate dominantly strike-slip and reverse-slip motion (Herrmann, 1979 \#733; Taylor and others, 1989 \#699; Langer and Bollinger, 1991 \#700). Without knowledge of the structural features that are present at hypocentral depths, it is impossible to determine the preferred nodal planes for the focal mechanisms.

Dip unknown

Dip direction unknown

Geomorphic expression Causative fault do not have any surface expression. The only evidence of the paleoearthquakes (related to the strong ground motion) is liquefaction features exposed along the banks of major rivers in the study area (Obermeier and others, 1991 \#601; Munson and others, 1992 \#697; Obermeier and others, 1992 \#698, 1993 \#704; Hajic and others, 1995 \#2834; Munson and Munson, 1996 \#2838; Munson and others, 1997 \#2839; 1997 \#2840; McNulty and Obermeier, 1999 \#3906).

Age of faulted deposits Holocene and late Pleistocene

Paleoseismological studies Detailed studies of these paleoliquefaction features are those of (Obermeier and others, 1993 \#2841; Munson and Munson, 1996 \#2838; Pond and Martin, 1997 \#1363; Munson and others, 1997 \#2839; Obermeier, 1997 \#2840; McNulty and Obermeier, 1999 \#3906). These studies describe the characteristics and distribution of the dikes and offer magnitude estimates of earthquakes that likely caused the liquefaction. 
The persistent historical seismicity in the region suggested the possibility of significant seismic source zones in the region. A systematic search for paleoliquefaction features was begun in 1990, and more than 1000 paleoliquefaction dikes have been discovered. The dikes are typically filled with sand and gravel, are planar, and have a near-vertical orientation. In the river-bank exposures, many of the dikes extend as much as $4 \mathrm{~m}$ above the source beds. The maximum dike widths exceed $2.5 \mathrm{~m}$ at one site, $50 \mathrm{~cm}$ at 8 sites and $30 \mathrm{~cm}$ at several tens of sites. Liquefaction features from the strongest paleoearthquake, a magnitude of about 7.5 event that struck in about 6,100 yr BP in the Wabash Valley, cover an area that has a diameter of about $300 \mathrm{~km}$; based on the size and distribution of the dikes, the source region for the strongest earthquakes is in the vicinity of Vincennes, Indiana.

Timing of most recent paleoevent latest Quaternary $(<15 \mathrm{ka})$

Comments: At least seven notable paleoevents probably occurred during the Holocene, and one occurred about 12,000 yr BP. Nearly all events probably had magnitudes in excess of M 6. No historical earthquakes in the Wabash Valley region have been strong enough to cause liquefaction. It is likely that numerous other M 6-7 Holocene earthquakes have struck the region, but did not leave a record because of the lack of liquefiable deposits in large parts of the region.

\section{Recurrence interval Not reported}

Comments: Studies have not definitively determined recurrence intervals on individual faults, however a regional recurrence interval for $M>6$ earthquakes of at least every 500-1,000 years is reasonable in the southern half of Indiana and Illinois.

\section{Slip-rate category unknown}

Comments: Causative faults have not been identified in the Wabash Valley area. In the absence of well-determined data on the timing of paleoevents and the amount of tectonic slip associated with those events, it is impossible to estimate reliable or even meaningful Holocene or late Quaternary slip rates.

Length (km) Not applicable

Average strike (azimuth) Not applicable

\section{References}

\#2833 Bear, G.W., Rupp, J.A., and Rudman, A.J., 1997, Seismic interpretation of the deep structure of the Wabash Valley fault system: Seismological Research Letters, v. 68, no. 4, p. 624-640.

\#702 Braile, L.W., Keller, G.R., Hinze, W.J., and Lidiak, E.G., 1982, An ancient rift complex and its relation to contemporary seismicity in the New Madrid seismic zone:

Tectonics, v. 1, p. 225-237.

\#703 Bristol, H.M., and Treworgy, J.D., 1979, The Wabash Valley fault system in southeastern Illinois: Illinois State Geological Survey Circular 509, 19 p.

\#2834 Hajic, E.R., Wiant, M.D., and Oliver, J.J., 1995, Distribution and dating of prehistoric earthquake liquefaction in southeastern Illinois, Central U. S.: Final Report to the U.S. Geological Survey, 33 p. 
\#733 Herrmann, R.B., 1979, Surface wave focal mechanisms for eastern North American earthquakes with tectonic implications: Journal of Geophysical Research, v. 84, no. B7, p. 3543-3552.

\#2835 Hildenbrand, T.G., and Ravat, D., 1997, Geophysical setting of the Wabash Valley fault system: Seismological Research Letters, v. 68, no. 4, p. 567-585.

\#700 Langer, C.J., and Bollinger, G.A., 1991, The southeastern Illinois earthquake of 10 June 1987-The later aftershocks: Bulletin of the Seismological Society of America, v. 81, p. 423-445.

\#2836 McBride, J.H., Sargent, M.L., and Potter, C.J., 1996, Investigating possible earthquakerelated structure beneath the southern Illinois basin from seismic reflection: Seismological Research Letters, v. 67, no. 4, p. 641-649.

\#3906 McNulty, W.E., and Obermeier, S.F., 1999, Liquefaction evidence for at least two strong Holocene paleo-earthquakes in central and southwestern Illinois, USA: Environmental \& Engineering Geoscience, v. 5, no. 2, p. 133-146.

\#2838 Munson, P.J., and Munson, C.A., 1996, Paleoliquefaction evidence for recurrent strong earthquakes since 20,000 yr BP in the Wabash Valley area of Indiana: U.S. Geological Survey Final Report, 137 p.

\#697 Munson, P.J., Munson, C.A., Bleuer, N.K., and Labitzke, M.D., 1992, Distribution and dating of prehistoric earthquake liquefaction in the Wabash Valley of the Central U.S., in Johnston, A.C., Shedlock, K.M., Herrmann, R.B., and Hopper, M.G., eds., New Madrid special issue: Seismological Research Letters, v. 63, p. 337-342.

\#2839 Munson, P.J., Obermeier, S.F., Munson, C.A., and Hajic, E.R., 1997, Liquefaction evidence for Holocene and latest Pleistocene seismicity in the southern halves of Indiana and Illinois-A preliminary overview: Seismological Research Letters, v. 68, no. 4, p. 521-536.

\#2837 Nelson, W.J., 1996, Late Tertiary/Quaternary tectonism in southernmost Illinois [abs]: Seismological Research Letters, v. 67, no. 2, p. 48.

\#756 Nuttli, O.W., 1979, Seismicity of the Central United States, in Hatheway, A.W., and McClure, C.R., Jr., eds., Geology in the siting of nuclear power plants: Geological Society of America Reviews in Engineering Geology, v. 4, p. 67-93.

\#2840 Obermeier, S.F., 1997, Overview of liquefaction evidence for strong earthquakes of Holocene and latest Pleistocene ages in southern Indiana and Illinois: U.S. Geological Survey Open-File Report 96-724, 39 p.

\#601 Obermeier, S.F., Bleuer, N.R., Munson, C.A., Munson, P.J., Martin, W.S., McWilliams, K.M., Tabaczynski, D.A., Odum, J.K., Rubin, M., and Eggert, D.L., 1991, Evidence of strong earthquake shaking in the lower Wabash Valley from prehistoric liquefaction features: Science, v. 251, p. 1061-1063.

\#704 Obermeier, S.F., Martin, J.R., Frankel, A.D., Youd, T.L., Munson, P.J., Munson, C.A., and Pond, E.C., 1993, Liquefaction evidence for one or more strong Holocene earthquakes in the Wabash Valley of southern Indiana and Illinois, with a preliminary estimate of magnitude: U.S. Geological Survey Professional Paper 1536, 27 p. 
\#2841 Obermeier, S.F., Martin, J.R., Frankel, T.L., Munson, P.J., Munson, C.A., and Pond, E.C., 1993, Liquefaction evidence for one or more strong Holocene earthquakes in the Wabash Valley of southern Indiana and Illinois-U.S. estimated magnitudes and accelerations associated with prehistoric earthquakes in the Wabash Valley region of the Central United States: Seismological Research Letters, v. 68, no. 4, p. 611-623.

\#698 Obermeier, S.F., Munson, P.J., Munson, C.A., Martin, J.R., Frankel, A.D., Youd, T.L., and Pond, E.C., 1992, Liquefaction evidence for strong Holocene earthquake(s) in the Wabash Valley of Indiana-Illinois, in Johnston, A.C., Shedlock, K.M., Herrmann, R.B., and Hopper, M.G., eds., New Madrid special issue: Seismological Research Letters, v. 63, p. 321-335.

\#1363 Pond, E.C., and Martin, J.R., 1997, Estimated magnitudes and accelerations associated with prehistoric earthquakes in the Wabash Valley region of the Central United States: Seismological Research Letters, v. 68, p. 611-623.

\#699 Taylor, K.B., Herrmann, R.B., Hamburger, M.W., Pavlis, G.L., Johnston, A., Langer, C., and Lam, C., 1989, The southeastern Illinois earthquake of 10 June 1987:

Seismological Research Letters, v. 60, p. 101-110. 


\section{7, Faults of Thebes Gap area (Class A)}

Structure Number 1027

Structure Name Faults of Thebes Gap area (Class A)

Comments: The individual named faults discussed here are not sections of a single long fault. Instead, they are individual strands in a fault complex. They have different strikes, dips, slip senses, and slip histories, and they are only the best studied faults in an unnamed complex of named and unnamed faults that covers most of two adjacent 7.5-minute quadrangles. Most individual faults in the fault complex, and the longest faults, strike northeasterly to northnortheasterly, but numerous shorter cross faults strike easterly and northwest. Several Quaternary faults occur in the Thebes Gap area. The better known faults recognized to date are: English Hill fault zone, Commerce fault, Happy Hollow fault, Sassafras Canyon faults, Albrecht Creek fault, and Lambert trench at intersection of English Hill and Albrecht Creek faults.

Synopsis Quaternary faulting at English Hill was first recognized by in the early 1940's and described as a northeast-striking graben that down dropped the late Wisconsinan Peoria Loess. No further investigations were made on faulting at English Hill until the 1990's when the U.S. Geological Survey (USGS) and the Missouri Department of Natural Resources/Division of Geology and Land Survey (MDNR/DGLS) began cooperative studies in the area. These studies included trenching and geophysical investigations. Quaternary faulting along the Commerce fault was first recognized in 1994 from exposures in a road cut in Commerce, Missouri; the Happy Hollow fault and Sassafras Canyon faults were discovered in 1997 from fault-exploration trenching; and Quaternary faulting along the Albrecht Creek fault was discovered from detailed geologic mapping in 1994. The possibility of Quaternary faulting at the intersection of the English Hill and Albrecht Creek faults was raised by detailed geologic mapping and was substantiated by the Lambert trench.

Date of compilation 11/17/97; edited and reformatted as sectioned fault 5/27/99 by R.L. Wheeler

Compiler and affiliation Richard W. Harrison, U.S. Geological Survey

State Missouri, Illinois

County Scott (Missouri); Alexander (Illinois)

$1^{\circ} \times 2^{\circ}$ sheet Paducah, Kentucky, Illinois, Missouri, Indiana

Province Coastal Plain

Geologic setting The Thebes Gap area is located at the head of the Mississippi Embayment, approximately 15-20 miles north of the New Madrid seismic zone. Numerous north-northeast- to northeast-striking strike-slip faults and associated normal faults, high-angle reverse faults, folds, and transtensional pull-apart grabens have been recognized in the area (Harrison and Schultz, 1994 \#2822; Harrison, 1999 \#2821; Harrison and others, 1999 \#3415). These structures have had a long-lived and complex Phanerozoic tectonic history. Fault-zone kinematics indicate an overall right-lateral sense of movement on the north-northeast- to northeast-striking faults. However, individual faults typically display complex patterns. Step-overs 
in displacement between different strands have produced zones of transtension and transpression.

\section{Number of sections 6}

Comments: The faults discussed in detail in the following sections are part of a complex network of faults mapped by Harrison [1999 \#2821]. The individual "sections" described below are not sections of a single, continuous fault, but rather are descriptions of parts of individual faults that are members of this complex system.

Length not determined

Comments: The lengths of these individual faults is difficult to determine because they are part of an array of subparallel and interconnected faults that merge and diverge along strike. Because of these complex relations, it is difficult, if not impossible, to clearly identify terminations of specific faults.

Average strike (azimuth) not determined

Comments: The major faults in the complex system of faults in the Thebes Gap area trend north-northeasterly to northeasterly, but the converging and diverging character of the individual faults makes it difficult to identify termination points and thus compute an average strike.

\section{7a, English Hill fault zone}

Section number $1027 \mathrm{a}$

Section name English Hill fault zone

\section{Quality of location Good}

Comments: The fault zone was mapped at a scale of 1:24,000 by (Harrison, 1999 \#2821). Fault locations in trenches, cut banks, and road cuts are well known; extensions along strike are poorly constrained because of dense vegetation, extensive colluvial sedimentation, and the blanket-like nature of Quaternary loess that covers the area.

Sense of movement Dextral or Sinistral, Thrust, Reverse and Normal

Comments: Strike-slip, thrust, normal, and high-angle reverse faults are all represented at English Hill. See Harrison and others (1997 \#2823; 1999 \#3415) and Nelson and others (1999 \#3890) for details.

State Missouri, Illinois

County Scott, Missouri; Alexander, Illinois

$1^{\circ} \times 2^{\circ}$ sheet Paducah

Province Coastal Plain

\section{Sense of movement}

Dip $8^{\circ}$ - vertical

Comments: See Harrison and others (1999 \#3415) and Nelson and others (1999 \#3890) for details. 


\section{Main dip direction NW, SE, NE}

Geomorphic expression Subtle breaks in slope observed along some faults at English Hill.

Age of faulted deposits At least six and possibly seven Quaternary fault episodes are recognized at English Hill (Harrison and others, 1997 \#2823; 1999 \#3415). Faulted deposits include Pliocene-Pleistocene Mounds Gravel, Sangamon Geosol, Wisconsinan Roxana Silt, late Wisconsinan Peoria Loess, and Holocene colluvial-wedge deposits. The identification of faulted loesses was confirmed by thermoluminescence dating (see Harrison and others, 1997 \#2823; Nelson and others, 1999 \#3890). Faulted Holocene colluvial-wedge material contains charcoal that has yielded bimodal ${ }^{14} \mathrm{C}$ ages: eight samples from 4,980-4,740 yr B.P. and 1,310-1,210 yr B.P. (Harrison and others, 1999 \#3415).

Paleoseismological studies English Hill: (Palmer and others, 1997 \#1364; Harrison and others, 1997 \#2823; Palmer and others, 1997 \#2824; Nelson and others, 1999 \#3890). The approximate center of the English Hill site and its 11 trenches is at $37^{\circ} 08^{\prime} \mathrm{N}, 89^{\circ} 30^{\prime} \mathrm{W}$; center W1/2, sec. 34, T29N, R14E.

Timing of most prehistoric faulting latest Quaternary $(<15 \mathrm{ka})$

Recurrence interval Not reported

Slip-rate category unknown; probably $<0.2 \mathrm{~mm} / \mathrm{yr}$

Comments: No slip rate has been reported. However, a sustained slip rate of $0.2 \mathrm{~mm} / \mathrm{yr}$ would produce a cumulative slip of more than $2 \mathrm{~m}$ in Holocene time, which should leave a detectable geologic record. In the absence of any significant geomorphic expression of the fault, a slip rate of less than $0.2 \mathrm{~mm} / \mathrm{yr}$ seems likely.

Length not determined

Comments: Fault length is uncertain. The length of the English Hill fault zone is difficult to determine because it is part of an array of subparallel and interconnected faults that merge and diverge along strike. Because of these complex relations, it is difficult, if not impossible, to clearly identify the termination of a specific fault. If the English Hill, Albrecht Creek, and Lambert trench faults are the same and continuous, then their joint length could be as much as $12.8 \mathrm{~km}$

Average strike (azimuth) not determined

Comments: The major faults in the complex system of faults in the Thebes Gap area trend north-northeasterly to northeasterly, but the converging and diverging character of the individual faults makes it difficult to identify termination points and thus compute an average strike.

\section{$1027 b$, Commerce fault}

\section{Section number $1027 \mathrm{~b}$}

Section name Commerce fault

Quality of location Good

Comments: The fault was mapped at a scale of 1:24,000 by Harrison (1999 \#2821). Fault locations in trenches, cut banks, and road cuts are well known; extensions along strike are 
poorly constrained because of dense vegetation, extensive colluvial sedimentation, and the blanket-like nature of Quaternary loess that covers the area.

State Missouri, Illinois

County Scott, Missouri; Alexander, Illinois

$1^{\circ} \times 2^{\circ}$ sheet Paducah

Province Coastal Plain

\section{Sense of movement Not reported}

Comments: See Harrison and others (1999 \#3415) for details. Dextral faulting is constrained only to post-date the Pliocene-Miocene Mounds Gravel and pre-date the post-Wisconsinan Peoria Loess. Thus, dextral faulting might be of Pliocene age, and no proven Quaternary faulting is reported on this section of the fault complex.

Dip vertical

Comments: See Harrison (1995 \#2820) for details.

Main dip direction Not reported

\section{Geomorphic expression none}

Age of faulted deposits Cuts Pliocene-Pleistocene Mounds Gravel, does not cut late Wisconsinan Peoria Loess.

Paleoseismological studies Harrison and others (1999 \#3415). The studied exposure of the Commerce fault is at $37^{\circ} 09^{\prime} 31^{\prime \prime} \mathrm{N}, 89^{\circ} 26^{\prime} 57^{\prime \prime} \mathrm{W}$, or SW1/4 SW1/4 sec9, T16S, R3W.

Timing of most recent paleoevent late Quaternary $(<130 \mathrm{ka})$

\section{Recurrence interval Not reported}

Slip-rate category unknown; probably $<0.2 \mathrm{~mm} / \mathrm{yr}$

Comments: No slip rate has been reported. However, a sustained slip rate of $0.2 \mathrm{~mm} / \mathrm{yr}$ would produce a cumulative slip of more than $2 \mathrm{~m}$ in Holocene time, which should leave a detectable geologic record. In the absence of any significant geomorphic expression of the fault, a slip rate of less than $0.2 \mathrm{~mm} / \mathrm{yr}$ seem likely.

\section{Length:not determined}

Comments: Fault length is uncertain. The length of the Commerce fault is difficult to determine because it is poorly exposed, is largely mapped as a concealed structure, and is part of an array of subparallel and interconnected faults that merge and diverge along strike. Because of the poor exposure and these complex relations, it is difficult to clearly identify the termination of a specific fault. Therefore, a fault length has not been computed.

Average strike (azimuth) not determined

Comments: The general strike of the fault is northeasterly. However, the Commerce fault is poorly exposed, is mapped largely as a concealed structure, and studies of the fault are based on examination of limited exposures. Also, it is a member of a complex system of faults in the Thebes Gap area that trend north-northeasterly to northeasterly, but the converging and 
diverging character of the individual faults makes it difficult to identify termination points and thus compute an average strike.

\section{7c, Happy Hollow fault}

Section number $1027 \mathrm{c}$

Section name Happy Hollow fault

\section{Quality of location Good}

Comments: The fault was mapped at a scale of 1:24,000 by (Harrison, 1999 \#2821). Fault locations in trenches, cut banks, and road cuts are well known; extensions along strike are poorly constrained because of dense vegetation, extensive colluvial sedimentation, and the blanket-like nature of Quaternary loess that covers the area.

Sense of movement Reverse, Thrust

Comments: See Harrison and others (1999 \#3415) and Nelson and others (1999 \#3890) for details.

State Missouri

County Scott, Missouri

$1^{\circ} \times 2^{\circ}$ sheet Paducah

Province Coastal Plain

Dip $42^{\circ}-85^{\circ}$

Comments: See Harrison and others (1999 \#3415) and Nelson and others (1999 \#3890) for details.

Main dip direction NW, SE, SW

Geomorphic expression none

Age of faulted deposits Cuts Sangamon Geosol, Illinoian (?) colluvial-fluvial deposits of Metropolis Fm. (informal), and Pliocene-Pleistocene Mounds Gravel.

Paleoseismological studies Harrison and others (1999 \#3415) and Nelson and others (1999 \#3890). Fault length is uncertain. The trench exposure of the Happy Hollow fault is at $37^{\circ} 09^{\prime}$ $36.3^{\prime \prime} \mathrm{N}, 8^{\circ} 2^{\circ}$ 01.8"W, or SE1/4 SE1/4 sec24, T29N, R14E.

Timing of most recent paleoevent late Quaternary $(<130 \mathrm{ka})$

Recurrence interval Not reported

Slip-rate category unknown; probably $<0.2 \mathrm{~mm} / \mathrm{yr}$

Comments: No slip rate has been reported. However, a sustained slip rate of $0.2 \mathrm{~mm} / \mathrm{yr}$ would produce a cumulative slip of more than $2 \mathrm{~m}$ in Holocene time, which should leave a detectable geologic record. In the absence of any significant geomorphic expression of the fault, a slip rate of less than $0.2 \mathrm{~mm} / \mathrm{yr}$ seem likely. 


\section{Length:not determined}

Comments: Fault length is uncertain. The length of the Happy Hollow fault is difficult to determine because it is poorly exposed and is part of an array of subparallel and interconnected faults that merge and diverge along strike. Because of the poor exposure and these complex relations, it is difficult to clearly identify the termination of a specific fault. Therefore, a fault length has not been computed.

Average strike (azimuth) not determined

Comments: The general strike of the fault is northeasterly. However, the Happy Hollow fault is poorly exposed, is mapped largely as a concealed structure, and studies of the fault are based on examination of limited exposures. Also, it is a member of a complex system of faults in the Thebes Gap area that trend north-northeasterly to northeasterly, but the converging and diverging character of the individual faults makes it difficult to identify termination points and thus compute an average strike.

\section{7d, Sassafras Canyon faults}

\section{Section number $1027 \mathrm{~d}$}

Section name Sassafras Canyon faults

\section{Quality of location Good}

Comments: The faults were mapped at a scale of 1:24,000 by (Harrison, 1999 \#2821). Fault locations in trenches, cut banks, and road cuts are well known; extensions along strike are poorly constrained because of dense vegetation, extensive colluvial sedimentation, and the blanket-like nature of Quaternary loess that covers the area.

State Missouri

County Scott, Missouri

$1^{\circ} \times 2^{\circ}$ sheet Paducah

Province Coastal Plain

Sense of movement Reverse, Thrust, Dextral

Comments: See Harrison and others (1999 \#3415) and Nelson and others (1999 \#3890) for details.

Dip $20^{\circ}$ - vertical

Comments: See Harrison and others (1999 \#3415) and Nelson and others (1999 \#3890) for details.

Main dip direction NW, SW, SE, NE

Geomorphic expression none

Age of faulted deposits Faults cut Pliocene-Pleistocene Mounds Gravel and Holocene colluvial deposits $\left({ }^{14} \mathrm{C}\right.$ ages pending), related folds deform Illinoisian (?) Metropolis Fm. 
Paleoseismological studies Harrison and others (1999 \#3415) and Nelson and others (1999 \#3890). The trench exposures of the faults in Sassafras Canyon are at 37 09' 39.3'N, 89 $27^{\prime}$ 10.4"W, or NW1/4 SE1/4 sec24, T29N, R14E.

Timing of most recent paleoevent late Quaternary $(<130 \mathrm{ka})$

Recurrence interval Not reported

Slip-rate category unknown; probably $<0.2 \mathrm{~mm} / \mathrm{yr}$

Comments: No slip rate has been reported. However, a sustained slip rate of $0.2 \mathrm{~mm} / \mathrm{yr}$ would produce a cumulative slip of more than $2 \mathrm{~m}$ in Holocene time, which should leave a detectable geologic record. In the absence of any significant geomorphic expression of the fault, a slip rate of less than $0.2 \mathrm{~mm} / \mathrm{yr}$ seem likely.

\section{Length not determined}

Comments: Fault length is uncertain. The length of the Sassafras Canyon fault is difficult to determine because it is poorly exposed and is part of an array of subparallel and interconnected faults that merge and diverge along strike. Because of the poor exposure and these complex relations, it is difficult to clearly identify the termination of a specific fault. Therefore, a fault length has not been computed.

Average strike (azimuth) not determined

Comments: The general strike of the fault is northeasterly. However, the Sassafras Canyon fault is poorly exposed, is mapped largely as a concealed structure, and studies of the fault are based on examination of limited exposures. Also, it is a member of a complex system of faults in the Thebes Gap area that trend north-northeasterly to northeasterly, but the converging and diverging character of the individual faults makes it difficult to identify termination points and thus compute an average strike.

\section{7e, Albrecht Creek fault}

\section{Section number $1027 \mathrm{e}$}

Section name Albrecht Creek fault

\section{Quality of location Good}

Comments: The fault was mapped at a scale of 1:24,000 by (Harrison, 1999 \#2821). Fault locations in trenches, cut banks, and road cuts are well known; extensions along strike are poorly constrained because of dense vegetation, extensive colluvial sedimentation, and the blanket-like nature of Quaternary loess that covers the area.

State Missouri, Illinois

County Scott, Missouri; Alexander, Illinois

$1^{\circ} \times 2^{\circ}$ sheet Paducah

Province Coastal Plain

Sense of movement Sinistral, Reverse

Comments: See Harrison and others (1999 \#3415) and Nelson and others (1999 \#3890) for details. 
Dip $68^{\circ}-85^{\circ}$

Comments: See Harrison and others (1999 \#3415) and Nelson and others (1999 \#3890) for details.

Main dip direction NE, NW, SW

Geomorphic expression none

Age of faulted deposits Fault cuts Pliocene-Pleistocene Mounds Gravel and Ilinoisian (?) Metropolis Formation; it does not cut Holocene terrace deposits that contains charcoal dated by ${ }^{14} \mathrm{C}$ at 1,540 B.P.

Paleoseismological studies Harrison and others (1999 \#3415) and Nelson and others (1999 \#3890). The cutbank that exposes the Albrecht Creek fault is at $37^{\circ} 10^{\prime} 58.5^{\prime \prime} \mathrm{N}, 89^{\circ} 27^{\prime}$ 54.8"W, or NW1/4 SW1/4 sec13, T29N, R14E.

Timing of most recent paleoevent late Quaternary $(<130 \mathrm{ka})$

Recurrence interval Not reported

Slip-rate category unknown; probably $<0.2 \mathrm{~mm} / \mathrm{yr}$

Comments: No slip rate has been reported. However, a sustained slip rate of $0.2 \mathrm{~mm} / \mathrm{yr}$ would produce a cumulative slip of more than $2 \mathrm{~m}$ in Holocene time, which should leave a detectable geologic record. In the absence of any significant geomorphic expression of the fault, a slip rate of less than $0.2 \mathrm{~mm} / \mathrm{yr}$ seem likely.

Length:not determined

Comments: Fault length is uncertain. The length of the Albrecht Creek fault is difficult to determine because it is poorly exposed and is part of an array of subparallel and interconnected faults that merge and diverge along strike. Because of the poor exposure and these complex relations, it is difficult to clearly identify the termination of a specific fault.

Therefore, a fault length has not been computed.

Average strike (azimuth) not determined

Comments: The general strike of the fault is north-northeasterly. However, the Albrecht Creek fault is poorly exposed and studies of the fault are based on examination of limited exposures. Also, it is a member of a complex system of faults in the Thebes Gap area that trend north-northeasterly to northeasterly, but the converging and diverging character of the individual faults makes it difficult to identify termination points and thus compute an average strike. If the English Hill, Albrecht Creek and Lambert trench faults are the same structure and are continuous, then their joint length could be as much as $12.8 \mathrm{~km}$.

1027f, Lambert trench at intersection of English Hill and Albrecht Creek faults

\section{Section number $1027 \mathrm{f}$}

Section name Lambert trench at intersection of English Hill and Albrecht Creek faults

\section{Quality of location Good}

Comments: The faults were mapped at a scale of 1:24,000 by (Harrison, 1999 \#2821). Fault locations in trenches, cut banks, and road cuts are well known; extensions along strike are 
poorly constrained because of dense vegetation, extensive colluvial sedimentation, and the blanket-like nature of Quaternary loess that covers the area.

State Illinois

County Alexander

$1^{\circ} \times 2^{\circ}$ sheet Paducah

Province Coastal Plain

Sense of movement Not reported

Comments: See Harrison and others (1999 \#3415) for details. Two faults show normal slip.

Dip Not reported

Comments: See Harrison and others (1999 \#3415) for details. Faults dipping nearly vertically to the SE and $\mathrm{W}$ were exposed in the bottom of a trench, but dip values are not reported.

Main dip direction SE, $\mathrm{W}$

Geomorphic expression none

Age of faulted deposits Fault offsets Holocene gravel dated by the radiocarbon method at $6,310 \pm 100$ yr B.P. by ${ }^{14} \mathrm{C}$ but does not cut Holocene gravel dated at $6,085 \pm 95 \mathrm{yr}$ B.P.

Paleoseismological studies Lambert trench: (Wiscombe, 1997, unpublished \#2826). The trench is at $37^{\circ} 14^{\prime} 45.6^{\prime \prime} \mathrm{N}, 89^{\circ} 25^{\prime} 50.8^{\prime \prime} \mathrm{W}$, or NE1/4 SW1/4 sec3, T15S, R3W.

Timing of most recent paleoevent latest Quaternary $(<15 \mathrm{ka})$

\section{Recurrence interval Not reported}

Slip-rate category unknown; probably $<0.2 \mathrm{~mm} / \mathrm{yr}$

Comments: No slip rate has been reported. However, a sustained slip rate of $0.2 \mathrm{~mm} / \mathrm{yr}$ would produce a cumulative slip of more than $2 \mathrm{~m}$ in Holocene time, which should leave a detectable geologic record. In the absence of any significant geomorphic expression of the fault, a slip rate of less than $0.2 \mathrm{~mm} / \mathrm{yr}$ seem likely.

Length End to end (km): Not applicable

Cumulative trace $(\mathrm{km})$ : Not applicable

Comments: This discussion refers to a paleoseismic study at a specific site where the Engish Hill and Albrecht Creek faults converge. Therefore it is not appropriate to determine a length from a single point on a fault. However, if the English Hill, Albrecht Creek and Lambert trench faults are the same structure and are continuous, then their joint length could be as much as $12.8 \mathrm{~km}$.

Average strike (azimuth) not determined

Comments: The general strikes of faults in the Thebes Gap area are north-northeasterly to northeasterly, but the converging and diverging character of the individual faults makes it difficult to identify termination points and thus compute an average strike. Furthermore, the relations of faults studied at this site to faults that were mapped in the area are not definitively known. 


\section{References}

\#2820 Harrison, R.W., 1995, Chapter 7. Report on investigations of the Benton Hills, Scott County, Missouri, in Esling, S.P., and Blum, M.D., eds., Quaternary sections in southern Illinois and southeast Missouri: Midwest Friends of the Pleistocene, 42nd Annual Meeting, Southern Illinois University, Carbondale, May 19-21, 1995, Guidebook.

\#2821 Harrison, R.W., 1999, Geologic map of the Thebes 7.5-minute quadrangle, Illinois and Missouri: U.S. Geological Survey Geologic Quadrangle Map GQ-1779, scale $1: 24,000$.

\#3415 Harrison, R.W., Hoffman, D., Vaughn, J.D., Palmer, J.R., Wiscombe, C.L., McGeehin, J.P., Stephenson, W.J., Odum, J.K., Williams, R.A., and Forman, S.L., 1999, An example of neotectonism in a continental interior-Thebes Gap, Midcontinent, United States: Tectonophysics, v. 305, no. 1-3, p. 399-417.

\#2823 Harrison, R.W., Palmer, J.R., Hoffman, D., Vaughn, J.D., Forman, S.L., McGeehin, J., and Frederiksen, N.O., 1997, Profiles and documentation of fault-exploration trenches in the English Hill area, Scott City 7.5-minute quadrangle, Missouri: U.S. Geological Survey Open-File Report 97-474, 111 p.

\#2822 Harrison, R.W., and Schultz, A., 1994, Strike-slip faulting at Thebes Gap, MissouriIllinois-Implications for New Madrid tectonism: Tectonics, v. 13, no. 2, p. 246-257.

\#3890 Nelson, W.J., Harrison, R.W., and Hoffman, D., 1999, Neotectonics of the northern Mississippi embayment: Illinois State Geological Survey Guidebook 30, 34 p.

\#2824 Palmer, J.R., Hoffman, D., Stephenson, W.J., Odum, J.K., and Williams, R.A., 1997, Shallow seismic reflection profiles and geologic structure in the Benton Hills, southeast Missouri: Engineering Geology, v. 46, p. 217-233.

\#1364 Palmer, J.R., Shoemaker, M., Hoffman, D., Anderson, N.L., Vaughn, J.D., and Harrison, R.W., 1997, Seismic evidence of Quaternary faulting in the Benton Hills area, southeast Missouri: Seismological Research Letters, v. 68, p. 650-661.

\#2825 Stewart, D.R., 1942, unpublished, The Mesozoic and Cenozoic geology of southeastern Missouri: Missouri Division of Geology and Water Resources, 115 p.

\#2826 Wiscombe, C., 1997, Evidence of Neotectonic activity north of the New Madrid seismic zone, Thebes quadrangle, Illinois: Southern Illinois University, unpublished M.S. thesis, $177 \mathrm{p}$. 


\section{8, Fluorspar Area Fault Complex (Class A)}

\section{Structure Number 1028}

\section{Structure Name Fluorspar Area Fault Complex (class A)}

Comments: The name Fluorspar Area fault complex refers to the multitude of fractures in the fluorspar-mining district of southern Illinois and western Kentucky. Fault orientations vary, but most trend NE-SW in Illinois, curving to ENE-WSW eastward into Kentucky. Most faults dip 65 degrees or steeper and they comprise normal, reverse, strike-slip, and obliqueslip faults, many showing evidence of two or more episodes of movement. Associated with faulting are Permian ultramafic dikes, sills, diatremes, and a large intrusive breccia structure known as Hicks Dome. This was historically the richest fluorite-mining district in the United States. Sizeable quantities of lead, zinc, silver, barite, and other minerals also were mined from vein and bedded-replacement deposits. The Fluorspar Area Fault Complex overlies the junction area of a Proterozoic-Cambrian failed rift complex that consists of the northeasttrending Reelfoot rift and the east-trending Rough Creek graben. Of more than passing significance, the New Madrid seismic zone also lies within the Reelfoot Rift and is directly in line with the Fluorspar Area fault complex. Good overviews of the structure of the Fluorspar Area Fault Complex are found in Hook (1974 \#3885), Trace and Amos (1984 \#3895), Nelson (1991 \#3887), and Potter and others (1995 \#3892).

See other fields on individual sections that show Quaternary movement.

Synopsis: In most of the area of the Fluorspar Area fault complex, thin and patchy Quaternary sediments overlie Paleozoic bedrock, and the time of faulting is known only to be postPennsylvanian. Younger movement comes to light where the faults pass southwestward into thicker Cretaceous, Tertiary, and Quaternary deposits of the Mississippi Embayment. Mapping in southernmost Illinois, Ross (1963 \#3893; 1964 \#3894) interpreted Tertiary and possible Quaternary displacements on some faults of the complex. However, Kolata and others (1981 \#3886), reviewing the evidence, concluded that no post-Cretaceous tectonism could be demonstrated. Tertiary and Quaternary activity in the Fluorspar Area fault complex finally was documented through detailed geologic mapping combined with test drilling, highresolution seismic surveys, and trenching (Nelson and others, 1997 \#3888; 1999 \#3889; 1999 \#3890). In Kentucky, geologic quadrangle maps depict faults of the Fluorspar Area fault complex displacing the Mounds Gravel, which is of late Miocene to early Pleistocene age (Amos and Wolfe, 1966 \#3882; Amos, 1967 \#3880; 1974 \#3881). Together, these studies reveal multiple episodes of post-Cretaceous tectonic activity in the Fluorspar Area fault complex. Narrow NE- to NNE-trending grabens that contain Tertiary and Pleistocene (Illinoian and older) sediments are characteristic. Several grabens show more than $30 \mathrm{~m}$ of dip-slip offset on Pleistocene units; in one case the throw may exceed $150 \mathrm{~m}$. Deformation of Wisconsinan sediments is localized and small, less than $3 \mathrm{~m}$. No Holocene movement has been detected.

Date of compilation $12 / 28 / 99$; edited $1 / 28 / 00$ by R.L. Wheeler

Compiler and affiliation W. John Nelson, Illinois State Geological Survey

State Illinois; Kentucky 
County Massac, Pulaski (Illinois); Livingston (Kentucky)

$1^{\circ} \times 2^{\circ}$ sheet Paducah

Province Interior Low Plateaus; Coastal Plain

Geologic setting The area where Quaternary displacements of the Fluorspar Area fault complex are known is at the northern edge of the Mississippi Embayment, an extension of the Coastal Plain. Cretaceous and lower Tertiary sediments of the Embayment overlap mainly Mississippian-age bedrock of the Shawnee Hills. The study area lies just south of the southernmost limit of Pleistocene continental glaciation. All uplands are mantled in wind-blown Pleistocene silt known as loess. Valley bottoms contain a variety of Quaternary fluvial and lacustrine deposits. Following are descriptions of field work done on each section.

Section 1028a (Rock Creek graben): A 10-meter-wide section of the bank of Mallard Creek was cleared with a backhoe, and we drilled several shallow test holes close to the creek (Nelson and others, 1999 \#3889). The test holes did not indicate significant displacement of Quaternary deposits. However, the backhoe exposure showed two episodes of Quaternary faulting.

Section 1028b (Barnes Creek fault zone): Exposures in the banks of Barnes Creek were examined repeatedly and logged, and some were improved using hand tools and heavy equipment. No datable material was found. A seismic reflection profile, $2 \mathrm{~km}$ long, was conducted along the creek, and numerous test borings were made. See Nelson and others (1997 \#3888; 1999 \#3889; 1999 \#3890). Kolata and others (1981 \#3886) discussed the "Metropolis site", which may be part of the Barnes Creek fault zone. Faults formerly were exposed (at low water) on the bank of the Ohio River near historic Fort Massac in the city of Metropolis. One fault displaced the Mounds Gravel, four others displaced Cretaceous strata but not the Mounds. The faults described by Kolata and others now are covered by concrete and riprap.

Section 1028c (Hobbs Creek fault zone): Ross (1963 \#3893; 1964 \#3894) and Kolata and others (1981 \#3886) reported an outcrop of tilted Mounds Gravel at abnormally low elevation along a narrow, linear valley in line with known faults. Kolata and others conducted seismic and earth-resistivity surveys, but the results were ambiguous, and origin of the structure remained unknown. Nelson (1996 \#3898) mapped the area at 1:24,000 scale, finding additional outcrops that strengthened the tectonic hypothesis. A cored test hole drilled in 1995 demonstrated a deep graben filled with Neogene to Quaternary sediment. Follow-up studies included two seismic-reflection surveys, a ground-penetrating radar survey (inconclusive), many shallow test holes, and a second, deeper, cored test hole (Nelson and others, 1997 \#3888; 1999 \#3889; 1999 \#3890).

Section 1028d (Raum fault zone): Post-Cretaceous tectonic faulting along this zone was first identified at the Reineking Hill site (Nelson, 1996 \#3898; Nelson and others, 1997 \#3888). Geologic mapping farther southwest at 1:24,000 scale (W.J. Nelson and J.M. Masters, unpublished data) indicated that the Mounds Gravel, and locally the Metropolis Formation is faulted. Follow-up studies included a seismic reflection survey, ground-penetrating radar (which yielded no useful data), and numerous test borings (Nelson and others, 1999 \#3889).

Section 1028e (Lusk Creek fault zone): Geologic mapping in the Joppa Quadrangle at 1:24,000 scale indicated possible Quaternary displacement along the Lusk Creek (W.J. Nelson 
and J.M. Masters, unpublished data). The log and samples (incomplete) from a water well at the Maple Grove School suggested a graben. We ran a high-resolution seismic survey and drilled seven shallow test holes along the seismic line. Then we drilled a cored test hole to bedrock at the Maple Grove School.

Section 1028f (Kelley structure): Many test pits and soil borings were made in the railroad cut, then a backhoe removed soil from the entire width of the structure on the north side of the tracks, and the geology was logged in detail. Two seismic-reflection profiles were run, one adjacent to the railroad, the other about $0.4 \mathrm{~km}$ south of and parallel to the tracks (Nelson and others, $1999 \# 3889$ ).

\section{Number of sections 6}

Length Not applicable

Comments: Nelson and others (1999 \#3889) demonstrated Quaternary faulting at seven sites on six fault sections. The lengths of Quaternary ruptures are unknown.

Average strike Not applicable

Comments: Average strikes are given for each section, where available. The sections are parallel, independent faults, instead of adjoining sections of the same fault.

\section{8a, Rock Creek graben}

\section{Section number $1028 \mathrm{a}$}

Section name Rock Creek graben

Comments: The Rock Creek graben is a large, complex graben of the Fluorspar Area Fault Complex. The Rock Creek follows a curving path southwestward from Union County, Kentucky into Hardin County, Illinois, back into Kentucky, finally returning to Pope and Massac Counties, Illinois where Quaternary activity is in evidence.

\section{Reliability of location Good}

Comments: Like other structures of the Fluorspar Area Fault Complex, the Rock Creek graben is exposed directly in a few places, accurately mapped at some, and covered by surficial materials along much of its trace. Quaternary displacements are known from a single site, the bank of Mallard Creek in NE 1/4 SW 1/4, Sec. 20, T15S, R6E, Massac County, Illinois.

\section{Sense of movement Normal; reverse}

Comments: The exposure on Mallard Creek that showed Quaternary faulting was only $10 \mathrm{~m}$ wide, and it revealed two faults that strike N. $25^{\circ}$ E., two that strike N. $55^{\circ} \mathrm{W}$., and one that strikes N. $10^{\circ}$ E. On none of these were any slip indicators observed. Overall, the Rock Creek graben is composed dominantly of high-angle normal faults that trend northeast.

Dip $80^{\circ}-90^{\circ}$

Comments: At Mallard Creek. 


\section{Dip direction E, NE, W, NW}

Comments: The small exposure on Mallard Creek shows faults having a variety of trends (see "Sense of movement" entry).

Geomorphic expression Linear ridges and valleys along the fault zone reflect differential erosion of hard and soft material. Within the Mississippi Embayment area, several streams run parallel with the inferred fault trace, but this may be coincidence. At Mallard Creek the fault zone is not expressed in the topography.

Age of faulted deposits At Mallard Creek, faults offset a gravel younger than the Pleistocene Metropolis Formation, the Metropolis Formation (Pleistocene; Illinoian and older), and the McNairy Formation (Cretaceous). Age of the younger gravel was not determined due to lack of dateable material; most likely, the gravel is Wisconsinan. The uppermost $1 \mathrm{~m}$ of sediment, which almost certainly is Holocene, is not deformed (Nelson and others, 1999 \#3889).

\section{Paleoseismological studies None}

Timing of most recent paleoevent late Quaternary $(<130 \mathrm{ka})$

Recurrence interval Not reported

Slip-rate category $<0.2 \mathrm{~mm} / \mathrm{yr}$

Comments: Sediments more than 100,000 years old are displaced only about 1 meter.

Length Not applicable

Comments: The length of Quaternary rupture is unknown because it was demonstrated at only one site.

Average strike $+35^{\circ}$

Comments: This value was measured on fig. 2 of Nelson and others (1999 \#3889), as the strike of the fault zone at the Mallard Creek site.

\section{8b, Barnes Creek fault zone}

\section{Section number $1028 \mathrm{~b}$}

Section name Barnes Creek fault zone

Comments: The fault zone has been mapped about $40 \mathrm{~km}$ across Illinois (Baxter and others, 1967 \#3883, W.J. Nelson, unpublished mapping). It strikes NE-SW, and along most of its length consists of either a single fault or a pair of faults that outline a graben less than $300 \mathrm{~m}$ wide. Where it enters the Mississippi Embayment, the Barnes Creek widens to nearly $2 \mathrm{~km}$ and becomes much more complex. It is here that Quaternary deformation has been demonstrated.

\section{Reliability of location Good}

Comments: Like other elements of the Fluorspar Area Fault Complex, the Barnes Creek fault zone is largely concealed by surficial materials, but it is accurately mapped in a number of places, and numerous exposures of fault surfaces have been found or dug out. Quaternary displacements are principally known from Barnes Creek in Massac County, Illinois (Sec. 9, T15S, R5E). 
Sense of movement Normal; reverse

Comments: Strike-slip component is strongly suspected, but unproven. A seismic profile shows positive and negative flower structures. Deep, narrow grabens that resemble pull-apart grabens are common.

Dip $45^{\circ}-90^{\circ}$

Comments: Most faults dip 65 degrees or steeper.

\section{Dip direction E, W}

Comments: Most common is ESE-WNW to SE-NW, but some faults dip E-W to ENE-WSW. East and west dips are about equally represented. Pairs of faults commonly outline grabens that range from a few $\mathrm{cm}$ to tens of meters wide.

Geomorphic expression In Paleozoic bedrock uplands, well-defined linear valleys mark the fault trace(s), and probably reflect enhanced erosion of fractured rock in the fault zone. Within the Mississippi Embayment, northeast-southwest alignment of ridges and valleys is apparent in some places, but not in others. There is no sign of the fault zone where it passes under late Wisconsinan and Holocene alluvial/lacustrine valley fill.

Age of faulted deposits Many faults juxtapose the Cretaceous McNairy Formation with the Metropolis Formation, a pebbly silt/sand unit of early to middle Pleistocene age. The youngest part of the Metropolis is probably Illinoian, as indicated by Sangamon Geosol developed in the upper part of the unit. In one graben, the base of the Metropolis is displaced at least $27 \mathrm{~m}$. A few faults offset the Sangamon Geosol itself, along with overlying silts and gravels. These deposits most likely are Wisconsinan age, although Holocene age cannot be ruled out. The largest post-Sangamon displacement is approximately 1 meter. No faults penetrate the uppermost $3 \mathrm{~m}$ of sediment, which is probably Holocene.

Paleoseismological studies Exposures in the banks of Barnes Creek were examined repeatedly and logged, and some were improved using hand tools and heavy equipment. No datable material was found. A seismic reflection profile $2 \mathrm{~km}$ long was conducted along the creek, and numerous test borings were made. See Nelson and others (1997 \#3888; 1999 \#3889; 1999 \#3890). Five kilometers north of the Barnes Creek site, along Massac Creek, another exposure of the Barnes Creek fault zone also shows Quaternary faulting. Kolata and others (1981 \#3886) discussed the "Metropolis site", which may be part of the Barnes Creek fault zone. Faults formerly were exposed (at low water) on the bank of the Ohio River near historic Fort Massac in the city of Metropolis. One fault displaced the Mounds Gravel, four others displaced Cretaceous strata but not the Mounds. The faults described by Kolata and others now are covered by concrete and riprap.

Timing of most recent paleoevent late Quaternary $(<130 \mathrm{ka})$

\section{Recurrence interval Not reported}

Comments: Nelson and others (1999 \#3889, p. 394) estimated tens of thousands of years between events that produced surface rupture.

Slip-rate category $<0.2 \mathrm{~mm} / \mathrm{yr}$

Comments: Nelson and others (1999 \#3889, p. 394) estimated a rate of 0.01 to $0.03 \mathrm{~mm} /$ year 
for dip-slip displacement in Quaternary grabens. If the faults have a strike-slip component, the net slip rate may be considerably different from the measured dip-slip.

\section{Length $5 \mathrm{~km}$}

Comments: Probably the length of Quaternary rupture is at least $5 \mathrm{~km}$, because Quaternary ruptures were demonstrated at two sites that far apart along the fault zone (see "Paleoseismological studies").

Average strike $+45^{\circ}$

Comments: This value was measured on fig. 2 of Nelson and others (1999 \#3889), as the strike of the fault zone at the Westerman graben site.

\section{8c, Hobbs Creek fault zone}

\section{Section number $1028 \mathrm{c}$}

Section name Hobbs Creek fault zone

\section{Reliability of location Good}

Comments: Like other elements of the Fluorspar Area Fault Complex, the Hobbs Creek is exposed in a few places, accurately located in many places, and totally concealed by surficial deposits in other places. At the Massac Creek site, where Quaternary deformation is documented, the faults are accurately located by means of borehole and geophysical data.

Sense of movement Normal; reverse

Comments: Seismic profiles show that most faults are high-angle normal, but a few reverse faults are present. As with other faults listed here, strike-slip appears likely, but no information on the magnitude or direction of strike-slip is available.

Dip $70^{\circ}-90^{\circ}$

\section{Dip direction SE, NW}

Comments: Northwest and southeast dips are about equally represented. Pairs of faults commonly outline grabens and horsts. The southeast dip is listed first and regarded as dominant, because the interior of the Massac Creek graben at the study site dips northwest into the southeast-dipping normal fault (Nelson and others, 1997 \#3888).

Geomorphic expression Like other fault zones of the Fluorspar Area Fault Complex, the Hobbs Creek is expressed by linear ridges and valleys where it crosses bedrock uplands. At the Massac Creek site, within the Mississippi Embayment, a valley coincides with the fault zone. Faults have no expression where they pass under Quaternary alluvium.

Age of faulted deposits At the Massac Creek site the youngest unit known to be faulted is the Metropolis Formation, which comprises Illinoian and older Pleistocene alluvial deposits. Core-drilling in a deep graben shows the Metropolis downthrown approximately $30 \mathrm{~m}$. Beneath the Metropolis are found, in descending order, $79 \mathrm{~m}$ of unidentified Neogene to lower Pleistocene sand, silt, and clay; $12 \mathrm{~m}$ of Miocene to Pliocene Mounds Gravel, $11 \mathrm{~m}$ of Paleocene Midway Group, and finally $37 \mathrm{~m}$ of Cretaceous strata (bottom not reached). Evidently, this graben subsided intermittently through much of Tertiary and Pleistocene time. No displacement of Wisconsinan loess or Holocene alluvium can be detected. 


\section{Paleoseismological studies None}

Timing of most recent paleoevent middle and late Quaternary $(<750 \mathrm{ka})$

Recurrence interval Not reported

Comments: Nelson and others (1999 \#3889, p. 394) estimated tens of thousands of years between events that produced surface rupture.

Slip-rate category $<0.2 \mathrm{~mm} / \mathrm{yr}$

Comments: The Massac Creek graben contains about $120 \mathrm{~m}$ of upper Miocene and younger sediments. Dividing $120 \mathrm{~m}$ into roughly 10 million years yields $0.012 \mathrm{~mm} / \mathrm{year}$ for the average rate of graben subsidence. This estimate does not allow for possible strike-slip motion.

\section{Length $1 \mathrm{~km}$}

Comments: The length of Quaternary rupture is probably at least $1 \mathrm{~km}$. Drilling showed that the Pleistocene Metropolis Formation is displaced in the Massac Creek graben at Weaver farms and Rosebud Road, $1 \mathrm{~km}$ apart.

Average strike $+20^{\circ}$

Comments: This value was measured on fig. 2 of Nelson and others (1999 \#3889), as the strike of the fault zone at the Massac Creek site.

\section{8d, Raum fault zone}

\section{Section number $1028 \mathrm{~d}$}

Section name Raum fault zone

Comments: The Raum fault zone outlines the southeast side of the Dixon Springs graben, one of several large, complex grabens within the Fluorspar Area Fault Complex. Where the Raum enters the Mississippi Embayment, it displaces Cretaceous strata and the Miocene to lower Pleistocene Mounds Gravel. Detailed investigations were carried out at the Choat site in western Massac County, Illinois.

\section{Reliability of location Good}

Comments: As with other segments of the Fluorspar Area Fault Complex, a few faults of the Raum fault zone are exposed, some are accurately located by outcrop and borehole data, but large extents of the zone are concealed by surficial deposits.

Sense of movement Normal; reverse

Comments: Most faults are high-angle normal, but high-angle reverse faults are present. Two or more episodes of displacement are indicated (Weibel and others, 1993 \#3896). A strikeslip component is suspected, but cannot be documented.

Dip $70^{\circ}-90^{\circ}$

Comments: Most faults dip 70 degrees or steeper. 


\section{Dip direction SE, NW}

Comments: Southeast and northwest dips are about equally represented. Faults commonly outline narrow grabens and horsts. The southeast dip is listed first and considered dominant, because the southeast-dipping border fault of a graben that contains the study site is longer than the northwest-dipping border fault (Nelson and others, 1997 \#3888).

Geomorphic expression Linear ridges and valleys mark the fault trace across bedrock uplands. Subtle alignment of ridges and valleys can be detected within the Mississippi Embayment. There is no topographic expression in alluvial bottom lands.

Age of faulted deposits The youngest unit affected is the Metropolis Formation, an alluvial deposit of early to middle Pleistocene (Illinoian) age. Small northeast-trending faults having $1 \mathrm{~m}$ or less of throw were observed cutting Metropolis Formation along a stream southwest of Choat. These faults are truncated by undisturbed Holocene alluvium. At the Metropolis city landfill, part of the Choat site, the Mounds Gravel (Miocene to lower Pleistocene) is tilted and faulted, and unconformably overlain by horizontal, unfaulted loesses: the Loveland Silt (Illinoian), and the Roxana and Peoria Silts (Wisconsinan). Drilling elsewhere in the Choat area suggests the Metropolis Formation is faulted, but younger sediments are unaffected.

\section{Paleoseismological studies None}

Timing of most recent paleoevent middle and late Quaternary (<750 ka)

\section{Recurrence interval Not reported}

Slip-rate category unknown; probably $<0.2 \mathrm{~mm} / \mathrm{yr}$

\section{Length Not applicable}

Comments: The length of Quaternary rupture is unknown because it was demonstrated at only two sites, which are on different strands of the same fault zone.

\section{Average strike $+24^{\circ}$}

Comments: This value was measured on fig. 2 of Nelson and others (1999 \#3889), as the average of the strikes of the fault zone at Reineking Hill site $\left(+20^{\circ}\right)$ and the Choat site $\left(+27^{\circ}\right)$.

\section{8e, Lusk Creek fault zone}

\section{Section number $1028 \mathrm{e}$}

\section{Section name Lusk Creek fault zone}

Comments: The Lusk Creek fault zone delimits the northwest margin of the Fluorspar Area Fault Complex and also was a northwest boundary fault of the Proterozoic-Cambrian Reelfoot Rift. The southeast-dipping master fault was a normal fault during the Cambrian, a reverse fault during the Alleghenian Orogeny, and a normal fault again later (Nelson, 1991 \#3887). The net displacement is down to the southeast and increases toward the northeast, where the Lusk Creek merges with the western end of the Rough Creek Fault System.

\section{Reliability of location Good}

Comments: In bedrock uplands this fault zone has strong geomorphic expression, and outcrops of deformed rocks are numerous. Within the Mississippi Embayment, mapping is 
based almost entirely on subsurface data. At the Maple Grove site, faults are imaged on a high-resolution seismic profile.

Sense of movement Normal; reverse

Comments: Principally high-angle normal faults, but high-angle reverse faults are present. The fault zone has undergone at least two reversals of displacement. In the northeastern part of the fault zone, outcrop data signify dominantly dip-slip displacements.

Dip $70^{\circ}-90^{\circ}$

Comments: Most faults dip 70 degrees or steeper.

\section{Dip direction SE}

Comments: The master fault dips southeast and becomes slightly listric at depth (Bertagne and Leising, 1991 \#3884). Smaller faults, mainly in the hanging wall of the master fault, dip either northwest or southeast and probably intersect the master fault at depth.

Geomorphic expression Strongly linear ridges and valleys mark the fault zone across bedrock uplands. Topographic expression in the Mississippi Embayment is subtle, at best. The fault zone has no topographic expression in alluvial bottom lands.

Age of faulted deposits At the Maple Grove site, the Cretaceous McNairy Formation is faulted extensively. Core-drilling at the Maple Grove School revealed a graben that contains sand and gravel, tentatively identified as Eocene, overlain by the lower to middle Pleistocene (Illinoian and older) Metropolis Formation. We interpret the Metropolis to be displaced a maximum of $10 \mathrm{~m}$. The Peoria and Roxana Silts (Wisconsinan) and the Loveland Silt (Illinoian) are not faulted. Along a stream west of Maple Grove School, systematic vertical joints and a few small $(<30 \mathrm{~cm}$ throw) normal faults were observed in the Metropolis Formation.

\section{Paleoseismological studies None}

Timing of most recent paleoevent middle and late Quaternary $(<750 \mathrm{ka})$

\section{Recurrence interval Not reported}

Slip-rate category unknown; probably $<0.2 \mathrm{~mm} / \mathrm{yr}$

\section{Length Not applicable}

Comments: The length of Quaternary rupture is unknown because it was demonstrated at only one site.

\section{Average strike $+30^{\circ}$}

Comments: This value was measured on fig. 2 of Nelson and others (1999 \#3889), as the strike of the fault zone at Maple Grove site. 


\section{8f, Kelley structure}

\section{Section number $1028 \mathrm{f}$}

\section{Section name Kelley structure}

Comments: The Kelley structure, which trends N-S to NNW-SSE, lies along what may be a cross-fault connecting the Lusk Creek and Raum fault zones. The site takes its name from exposures in a railroad cut known as Kelley Switch (Nelson and others, 1999 \#3889).

\section{Reliability of location Good}

Comments: The structure is known from exposures in a railroad cut and two seismic profiles less than $0.5 \mathrm{~km}$ apart. Its extent beyond these points is not known.

\section{Sense of movement Normal; reverse}

Comments: The near-surface structure visible in the railroad cut is a graben, but seismic reflection profiles indicate a positive flower structure, containing high-angle reverse faults, in Paleozoic bedrock. Evidently, this structure underwent (1) an episode of compression, followed by extension, and/or (2) a component of strike-slip motion. No slip indicators were found.

\section{Dip $45^{\circ}-90^{\circ}$}

Comments: Faults that dip as gently as 40-50 degrees at the surface appear to steepen to nearly vertical at depth.

\section{Dip direction E, W}

Comments: East and west dips are about equally represented. There is no evidence with which to select faults dipping in either direction as dominant, larger, or younger. Seismicreflection profiles (see "Geologic setting") indicate the graben is nearly symmetrical with respect to fault displacements.

Geomorphic expression No linear topography is evident. Projected to the north, the Kelley structure passes beneath alluvial bottom lands of the Cache Valley.

Age of faulted deposits The Mounds Gravel (Miocene to lower Pleistocene) is downdropped at least $30 \mathrm{~m}$ into a graben. The Loveland Silt (Illinoian) is confined to the central trough of the structure, and may be faulted. The Roxana Silt (mid-Wisconsinan) and Peoria Silt (late Wisconsinan) both thicken into the trough, but are not faulted. These observations imply that major faulting was pre-Illinoian, but the graben continued to subside approximately $3 \mathrm{~m}$ during the Wisconsinan.

Paleoseismological studies Many test pits and soil borings were made in the railroad cut, then a backhoe removed soil from the entire width of the structure on the north side of the tracks, and the geology was logged in detail. Two seismic-reflection profiles were run, one adjacent to the railroad, the other about $0.4 \mathrm{~km}$ south of and parallel to the tracks (Nelson and others, 1999 \#3889). Six thermo-luminescence analyses on silts produced dates much younger than expected from the stratigraphy, so the stratigraphic age constraints were used instead.

Timing of most recent paleoevent late Quaternary $(<130 \mathrm{ka})$ 
Recurrence interval Not reported

Slip-rate category unknown; probably $<0.2 \mathrm{~mm} / \mathrm{yr}$

\section{Length}

Comments: Known length is only $0.5 \mathrm{~km}$, but if this fault zone links the Lusk Creek and Raum fault zones, it may be as long as $8 \mathrm{~km}$.

\section{Average strike $-10^{\circ}$}

Comments: North-south. In the railroad cut, the eastern boundary fault of the graben strikes N. $20^{\circ} \mathrm{W}$. and the western fault trends N. $10^{\circ}$ E. Using the two seismic profiles along with the outcrop data, we map a cluster of faults that seems to be narrowing and converging toward the north.

\section{References}

\#3880 Amos, D.H., 1967, Geologic map of part of the Smithland quadrangle, Livingston County, Kentucky: U.S. Geological Survey Geologic Quadrangle Map GQ-657, 1 sheet, scale 1:24,000.

\#3881 Amos, D.H., 1974, Geologic map of the Burna quadrangle, Livingston County, Kentucky: U.S. Geological Survey Geologic Quadrangle Map GQ-1150, 1 sheet, scale $1: 24,000$.

\#3882 Amos, D.H., and Wolfe, E.W., 1966, Geologic map of the Little Cypress quadrangle, Kentucky-Illinois: U.S. Geological Survey Geologic Quadrangle Map GQ-554, 1 sheet, scale 1:24,000.

\#3883 Baxter, J.W., Desborough, G.A., and Shaw, C.W., 1967, Areal geology of the Illinois Fluorspar District-Part 3-Herod and Shetlerville quadrangles: Illinois State Geological Survey Circular 413, 41 p., 1 plate, scale 1:24,000.

\#3884 Bertagne, A.J., and Leising, T.C., 1991, Interpretation of seismic data from the Rough Creek Graben of Western Kentucky and Southern Illinois, in Leighton, M.W., Kolata, D.R., Oltz, D.F., and Eidel, J.J., eds., Interior cratonic basins: Tulsa, Oklahoma, The American Association of Petroleum Geologists, Memoir 51, p. 199-208.

\#3885 Hook, J.W., 1974, Structure of the fault systems in the Illinois-Kentucky Fluorspar District, in Hutcheson, D.W., ed., A symposium of the geology of Fluorspar: Kentucky Geological Survey Special Publication 22, p. 77-86.

\#3886 Kolata, D.R., Treworgy, J.D., and Masters, J.M., 1981, Structural framework of the Mississippi embayment of southern Illinois: Illinois Institute of Natural Resources State Geological Survey Division Circular 516, 30 p.

\#3887 Nelson, W.J., 1991, Structural styles of the Illinois Basin, in Leighton, M.W., Kolata, D.R., Oltz, D.F., and Eidel, J.J., eds., Interior cratonic basins: Tulsa, Oklahoma, The American Association of Petroleum Geologists, Memoir 51, p. 209-243.

\#3898 Nelson, W.J., 1996, Geologic map of the Reevesville quadrangle, Illinois: Illinois Geologic Quadrangle Map IGQ-18, 1 sheet, scale 1:24,000.

\#3889 Nelson, W.J., Denny, B.F., Follmer, L.R., and Masters, J.M., 1999, Quaternary grabens in southernmost Illinois-Deformation near an active intraplate seismic zone:

Tectonophysics, v. 305, p. 381-397. 
\#3888 Nelson, W.J., Denny, F.B., Devera, J.A., Follmer, L.R., and Masters, J.M., 1997, Tertiary and Quaternary tectonic faulting in southernmost Illinois: Engineering Geology, v. 46, p. 235-258.

\#3890 Nelson, W.J., Harrison, R.W., and Hoffman, D., 1999, Neotectonics of the northern Mississippi embayment: Illinois State Geological Survey Guidebook 30, 34 p.

\#3892 Potter, C.J., Goldhaber, M.B., and Heigold, P.C., 1995, Structure of the Reelfoot-Rough Creek Rift System, Fluorspar Area Fault Complex, and Hicks Dome, southern Illinois and western Kentucky-New constraints from regional seismic reflection data, in Shedlock , K.M., and Johnston, A.C., eds., Investigations of the New Madrid Seismic Zone: U.S. Geological Survey Professional Paper 1539-Q, p. 19, 1 plate.

\#3893 Ross, C.A., 1963, Structural framework of southernmost Illinois: Illinois State Geological Survey Circular 351, 28 p.

\#3894 Ross, C.A., 1964, Geology of the Paducah and Smithland quadrangles in Illinois: Illinois State Geological Survey Circular 360, 32 p., 1 plate, scale 1:62,500.

\#3895 Trace, R.D., and Amos, D.H., 1984, Stratigraphy and structure of the western Kentucky Fluorspar District: U.S. Geological Survey Professional Paper 1151-D, 41 p., 1 plate, scale 1:48,000.

\#3896 Weibel, C.P., Nelson, W.J., Oliver, L.B., and Esling, S.P., 1993, Geology of the Waltersburg quadrangle Pope County, Illinois: Illinois State Geological Survey Bulletin $98,41 \mathrm{p}$. 


\section{9, Western Lowlands liquefaction features (Class A)}

Structure Number 1029

Structure Name Western Lowlands liquefaction features (Class A)

Comments: The Western Lowlands of Missouri and Arkansas form the part of the northwestern Mississippi embayment that lies west of the uplands of northeast-trending Crowleys Ridge (Saucier and Snead, 1991 \#2021). Several prehistoric liquefaction features west of Crowleys Ridge are here informally grouped under the name Western Lowlands.

Synopsis: The evidence for Quaternary faulting in the Western Lowlands of Missouri and Arkansas consists of late Quaternary liquefaction features that are attributed to prehistoric earthquakes, and of seismic-reflection profiles that show offsets of Quaternary reflectors.

Date of compilation 02/23/00; revised 04/20/00

Compiler and affiliation Russell L. Wheeler, U.S. Geological Survey

State Missouri; Arkansas

County Stoddard, New Madrid (Missouri); Randolph (Arkansas)

$1^{\circ} \times 2^{\circ}$ sheet Poplar Bluff

Province Coastal Plain

\section{Reliability of location Poor}

Comments: The liquefaction was recognized as the type that is caused by strong ground motion for example, (Obermeier, 1996 \#2256), and the strong motions are presumed to have been caused by slip on one or more preexisting faults. However, the causative faults have not been identified and the locations and sizes of the liquefaction features identified to date provide poor constraints on the sources of the shaking.

Geologic setting The northern Mississippi embayment is approximately bisected by the Mississippi River. West of the Holocene meander belt of the river, the embayment is dominated by lowlands of nearly flat, terraced, outwash deposits of late Wisconsinan braided streams (Saucier and Snead, 1991 \#2021). The part of the embayment west of the Mississippi River is itself approximately bisected by the uplands of north-northeast-trending Crowleys Ridge. Thus, the ridge divides the outwash deposits, and smaller areas of late Wisconsinan dunes and Holocene floodplains, into the Western Lowlands and Eastern Lowlands (Vaughn, 1994 \#3924; Vaughn and others, 1996 \#3925).

The New Madrid seismic zone is east of Crowleys Ridge, in and east of the Eastern Lowlands and the Mississippi River (for example, Wheeler and Rhea, 1994 \#754). Therefore, the seismic zone is generally $30 \mathrm{~km}$ or more east of the area summarized here. The New Madrid seismic zone is spatially associated with the Reelfoot rift. The main upper crustal expression of the rift is the Mississippi Valley graben. All of the Western Lowlands paleoseismological sites studied by Vaughn (1994 \#3924), Tuttle and others (1998 \#3817), and Tuttle (1999 \#3921) lie several tens of kilometers northwest of the floor of the graben, and also northwest of the wide, step-faulted margin of the graben (see summary by Rhea and Wheeler, 1994 \#3919). However, several of the sites lie near or on an aeromagnetic lineament that trends 
northeast (Vaughn, 1991 \#3922; Tuttle, 1999 \#3921). The lineament is part of the Commerce geophysical lineament, which, after magnetic and gravity modeling, Langenheim and Hildenbrand (1997 \#3917) attributed to a mafic dike swarm that they suggested may have formed parallel to and coevally with the Reelfoot rift. If this part of the lineament, the inferred dike swarm, and the rift formed coevally, then likely the mafic magmas intruded fractures that formed or reopened with an extensional component of movement. Thus, the formation of the source of the Commerce geophysical lineament may have involved at least a component of normal faulting. This reasoning indicates that the paleoseismological sites in the Western Lowlands may lie near one of the northwesternmost normal or normal-oblique faults of the rift, even if the sites lie outside the main part of the step-faulted rift margin.

Paleoliquefaction sites 1, 2, 6, and 7 of Vaughn (1994 \#3924) surround Dudley ridge. Two high-resolution seismic-reflection profiles across the western slope of the ridge are interpreted as showing three faults that extend from Paleozoic and Cretaceous bedrock upward into Quaternary sediments (Shoemaker and others, 1997 \#3920; Shoemaker and others, 1998 \#3955). Another high-resolution reflection profile across the Commerce geophysical lineament approximately $30 \mathrm{~km}$ southwest of Dudley ridge shows about $20 \mathrm{~m}$ of dip separation on a reflector within the Quaternary sequence (Stephenson and others, 1999 \#3954). Thus, the profile interpretations support the liquefaction evidence (see "Paleoseismological studies") of Quaternary faulting.

Vaughn (1991 \#3922) and Boyd and Schumm (1995 \#3916) identified several geomorphic anomalies, including diverted rivers, in the Western Lowlands, and speculated about possible Quaternary tectonism. However, any such tectonism need not occur coseismically, or even involve faulting. Accordingly, this assessment of the Western Lowlands focuses on paleoseismological evidence for prehistoric earthquakes.

\section{Sense of movement Not reported}

Comments: The prehistoric earthquakes are known only from locations and age estimates of liquefaction. No surface ruptures are known from the earthquakes.

\section{Dip Not reported}

Comments: The causative fault or faults remain unidentified and uncharacterized.

\section{Dip direction Not reported}

Geomorphic expression The liquefaction features generally lack geomorphic expression, being exposed in walls of excavations and cut banks. Some sand blows are exposed at ground level (Vaughn, 1994 \#3924; Tuttle, 1999 \#3921).

Age of faulted deposits late Wisconsinan (Saucier and Snead, 1991 \#2021)

Paleoseismological studies The main reports on liquefaction features in the Western Lowlands are those of Vaughn (1994 \#3924), Tuttle and others (1998 \#3817), and Tuttle (1999 \#3921). Vaughn (1994 \#3924) summarized results from 12 sites. Four of the sites are east of Crowleys Ridge in the Eastern Lowlands and will not be considered further here. Of the eight sites in the Western Lowlands, all contained liquefaction features attributed to prehistoric earthquakes. However, dateable materials were recovered only at sites 1 (Dudley Main Ditch, site DM-1 of Wheeler and Rhea, 1994 \#754; site V1 of Tuttle, 1999 \#3921), 2 (Mingo Ditch, 
site MD-1 of Wheeler and Rhea, 1994 \#754; site V2 of Tuttle, 1999 \#3921), 3 (Wilhelmina Cutoff of the St. Francis River, site SF-2 of Wheeler and Rhea, 1994 \#754; site V3 of Tuttle, 1999 \#3921), and 6 (Dudley Main Ditch). These four sites yielded evidence of at least four prehistoric events (individual earthquakes or sequences of earthquakes). Vaughn (1994 \#3924) suggested that a small surficial sand blow at site 3 may have formed during the 181112 New Madrid earthquakes. The sites are within $27 \mathrm{~km}$ of each other (Vaughn, 1994 \#3924, fig. 2).

The first two events are best represented by crosscutting dikes at site 1 . A dike of event 1 fed a crater and a sand blow. Three dikes of event 2 cut the older dike, crater, and sand blow.

Both events are bracketed by dates of 22,750 radiocarbon yr B.P., from wood $35 \mathrm{~cm}$ below the event 1 sand blow, and of 3,570 yr B.P., from wood at the base of a paleochannel that postdates both events. Elsewhere at site 1, a late Wisconsinan channel deposit contained a bone dated at 12,570 yr B.P. The channel deposit is cut by a dike, which is itself cut by a younger dike. The younger dike is truncated by a second, late Holocene channel deposit with wood at its base that yielded a date of $590 \mathrm{yr}$ B.P. Therefore, the two dikes represent two liquefaction episodes between 12,570 yr B.P. and $590 \mathrm{yr}$ B.P. These episodes might or might not correspond to events 1 and 2 . At site 6 , deformed beds beneath a sand blow contain wood and bone; the bone gave a date of 17,990 \pm 150 yr B.P. Vaughn (1994 \#3924) assumed that the sand blow was coeval with event 1. Thus, events 1 and 2 are younger than 22,750 yr B.P. Note that, depending on the validity of the correlations elsewhere in site 1 and to site 6 , both events may be younger than 17,990 yr B.P. Alternatively, the dikes elsewhere in site 1 might have formed in unrecognized events between events 2 and 3. Regardless, events 1 and 2 occurred before 3,570 yr B.P.

Dikes and buried sand blows at site 2 were attributed to event 2. A carbonaceous silt 58-62 $\mathrm{cm}$ below a sand blow was dated at $13,430 \pm 170$ yr B.P. Early Archaic archeological artifacts are on the terrace surface that overlies the sand blow, indicating that the event predated 9,00010,000 yr B.P. (Vaughn, 1994 \#3924).

Events 3 and 4 are known only from site 3 (Vaughn, 1994 \#3924). Two surficial sand blows about $100 \mathrm{~m}$ apart bury dated soils, and Vaughn (1994 \#3924) suggested that the ages of the soils approximate the ages of the events. Organic material in the soil horizon immediately beneath the larger sand blow was dated as $1660 \pm 70$ and $1110 \pm 65$ yr. B.P., which give calibrated ages of A.D. 240-560 and 770-1020, respectively (Vaughn and others, 1993 \#3923; Vaughn, 1994 \#3924). Thus, event 3 was estimated to have occurred during A.D. 240-1020. Similarly, organic material from the soil horizon immediately beneath the smaller sand blow was dated as A.D. 1440-1540 (calibrated), which is the estimated age of event 4.

Tuttle and others (1998 \#3817), and Tuttle (1999 \#3921) sought to define the ages and size distribution of liquefaction features in and near the New Madrid seismic zone, including the Western Lowlands. She summarized results from 116 liquefaction and archeological sites, of which 25 are in the Western Lowlands. Of these 25 sites, 15 contained prehistoric liquefaction features attributed to earthquakes. Most of the features are sand dikes. Only three sand blows were found and two of these were dated at Current River 8 and at Current River 2 of Tuttle (1999 \#3921). Current River 8 is at or near site 4 of Vaughn (1994 \#3924), and Current River 2 is newly discovered. 
At the Current River 2 site, a sand blow buried a cypress knee. Later, a tree root, now burned, penetrated a paleosol above the sand blow. Calibrated dates on the cypress knee and the burned root constrained the sand blow to have formed during A.D. 1310-1450 (Tuttle, 1999 \#3921).

The Current River 8 site records two to four liquefaction episodes (Tuttle, 1999 \#3921). Sand dikes and a sand blow (episode I) were intruded by later sand sills (episode II). Other sills were intruded (episode III) into sediment that had been deposited on top of the sand blow. The sills of episode III were themselves cut by younger dikes (episode IV). No structural or stratigraphic evidence precludes episodes II-IV from having formed during the same earthquake or earthquake sequence. The only age control is from wood found $15 \mathrm{~cm}$ below the episode I sand blow. The wood yielded a calibrated date of 3490-3470 B.C. and 3380-3090 B.C. Thus, episodes I-IV postdate 3490 B.C. (Tuttle, 1999 \#3921).

Tuttle (1999 \#3921) combined her results with those of several other paleoliquefaction studies, including that of Vaughn (1994 \#3924), to deduce the occurrence of very large to great earthquakes or earthquake sequences in the New Madrid seismic zone in A.D. $900 \pm 100$ yr, A.D. $1530 \pm 130 \mathrm{yr}$, and, of course, 1811-12. Additional liquefaction events occurred before A.D. 900, but their ages and geographic distributions remain poorly constrained. Because no sand blows were found in the area that could be attributed to the 1811-12 New Madrid earthquakes, Tuttle (1999 \#3921) suggested that the sand blow at Current River 2, which formed in A.D. $1380 \pm 70 \mathrm{yr}$, may be too large to have been caused by an earthquake in the New Madrid seismic zone $80 \mathrm{~km}$ or more distant. Instead, Tuttle (1999 \#3921) suggested that the sand blow may be related to a separate source in the Western Lowlands. Earlier, Vaughn (1994 \#3924) had attributed his event 2 to a possible source in a different part of the Western Lowlands. The two to four liquefaction episodes at Current River 8 (site V4 of Vaughn, 1994 \#3924) are known only to postdate 3490 B.C. One or more of liquefaction episodes II-IV at Current River 8 might have been coeval with the single episode at Current River 2 (Tuttle, 1999 \#3921). Events 3 and 4 at site 3 of Vaughn (1994 \#3924; site V3 of Tuttle, 1999 \#3921) are attributed to the A.D. $900 \pm 100 \mathrm{yr}$ and A.D. $1530 \pm 130 \mathrm{yr}$ earthquakes or earthquake sequences in the New Madrid seismic zone (Tuttle, 1999 \#3921, figure 47). The zone is only approximately $50 \mathrm{~km}$ away from site 3, at which Vaughn (1994 \#3924) suggested that a smaller surficial sand blow may be attributed to the 1811-12 New Madrid earthquakes.

Timing of most recent paleoevent latest Quaternary $(<15 \mathrm{ka})$

Comments: Probably A.D. $1380 \pm 70$ yr (Tuttle, 1999 \#3921) (see "Paleoseismological studies").

\section{Recurrence interval Not reported}

Comments: Vaughn (1994 \#3924) attributed his event 2 to a possible source in the Western Lowlands between 22,750 yr BP and 3,570 yr BP. Tuttle (1999 \#3921) also attributed a liquefaction event at A.D. $1380 \pm 70 \mathrm{yr}$ to a Western Lowlands source. However, the two events were recognized at sites approximately $70 \mathrm{~km}$ apart, and are poorly characterized as to the geographic distributions of coeval liquefaction features. Accordingly, neither potential source is known to have had more than one earthquake, so no recurrence interval can be calculated. 


\section{Slip-rate category unknown}

Comments: No causal fault, surface rupture, or dated fault offset is known.

\section{Length Not applicable}

Comments: No causal fault is known. The only paleoseismological expression of faulting is prehistoric liquefaction features of poorly constrained and widely different ages at widely separated sites.

\section{Average strike Not applicable}

Comments: No causal fault is known. The only paleoseismological expression of faulting is prehistoric liquefaction features of poorly constrained and widely different ages at widely separated sites.

\section{References}

\#3916 Boyd, K.F., and Schumm, S.A., 1995, Geomorphic evidence of deformation in the northern part of the New Madrid seismic zone: U.S. Geological Survey Professional Paper 1538-R, 35 p.

\#3917 Langenheim, V.E., and Hildenbrand, T.G., 1997, Commerce geophysical lineament-Its source, geometry, and relation to the Reelfoot rift and New Madrid seismic zone: Geological Society of America Bulletin, v. 109, no. 5, p. 580-595.

\#2256 Obermeier, S.F., 1996, Use of liquefaction-induced features for paleoseismic analysisAn overview of how seismic liquefaction features can be distinguished from other features and how their regional distribution and properties of source sediment can be used to infer the location and strength of Holocene paleo-earthquakes: Engineering Geology, v. 44, p. 1-76.

\#3919 Rhea, S., and Wheeler, R.L., 1994, Map showing large structures interpreted from geophysical data in the vicinity of New Madrid, Missouri: U.S. Geological Survey Miscellaneous Field Studies Map MF-2264-B, 1 sheet, scale 1:250,000.

\#2021 Saucier, R.T., and Snead, J.I., 1991, Quaternary geology of the Lower Mississippi Valley, in Morrison, R.B., ed., Quaternary nonglacial geology; conterminous U.S.: Boulder, Colorado, Geological Society of America, The Geology of North America, v. K-2, plate 6 , scale 1:1,000,000.

\#3920 Shoemaker, M., Anderson, N., Vaughn, J.D., Hoffman, D., and Palmer, J.R., 1997, Dudley Ridge-Late Wisconsinan terrace of fault scarp?, in Palmer, J., Hoffman, D., Vaughn, J.D., and Harrison, R.W., eds., Late Quaternary faulting and earthquake liquefaction features in southeast Missouri-The identification of new earthquake hazards: Missouri Division of Geology and Land Survey Open File Report OFR-97-96-GS, Association of Missouri Geologist 43rd annual meeting and field trip, Cape Girardeau, Missouri, September 20-21, 1996, p. 13-22.

\#3955 Shoemaker, M., Vaughn, J.D., Anderson, N.L., Hoffman, D., and Palmer, J.R., 1998, A shallow high-resolution seismic reflection study of Dudley Ridge, south-east Missouri: Computers \& Geosciences, v. 23, no. 10, p. 1113-1120. 
\#3954 Stephenson, W.J., Odum, J.K., Williams, R.A., Pratt, T.L., Harrison, R.W., and Hoffman, D., 1999, Deformation and Quaternary faulting in southeast Missouri across the Commerce geophysical lineament: Bulletin of the Seismological Society of America, v. 89 , no. 1 , p. $140-155$.

\#3921 Tuttle, M.P., 1999, Late Holocene earthquakes and their implications for earthquake potential of the New Madrid seismic zone, central United States: University of Maryland, unpublished Ph.D dissertation, $250 \mathrm{p}$.

\#3817 Tuttle, M.P., Lafferty, R.H., III, and Schweig, E.S., III, 1998, Dating of liquefaction in the New Madrid seismic zone and implications for seismic hazard: U.S. Nuclear Regulatory Commission NUREG/CR-0017, $77 \mathrm{p}$.

\#3922 Vaughn, J.D., 1991, Active tectonics in the Western Lowlands of southeast Missouri-An initial assessment, in Louis Unfer Jr. conference on the geology of the Mid-Mississippi Valley, Cape Girardeau Missouri, extended abstracts: Missouri Division of Geology and Land Survey Special Publication 8, p. 54-59.

\#3924 Vaughn, J.D., 1994, Paleoseismological studies in the western lowlands of southeast Missouri: Technical report to U.S. Geological Survey, Rolla, Missouri, under Contract 14-08-0001-G1931, $27 \mathrm{p}$.

\#3923 Vaughn, J.D., Hoffman, D., and Palmer, J.R., 1993, A Late-Holocene surficial sandblow in the western lowlands of southeast Missouri-A paleoseismic milestone: Geological Society of America Abstracts with Programs, v. 25, no. 3, p. 87.

\#3925 Vaughn, J.D., Palmer, J.R., and Hoffman, D., 1996, Dudley Main Ditch-Multiple late Quaternary earthquake induced liquefaction events, in Palmer, J., Hoffman, D., Vaughn, J.D., and Harrison, R.W., eds., Late Quaternary faulting and earthquake liquefaction features in southeast Missouri-The identification of new earthquake hazards: Missouri Division of Geology and Land Survey Open File Report OFR-97-96-GS, Association of Missouri Geologist 43rd annual meeting and field trip, Cape Girardeau, Missouri, September 20-21, 1996, p. 1-12.

\#754 Wheeler, R.L., and Rhea, S., 1994, Map showing surficial and hydrologic features in the vicinity of New Madrid, Missouri: U.S. Geological Survey Miscellaneous Field Studies Map MF-2264-E, 1 sheet, scale 1:250,000. 


\section{0, St. Louis-Cape Girardeau liquefaction features (class A)}

\section{Structure Number 1030}

Structure Name St. Louis-Cape Girardeau liquefaction features (class A)

Comments: Tuttle and others (1999 \#3904) examined sand blows, sand dikes, and sand sills that were found during systematic searches of streams in southeastern Missouri and southwestern Illinois. The search extended approximately 50 to $90 \mathrm{~km}$ west and east of the Mississippi River, between the St. Louis area on the northwest and the Cape Girardeau area on the southeast. The study area is named here informally after these two cities.

Synopsis: Correlation and dating of the liquefaction features remain uncertain. The present interpretation involves an earthquake of moment magnitude $\mathbf{M}>6$, and perhaps exceeding 7, occurring approximately 6,500 years ago, roughly $60 \mathrm{~km}$ east of St. Louis. The smaller the earthquake east of St. Louis, the more likely it is that another earthquake of $\mathbf{M}>5.2$ occurred in or very near St. Louis. A second earthquake caused strong ground shaking in the area during the past 4,000 years.

Date of compilation 01/28/00; revised 04/26/00

Compiler and affiliation Russell L. Wheeler, U.S. Geological Survey

State Missouri; Illinois

County Bollinger, Cape Girardeau, Franklin, Jefferson, Perry, St. Francois, St. Louis, Ste. Genevieve, Washington, Wayne (Missouri); Clinton, Jackson, Johnson, Madison, Massac, Monroe, Pulaski, Randolph, St. Clair, Washington (Illinois)

$1^{\circ} \times 2^{\circ}$ sheet St. Louis, Paducah, Belleville, Rolla

Province Central Lowland, Ozark Plateaus, Interior Low Plateaus, Coastal Plain

\section{Reliability of location Poor}

Comments: The liquefaction was recognized as the type that is caused by strong ground motion (Obermeier, 1996 \#2256), and the strong motions are presumed to have been caused by slip on one or more preexisting faults. However, the causative faults have not been identified and the locations and sizes of the liquefaction features studied to date provide poor constraints on the sources of the shaking.

Geologic setting The study area straddles the Mississippi River and the western edge of the Illinois basin, spanning approximately $37^{\circ}-39^{\circ} \mathrm{N}$. Immediately southeast of the study area is the New Madrid seismic zone. Regionally, bedrock consists of Paleozoic strata that dip northeastward from the Ozark uplift toward the center of the Illinois basin. Historical earthquakes are scattered throughout the study area. The earthquakes are part of the broad, diffuse halo of scattered seismicity that surrounds the New Madrid seismic zone. Numerous large faults, monoclines, and other folds of Paleozoic age are known throughout the region, and most involved the basement.

\section{Sense of movement Not reported}

Comments: The prehistoric earthquakes are known only from locations and age estimates of liquefaction. No surface ruptures or other deformation are known from the earthquakes. 


\section{Dip Not reported}

Comments: The causative fault or faults remain unidentified and uncharacterized.

\section{Dip direction Not reported}

Geomorphic expression None. Sand blows, dikes, and sills are exposed in cut banks of streams. Among the recognized liquefaction features, sand dikes are far more numerous than sills or sand blows.

Age of faulted deposits The liquefaction features are in late Wisconsinan and Holocene deposits (Tuttle and others, 1999 \#3904; McNulty and Obermeier, 1999 \#3906).

Paleoseismological studies Two coeval, multiple-year studies covered areas that overlap in west-central Illinois. (1) Tuttle and others (1996 \#3956; 1998 \#3957; 1999 \#3904) searched for liquefaction features along $447 \mathrm{~km}$ of stream cutbanks in southeastern Missouri and southwestern Illinois, within approximately 50 to $90 \mathrm{~km}$ east and west of the Mississippi River. The search area was chosen to include several large faults and anticlines that are near clusters of epicenters; however, no faults were found to cut Quaternary strata. In addition, Tuttle and others (1999 \#3904) documented 308 sites having liquefaction and soft-sediment structures and dateable materials. They found possible or confirmed liquefaction features (sand dikes, blows, or sills) at 48 sites, and soft-sediment structures of less certain origin (folds, small faults, sand diapirs, load structures, slumps, and the like) at some of these sites as well as at another 24 sites. Geotechnical data from 51 boreholes at 15 locations near liquefaction features allowed estimation of the magnitudes and distances of earthquakes that could have produced the observed liquefaction features. (2) McNulty and Obermeier (1997 \#3900; 1997 \#3901; 1999 \#3906) reported results from 21 sites, some of which were also documented by Tuttle and others (1999 \#3904). The 21 sites had been found during extensive surveys of the region that is immediately to the east of, and overlapped by, the study area of Tuttle and others (1999 \#3904) (Obermeier, 1996 \#3903; Munson and others, 1997 \#2839; McNulty and Obermeier, 1997 \#3900; 1997 \#3901; Obermeier, 1998 \#3902; McNulty and Obermeier, 1999 \#3906).

Tuttle and others (1999 \#3904) suggested three alternative scenarios that could explain the results: (1) an earthquake of moment magnitude $\mathbf{M}>7$ with an epicentral area 50-60 km east of St. Louis, near Germantown, Illinois; (2) an earthquake of $\mathbf{M}>7.5$ with an epicentral area $35 \mathrm{~km}$ farther east near Centralia, Illinois, perhaps on the Centralia fault-Du Quoin monocline; or (3) three separate earthquakes, an $\mathbf{M}>6$ near Germantown (McNulty and Obermeier, 1997 \#3900; 1997 \#3901; 1999 \#3906), an $\mathbf{M}>5.2$ near St. Louis, and an $\mathbf{M}>$ 7.5 near New Madrid, Missouri. The absence of dikes in liquefiable deposits of suitable age near Centralia argues against scenario (2) (McNulty and Obermeier, 1999 \#3906). Consistent with scenario (1), McNulty and Obermeier (1999 \#3906) estimated that the earthquake near Germantown was at least as large as M 6.5, based on the greatest distance to observed liquefaction features. Under scenarios (1) and (2), other liquefaction features that formed during the last 4,000 years might have been caused by one or more of the very large earthquakes that other studies have shown occurred in the New Madrid seismic zone in approximately A.D. $900+/-100 \mathrm{yr}$ and A.D. $1530+/-140 \mathrm{yr}$, and during the winter of 1811-1812 (see review in Tuttle and others, 1999, p. 1-5). 


\section{Timing of most recent paleoevent latest Quaternary $(<15 \mathrm{ka})$}

Comments: Timing remains uncertain, and depends on how liquefaction features are correlated. Resolution of the uncertainty requires more study, dates, and geotechnical work (Tuttle and others, 1999 \#3904; McNulty and Obermeier, 1999 \#3906). See "Paleoseismological studies."

\section{Recurrence interval Not reported}

Comments: The number, location, and size of prehistoric earthquakes in the study area remain uncertain, and depend on uncertain correlation of liquefaction features. See "Paleoseismological studies."

Slip-rate category unknown; probably $<0.2 \mathrm{~mm} / \mathrm{yr}$

Comments: No dated fault offset is known, so no slip rate can be calculated. Nonetheless, the plotting program that makes maps of the active faults in this compilation requires an estimation of the slip rate, so the slowest was chosen for this reason alone. This rate has no other meaning and should not be used for hazard estimates.

Length $(\mathrm{km})$ Not applicable

Comments: Individual Quaternary faults have not been identified. Instead, prehistoric liquefaction features are recognized over a large area and attributed to several earthquakes that occurred on unidentified faults.

Average strike (azimuth) Not applicable

Comments: Individual Quaternary faults have not been identified. Instead, prehistoric liquefaction features are recognized over a large area and attributed to several earthquakes that occurred on unidentified faults.

\section{References}

\#3900 McNulty, W.E., and Obermeier, S.F., 1997, Liquefaction evidence for Holocene paleoearthquakes in central and southwestern Illinois: Eos, Transactions of the American Geophysical Union, v. 78, no. 17, p. S316.

\#3901 McNulty, W.E., and Obermeier, S.F., 1997, Liquefaction evidence for two Holocene paleo-earthquakes in central and southwestern Illinois: U.S. Geological Survey OpenFile Report 97-435, 22 p.

\#3906 McNulty, W.E., and Obermeier, S.F., 1999, Liquefaction evidence for at least two strong Holocene paleo-earthquakes in central and southwestern Illinois, USA: Environmental \& Engineering Geoscience, v. 5, no. 2, p. 133-146.

\#2839 Munson, P.J., Obermeier, S.F., Munson, C.A., and Hajic, E.R., 1997, Liquefaction evidence for Holocene and latest Pleistocene seismicity in the southern halves of Indiana and Illinois-A preliminary overview: Seismological Research Letters, v. 68, no. 4, p. 521-536.

\#2256 Obermeier, S.F., 1996, Use of liquefaction-induced features for paleoseismic analysisAn overview of how seismic liquefaction features can be distinguished from other fea- 
tures and how their regional distribution and properties of source sediment can be used to infer the location and strength of Holocene paleo-earthquakes: Engineering Geology, v. 44, p. 1-76.

\#3903 Obermeier, S.F., 1996, Seismically induced paleoliquefaction features in southern half of Illinois: Seismological Research Letters, v. 67, no. 2, p. 49.

\#3902 Obermeier, S.F., 1998, Liquefaction evidence for strong earthquakes of Holocene and latest Pleistocene ages in the states of Indiana and Illinois, USA: Engineering Geology, v. 50, p. 227-254.

\#3904 Tuttle, M., Chester, J., Lafferty, R., Dyer-Williams, K., and Cande, R., 1999, Paleoseismology study northwest of the New Madrid seismic zone: U.S. Nuclear Regulatory Commission Report NUREG/CR-5730, xi + 155 p.

\#3957 Tuttle, M., Chester, J., Lafferty, R., Dyer-Williams, K., Haynes, M., Cande, R., and Sierzchula, M., 1998, Liquefaction features in southwestern Illinois and southeastern Missouri and thier implications for paleoseismicity: Eos, Transactions of the American Geophysical Union, v. 79, no. 17, p. S342.

\#3956 Tuttle, M.P., Lafferty, R.H., Cande, R.F., Chester, J.S., and Haynes, M., 1996, Evidence of earthquake-induced liquefaction north of the New Madrid seismic zone, Central United States: Seismological Research Letters, v. 67, no. 2, p. 58. 


\section{0, Cheraw fault (Class A)}

Structure Number 2330

Structure Name Cheraw fault (Class A)

Comments: The Cheraw fault was first recognized during regional geologic mapping in the late 1960's and 1970's (Sharps, 1976 \#2741). Kirkham and Rogers (1981 \#792) formally named the fault for the small town of Cheraw, Colorado, which is located about $10 \mathrm{~km}$ south of the scarp.

Synopsis: The Cheraw fault was originally mapped in the 1970's as part of a regional mapping program (1:250,000 scale) and was considered as a possible source of earthquakes. No detailed studies of the fault were conducted during the next two decades. In 1994 a trench was excavated across the scarp and exposed a record of late Quaternary surface ruptures. Thus the trenching confirmed the fault as a potential source of future strong earthquakes. This documentation establishes the Cheraw fault as only the second confirmed (after the Meers fault, Oklahoma) late Quaternary fault east of the Rocky Mountains in the U.S.

\section{Date of compilation $10 / 31 / 97$}

Compiler and affiliation Anthony J. Crone, U.S. Geological Survey

State Colorado

County Crowley, Kiowa, Otero

$1^{\circ} \times 2^{\circ}$ sheet: Lamar

Province Great Plains

\section{Quality of location Good}

Comments: Trace from 1:24,000-scale mapping, transferred to 1:250,000-scale base. Along much of its trace, the fault is conspicuous because of its down-to-the-northwest sense of throw that opposes the southeasterly regional slope. This sense of motion results in overland flow forming local ponds against the scarp and enhancing vegetation adjacent to the scarp (the region has a semi-arid climate, and vegetation is sparse). The increase in the density of vegetation along the scarp makes it a distinctive feature that is relatively easy to map on aerial photographs. For this reason, the reliability of the fault's location is considered to be good.

Scale of digital trace 1:250,000-scale

Geologic setting The Cheraw fault is located on the High Plains of southeastern Colorado, about $100 \mathrm{~km}$ east of the city of Pueblo, Colorado, and about $140 \mathrm{~km}$ east of the range front of the Rocky Mountains (Crone and others, 1997 \#2680). Structurally, the fault is located above the west-northwesterly sloping basement surface between the north-trending Las Animas arch to the east and the Denver basin to the northwest (Curtis, 1988 \#2682); accordingly, the fault lies on the western side of the arch and along the southeastern margin of the basin. The down-to-the northwest sense of motion that occurred during late Quaternary faulting events has the same vertical sense as the tectonic relief on the Precambrian crystalline rocks.

The Las Animas arch is a prominent, but relatively low-relief, 300-km-long, positive structural element in southeastern Colorado. The crest of the arch is approximately $20-40 \mathrm{~km}$ east of 
the fault. Minor uplift probably occurred along the arch in late Paleozoic time, but most of the present structural relief formed in Laramide time when the gentle westward slope on the western side of the arch developed as a result of downwarping of the Denver basin (Curtis, 1988 \#2682). As the basin subsided, Cretaceous rocks were tilted westward from their original eastward-sloping depositional gradient.

There is little evidence that throw on the fault has substantially offset the bedrock (only tens of meters are demonstrable), thus the fault does not appear to have a long history of recurrent movement. For example, the cumulative throw on the fault is less than the thickness of the Smoky Hill Shale Member (150-215 m thick in the area) because neither the Fort Hays Limestone Member nor the Pierre Shale (all Upper Cretaceous), which are stratigraphically below and above the Smoky Hill Shale Member, respectively, are exposed along the fault.

As part of his regional mapping, Sharps (1976 \#2741) drew a structure-contour map on the top of the Lower Cretaceous Dakota Sandstone. The subsurface control for the structure contours is sparse, and the elevation control suggests that the contours could contain a significant amount of uncertainty. Nevertheless, a direct interpretation of the contours indicates an estimated 6-8 $\mathrm{m}$ of down-to-the-northwest throw on the fault, with is comparable with the amount of throw on early Quaternary alluvial deposits. The Cheraw fault disrupts the gradual westward gradient of Cretaceous rocks that rise up onto the arch; immediately east of the fault, these rocks have a gradient of about $5 \mathrm{~m} / \mathrm{km}$, and west of the fault they have a gradient of about $8 \mathrm{~m} / \mathrm{km}$. Even if the cumulative offset of Cretaceous rocks is four or five times greater than the estimated 6-8 m, the average Neogene slip rate on the fault is very low, and the fault could not have a long history of movement at rates comparable to the latest Pleistocene rate.

\section{Sense of movement Normal}

Comments: The sense of motion on the fault is not well known, but is inferred to be a downto-the-northwest motion on a normal fault based on the attitude of the faults exposed in the trench across the scarp (Crone and others, 1997 \#2680).

\section{Dip $66^{\circ}$}

Comments: Dip measurement is based on the average dip of the main fault as mapped by Crone and others (1997 \#2680) the trench across the fault. This 3-4 m deep trench provided the only known exposure of the fault.

\section{Main dip direction NW}

Comments: Dip direction and attitude are based on the fault exposed in trench of Crone and others (1997 \#2680).

Geomorphic expression In his regional mapping, Sharps (1976 \#2741) showed the fault as approximately located where it crosses the Upper Cretaceous Smoky Hill Shale member of the Niobrara Formation, and showed it as inferred or concealed where it crosses lower Pleistocene Rocky Flats Alluvium and middle (?) Pleistocene Verdos Alluvium. Locally, the fault forms a rounded but distinct scarp on lower Pleistocene Rocky Flats Alluvium; this scarp vertically offsets the alluvium about 7-8 m (Crone and Machette, 1995 \#2679).

At the trench site of Crone and others (1997 \#2680), the scarp is $3.6 \mathrm{~m}$ high and has a maximum slope angle of $11^{\circ}$. Based on fault-scarp morphology studies in the nearby Basin and 
Range Province of the Western U.S., a fault scarp of this size having this morphology would be inferred to be considerably older than the Holocene age indicated by the trenching studies. However, comparing the scarp on the Cheraw fault with Basin and Range fault scarps is complicated by the fact that the Cheraw scarp is the product of multiple surface-faulting events, whereas Basin and Range scarp-morphology studies focus on features formed during single rupture events. In addition, eolian deposition and ponded alluvium has partially buried the hanging wall of the Cheraw scarp fault, both of which contribute to the scarp's subdued morphology. The net result is that, morphologically, the scarp appears to be an older feature than was documented by the trenching study.

Age of faulted deposits at the surface Lower Pleistocene (Rocky Flats Alluvium), middle (?) Pleistocene Verdos Alluvium, locally unnamed latest Pleistocene loess and alluvium, and Holocene colluvium.

Paleoseismological studies The only detailed paleoseismologic study of the fault conducted to date is that reported by Crone and others (1997 \#2680). In that study, they excavated a 110m-long trench across a 3.6-m-high scarp and reported evidence of two latest Pleistocene faulting events and an early Holocene event. The timing of these events was constrained by one radiocarbon age on charcoal fragments, four radiocarbon ages on soil organic concentrates, and nine thermoluminescence age estimates. The trench exposed Cretaceous Smoky Hill Shale bedrock in the footwall of the fault, but only exposed a mixture of scarp-derived colluvium and paludal deposits on the hanging wall side. Within the colluvial sequence, there is clear evidence of three events.

Timing of most prehistoric faulting: latest Quaternary $(<15 \mathrm{ka})$

Comments: The age of the most recent event is relatively well constrained by radiocarbon and TL age estimates (Crone and others, 1997 \#2680), although these estimates only provide a maximum limit on the timing of the events. Detrital charcoal fragments deposited within a faulted A-horizon (soil) have a calibrated AMS radiocarbon age of $8.4 \mathrm{ka}$. Based on the proximity of these charcoal fragments to the paleo-ground surface, Crone and others (1997 \#2680) argue that the most recent event has an age of about $8 \mathrm{ka}$ (early Holocene).

\section{Recurrence interval 8 k.y.}

Comments: The average recurrence interval is about $8 \mathrm{ka}$ in the past about $25 \mathrm{ka}$ with a range of 4-12 ka between individual events. Crone and others (1997 \#2680) estimated that surfacerupturing events on the fault occurred at about $8 \mathrm{ka}, 12 \mathrm{ka}$, and 20-25 ka based on their trenching study. They also speculated that events older than about 25 k.y. must have occurred before about $100 \mathrm{ka}$ because of the time needed to incise, widen, and backfill the paleo-stream channel that is now filled with latest Pleistocene deposits. The latest Pleistocene deposits at the trench site was deposited in a low-gradient paleo-stream channel that was cut into Cretaceous shale. The length of time required to erode this wide channel down through older Pleistocene alluvial deposits and into the bedrock is thought to be on the order of 100,000 years or longer. The cumulative vertical offset on the Cretaceous shale is 3.2-4.1 m, which is the total offset from the three late Quaternary events. Thus the evidence suggests that during the past 100,000 years or longer, the only surface-faulting events have occurred in the past 25,000 years. 
The frequency of surface-faulting earthquakes that occurred in the past about 25 ky could not have been sustained throughout all of the Pleistocene because, if this frequency had been sustained, then a scarp on the Rocky Flats Alluvium (estimated age of about 1.2 Ma) would have to be more than $100 \mathrm{~m}$ high. However, the Rocky Flats Alluvium is only offset about 7 to 8 $\mathrm{m}$ by the fault.

Based on this apparent temporal pattern, Crone and others speculated that the fault's longterm behavior is characterized by temporal clustering of earthquakes, in which relatively short time intervals of activity (e.g., 15-20 k.y.) are separated by long intervals of quiescence (e.g., 100 k.y.). If correct, this pattern of temporal clustering makes it difficult to assign a realistic recurrence interval for the fault. The suggested $8 \mathrm{ka}$ average recurrence interval is based solely on the estimated timing of the latest Pleistocene and Holocene events documented in the trenching study. This recurrence interval may only apply to periods of time when the fault is in an active phase; during a quiescent phase, surface-faulting earthquakes may not occur for hundreds of thousands of years.

Slip-rate category unknown; probably $<0.2 \mathrm{~mm} / \mathrm{yr}$

Comments: The latest Pleistocene to Holocene slip rate on the Cheraw fault is much less than $1 \mathrm{~mm} / \mathrm{yr}$. A rigorous calculation of latest Pleistocene to Holocene slip rates yields values of 0.23-0.09 mm/yr based on the data of Crone and others (1997 \#2680). During the time interval between $20-25 \mathrm{ka}$ and $8 \mathrm{ka}$, two surface-faulting events occurred. The cumulative vertical offset of these two events ranges between $1.6 \mathrm{~m}$ and $2.7 \mathrm{~m}$. A maximum latest Pleistocene slip rate would be based on the shortest time interval between these events $(20 \mathrm{ka}$ to $8 \mathrm{ka}$ ) and the maximum vertical offset in that time interval $(2.7 \mathrm{~m})$; this yields a slip rate of $0.225 \mathrm{~mm} / \mathrm{yr}$. Similarly, a minimum latest Pleistocene slip rate would be calculated by taking the longest time interval between events $(25 \mathrm{ka}$ and $8 \mathrm{ka}$ ) and the minimum vertical offset during that time interval $(1.6 \mathrm{~m})$; this yields a slip rat of $0.094 \mathrm{~mm} / \mathrm{yr}$. These slip-rate values apply to periods of time when the fault is in an active phase.

More simplistic calculations (but not rigorously correct) of a latest Pleistocene-Holocene slip rate are between $0.14-0.18 \mathrm{~mm} / \mathrm{yr}$. These rough slip rates are determined by dividing the amount of offset $(3.6 \mathrm{~m})$ on the oldest faulted deposits by the age of the deposits $(20-25 \mathrm{ka})$; these resulting slip rates are similar to the more rigorous values described above.

The long-term slip rate on the Cheraw fault would be extremely low if one were to include the effect of quiescent phases of activity. The best estimate of a long-term slip rate is $\leq 0.007$ $\mathrm{mm} / \mathrm{yr}$ based on a cumulative offset of about $8 \mathrm{~m}$ on the $1.2 \mathrm{Ma}$ Rocky Flats Alluvium. However, because of the apparent temporal clustering of events, one might question whether using a single slip-rate value is an appropriate way to characterize the rate of movement on this fault.

Length End to end (km): 44.27 Cumulative trace $(\mathrm{km}): 45.39$

Comments: The length of the fault is about $44 \mathrm{~km}$ based on mapping by Sharps (1976 \#2741).

Average strike $+45.6^{\circ}$ 


\section{References}

\#2679 Crone, A.J., and Machette, M.N., 1995, Holocene movement on the Cheraw fault, SE Colorado-Another hazardous late Quaternary fault in the stable continental interior: Eos, Transactions of the American Geophysical Union, v. 76, no. 46, November 7, 1995 supplement, p. F362.

\#2680 Crone, A.J., Machette, M.N., Bradley, L.-A., and Mahan, S.A., 1997, Late Quaternary surface faulting on the Cheraw fault, southeastern Colorado: U.S. Geological Survey Miscellaneous Geologic Investigations I-2591, 7 p. pamphlet, 1 oversize pl.

\#2682 Curtis, B.F., 1988, Sedimentary rocks in the Denver basin, in Baars, D.L., and 15 others, eds., Basins of the Rocky Mountain region-Decade of North American geology: Boulder, Colorado, Geological Society of America, The Geology of North America, v. D-2, p. 109-221.

\#792 Kirkham, R.M., and Rogers, W.P., 1981, Earthquake potential in Colorado-A preliminary evaluation: Colorado Geological Survey Bulletin 43, 171 p., 3 pls.

\#1141 Scott, G.R., 1970, Quaternary faulting and potential earthquakes in east-central Colorado: U.S. Geological Survey Professional Paper 700-C, C11-C18 p.

\#2741 Sharps, J.A., 1976, Geologic map of the Lamar quadrangle, Colorado and Kansas: U.S. Geological Survey Miscellaneous Geologic Investigations I-944, scale 1:250,000. 


\section{1, Newbury liquefaction features (Class A)}

Structure Number 2651

Structure Name Newbury liquefaction features (Class A)

Synopsis: The evidence for Quaternary faulting at this locale in northeastern Massachusetts consists of (1) eyewitness reports of liquefaction during an earthquake of MMI VII ( moment magnitude $\mathbf{M} 4.8$ ) in 1727, (2) sand dikes found in trenches and attributed to the 1727 earthquake, and (3) mid- to late Holocene sand dikes and a sand sill that are cut by the 1727 dikes. The causative fault remains unidentified.

Date of compilation 04/10/98; revised 01/28/00

Compiler and affiliation Russell L. Wheeler, U.S. Geological Survey; Martitia P. Tuttle, University of Maryland

State Massachusetts

County Essex

$1^{\circ} \times 2^{\circ}$ sheet Boston

Province New England

\section{Reliability of location Poor}

Comments: The liquefaction was recognized as the type that is caused by strong ground motion (Tuttle and Seeber, 1991 \#1911), and the strong ground motion is presumed to have been caused by slip on a preexisting fault (for example Hamilton, 1981 \#2035). However, despite the presence of large, mapped faults in the vicinity (Tuttle and Seeber, 1991 \#1911), the fault responsible for the liquefaction remains unidentified.

Geologic setting The study site in northeasternmost coastal Massachusetts is within the area in which liquefaction occurred during an earthquake of MMI VII in 1727 (Tuttle and others, 1987 \#2061). Johnston (1994 \#2042) estimated the moment magnitude as M 4.8. This part of New England has been seismically active during and since colonial times (Ebel and Kafka, 1991 \#2008). The area is underlain by Paleozoic and Precambrian metamorphic and igneous rocks that were folded and juxtaposed by slip on numerous mapped faults during the assembly of the northern Appalachians (Zen and others, 1983 \#1960). However, the locations of both earthquakes and faults at depth have large uncertainties. Thus, to date no New England earthquakes have been convincingly associated with known faults.

Sense of movement Not reported

Comments: The 1727 earthquake is known only from reports of shaking and of liquefaction. No other deformation is known from this or any older earthquake at the site.

Dip Not reported

Comments: The causative fault remains unidentified and uncharacterized.

Dip direction Not reported

Geomorphic expression The geomorphic expression is chiefly liquefaction features: sandblows at the surface and sand dikes in excavations (Tuttle and Seeber, 1991 \#1911). In addition, two 
new springs formed in 1727, and localized elevation of marshland at the same time might have been caused by a lateral spread (Tuttle and others, 1987 \#2061).

Age of faulted deposits The location of the fault is unknown. The area is underlain by Late Pleistocene, glaciomarine deposits: clay at the surface is underlain by sand and then bedrock (Tuttle and others, 1987 \#2061). The sand is very susceptible to liquefaction. Tuttle and Seeber (1991 \#1911) presumed the sand to be the source of the sand dikes.

Paleoseismological studies The only paleoseismological study is that of Tuttle and Seeber (1991 \#1911). During reconnaissance of sand and gravel pits and other excavations in Late Pleistocene glacial deposits in northeastern Massachusetts and southeastern New Hampshire, Tuttle and Seeber (1991 \#1911) found abundant soft-sediment deformation features. None of the features could be attributed solely to earthquakes. However, accounts of the 1727 earthquake described several areas of ground failure typical of earthquake-induced liquefaction. Tuttle and Seeber (1991 \#1911) relocated these areas by studying family genealogies, transfer of property through wills and deeds, and old maps. They then excavated trenches at these sites. In one or more trenches at a single site, they observed that dikes of white, very finegrained sand cut the Late Pleistocene, glaciomarine clay and a sandy soil B horizon. The glaciomarine clay also contains reddish, medium-grained sand domains that Tuttle and Seeber (1991 \#1911) suggested are remnants of dikes older than those of the white, fine-grained sand. At a second site $5 \mathrm{~km}$ away, the sandy B horizon contains a basal layer of gray, silty, virtually unweathered sand, which Tuttle and Seeber (1991 \#1911) interpreted as a sill emplaced beneath possibly frozen ground. Some dikes appear to feed the sill, whereas other dikes cut across it. Tuttle and Seeber (1991 \#1911) took the sill and the dikes that cut it as evidence of two episodes of liquefaction. Tuttle and Seeber (1991 \#1911) suggested that the younger liquefaction episode was caused by the 1727 earthquake. A separate reconnaissance of riverbank and marsh outcrops in northeastern Massachusetts and nearby New Hampshire found no evidence of liquefaction in salt marsh deposits that are 1500-3000 years old and underlain by highly liquefiable sands (Gelinas and others, 1993 \#1826).

Timing of most recent paleoevent latest Quaternary $(<15 \mathrm{ka})$

Comments: Accelerator mass spectrometric (AMS) dates on wood samples that are stratigraphically related to the sand dikes constrain both liquefaction episodes to between 110 and 4,430 yr B.P.

Recurrence interval 4 k.y. (4,430yr B.P. - 1727 A.D.)

Comments: From the AMS dates, Tuttle and Seeber (1991 \#1911) suggested a maximum recurrence interval of approximately 4,000 years for earthquakes large enough to cause liquefaction in the study area.

\section{Slip-rate category Unknown}

Comments: No dated fault offset is known, so no slip rate can be calculated.

Length Not applicable

Comments: The causative fault or faults are unknown. The only evidence of prehistoric faulting is sand dikes at two sites $5 \mathrm{~km}$ apart. 
Average strike Not applicable

Comments: The causative fault or faults are unknown. The only evidence of prehistoric faulting is sand dikes at two sites $5 \mathrm{~km}$ apart.

\section{References}

\#2008 Ebel, J.E., and Kafka, A.L., 1991, Earthquake activity in the northeastern United States, in Slemmons, D.B., Engdahl, E.R., Zoback, M.D., and Blackwell, D.D., eds., Neotectonics of North America: Boulder, Colorado, Geological Society of America, Decade Map Volume 1, p. 277-290.

\#1826 Gelinas, R.L., Kemppinen, H.M.A., and Amick, D.C., 1993, Evaluation of liquefactionsusceptible materials near moderate magnitude historical earthquakes in New England [abs.]: Seismological Research Letters, v. 64, p. 259-260.

\#2035 Hamilton, R.M., 1981, Geologic origin of Eastern U.S. seismicity, in Beavers, J.E., ed., Earthquakes and earthquake engineering-The Eastern United States: Ann Arbor, Michigan, Ann Arbor Science, p. 3-23.

\#2042 Johnston, A.C., 1994, Appendix C-Summary tables, SCR seismicity data base, in Schneider, J.F., ed., The earthquakes of stable continental regions - v. 2-Appendices A to E: Technical report to Electric Power Research Institute TR-102261-V2, Palo Alto, California, December 1994, p. C-1-C-46.

\#1911 Tuttle, M., and Seeber, L., 1991, Historic and prehistoric earthquake-induced liquefaction in Newbury, Massachusetts: Geology, v. 19, p. 594-597.

\#2061 Tuttle, M.P., Seeber, L., and Bradley, L., 1987, Liquefaction of glaciomarine sediments during the 1727 earthquake in Newburyport, Massachusetts, in Jacob, K.H., ed., Proceedings from the symposium on seismic hazards, ground motions, soil-liquefaction and engineering practice in eastern North America: National Center for Earthquake Engineering Research Technical Report NCEER-87-0025, p. 467-479.

\#1960 Zen, E.-a., ed., Goldsmith, R., Ratcliffe, N.M., Robinson, P., Stanley, R.S., compilers, Hatch, N.L., Jr., Shride, A.F., Weed, E.G.A., and Wones, D.R., 1983, Bedrock geologic map of Massachusetts: U.S. Geologic Survey in cooperation with The Commonwealth of Massachusetts Department of Public Works, 3 sheets, scale 1:250,000. 


\section{3, Central Virginia seismic zone (Class A)}

Structure Number 2653

Structure Name Central Virginia seismic zone (Class A)

Comments: The Central Virginia seismic zone was named by Bollinger (1973 \#1797; 1973

\#1798). It is a roughly circular area with a diameter of $120-150 \mathrm{~km}$, with a low level of diffuse seismicity, three-quarters of which is in the upper $11 \mathrm{~km}$ of the crust (1985 \#1801).

Synopsis: The geologic evidence for Quaternary faulting in the Central Virginia seismic zone consists of one site with a few, small, latest Holocene sand dikes, and a second site several tens of kilometers away with a few, small, possible dikes of early Holocene or lesser age (Obermeier and McNulty, 1998 \#1872). The causative faults remain unidentified.

Date of compilation 05/21/98; revised 9/11/98

Compiler and affiliation Russell L. Wheeler, U.S. Geological Survey

State Virginia

County Amelia; Buckingham; Caroline; Chesterfield; Cumberland; Fluvanna; Goochland; Hanover; Henrico; Louisa; Orange; Powhatan; Richmond; Spotsylvania

$1^{\circ} \times 2^{\circ}$ sheet Richmond; Roanoke; Washington; Charlottesville

Physiographic province Piedmont

Reliability of location Poor

Comments: The largest historical earthquake in the zone occurred in 1875 near the center of the zone (Oaks and Bollinger, $1986 \# 2216$ ). Intensity was MMI VII and magnitude was $\mathrm{m}_{\mathrm{b}}$ 5.0 and M 4.8 (Bollinger and Hopper, 1971 \#1799; Bollinger and Sibol, 1985 \#1801; Johnston, 1994 \#2042). No surface rupture or liquefaction is reported. Similarly, no prehistoric surface rupture is known in the seismic zone, and the only reported paleoliquefaction features are those few described below under "Paleoseismological studies". Hypocenters of microearthquakes plot within an upper crustal complex of thrust sheets (Çoruh and others, 1988 \#1807), but the locational uncertainties of both the hypocenters and the individual thrust faults are typically a few kilometers. Therefore, hypocenters and faults cannot be convincingly associated with each other. The result is that the individual seismogenic faults in the Central Virginia seismic zone remain unidentified.

Geologic setting The Central Virginia seismic zone is underlain by Precambrian and Paleozoic metamorphic and igneous rocks that were folded, juxtaposed, and superimposed by numerous nappes and thrust faults, mostly southeast-dipping, during the assembly of the Appalachians (for example Glover and others, 1983 \#1827; Glover and others, 1989 \#2034; Hatcher and others, 1989 \#2036).

\section{Sense of movement Not reported}

Comments: Single-earthquake focal mechanisms from the seismic zone are variously oriented and show reverse and strike-slip faulting (Munsey and Bollinger, 1985 \#1867; Davison, 1988 \#2027). However, the associated hypocenters are scattered geographically, and no surface ruptures are known, so no systematic sense of movement is known. 


\section{Dip Not reported}

Comments: The causative faults remain unidentified and uncharacterized. However, singleearthquake focal mechanisms have nodal planes with generally steep dips, averaging 61ํ(Bollinger, $1987 \# 2196$ ).

\section{Dip direction Not reported}

Geomorphic expression There is no geomorphic expression of the seismic zone beyond the few, small sand dikes described in "Paleoseismological studies" below.

Age of faulted deposits No Quaternary fault is known.

Paleoseismological studies Obermeier and McNulty (1998 \#1872) examined cutbanks along more than $300 \mathrm{~km}$ of many streams throughout the seismic zone, searching for geologic evidence of paleoliquefaction. The geologic record that should have recorded any paleoliquefaction extends back 2,000-3,000 years throughout the seismic zone, and at least 5,000 years in the east. One site has a few small clastic dikes that formed within the last few centuries. A second site tens of kilometers away has a few small, severely weathered, probable dikes that might have formed as long ago as early Holocene. From the close spacing of the searched streams and the paucity of observed dikes, Obermeier and McNulty (1998 \#1872) concluded that (1) the seismic zone has not had an earthquake of magnitude larger than approximately 7 for the last 2,000-3,000 years, and for the last 5,000 years in the east, and (2) the geologic records of one or a few earthquakes of magnitudes 6-7 might be concealed between streams or between cutbanks, but such earthquakes could not have been abundant in the seismic zone.

Timing of most recent paleoevent latest Quaternary $(<15 \mathrm{ka})$

Comments: One and perhaps two sites contain clastic dikes of Holocene age.

\section{Recurrence interval Not reported}

Comments: Two exposures each contain a few small dikes (Obermeier and McNulty, 1998 \#1872). Radiocarbon data and lack of severe weathering indicate that the dikes in one exposure are a few centuries old. Severity of weathering indicates that the dikes in the other exposure could be as old as early Holocene. However, the two exposures are several tens of kilometers apart across the regional structural grain, so they are unlikely to record earthquakes on the same fault. Accordingly, no recurrence interval for an individual Quaternary fault can be calculated.

\section{Slip-rate category unknown}

Comments: No dated offset is known, so no slip rate can be calculated.

Length Not applicable

Comments: The causal fault or faults are unknown. The evidence for prehistoric faulting consists of sand dikes at two sites tens of kilometers apart.

Average strike (azimuth) Not applicable

Comments: The causal fault or faults are unknown. The evidence for prehistoric faulting consists of sand dikes at two sites tens of kilometers apart. 


\section{References}

\#1797 Bollinger, G.A., 1973, Seismicity and crustal uplift in the southeastern United States: American Journal of Science, v. 273-A, p. 396-408.

\#1798 Bollinger, G.A., 1973, Seismicity of the southeastern United States: Bulletin of the Seismological Society of America, v. 63, p. 1785-1808.

\#2196 Bollinger, G.A., 1987, Seimotectonics of the Virginia and eastern Tennesse seismic zones, in Jacob, K.H., ed., Symposium on seismic hazards, ground motions, soil-liquefaction and engineering practice in eastern North America: Proceedings - National Center for Earthquake Engineering Reserach Technical Report NCEER-87-0025, p. 202216.

\#1799 Bollinger, G.A., and Hopper, M.G., 1971, Virginia's two largest earthquakes-December 22, 1875 and May 31, 1897: Bulletin of the Seismological Society of America, v. 61, p. 1033-1039.

\#1801 Bollinger, G.A., and Sibol, M.S., 1985, Seismicity, seismic reflection studies, gravity and geology of the central Virginia seismic zone-Part I. Seismicity: Geological Society of America Bulletin, v. 96, p. 49-57.

\#1807 Çoruh, C., Bollinger, G.A., and Costain, J.K., 1988, Seismogenic structures in the central Virginia seismic zone: Geology, v. 16, p. 748-751.

\#2027 Davison, F.C., Jr., 1988, Stress tensor estimates derived from focal mechanism solutions of sparse data sets-Applications to seismic zones in Virginia and eastern Tennessee: Blacksburg, Virginia Polytechnic Institute and State University, unpublished Ph.D. dissertation, $189 \mathrm{p}$.

\#2034 Glover, L., III, Evans, N.H., Patterson, J.G., Brown, W.R., Wehr, F., and Mose, D., 1989, Tectonics of the Virginia Blue Ridge and Piedmont: Washington, D.C., American Geophysical Union, 28th International Geological Congress Field Trip Guidebook T363, 59 p.

\#1827 Glover, L., III, Speer, J.A., Russell, G.S., and Farrar, S.S., 1983, Ages of regional metamorphism and ductile deformation in the central and southern Appalachians: Lithos, $\mathrm{V}$. 16, p. 223-245.

\#2036 Hatcher, R.D., Jr., Osberg, P.H., Drake, A.A., Jr., Robinson, P., and Thomas, W.A., 1989, Tectonic map of the U.S. Appalachians, in Hatcher, R.D., Jr., Thomas, W.A., and Viele, G.W., eds., The Appalachian-Ouachita orogen in the United States: Boulder, Colorado, Geological Society of America, The Geology of North America, v. F-2, plate 1.

\#2042 Johnston, A.C., 1994, Appendix C-Summary tables, SCR seismicity data base, in Schneider, J.F., ed., The earthquakes of stable continental regions-v. 2-Appendices A to E: Technical report to Electric Power Research Institute TR-102261-V2, Palo Alto, California, December 1994, p. C-1-C-46.

\#1867 Munsey, J.W., and Bollinger, G.A., 1985, Focal mechanism analyses for Virginia earthquakes (1978-1984): Bulletin of the Seismological Society of America, v. 75, p. 16131636. 
\#2216 Oaks, S.D., and Bollinger, G.A., 1986, The epicenter of the $m_{b}$, December 22, 1875 Virginia earthquake-New finds from documentary sources: Earthquake Notes, v. 57, no. 3 , p. $65-75$.

\#1872 Obermeier, S.F., and McNulty, W.E., 1998, Paleoliquefaction evidence for seismic quiescence in central Virginia during late and middle Holocene time [abs.]: Eos, Transactions of the American Geophysical Union, v. 79, no. 17, p. S342. 


\section{7, Charleston liquefaction features (Class A)}

Structure Number 2657

Structure Name Charleston liquefaction features (Class A)

Synopsis The evidence for Quaternary faulting at this locale in central coastal South Carolina consists of (1) eyewitness reports of widespread liquefaction during an earthquake in 1886 of moment magnitude M 7.3 and intensity MMI X (Bollinger, 1977 \#1966; Johnston, 1996 \#1842), (2) middle to late Holocene craters, sand blows, and sand fissures produced by large, prehistoric earthquakes, and (3) the recognition that the liquefaction and paleoliquefaction features are attributable to strong shaking caused by seismic faulting (Obermeier and others, 1987 \#2050; Obermeier, 1996 \#2256).

Date of compilation 08/05/98; revised 12/15/98

Compiler and affiliation Russell L. Wheeler, U.S. Geological Survey

State South Carolina

County Charleston; Dorchester; Berkeley

$1^{\circ} \times 2^{\circ}$ sheet Savannah; Augusta; James Island; Georgetown

Physiographic province Coastal Plain

\section{Reliability of location Poor}

Comments: The liquefaction was recognized as the type that is caused by strong ground motion (Obermeier, 1996 \#2256), and the strong motions are presumed to have been caused by slip on one or more preexisting faults. However, the causative fault or faults have not been identified and the locations and sizes of the liquefaction features provide poor constraints on the source or sources of the shaking.

Geologic setting The land is flat and near sea level, and the water table is near or at the surface (Obermeier, 1996 \#2256). Five to 25 meters of Quaternary beach, marine, and fluvial deposits overlie 500-1100 m of Tertiary and Cretaceous Coastal Plain strata, which in turn overlie Triassic and Jurassic basalt and rift basins and Paleozoic metamorphic and igneous rocks (Ackermann, 1983 \#1961; Daniels and others, 1983 \#1962; McCartan and others, 1990 \#1969).

The Charleston area is part of a seismically active region that spans most of South Carolina (Bollinger, 1973 \#1798; Bollinger and others, 1991 \#2005). Seismicity in the region surrounding the 1886 earthquake has been higher than typical for the Southeast as a whole since 1886, but was markedly lower during the preceding half century than it has been since 1886 (Bollinger and Visvanathan, 1977 \#1967; Armbruster and Seeber, 1984 \#1790). McCartan and others (1990 \#1969) reported that no faults were known to cut Quaternary deposits. However, study of paleoliquefaction features has led to a chronology of large, prehistoric earthquakes that spans at least the latter half of the Holocene (Amick and Gelinas, 1991 \#1787; Talwani, 1994 \#1977; Talwani, 1996 \#2234; Obermeier, 1996 \#2256, and preceding reports summarized by these authors). Amick and Gelinas (1991 \#1787) and D. Amick (oral commun., 1998) noted that ground-water level was lower before $3 \mathrm{ka}$ than at present, and still lower before 
5 ka. Low water tables can suppress liquefaction (Obermeier, 1996 \#2256). Thus, earthquakes older than 3-5 ka. and large enough to cause liquefaction may be underrepresented in the South Carolina earthquake chronology, and their magnitudes may be underestimated.

Despite considerable geological, seismological, and other geophysical work conducted over more than two decades, the fault or faults that slipped to produce the 1886 earthquake remain unknown (for example Rankin, 1977 \#1970; Gohn, 1983 \#1964; Dewey, 1985 \#2030; Talwani, 1990 \#2013). Geomorphic and geodetic anomalies in and near the meizoseismal area of the 1886 earthquake have not yet been clearly linked to seismogenic faulting, partly because many kinds of neotectonic evidence cannot demonstrate that prehistoric deformation of the ground surface occurred suddenly (Rhea, 1989 \#1886; Talwani, 1990 \#2013; Marple and Talwani, 1993 \#1857; Talwani and others, 1997 \#2058; Talwani and Marple, 1997 \#2236).

\section{Sense of movement Not reported}

Comments: The 1886 earthquake is known only from reports of damage, shaking, lateral spreading, and liquefaction. The prehistoric earthquakes are known only from locations and dates of liquefaction. No surface ruptures or other deformation are known from any of the earthquakes. Single-earthquake focal mechanisms and hypocenter locations that were calculated with corrected polarities and a three-dimensional velocity structure (Shedlock, 1987 \#1982) have not yet yielded constraints on the movement sense of the 1886 earthquake.

Dip Not reported

Comments: The causative fault or faults remain unidentified and uncharacterized.

\section{Dip direction Not reported}

Geomorphic expression The numerous sandblows that formed in 1886 can be expressed as shallow craters as wide as several meters. However, all craters of prehistoric sandblows are filled with sediment. Consequently, the prehistoric craters lack geomorphic expression and are recognized only in the walls of excavations (Obermeier, 1996 \#2048).

Age of faulted deposits The liquefaction features formed in Quaternary deposits (McCartan and others, $1990 \# 1969)$. Most areas searched for liquefaction features are those underlain by deposits 80,000-250,000 years old, because older deposits have low liquefaction susceptibility and younger ones have too high a water table to permit searches of excavation walls (Obermeier, 1996 \#2048).

Paleoseismological studies Obermeier and others (1985 \#1871) and Talwani and Cox (1985 \#1902) first reported pre-1886 liquefaction features of the sorts produced by prehistoric earthquakes. Obermeier and others (1987 \#2050; 1989 \#2218), Weems and Obermeier (1989 \#2241), and Amick and others (1990 \#1788) described criteria for searching for, recognizing, and dating prehistoric liquefaction features throughout coastal South Carolina. Amick and Gelinas (1991 \#1787), Rajendran and Talwani (1993 \#1882), and Talwani (1994 \#1977; 1996 \#2234) reported results in the form of an evolving chronology of large earthquakes.

Interpretations of the number of large Charleston earthquakes are complicated by the fact that the main source at Charleston appears to be flanked on both sides by secondary sources of liquefaction, approximately $100 \mathrm{~km}$ to the northeast near Georgetown, South Carolina, and 
approximately $100 \mathrm{~km}$ to the southwest near Bluffton, South Carolina. Each secondary source is described separately in this compilation. Approximately synchronous liquefaction at two adjacent sources or at all three sources could be caused by a single large earthquake at one of the sources, or by smaller, coeval earthquakes at each source.

Additional complications arise because a prehistoric liquefying earthquake is assigned to one source or another according to the number and sizes of liquefaction features of appropriate ages that have been found at each source. However, continuing fieldwork leads to the recognition of additional paleoliquefaction features and to revised age estimates for the liquefying earthquakes. Thus, for example, Amick and Gelinas (1991 \#1787) reported evidence of a liquefying earthquake at or near the Charleston source $580 \pm 104$ years ago. Rajendran and Talwani (1993 \#1882) reported new results and revised the estimated location to the Bluffton area and the estimated time to $500 \pm 180$ years ago. More complete results returned the most likely location to the Charleston area and revised the estimated age to $546 \pm 17$ years ago (Talwani, 1996 \#2234, and S.F. Obermeier, written commun., 1998).

The following chronology of large, liquefying earthquakes follows Talwani (1996 \#2234), who applied dendrochronological corrections to all previous age estimates (P. Talwani, oral communs., 1998). Eight earthquakes occurred in coastal South Carolina, in 1886, and prehistorically at $0.55 \mathrm{ka}, 1.00 \mathrm{ka}, 1.64 \mathrm{ka}, 1.96 \mathrm{ka}(1754-2177 \mathrm{yr}$ B.P.), $3.55 \mathrm{ka}, 5.04 \mathrm{ka}$, and 5.80 ka. The first two and last three age estimates correspond straightforwardly to estimates reported by earlier workers. The earthquake at $1.00 \mathrm{ka}$ corresponds to the events dated between $1.13 \mathrm{ka}$ and $1.25 \mathrm{ka}$ by Amick and Gelinas (1991 \#1787), Obermeier (1996 \#2256), Rajendran and Talwani (1993 \#1882), and Talwani (1994 \#1977). The earthquake at $1.64 \mathrm{ka}$ corresponds to the events dated at $1.72 \mathrm{ka}$ (Amick and Gelinas, 1991 \#1787) and $1.80 \mathrm{ka}$ (Talwani, 1994 \#1977). Paleoliquefaction features attributed to the $1.64 \mathrm{ka}$ earthquake have been reported only from the Georgetown source area thus far. The earthquake at 1.96 ka corresponds to the events dated at $2.35 \mathrm{ka}$ (Rajendran and Talwani, 1993 \#1882) and $2.20 \mathrm{ka}$ (Talwani, 1994 \#1977). Evidence for the $1.96 \mathrm{ka}$ earthquake has thus far been reported only from the Bluffton source area.

Amick and Gelinas (1991 \#1787) and Obermeier (1996 \#2256) considered the relative sizes of the prehistoric liquefaction features as compared to those from 1886 and elsewhere in the world, the geographic distribution of features of a particular age, source sand compactness, water table depth, and other factors in arguing that the prehistoric earthquakes were larger than $\mathbf{M} 5$ and probably larger than $\mathbf{M}$ 5.5, and that some might have exceeded the magnitude of the 1886 shock. Amick and Gelinas (1991 \#1787) and D. Amick (oral commun., 1998) noted that ground-water level was lower before $3 \mathrm{ka}$ than at present, and still lower before 5 ka. Thus, large earthquakes older than 3-5 ka might be underrepresented in the South Carolina earthquake chronology, and their magnitudes might be underestimated.

Timing of most recent paleoevent latest Quaternary ( $<15 \mathrm{ka})$

Comments: The most recent prehistoric earthquake at the Charleston source that was large enough to produce liquefaction occurred at $0.55 \mathrm{ka}$ (Amick and Gelinas, 1991 \#1787; Obermeier, 1996 \#2048; Talwani, 1996 \#2234) 
Recurrence interval 0.44 or 0.46 k.y. $(<3.2 \mathrm{ka})$

Comments: There are two suggested earthquake chronologies for the Charleston source. As noted above under "Detailed studies", eight liquefying earthquakes occurred at approximately $0.11,0.55,1.00,1.64,1.96,3.55,5.04$, and $5.80 \mathrm{ka}$ (Talwani, 1996). One chronology has all occurring in the Charleston source area, and the second has the 1.64 ka earthquake occurring at or near Georgetown and the $1.96 \mathrm{ka}$ earthquake at or near Bluffton (P. Talwani, oral communs., 1997, 1998). In addition, as noted above under "Geologic setting", the water table was lower than at present before $3 \mathrm{ka}$, and still lower prior to $5 \mathrm{ka}$ (Amick and Gelinas, 1991 \#1787, and D. Amick, oral commun., 1998). Lower water tables could produce an incomplete record of large prehistoric earthquakes.

If all eight earthquakes occurred in the Charleston source area, the resulting seven intervals would have a mean of $0.81 \mathrm{k} . \mathrm{y}$. If the 1.64 and $1.96 \mathrm{ka}$ earthquakes occurred at or near Georgetown and Bluffton, respectively, the resulting five intervals would average to $1.14 \mathrm{k} . \mathrm{y}$. Excluding the two earthquakes that occurred before $5 \mathrm{ka}$, when the water table was lowest, would result in a recurrence estimate of 0.69 k.y. ( 5 intervals) if all earthquakes were in the Charleston source area, and $1.15 \mathrm{k} . \mathrm{y}$. (3 intervals) if the 1.64 and $1.96 \mathrm{ka}$ earthquakes occurred at or near Georgetown and Bluffton. Excluding all three earthquakes that occurred before $3 \mathrm{ka}$, when the water table was lower than at present, would result in a recurrence estimate of $0.46 \mathrm{k} . y$. (4 intervals) if all earthquakes were in the Charleston source area, and 0.44 k.y. ( 2 intervals) if the 1.64 and 1.96 ka earthquakes were at or near Georgetown and Bluffton. The last two estimates, 0.44 and 0.46 k.y., are preferred. The preferred estimates use only earthquakes younger than $3 \mathrm{ka}$. The five earthquakes since $3 \mathrm{ka}$ occurred 0.32-0.64 k.y. apart, whereas the three before $3 \mathrm{ka}$ occurred 0.76-1.59 k.y. apart. Two possible explanations for this decrease in recurrence intervals are that (1) lower water tables before 3 ka produced an incomplete paleoseismological record of liquefaction, and (2) the record is complete and recurrence intervals decreased markedly between 3.55 and $1.96 \mathrm{ka}$. In either case, earthquakes since $3 \mathrm{ka}$ are the most likely to represent the current and continuing behavior of the Charleston source. Note also that whether the earthquakes at 1.64 and 1.96 ka occurred at Charleston, or at Georgetown and Bluffton, has only a negligible effect on the recurrence rate estimated for the Charleston source.

Slip-rate category unknown

Comments: No causal fault, surface rupture, or dated fault offset is known. Talwani (1999 \#2235) showed that a slip rate estimated from Global Positioning System data could produce an 1886-sized earthquake in approximately the recurrence interval given above ("Recurrence interval").

\section{Length Not applicable}

Comments: The causative fault of faults are unknown. The only recognized expression of the prehistoric faulting is liquefaction features scattered over an area. The area adjoins of merges with the areas of liquefaction that can be attributed to earthquakes farther southwest, near Bluffton, and father northeast, near Georgetown. 
Average strike Not applicable

Comments: The causative fault of faults are unknown. The only recognized expression of the prehistoric faulting is liquefaction features scattered over an area. The area adjoins of merges with the areas of liquefaction that can be attributed to earthquakes farther southwest, near Bluffton, and farther northeast, near Georgetown.

\section{References}

\#1961 Ackermann, H.D., 1983, Seismic-refraction study in the area of the Charleston, South Carolina, 1886 earthquake, in Gohn, G.S., ed., Studies related to the Charleston, South Carolina, earthquake of 1886-Tectonics and seismicity: U.S. Geological Survey Professional Paper 1313-F, p. 1-20.

\#1787 Amick, D., and Gelinas, R., 1991, The search for evidence of large prehistoric earthquakes along the Atlantic seaboard: Science, v. 251, p. 655-658.

\#1788 Amick, D., Maurath, G., and Gelinas, R., 1990, Characteristics of seismically induced liquefaction sites and features located in the vicinity of the 1886 Charleston, South Carolina earthquake: Seismological Research Letters, v. 61, p. 117-130.

\#1790 Armbruster, J.G., and Seeber, L., 1984, Low seismicity in South Carolina prior to the 1886 earthquake [abs.]: Eos, Transactions of the American Geophysical Union, v. 65, p. 241.

\#1798 Bollinger, G.A., 1973, Seismicity of the southeastern United States: Bulletin of the Seismological Society of America, v. 63, p. 1785-1808.

\#1966 Bollinger, G.A., 1977, Reinterpretation of the intensity data for the 1886 Charleston, South Carolina, earthquake, in Rankin, D.W., ed., Studies related to the Charleston, South Carolina, earthquake of 1886-A Preliminary Report: U.S. Geological Survey Professional Paper 1028-B, p. 17-32.

\#2005 Bollinger, G.A., Johnston, A.C., Talwani, P., Long, L.T., Shedlock, K.M., Sibol, M.S., and Chapman, M.C., 1991, Seismicity of the southeastern United States; 1698 to 1986, in Slemmons, D.B., Engdahl, E.R., Zoback, M.D., and Blackwell, D.D., eds., Neotectonics of North America: Boulder, Colorado, Geological Society of America, Decade Map Volume 1, p. 291-308.

\#1967 Bollinger, G.A., and Visvanathan, T.R., 1977, The seismicity of South Carolina prior to 1886, in Rankin, D.W., ed., Studies related to the Charleston, South Carolina, earthquake of 1886 - A preliminary report: U.S. Geological Survey Professional Paper 1028C, p. 33-41.

\#1962 Daniels, D.L., Zietz, I., and Popenoe, P., 1983, Distribution of subsurface lower Mesozoic rocks in southeastern United States, as interpreted from regional aeromagnetic and gravity maps, in Gohn, G.S., ed., Studies related to the Charleston, South Carolina, earthquake of 1886-Tectonics and seismicity: U.S. Geological Survey Professional Paper 1313-K, p. K1-K24.

\#2030 Dewey, J.W., 1985, A review of recent research on the seismotectonics of the southeastern seaboard and an evaluation of hypotheses on the source of the 1886 Charleston, 
South Carolina, earthquake: U.S. Nuclear Regulatory Commission Report NUREG/CR4339, $44 \mathrm{p}$.

\#1964 Gohn, G.S., ed., 1983, Studies related to the Charleston, South Carolina, earthquake of 1886-Tectonics and seismicity: U.S. Geological Survey Professional Paper 1313, 423 p., 8 pls.

\#1842 Johnston, A.C., 1996, Seismic moment assessment of earthquakes in stable continental regions-III. New Madrid 1811-1812, Charleston 1886 and Lisbon 1755: Geophysical Journal International, v. 126, p. 314-344.

\#1857 Marple, R.T., and Talwani, P., 1993, Evidence of possible tectonic upwarping along the South Carolina coastal plain from an examination of river morphology and elevation data: Geology, v. 21, p. 651-654.

\#1969 McCartan, L., Weems, R.E., and Lemon, E.M., Jr., 1990, Quaternary stratigraphy in the vicinity of Charleston, South Carolina, and its relationship to local seismicity and regional tectonism, in Studies related to the Charleston, South Carolina, earthquake of 1886 - Neogene and Quaternary lithostratigraphy and biostratigraphy: U.S. Geological Survey Professional Paper 1367-A, p. 39.

\#2048 Obermeier, S.F., 1996, Using liquefaction-induced features for paleoseismic analysis, in McCalpin, J.P., ed., Paleoseismology: San Diego, Academic Press, p. 331-396.

\#2256 Obermeier, S.F., 1996, Use of liquefaction-induced features for paleoseismic analysisAn overview of how seismic liquefaction features can be distinguished from other features and how their regional distribution and properties of source sediment can be used to infer the location and strength of Holocene paleo-earthquakes: Engineering Geology, v. 44 , p. $1-76$.

\#1871 Obermeier, S.F., Gohn, G.S., Weems, R.E., Gelinas, R.L., and Rubin, M., 1985, Geologic evidence for recurrent moderate to large earthquakes near Charleston, South Carolina: Science, v. 227, p. 408-411.

\#2050 Obermeier, S.F., Weems, B.E., and Jacobson, R.B., 1987, Earthquake-induced liquefaction features in the coastal South Carolina region, in Jacob, K.H., ed., Proceedings from the symposium on seismic hazards, ground motions, soil-liquefaction and engineering practice in eastern North America: National Center for Earthquake Engineering Research Technical Report NCEER-87-0025, p. 480-493.

\#2218 Obermeier, S.F., Weems, R.E., Jacobson, R.B., and Gohn, G.S., 1989, Liquefaction evidence for repeated Holocene earthquakes in the coastal region of South Carolina, in Jacob, K.H., and Turkstra, C.J., eds., Earthquake hazards and the design of constructed facilities in the eastern United States: Annals of the New York Academy of Sciences, v. 558, p. 183-195.

\#1882 Rajendran, C.P., and Talwani, P., 1993, Paleoseismic indicators near Bluffton, South Carolina-An appraisal of their tectonic implications: Geology, v. 21, p. 987-990.

\#1970 Rankin, D.W., ed., 1977, Studies related to the Charleston, South Carolina, earthquake of 1886-A preliminary report: U.S. Geological Survey Professional Paper 1028, 204 p. 
\#1886 Rhea, S., 1989, Evidence of uplift near Charleston, South Carolina: Geology, v. 17, p. 311-315.

\#1982 Shedlock, K.M., 1987, Earthquakes recorded by the South Carolina seismic network (1974-1986): U.S. Geological Survey Open-File Report 87-437, 92 p.

\#2013 Talwani, P., 1990, Neotectonics in the southeastern United States with emphasis on the Charleston, South Carolina, area, in Krinitzsky, E.L., and Slemmons, D.B., eds., Neotectonics in earthquake evaluation: Geological Society of America Reviews in Engineering Geology, v. 8, p. 59-75.

\#1977 Talwani, P., 1994, Paleoseismological studies in South Carolina, in Prentice, C.S., Schwartz, D.P., and Yeats, R.S., eds., Proceedings of the workshop on paleoseismology, September 18-22, 1994, Marshall, California: U.S. Geological Survey Open-File Report 94-568, p. 180-181.

\#2234 Talwani, P., 1996, Prehistoric earthquakes in the South Carolina coastal plain:

Geological Society of America Abstracts with Programs, v. 28, no. 7, p. A-283.

\#2235 Talwani, P., 1999, Fault geometry and earthquakes in continental interiors:

Tectonophysics, v. 305, p. 371-379.

\#1902 Talwani, P., and Cox, J., 1985, Paleoseismic evidence for recurrence of earthquakes near Charleston, South Carolina: Science, v. 229, p. 379-381.

\#2058 Talwani, P., Kellogg, J.N., and Trenkamp, R., 1997, Validation of tectonic models for an intraplate seismic zone, Charleston, South Carolina, with GPS geodetic data: U.S. Nuclear Regulatory Commission Report NUREG/CR-6529, 41 p.

\#2236 Talwani, P., and Marple, R.T., 1997, Evidence of neotectonic activity in the South Carolina Coastal Plain, in Hong, Y., ed. Contemporary lithospheric motion/seismic geology: Utrecht, The Netherlands, VSP, International Geological Congress, 30th, Beijing, China, August 4-14, 1996, Proceedings, v. 5, p. 49-61.

\#2241 Weems, R.E., and Obermeier, S.F., 1989, The 1886 Charleston earthquake-An overview of geological studies, in Proceedings of the U.S. Nuclear Regulatory CommissionSeventeenth Water Reactor Safety Meeting: U.S. Nuclear Regulatory Commission NUREG/CP-0105, v. 2, p. 289-313. 


\section{8, Bluffton liquefaction features (Class A)}

Structure Number 2658

Structure Name Bluffton liquefaction features (Class A)

Comments: Obermeier and others (1987 \#2050; 1989 \#2218) and Weems and Obermeier (1989 \#2241) reported prehistoric liquefaction features near Bluffton, South Carolina, approximately $100 \mathrm{~km}$ southwest of Charleston, South Carolina. Amick and Gelinas (1991 \#1787) and Talwani (1994 \#1977) referred to the Bluffton area as the southern area. Widespread and longstanding practice is to refer to the liquefaction features near Charleston by the name of that city, and Rajendran and Talwani (1993) implicitly followed this practice in referring to the features near Bluffton. This compilation follows the same practice in use for the Charleston features.

Synopsis: The evidence for Quaternary faulting at this locale in southwestern coastal South Carolina consists of late Holocene liquefaction features produced by a large, prehistoric earthquake. The causative fault remains unidentified.

Date of compilation 08/05/98; revised 12/15/98

Compiler and affiliation Russell L. Wheeler, U.S. Geological Survey

State South Carolina

County Beaufort

$1^{\circ} \times 2^{\circ}$ sheet Savannah

Physiographic province Coastal Plain

\section{Reliability of location Poor}

Comments: The liquefaction was recognized as the type that is caused by strong ground motion (Obermeier, 1996 \#2256), and the strong motions are presumed to have been caused by slip on a preexisting fault. However, the causative fault has not been identified and the locations and sizes of the liquefaction features provide poor constraints on the source of the shaking.

Geologic setting The land is flat and near sea level, and the water table is near or at the surface (Obermeier, 1996 \#2256). Several meters of Quaternary beach, marine, and fluvial deposits overlie approximately $1 \mathrm{~km}$ of Tertiary and Cretaceous Coastal Plain strata, which in turn overlie Triassic and Jurassic basalt and rift basins and Paleozoic metamorphic and igneous rocks (Ackermann, 1983 \#1961; Daniels and others, 1983 \#1962; McCartan and others, 1990 $\# 1969$ ). The locale is inside the southwestern edge of a seismically active region that spans most of South Carolina (Bollinger and others, 1991 \#2005). Amick and Gelinas (1991 \#1787) and D. Amick (oral commun., 1998) noted that ground-water level was lower before 3 ka than at present, and still lower before $5 \mathrm{ka}$. Thus, earthquakes older than 3-5 ka and large enough to cause liquefaction may be underrepresented in the South Carolina chronology.

\section{Sense of movement Not reported}

Comments: The prehistoric earthquake is known only from locations and age estimates of liquefaction. No surface ruptures or other deformation is known from the earthquake. 


\section{Dip Not reported}

Comments: The causative fault remains unidentified and uncharacterized.

Dip direction Not reported

Geomorphic expression The craters of prehistoric sandblows are filled with sediment. Consequently, the prehistoric craters lack geomorphic expression and are recognized only in the walls of excavations (Obermeier, 1996 \#2256).

Age of faulted deposits Most areas searched for liquefaction features are those underlain by deposits 80,000-250,000 years old, because older deposits have low liquefaction susceptibility and younger ones have too high a water table to permit searches of excavation walls (Obermeier, 1996 \#2256).

Paleoseismological studies The Bluffton source is approximately $100 \mathrm{~km}$ southwest of the Charleston source. Obermeier and others (1987 \#2050; 1989 \#2218), Weems and Obermeier (1989 \#2241), and Amick and others (1990 \#1788) described criteria for searching for, recognizing, and dating prehistoric liquefaction features throughout coastal South Carolina. Amick and Gelinas (1991 \#1787), Rajendran and Talwani (1993 \#1882), and Talwani (1994 \#1977; 1996 \#2234) summarized results for the Bluffton area in the form of an evolving chronology of liquefying earthquakes.

The following and other factors complicate interpretation. First, approximately synchronous liquefaction at the Charleston and Bluffton sources could be caused by a single large earthquake at one of the sources, or by smaller, coeval earthquakes at each source. Second, additional complications arise because a prehistoric liquefying earthquake is assigned to one source or another according to the number and sizes of liquefaction features of appropriate age that have been found at each source. However, continuing fieldwork leads to the recognition of additional paleoliquefaction features and to revised age estimates for the liquefying earthquakes. Thus, for example, Amick and Gelinas (1991 \#1787) reported evidence of a liquefying earthquake at or near the Charleston source $580 \pm 104$ years ago. Rajendran and Talwani (1993 \#1882) reported new results and revised the estimated location to the Bluffton area and the estimated time to $500 \pm 180$ years ago. More complete results returned the most likely location to the Charleston area and revised the estimated age to $546 \pm 17$ years ago (Talwani, 1996 \#2234, and S.F. Obermeier, written commun., 1998). Third, Amick and Gelinas (1991 \#1787) and D. Amick (oral commun., 1998) noted that ground-water level was lower before $3 \mathrm{ka}$ than at present, and still lower before $5 \mathrm{ka}$. Thus, earthquakes older than 3-5 $\mathrm{ka}$ and large enough to cause liquefaction may be underrepresented in the South Carolina earthquake chronology.

Amick and Gelinas (1991 \#1787) and Obermeier (1996 \#2256) considered the relative sizes of the prehistoric liquefaction features as compared to those from 1886 and elsewhere in the world, the geographic distribution of features of a particular age, source sand compactness, water table depth, and other factors. They argued that the prehistoric earthquakes of coastal South Carolina, including the Bluffton area, were larger than moment magnitude $\mathbf{M} 5$ and probably M 5.5 or larger, and that some might have exceeded the magnitude of the 1886 shock at Charleston. Talwani (1996 \#2234) applied dendrochronological corrections to all previous age estimates from coastal South Carolina, including those from the Bluffton area. He 
concluded that eight liquefying earthquakes occurred in coastal South Carolina between 1886 and $5.8 \mathrm{ka}$, but only one of these at $1.96 \mathrm{ka}$ may have occurred in the Bluffton source area (2.35 ka earthquake of Rajendran and Talwani, 1993 \#1882; 2.20 ka earthquake of Talwani, 1994 \#1977). P. Talwani (oral communs., 1997, 1998) holds open the possibility that the 1.96 ka liquefaction might have been a distant effect of a large earthquake near Charleston.

Timing of most recent paleoevent latest Quaternary $(<15 \mathrm{ka})$

Comments: The most recent prehistoric earthquake large enough to cause detected liquefaction may have occurred at $1.96 \mathrm{ka}$ (Rajendran and Talwani, 1993 \#1882; Talwani, 1994 \#1977; 1996 \#2234). Alternatively, the liquefaction features that formed at $1.96 \mathrm{ka}$ in the Bluffton area might be distant effects of an earthquake at the Charleston source (P. Talwani, oral communs., 1997, 1998). In the latter case, there would be no evidence for paleoevents at or near Bluffton, nor evidence of a discrete source there.

\section{Recurrence interval Not reported}

Comments: As noted above under "Paleoseismological studies", a liquefying earthquake at $1.96 \mathrm{ka}$ occurred in either the Charleston or the Bluffton source areas. In neither case can one calculate an estimate of the Bluffton recurrence interval.

Slip-rate category unknown

Comments: No causal fault, surface rupture, or dated fault offset is known, so no slip rate can be calculated.

\section{Length $(\mathrm{km})$ Not applicable}

Comments: The causative fault or faults are unknown. The only recognized expression of the prehistoric faulting is liquefaction features scattered over an area. The area adjoins of merges with the area of liquefaction that is attributed to Charleston earthquakes.

Average strike (azimuth) Not applicable

Comments: The causative fault or faults are unknown. The only recognized expression of the prehistoric faulting is liquefaction features scattered over an area. The area adjoins of merges with the area of liquefaction that is attributed to Charleston earthquakes.

\section{References}

\#1961 Ackermann, H.D., 1983, Seismic-refraction study in the area of the Charleston, South Carolina, 1886 earthquake, in Gohn, G.S., ed., Studies related to the Charleston, South Carolina, earthquake of 1886-Tectonics and seismicity: U.S. Geological Survey Professional Paper 1313-F, p. 1-20.

\#1787 Amick, D., and Gelinas, R., 1991, The search for evidence of large prehistoric earthquakes along the Atlantic seaboard: Science, v. 251, p. 655-658.

\#1788 Amick, D., Maurath, G., and Gelinas, R., 1990, Characteristics of seismically induced liquefaction sites and features located in the vicinity of the 1886 Charleston, South Carolina earthquake: Seismological Research Letters, v. 61, p. 117-130.

\#2005 Bollinger, G.A., Johnston, A.C., Talwani, P., Long, L.T., Shedlock, K.M., Sibol, M.S., and Chapman, M.C., 1991, Seismicity of the southeastern United States; 1698 to 1986, 
in Slemmons, D.B., Engdahl, E.R., Zoback, M.D., and Blackwell, D.D., eds., Neotectonics of North America: Boulder, Colorado, Geological Society of America, Decade Map Volume 1, p. 291-308.

\#1962 Daniels, D.L., Zietz, I., and Popenoe, P., 1983, Distribution of subsurface lower Mesozoic rocks in southeastern United States, as interpreted from regional aeromagnetic and gravity maps, in Gohn, G.S., ed., Studies related to the Charleston, South Carolina, earthquake of 1886-Tectonics and seismicity: U.S. Geological Survey Professional Paper 1313-K, p. K1-K24.

\#1969 McCartan, L., Weems, R.E., and Lemon, E.M., Jr., 1990, Quaternary stratigraphy in the vicinity of Charleston, South Carolina, and its relationship to local seismicity and regional tectonism, in Studies related to the Charleston, South Carolina, earthquake of 1886 - Neogene and Quaternary lithostratigraphy and biostratigraphy: U.S. Geological Survey Professional Paper 1367-A, p. 39.

\#2256 Obermeier, S.F., 1996, Use of liquefaction-induced features for paleoseismic analysisAn overview of how seismic liquefaction features can be distinguished from other features and how their regional distribution and properties of source sediment can be used to infer the location and strength of Holocene paleo-earthquakes: Engineering Geology, v. 44, p. 1-76.

\#2050 Obermeier, S.F., Weems, B.E., and Jacobson, R.B., 1987, Earthquake-induced liquefaction features in the coastal South Carolina region, in Jacob, K.H., ed., Proceedings from the symposium on seismic hazards, ground motions, soil-liquefaction and engineering practice in eastern North America: National Center for Earthquake Engineering Research Technical Report NCEER-87-0025, p. 480-493.

\#2218 Obermeier, S.F., Weems, R.E., Jacobson, R.B., and Gohn, G.S., 1989, Liquefaction evidence for repeated Holocene earthquakes in the coastal region of South Carolina, in Jacob, K.H., and Turkstra, C.J., eds., Earthquake hazards and the design of constructed facilities in the eastern United States: Annals of the New York Academy of Sciences, v. 558, p. 183-195.

\#1882 Rajendran, C.P., and Talwani, P., 1993, Paleoseismic indicators near Bluffton, South Carolina-An appraisal of their tectonic implications: Geology, v. 21, p. 987-990.

\#1977 Talwani, P., 1994, Paleoseismological studies in South Carolina, in Prentice, C.S., Schwartz, D.P., and Yeats, R.S., eds., Proceedings of the workshop on paleoseismology, September 18-22, 1994, Marshall, California: U.S. Geological Survey OpenFile Report 94-568, p. 180-181.

\#2234 Talwani, P., 1996, Prehistoric earthquakes in the South Carolina coastal plain: Geological Society of America Abstracts with Programs, v. 28, no. 7, p. A-283.

\#2241 Weems, R.E., and Obermeier, S.F., 1989, The 1886 Charleston earthquake-An overview of geological studies, in Proceedings of the U.S. Nuclear Regulatory CommissionSeventeenth Water Reactor Safety Meeting: U.S. Nuclear Regulatory Commission NUREG/CP-0105, v. 2, p. 289-313. 


\section{9, Georgetown liquefaction features (Class A)}

Structure Number 2659

Structure Name Georgetown liquefaction features (Class A)

Comments: Obermeier and others (1987 \#2050; 1989 \#2218) and Weems and Obermeier (1989 \#2241) reported prehistoric liquefaction features near Georgetown, South Carolina, approximately $100 \mathrm{~km}$ northeast of Charleston, South Carolina. Weems and Obermeier (1989 \#2241) concluded that the features near Georgetown were caused by local earthquakes instead of by a distant earthquake source near Charleston. Amick and Gelinas (1991 \#1787) and Talwani (1994 \#1977) referred to the Georgetown area of prehistoric liquefaction features as the northern area. Widespread and longstanding practice is to refer to the liquefaction features near Charleston by the name of that city. This compilation follows the same practice, and uses the name of Georgetown, near which many of the northern liquefaction features exist, and the seat of Georgetown County, South Carolina.

Synopsis: The evidence for Quaternary faulting at this locale in northeastern coastal South Carolina consists of late Holocene liquefaction features that are attributed to a single large, prehistoric earthquake. The causative fault remains unidentified

Date of compilation 08/05/98; revised $01 / 28 / 00$

Compiler and affiliation Russell L. Wheeler, U.S. Geological Survey

State South Carolina; North Carolina

County Georgetown; Horry (South Carolina); Brunswick (North Carolina)

$1^{\circ} \times 2^{\circ}$ sheet Georgetown; Florence

Physiographic province Coastal Plain

\section{Reliability of location Poor}

Comments: The liquefaction was recognized as the type that is caused by strong ground motion (Obermeier, 1996 \#2256), and the strong motions are presumed to have been caused by slip on a preexisting fault. However, the causative fault has not been identified and the locations and sizes of the liquefaction features provide poor constraints on the source of the shaking.

Geologic setting The land is flat and near sea level, and the water table is near or at the surface (Obermeier, 1996 \#2256). Several meters of Quaternary beach, marine, and fluvial deposits overlie several hundred meters of Tertiary and Cretaceous Coastal Plain strata, which in turn overlie Triassic and Jurassic basalt and rift basins and Paleozoic metamorphic and igneous rocks (Ackermann, 1983 \#1961; Daniels and others, 1983 \#1962; McCartan and others, 1990 \#1969). The locale is on the northeastern edge of a seismically active region that spans most of South Carolina (Bollinger and others, 1991 \#2005). Amick and Gelinas (1991 \#1787) and D. Amick (oral commun., 1998) noted that ground-water level was lower before $3 \mathrm{ka}$ than at present, and still lower before $5 \mathrm{ka}$. Thus, earthquakes older than 3-5 ka and large enough to cause liquefaction might be underrepresented in the South Carolina chronology. 


\section{Sense of movement Not reported}

Comments: The prehistoric earthquake is known only from locations and age estimates of liquefaction. No surface rupture or other deformation is known from the earthquake.

\section{Dip Not reported}

Comments: The causative fault remains unidentified and uncharacterized.

\section{Dip direction Not reported}

Geomorphic expression The few sandblows that formed in 1886 this far northeast of the causative earthquake at Charleston can be expressed as shallow craters. However, the craters of prehistoric sandblows are filled with sediment. Consequently, the prehistoric craters lack geomorphic expression and are recognized only in the walls of excavations (Obermeier, 1996 \#2256).

Age of faulted deposits Most areas searched for liquefaction features are those underlain by deposits 80,000-250,000 years old, because older deposits have low liquefaction susceptibility and younger ones have too high a water table to permit searches of excavation walls (Obermeier, 1996 \#2256).

Paleoseismological studies The Georgetown source is approximately $100 \mathrm{~km}$ northeast of the Charleston source, and might have caused liquefaction of poorly constrained age in southeastern North Carolina. Obermeier and others (1987 \#2050; 1989 \#2218), Weems and Obermeier (1989 \#2241), and Amick and others (1990 \#1788) described criteria for searching for, recognizing, and dating prehistoric liquefaction features throughout coastal South Carolina and southeastern North Carolina. Amick and Gelinas (1991 \#1787) and Talwani (1994 \#1977; 1996 \#2234) summarized results for the Georgetown area in the form of an evolving chronology of large earthquakes. Talwani (1996 \#2234) recognized one prehistoric earthquake at $1.64 \mathrm{ka}$ that may have occurred in the Georgetown area (the $1.7 \mathrm{ka}$ earthquake of Amick and Gelinas, 1991 \#1787; the 1.80 ka earthquake of Talwani, 1994 \#1977). Known liquefaction features of that age are restricted to the Georgetown area. Most liquefaction features of other ages are interpreted as distant effects of earthquakes near Charleston. P. Talwani (oral communs., 1997, 1998) holds open the possibility that the 1.64 ka liquefaction could be similarly attributed to the Charleston source. Amick and Gelinas (1991 \#1787) and Obermeier (1996 \#2256) considered the relative sizes of the prehistoric liquefaction features as compared to those from 1886 and elsewhere in the world, the geographic distribution of features of a particular age, source sand compactness, water table depth, and other factors. They argued that the prehistoric earthquake that may have occurred near Georgetown was larger than moment magnitude $\mathbf{M} 5$ and probably larger than M 5.5. Amick and Gelinas (1991 \#1787) and D. Amick (oral commun., 1998) noted that ground-water level was lower before 3 ka than at present, and still lower before $5 \mathrm{ka}$. Thus, earthquakes older than 3-5 ka and large enough to cause liquefaction may be underrepresented in the South Carolina earthquake chronology.

\section{Timing of most recent paleoevent latest Quaternary $(<15 \mathrm{ka})$}

Comments: Talwani (1996 \#2234) reported liquefaction dated at 1.64 ka near Georgetown. Alternatively, the liquefaction features that formed at $1.64 \mathrm{ka}$ might be distant effects of an earthquake in the Charleston source area (P. Talwani, oral communs., 1997, 1998). In the 
latter case, there would be no evidence for paleoevents centered at or near Georgetown, nor evidence for a discrete source there.

\section{Recurrence interval Not reported}

Comments: As noted above under "Paleoseismological Studies", a liquefying earthquake at $1.64 \mathrm{ka}$ occurred in either the Charleston or Georgetown source areas. In neither case can one calculate an estimate of the Georgetown recurrence interval.

Slip-rate category unknown

Comments: No dated fault offset is known, so no slip rate can be calculated.

Length Not applicable

Comments: The causative fault or faults are unknown. The only recognized expression of prehistoric faulting is liquefaction features scattered over an area. The area adjoins or merges with the area of liquefaction that is attributed to earthquakes near Chalreston.

Average strike Not applicable

Comments: The causative fault or faults are unknown. The only recognized expression of prehistoric faulting is liquefaction features scattered over an area. The area adjoins or merges with the area of liquefaction that is attributed to earthquakes near Chalreston.

\section{References}

\#1961 Ackermann, H.D., 1983, Seismic-refraction study in the area of the Charleston, South Carolina, 1886 earthquake, in Gohn, G.S., ed., Studies related to the Charleston, South Carolina, earthquake of 1886-Tectonics and seismicity: U.S. Geological Survey Professional Paper 1313-F, p. 1-20.

\#1787 Amick, D., and Gelinas, R., 1991, The search for evidence of large prehistoric earthquakes along the Atlantic seaboard: Science, v. 251, p. 655-658.

\#1788 Amick, D., Maurath, G., and Gelinas, R., 1990, Characteristics of seismically induced liquefaction sites and features located in the vicinity of the 1886 Charleston, South Carolina earthquake: Seismological Research Letters, v. 61, p. 117-130.

\#2005 Bollinger, G.A., Johnston, A.C., Talwani, P., Long, L.T., Shedlock, K.M., Sibol, M.S., and Chapman, M.C., 1991, Seismicity of the southeastern United States; 1698 to 1986, in Slemmons, D.B., Engdahl, E.R., Zoback, M.D., and Blackwell, D.D., eds., Neotectonics of North America: Boulder, Colorado, Geological Society of America, Decade Map Volume 1, p. 291-308.

\#1962 Daniels, D.L., Zietz, I., and Popenoe, P., 1983, Distribution of subsurface lower Mesozoic rocks in southeastern United States, as interpreted from regional aeromagnetic and gravity maps, in Gohn, G.S., ed., Studies related to the Charleston, South Carolina, earthquake of 1886-Tectonics and seismicity: U.S. Geological Survey Professional Paper 1313-K, p. K1-K24.

\#1969 McCartan, L., Weems, R.E., and Lemon, E.M., Jr., 1990, Quaternary stratigraphy in the vicinity of Charleston, South Carolina, and its relationship to local seismicity and 
regional tectonism, in Studies related to the Charleston, South Carolina, earthquake of 1886 - Neogene and Quaternary lithostratigraphy and biostratigraphy: U.S. Geological Survey Professional Paper 1367-A, p. 39.

\#2256 Obermeier, S.F., 1996, Use of liquefaction-induced features for paleoseismic analysisAn overview of how seismic liquefaction features can be distinguished from other features and how their regional distribution and properties of source sediment can be used to infer the location and strength of Holocene paleo-earthquakes: Engineering Geology, v. 44 , p. $1-76$.

\#2050 Obermeier, S.F., Weems, B.E., and Jacobson, R.B., 1987, Earthquake-induced liquefaction features in the coastal South Carolina region, in Jacob, K.H., ed., Proceedings from the symposium on seismic hazards, ground motions, soil-liquefaction and engineering practice in eastern North America: National Center for Earthquake Engineering Research Technical Report NCEER-87-0025, p. 480-493.

\#2218 Obermeier, S.F., Weems, R.E., Jacobson, R.B., and Gohn, G.S., 1989, Liquefaction evidence for repeated Holocene earthquakes in the coastal region of South Carolina, in Jacob, K.H., and Turkstra, C.J., eds., Earthquake hazards and the design of constructed facilities in the eastern United States: Annals of the New York Academy of Sciences, v. 558, p. 183-195.

\#1977 Talwani, P., 1994, Paleoseismological studies in South Carolina, in Prentice, C.S., Schwartz, D.P., and Yeats, R.S., eds., Proceedings of the workshop on paleoseismology, September 18-22, 1994, Marshall, California: U.S. Geological Survey Open-File Report 94-568, p. 180-181.

\#2234 Talwani, P., 1996, Prehistoric earthquakes in the South Carolina coastal plain: Geological Society of America Abstracts with Programs, v. 28, no. 7, p. A-283.

\#2241 Weems, R.E., and Obermeier, S.F., 1989, The 1886 Charleston earthquake-An overview of geological studies, in Proceedings of the U.S. Nuclear Regulatory CommissionSeventeenth Water Reactor Safety Meeting: U.S. Nuclear Regulatory Commission NUREG/CP-0105, v. 2, p. 289-313. 


\section{XX, Brockton-Froid fault zone (Class B)}

\section{Structure Number 707XX}

Comments: The Brockton-Froid fault zone forms the northeastern part of entry 147 of Johns and others (1982 \#259).

Structure Name Brockton-Froid fault zone (Class B)

Comments: The fault zone was mapped by Colton (1963 \#3653; 1963 \#3654) and named by Colton and Bateman (1956 \#3655; 1956 \#3656). Thomas (1974 \#3688) referred to its expression on 1:20,000-scale aerial photographs as the Brockton-Froid lineament. Johns and others (1982 \#259) combined the fault zone with the Weldon fault, which is parallel to the BrocktonFroid fault zone and on strike several tens of kilometers to the southwest, and named the combination the Weldon-Brockton-Froid fault zone. The most detailed mapping of the fault zone is by Colton (1963 \#3653; $1963 \# 3654$ ), who showed its southwesternmost $24 \mathrm{~km}$. As Colton mapped the zone, it strikes N. $55^{\circ}$ E. across the Brockton 15' quadrangle and beyond to the northeast, and extends southwest $2 \mathrm{~km}$ into the Poplar 15' quadrangle. Colton (1963 \#3653; 1963 \#3654) mapped the zone as straight, approximately $0.5 \mathrm{~km}$ wide, and made of two nearly parallel faults that bound a structurally lower block.

Synopsis: Quaternary outwash, alluvium, and colluvium deposits are mapped in a long, narrow, straight zone with tills on both sides. The zone has been mapped as fault-bounded, but it is unclear whether the faults penetrate deeply enough to pose a seismic hazard, and whether the hazard remains high now or decreased shortly after the ice sheets melted. Accordingly, the zone is classified as Class B.

Date of compilation 07/27/99; revised 01/31/00

Compiler and affiliation Russell L. Wheeler, U.S. Geological Survey

State Montana

County Roosevelt

$1^{\circ} \times 2^{\circ}$ sheet Wolf Point

Province Great Plains

\section{Reliability of location Good}

Comments: The Brockton-Froid fault zone was mapped by Colton (1963 \#3653; 1963 \#3654) at a scale of $1: 62,500$.

Geologic setting The Brockton-Froid fault zone strikes northeast in the glaciated plains of northeastern Montana. Bedrock dips are low. Local relief between streams and uplands is generally $100 \mathrm{ft}(30 \mathrm{~m})$ or less, and the ground is covered by glacial deposits (Witkind, 1959 \#3702).

The nature of the fault zone is uncertain and its origin is enigmatic. No dip directions are indicated, so it is unknown whether the dip-slip components of the faulting are normal or reverse. At several places, one or two smaller faults are also mapped. The lower block between the faults exposes mainly late Wisconsinan sandy gravel and silt that were deposited as outwash in contact with melting ice, and Quaternary sheetwash alluvium and colluvium 
(Colton, $1963 \# 3653 ; 1963$ \#3654, D. S. Fullerton, oral commun., 1999). Outside the fault zone are mainly pre-Illinoian, Illinoian, and late Wisconsinan tills, Quaternary dune sand, and Tertiary and Cretaceous bedrock (Colton, 1963 \#3653; 1963 \#3654, D. S. Fullerton, oral commun., 1999). Two traverses of auger holes across the fault zone show markedly thicker Quaternary sequences between the faults than outside them (Colton, 1963 \#3653). A third auger traverse shows the same thing, and a fourth traverse based on outcrops indicates that exposed lignites are offset $75 \mathrm{ft}(23 \mathrm{~m})$ vertically across the fault zone with the southeast side down (D. S. Fullerton, oral commun., 1999, based on R. B. Colton, unpub. data). Faulting is inferred from the auger traverses; nowhere was a fault found exposed with outwash in one wall and till in the other (R. B. Colton, oral commun., 1999).

Earlier, Colton and Bateman (1956 \#3656) mapped the fault zone at a scale of 1:125,000, showing it as a pair of parallel faults. Colton and Bateman traced the fault zone for $42 \mathrm{~km}$, including $21 \mathrm{~km}$ of the length mapped by Colton (1963 \#3653; 1963 \#3654) and an additional $21 \mathrm{~km}$ to the northeast. Colton and Bateman used petroleum well data to draw structure contours on the Cretaceous Greenhorn limestone, which underlies the fault zone approximately 1 $\mathrm{km}$ below ground level. The regional pattern of the structure contours indicates that the fault zone offsets the Greenhorn limestone as much as $300 \mathrm{ft}(90 \mathrm{~m})$, with the southeast side down. The fault traces mapped by (Colton, 1963 \#3653; 1963 \#3654) at the surface are 100-300 m farther northwest than the faults mapped by Colton and Bateman (1956 \#3656) on the Greenhorn, and this difference is consistent with the normal separation indicated by Colton and Bateman. However, only four widely-spaced wells control the Greenhorn structure near the fault zone. These four control points could be honored with contours that show no faulting at the Greenhorn level. Thus, from the evidence presented by Colton and Bateman (1956 \#3656), it is unclear how deeply the fault zone mapped by Colton (1963 \#3653; 1963 \#3654) extends.

In contrast, Gott and others (1959 \#3701) mapped a still larger extent of the fault zone as an unfaulted glacial outwash channel. Their 1:62,500-scale map shows four linear, northeasttrending, aligned, discontinuous deposits of outwash and colluvium. The four deposits together span $41 \mathrm{~km}$, including the northeasternmost $12 \mathrm{~km}$ mapped by Colton (1963 \#3654) and another $29 \mathrm{~km}$ northeast of that. Of the $41 \mathrm{~km}$, the linear deposits of outwash and colluvium cover $26 \mathrm{~km}$ with $15 \mathrm{~km}$ of gaps that lack outwash and colluvium. The linear deposits are 100-400 m wide and 4-12 km long. Witkind (1959 \#3702, p. 38-39) named the aligned linear deposits the "Linear channel". As described here under "Geomorphic expression", the Linear channel contains elongated, closed depressions that are anomalously large for the area traversed by the Linear channel. The floor of the Linear channel slopes inward and downward from both ends, toward where Big Muddy Creek crosses and interrupts the Linear channel near its middle. "This channel deposit is unusual and difficult to explain" (Witkind, 1959 \#3702, p. 39). Witkind speculated about alternative origins, including an ice contact feature, a buried fault-controlled valley, and drainage for a long, straight crevasse in glacier ice.

Finally, Thomas (1974 \#3688) used 1:20,000-scale aerial photographs to map a photolineament that coincides with the Brockton-Froid fault zone. The readily visible photolineament begins approximately $2 \mathrm{~km}$ northeast of the eastern edge of the map area of Colton (1963 \#3653; 1963 \#3654), and extends $38 \mathrm{~km}$ to the northeast (fig. 3 of Thomas, 1974 \#3688). Thus, the Brockton-Froid fault zone was mapped over $24 \mathrm{~km}$ by Colton $(1963 \# 3653 ; 1963$ 
\#3654), and it appears to extend another $40 \mathrm{~km}$ to the northeast (Colton and Bateman, 1956 \#3656; Gott and others, 1959 \#3701; Thomas, 1974 \#3688).

The Brockton-Froid fault zone is a real feature, but, as mentioned at the start of this section, its nature is unclear and its origin is enigmatic. Its straightness and its path uphill and downhill across streams and interfluves argue against an origin in fluvial processes or outwash streams. Similarly, the fault zone has no obvious glacial origin, according to D. S. Fullerton (oral communs., 1999), who has examined it in the field. Glaciotectonic structures can involve bedrock, but typically are folds or reverse faults that trend at high angles to the direction of ice movement. In this part of northeastern Montana, Wisconsinan ice advanced from northeast to southwest (Flint and others, 1959 \#3663; Colton, 1963 \#3653). However, the fault zone trends nearly parallel to this direction, and, as suggested previously in this section, any dip slip components are more likely to be normal than reverse.

Another puzzling aspect of the fault zone is the absence of till in three of the auger holes in the structurally lower block. Each of the three auger traverses that crosses the fault zone has two holes inside the zone and another two bracketing it (Colton, 1963 \#3653; D. S. Fullerton, oral commun., 1999, based on R. B. Colton, unpub. data). On each traverse, one hole inside the fault zone lacks till, having outwash directly overlying bedrock; whereas, the other three holes of the traverse have till separating outwash from bedrock. Normally one might attribute the absence of till to scouring by flowing meltwater. For example, Colton (1963 \#3653) showed several examples of logged holes without till, in a meandering meltwater channel in the northwest part of the Brockton quadrangle. However, till is widely exposed adjacent to the fault zone (Colton, 1963 \#3653; 1963 \#3654), so probably any scouring meltwater would have flowed along the fault zone. This is unlikely because, as explained under "Geomorphic expression", the zone rises and falls tens of feet to follow a straight line across present-day topography. Therefore, the local absence of till inside the fault zone remains unexplained.

The simplest explanation of the fault zone is that of a basement fault that was reactivated during glacial or post-glacial time. The Weldon fault is $74 \mathrm{~km}$ southwest of, and on trend with, the Brockton-Froid fault zone (Collier and Knechtel, 1939 \#3651). The Weldon fault strikes northeast. It is $13 \mathrm{~km}$ long and its southeast side has slipped down in the subsurface for 100-160 ft (30-50 m) at the level of the Upper Cretaceous Fox Hills sandstone (Collier and Knechtel, 1939 \#3651). At greater depth, the Mississippian Kibby limestone is similarly offset, with its southeast side down 300-400 ft (90-120 m) (Edmisten and Foster, 1985 \#3658). At ground level, the Weldon fault appears to be expressed as a concentration of northeast-trending LANDSAT lineaments (Larson, 1985 \#3678). Feltis (1981 \#3660; 1981 \#3661) used well data to draw structure contours on the Mississippian Madison Group. Feltis interpreted the Weldon fault as extending $84 \mathrm{~km}$ farther southwest than did Collier and Knechtel (1939 \#3651), and $36 \mathrm{~km}$ farther northeast, for a total inferred length of $133 \mathrm{~km}$. The separation at the level of the Madison Group is well constrained by pairs of wells, and is as great as $600-700 \mathrm{ft} \mathrm{(180-210} \mathrm{m),} \mathrm{although} \mathrm{the} \mathrm{separation} \mathrm{decreases} \mathrm{to} \mathrm{the} \mathrm{northeast.} \mathrm{Thus,} \mathrm{Feltis} \mathrm{(1981}$ \#3660) extended the Weldon fault to within $38 \mathrm{~km}$ of the Brockton-Froid fault zone as mapped by Colton (1963 \#3654). Indeed, Johns and others (1982 \#259) used an aeromagnetic map to speculate that the Brockton-Froid and Weldon faults are two parts of the same long basement fault, and Hansen (1966 \#3666) and Thomas (1974 \#3688) speculated that the Brockton-Froid fault zone is underlain by a basement fault zone. Horner and Hasegawa (1978 
\#3671) speculated that four historical and early instrumental earthquakes in the region might have occurred on the Brockton-Froid fault and a southwestward extension; however, these early earthquakes are too poorly located to test the speculation.

Unfortunately, the basement-fault explanation is a poor fit to some of the observed properties of the fault zone. Three arguments cast some doubt on the attribution of the Brockton-Froid fault zone to tectonic faulting that extends to basement. (1) Exposed bedrock near the fault zone is Paleocene, lignite-bearing Fort Union Formation (Colton, 1963 \#3653; 1963 \#3654). Nine subsurface lignites were correlated and mapped near and beneath the fault zone at depths of approximately $800 \mathrm{ft}(240 \mathrm{~m}$ ) or less (Hardie and Van Gosen, 1986 \#3670; Hardie and Arndt, 1989 \#3668; 1990 \#3669). Neither structure contours on the individual lignites, isopachs of the lignites, nor structure contours on the base of the Fort Union Formation show detectable offset across the Brockton-Froid fault zone (Hardie and Arndt, 1988 \#3667; Biewick and others, 1990 \#3649). In addition, at greater depth, Feltis (1981 \#3662) extended the Madison-level structure contours into the vicinity of the fault zone. Well control there was sparse, and could not rule out small offsets, but Feltis did not draw the fault zone on his map. In North America east of the Rocky Mountains, earthquake depths are typically 5-15 km, with a median of approximately $10 \mathrm{~km}$ (Wheeler and Johnston, 1992 \#2243). If the fault zone does not penetrate into basement and reach hypocentral depths, then it is unlikely to pose much seismic hazard. (2) As already mentioned, no exposures of the fault have been observed (Colton, oral commun., 1999). (3) As noted previously in this section, any dip-slip component of the faulting is more likely to be normal than reverse. However, the Brockton-Froid area is part of the North American stable continental region (SCR) (Johnston, 1989 \#2039), and SCRs worldwide typically undergo contractional deformation (Zoback and others, 1989 \#1923). Extensional faulting occurs in SCRs in thermally uplifted areas and in gravitationalcollapse settings like the Gulf coast of the U.S., but neither analogy would apply to northeastern Montana.

However, tectonic faulting is not the only alternative to fluvial, glacial, or glaciotectonic formation of the Brockton-Froid linear features. The Brockton-Froid fault zone might have formed by post-glacial faulting, as summarized below. Attribution of the Brockton-Froid fault zone to reactivation of a basement fault and to post-glacial faulting are equally speculative; in both cases the phenomenon is real, but in neither case is there evidence that it applies to the Brockton-Froid fault zone. However, the following speculation demonstrates the existence of at least one alternative explanation for the fault zone. Northern Scandinavia and northern North America contain exceptionally large, reverse-faulting, surface ruptures that formed in early post-glacial times, in cratonic areas that are now sparsely seismic (for example, Johnston, 1996 \#2205). The scarps along the surface ruptures can be meters high and tens of kilometers long. Johnston (1989 \#3676) and Thorson (1996 \#3689) demonstrated that loading of the upper crust by an ice sheet could stabilize faults that would otherwise slip in occasional earthquakes. In such a case, horizontal tectonic stress could accumulate unrelieved. When the ice melted, the vertical stress would decrease and the accumulated excess horizontal stress could be released relatively quickly, in a cluster of earthquakes larger and more frequent than normal for the region. Afterward the region would return to its normal low level of seismicity. The Brockton-Froid fault zone is approximately parallel to the northeasterly direction of $\mathrm{S}_{\mathrm{Hmax}}$ (greatest horizontal compressive stress) in this part of North America (Zoback and Zoback, 
1989 \#1922). If post-glacial stress release reactivated the fault zone, the faulting would not be reverse, but normal or normal-oblique, consistent with the mapping by Colton (1963 \#3653), to allow northwest-southeast extension in response to $\mathrm{S}_{\mathrm{Hmax}}$. This speculation, if borne out by testing, would also indicate that the fault zone may pose little or no seismic hazard today, because probably the strain stored during ice loading has since been released.

In summary, the Brockton-Froid fault zone contains Quaternary deformation, and the deformation probably, but not certainly, occurred by faulting. However, it is not clear whether the faults penetrate deeply enough into the crust to pose a seismic hazard. Even if they do penetrate deeply, it is not clear whether the hazard remains high now, or was only high shortly after the ice melted. For these reasons, the fault zone is placed in class B. What is questionable is primarily the potential for seismic faulting, and only secondarily the presence of faulting. Perhaps the most effective way to answer these questions is with (1) high-resolution seismic-reflection profiles across the fault zone to determine whether faulting penetrates deeply into bedrock, and preferably into basement, and (2) paleoseismological study, including trenching and dating, to test the presence of faulted Quaternary materials and to constrain the time of faulting.

\section{Sense of movement Not reported}

Comments: The geologic maps of Colton (1963 \#3653; 1963 \#3654) show no indications of strike slip along the fault zone, nor any indications of dip direction of the individual faults. The maps show the fault zone as a straight, fault-bounded block a few hundred meters wide and at least $24 \mathrm{~km}$ long, with the block structurally lower than the areas on either side of the fault zone. Accordingly, only dip slip is inferred, and present information cannot determine whether it was normal or reverse.

The sense of movement on the fault zone is unknown. The straightness of the zone favors strike slip, but Colton (1963 \#3653; 1963 \#3654) showed no indications of strike slip along the zone. Any dip-slip components of the faulting are more probably normal than reverse. The nearly constant width of the structurally lower block along the mapped length of the fault zone is reminiscent of a graben formed between a single, large normal fault and a smaller, antithetic normal fault that dips toward the main fault. Such structures are common in extended terranes, for example along young faults of the Basin and Range province. In reverse-faulted terranes, such long, narrow, structurally low blocks of such constant width are uncommon except on the crests of anticlines; no such fold is known under the Brockton-Froid fault zone.

\section{Dip Not reported}

Comments: It is unknown whether the dip slip, if any, was normal or reverse

\section{Dip direction Not reported}

Geomorphic expression As mapped by Colton (1963 \#3653; 1963 \#3654), Gott and others (1959 \#3701), and Thomas (1974 \#3688), the Brockton-Froid fault zone strikes northeast across ten 1:24,000-scale topographic quadrangles. The zone extends from the Poplar NE and Sprole quadrangles on the southwest to the Capeneys Lake quadrangle on the northeast. In some areas the zone is expressed as alignments of northeast-trending stream segments and 
valleys, ridges and elongated hills, and closed depressions that are unusually large for the area. The grain is most pronounced in the northeastern quadrangles, in parts of the Medicine Lake, Johnson Lake, and Rocky Point quadrangles, which have a contour interval of five feet $(2 \mathrm{~m})$, and in part of the Calais quadrangle, which has a contour interval of $10 \mathrm{ft}(3 \mathrm{~m})$. Where the geomorphic expression of the zone is well developed, the zone descends into valleys to cross streams and climbs to cross interfluves, both without obvious deflection. The zone descends and rises several tens of feet at several places, and in part of the Calais quadrangle, the elevation change along the zone is approximately $200 \mathrm{ft}(60 \mathrm{~m})$.

Age of faulted deposits late Quaternary

\section{Paleoseismological studies None}

\section{Timing of most recent paleoevent late Quaternary}

Comments: Colton (1963 \#3653) showed the faults in the zone cutting the younger of two Wisconsinan tills and late Wisconsinan outwash deposits, as well as Quaternary fan alluvium and colluvium and Quaternary dune sands. Depending on the ages of the till and outwash deposits, the faulting could have been either late Pleistocene or early Holocene.

\section{Recurrence interval Not reported}

Comments: No individual faulting events have been identified.

\section{Slip-rate category unknown}

Comments: The vertical displacement on the faults is unknown.

\section{Length $53.7 \mathrm{~km}$}

Comments: Measured as $40.62 \mathrm{~km}$ (Gott and others, 1959 \#3701), plus an additional 11.19 $\mathrm{km}$ on the remaining (western) half of the overlapping map of Colton (1963 \#3653), plus a final $1.88 \mathrm{~km}$ (Colton, 1963 \#3654). The measured length includes gaps and solid, dashed, and dotted lines on the three maps. Measurement was along a ruler fit to the center of the $0.5 \mathrm{~km}$-wide feature.

\section{Average strike $+55^{\circ}$}

Comments: The northeastern $40.62 \mathrm{~km}$ trend $+55^{\circ}$ and the southwestern $24.26 \mathrm{~km}$ trend $+57^{\circ}$. A length-weighted mean strike is $+55^{\circ}$.

\section{References}

\#3649 Biewick, L.R.H., Hardie, J.K., Williamson, C., and Arndt, H.H., 1990, Evaluation of coal resources in the Eastern part of the Fort Peck Indian Reservation, Montana: U.S. Geological Survey Bulletin 1869, 136 p.

\#3651 Collier, A.J., and Knechtel, M.M., 1939, The coal resources of McCone County, Montana: U.S. Geological Survey Bulletin 905, 80 p., 1 pl., scale 1:250,000.

\#3653 Colton, R.B., 1963, Geologic map of the Brockton Quadrangle, Roosevelt and Richland Counties, Montana: U.S. Geological Survey Miscellaneous Geologic Investigations I362,1 sheet, scale 1:62,500. 
\#3654 Colton, R.B., 1963, Geologic map of the Poplar Quadrangle, Roosevelt, Richland and McCone Counties, Montana: U.S. Geological Survey Miscellaneous Geologic Investigations I-367, 1 sheet, scale 1:62,500.

\#3655 Colton, R.B., and Bateman, F.A., Jr., 1956, Brockton-Froid fault zone in Northeastern Montana: Geological Society of America Bulletin, v. 67, no. 12, p. 1792.

\#3656 Colton, R.B., and Bateman, F.A., Jr., 1956, Geologic and structure contour map of the Fort Peck Indian Reservation and vicinity, Montana: U.S. Geological Survey Miscellaneous Geologic Investigations I-225, 1 sheet, scale 1:125,000.

\#3658 Edmisten, N., and Foster, N.H., 1985, Weldon Field, in Tonnsen, J.J., ed., Montana oil and gas fields symposium 1985, v. 2: Billings, Montana, Montana Geological Society, p. 1163-1166.

\#3660 Feltis, R.D., 1981, Glendive $1^{\circ}$ x $2^{\circ}$ quadrangle, northeastern Montana: Montana Bureau of Mines and Geology Geologic Map 15, 1 sheet, scale 1:250,000.

\#3661 Feltis, R.D., 1981, Jordan $1^{\circ}$ x $2^{\circ}$ quadrangle, northeastern Montana: Montana Bureau of Mines and Geology Geologic Map 16, 1 sheet, scale 1:250,000.

\#3662 Feltis, R.D., 1981, Wolf Point $1^{\circ}$ x $2^{\circ}$ quadrangle, northeastern Montana: Montana Bureau of Mines and Geology Geologic Map 17, 1 sheet, scale 1:250,000.

\#3663 Flint, R., Colton, R.B., Goldthwait, R.P., and Williams, H.B., 1959, Glacial map of the United States east of the Rocky Mountains: .

\#3701 Gott, G.B., Witkind, I.J., Hansen, W.R., Lindvall, R.M., Prouty, C.E., Smith, J.H., Basile, R.E., and Kaye, C.A., 1959, Geologic map of the Smoke Creek-Medicine Lake-Grenora area, Montana and South Dakota, in Witkind, I.J., ed., Quaternary geology of the Smoke Creek-Medicine Lake-Grenora Area, Montana and South Dakota: U.S. Geological Survey Bulletin 1073, p. 80, 2 sheets, scale 1:62,500.

\#3666 Hansen, A.R., 1966, Reef trends of Mississippian Ratcliffe zone, northeast Montana and northwest North Dakota: Bulletin of the American Association of Petroleum Geologists, v. 50, no. 10, p. 2260 .

\#3667 Hardie, J.K., and Arndt, H.H., 1988, Geology, structure, and coal beds of the Fort Union Formation in the eastern part of the Fort Peck Indian Reservation, Daniels, Roosevelt, and Sheridan Counties, Montana: U.S. Geological Survey Coal Investigations Map C122-A, 1 sheet, scale 1:100,000.

\#3668 Hardie, J.K., and Arndt, H.H., 1989, Stratigraphy of the Fort Union Formation in the eastern part of the Fort Peck Indian Reservation, Daniels, Roosevelt, and Sheridan Counties, Montana: U.S. Geological Survey Coal Investigations Map C-122-B, 1 sheet, scale $1: 100,00$.

\#3669 Hardie, J.K., and Arndt, H.H., 1990, Stratigraphic framework of coal beds in the Fort Union Formation, eastern part of the Fort Peck Indian Reservation, Daniels, Roosevelt, and Sheridan Counties, Montana: U.S. Geological Survey Coal Investigations Map C122-C, 1 sheet, scale 1:100,000. 
\#3670 Hardie, J.K., and Van Gosen, B.S., 1986, Stratigraphic framework of coal beds underlying the northeast part of the Fort Peck Indian Reservation, Montana: U.S. Geological Survey Miscellaneous Field Studies Map MF-1775, 1 sheet, scale 1:125,000.

\#3671 Horner, R.B., and Hasegawa, H.S., 1978, The seismotectonics of southern Saskatchewan: Canadian Journal of Earth Science, v. 15, p. 1341-1355.

\#259 Johns, W.M., Straw, W.T., Bergantino, R.N., Dresser, H.W., Hendrix, T.E., McClernan, H.G., Palmquist, J.C., and Schmidt, C.J., 1982, Neotectonic features of southern Montana east of $112^{\circ} 30^{\prime}$ west longitude: Montana Bureau of Mines and Geology OpenFile Report 91, 79 p., 2 sheets.

\#2039 Johnston, A.C., 1989, The seismicity of 'stable continental interiors', in Gregersen, S., and Basham, P.W., eds., Earthquakes at North Atlantic passive margins-Neotectonics and postglacial rebound: Dordrecht, The Netherlands, Kluwer Academic Publishers, p. 299-327.

\#3676 Johnston, A.C., 1989, The effect of large ice sheets on earthquake genesis, in Gregersen, S., and Basham, P.W., eds., Earthquakes at North-Atlantic passive margins; neotectonics and postglacial rebound, v. 266: D. Reidel Publishing Company, p. 581-599.

\#2205 Johnston, A.C., 1996, A wave in the earth: Science, v. 274, p. 735.

\#3678 Larson, B.S., 1985, Geology associated with lineaments in the Weldon-Richfield Area, Williston Basin, Montana, in Aldrich, M.J., Jr., and Laughlin, A.W., eds., Proceedings of the sixth international conference on basement tectonics: Salt Lake City, Utah, International Basement Tectonics Association, p. 200.

\#3688 Thomas, G.E., 1974, Lineament-block tectonics-Williston-Blood Creek Basin: Bulletin of the American Association of Petroleum Geologists, v. 58, no. 7, p. 1305-1322.

\#3689 Thorson, R.M., 1996, Earthquake recurrence and glacial loading in western Washington: Geological Society of America Bulletin, v. 108, no. 9, p. 1182-1191.

\#2243 Wheeler, R.L., and Johnston, A.C., 1992, Geologic implications of earthquake source parameters in central and eastern North America: Seismological Research Letters, v. 63, no. 4, p. 491-514.

\#3702 Witkind, I.J., 1959, Quaternary geology of the Smoke Creek - Medicine Lake - Grenora area, Montana and South Dakota: U.S. Geological Survey Bulletin 1073, 80 p., 5 plates.

\#1922 Zoback, M.L., and Zoback, M.D., 1989, Tectonic stress field of the continental United States, in Pakiser, L.C., and Mooney, W.D., eds., Geophysical framework of the continental United States: Geological Society of America Memoir 172, p. 523-539.

\#1923 Zoback, M.L., Zoback, M.D., Adams, J., Assumpcão, M., Bell, S., Bergman, E.A., Blümling, P., Brereton, N.R., Denham, D., Ding, J., Fuchs, K., Gay, N., Gergersen, S., Gupta, H.K., Gvishiani, A., Jacob, K., Klein, R., Knoll, P., Magee, M., Mercier, J.L., Müller, B.C., Paquin, C., Rajendran, K., Stephansson, O., Suarez, G., Suter, M., Udias, A., Xu, Z.H., and Zhizhin, M., 1989, Global patterns of tectonic stress: Nature, v. 341, no. 6240 , p. 291-298. 


\section{XX, Gulf-margin normal faults, Texas (Class B)}

\section{Structure Number 924XX}

Structure Name Gulf-margin normal faults, Texas (Class B)

Comments: A belt of mostly seaward-facing normal faults borders the northern Gulf of Mexico, in westernmost Florida, southwestern Alabama, southern Mississippi, all of Louisiana and southernmost Arkansas, and eastern and southern Texas (Ewing and Lopez, 1991 \#2032). This compilation evaluates the faults in four large groups because faults number in the hundreds, and because their ability to have significant earthquakes is doubtful. To reflect regional differences in the characteristics of the faults, those in Florida and Alabama are evaluated together in a single group, as are those in Mississippi, those in Louisiana and Arkansas, and those in Texas.

Synopsis: The gulf-margin normal faults are categorized in Class B because they exist in sediments and poorly lithified rocks, which are materials that may not be unable to endure the stresses required for the propagation of significant seismic ruptures that could cause damaging ground motions.

Date of compilation 07/28/99; revised 01/28/00

Compiler and affiliation Russell L. Wheeler, U.S. Geological Survey

\section{State Texas}

County Anderson; Angelina; Aransas; Atascosa; Austin; Bastrop; Bee; Bowie; Brazoria; Brazos; Brooks; Burleson; Calhoun; Cameron; Camp; Cass; Chambers; Cherokee; Colorado; De Witt; Delta; Duval; Falls; Fayette; Fort Bend; Franklin; Freestone; Frio; Galveston; Goliad; Gonzales; Gregg; Grimes; Hardin; Harris; Harrison; Henderson; Hidalgo; Hopkins; Houston; Hunt; Jackson; Jasper; Jefferson; Jim Hogg; Jim Wells; Karnes; Kaufman; Kenedy; Kleberg; La Salle; Lavaca; Lee; Leon; Liberty; Limestone; Live Oak; Madison; Marion; Matagorda; McMullen; Milam; Montgomery; Morris; Nacagdoches; Navarro; Newton; Nueces; Orange; Panola; Polk; Rains; Refugio; Robertson; Rusk; Sabine; San Augustine; San Jacinto; San Patricio; Shelby; Smith; Starr; Titus; Trinity; Tyler; Upshur; Van Zandt; Victoria; Walker; Waller; Washington; Webb; Wharton; Willacy; Wilson; Wood; Zapata

$1^{\circ} \times 2^{\circ}$ sheet Alexandria; Austin; Bay City; Beaumont; Beeville; Brownsville; Corpus Christi; Crystal City; Dallas; Houston; Lake Charles; Laredo; McAllen; Palestine; Port Arthur; Sequin; Sherman; Shreveport; Texarkana; Tyler; Waco

\section{Province Coastal Plain}

\section{Reliability of location Poor}

Comments: Most of the area was evaluated with regional maps at scales smaller than 1:250,000, because no individual fault has sufficient evidence of seismic slip to justify singling it out for attention here at a larger map scale. Faults in some areas, particularly the Houston metropolitan area, are mapped at scales as large as 1:24,000. Faults in areas with many well logs may be better located in the subsurface than at the surface.

Geologic setting A belt of mostly seaward-facing normal faults borders the northern Gulf of Mexico. These gulf-margin faults face southwest in westernmost Florida, southwestern 
Alabama, and southern Mississippi; south in Louisiana and southernmost Arkansas; and southeast in eastern and southern Texas (Ewing and Lopez, 1991 \#2032). In early to middle Mesozoic time, the opening of the Gulf of Mexico formed a south-facing, rifted, passive margin at the southern edge of North America (DuBar and others, 1991 \#2010; Salvador, 1991 \#2019; Salvador, 1991 \#2020). Subsequently, the rifted margin was buried beneath the thick, Middle Jurassic, Louann Salt and an overlying, carbonate and clastic, marine sequence that continues to accumulate today. This post-rift sequence thickens seaward (Salvador, 1991 \#2020). It is at least $2 \mathrm{~km}$ thick everywhere in the belt of gulf-margin normal faults. At the coastline, the sequence is at least $10 \mathrm{~km}$ thick west of the Mississippi River and at least $5 \mathrm{~km}$ thick farther east. Thicknesses exceed $12 \mathrm{~km}$ under coastal Texas and southern Louisiana and perhaps $16 \mathrm{~km}$ offshore Louisiana.

Rapid deposition and the resulting enormous thickness of the post-rift sediment pile caused it to collapse and spread seaward. Salt flowed southward and pierced upward, and the overlying pile extended on listric, normal, growth faults that flatten downward into detachments in the salt and in overpressured shales (Ewing, 1991 \#1994; Nelson, 1991 \#1995). These listric normal faults, their splays, and their antithetic and transfer faults make up the belt of gulfmargin normal faults that concern us here.

Regional fluctuations in the overall deposition rate led to division of the belt of gulf-margin faults into two parts with different main ages of faulting and different degrees of Quaternary faulting. (1) The Interior zone of Ewing (1991 \#1994) includes the entire belt except southern Louisiana, coastal Texas, and their offshore extensions. Triassic-Jurassic rifting and sedimentation, including deposition of the Louann Salt, led to Mesozoic growth faulting and salt tectonism. A line of large grabens approximates the landward limit of Jurassic salt, and Cenozoic faulting is sparse in the Interior zone (Ewing, 1991 \#1994; Salvador, 1991 \#2019; Ewing and Lopez, 1991 \#2032). The San Marcos arch plunges southeastward, from the Llano uplift of central Texas toward the coast. On the arch the landward limit of the Louann salt is embayed southeastward to within $60 \mathrm{~km}$ of the coast (Ewing, 1990 \#3659; Ewing and Lopez, 1991 \#2032). Accordingly, on the arch the landward edge of the Interior zone departs southeastward from the line of large grabens just mentioned, to the Karnes fault zone (Ewing, 1991 \#1994, his Figure 1 and p. 35). Approximately $100 \mathrm{~km}$ west of the Karnes fault zone, at the western end of the Charlotte-Jourdantown fault zone, the landward limit of the belt of normal faults steps gulfward approximately $40 \mathrm{~km}$ to exclude most of the Rio Grande embayment (Ewing, 1990 \#3659; Ewing and Lopez, 1991 \#2032). The embayment contains some thin salt but lacks the large, southeast-facing, normal faults that indicate gulfward gravitational collapse (Ewing, 1991 \#1994, p. 33). (2) The Coastal zone of Ewing (1991 \#1994) covers southern Louisiana, coastal Texas, and their offshore extensions, and is separated from the Interior zone by the Early Cretaceous shelf edge (Ewing, 1991 \#1994; Ewing and Lopez, 1991 \#2032). Sawyer and others (1991 \#3685) summarized total tectonic subsidence (TTS) analyses to infer that the Early Cretaceous shelf edge formed above a crustal boundary that was inherited from the crustal thinning accompanying Triassic-Jurassic rifting. The boundary separates less thinned continental crust on the north from more thinned continental crust on the south. The TTS results indicate that the boundary approximately overlies crust that was thinned to half its original thickness before deposition of the post-rift sequence (Sawyer and others, 1991 \#3685, figures 5 and 6). After formation of the Early Cretaceous shelf edge, 
Late Cretaceous and especially Cenozoic clastic sediments prograded southward, and their load led to abundant Cenozoic and continuing growth faulting and salt tectonism (for example DuBar and others, 1991 \#2010, p. 584-585; Salvador, 1991 \#2019). The post-rift sequence as a whole is at least 9-11 km thick throughout the Coastal zone (Salvador, 1991 \#2020). In addition to causing seaward gravitational collapse of the thick post-rift sequence, the crustal load from rapid Quaternary sedimentation may also aid Quaternary normal faulting and reactivate Tertiary faults of the Coastal zone by imposing extensional bending stresses on the postrift sequence; older extensional stresses imposed by the Mesozoic sediment load have had time to relax (Nunn, $1985 \# 2215$ ).

Epicenter maps show only sparse, low-magnitude seismicity within the belt of normal faults (Engdahl, 1988 \#1959; Stover and Coffman, 1993 \#1986). The only damaging earthquakes reported through 1989 in this huge tract of land are four MMI VI earthquakes in westernmost Florida (1780), southern Louisiana (1930), and eastern Texas (1891, 1932) (Stover and Coffman, 1993 \#1986). This level of seismicity is even less than that of sparsely seismic North and South Dakota, which together cover approximately the same area as the belt of gulf-margin faults, and had seven earthquakes of MMI VI since 1909 (Stover and Coffman, 1993 \#1986). Furthermore, global analogs suggest that some of the sparse seismicity in the normal-fault belt may be artificially induced (Yerkes and Castle, 1976 \#3700). Earthquakes of $\mathrm{m}_{\mathrm{bLg}} 3.4$ and 3.9 and $\mathrm{M}_{\mathrm{fa}} 4.0$ and 4.7 in southeastern Texas and $\mathbf{M} 4.9$ in southwestern Alabama may have been induced by extraction of oil and gas or injection of fluids for secondary recovery (Pennington and others, 1986 \#1876; Chang and others, 1998 \#1806; Gomberg and others, 1998 \#1828; Gomberg and Wolf, 1999 \#3440). Therefore, the natural seismicity rate in the normal-fault belt might be even less than the recent historical record would indicate.

Perhaps seismicity is low because the post-rift sequence and its belt of gulf-margin normal faults are mechanically decoupled from the underlying crust. There are two reasons why one might expect this to be true. First, one horizontal deviatoric component of the stress field is extensional throughout the post-rift sequence in both the Interior and Coastal zones of the normal-fault belt, as determined mostly from well data that demonstrate fault slips and well bore breakouts (Zoback and Zoback, 1991 \#2006). The orientations of $\mathrm{S}_{\mathrm{hmin}}$ are radial to the Gulf of Mexico, in contrast to the east-northeast trends of $\mathrm{S}_{\mathrm{Hmax}}$ that characterize most of North America east of the Rocky Mountains; the stress field in the crust beneath the thick post-rift sequence is unknown (Zoback and Zoback, 1991 \#2006). Consistent with the stress field in the post-rift sequence, the normal-faulting focal mechanism of the 1997, M 4.9 earthquake in southwestern Alabama recorded south-southwest extension (Chang and others, 1998 \#1806). Second, the presence of the seaward-facing normal faults throughout the post-rift sequence from westernmost Florida to southern Texas (Ewing and Lopez, 1991 \#2032) indicates that probably the sequence is sliding and extending seaward on detachments in weak salt and overpressured shales. The salt and overpressured shales may be too ductile to transmit tectonic stresses upward from the underlying crust into the post-rift sequence. Additionally, the post-rift sequence itself is young, only partly dewatered, and poorly lithified, particularly in its Cenozoic part. The post-rift sequence lacks the elastic strength to transmit tectonic stresses as efficiently as upper crustal metamorphic and igneous rocks. In particular, the postrift sequence may be unable to support the widespread, high stresses that are necessary to 
drive a large, seismogenic rupture. Locally, individual beds may dewater and lithify before surrounding sediments, and become able to support local stress concentrations that could cause small earthquakes. The sequence may be similarly unable to support the propagation of high stresses or seismogenic ruptures that might enter it from the underlying crust. This suggestion is consistent with the observation that low velocity, near-surface materials, whether they are thick fault gouge or poorly lithified sediments, tend to suppress the propagation of seismic ruptures (Marone and Scholz, 1988 \#1856).

In summary, the belt of gulf-margin normal faults from Florida through Texas is assigned to class $\mathrm{B}$, because much of the fault system might be unable to generate as many significant earthquakes as can the faults in continental crust that lies north of the gulf-margin fault system.

\section{Sense of movement Normal}

Comments: There might be a few strike-slip faults that form transtensional links between normal faults.

\section{Dip $0^{\circ}-90^{\circ}$}

Comments: Dips vary, but faults are generally steeper in their upper parts and they flatten downward. Dips are dominantly southeast in the Coastal zone, seaward of the early Cretaceous shelf edge. However, in the Interior zone, northwest of the shelf edge, southeast and northwest dips are locally paired in grabens (Ewing and Lopez, 1991 \#2032).

\section{Dip direction SE, NW}

Geomorphic expression Scarps and drainage, topographic, and tonal lineaments (DuBar and others, 1991 \#2010), particularly near the coast (see "Timing of most recent paleoevent" below).

Age of faulted deposits Cretaceous to Holocene (Winker, 1990 \#3698; Barnes, 1992 \#3703). See also "Timing of most recent paleoevent" below.

Paleoseismological studies None. No detailed paleoseismological studies involving trenching are reported.

Timing of most recent paleoevent latest Quaternary $(<15 \mathrm{ka})$

Comments: A belt of mostly seaward-facing normal faults borders the northern Gulf of Mexico (Ewing and Lopez, 1991 \#2032). Ewing (1991 \#1994) and Ewing and Lopez (1991 \#2032) divided the faults into an Interior Zone and a Coastal Zone, which are separated by a boundary that begins in southeastern Louisiana and runs westward across Louisiana and Texas, approximately $100 \mathrm{~km}$ inland from the coast in eastern Texas and more than $200 \mathrm{~km}$ inland in southwestern Texas. In the Interior Zone, Quaternary slip is rarely reported (but see figure 3 in DuBar and others (1991 \#2010) ). In contrast, the Coastal zone contains more

abundant evidence of Quaternary slip. Widespread Quaternary and historical normal faulting has long been recognized at the surface from Louisiana to Mexico (Groat, 1973 \#3665; Verbeek, 1979 \#3691; 1979 \#3692; Berryhill and Trippet, 1980 \#3648; O’Neil and Van Siclen, 1984 \#3681; Ewing, 1990 \#3659; Ruhl and Norman, 1992 \#3684; White and Morton, 1997 \#3697). The faulting is generally attributed to regional, late Cenozoic, gravitational col- 
lapse of the thick, unlithified to partly lithified, water-saturated materials of the Coastal zone, locally greatly accelerated by subsidence that arises from pumping of oil, gas, and water.

Historical subsidence and surface normal faulting are particularly pronounced in and around Houston (Pratt and Johnson, 1926 \#3682; Verbeek and Clanton, 1978 \#3693; Clanton, 1979 \#3650; Sheets, 1979 \#3686; 1979 \#3694; Verbeek and others, 1979 \#3695; Holzer and Verbeek, 1980 \#3675; Mastroianni and Norman, 1992 \#3680). The subsidence, faulting, and occasional small earthquakes resemble the effects of withdrawal of subsurface fluids in other urban areas worldwide (Yerkes and Castle, 1976 \#3700; Holzer, 1980 \#3672). At Houston, slowing of pumping to allow recovery of ground water levels was followed by slowing of subsidence and faulting (Holzer and Gabrysch, 1982 \#3673; Holzer and others, 1983 \#3674).

\section{Recurrence interval Not reported}

Comments: Estimates of recurrence interval are premature because it is not yet clear whether these faults can generate significant tectonic earthquakes, as explained under "Geologic setting".

\section{Slip-rate category unknown}

Comments: The tectonic slip rate is unknown. However, a slip rate of $0.2 \mathrm{~mm} / \mathrm{yr}$ would produce $320 \mathrm{~m}$ of slip during the 1,600,000 years of the Quaternary. It is unlikely that any single fault in the gulf-margin belt of normal faults has such a large Quaternary offset. Therefore, probably the long-term rate is less than $0.2 \mathrm{~mm} / \mathrm{yr}$.

\section{Length Not applicable}

Comments: Many faults are mapped, of widely varying lengths.

Average strike $+50^{\circ}$

Comments: Faults vary widely in strike, from approximately $+00^{\circ}$ to $+90^{\circ}$

\section{References}

\#3703 Barnes, V.E., supervisor, 1992, Geologic map of Texas: Bureau of Economic Geology, The University of Texas at Austin, 4 sheets, scale 1:500,000.

\#3648 Berryhill, H.L., and Trippet, A.R., 1980, Map showing post-Wisconsin sedimentation patterns and faulting in the Port Isabel 1 x 2 Quadrangle, Texas: U.S. Geological Survey Miscellaneous Investigations Map I-1254-D, 1 sheet, scale 1:250,000.

\#1806 Chang, T.M., Ammon, C.J., and Herrmann, R.B., 1998, Faulting parameters of the October 24, 1997 southern Alabama earthquake [abs.]: Seismological Research Letters, v. 69, p. 175-176.

\#3650 Clanton, U.S., 1979, Faults offsetting land surfaces in southeastern Houston metropolitan area, Texas: Bulletin of the American Association of Petroleum Geologists, v. 63, no. 3, p. 432.

\#2010 DuBar, J.R., Ewing, T.E., Lundelius, E.L., Jr., Otvos, E.G., and Winker, C.D., 1991, Quaternary geology of the Gulf of Mexico Coastal Plain, in Morrison, R.B., ed., Quaternary nonglacial geology; conterminous U.S.: Boulder, Colorado, Geological Society of America, The Geology of North America, v. K-2, p. 583-610. 
\#1959 Engdahl, E.R., compiler, 1988, Seismicity map of North America: Boulder, Colorado, Geological Society of America Continent-Scale Map 004, 4 sheets, scale 1:5,000,000.

\#3659 Ewing, T.E., 1990, Tectonic map of Texas: Bureau of Economic Geology, The University of Texas at Austin, 4 sheets, scale 1:750,000.

\#1994 Ewing, T.E., 1991, Structural framework, in Salvador, A., ed., The Gulf of Mexico basin: Boulder, Colorado, Geological Society of America, The Geology of North America, v. J, p. 31-52.

\#2032 Ewing, T.E., and Lopez, R.F., 1991, Principal structural features, Gulf of Mexico basin, in Salvador, A., ed., The Gulf of Mexico basin: Boulder, Colorado, Geological Society of America, The Geology of North America, v. J, plate 2, scale 1:2,500,000.

\#3440 Gomberg, J., and Wolf, L., 1999, Possible cause for an improbable earthquake-The $1997 \mathrm{M}_{\mathrm{W}} 4.9$ southern Alabama earthquake and hydrocarbon recovery: Geology, v. 27, p. 367-370.

\#1828 Gomberg, J., Wolf, L., Raymond, D., Raymond, R., Barnes, A., Carver, D., Bice, T., Cranswick, E., Meremonte, M., Frankel, A., Overturf, D., Hopper, M., Rhea, S., and Eckhoff, O., 1998, A noteworthy earthquake in an unlikely place [abs.]: Seismological Research Letters, v. 69, p. 175.

\#3665 Groat, C.G., 1973, Holocene faulting and subsidence in the Texas coastal zone: Geological Society of America Abstracts with Programs, v. 5, no. 7, p. 645.

\#3674 Holzer, T., Gabrysch, R.K., and Verbeek, E.R., 1983, Faulting arrested by control of ground-water withdrawal in Houston, Texas: Earthquake Information Bulletin, v. 15, no. 6, p. 204-209.

\#3672 Holzer, T.L., 1980, Land subsidence and ground failure induced by fluid withdrawal in urban areas: Geological Society of America Abstracts with Programs, v. 12, no. 7, p. 449.

\#3673 Holzer, T.L., and Gabrysch, R.K., 1982, Historical surface faulting in part of the Houston-Galveston, Texas, subsidence bowl arrested by partial water-level recoveries: Geological Society of America Abstracts with Programs, v. 14, no. 7, p. 517.

\#3675 Holzer, T.L., and Verbeek, E.R., 1980, Modern surface faulting in the Goose Creek Oil Field (Baytown, Texas) - A reexamination: Geological Society of America Abstracts with Programs, v. 12, no. 7, p. 449.

\#1856 Marone, C., and Scholz, C.H., 1988, The depth of seismic faulting and the upper transition from stable to unstable slip regimes: Geophysical Research Letters, v. 15, p. 621624.

\#3680 Mastroianni, J.J., and Norman, C.E., 1992, A study of active fault movement, Houston, Texas and vicinity: Geological Society of America Abstracts with Programs, v. 24, no. 1, p. 18.

\#1995 Nelson, R.H., 1991, Salt tectonics and listric-normal faulting, in Salvador, A., ed., The Gulf of Mexico basin: Boulder, Colorado, Geological Society of America, The Geology of North America, v. J, p. 73-89. 
\#2215 Nunn, J.A., 1985, State of stress in the northern Gulf Coast: Geology, v. 13, p. 429-432.

\#3681 O’Neil, M.W., and Van Siclen, D.C., 1984, Activation of Gulf Coast faults by depressuring of aquifers and an engineering approach to siting structures along their traces: Bulletin of the Association of Engineering Geologists, v. 21, no. 1, p. 73-87.

\#1876 Pennington, W.D., Davis, S.D., Carlson, S.M., DuPree, J., and Ewing, T.E., 1986, The evolution of seismic barriers and asperities caused by the depressuring of fault planes in oil and gas fields of south Texas: Bulletin of the Seismological Society of America, v. 76, p. 939-948.

\#3682 Pratt, W.E., and Johnson, D.W., 1926, Local subsidence of the Goose Creek Oil Field: Journal of Geology, v. 34, no. 7, p. 577-590.

\#3684 Ruhl, J.H., and Norman, C.E., 1992, Identification, geometry, and movement history of active surface faults in Fort Bend County, Texas: Geological Society of America Abstracts with Programs, v. 24, no. 1, p. 44.

\#2019 Salvador, A., compiler, 1991, Cross sections of the Gulf of Mexico basin, in Salvador, A., ed., The Gulf of Mexico basin: Boulder, Colorado, Geological Society of America, The Geology of North America, v. J, plate 6.

\#2020 Salvador, A., compiler, 1991, Structure at the base and subcrop below Mesozoic marine section, Gulf of Mexico basin, in Salvador, A., ed., The Gulf of Mexico basin:

Boulder, Colorado, Geological Society of America, The Geology of North America, v. J, plate 3, scale 1:2,500,000.

\#3685 Sawyer, D.S., Buffler, R.T., and Pilger, R.H., Jr., 1991, The crust under the Gulf of Mexico basin, in Salvador, A., ed., The Gulf of Mexico Basin: Boulder, Colorado, Geological Society of America, The Geology of North America, v. J, p. 53-72.

\#3686 Sheets, M.M., 1979, Oil fields and their relation to subsidence and active surface faulting in the Houston area: Houston, Texas, Houston Geological Society, 20 p.

\#1986 Stover, C.W., and Coffman, J.L., 1993, Seismicity of the United States, 1568-1989 (revised): U.S. Geological Survey Professional Paper 1527, 418 p.

\#3691 Verbeek, E.R., 1979, Quaternary fault activity in Texas Gulf Coast: Bulletin of the American Association of Petroleum Geologists, v. 63, no. 3, p. 545.

\#3692 Verbeek, E.R., 1979, Surface faults in the gulf coastal plain between Victoria and Beaumont, Texas: Tectonophysics, v. 52, p. 373-375.

\#3693 Verbeek, E.R., and Clanton, U.S., 1978, Map showing surface faults in the southeastern Houston metropolitan area, Texas: U.S. Geological Survey Open-File Report 78-797, 20 p., 1 pl., scale 1:24,000.

\#3694 Verbeek, E.R., and Clanton, U.S., 1979, Clodine Fault, southwestern Houston metropolitan area, Texas: U.S. Geological Survey Open-File Report 79-947, 25 p., 1 pl., scale $1: 24,000$.

\#3695 Verbeek, E.R., Ratzlaff, K.W., and Clanton, U.S., 1979, Faults in parts of north-central and western Houston metropolitan areas, Texas: U.S. Geological Survey Miscellaneous Field Studies Map MF-1136, 1 sheet, scale 1:24,000. 
\#3697 White, W.A., and Morton, R.A., 1997, Wetland losses related to fault movement and hydrocarbon production, southeastern Texas coast: Journal of Coastal Research, v. 13, no. 4, p. 1305-1320.

\#3698 Winker, C.D., 1990, Quaternary geology, northwestern Gulf Coast, in Morrison, R.B., ed., Quaternary nonglacial geology; conterminous U.S.: Boulder, Colorado, Geological Society of America, The Geology of North America, v. K-2, 1 pl., scale $1: 2,000,000$.

\#3700 Yerkes, R.F., and Castle, R.O., 1976, Seismicity and faulting attributable to fluid extraction: Engineering Geology, v. 10, p. 151-167.

\#2006 Zoback, M.D., and Zoback, M.L., 1991, Tectonic stress field of North America and relative plate motions, in Slemmons, D.B., Engdahl, E.R., Zoback, M.D., and Blackwell, D.D., eds., Neotectonics of North America: Boulder, Colorado, Geological Society of America, Decade Map Volume 1, p. 339-366. 


\section{XX, Crooked Creek Fault (Class B)}

\section{Structure Number $1021 \mathrm{XX}$}

Structure Name Crooked Creek fault (Class B)

Comments: Also called the Crooked Creek-Fowler fault by Gutentag and others (1981 \#2811).

Synopsis: This feature is classified as a Class B feature because of the uncertainty concerning the cause of the subsurface deformation. As discussed below, it is uncertain if the stratigraphic offset related to the Crooked Creek fault is solely the result of dissolution of soluble subsurface strata or is related to genuine, deep-seated tectonic movements (Frye and Hibbard, 1941 \#2810). The fault is defined largely on the basis of drill-hole data (Izett and Honey, 1995 \#2812) and anomalous geomorphic features above the subsurface structure. No exposures of the fault are known. Deformation associated with the feature has resulted in a structural depression in the subsurface and an elongate topographic trough (Smith, 1940 \#2813).

Date of compilation $09 / 22 / 98$

Compiler and affiliation Anthony J. Crone, U.S. Geological Survey

State Kansas

County Meade, Ford

$1^{\circ} \times 2^{\circ}$ sheet Dodge City

Province Great Plains

\section{Reliability of location Poor}

Comments: Subsurface location of the fault is based on scattered drill-hole data that indicates the presence of an anomalously large change in the elevation of stratigraphic units between adjacent drill holes (Izett and Honey, 1995 \#2812). This large change suggests the presence of a fault because stratigraphic units throughout the region are nearly flat-lying, having regional dips of only 1.8-3.6 m per km (Smith, 1940 \#2813).

Geologic setting The oldest exposed rocks in the Meade County area are Lower Permian sedimentary rocks, although older Paleozoic rocks are present in the subsurface. Shallow seas covered the region periodically during Paleozoic time, and in Permian time, there was a progressive transition to non-marine sedimentation. At times during this transition, extensive evaporation of isolated inland seas resulted in the deposition of salt and gypsum (Hutchinson Salt Member of the Wellington Formation; estimated to be about $165 \mathrm{~m}$ thick based on geophysical logs shown in Figure 3 of Izett and Honey, (1995 \#2812). Non-deposition and erosion during much of the Mesozoic created an unconformity between Paleozoic rocks and the overlying Tertiary sediments (Frye, 1942 \#2809). The Miocene-age, silty sandstone and gravels that comprise the Ogallala Formation are the most widespread Tertiary rocks in southwestern Kansas. In the area of the Crooked Creek fault in Meade County, the Ogallala Formation is overlain by claystone, siltstone, sand, and gravels of the Pliocene Rexroad Formation and Stump Arroyo Member, and the Pliocene/Pleistocene Crooked Creek Formation (Izett and Honey, 1995 \#2812). All of these materials are generally undeformed and nearly flat lying. 


\section{Sense of movement Not reported}

Comments: The sense of movement on the inferred fault is not well known because the Crooked Creek fault is only known from subsurface data. Stratigraphic relations based on subsurface data suggest a significant vertical offset (the amount of offset is not explicitly stated), but no information exists to determine if the offset is the product of normal or reverse slip. Based on the current topography, the southern part of the fault would have a down-tothe-west vertical offset. The stratigraphic offsets between adjacent drill holes in the area are certainly suggestive of faulting, but as Smith (1940 \#2813) correctly observes, some of the structural depression in the subsurface could be described as a structural trough, and the depression may not be caused wholly by faulting.

The exact origin of the stratigraphic offset remains uncertain. Some authors propose that these offsets are related to tectonic faulting (Haworth, 1896 \#2814; Smith, 1940 \#2813) whereas others propose that they are the result of dissolution of evaporite minerals in the Permian rocks (Gutentag and others, 1981 \#2811; Izett and Honey, 1995 \#2812). Smith (1940 \#2813, p. 133-136) summarized the strengths and weaknesses of the interpretations of faulting and dissolution to explain the Crooked Creek fault.

Dip Not reported

Comments: For reasons similar to those described above, the dip of the fault is unknown.

\section{Dip direction Not reported}

Geomorphic expression An abrupt, anomalous change in the course of Crooked Creek in Meade County, an area of unusual artesian flow of groundwater, and unusual surficial depressions (sinkholes) first drew attention to the area of the Crooked Creek fault. The prevailing topographic slope in southwestern Kansas is about $2.37 \mathrm{~m} / \mathrm{km}$ in a southeasterly direction (Gutentag and others, 1981 \#2811). The upper 30-40 km of Crooked Creek flows in a generally east to southeasterly direction, but at the eastern border of Meade County about $10 \mathrm{~km}$ north of the town of Fowler, the stream valley turns abruptly to the southwest, and maintains this flow direction for about $45 \mathrm{~km}$ before it turns abruptly and again flows to the southeast. The anomalous southwesterly-flowing reach of the stream coincides with the area of artesian aquifers and the area of sinkholes. The spatial coincidence of these unusual geomorphic features and the groundwater condition suggest a common explanation.

The exact cause of the unusual geomorphology in the area still remains uncertain. Haworth (1896 \#2814) first suggested that these features could be related to faulting, whereas other authors contend that dissolution of subsurface evaporites and subsequent collapse of overlying strata have played a major role in the area's geomorphology (Frye, 1942 \#2809). Gutentag and others (1981 \#2811) and Izett and Honey (1995 \#2812) report that the stratigraphic offsets are only the result of dissolution of subsurface evaporites.

Age of faulted deposits The age of the youngest faulted deposits is uncertain. If the stratigraphic offsets are solely caused by dissolution, then Holocene deposits are "faulted" because sinkholes have formed during historical time (Frye, 1942 \#2809). The geological history related to the Crooked Creek fault is poorly known, but Smith (1940 \#2813) suggests that the late stages of movement history included ". . . renewal of downward movement along the southern part of the trough in early Pleistocene time, leading to the deposition of the Odee 
formation; and continued movement in later Quaternary time, outlining the details of the present topography .." Frye and Hibbard (1941 \#2810 p. 397) state that "The latest movement along the Crooked Creek fault occurred in the Recent epoch, displacing the Pleistocene formations and again giving surface expression to the basin."

Paleoseismological studies None. No detailed studies of the faulting history of this feature have been completed to date. The historical formation of sinkholes shows that subsurface dissolution continues to play an important role in the region's geomorphology. A key unresolved question is whether the localized occurrence of dissolution features is a secondary effect of deep-seated tectonic faulting, which has fractured bedrock and enhanced groundwater circulation, or is all of the stratigraphic offset solely the result of dissolution. Because of this uncertainty concerning the tectonic aspects of the feature, it is categorized as a Class B feature.

Timing of most recent paleoevent Not reported

Comments: Because the uncertainty related to the origin of Crooked Creek fault, it is not possible to assign a time of the most recent paleoevent.

Recurrence interval Not reported

Comments: Because the uncertainty related to the origin of Crooked Creek fault, it is not possible to assign a recurrence interval.

Slip-rate category unknown

Comments: Because the uncertainty related to the origin of Crooked Creek fault, it is not possible to assign a slip rate.

Length not determined

Comments: The Crooked Creek fault is only known from subsurface data; it does not have any clear surface expression, therefore, is poorly located and defined. Thus, it is not possible to determine a length for the fault.

Average strike not determined

Comments: The Crooked Creek fault is only known from subsurface data; it does not have any clear surface expression, therefore, is poorly located and defined. Thus, it is not possible to determine an average strike for the fault.

\section{References}

\#2809 Frye, J.C., 1942, Geology and ground-water resources of Meade County, Kansas: Bulletin of the University of Kansas, State Geological Survey of Kansas 45, 152 p.

\#2810 Frye, J.C., and Hibbard, C.W., 1941, Pliocene and Pleistocene stratigraphy and paleontology of the Meade basin, southwestern Kansas: State Geological Survey of Kansas Bulletin 38, 390-424 p.

\#2811 Gutentag, E.D., Lobmeyer, D.H., and Slagle, S.E., 1981, Geohydrology of southwestern Kansas: Kansas Geological Survey Irrigation Series 7, 73 p., 3 oversized pls.

\#2814 Haworth, E., 1896, Local deformation of strata in Meade County, Kansas and adjoining territory (preliminary): American Journal of Science, v. 2, p. 368-373. 
\#2812 Izett, G.A., and Honey, J.G., 1995, Geologic map of the Irish Flats NE quadrangle, Meade County, Kansas: U.S. Geological Survey Miscellaneous Investigations Map I2498, scale 1:24,000.

\#2813 Smith, H.T.U., 1940, Geological studies in southwestern Kansas: Bulletin of the University of Kansas, State Geological Survey of Kansas 34, 212 p. 


\section{XX, Gulf-margin normal faults, Louisiana and Arkansas (Class B)}

\section{Structure Number 1022XX}

Structure Name Gulf-margin normal faults, Louisiana and Arkansas (Class B)

Comments: A belt of mostly seaward-facing normal faults borders the northern Gulf of Mexico, in westernmost Florida, southwestern Alabama, southern Mississippi, all of Louisiana and southernmost Arkansas, and eastern and southern Texas (Ewing and Lopez, 1991 \#2032). This compilation evaluates the faults in four large groups because faults number in the hundreds, and because their ability to have significant earthquakes is doubtful. To reflect regional differences in the characteristics of the faults, those in Florida and Alabama are evaluated together in a single group, as are those in Mississippi, those in Louisiana and Arkansas, and those in Texas.

Synopsis: The gulf-margin normal faults are assigned to class B because they exist in sediments and poorly lithified rocks. Most of these materials may be unable to support the stresses required for the propagation of significant seismic ruptures that could cause damaging ground motions.

Date of compilation $08 / 11 / 98$; revised $01 / 28 / 00$

Compiler and affiliation Russell L. Wheeler, U.S. Geological Survey; Paul V. Heinrich, Louisiana Geological Survey

State Louisiana; Arkansas

County Acadia; Allen; Ascension; Assumption; Avoyelles; Beauregard; Bienville; Bossier; Caddo; Calcasieu; Caldwell; Cameron; Catahoula; Claiborne; Concordia; De Soto; East Baton Rouge; East Carroll; East Feliciana; Evangeline; Franklin; Grant; Iberia; Iberville; Jackson; Jefferson; Jefferson Davis; Lafayette; Lafourche; La Salle; Lincoln; Livingston; Madison; Morehouse; Natchitoches; Orleans; Ouachita; Plaquemines; Pointe Coupee; Rapides; Red River; Richland; Sabine; Saint Bernard; Saint Charles; Saint Helena; Saint James; Saint John the Baptist; Saint Landry; Saint Martin; Saint Mary; Saint Tammany; Tangipahoa; Tensas; Terrebonne; Union; Vermilion; Vernon; Washington; Webster; West Baton Rouge; West Carroll; West Feliciana; Winn (Louisiana); Ashley; Bradley; Calhoun; Chicot; Columbia; Hempstead; Lafayette; Miller; Nevada; Ouachita; Union (Arkansas)

$1^{\circ} \times 2^{\circ}$ sheet Alexandria; Baton Rouge; Breton Sound; Jackson; Lake Charles; Mobile; Natchez; New Orleans; Port Arthur; Shreveport; Tyler (Louisiana); El Dorado; Greenwood; Texarkana (Arkansas)

\section{Province Coastal Plain}

\section{Reliability of location Poor}

Comments: Most of the cited maps are regional compilations at 1:2,500,000, because no individual fault has sufficient evidence of seismic slip to justify singling it out for attention here at a larger map scale. Faults in areas with many well logs may be better located in the subsurface than at the surface.

Geologic setting A belt of mostly seaward-facing normal faults borders the northern Gulf of Mexico. These gulf-margin faults face southwest in westernmost Florida, southwestern 
Alabama, and southern Mississippi; south in Louisiana and southernmost Arkansas; and southeast in eastern and southern Texas (Ewing and Lopez, 1991 \#2032). In early to middle Mesozoic time, the opening of the Gulf of Mexico formed a south-facing, rifted, passive margin at the southern edge of North America (DuBar and others, 1991 \#2010; Salvador, 1991 \#2019; Salvador, 1991 \#2020). Subsequently, the rifted margin was buried beneath the thick, Middle Jurassic, Louann Salt and an overlying, carbonate and clastic, marine sequence that continues to accumulate today. This post-rift sequence thickens seaward (Salvador, 1991 \#2020). It is at least $2 \mathrm{~km}$ thick everywhere in the belt of gulf-margin normal faults. At the coastline, the sequence is at least $10 \mathrm{~km}$ thick west of the Mississippi River and at least $5 \mathrm{~km}$ thick farther east. Thicknesses exceed $12 \mathrm{~km}$ under coastal Texas and southern Louisiana and perhaps $16 \mathrm{~km}$ offshore Louisiana.

Rapid deposition and the resulting enormous thickness of the post-rift sediment pile caused it to collapse and spread seaward. Salt flowed southward and pierced upward, and the overlying pile extended on listric, normal, growth faults that flatten downward into detachments in the salt and in overpressured shales (Ewing, 1991 \#1994; Nelson, 1991 \#1995). These listric normal faults, their splays, and their antithetic and transfer faults make up the belt of gulfmargin normal faults that concern us here.

Regional fluctuations in the overall deposition rate led to division of the belt of gulf-margin faults into two parts with different main ages of faulting and different degrees of Quaternary faulting. (1) The Interior zone of Ewing (1991 \#1994) includes the entire belt except southern Louisiana, coastal Texas, and their offshore extensions. Triassic-Jurassic rifting and sedimentation, including deposition of the Louann Salt, led to Mesozoic growth faulting and salt tectonism. A line of large grabens approximates the landward limit of Jurassic salt, and Cenozoic faulting is sparse in the Interior zone (Ewing, 1991 \#1994; Salvador, 1991 \#2019; Ewing and Lopez, 1991 \#2032). (2) The Coastal zone of Ewing (1991 \#1994) covers southern Louisiana, coastal Texas, and their offshore extensions, and is separated from the Interior zone by the Early Cretaceous shelf edge (Ewing, 1991 \#1994; Ewing and Lopez, 1991 \#2032). Late Cretaceous and especially Cenozoic clastic sediments prograded southward and led to abundant Cenozoic and continuing growth faulting and salt tectonism (for example DuBar and others, 1991 \#2010, p. 584-585; Salvador, 1991 \#2019). The post-rift sequence as a whole is at least 9-11 km thick throughout the Coastal zone (Salvador, 1991 \#2020). Calculations show that the crustal load from rapid Quaternary sedimentation may aid Quaternary normal faulting and reactivate Tertiary faults of the Coastal zone, by imposing extensional bending stresses on the post-rift sequence; older extensional stresses imposed by the Mesozoic sediment load have had time to relax (Nunn, 1985 \#2215).

Epicenter maps show only sparse, low-magnitude seismicity within the fault belt (Engdahl, 1988 \#1959; Stover and Coffman, 1993 \#1986). The only damaging earthquakes reported through 1989 in this huge tract of land are four MMI VI earthquakes in westernmost Florida (1780), southern Louisiana (1930), and eastern Texas $(1891,1932)$ (Stover and Coffman, 1993 \#1986). This level of seismicity is even less than that of sparsely seismic North and South Dakota, which together cover approximately the same area as the belt of gulf-margin faults, and had seven earthquakes of MMI VI since 1909 (Stover and Coffman, 1993 \#1986). Furthermore, some of the sparse seismicity in the normal-fault belt may be artificially 
induced. Earthquakes of $\mathrm{m}_{\mathrm{bLg}} 3.4$ and 3.9 in southeastern Texas and $\mathbf{M} 4.9$ in southwestern Alabama may have been induced by extraction of oil and gas or injection of fluids for secondary recovery (Pennington and others, 1986 \#1876; Chang and others, 1998 \#1806; Gomberg and others, 1998 \#1828; Gomberg and Wolf, 1999 \#3440). Therefore, the natural seismicity rate in the normal-fault belt might be even less than the recent historical record would indicate.

There are two reasons to suspect that the post-rift sequence and its belt of gulf-margin normal faults may be mechanically decoupled from the underlying crust. First, the stress field is extensional throughout the post-rift sequence in both the Interior and Coastal zones of the normal-fault belt, as determined mostly from well data that demonstrate fault slips and well bore breakouts (Zoback and Zoback, 1991 \#2006). The orientations of $\mathrm{S}_{\mathrm{hmin}}$ are radial to the Gulf of Mexico, in contrast to the east-northeast trends of $\mathrm{S}_{\mathrm{Hmax}}$ that characterize most of North America east of the Rocky Mountains; the stress field in the crust beneath the thick post-rift sequence is unknown (Zoback and Zoback, 1991 \#2006). Consistent with the stress field in the post-rift sequence, the normal-faulting focal mechanism of the 1997, M 4.9 earthquake in southwestern Alabama recorded south-southwest extension (Chang and others, 1998 \#1806). Second, the presence of the normal faults throughout the post-rift sequence from westernmost Florida to southern Texas (Ewing and Lopez, 1991 \#2032) demonstrates that the sequence is sliding and extending seaward on detachments in weak salt and overpressured shales. The salt and overpressured shales may be too ductile to transmit tectonic stresses upward from the underlying crust into the post-rift sequence. Additionally, the post-rift sequence itself is young, only partly dewatered, and poorly lithified, particularly in its Cenozoic part. The post-rift sequence lacks the elastic strength to transmit tectonic stresses as efficiently as upper crustal metamorphic and igneous rocks. In particular, the post-rift sequence may be unable to support the widespread, high stresses that are necessary to drive a large, seismogenic rupture. Locally, individual beds may dewater and lithify before surrounding sediments, and become able to support local stress concentrations that could cause small earthquakes. The sequence may be similarly unable to support the propagation of high stresses or seismogenic ruptures that might enter it from the underlying crust. This suggestion is consistent with the observation that low velocity, near-surface materials, whether they are thick fault gouge or poorly lithified sediments, tend to suppress the propagation of seismic ruptures (Marone and Scholz, 1988 \#1856).

In summary, the belt of gulf-margin normal faults from Florida through Texas is assigned to class $B$, because much of the fault system might be unable to generate as many significant earthquakes as the continental crust that borders it on the north.

\section{Sense of movement Normal}

Comments: There might be a few strike-slip faults that form transtensional links between normal faults.

\section{Dip $0^{\circ}-90^{\circ}$}

Comments: Dips vary, but faults are generally steeper in their upper parts and they flatten downward. Dips are dominantly south in southern Louisiana, with south and north dips paired in grabens in northern Louisiana and southern Arkansas. 


\section{Dip direction $\mathrm{S}, \mathrm{N}$}

Geomorphic expression Scarps and drainage, topographic, and tonal lineaments (DuBar and others, 1991 \#2010), particularly in southern Louisiana (see "Timing of most recent paleoevent" below).

Age of faulted deposits Eocene to Holocene (Saucier and Snead, 1991 \#2021; Haley and others, 1993 \#1932). See also "Timing of most recent paleoevent" below.

Paleoseismological studies None. No detailed paleoseismological studies involving trenching are reported.

\section{Timing of most recent paleoevent Quaternary $(<1.6 \mathrm{Ma})$}

Comments: A belt of mostly seaward-facing normal faults borders the northern Gulf of Mexico (Ewing and Lopez, 1991 \#2032). Ewing (1991 \#1994) and Ewing and Lopez (1991 \#2032) divided the faults into an Interior Zone and a Coastal Zone, which are separated by a boundary that begins in southeastern Louisiana and runs westward across Louisiana and Texas approximately $100 \mathrm{~km}$ inland from the coast. In the Interior Zone, which includes central and northern Louisiana and southernmost Arkansas, Quaternary slip is not reported (but see figure 3 in DuBar and others, 1991 \#2010). In contrast, the Coastal Zone contains more abundant evidence for more widespread Quaternary slip (Hanor, 1982 \#2200; Heinrich, 1988 \#2201; McCulloh, 1991 \#2210; McCulloh and Autin, 1991 \#2253; McCulloh, 1996 \#2211; Heinrich, 1997 \#2202). Quaternary and historical faulting have been demonstrated in southern

Louisiana, along the Tepetate and Baton Rouge fault systems and related faults (Durham and Peeples, 1956 \#3829; Hanor, 1982 \#2200; Heinrich, 1988 \#2201; McCulloh, 1991 \#2210; McCulloh and Autin, 1991 \#2253; McCulloh, 1996 \#2211; Heinrich, 1997 \#2202). Together these active faults cross the State from Beauregard and Calcasieu Parishes in the west to St. Tammany and St. Bernard Parishes in the east, between approximately latitudes $30^{\circ}$ and $30^{\circ} 30^{\prime}$ N. Geologic mapping and analyses of well logs, soil surveys, topographic maps, and aerial photographs documented Quaternary scarps on active and reactivated normal faults in the Coastal zone of Ewing (1991 \#1994). However, as explained in "Geologic setting" above, it is unclear whether such slip was seismic or is likely to occur seismically.

\section{Recurrence interval Not reported}

Comments: Estimates of recurrence interval are premature because it is not yet clear whether these faults can generate significant tectonic earthquakes, as explained under "Geologic setting".

\section{Slip-rate category unknown}

Comments: The slip rate is unknown. However, a slip rate of $0.2 \mathrm{~mm} / \mathrm{yr}$ would produce $320 \mathrm{~m}$ of slip during the 1,600,000 years of the Quaternary. It is unlikely that any single fault in the gulf-margin belt of normal faults has such a large Quaternary offset. Therefore, probably the long-term rate is less than $0.2 \mathrm{~mm} / \mathrm{yr}$.

Length Not applicable

Comments: Many faults are mapped, of widely varying lengths. 


\section{Average strike $-80^{\circ}$}

Comments: Faults vary widely in strike, from approximately $-30^{\circ}$ to $+50^{\circ}$.

\section{References}

\#1806 Chang, T.M., Ammon, C.J., and Herrmann, R.B., 1998, Faulting parameters of the October 24, 1997 southern Alabama earthquake [abs.]: Seismological Research Letters, v. 69, p. 175-176.

\#2010 DuBar, J.R., Ewing, T.E., Lundelius, E.L., Jr., Otvos, E.G., and Winker, C.D., 1991, Quaternary geology of the Gulf of Mexico Coastal Plain, in Morrison, R.B., ed., Quaternary nonglacial geology; conterminous U.S.: Boulder, Colorado, Geological Society of America, The Geology of North America, v. K-2, p. 583-610.

\#3829 Durham, C.O., Jr., and Peeples, E.M., III, 1956, Pleistocene fault zone in southeastern Louisiana, in Rogers, J.K., ed. Transactions of the Gulf Coast Association of Geological Societies: Gulf Coast Section of the Society of Economic Paleontologists and Mineralogists, Annual meeting, San Antonio, Texas, October 31-November 2, 1956 , v. 6, p. 65-66.

\#1959 Engdahl, E.R., compiler, 1988, Seismicity map of North America: Boulder, Colorado, Geological Society of America Continent-Scale Map 004, 4 sheets, scale 1:5,000,000.

\#1994 Ewing, T.E., 1991, Structural framework, in Salvador, A., ed., The Gulf of Mexico basin: Boulder, Colorado, Geological Society of America, The Geology of North America, v. J, p. 31-52.

\#2032 Ewing, T.E., and Lopez, R.F., 1991, Principal structural features, Gulf of Mexico basin, in Salvador, A., ed., The Gulf of Mexico basin: Boulder, Colorado, Geological Society of America, The Geology of North America, v. J, plate 2, scale 1:2,500,000.

\#3440 Gomberg, J., and Wolf, L., 1999, Possible cause for an improbable earthquake-The $1997 \mathrm{M}_{\mathrm{W}} 4.9$ southern Alabama earthquake and hydrocarbon recovery: Geology, v. 27, p. 367-370.

\#1828 Gomberg, J., Wolf, L., Raymond, D., Raymond, R., Barnes, A., Carver, D., Bice, T., Cranswick, E., Meremonte, M., Frankel, A., Overturf, D., Hopper, M., Rhea, S., and Eckhoff, O., 1998, A noteworthy earthquake in an unlikely place [abs.]: Seismological Research Letters, v. 69, p. 175.

\#1932 Haley, B.R., Glick, E.E., Bush, W.V., Clardy, B.F., Stone, C.G., Woodward, M.B., and Zachry, D.L., 1993, Geologic map of Arkansas: Arkansas Geological Commission and U. S. Geological Survey, 1 sheet, scale 1:500,000.

\#2200 Hanor, J.S., 1982, Reactivation of fault movement, Tepetate fault zone, south central Louisiana: Transactions of the Gulf Coast Association of Geological Societies, v. 32, p. 237-245.

\#2201 Heinrich, P.V., 1988, Tectonic origin of Montgomery terrace scarp of southwestern Louisiana [abs]: Transactions of the Gulf Coast Association of Geological Societies, v. 38, p. 582. 
\#2202 Heinrich, P.V., 1997, Pleistocene fault-line scarps and neotectonics in southwest Louisiana: Geological Society of America Abstracts with Programs, v. 29, no. 3, p. 23.

\#1856 Marone, C., and Scholz, C.H., 1988, The depth of seismic faulting and the upper transition from stable to unstable slip regimes: Geophysical Research Letters, v. 15, p. 621624.

\#2210 McCulloh, R.P., 1991, Surface faults in East Baton Rouge Parish: Louisiana Geological Survey Open File Series No. 96-01, 25 p., 5 plates, scale 1:24,000.

\#2211 McCulloh, R.P., 1996, Topographic criteria bearing on the interpreted placement of the traces of faults of the Baton Rouge system in relation to their fault-line scarps: Louisiana Geological Survey Open-File Series No. 96-01, 13 p.

\#2253 McCulloh, R.P., and Autin, W.J., 1991, Revised mapping of surface faults, East Baton Rouge Parish, Louisiana: Transactions of the Gulf Coast Association of Geological Societies, v. 41, p. 473-474.

\#1995 Nelson, R.H., 1991, Salt tectonics and listric-normal faulting, in Salvador, A., ed., The Gulf of Mexico basin: Boulder, Colorado, Geological Society of America, The Geology of North America, v. J, p. 73-89.

\#2215 Nunn, J.A., 1985, State of stress in the northern Gulf Coast: Geology, v. 13, p. 429-432.

\#1876 Pennington, W.D., Davis, S.D., Carlson, S.M., DuPree, J., and Ewing, T.E., 1986, The evolution of seismic barriers and asperities caused by the depressuring of fault planes in oil and gas fields of south Texas: Bulletin of the Seismological Society of America, v. 76, p. 939-948.

\#2019 Salvador, A., compiler, 1991, Cross sections of the Gulf of Mexico basin, in Salvador, A., ed., The Gulf of Mexico basin: Boulder, Colorado, Geological Society of America, The Geology of North America, v. J, plate 6.

\#2020 Salvador, A., compiler, 1991, Structure at the base and subcrop below Mesozoic marine section, Gulf of Mexico basin, in Salvador, A., ed., The Gulf of Mexico basin:

Boulder, Colorado, Geological Society of America, The Geology of North America, v. J, plate 3, scale 1:2,500,000.

\#2021 Saucier, R.T., and Snead, J.I., 1991, Quaternary geology of the Lower Mississippi Valley, in Morrison, R.B., ed., Quaternary nonglacial geology; conterminous U.S.: Boulder, Colorado, Geological Society of America, The Geology of North America, v. K-2, plate 6 , scale $1: 1,000,000$.

\#1986 Stover, C.W., and Coffman, J.L., 1993, Seismicity of the United States, 1568-1989 (revised): U.S. Geological Survey Professional Paper 1527, 418 p.

\#2006 Zoback, M.D., and Zoback, M.L., 1991, Tectonic stress field of North America and relative plate motions, in Slemmons, D.B., Engdahl, E.R., Zoback, M.D., and Blackwell, D.D., eds., Neotectonics of North America: Boulder, Colorado, Geological Society of America, Decade Map Volume 1, p. 339-366. 


\section{XX, Gulf-margin normal faults, Alabama and Florida (Class B)}

\section{Structure Number 2654XX}

Structure Name Gulf-margin normal faults, Alabama and Florida (Class B)

Comments: A belt of mostly seaward-facing normal faults borders the northern Gulf of Mexico, in westernmost Florida, southwestern Alabama, southern Mississippi, all of Louisiana and southernmost Arkansas, and eastern and southern Texas (Ewing and Lopez, 1991 \#2032). This compilation evaluates the faults in four large groups because faults number in the hundreds, and because their ability to have significant earthquakes is doubtful. To reflect regional differences in the characteristics of the faults, those in Florida and Alabama are evaluated together in a single group, as are those in Mississippi, those in Louisiana and Arkansas, and those in Texas.

Synopsis: The gulf-margin normal faults are in class B because they exist in sediments and poorly lithified rocks. Most of these materials may be unable to support the stresses required for the propagation of significant seismic ruptures that could cause damaging ground motions.

Date of compilation 08/11/98; revised 01/28/00

Compiler and affiliation Russell L. Wheeler, U.S. Geological Survey

State Alabama; Florida

County Baldwin; Choctaw; Clarke; Escambia; Mobile; Monroe; Washington (Alabama); Escambia; Santa Rosa (Florida)

$1^{\circ} \times 2^{\circ}$ sheet Andalusia; Hattiesburg; Mobile; Pensacola

Province Coastal Plain

\section{Reliability of location Poor}

Comments: Most of the cited maps are regional compilations at 1:2,500,000, because no individual fault has sufficient evidence of seismic slip to justify singling it out for attention at a larger map scale. Faults in areas with many well logs may be better located in the subsurface than at the surface.

Geologic setting A belt of mostly seaward-facing normal faults borders the northern Gulf of Mexico. These gulf-margin faults face southwest in westernmost Florida, southwestern Alabama, and southern Mississippi; south in Louisiana and southernmost Arkansas; and southeast in eastern and southern Texas (Ewing and Lopez, 1991 \#2032). In early to middle Mesozoic time, the opening of the Gulf of Mexico formed a south-facing, rifted, passive margin at the southern edge of North America (DuBar and others, 1991 \#2010; Salvador, 1991 \#2019; Salvador, 1991 \#2020). Subsequently, the rifted margin was buried beneath the thick, Middle Jurassic Louann Salt and an overlying, carbonate and clastic, marine and paralic sequence that continues to accumulate today. This post-rift sequence thickens seaward (Salvador, 1991 \#2020). It is at least $2 \mathrm{~km}$ thick everywhere in the belt of gulf-margin normal faults. At the coastline, the sequence is at least $10 \mathrm{~km}$ thick west of the Mississippi River and at least $5 \mathrm{~km}$ thick farther east. Thicknesses exceed $12 \mathrm{~km}$ in coastal Texas and southern Louisiana and perhaps $16 \mathrm{~km}$ in offshore Louisiana. 
Rapid Mesozoic and Cenozoic deposition by large rivers and the resulting enormous thickness of the post-rift sediment pile caused it to collapse and spread seaward. Salt flowed southward and pierced upward, and the overlying pile extended on listric, normal, growth faults that flatten downward into detachments in the salt and in overpressured shales (Ewing, 1991; Nelson, 1991). These listric normal faults, their splays, and their antithetic and transfer faults make up the belt of gulf-margin normal faults that concern us here. The faults decrease in size and abundance inland to the landward limit of Jurassic salt, which is marked in many places by large grabens of the normal-fault belt (Ewing and Lopez, 1991 \#2032). The belt of normal faults remains active as a whole, and particularly in its seaward parts, because the prograding fluvial deposition that loads the sediment pile and drives its seaward collapse continues (for example DuBar and others, 1991 \#2010 p. 584-585, 594; Salvador, 1991 \#2019).

Epicenter maps show only sparse, low-magnitude seismicity within the fault belt (Engdahl, 1988 \#1959; Stover and Coffman, 1993 \#1986). The only damaging earthquakes reported through 1989 in this huge tract of land are four MMI VI earthquakes in westernmost Florida (1780), southern Louisiana (1930), and eastern Texas $(1891,1932)$ (Stover and Coffman, 1993 \#1986). This level of seismicity is even less than that of sparsely seismic North and South Dakota, which together cover approximately the same area as the belt of gulf-margin faults, and had seven earthquakes of MMI VI since 1909 (Stover and Coffman, 1993 \#1986). Furthermore, some of the sparse seismicity in the normal-fault belt may be artificially induced. Earthquakes of $\mathrm{m}_{\mathrm{bLg}} 3.4$ and 3.9 in southeastern Texas and moment magnitude $\mathbf{M} 4.9$ in southwestern Alabama may have been induced by extraction of oil and gas or injection of fluids for secondary recovery (Pennington and others, 1986 \#1876; Chang and others, 1998 \#1806; Gomberg and others, 1998 \#1828; Gomberg and Wolf, 1999 \#3440). Therefore, the natural seismicity rate in the normal-fault belt might be even less than the recent historical record would indicate.

There are two reasons to suspect that the post-rift sequence and its belt of gulf-margin normal faults may be mechanically decoupled from the underlying crust. First, the stress field in the post-rift sequence and in the normal-fault belt is extensional, as determined mostly from well data that demonstrate fault slips and wellbore breakouts (Zoback and Zoback, 1991 \#2006). The orientations of $S_{\text {hmin }}$ are radial to the Gulf of Mexico, in contrast to the east-northeast trends of $\mathrm{S}_{\mathrm{Hmax}}$ that characterize most of North America east of the Rocky Mountains; the stress field in the crust beneath the thick post-rift sequence is unknown (Zoback and Zoback, 1991 \#2006). Consistent with the stress field in the post-rift sequence, the normal-faulting focal mechanism of the 1997, M 4.9 earthquake in southwestern Alabama recorded southsouthwest extension (Chang and others, 1998 \#1806). Second, the presence of the normal faults throughout the post-rift sequence from westernmost Florida to southern Texas (Ewing and Lopez, 1991 \#2032) demonstrates that the sequence is sliding and extending seaward on detachments in weak salt and overpressured shales. The salt and overpressured shales may be too ductile to transmit tectonic stresses upward from the underlying crust into the post-rift sequence. Additionally, the post-rift sequence itself is young, only partly dewatered, and poorly lithified, particularly in its Cenozoic part. The post-rift sequence lacks the elastic strength to transmit tectonic stresses as efficiently as upper crustal metamorphic and igneous rocks. In particular, the post-rift sequence may be unable to support the widespread, high 
stresses that are necessary to drive a large, seismogenic rupture. Locally, individual beds may dewater and lithify before surrounding sediments, and become able to support local stress concentrations that could cause small earthquakes. The sequence may be similarly unable to support the propagation of high stresses or seismogenic ruptures that might enter it from the underlying crust. This suggestion is consistent with the observation that low velocity, nearsurface materials, whether they are thick fault gouge or poorly lithified sediments, tend to suppress the propagation of seismic ruptures (Marone and Scholz, 1988 \#1856).

In summary, the belt of gulf-margin normal faults from Florida through Texas is assigned to class $\mathrm{B}$, because much of the fault system might be unable to generate as many significant earthquakes as the continental crust that borders it on the north.

\section{Sense of movement Normal}

Comments: There might be a few strike-slip faults that form transtensional links between normal faults.

\section{Dip $0^{\circ}-90^{\circ}$}

Comments: Dips vary, but faults are generally steeper in their upper parts and shallow downward. Dip direction is dominantly southwest, with southwest and northeast dips paired in grabens.

\section{Dip direction SW, NE}

Geomorphic expression Scarps and drainage, topographic, and tonal lineaments (DuBar and others, 1991 \#2010)

Age of faulted deposits Eocene to Holocene (Szabo and Copeland, 1988 \#1946; DuBar and others, 1991 \#2010)

\section{Paleoseismological studies None}

\section{Timing of most recent paleoevent Quaternary $(<1.6 \mathrm{Ma})$}

Comments: A belt of mostly seaward-facing normal faults borders the northern Gulf of Mexico (Ewing and Lopez, 1991 \#2032). Ewing (1991 \#1994) and Ewing and Lopez (1991 \#2032) divided the faults into an Interior Zone and a Coastal Zone, which are separated by a boundary that begins in southeastern Louisiana and runs westward across Louisiana and Texas approximately $100 \mathrm{~km}$ inland from the coast. In the Interior Zone, which includes southwestern Alabama and westernmost Florida, Quaternary slip is little documented (but see figure 3 in DuBar and others, 1991 \#2010). However, probably many or most faults in the Interior Zone have potential for Quaternary to present-day slip. As explained in "Geologic setting", it is unclear whether such slip was or is likely to occur seismically. In contrast, the Coastal Zone contains more abundant evidence for more widespread Quaternary slip, but this slip may be even less likely to occur seismically than slip in the Interior Zone.

\section{Recurrence interval Not reported}

Comments: Estimates of recurrence interval are premature because it is not yet clear whether these faults can generate significant tectonic earthquakes, as explained under "Geologic setting". 


\section{Slip-rate category unknown}

Comments: The slip rate is unknown. However, a slip rate of $0.2 \mathrm{~mm} / \mathrm{yr}$ would produce 320 $\mathrm{m}$ of slip during the 1,600,000 years of the Quaternary. It is unlikely that any single fault in the gulf-margin belt of normal faults has such a large Quaternary offset. Therefore, probably the long-term rate is less than $0.2 \mathrm{~mm} / \mathrm{yr}$.

\section{Length Not applicable}

Comments: Many faults are mapped, of widely varying lengths.

\section{Average strike $-50^{\circ}$}

Comments: Faults vary widely in strike, from approximately $-10^{\circ}$ to $-80^{\circ}$

\section{References}

\#1806 Chang, T.M., Ammon, C.J., and Herrmann, R.B., 1998, Faulting parameters of the October 24, 1997 southern Alabama earthquake [abs.]: Seismological Research Letters, v. 69, p. 175-176.

\#2010 DuBar, J.R., Ewing, T.E., Lundelius, E.L., Jr., Otvos, E.G., and Winker, C.D., 1991, Quaternary geology of the Gulf of Mexico Coastal Plain, in Morrison, R.B., ed., Quaternary nonglacial geology; conterminous U.S.: Boulder, Colorado, Geological Society of America, The Geology of North America, v. K-2, p. 583-610.

\#1959 Engdahl, E.R., compiler, 1988, Seismicity map of North America: Boulder, Colorado, Geological Society of America Continent-Scale Map 004, 4 sheets, scale 1:5,000,000.

\#1994 Ewing, T.E., 1991, Structural framework, in Salvador, A., ed., The Gulf of Mexico basin: Boulder, Colorado, Geological Society of America, The Geology of North America, v. J, p. 31-52.

\#2032 Ewing, T.E., and Lopez, R.F., 1991, Principal structural features, Gulf of Mexico basin, in Salvador, A., ed., The Gulf of Mexico basin: Boulder, Colorado, Geological Society of America, The Geology of North America, v. J, plate 2, scale 1:2,500,000.

\#3440 Gomberg, J., and Wolf, L., 1999, Possible cause for an improbable earthquake-The $1997 \mathrm{M}_{\mathrm{W}} 4.9$ southern Alabama earthquake and hydrocarbon recovery: Geology, v. 27 , p. $367-370$.

\#1828 Gomberg, J., Wolf, L., Raymond, D., Raymond, R., Barnes, A., Carver, D., Bice, T., Cranswick, E., Meremonte, M., Frankel, A., Overturf, D., Hopper, M., Rhea, S., and Eckhoff, O., 1998, A noteworthy earthquake in an unlikely place [abs.]: Seismological Research Letters, v. 69, p. 175.

\#1856 Marone, C., and Scholz, C.H., 1988, The depth of seismic faulting and the upper transition from stable to unstable slip regimes: Geophysical Research Letters, v. 15, p. 621624.

\#1876 Pennington, W.D., Davis, S.D., Carlson, S.M., DuPree, J., and Ewing, T.E., 1986, The evolution of seismic barriers and asperities caused by the depressuring of fault planes in oil and gas fields of south Texas: Bulletin of the Seismological Society of America, v. 76, p. 939-948. 
\#2019 Salvador, A., compiler, 1991, Cross sections of the Gulf of Mexico basin, in Salvador, A., ed., The Gulf of Mexico basin: Boulder, Colorado, Geological Society of America, The Geology of North America, v. J, plate 6.

\#2020 Salvador, A., compiler, 1991, Structure at the base and subcrop below Mesozoic marine section, Gulf of Mexico basin, in Salvador, A., ed., The Gulf of Mexico basin:

Boulder, Colorado, Geological Society of America, The Geology of North America, v. $\mathrm{J}$, plate 3 , scale 1:2,500,000.

\#1986 Stover, C.W., and Coffman, J.L., 1993, Seismicity of the United States, 1568-1989 (revised): U.S. Geological Survey Professional Paper 1527, 418 p.

\#1946 Szabo, M.W., and Copeland, C.W., Jr., 1988, Geologic map of Alabama, southwest sheet: Geological Survey of Alabama Special Map 220, 1 sheet, scale 1:250,000.

\#2006 Zoback, M.D., and Zoback, M.L., 1991, Tectonic stress field of North America and relative plate motions, in Slemmons, D.B., Engdahl, E.R., Zoback, M.D., and Blackwell, D.D., eds., Neotectonics of North America: Boulder, Colorado, Geological Society of America, Decade Map Volume 1, p. 339-366. 


\section{XX, Gulf-margin normal faults, Mississippi (Class B)}

\section{Structure Number 2655XX}

Structure Name Gulf-margin normal faults, Mississippi (Class B)

Comments: A belt of mostly seaward-facing normal faults borders the northern Gulf of Mexico, in westernmost Florida, southwestern Alabama, southern Mississippi, all of Louisiana and southernmost Arkansas, and eastern and southern Texas (Ewing and Lopez, 1991 \#2032). This compilation evaluates the faults in four large groups because faults number in the hundreds, and because their ability to have significant earthquakes is doubtful. To reflect regional differences in the characteristics of the faults, those in Florida and Alabama are evaluated together in a single group, as are those in Mississippi, those in Louisiana and Arkansas, and those in Texas.

Synopsis The gulf-margin normal faults are assigned to class B because they exist in sediments and poorly lithified rocks. Most of these materials may be unable to support the stresses required for the propagation of significant seismic ruptures that could cause damaging ground motions.

Date of compilation $08 / 11 / 98$; revised $01 / 28 / 00$

Compiler and affiliation Russell L. Wheeler, U.S. Geological Survey

State Mississippi

County Adams; Amite; Attala; Claiborne; Clarke; Copiah; Covington; Forrest; Franklin; George; Greene; Hancock; Harrison; Hinds; Holmes; Humphreys; Issaquena; Jackson; Jasper; Jefferson; Jefferson Davis; Jones; Lamar; Lawrence; Leake; Lincoln; Madison; Marion; Newton; Pearl River; Perry; Pike; Rankin; Scott; Sharkey; Simpson; Smith; Stone; Walthall; Warren; Washington; Wayne; Wilkinson; Yazoo

$1^{\circ} \times 2^{\circ}$ sheet Greenwood; Hattiesburg; Jackson; Meridian; Mobile; Natchez

Province Coastal Plain

\section{Reliability of location Poor}

Comments: Most of the cited maps are regional compilations at 1:2,500,000, because no individual fault has sufficient evidence of seismic slip to justify singling it out for attention at a larger map scale. Faults in areas with many well logs may be better located in the subsurface than at the surface.

Geologic setting A belt of mostly seaward-facing normal faults borders the northern Gulf of Mexico. These gulf-margin faults face southwest in westernmost Florida, southwestern Alabama, and southern Mississippi; south in Louisiana and southernmost Arkansas; and southeast in eastern and southern Texas (Ewing and Lopez, 1991 \#2032). In early to middle Mesozoic time, the opening of the Gulf of Mexico formed a south-facing, rifted, passive margin at the southern edge of North America (DuBar and others, 1991 \#2010; Salvador, 1991 \#2019; Salvador, 1991 \#2020). Subsequently, the rifted margin was buried beneath the thick, Middle Jurassic Louann Salt and an overlying, carbonate and clastic, marine and paralic sequence that continues to accumulate today. This post-rift sequence thickens seaward (Salvador, 1991 \#2020). It is at least $2 \mathrm{~km}$ thick everywhere in the belt of gulf-margin normal 
faults. At the coastline, the sequence is at least $10 \mathrm{~km}$ thick west of the Mississippi River and at least $5 \mathrm{~km}$ thick farther east. Thicknesses exceed $12 \mathrm{~km}$ in coastal Texas and southern Louisiana and perhaps $16 \mathrm{~km}$ in offshore Louisiana.

Rapid Mesozoic and Cenozoic deposition by large rivers and the resulting enormous thickness of the post-rift sediment pile caused it to collapse and spread seaward. Salt flowed southward and pierced upward, and the overlying pile extended on listric, normal, growth faults that flatten downward into detachments in the salt and in overpressured shales (Ewing, 1991; Nelson, 1991). These listric normal faults, their splays, and their antithetic and transfer faults make up the belt of gulf-margin normal faults that concern us here. The faults decrease in size and abundance inland to the landward limit of Jurassic salt, which is marked in many places by large grabens of the normal-fault belt (Ewing and Lopez, 1991 \#2032). Over the entire northern Gulf margin the belt of normal faults remains active as a whole, and particularly in its seaward parts, because the prograding fluvial deposition that loads the sediment pile and drives its seaward collapse continues (for example DuBar and others, 1991 \#2010, p. 584-585, 594; Salvador, 1991 \#2019). However, locally in central Mississippi and adjacent Alabama, the Pickens-Gilbertown fault zone at the landward limit of Jurassic salt is longer and more important structurally than the belt of younger, more numerous faults in southern Mississippi (Ewing, 1991 \#1994).

Epicenter maps show only sparse, low-magnitude seismicity within the fault belt (Engdahl, 1988 \#1959; Stover and Coffman, 1993 \#1986). The only damaging earthquakes reported through 1989 in this huge tract of land are four MMI VI earthquakes in westernmost Florida (1780), southern Louisiana (1930), and eastern Texas $(1891,1932)$ (Stover and Coffman, 1993 \#1986). This level of seismicity is even less than that of sparsely seismic North and South Dakota, which together cover approximately the same area as the belt of gulf-margin faults, and had seven earthquakes of MMI VI since 1909 (Stover and Coffman, 1993 \#1986). Furthermore, some of the sparse seismicity in the normal-fault belt may be artificially induced. Earthquakes of $\mathrm{m}_{\mathrm{bLg}} 3.4$ and 3.9 in southeastern Texas and moment magnitude $\mathbf{M} 4.9$ in southwestern Alabama may have been induced by extraction of oil and gas or injection of fluids for secondary recovery (Pennington and others, 1986 \#1876; Chang and others, 1998 \#1806; Gomberg and others, 1998 \#1828; Gomberg and Wolf, 1999 \#3440). Therefore, the natural seismicity rate in the normal-fault belt might be even less than the recent historical record would indicate.

There are two reasons to suspect that the post-rift sequence and its belt of gulf-margin normal faults may be mechanically decoupled from the underlying crust. First, the stress field in the post-rift sequence and in the normal-fault belt is extensional, as determined mostly from well data that demonstrate fault slips and wellbore breakouts (Zoback and Zoback, 1991 \#2006). The orientations of $S_{\text {hmin }}$ are radial to the Gulf of Mexico, in contrast to the east-northeast trends of $\mathrm{S}_{\mathrm{Hmax}}$ that characterize most of North America east of the Rocky Mountains; the stress field in the crust beneath the thick post-rift sequence is unknown (Zoback and Zoback, 1991 \#2006). Consistent with the stress field in the post-rift sequence, the normal-faulting focal mechanism of the 1997, M 4.9 earthquake in southwestern Alabama recorded southsouthwest extension (Chang and others, 1998 \#1806). Second, the presence of the normal faults throughout the post-rift sequence from westernmost Florida to southern Texas (Ewing and Lopez, 1991 \#2032) demonstrates that the sequence is sliding and extending seaward on 
detachments in weak salt and overpressured shales. The salt and overpressured shales may be too ductile to transmit tectonic stresses upward from the underlying crust into the post-rift sequence. Additionally, the post-rift sequence itself is young, only partly dewatered, and poorly lithified, particularly in its Cenozoic part. The post-rift sequence lacks the elastic strength to transmit tectonic stresses as efficiently as upper crustal metamorphic and igneous rocks. In particular, the post-rift sequence may be unable to support the widespread, high stresses that are necessary to drive a large, seismogenic rupture. Locally, individual beds may dewater and lithify before surrounding sediments, and become able to support local stress concentrations that could cause small earthquakes. The sequence may be similarly unable to support the propagation of high stresses or seismogenic ruptures that might enter it from the underlying crust. This suggestion is consistent with the observation that low velocity, nearsurface materials, whether they are thick fault gouge or poorly lithified sediments, tend to suppress the propagation of seismic ruptures (Marone and Scholz, 1988 \#1856).

In summary, the belt of gulf-margin normal faults from Florida through Texas is assigned to class $\mathrm{B}$, because much of the fault system might be unable to generate as many significant earthquakes as the continental crust that borders it on the north.

\section{Sense of movement Normal}

Comments: There might be a few strike-slip faults that form transtensional links between normal faults.

\section{Dip $0^{\circ}-90^{\circ}$}

Comments: Dips vary, but faults are generally steeper in their upper parts and they flatten downward. Dips are dominantly southwest, with southwest and northeast dips paired in grabens.

\section{Dip direction SW, NE}

Geomorphic expression Scarps and drainage, topographic, and tonal lineaments (DuBar and others, 1991 \#2010)

Age of faulted deposits Eocene to Holocene ? (Bicker, 1969 \#1925; DuBar and others, 1991 \#2010; Saucier and Snead, 1991 \#2021)

\section{Paleoseismological studies None}

\section{Timing of most recent paleoevent Quaternary $(<1.6 \mathrm{Ma})$}

Comments: A belt of mostly seaward-facing normal faults borders the northern Gulf of Mexico (Ewing and Lopez, 1991 \#2032). Ewing (1991 \#1994) and Ewing and Lopez (1991 \#2032) divided the faults into an Interior Zone and a Coastal Zone, which are separated by a boundary that begins in southeastern Louisiana and runs westward across Louisiana and Texas approximately $100 \mathrm{~km}$ inland from the coast. In the Interior Zone, which includes southern Mississippi, Quaternary slip is little documented (but see figure 3 in DuBar and others, 1991 \#2010). However, probably many or most faults in the Interior Zone have potential for Quaternary to present-day slip. As explained in "Geologic setting", it is unclear whether such slip was or is likely to occur seismically. In contrast, the Coastal Zone contains more abundant evidence for more widespread Quaternary slip, but this slip may be even less likely to occur seismically than slip in the Interior Zone. 


\section{Recurrence interval Not reported}

Comments: Estimates of recurrence interval are premature because it is not yet clear whether these faults can generate significant tectonic earthquakes, as explained under "Geologic setting".

\section{Slip-rate category unknown}

Comments: The slip rate is unknown. However, a slip rate of $0.2 \mathrm{~mm} / \mathrm{yr}$ would produce 320 $\mathrm{m}$ of slip during the 1,600,000 years of the Quaternary. It is unlikely that any single fault in the gulf-margin belt of normal faults has such a large Quaternary offset. Therefore, probably the long-term rate is less than $0.2 \mathrm{~mm} / \mathrm{yr}$.

\section{Length Not applicable}

Comments: Many faults are mapped, of widely varying lengths.

Average strike $-60^{\circ}$

Comments: Faults vary widely in strike, from approximately $-30^{\circ}$ to $-90^{\circ}$.

\section{References}

\#1925 Bicker, A.R., Jr., compiler, 1969, Geologic map of Mississippi: Mississippi Geological Survey, 1 sheet, scale 1:500,000.

\#1806 Chang, T.M., Ammon, C.J., and Herrmann, R.B., 1998, Faulting parameters of the October 24, 1997 southern Alabama earthquake [abs.]: Seismological Research Letters, v. 69, p. 175-176.

\#2010 DuBar, J.R., Ewing, T.E., Lundelius, E.L., Jr., Otvos, E.G., and Winker, C.D., 1991, Quaternary geology of the Gulf of Mexico Coastal Plain, in Morrison, R.B., ed., Quaternary nonglacial geology; conterminous U.S.: Boulder, Colorado, Geological Society of America, The Geology of North America, v. K-2, p. 583-610.

\#1959 Engdahl, E.R., compiler, 1988, Seismicity map of North America: Boulder, Colorado, Geological Society of America Continent-Scale Map 004, 4 sheets, scale 1:5,000,000.

\#1994 Ewing, T.E., 1991, Structural framework, in Salvador, A., ed., The Gulf of Mexico basin: Boulder, Colorado, Geological Society of America, The Geology of North America, v. J, p. 31-52.

\#2032 Ewing, T.E., and Lopez, R.F., 1991, Principal structural features, Gulf of Mexico basin, in Salvador, A., ed., The Gulf of Mexico basin: Boulder, Colorado, Geological Society of America, The Geology of North America, v. J, plate 2, scale 1:2,500,000.

\#3440 Gomberg, J., and Wolf, L., 1999, Possible cause for an improbable earthquake-The $1997 \mathrm{M}_{\mathrm{W}} 4.9$ southern Alabama earthquake and hydrocarbon recovery: Geology, v. 27, p. $367-370$.

\#1828 Gomberg, J., Wolf, L., Raymond, D., Raymond, R., Barnes, A., Carver, D., Bice, T., Cranswick, E., Meremonte, M., Frankel, A., Overturf, D., Hopper, M., Rhea, S., and Eckhoff, O., 1998, A noteworthy earthquake in an unlikely place [abs.]: Seismological Research Letters, v. 69, p. 175. 
\#1856 Marone, C., and Scholz, C.H., 1988, The depth of seismic faulting and the upper transition from stable to unstable slip regimes: Geophysical Research Letters, v. 15, p. 621624.

\#1876 Pennington, W.D., Davis, S.D., Carlson, S.M., DuPree, J., and Ewing, T.E., 1986, The evolution of seismic barriers and asperities caused by the depressuring of fault planes in oil and gas fields of south Texas: Bulletin of the Seismological Society of America, v. 76, p. 939-948.

\#2019 Salvador, A., compiler, 1991, Cross sections of the Gulf of Mexico basin, in Salvador, A., ed., The Gulf of Mexico basin: Boulder, Colorado, Geological Society of America, The Geology of North America, v. J, plate 6.

\#2020 Salvador, A., compiler, 1991, Structure at the base and subcrop below Mesozoic marine section, Gulf of Mexico basin, in Salvador, A., ed., The Gulf of Mexico basin: Boulder, Colorado, Geological Society of America, The Geology of North America, v. J, plate 3, scale 1:2,500,000.

\#2021 Saucier, R.T., and Snead, J.I., 1991, Quaternary geology of the Lower Mississippi Valley, in Morrison, R.B., ed., Quaternary nonglacial geology; conterminous U.S.: Boulder, Colorado, Geological Society of America, The Geology of North America, v. K-2, plate 6 , scale 1:1,000,000.

\#1986 Stover, C.W., and Coffman, J.L., 1993, Seismicity of the United States, 1568-1989 (revised): U.S. Geological Survey Professional Paper 1527, 418 p.

\#2006 Zoback, M.D., and Zoback, M.L., 1991, Tectonic stress field of North America and relative plate motions, in Slemmons, D.B., Engdahl, E.R., Zoback, M.D., and Blackwell, D.D., eds., Neotectonics of North America: Boulder, Colorado, Geological Society of America, Decade Map Volume 1, p. 339-366. 


\section{XX, Kentucky River fault system (Class B)}

Structure Number 2650XX

Structure Name Kentucky River fault system (Class B)

Synopsis: Kentucky River fault system is one of a series of major regional fault systems that extends east-northeasterly across Kentucky. The western members of these fault systems are the Shawneetown and Rough Creek (discussed separately as Class C faults) fault systems in southern Illinois and western Kentucky. The Kentucky River fault system crosses central and eastern Kentucky, and the Woodward fault is the eastern member of this network in western West Virginia. Information on Quaternary faulting in the fault system is based on work of Van Arsdale (1986 \#684). Although this study found evidence of Quaternary deformation in trenches across various strands of the fault system, the amount of deformation is generally small and could be related to collapse from solution of the underlying bedrock. The evidence is equivocal, and thus the feature is assigned to Class B in this compilation.

Date of compilation $03 / 17 / 94$

Compiler and affiliation Anthony J. Crone, U.S. Geological Survey

State Kentucky

County Clark; Madison

$1^{\circ} \times 2^{\circ}$ sheet Winchester

Physiographic province Interior Low Plateaus

\section{Reliability of location Good}

Geologic setting The Kentucky River fault system (KRFS) forms part of the northern boundary of the Rome trough, which is interpreted to be part of an east-trending aulacogen of late Precambrian to early Paleozoic in age. In Early Paleozoic time, the north-south-trending Cincinnati arch developed in central Kentucky. The part of the KRFS studied by Van Arsdale (1986 \#684) lies on the eastern flank of the arch. Throughout their history, faults in the system have had senses of slip that included sinistral, dextral, normal, and reverse slip. The net throw on the faults is down-to-the-south, and cumulative displacement of Precambrian rocks in Van Arsdale's study area is approximately 463 m (cited by Van Arsdale).

\section{Sense of movement Reverse}

Comments: Van Arsdale (1986 \#684) documents folding and faulting in trenches at several sites, all of which indicate compressional deformation in Quaternary deposits. In contrast, these faults are mapped as normal faults on the state geologic map McDowell and others (1981 \#693).

Dip $25^{\circ}-80^{\circ}$

Comments: Dips reported in the trenches range between $25^{\circ}-80^{\circ}$

Dip direction SW, NE

Geomorphic expression none 
Age of faulted deposits Quaternary terrace deposits of the Kentucky River. Age of deposits is uncertain but is believed to be Pliocene-Pleistocene.

Paleoseismological studies Van Arsdale (1986 \#684) describes detailed studies at four sites along the fault system. These detailed study sites were identified following reconnaissance work that consisted of electrical-resistivity surveys and drilling a series of auger holes across the projected traces of faults at 25 sites.

At one site, no deformation was documented in Quaternary deposits.

At the second site, Van Arsdale excavated five trenches across these faults and found faulted Quaternary deposits in two of the trenches. Faulted Quaternary deposits in one trench have a maximum stratigraphic separation of $0.7 \mathrm{~m}$ across a reverse fault that dips $70^{\circ}$ to the northeast, and in another trench, two N. $40^{\circ}$ W.-trending faults formed a small graben.

At a third site, Van Arsdale (1986 \#684) describes evidence of folding that post-dates deposition of Kentucky River terrace deposits; these deposits may have as much as $1.1 \mathrm{~m}$ of stratigraphic separation. He cites three possible explanations for the folding including solution collapse. On the basis of one radiocarbon date, he concludes that the deformation occurred within the past 350 years.

At the fourth site, he did not find evidence of faulting or deformation in Quaternary deposits. Van Arsdale (1986 \#684) argues that solution collapse is not likely to be responsible for the features found in the trenches. However the characteristics of the deformation are not inconsistent with minor subsidence related to the development of solution-collapse features in carbonate rocks. The existing evidence of a tectonic origin for these features is equivocal, and therefore they are classified as Class B features.

Timing of most recent paleoevent Quaternary $(<1.6 \mathrm{Ma})$

Comments: The age of faulted Quaternary deposits is poorly known. At Van Arsdale's second site (1986 \#684), he indicates that the faulted deposits are estimated to be pre-Illinoian (730,000-900,000) based on the weathering profile formed in the deposits.

Recurrence interval Not reported

Slip-rate category unknown; probably $<0.2 \mathrm{~mm} / \mathrm{yr}$.

Comments: The greatest vertical displacement of Quaternary deposits reported by Van Arsdale (1986 \#684) is $0.7 \mathrm{~m}$ at the second site. At the third site, Quaternary deposits, conservatively estimated to be $500,000 \mathrm{yr}$ old, may have as much as $1.1 \mathrm{~m}$ of stratigraphic separation. On the basis of this information, the lowest slip-rate category is suggested for the KRFS.

\section{Length $(\mathrm{km})$ Not applicable}

Comments: The Kentucky River fault system is known and defined from faulted Paleozoic strata and is not expressed in Quaternary deposits. The studies cited above that suggest possible Quaternary deformation were conducted as several localized sites. On the basis of these studies, it is not clear if faulting at one site would necessarily be connected to another site, so it is not valid to infer any length value for a possible Quaternary rupture. 
Average strike (azimuth) $+71^{\circ}$

Comments: This azimuth value is the general strike of the fault zone as expressed in Paleozoic rocks, but because evidence of possible Quaternary deformation is limited and is only known from a few specific locations, it is not possible to determine an azimuth for features that might possibly be related to Quaternary deformation.

\section{References}

\#693 McDowell, R.C., Grabowski, G.J., Jr., and Moore, S.L., 1981, Geologic map of Kentucky: U.S. Geological Survey in cooperation with The Eleventh Kentucky Geological Survey, 4 sheets, scale 1:250,000.

\#684 Van Arsdale, R.B., 1986, Quaternary displacement on faults within the Kentucky River fault system of east-central Kentucky: Geological Society of America Bulletin, v. 97, p. 1382-1392. 


\section{XX, Monroe Uplift (Class B)}

Structure Number $1025 \mathrm{XX}$

Structure Name Monroe uplift (Class B)

Comments: The Monroe uplift is a subsurface structure that is defined largely on the basis of unconformities and stratigraphic pinch-outs of Jurassic through Upper Cretaceous rocks (Ewing, 1991 \#1994). The uplift has been also referred to as the Ouachita uplift and the Sharkey platform; it has also been included as part of the Sabine uplift by some authors (Johnson, 1958 \#2816).

Synopsis: This feature is classified as a Class B feature because the results of a study described by Burnett and Schumm (1983 \#2815) and Schumm (1986 \#2817), which suggests the possibility of Quaternary deformation, but the available evidence is not compelling. The evidence of possible Quaternary uplift is based on an analysis of the fluvial geomorphology of rivers and streams that cross the Monroe uplift. Burnett and Schumm (1983 \#2815) also briefly describe corroborative evidence of uplift from repeat geodetic surveys. Furthermore, if Quaternary deformation is occurring, it is not clear if the deformation is truly tectonic in origin or if it could be related to non-tectonic processes such as salt tectonics or differential subsidence.

\section{Date of compilation $04 / 16 / 98$}

Compiler and affiliation Anthony J. Crone, U.S. Geological Survey

State Louisiana, Arkansas, Mississippi

County: Morehouse, Madison, East Carroll, West Carroll, Richland, Franklin, Ouachita (Louisiana); Ashley, Chicot (Arkansas); Issaquena, Sharkey, Warren, Washington, Yazoo (Mississippi)

$1^{\circ} \times 2^{\circ}$ sheet Greenwood, Jackson, Shreveport

Physiographic province Coastal Plain

\section{Reliability of location Poor}

Comments: The feature's location is poorly known because it is largely defined on the basis of drill-hole data; it does not have any prominent surficial expression. Furthermore, the limits of the uplift vary depending on the stratigraphic truncation that is used to define its boundary. If the uplift is defined on the truncation of the Annona chalk (Cretaceous age), then it is approximately 80 miles $(129 \mathrm{~km})$ in diameter; this is the generally accepted limit of the uplift according to Johnson (1958 \#2816).

Geologic setting The Monroe uplift is a small feature centered in extreme northeastern Louisiana and is defined on the basis of subsurface data. It is a second-order structural feature (Ewing, 1991 \#1994) located along the northern flank of the Gulf of Mexico basin. The uplift is a complex structural dome that blends into the regional structure to the north and northwest (Johnson, 1958 \#2816). It is bounded by the North Louisiana salt basin and the Mississippi salt basin on the southwest and southeast, respectively (Ewing, 1991 \#1994). The uplift is associated with Late Cretaceous igneous activity. The Monroe uplift developed as a 
discrete structural feature in Late Cretaceous time when uplift resulted in as much as $3 \mathrm{~km}$ of strata being eroded from the top of the feature. Uplift ended in latest Cretaceous time, and the feature was buried by Paleocene and younger sediments.

\section{Sense of movement Not reported}

Comments: No movement on specific faults is reported. The geomorphic evidence reported by Burnett and Schumm (1983 \#2815) and Schumm (1986 \#2817) infers vertical uplift of the feature; there is no evidence of movement on specific faults.

\section{Dip Not reported}

\section{Dip direction Not reported}

Geomorphic expression The Monroe uplift does not have any conspicuous geomorphic expression, but the evidence used to infer Quaternary movement is derived from analysis of the area's fluvial geomorphology. The uplift is located in the floodplains of the Ouachita, Mississippi, and Yazoo Rivers (Johnson, 1958 \#2816). The evidence of Quaternary uplift reported by Burnett and Schumm (1983 \#2815) and Schumm (1986 \#2817) includes longitudinal valley profiles and changes in channel morphology of five rivers across the uplift. Longitudinal profiles of Pleistocene and Holocene terraces along these drainages show pronounced convexities that are indicative of deformation (Schumm, 1986 \#2817). Changes in the sinuosity, gradient, depth, and channel erosion and deposition of the rivers across the uplift are also interpreted as evidence of fluvial responses to uplift. Schumm (1986 \#2817) notes that the Mississippi River has a highly irregular thalweg profile through the uplift and that the gradient of the thalweg slope is reduced and even reversed in part of the uplift.

Burnett and Schumm (1983 \#2815) and Schumm (1986 \#2817) suggest that modern uplift may be responsible for these changes in the river's fluvial geomorphology and that the uplift is currently occurring because these geomorphic changes are affecting the modern river channels.

As further support for their contention of modern uplift, they report that repeat geodetic surveys across the Monroe and the nearby Wiggins uplift indicate uplift rates of about $5 \mathrm{~mm} / \mathrm{yr}$. Other than simply noting these rates, they do not provide any detailed description or cite any references concerning the geodetic data.

Age of faulted deposits Holocene. See comments in "Timing of most recent paleoevent" section.

Paleoseismological studies Information indicative of possible neotectonic uplift of the Monroe uplift is from a study described by Burnett and Schumm (1983 \#2815) and Schumm (1986 \#2817). This study analyzed the channel morphology and longitudinal profiles of several major drainages that cross the uplift. They report that recent uplift has reduced the slope of stream valleys across the Monroe uplift, and as a result, sinuosity of the streams has been reduced and an anastamosing drainage pattern has developed. They also report that repeat geodetic surveys suggest an uplift rate of about $5 \mathrm{~mm} / \mathrm{yr}$ on the Monroe uplift. See the "Slip Rate" section of this discussion for further details. No additional studies have been conducted to confirm the conclusions of the geodetic or geomorphic investigations. Without additional confirmation, the Monroe uplift is considered to be a Class B feature because it is located in a 
region of minimal historical seismicity and because the inferred deformation rates are anomalous for the geologic setting of the Gulf Coastal plain.

Timing of most recent paleoevent latest Quaternary $(<15 \mathrm{ka})$

Comments: Deposits associated with the uplift are not faulted, but Burnett and Schumm (1983 \#2815) and Schumm (1986 \#2817) note that the modern river channels are responding to the deformation, which is indicative of contemporary deformation. Thus, the most recent deformation is Holocene in age.

\section{Recurrence interval Not reported}

Comments: The geomorphic evidence of Quaternary uplift implies that the deformation is a steady, on-going process. It is not clear that the deformation is episodic or coseismic, so it is impossible to quantify the deformation in terms of recurrence intervals.

\section{Slip-rate category $<0.2 \mathrm{~mm} / \mathrm{yr}$}

Comments: The inferred "slip rate" of this feature is not a "slip rate" in the conventional sense; it is really a an inferred uplift rate of the entire feature.

Burnett and Schumm (1983 \#2815) cite that geodetic data that suggest an uplift rate of about $5 \mathrm{~mm} / \mathrm{yr}$, and Schumm (1986 \#2817) estimates uplift rates of 0.01-1.4 mm/yr based on the amount of deformation that has affected terraces of various ages. A profile of Macon Ridge, the oldest, highest terrace described by Schumm (1986 \#2817), has been affected by about 3.8 $\mathrm{m}$ of deformation. This terrace has an estimated age of about $33 \mathrm{ka}$, which indicates a low late Pleistocene uplift rate. If the amount of deformation and age of the terrace given by Schumm (1986 \#2817) are correct, then the calculated uplift rate is an order of magnitude lower than the $1.0 \mathrm{~mm} / \mathrm{yr}$ rate given by Schumm (1986 \#2817). The slip-rate category cited favors a low geologic rate, in contrast to the high geodetic rate (see following discussion).

The $5 \mathrm{~mm} / \mathrm{yr}$ geodetic uplift rate is exceedingly high and is incompatible with the geologic and broad tectonic setting of the Gulf Coast province. If this rate were sustained for a geologically significant period of time, then the geomorphic and geologic expression of the uplift would be far more pronounced than it is at present. Thus, this geodetic rate is suspect in terms of it accurately reflecting a long-term uplift rate.

The geologic rates of 0.01-1.4 mm/yr reported by Schumm (1986 \#2817) are more consistent with the regional geologic setting, but it is not clear if this uplift occurs seismically or aseismically. Based of the sparse historical earthquakes in the region, aseismic deformation seems more likely. Furthermore, it is not clear if the uplift reflects long-term tectonic processes that produce tectonic strain that could be released by damaging earthquakes. Until some of these fundamental questions about the nature of the deformation are answered, the Monroe uplift is classified as a Class B feature.

Length $(\mathrm{km})$ Not applicable

Comment: The Monroe uplift is a structural feature defined on the basis of subsurface data. It has an areal extent, and is not a linear feature therefore, determining its length is inappropriate. 
Average strike (azimuth) Not applicable

Comment: It is inappropriate to determine a average strike for this feature for the same reasons cited in the comments on the length determination.

\section{References}

\#2815 Burnett, A.W., and Schumm, S.A., 1983, Alluvial-river response to neotectonic deformation in Louisiana and Mississippi: Science, v. 222, p. 49-50.

\#1994 Ewing, T.E., 1991, Structural framework, in Salvador, A., ed., The Gulf of Mexico basin: Boulder, Colorado, Geological Society of America, The Geology of North America, v. J, p. 31-52.

\#2816 Johnson, O.H., Jr., 1958, The Monroe uplift: Transactions of the Gulf Coast Association of Geological Societies, v. 8, p. 24-32.

\#2817 Schumm, S.A., 1986, Alluvial river response to active tectonics, in Active tectonics:

Washington, D. C., National Academy Press, p. 80-94. 


\section{XX, Pembroke faults (Class B)}

\section{Structure Number 2652XX}

Structure Name Pembroke faults (Class B)

Comments: Five faults in terrace deposits of probable Quaternary age were reported but not named by Bollinger and others (1992 \#1800) and Law and others (1992 \#1850). Mills (1994 \#1864) referred to the faults collectively as "the Pembroke fault". The faulted locality is along the north side of the New River Valley, between Pembroke and Pearisburg, Virginia, approximately $1 \mathrm{~km}$ west of Pembroke.

Synopsis: Probable Quaternary faults overlie a steeply dipping, tabular zone of hypocenters. However, it has not yet been determined whether the faults are tectonic or the result of solution collapse.

Date of compilation 05/26/98; revised 01/28/00

Compiler and affiliation Russell L. Wheeler, U.S. Geological Survey

State Virginia

County Giles

$1^{\circ} \times 2^{\circ}$ sheet Bluefield

Physiographic province Valley and Ridge

\section{Reliability of location Good}

Comments: The faulted locality is shown on a 1:24,000 topographic base in Figure 25 of Dennison and Stewart (1998 \#2029).

The faults are in terrace deposits of the New River, which flows northwestward across the Valley and Ridge province. The New River crosses the Giles County seismic zone at Pearisburg and Pembroke. The terrace deposits are underlain by N. $60^{\circ}$ E.-trending, folded and thrust faulted, Ordovician carbonate rocks of the southern Appalachian Valley and Ridge province (McDowell and Schultz, 1990 \#1974; Virginia Division of Mineral Resources, 1993 \#1952). The terrace deposits are arched into a broad anticline, approximately $100 \mathrm{~m}$ wide, that trends N. $64^{\circ}$ E. and has limb dips up to $30^{\circ}$ (Law and others, 1993 \#1851; 1998 \#2045).

Hundreds of small extensional faults cut the terrace strata with individual dip separations that typically are less than $30 \mathrm{~cm}$ (Law and others, 1997 \#1852; 1998 \#2045). In addition, reverse faults on both limbs of the anticline dip inward under its crest with slips of several decimeters (Law and others, 1994 \#2044). In contrast to the small extensional and reverse faults, five extensional faults have dip separations measured in meters, as described in "Sense of movement" below.

Law and others (1992 \#1850; 1993 \#1851; 1994 \#2044; 1997 \#1852; 1998 \#2045) excavated new benches and trenches across the Pembroke faults and the anticline, and reported analyses and descriptions of the structures. Results of seismic refraction, electrical, gravity, and magnetometer surveys allowed the fault system that is exposed in an embankment to be traced southwestward at least $100 \mathrm{~m}$ from its exposure, into a hay field (Law and others, 1994 \#2044; Robinson and others, 1994 \#1887; Law and others, 1998 \#2045; Peavy and Sayer, 
1998 \#1878). Law and others (1992 \#1850; 1994 \#2044; 1997 \#1852; 1998 \#2045) suggested that the faults might be tectonic, but alternatively that they might have formed above solution collapses or slumps. Seismic reflection and ground-penetrating radar results indicate that the anticline and extensional faults might both be caused by stratal drape over an underlying reverse fault (Williams and Callis, 1996 \#1917; Callis and Williams, 1997 \#1805). Law and others (1997 \#1852) interpreted all the data together in terms of the exposed graben system being nested in the center of a larger, subsurface graben.

Sense of movement normal dextral and normal sinistral

Comments: The five largest extensional faults have dip separations of 1.0 to at least $8.5 \mathrm{~m}$ (Law and others, 1993 \#1851; 1998 \#2045). The five faults bound two grabens and one half graben in or near the hinge of the anticline, strike N. $46^{\circ}-80^{\circ}$ E., dip $46^{\circ}-70^{\circ} \mathrm{NW}$ and SE, and have slickenlines that plunge $37^{\circ}-70^{\circ}$ west to southwest, thereby indicating normal slip that slightly exceeds dextral and sinistral strike slip (Law and others, 1992 \#1850; 1993 \#1851; 1994 \#2044; 1997 \#1852; 1998 \#2045).

\section{Dip $54^{\circ}-72^{\circ}$}

Comments: The five extensional faults bound two grabens and a half graben, as described in "Sense of movement" above.

\section{Dip direction NW and SE}

Geomorphic expression The faults near Pembroke have no geomorphic expression, having been discovered in an embankment produced by excavations for landfill material (Bollinger and others, 1992 \#1800; Law and others, $1992 \# 1850 ; 1998$ \#2045). On a more regional scale, Mills (1986 \#1863; 1994 \#1864) and Mills and Bartholomew (1986 \#1865) examined elevations of stream terraces for several tens of kilometers along the New River, within and upstream and downstream of the Giles County seismic zone and the Pearisburg-Pembroke area. Mills (1986 \#1863) noted that terraces downstream (northwest) of the seismic zone were higher above modern river level than those upstream (southeast) of the zone. He noted that the location and sense of the change in terrace elevation was what would be expected from seismic slip in the seismic zone. However, later Mills and Bartholomew (1986 \#1865) and Mills (1994 \#1864) found evidence of a prehistoric course change in the New River, which could also explain the change in terrace elevation without recourse to earthquakes. Nonetheless, Granger and others (1997 \#2199) used a novel application of ${ }^{26} \mathrm{Al} /{ }^{10} \mathrm{Be}$ dating to estimate rates of New River downcutting on both sides of the Giles County seismic zone. Granger and others (1997 \#2199) suggested faster downcutting downstream (northwest) of the seismic zone, consistent with the observation of Mills (1986 \#1863).

Age of faulted deposits Early Quaternary to latest Pliocene (1.5 \pm 0.4 to $2.0 \pm 0.4 \mathrm{Ma}$ : 26A1/10Be burial ages of D. Granger, reported by Law and others, 1997 \#1852; 1998 \#2045).

Paleoseismological studies No paleoseismological studies have been reported of the anticline and faults in the terrace deposits near Pembroke. More regionally, in 1981 Mills (1985 \#1981) found no evidence of seismic shaking, faulting, or surface rupture along the New River in two trenches in the Giles County seismic zone and 18 trenches near the zone. 


\section{Timing of most recent paleoevent Not reported}

Comments: Folding and faulting followed deposition of the terrace deposits near Pembroke. The deposits could be as old as latest Pliocene (see "Age of faulted deposits" above), so probably the deformation is Quaternary in age.

\section{Recurrence interval Not reported}

Comments: The ages of the faults are constrained only by the age of the terrace deposits, and no information indicates the relative ages of the individual faults. If the folding and faulting were contemporaneous (Law and others, 1997 \#1852), then all the faults might be of similar ages. More fundamentally, until it can be determined whether the faults are tectonic or surficial, any question about earthquake recurrence is premature.

\section{Slip-rate category unknown}

Comments: The largest slip calculated for any of the faults is $11.4 \mathrm{~m}$ of normal dextral slip; the other calculated slips are 1.1-11.1 m (Law and others, 1993 \#1851; 1998 \#2045). The 11.4 $\mathrm{m}$ has accumulated during the duration of the faulting, which is constrained only by the 1.12.4 Ma age of the faulted terrace deposits. These values yield a possible average slip rate much less than $0.2 \mathrm{~mm} / \mathrm{yr}$. The rate could be greater if the faults are considerably younger than the terrace deposits, but in order for the rate to equal $0.2 \mathrm{~mm} / \mathrm{yr}$ all the faulting would have to date from the last twentieth or less of the history of the faulted terrace deposits. This is possible but unlikely. More fundamentally, no such slip rates are meaningful until it can be demonstrated whether the exposed faults are of tectonic or surficial origin.

\section{Length Not applicable}

Comments: The faults strike into the side of an excavation, so their lengths are unknown. However, their small slips indicate that they may be only a few meters to a few hundreds of meters long.

\section{Average strike $+64^{\circ}$}

Comments: The numerous small faults strike approximately parallel to the trend of an anticline whose limbs and crest they cut. The anticline trends $+64^{\circ}$. Five larger extensional faults have dip separations of 1.0 to $8.5 \mathrm{~m}$ or more, and they strike $+46^{\circ}$ to $+80^{\circ}$.

\section{References}

\#1800 Bollinger, G.A., Law, R.D., Pope, M.C., Wirgart, R.H., and Whitmarsh, R.S., 1992, Geologically recent near-surface faulting in the Valley and Ridge province-New exposures of extensional faults in alluvial deposits, Giles County, SW Virginia: Geological Society of America Abstracts with Programs, v. 24, no. 1, p. A152.

\#1802 Bollinger, G.A., and Wheeler, R.L., 1980, The Giles County, Virginia, seismogenic zone: Geological Society of America Abstracts with Programs, v. 12, no. 7, p. 389.

\#1803 Bollinger, G.A., and Wheeler, R.L., 1983, The Giles County, Virginia, seismic zone: Science, v. 219, p. 1063-1065.

\#1968 Bollinger, G.A., and Wheeler, R.L., 1988, The Giles County, Virginia, seismic zoneSeismological results and geologic interpretations: U.S. Geological Survey Professional Paper 1355, 85 p. 
\#1805 Callis, J.G., and Williams, R.T., 1997, Geophysical images and geologic models for Quaternary faults near Pembroke, Virginia, using seismic reflection and ground penetrating radar [abs.]: Seismological Research Letters, v. 68, p. 815.

\#2029 Dennison, J.M., and Stewart, K.G., eds., 1998, Geologic field guide to extensional structures along the Allegheny Front in Virginia and West Virginia near the Giles County seismic zone: Southeastern Section, Geological Society of America, Charleston, West Virginia, March 28-29, 1998, Guidebook, 102 p.

\#2199 Granger, D.E., Kirchner, J.W., and Finkel, R.C., 1997, Quaternary downcutting rate of the New River, Virginia, measured from differential decay of cosmogenic ${ }^{26} \mathrm{Al}$ and ${ }^{10} \mathrm{Be}$ in cave-deposited alluvium: Geology, no. 25, p. 107-110.

\#2042 Johnston, A.C., 1994, Appendix C-Summary tables, SCR seismicity data base, in Schneider, J.F., ed., The earthquakes of stable continental regions - v. 2-Appendices A to E: Technical report to Electric Power Research Institute TR-102261-V2, Palo Alto, California, December 1994, p. C-1—C-46.

\#1850 Law, R.D., Pope, M.C., Wirgart, R.H., Bollinger, G.A., and Whitmarsh, R.S., 1992, Geologically recent near-surface folding and faulting in the Valley and Ridge provinceNew exposures of extensional faults in alluvial sediments, Giles County, SW Virgina [abs.]: Seismological Research Letters, v. 63, p. 609-610.

\#1851 Law, R.D., Pope, M.C., Wirgart, R.H., Eriksson, K.A., Carpenter, D., Robinson, E.S., and Bollinger, G.A., 1993, Geologically recent near-surface folding and faulting in the Valley and Ridge province-New exposures of extensional faults in alluvial sediments, Giles County, SW Virginia [abs.]: Eos, Transactions of the American Geophysical Union, v. 74, p. 282.

\#2044 Law, R.D., Pope, M.C., Wirgart, R.H., Eriksson, K.A., Robinson, E.S., Sayer, S., Phinney, E.J., and Bollinger, G.A., 1994, Geologically recent near-surface folding and faulting in Giles County, southwest Virginia-New exposures of extensional and apparent reverse faults in alluvial sediments between Pembroke and Pearisburg, in Proceedings of the U.S. Nuclear Regulatory Commission, Twenty-First Water Reactor Safety Information Meeting: U.S. Nuclear Regulatory Commission Report NUREG/CP-0133, v. 3, p. 415-432.

\#1852 Law, R.D., Robinson, E.S., Cyrnak, J.S., Sayer, S., Williams, R.T., Callis, J., and Pope, M., 1997, Geologically-recent faulting and folding of alluvial sediments near Pearisburg, Giles County, Virginia-Tectonic faulting or karst subsidence in origin? [abs.]: Eos, Transactions of the American Geophysical Union, v. 78, no. 17 (supplement), p. S316.

\#2045 Law, R.D., Robinson, E.S., Sayer, S., Cyrnak, J.S., Williams, R.T., Callis, J., and Pope, M., 1998, Geologically-recent faulting and folding of alluvial sediments near Pearisburg, Giles County, Virginia-Tectonic faulting or karst subsidence in origin?, in Dennison, J.M., and Stewart, K.G., eds., Geologic field guide to extensional structures along the Allegheny Front in Virginia and West Virginia near the Giles County seismic zone: Southeastern Section, Geological Society of America, Charleston, West Virginia, March 28-29, 1998, Guidebook, p. 95-101. 
\#1974 McDowell, R.C., and Schultz, A.P., 1990, Structural and stratigraphic framework of the Giles County area, a part of the Appalachian Basin of Virginia and West Virginia, in Evolution of sedimentary basins-Appalachian Basin: U.S. Geological Survey Bulletin 1839, p. E1-E24, 1 pl., scale 1:125,000.

\#1981 Mills, H.H., 1985, Descriptions of backhoe trenches dug on New River terraces between Radford and Pearisburg, Virginia, June, 1981: U.S. Geological Survey Open-File Report $85-474,63 \mathrm{p}$.

\#1863 Mills, H.H., 1986, Possible differential uplift of New River terraces in southwestern Virginia: Neotectonics, v. 1, p. 75-86.

\#1864 Mills, H.H., 1994, Distribution of high-level gravels along the course of the New River in southwestern Virginia-Implications for neotectonics: Geological Society of America Abstracts with Programs, v. 26, no. 4, p. 56.

\#1865 Mills, H.H., and Bartholomew, M.J., 1986, Evolution of the course of the New River in southwest Virginia - Some interpretations based on distribution of high-level gravels in Giles, Montgomery, Pulaski, and Floyd Counties: Geological Society of America Abstracts with Programs, v. 18, no. 3, p. 255.

\#1878 Peavy, S.T., and Sayer, S., 1998, Analysis of a possible neotectonic feature in SW Virginia using potential field attributes (PFA): Geological Society of America Abstracts with Programs, v. 30, no. 1, p. 66.

\#1887 Robinson, E.S., Sayer, S., Phinney, E.J., and Law, R.D., 1994, A geophysical survey of faulted alluvial 'terrace' deposits near Pembroke, Virginia: Geological Society of America Abstracts with Programs, v. 26, no. 4, p. 59-60.

\#1952 Virginia Division of Mineral Resources, 1993, Geologic map of Virginia: Virginia Division of Mineral Resources, 1 sheet, scale 1:500,000.

\#1917 Williams, R.T., and Callis, J.G., 1996, Collocated seismic reflection and radar profiles over Quaternary normal faults in southwestern Virginia [abs.]: Eos, Transactions of the American Geophysical Union, v. 77, no. 46 (supplement), p. F497-F498. 


\section{XX, Saline River fault zone (Class B)}

\section{Structure Number 1026XX}

Comments:

Structure Name Saline River fault zone (Class B)

Comments: Cox and Van Arsdale (1997 \#2805) and Cox and others (1998 \#2806) have conducted field studies of small-displacement faults near Monticello, Arkansas and related them to a zone of diffuse seismicity along the Saline River lineament. They informally name the faults the "Saline River fault zone" (Cox and Van Arsdale, 1997 \#2805).

Synopsis Cox and Van Arsdale describe a northwesterly trending alignment of earthquake epicenters that follow the Saline River in central and southeastern Arkansas and is colinear with the northeastern margin of the Monroe uplift. Geomorphic evidence has been used to suggest that the Monroe uplift is the site of late Quaternary deformation (see feature 1025, Monroe uplift in this compilation). The epicenter alignment is cited as evidence that active structures exist in the area of the Saline River lineament. In their search for surficial expression of these active structures, Cox and Van Arsdale describe several small-displacement faults having various strikes that are exposed in several road cuts along a 2.2-km-long section of U.S. Highway 425, south of Monticello, Arkansas. The faults and minor deformation exposed in these road cuts and in nearby trenches that they excavated are small-scale features; the relationship of these features to deeper structures and to the diffuse regional seismicity are not well determined and therefore, these features (collectively named the Saline River fault zone by Cox and Van Arsdale) are classified as Class B features. This classification is further justified because no compelling evidence indicates that the faults visible at the surface are related to a significant seismogenic source that might generate damaging earthquakes.

Date of compilation $09 / 30 / 98$

Compiler and affiliation Anthony J. Crone, U.S. Geological Survey

State Arkansas

County Drew

$1^{\circ} \times 2^{\circ}$ sheet Greenwood, Mississippi \& Arkansas

Physiographic province Coastal Plain

\section{Reliability of location Poor}

Comments: The individual features investigated by Cox and Van Arsdale are relatively well located on the basis of their descriptions of their field study sites. However, if a Saline River fault zone exists, it is not mapped in any published source. Furthermore, Cox and Van Arsdale indicate that they name the feature in the reports cited here.

Geologic setting The faults described in the studies cited here are located in the southern part of the Mississippi embayment in the transition zone of structural styles between the broad downwarp of the embayment to the north and the Gulf of Mexico to the south. In late Precambrian and Early Paleozoic time, this area was located on the rifted margin of North America that flanked the Iapetus Ocean (Thomas, 1989 \#2808; Thomas, 1991 \#678). Later in Paleozoic time, compressional tectonics in the Ouachita orogen resulted in the transport of 
large thrust sheets over the margin of the craton. Starting in Late Triassic to Middle Jurassic time, break-up of the supercontinent Pangea resulted in the initial opening of the Gulf of Mexico. The opening continued through the late Jurassic, and from that time to the present, the northern Gulf of Mexico has been the depocenter for a thick section of primarily terrigenous clastic sediments derived from the North American craton (Salvador, 1991 \#2807).

During the Mesozoic and Cenozoic, the northern Gulf of Mexico and southern margin of the North American craton has been characterized by modest to minor deformation, which is expressed mainly in the form of broad downwarps (for example, the Mississippi embayment) and gentle uplifts (for example, the Monroe uplift). The New Madrid seismic zone, located $300-400 \mathrm{~km}$ to the northeast, is the most seismically active region in the central and eastern United States. However, in the vicinity of the study area, only 12 known earthquakes (maximum magnitude of about 4.3) have occurred historically (Cox and Van Arsdale, 1997 \#2805).

Sense of movement Normal, reverse, and inferred dextral or sinistral

Comments: In the road cuts and the adjacent trenches, Cox and Van Arsdale (1997 \#2805) identified small-displacement faults having all three styles of apparent or inferred senses of movement. Faults have orientations that range from $069^{\circ}$ for a southerly dipping reverse fault, to $305^{\circ}$ for a northerly dipping normal fault.

Dip $34^{\circ}-70^{\circ}$

Comments: Attitude and orientation of faults in the various road cuts and trenches are variable. Dips range from a low value of $34^{\circ} \mathrm{S}$ on a fault interpreted to be dominantly a lateral slip fault, to $70^{\circ}$ for a reverse fault.

\section{Dip direction N, S}

Comments: Similar to the style of displacement and dip amounts, the dip directions are variable. Reverse faults dip both to the north and to the south; one normal fault in a road cut dips to the north, whereas two normal faults recognized in a shallow seismic-reflection profile dip to the south.

Geomorphic expression No significant geomorphic expression of faults; the features were only exposed in road cuts along U.S. Highway 425 and in nearby trenches. All features have small displacements, in most cases less than $0.5 \mathrm{~m}$. In the absence of the road cuts, these features would not have been identified on the basis of any surficial expression.

Age of faulted deposits Range in age from Eocene (Jackson Formation), Pliocene (Lafayette Gravel) through latest Pleistocene deposits that are thought to be Peoria Loess and Loveland Loess.

Paleoseismological studies The most detailed information concerning these features is reported by Cox and Van Arsdale (1997 \#2805), who have made the only detailed examination of these features. The results of this study have been abstracted into the publication by Cox and others (1998 \#2806).

Cox and Van Arsdale (1997 \#2805) examined faults and deformation at six different sites along a 2.2-km-long, north-south-transect following the route of U.S. Highway 425, south of the town of Monticello, Arkansas. They examined road cuts along the highway and, where they found evidence of deformation, they excavated trenches short distances from the highway 
along the projected strike of features exposed in the roadcuts. They mapped the trench exposures in detail and dated a surficial silt deposit using thermoluminescence. In addition, they collected data along a 210-m-long shallow shear-wave seismic-reflection profile that traversed the feature that they interpret as the principal fault and a secondary fault.

In some road cuts and trenches, they found no faulting, only stratigraphic relations and contacts that suggest possible warping and minor deformation. In other road cuts or trenches, they found faults that had throws on the order of $0.5 \mathrm{~m}$ or more. In general, the scale and extent of deformation seems to be minor to modest and localized. They do interpret a group of three faults at one of the medial sites in their transect as being the principal fault zone of the Saline River fault zone. The single trace that they identify as the principal fault strikes $159^{\circ}$, dips $34^{\circ} \mathrm{S}$ and has a 20 - to $40-\mathrm{cm}$-wide breccia zone in the Jackson Formation. They also interpret moderate to steep dips in the adjacent Jackson Formation and Lafayette gravel as drag folding that is evidence of left transpression.

The reflection-profile line revealed two south-dipping normal faults that offset the base of the Jackson Formation a total of about $20 \mathrm{~m}$. The total offset of reflectors appears to decrease in stratigraphically younger units, which suggests to them that these faults were active as downto-the-basin normal faults during Eocene subsidence of the Gulf of Mexico margin. The two faults defined by the seismic-reflection data project upward to the traces of the faults exposed in nearby trenches.

Cox and Van Arsdale (1997 \#2805) collectively interpret these various orientations, attitudes, and senses of motion to represent a main fault and secondary faults associated with a northwest-southeast-trending primary fault that they infer is related to the $135^{\circ}$-trending Saline River seismicity alignment. They speculate that the Eocene-age normal faults have been reactivated as transpressional faults in the contemporary ENE-WSW compressional stress field. They propose two deformation events that postdate deposition of the late Wisconsin Peoria Loess, and note that even though the cumulative vertical offset from these events is less than 1 $\mathrm{m}$, the amount of lateral slip is unknown. Furthermore, they indicate that the features they studied are oblique to the Saline River fault zone, and therefore could be only part of a discontinuous, en echelon, strike-slip array. Lastly, they caution that the Saline River fault zone may be only one of an unknown number of concealed faults that might pose a seismic hazard to the region.

\section{Timing of most recent paleoevent latest Quaternary $(<15 \mathrm{ka})$}

Comments: Based on stratigraphic evidence, Cox and Van Arsdale (1997 \#2805) propose two deformation events younger than deposition of the Peoria Loess, but the evidence of these events is not compelling and the cumulative vertical offset is small $(<1 \mathrm{~m})$. Without strong corroboration or confirmation of these proposed paleoseismic histories by additional studies, these events must be considered with caution because of the major implications that they have on seismic hazard assessments.

\section{Recurrence interval Not reported.}

Comments: Recurrence intervals are not reported because of lack of age control and information about specific faulting events. 


\section{Slip-rate category Unknown}

Comments: Impossible to determine or estimate realistic slip rates given the limited stratigraphic control, the uncertain amounts of slip, the generally small amount of cumulative deformation, and the difficulty in identifying specific datums whose offset can be measured with some degree of confidence. Based on the lack of geomorphic expression and the small amount of post-Eocene cumulative throw, the slip rates must certainly be very small, probably much less than $0.1 \mathrm{~mm} / \mathrm{yr}$.

Length $(\mathrm{km})$ : Not applicable

Average strike (azimuth) Not applicable

\section{References}

\#2805 Cox, R.T., and Van Arsdale, R.B., 1997, Investigation of surface faulting in the southern Mississippi embayment: Technical report to U.S. Geological Survey, under Contract 1434-HQ-97-GR-03014, 30 p.

\#2806 Cox, R.T., Van Arsdale, R.B., and Harris, J.B., 1998, Quaternary faulting in the southern Mississippi embayment: Eos, Transactions of the American Geophysical Union, v. 79, no. 17, p. S341.

\#2807 Salvador, A., 1991, Origin and development of the Gulf of Mexico basin, in Salvador, A., ed., The Gulf of Mexico basin: Geological Society of America, The Geology of North America, v. J, p. 389-444.

\#2808 Thomas, W.A., 1989, The Appalachian-Ouachita orogen beneath the Gulf Coastal Plain between the outcrops in the Appalachian and Ouachita Mountains, in Hatcher, R.D., Thomas, W.A., and Viele, G.W., eds., The Appalachian-Ouachita orogen in the United States: Geological Society of America, The Geology of North America, v. F-2, p. 537553.

\#678 Thomas, W.A., 1991, The Appalachian-Ouachita rifted margin of southeastern North America: Geological Society of America Bulletin, v. 103, p. 415-431. 


\section{XX, Wiggins Uplift (Class B)}

Structure Number 2660XX

Structure Name Wiggins uplift (Class B)

Comments: The Wiggins uplift is also known as the Wiggins arch (Cagle and Kahn, 1983 \#2819).

Synopsis: This feature is classified as a Class B feature solely because of results reported in studies by Burnett and Schumm. These studies offer the only evidence of possible Quaternary uplift of the feature but the data are only considered to be suggestive of Quaternary deformation and are not compelling. Burnett and Schumm base their conclusion of Quaternary uplift on evidence derived from fluvial geomorphology, and they report supporting evidence of uplift from geodetic surveys. If Quaternary deformation is occurring on the Wiggins uplift, then it is not clear if the deformation is truly tectonic or if it could be related to other non-tectonic processes such as salt tectonics or differential subsidence. Therefore, this feature is assigned to Class B in this compilation.

\section{Date of compilation $05 / 11 / 98$}

Compiler and affiliation Anthony J. Crone, U.S. Geological Survey

State Mississippi, Alabama, Louisiana

County Baldwin, Mobile (Alabama); Forrest, George, Hancock, Harrison, Jackson, Lamar, Marion, Pearl River, Perry, Stone, Walthall (Mississippi); Washington (Louisiana).

$1^{\circ} \times 2^{\circ}$ sheet Mobile, Hattiesburg, Natchez

Physiographic province Coastal Plain

\section{Reliability of location Poor}

Comments: The location of the Wiggins uplift is defined on the basis of subsurface data and is typically mapped by the absence of salt in extreme southeastern Louisiana and adjacent southwestern Mississippi (Cagle and Kahn, 1983 \#2819; Ewing, 1991 \#1994). This salt-free area is confined to the area of the Mobile $2^{\circ}$ sheet. However, the outline of the Wiggins uplift shown by Burnett and Schumm (1983 \#2815) and Schumm (1986 \#2817) is located north of the salt-free area and lies within the limits of the Hattiesburg and Natchez sheets. The counties listed above are determined from the location of the Wiggins uplift as shown by Cagle and Kahn.

Geologic setting The Wiggins uplift is a small feature centered in southern Mississippi and defined on the basis of subsurface data. It is a second-order structural feature (Ewing, 1991 \#1994) located along the northern flank of the Gulf of Mexico basin. It is bounded on the north by the Mississippi Salt basin and on the south by the deep basin of the Coastal zone. The uplift is mainly defined by the absence of salt and some Upper Jurassic strata over the crest of the feature (Cagle and Kahn, 1983 \#2819; Ewing, 1991 \#1994). 


\section{Sense of movement Not reported}

Comments: No movement on specific faults is reported. The geomorphic evidence reported by Burnett and Schumm (1983 \#2815) infers vertical uplift of the feature, but there is no evidence of movement on specific faults.

\section{Dip Not reported}

Comments: See comments in preceding "Sense of movement" section.

Dip direction Not reported

Geomorphic expression The Wiggins uplift does not have any conspicuous geomorphic expression, but Burnett and Schumm (1983 \#2815) and Schumm (1986 \#2817) describe fluvial geomorphic evidence used to infer Quaternary movement. They report changes in stream channel sinuosity and morphology, and channel incision resulting in the formation of terraces as evidence of continuing uplift. See discussion in the "Detailed Studies" section below.

Age of faulted deposits Holocene. See comments in "Timing of most recent paleoevent" section.

Paleoseismological studies The primary sources of information that suggest possible neotectonic uplift of the Wiggins uplift are reports by Burnett and Schumm (1983 \#2815) and Schumm (1986 \#2817). These reports briefly discuss fluvial geomorphic evidence that suggests contemporary uplift of the Wiggins uplift. The evidence includes changes in stream channel patterns and sinuosity across the uplift, and channel incision that has resulted in the formation of low terraces along Bogue Homo Creek. A gauging station on the Tallahala River provides evidence of as much as $12 \mathrm{~mm} / \mathrm{yr}$ of incision since 1940, and longitudinal profiles of terraces and the valley floor along the Pearl River suggest deformation.

As further support for their contention of modern uplift, they cite Brown and Oliver (1976 \#2818), who indicate an uplift rate of about $4 \mathrm{~mm} / \mathrm{yr}$ in the area of the uplift. However, Brown and Oliver note that the geodetic data they analyzed only detects relative motion and their data from the entire Coastal Plain of the eastern United States shows a pattern of tilting downward, away from the continental interior. Thus the apparent uplift could actually be the result of a more stable block beneath the uplift subsiding at a slower rate relative to the surrounding areas. Alternatively, the uplift could be the expression of a peripheral forebulge caused by sedimentation in the Mississippi River delta (Brown and Oliver, 1976 \#2818).

No additional studies have been conducted to confirm the conclusions of the geodetic or geomorphic investigations. Without additional confirmation, the Wiggins uplift is categorized as a Class B feature because it is located in a region of minimal historical seismicity and because the inferred deformation rates are anomalous for the geologic setting of the Gulf Coastal plain.

Timing of most recent paleoevent latest Quaternary $(<15 \mathrm{ka})$

Comments: Deposits are not faulted but Burnett and Schumm (1983 \#2815) and Schumm (1986 \#2817) note that the modern river channels are responding to the deformation, which is indicative of contemporary deformation. Thus, the most recent deformation is Holocene in age. 


\section{Recurrence interval Not reported}

Comments: The geomorphic evidence of Quaternary uplift implies that the deformation is a steady, on-going process. It is not clear that the deformation is episodic or coseismic, so it is impossible to quantify the deformation in terms of recurrence intervals.

\section{Slip-rate category unknown}

Comments: The inferred "slip rate" of this feature is not really a slip rate in the same sense as defining a slip rate on a fault; this "slip rate" is actually an inferred uplift rate of the entire feature.

The only reported information concerning deformation rates is from Brown and Oliver (1976 \#2818). They indicate a geodetic uplift rate of $4 \mathrm{~mm} / \mathrm{yr}$, but there is some question about whether this deformation is truly tectonic deformation (see discussion of "Paleoseismological Studies"). This high rate is generally incompatible with the geologic and tectonic setting of the Gulf Coast province, and if this rate were sustained for a significant period of geologic time, then the geomorphic and geologic expression of the uplift would be far more pronounced than it is at present. Thus, this geodetic rate is suspect in terms of it accurately reflecting a long-term tectonic uplift rate.

The sparse historical seismicity in the region of the Wiggins uplift contrasts with the unusually high uplift rate. It is not clear if the uplift reflects long-term tectonic processes that produce tectonic strain that could be released by damaging earthquakes. Until some of these fundamental questions about the nature of the deformation are answered, the Wiggins uplift is classified as a Class B feature.

Because of the uncertainties described above, the slip rate is defined as "unknown" until better information is available about the nature and rate of Quaternary deformation.

Length $(\mathrm{km})$ Not applicable

Comment: The Wiggins uplift is a structural feature defined on the basis of subsurface data. It has an areal extent, and is not a linear feature therefore, determining its length is inappropriate.

Average strike (azimuth) Not applicable

Comment: It is inappropriate to determine a average strike for this feature for the same reasons cited in the comments on the length determination.

\section{References}

\#2818 Brown, L.D., and Oliver, J.E., 1976, Vertical crustal movements from leveling data and their relation to geologic structure in the eastern United States: Reviews of Geophysics and Space Physics, v. 14, no. 1, p. 13-35.

\#2815 Burnett, A.W., and Schumm, S.A., 1983, Alluvial-river response to neotectonic deformation in Louisiana and Mississippi: Science, v. 222, p. 49-50.

\#2819 Cagle, J.W., and Kahn, M.A., 1983, Smackover-Norphlet stratigraphy, south Wiggins arch, Mississippi and Alabama: Transactions of the Gulf Coast Association of Geological Societies, v. 33, p. 23-29. 
\#1994 Ewing, T.E., 1991, Structural framework, in Salvador, A., ed., The Gulf of Mexico basin: Boulder, Colorado, Geological Society of America, The Geology of North America, v. J, p. 31-52.

\#2817 Schumm, S.A., 1986, Alluvial river response to active tectonics, in Active tectonics: Washington, D. C., National Academy Press, p. 80-94. 


\section{Anna seismic zone (Class C)}

Structure Name Anna seismic zone (Class C)

Comments: Schwartz and Christensen (1988 \#1891) noted that this seismically active area in central western Ohio is frequently called the Anna seismogenic zone. Hansen (1993 \#1829) referred to the area as the western Ohio seismic zone. We refer to it as the Anna seismic zone, for consistency with other active areas in the central and eastern United States. The zone spans approximately $80 \mathrm{~km}$, with most of the seismicity concentrated within an area 30-35 $\mathrm{km}$ across (Schwartz and Christensen, 1988 \#1891). Eight of the 15 damaging historical earthquakes in Ohio, including the two largest, occurred in the zone (Hansen, 1993 \#1829; Stover and Coffman, 1993 \#1986). The two largest shocks occurred on March 2 and 9, 1937. Their intensities and moment magnitudes were VII and VIII, and M 4.9 and 5.1, respectively (Stover and Coffman, 1993 \#1986; Johnston, 1994 \#2042). Focal mechanisms indicate strikeslip faulting and east-northeast-trending $\mathrm{S}_{\mathrm{Hmax}}$, parallel to the regional orientation (Zoback and Zoback, 1989 \#1922; LaForge and Ruff, 1991 \#1849).

Reason for assignment to class C: This evaluation of Quaternary faulting is not a reliable guide to seismic hazard of the Anna seismic zone. The most authoritative and reliable assessment of the seismic hazard in the area evaluated here is the national seismic hazard maps, which are published by the USGS (Open-File Report 97-131, 12 maps, scale 1:7,000,000; http://geohazards.cr.usgs.gov/eq/). In the Central and Eastern U.S. (CEUS) east of the Rocky Mountain Front, the distribution of historical earthquakes is a reasonable guide to seismic hazard. In the CEUS, the national seismic hazard maps rely mainly on the distribution of historical seismicity to calculate the hazard. In contrast to examining the area's historical seismicity, this discussion focuses on surficial evidence of large, prehistoric earthquakes. Where present, this surficial evidence will be integrated with the historical seismicity to improve future versions of the national hazard maps. In the CEUS, the most common types of surficial evidence of large, prehistoric earthquakes are liquefaction features and faults that offset young strata. However, in some areas the surficial record of large, prehistoric earthquakes is incomplete because of erosion, equivocal, or presently unrecognized. Nonetheless, the national hazard maps show that, for many parts of the CEUS, although convincing surficial evidence of large, prehistoric earthquakes is absent, these areas are NOT free of seismic hazard. The occurrence of significant historical earthquakes in the area described here demonstrates a notable level of seismic hazard.

The Anna seismic zone is assigned to class $\mathrm{C}$ because of a lack of paleoseismological evidence for faulting younger than Paleozoic. Faults are mapped in basement beneath the Paleozoic platform strata and overlying Quaternary glacial deposits (Schwartz and Christensen, 1988 \#1891). The faults strike north, north-northeast, and northwest, but are not known to extend above lower Paleozoic rocks (Thompson and others, 1976 \#1904; Schwartz and Christensen, 1988 \#1891). Most epicenters cluster along the northwest-striking AnnaChampaign fault (Schwartz and Christensen, 1988 \#1891). Obermeier (1995 \#1983) searched stream banks and sand and gravel pits for evidence of Quaternary liquefaction, but found none. The spacing of exposures of liquefiable materials allowed him to conclude that probably the seismogenic zone has not undergone an earthquake larger than $\mathbf{M} 7$ in the past several thousand years, although smaller ones could not be excluded. 
Date of compilation 06/19/98; revised 01/31/00

Compiler and affiliation Russell L. Wheeler, U.S. Geological Survey

State Ohio

County Shelby; Auglaize

$1^{\circ} \times 2^{\circ}$ sheet Muncie

Physiographic province Central Lowland

\section{References}

\#1829 Hansen, M.C., 1993, Earthquakes and seismic risk in Ohio: Ohio Geology, summer issue, p. 1 and 3-6.

\#2042 Johnston, A.C., 1994, Appendix C-Summary tables, SCR seismicity data base, in Schneider, J.F., ed., The earthquakes of stable continental regions-v. 2-Appendices A to E: Technical report to Electric Power Research Institute TR-102261-V2, Palo Alto, California, December 1994, p. C-1-C-46.

\#1849 LaForge, R., and Ruff, L.J., 1991, Seismicity and crustal structure in the Anna, Ohio region [abs.]: Eos, Transactions of the American Geophysical Union, v. 72, no. 17, p. 196.

\#1983 Obermeier, S., 1995, Paleoseismic liquefaction studies-Central U.S. and Pacific northwestern U.S., in Jacobson, M.L., ed., National earthquake hazards reduction program annual project summaries-XXXVI, v. 2: U.S. Geological Survey Open-File Report 95-210, p. 606-609.

\#1891 Schwartz, S.Y., and Christensen, D.H., 1988, The 12 July 1986 St. Marys, Ohio earthquake and recent seismicity in the Anna, Ohio seismogenic zone: Seismological Research Letters, v. 59, p. 57-62.

\#1986 Stover, C.W., and Coffman, J.L., 1993, Seismicity of the United States, 1568-1989 (revised): U.S. Geological Survey Professional Paper 1527, 418 p.

\#1904 Thompson, S.N., Peck, J.H., Patterson, A.R., and Willis, D.E., 1976, Faulting and seismicity in the Anna Ohio region: Geological Society of America Abstracts with Programs, v. 8, no. 6, p. 1139.

\#1922 Zoback, M.L., and Zoback, M.D., 1989, Tectonic stress field of the continental United States, in Pakiser, L.C., and Mooney, W.D., eds., Geophysical framework of the continental United States: Geological Society of America Memoir 172, p. 523-539. 


\section{Belair fault zone (Class C)}

\section{Structure Name Belair fault zone (Class C)}

Comments: Young faulting in the Belair fault zone is summarized in entries 69-72 of Prowell (1983 \#1951). The locality of entry 69 is the one summarized here. The localities of entries 70-72 are farther north along the fault zone.

Reverse offset of Coastal Plain deposits post-dates the Late Eocene, but predates at least $2 \mathrm{ka}$, and may also predate a time several thousand years younger than $26.3 \mathrm{ka}$. Prowell and others (fig. 1, 1978 \#1877) show the location of the entire fault zone on a planimetric base at a scale of 1:500,000. Prowell and others (1975 \#2251) and U.S. Geological Survey (1977\#2252) show the locations of two trenches across the fault zone on topographic bases at scales of $1: 12,000$.

The Belair fault zone of northeastern Georgia has been mapped for at least $24 \mathrm{~km}$, as a northeast-trending zone of at least eight left- and right-stepping reverse faults that are oriented $\mathrm{N}$. $25^{\circ}-30^{\circ}$ E. $/ 50^{\circ} \mathrm{SE}$; the fault zone as a whole also strikes N. $25^{\circ} \mathrm{E}$. (Prowell and $\mathrm{O}^{\prime}$ Connor, 1978 \#1877, and see previous reports cited there). The fault zone places Paleozoic phyllite over Late Cretaceous sands of the Coastal Plain province (Prowell and O'Connor, 1978 \#1877; Prowell, 1983 \#1951). The 50 dip applies to an exposure in a clay pit, another in a trench, and a regional dip (Prowell and others, 1975 \#2251; Prowell and O'Connor, 1978 \#1877).

The Belair fault zone offsets a Late Cretaceous unconformity at least $30 \mathrm{~m}$ in a reverse sense, and a Late Eocene clay at least $10 \mathrm{~m}$ in a reverse sense (Prowell and O'Connor, 1978 \#1877). However, the most recent episode of slip involved a dip slip component of at least $1 \mathrm{~m}$; a strike-slip component is unknown but cannot be ruled out (Prowell and others, 1975 \#2251). It is this most recent episode that might be Quaternary in age (Prowell and others, 1975 \#2251; U.S. Geological Survey, 1977 \#2252). No geomorphic expression of the fault zone has been reported.

A previously speculated strike-slip offset of $23 \mathrm{~km}$ is an artifact of viewing a large, threedimensional structure in two-dimensional map view. The Belair fault zone strikes north-northeast across the east-northeast to northeast striking Augusta fault zone. Both fault zones are of Paleozoic ancestry and dip southeast (Bramlett and others, 1982 \#2197). The trace of the Augusta fault zone is offset $23 \mathrm{~km}$ sinistrally where it crosses the trace of the Belair fault zone, and Prowell and O'Connor (1978 \#1877) speculated from the map-view shape of the Coastal Plain - Piedmont contact that this horizontal separation might be younger than Cretaceous. However, mapping by Bramlett and others (1982 \#2197) showed no significant offset of compositional layers across the northeastward projection of the Belair fault zone. Mapping and structural analysis indicated that the Belair fault zone is probably a tear fault or lateral ramp in the hanging wall of the Augusta fault zone (Bramlett and others, 1982 \#2197), which underwent southeastward directed, listric, normal slip during late Paleozoic orogenic collapse (Maher, 1987 \#2209). Thus, the $23 \mathrm{~km}$ of sinistral horizontal separation of the trace of the Augusta fault zone reflects mainly or entirely the late Paleozoic normal faulting on the Augusta fault zone. The Late Cretaceous or younger, brittle, reverse slip documented by Prowell and O'Connor (1978 \#1877) records local compressional reactivation of the favorably oriented lateral ramp in the late Paleozoic, normal fault zone. 
Reason for assignment to class $\mathbf{C}$ The most recent faulting is not demonstrably of Quaternary age. Two trenches were opened across the fault zone to constrain the age of latest faulting. Prowell and others (1975 \#2251) excavated the first trench and obtained age estimates of $2,450 \pm 1,000$ and $400 \pm 300$ yr. B.P. on composite samples from several lenses of gray, sandy clay that contains small, disseminated particles of fibrous woody material. One clay lens is dragged into the fault zone and others are cut by the fault zone or are in stratigraphic intervals that are cut by it. These relations indicated that at least $1 \mathrm{~m}$ of reverse slip has occurred since deposition of the clay lenses (Prowell and others, 1975 \#2251). U.S. Geological Survey (1977 \#2252) excavated the second trench $100 \mathrm{~m}$ southwest of the first to test the results of Prowell and others (1975 \#2251). Age estimates and stratigraphic relations in this second trench indicate that the most recent faulting predates a unit that is at least $2 \mathrm{k} . \mathrm{y}$. old and perhaps only several thousand years younger than $26.3 \mathrm{k} . \mathrm{y}$. The youngest documented slip is reverse offset of a Late Eocene clay (Prowell and O'Connor, 1978 \#1877). U.S. Geological Survey (1977 \#2252) speculated that the carbon from the gray lenses in the first trench might have been introduced by roots or ground water percolation. Regardless, Quaternary slip on the Belair fault is allowed by these results but not demonstrated.

Individual slip events, whether seismic or aseismic, have not been distinguished. The lack of reported geomorphic expression along the Belair fault zone favors a slow Quaternary slip rate. Slip rate averages approximately three orders of magnitude slower than $0.2 \mathrm{~mm} / \mathrm{yr}$ over the last 80 m.y. (Prowell, 1988 \#1993).

Date of compilation 12/15/98; revised 01/28/00

Compiler and affiliation Russell L. Wheeler, U.S. Geological Survey

State Georgia

County Richmond

$1^{\circ} \times 2^{\circ}$ sheet Richmond

Physiographic province Coastal Plain

\section{References}

\#2197 Bramlett, K.W., Secor, D.T., Jr., and Prowell, D.C., 1982, The Belair fault-A Cenozoic reactivation structure in the eastern Piedmont: Geological Society of America Bulletin, v. 93, p. 1109-1117.

\#2209 Maher, H.D., Jr., 1987, Kinematic history of mylonitic rocks from the Augusta fault zone, South Carolina and Georgia: American Journal of Science, v. 287, p. 795-816.

\#1951 Prowell, D.C., 1983, Index of faults of Cretaceous and Cenozoic age in the Eastern United States: U.S. Geological Survey Miscellaneous Field Studies Map MF-1269, 2 sheets, scale 1:2,500,000.

\#1993 Prowell, D.C., 1988, Cretaceous and Cenozic tectonism on the Atlantic coastal margin, in Sheridan, R.E., and Grow, J.A., eds., The Atlantic continental margin, U.S.:

Boulder, Colorado, Geological Society of America, The Geology of North America, v. I-2, p. 557-564. 
\#1877 Prowell, D.C., and O'Connor, B.J., 1978, Belair fault zone-Evidence of Tertiary fault displacement in eastern Georgia: Geology, v. 6, p. 681-684.

\#2251 Prowell, D.C., O'Connor, B.J., and Rubin, M., 1975, Preliminary evidence for Holocene movement along the Belair fault zone near Augusta, Georgia: U.S. Geological Survey Open-File Report 75-680, 20 p.

\#2252 U.S. Geological Survey, 1977, Preliminary report on Belair exploratory trench \#10-76 near Augusta, Georgia: U.S. Geological Survey Open-File Report 77-411, 20 p., 2 pls. 


\section{Cacoosing Valley earthquake (Class C)}

Structure Name Cacoosing Valley earthquake (Class C)

Comments: Shortly after the earthquake occurred on January 16, 1994 in southeastern Pennsylvania, it was referred to informally as the Reading earthquake because that was the closest urban area. Subsequently, most published accounts named the earthquake after the nearby town of Wyomissing Hills. Seeber and others (1998 \#1893; 1998 \#2228) renamed the shock after the Cacoosing Valley in which it occurred. I adopt the Cacoosing Valley name here because the epicenter location of Seeber and others (1998 \#2228) and an atlas show it to be the most accurate. The earthquake is the largest known to have occurred in the Lancaster seismic zone. The seismic zone is described separately in this compilation.

Reason for assignment to class $\mathbf{C}$ This evaluation of Quaternary faulting is not a reliable guide to seismic hazard of the vicinity of the Cacoosing Valley earthquake. The most authoritative and reliable assessment of the seismic hazard in the area evaluated here is the national seismic hazard maps, which are published by the USGS (Open-File Report 97-131, 12 maps, scale 1:7,000,000; http://geohazards.cr.usgs.gov/eq/). In the Central and Eastern U.S. (CEUS) east of the Rocky Mountain Front, the distribution of historical earthquakes is a reasonable guide to seismic hazard. In the CEUS, the national seismic hazard maps rely mainly on the distribution of historical seismicity to calculate the hazard. In contrast to examining the area's historical seismicity, this discussion focuses on surficial evidence of large, prehistoric earthquakes. Where present, this surficial evidence will be integrated with the historical seismicity to improve future versions of the national hazard maps. In the CEUS, the most common types of surficial evidence of large, prehistoric earthquakes are liquefaction features and faults that offset young strata. However, in some areas the surficial record of large, prehistoric earthquakes is incomplete because of erosion, equivocal, or presently unrecognized. Nonetheless, the national hazard maps show that, for many parts of the CEUS, although convincing surficial evidence of large, prehistoric earthquakes is absent, these areas are NOT free of seismic hazard. The occurrence of significant historical earthquakes in the area described here demonstrates a notable level of seismic hazard.

The earthquake is assessed here because its moderate magnitude and unusually shallow depth indicated the possibility of surface rupture; none has been found. A $\mathrm{m}_{\mathrm{bLg}} 4.0$ foreshock preceded by one hour the $\mathrm{m}_{\mathrm{bLg}} 4.6$ main shock ( $\mathrm{Mw} 4.0$ and $\mathrm{Mw} 4.6$, respectively, according to Armbruster and others, 1994 \#1792; Kim and others, 1994 \#1847; Ammon and others, 1998 \#1789; Mw 3.8 and Mw 4.3, respectively, according to Seeber and others, 1998 \#2228). Intensity was MMI VI-VII. The best 41 aftershock hypocenters occurred around the rim of an approximately tabular zone with a diameter of $2 \mathrm{~km}$, a depth range of 0-2.5 km, and an orientation of N. $43^{\circ} \mathrm{W} . / 54^{\circ} \mathrm{SW}$ (Seeber and others, 1998 \#2228). This diameter compares well to the $1.5 \mathrm{~km}$ rupture-zone diameter expected of a typical earthquake of $\mathrm{Mw} 4.6$ in a stable continental region (Johnston, 1993 \#1840). A depth phase shows the main shock to have occurred at $2 \mathrm{~km}$ depth (Kim and others, 1994 \#1847) and aftershocks extended up to zero depth (Seeber and others, 1998 \#2228). Ammon and others (1998 \#1789) modeled the preferred nodal plane of the main-shock focal mechanism as N. $45^{\circ} \mathrm{W}$. / $49^{\circ} \mathrm{SW}$, with mainly reverse faulting and a small component of sinistral strike slip. Seeber and others (1998 \#2228) modeled a nearly identical orientation of $\mathrm{N} .45^{\circ} \mathrm{W} . / 54^{\circ} \mathrm{SW}$, but with approximately equal 
reverse and sinistral components. Both $\mathrm{P}$ axes agree with the regional east-northeast trend of greatest horizontal compressive stress (Zoback and Zoback, 1989 \#1922).

The foreshock and main shock were the largest earthquakes in a sequence that began in May 1993 and continues to the present (Armbruster and others, 1994 \#1792; Seeber and others, 1998 \#1893; Seeber and others, 1998 \#2228). The main shock occurred under a quarry that had been abandoned in December 1992 and allowed to flood rapidly (Armbruster and others, 1994 \#1792; Seeber and others, 1998 \#1893). Seeber and others (1998 \#1893; 1998 \#2228) concluded that the Cacoosing Valley earthquake, and the sequence of which it is a part, were triggered by the combination of unloading caused by quarrying and increased pore pressure caused by the subsequent flooding. Therefore, the earthquake did not rupture the ground surface and thus produced no paleoseismological record, and consequently is assigned to class $\mathrm{C}$.

Date of compilation 08/06/98; revised 01/31/00

Compiler and affiliation Russell L. Wheeler, U.S. Geological Survey

State Pennsylvania

County Berks

$1^{\circ} \times 2^{\circ}$ sheet Harrisburg

Physiographic province Valley and Ridge

\section{References}

\#1789 Ammon, C.J., Herrmann, R.B., Langston, C.A., and Benz, H., 1998, Faulting parameters of the January 16, 1994 Wyomissing Hills, Pennsylvania earthquakes: Seismological Research Letters, v. 69, p. 261-269.

\#1792 Armbruster, J.G., Seeber, L., Barstow, N., Kim, W.Y., Horton, S., and Scharnberger, C.K., 1994, The Jan. 1994 Wyomissing Hills earthquakes (Mblg=4.0 \& 4.6) in southeastern Pennsylvania-A $2 \mathrm{~km}$-long northwest-striking fault illuminated by aftershocks [abs.]: Eos, Transactions of the American Geophysical Union, v. 75, no. 16 (supplement), p. 237.

\#1840 Johnston, A.C., 1993, Average stable continental earthquake source parameters based on constant stress drop scaling [abs.]: Seismological Research Letters, v. 64, p. 261.

\#1847 Kim, W.-Y., Gao, L., Horton, S., Such, R., Johnson, D., and Lerner-Lam, A., 1994, Analysis of digital records from Wyomissing Hills, PA. earthquakes of Jan. 16, 1994 [abs.]: Eos, Transactions of the American Geophysical Union, v. 75, no. 16 (supplement), p. 237.

\#1893 Seeber, L., Armbruster, J.G., and Kim, W.-Y., 1998, A quarry as the straw and stable continental crust as the camel's back-The Mblg4.6, 1994 Cacoosing earthquake in southeastern PA [abs.]: Eos, Transactions of the American Geophysical Union, v. 79, no. 17 (supplement), p. S339-340.

\#2228 Seeber, L., Armbruster, J.G., Kim, W.-Y., Barstow, N., and Scharnberger, C., 1998, The 1994 Cacoosing Valley earthquakes near Reading, Pennsylvania—A shallow rupture triggered by quarry unloading: Journal of Geophysical Research, v. 103, no. B10, p. 24,505-24,521. 
\#1922 Zoback, M.L., and Zoback, M.D., 1989, Tectonic stress field of the continental United States, in Pakiser, L.C., and Mooney, W.D., eds., Geophysical framework of the continental United States: Geological Society of America Memoir 172, p. 523-539. 


\section{Cape Fear arch (Class C)}

Structure Name Cape Fear arch (Class C)

Comments: Dall and Harris (1892 \#3930) were perhaps the first to summarize the observations from which the existence of the Cape Fear arch could be deduced by later workers. They noted that in North Carolina "The Miocene strata ... are generally exposed on the south side of the large rivers and on the north slopes of the divides or swells between the rivers. This formation thickens, deepens toward the northern border of the State, the beds being much thicker on the Tar and Roanoke than on the rivers farther south" (p. 68). In addition, Dall and Harris (1892 \#3930, p. 71) noted that, farther southwest in North Carolina along the upper part of the Cape Fear River, "Kerr represents, on the geological map accompanying his report for 1875, the Miocene formation as extending along the right flank of this river valley at least 20 miles above Elizabethtown". Nearly a century later, mapping by Markewich (1985 \#3933), Soller (1988 \#3937), and Owens (1989 \#3935) showed that in the upper and lower parts of the Cape Fear River valley, in southwestern North Carolina, and in the Pee Dee River valley, in nearby South Carolina, both rivers flow along the southwestern sides of their valleys, eroding bluffs there. Successively older deposits and successively older and higher terraces appear successively farther to the northeast in both river valleys, demonstrating migration of both rivers to the southwest in response to southwestward tilting of the land surface (Markewich, 1985 \#3933; Soller, 1988 \#3937). Nowhere in their chapters on North and South Carolina did Dall and Harris (1892 \#3930) deduce the presence of an arch or other tectonically uplifted area separating the northeasterly- and southwesterly-tilted river valleys. However, in subsequent decades the southeast-plunging arch was recognized and named for Cape Fear.

The crest of the arch approximately underlies the Cape Fear River (Soller, 1988 \#3937; Owens, 1989 \#3935), although the subcrop map of Owens (1989 \#3935, shown in more detail as figure 4 of Soller, 1988 \#3937) indicated that the crest has shifted tens of kilometers northeastward and southwestward since at least the middle of Late Cretaceous time (Soller, 1987 \#3938). Isopach and structure contour maps of middle Cretaceous units indicated that the basins northeast and southwest of the arch subsided then, leaving the arch comparatively high (Harris and others, 1979 \#3932). Isopach maps of early Paleocene, Oligocene, and Miocene strata indicated relative subsidence northeast of the arch (Harris, 1996 \#3931), and the presence of Miocene rocks northeast and southwest of the arch but not on it led Owens (1970 \#3934) to infer that it was a "physical barrier" (p. 24) then. Elevations of shorelines and river terraces indicated uplift of the crest of the arch relative to its southwestern limb during the Pliocene and Pleistocene (Winker and Howard, 1977 \#3939; Blackwelder, 1981 \#3927; Soller, 1988 \#3937). Farther northeast on the other side of the arch, shoreline elevations indicated alternating relative uplifts of the crest and northeast limb during the Pleistocene (Zullo and Harris, 1979 \#3940). Isopachs of early Pleistocene strata indicated relative subsidence on both flanks of the arch (Harris, 1996 \#3931). Finally, three decades of leveling data suggested historical uplift of the arch, perhaps centered offshore (Brown and Oliver, 1976 \#3929; Brown, 1978 \#3928).

Reason for assignment to class C: Lack of evidence for Quaternary faulting. Harris and others (1979 \#3932) and Zullo and others (1979 \#3940) collected earlier suggestions for the existence of three faults longer than $100 \mathrm{~km}$ on the arch and its northeastern limb. However, 
Soller (1988 \#3937, p. 49-50) suggested an alternative explanation of the evidence for one of the faults, and Prowell and Obermeier (1991 \#3936) noted that much evidence favors regional warping but none requires faulting. Harris (1996 \#3931) omitted two of the earlier faults and referred to the third as a hinge.

Date of compilation $02 / 18 / 00$

Compiler and affiliation Russell L. Wheeler, U.S. Geological Survey

State North Carolina; South Carolina

County Bladen; Brunswick; Columbus; Duplin; New Hanover; Pender; Robeson; Sampson (North Carolina); Dillon; Horry; Marion (South Carolina)

$1^{\circ} \times 2^{\circ}$ sheet Florence; Beaufort; Georgetown

Physiographic province Coastal Plain

\section{References}

\#3927 Blackwelder, B.W., 1981, Late Cenozoic marine deposition in the United States Atlantic coastal plain related to tectonism and global climate: Paleogeography, Paleoclimatology, Paleoecology, v. 34, p. 87-114.

\#3928 Brown, L.D., 1978, Recent vertical crustal movement along the east coast of the United States: Tectonophysics, v. 44, p. 205-231.

\#3929 Brown, L.D., and Oliver, J.E., 1976, Vertical crustal movements from leveling data and their relation to geologic structure in the Eastern United States: Reviews of Geophysics and Space Physics, v. 14, no. 1, p. 13-35.

\#3930 Dall, W.H., 1892, Correlation papers-Neocene: U.S. Geological Survey Bulletin 84, $349 \mathrm{p}$.

\#3931 Harris, W.B., 1996, An overview of the marine Tertiary and Quaternary deposits between Cape Fear and Cape Lookout, North Carolina, in Cleary, W.J., ed., Environmental coastal geology - Cape Lookout to Cape Fear, North Carolina: Carolina Geological Society Fieldtrip Guidebook, p. 1-10.

\#3932 Harris, W.B., Zullo, V.A., and Baum, G.R., 1979, Tectonic effects on Cretaceous, Paleogene, and early Neogene sedimentation, North Carolina, in Baum, G.R., Harris, W.B., and Zullo, V.A., eds., Structural and stratigraphic framework for the coastal plain of North Carolina: Carolina Geological Society and Atlantic Coastal Plain Geological Association, p. 17-29.

\#3933 Markewich, H.W., 1985, Geomorphic evidence for Pliocene-Pleistocene uplift in the area of the Cape Fear Arch, North Carolina, in Morisawa, M., and Hack, J.T., eds., Tectonic geomorphology: Boston, Allen \& Unwin, p. 279-297.

\#3934 Owens, J.P., 1970, Post-Triassic tectonic movements in the central and southern Appalachians as recorded by sediments of the Atlantic Coastal Plain, in Fisher, G.W., Pettijohn, F.J., Reed, J.C., Jr., and Weaver, K.N., eds., Studies of Appalachian geology —Central and southern: New York, John Wiley and Sons, p. 417-427. 
\#3935 Owens, J.P., 1989, Geologic map of the Cape Fear region, Florence $1^{\circ} \times 2^{\circ}$ quadrangle and northern half of the Georgetown $1^{\circ} \times 2^{\circ}$ quadrangle, North Carolina and South Carolina: U.S. Geological Survey Miscellaneous Investigations Map I-1948-A, 2 sheets, scale 1:250,000.

\#3936 Prowell, D.C., and Obermeier, S.F., 1991, Evidence of Cenozoic tectonism, in Horton, J.W., Jr., and Zullo, V.A., eds., The geology of the Carolinas: Knoxville, Tennessee, University of Tennessee Press, p. 309-318.

\#3938 Soller, D.R., 1987, Late Cenozoic tectonism of the Cape Fear Arch, central Atlantic coastal plain: Geological Society of America Abstracts with Programs, v. 19, no. 2, p. 130 .

\#3937 Soller, D.R., 1988, Geology and tectonic history of the lower Cape Fear River Valley, southeastern North Carolina: U.S. Geological Survey Professional Paper 1466-A, 60 p., 1 plate, scale 1:250,000.

\#3939 Winker, C.D., and Howard, J.D., 1977, Correlation of tectonically deformed shorelines on the southern Atlantic coastal plain: Geology, v. 5, p. 123-127.

\#3940 Zullo, V.A., and Harris, B.W., 1979, Plio-Pleistocene crustal warping in the outer coastal plain of North Carolina, in Baum, G.R., Harris, B.W., and Zullo, V.A., eds., Structural and stratigraphic framework for the coastal plain of North Carolina: Carolina Geological Society and Atlantic Coastal Plain Geological Assoication, Raleigh, North Carolina, October 19-21, 1979, Guidebook, p. 31-40. 


\section{Catlin Lake-Goodnow Pond lineament (Class C)}

Structure Name Catlin Lake-Goodnow Pond lineament (Class C)

Comments: This topographic lineament trends north-northwest in the central Adirondack Mountains. It passes approximately $2 \mathrm{~km}$ east of the epicenters of an earthquake sequence, which might have occurred on a fault zone that Dawers and Seeber (1991 \#1809) hypothesized to underlie the lineament. Dawers and Seeber (1991 \#1809) named the hypothesized fault zone the Catlin Lake fault zone. The name of the topographic lineament is used here instead because the existence of the fault zone has not been demonstrated.

Reason for assignment to class C: This evaluation of Quaternary faulting is not a reliable guide to seismic hazard of the Catlin Lake-Goodnow Pond lineament. The most authoritative and reliable assessment of the seismic hazard in the area evaluated here is the national seismic hazard maps, which are published by the USGS (Open-File Report 97-131, 12 maps, scale 1:7,000,000; http://geohazards.cr.usgs.gov/eq/). In the Central and Eastern U.S. (CEUS) east of the Rocky Mountain Front, the distribution of historical earthquakes is a reasonable guide to seismic hazard. In the CEUS, the national seismic hazard maps rely mainly on the distribution of historical seismicity to calculate the hazard. In contrast to examining the area's historical seismicity, this discussion focuses on surficial evidence of large, prehistoric earthquakes. Where present, this surficial evidence will be integrated with the historical seismicity to improve future versions of the national hazard maps. In the CEUS, the most common types of surficial evidence of large, prehistoric earthquakes are liquefaction features and faults that offset young strata. However, in some areas the surficial record of large, prehistoric earthquakes is incomplete because of erosion, equivocal, or presently unrecognized. Nonetheless, the national hazard maps show that, for many parts of the CEUS, although convincing surficial evidence of large, prehistoric earthquakes is absent, these areas are NOT free of seismic hazard. The occurrence of significant historical earthquakes in the area described here demonstrates a notable level of seismic hazard.

Seismological evidence summarized later indicates that a fault zone beneath the topographic lineament might be undergoing seismic reactivation in the present-day compressional stress field. However, clear evidence is lacking as to whether a single, connected fault zone exists, and no paleoseismological evidence for prehistoric Quaternary seismic reactivation of such a fault zone has been reported.

The Catlin Lake-Goodnow Pond lineament was considered in this compilation for two reasons. (1) On October 7, 1983, the Goodnow earthquake occurred, with a centroid approximately $7.5 \mathrm{~km}$ beneath a point $2 \mathrm{~km}$ west of the lineament (Seeber and Armbruster, 1986 \#2054; Nábelek and Suárez, 1989 \#1868). Epicentral intensity was MMI VI (Stover and Coffman, 1993 \#1986), and magnitude was $\mathrm{m}_{\mathrm{b}}(\mathrm{Lg})$ 5.2, equivalent to moment magnitude $\mathbf{M}$ 4.9 (Seeber and Armbruster, 1986 \#2054; Johnston, 1996 \#1841). A discoid distribution of aftershock hypocenters confirmed an analytical estimate of the rupture-zone diameter as 1.5 $\mathrm{km}$, as well as the choice of preferred nodal plane as one striking north and dipping $60^{\circ} \mathrm{W}$ (Seeber and Armbruster, 1986 \#2054; Nábelek and Suárez, 1989 \#1868). The preferred nodal plane and the discoid distribution of hypocenters project upward to ground level at or just east of the Catlin Lake-Goodnow Pond lineament (Dawers and Seeber, 1991 \#1809). (2) Joints and straight topographic features presumed to be controlled by fractures are most abundant 
and most parallel to the lineament inside a zone $12 \mathrm{~km}$ long, $2 \mathrm{~km}$ wide, and centered on the lineament. In addition, small faults parallel to the lineament are known from the area, although not within the lineament or the $12 \times 2 \mathrm{~km}$ zone that encloses it. From this indirect evidence, Dawers and Seeber (1991 \#1809) suggested that the lineament is underlain by a continuous fault or fault zone, and that the Goodnow earthquake and its aftershocks occurred on it. Dawers and Seeber (1991 \#1809) noted that any offset on such a fault or fault zone must be small, because geologic contacts trend across the lineament at high angles and no offset is visible on a geologic map that Seeber (1987 \#2053) estimated has a resolution of $50 \mathrm{~m}$.

Accordingly, the Catlin Lake-Goodnow Pond lineament and the Catlin Lake fault zone are assigned to class $\mathrm{C}$. Neither the existence of a continuous fault zone nor paleoseismological evidence of Quaternary motion on it has been demonstrated.

Date of compilation 04/27/98; revised 01/31/00

Compiler and affiliation Russell L. Wheeler, U.S. Geological Survey

State New York

County Essex; Hamilton

$1^{\circ} \times 2^{\circ}$ sheet Utica; Ogdensburg

Physiographic province Adirondack

\section{References}

\#1809 Dawers, N.H., and Seeber, L., 1991, Intraplate faults revealed in crystalline bedrock in the 1983 Goodnow and 1985 Ardsley epicentral areas, New York: Tectonophysics, v. 186, p. $115-131$.

\#1841 Johnston, A.C., 1996, Seismic moment assessment of earthquakes in stable continental regions-I. Instrumental seismicity: Geophysical Journal International, v. 124, p. 381414.

\#1868 Nábelek, J., and Suárez, G., 1989, The 1983 Goodnow earthquake in the central Adirondacks, New York-Rupture of a simple, circular crack: Bulletin of the Seismological Society of America, v. 79, p. 1762-1777.

\#2053 Seeber, L., 1987, Problems in intraplate seismogenesis and earthquake hazard, in Jacob, K.H., ed., Proceedings from the symposium on seismic hazards, ground motions, soilliquefaction and engineering practice in eastern North America: National Center for Earthquake Engineering Research Technical Report NCEER-87-0025, p. 143-162.

\#2054 Seeber, L., and Armbruster, J.G., 1986, A study of earthquake hazards in New York State and adjacent areas-Final report covering the period 1982-1985: U.S. Nuclear Regulatory Commission Report NUREG/CR-4750, 99 p.

\#1986 Stover, C.W., and Coffman, J.L., 1993, Seismicity of the United States, 1568-1989 (revised): U.S. Geological Survey Professional Paper 1527, 418 p. 


\section{Champlain lowlands normal faults (Class C)}

Structure Name Champlain lowlands normal faults (Class C)

Comments: The Champlain lowlands lie along the New York-Vermont border, between the Adirondack Mountains on the west and the Green Mountains and Taconic Mountains on the east. The lowlands extend southward to join a northward extension of the Hudson-Mohawk lowlands. Lakes Champlain and George occupy most of the Champlain lowlands. The Adirondack Mountains expose a broad dome of Proterozoic high-grade metamorphic rocks (Fisher and others, 1970 \#1930; Isachsen and Fisher, 1970 \#1933). In contrast, the Green and Taconic Mountains are built of west-verging thrust sheets of Cambrian and Ordovician rocks. The intervening lowlands are underlain by flat-lying to gently-dipping Cambrian and Ordovician platform strata. The platform strata in the lowlands have long been known to be cut by variously-striking systems of generally east-facing, steep to vertical, normal faults, which have the overall effect of stepping the platform rocks downward and eastward, off the updomed Proterozoic basement of the Adirondack Mountains, to disappear under the thrust sheets of the Green and Taconic Mountains (for example Quinn, 1933 \#1879). In addition, some of the normal faults are mapped as cutting the eastern parts of the exposed Proterozoic rocks in the Adirondack dome, and perhaps some of the westernmost thrust sheets of the Green and Taconic Mountains (Fisher and others, 1970 \#1930; Isachsen and Fisher, 1970 \#1933; Isachsen and McKendree, 1977 \#1934; Isachsen, 1985 \#2038).

Reason for assignment to class C: I found no paleoseismological evidence for Quaternary motion on the normal faults of the lowlands. However, the normal faults were considered in this compilation of geologic evidence for Quaternary faulting for four reasons.

Burke (1977 \#1804) suggested that the normal faults of the lowlands originated during early Paleozoic rifting, and speculated from geomorphological arguments that the faults might have undergone Neogene extensional reactivation. A worldwide survey of damaging earthquakes in stable continental regions found that large earthquakes occur preferentially in passive margins and continental rifts, with the preference being strongest for areas that underwent the youngest extension (Johnston, 1989 \#2039; Johnston, 1994 \#2040). Thus, Neogene extensional reactivation of the lowland normal faults could indicate elevated earthquake potential. However, eastern North America is presently under compression (Zoback and Zoback, 1989 \#1922). In addition, examination of the patterns and ages of sea-floor magnetic anomalies indicates little change over the last 50 million years in the plate motions that are thought to generate the present-day compressive stresses in eastern North America. Therefore, the present-day compression in and surrounding the lowlands is likely to have persisted through the Neogene. Thus, Neogene extensional reactivation of the lowland faults is unlikely.

Marine seismic-reflection profiles of the glacial and Holocene deposits in southern Lake George showed several places where growth faults have apparent offsets as large as $24 \mathrm{~m}$ (Wold and others, 1977 \#1918). However, additional profiles and further processing found no evidence of tectonic faulting (Hutchinson and others, 1981 \#1832). The preferred explanation for the apparent offsets is that they represent localized collapse above melting blocks of glacial ice that had been buried by the glacial and Holocene deposits (Hutchinson and others, 1981 \#1832; Isachsen, 1985 \#2038). A marine seismic-reflection survey in Lake Champlain allowed pre-Quaternary faults that had been mapped on land to be traced into bedrock beneath 
the lake (Turner, 1977 \#2060). However, post-glacial sediments continue across the faults beneath the lake without offset, thereby indicating the absence of post-glacial faulting larger than the one foot $(0.3 \mathrm{~m})$ resolution limit of the survey. A more recent reflection survey in Lake Champlain found possible folded, non-parallel, and disrupted depositional surfaces that are likely younger than $13 \mathrm{ka}$ (Hunt, 1989 \#2037). Origins by differential compaction, submarine slumping, or ancient faults reactivated during post-glacial rebound are similarly possible, so Hunt (1989 \#2037) considered this evidence for possible faulting to be inconclusive.

Numerous mapped and inferred, normal, lowland faults are shown as bounding or crossing Quaternary glacial and alluvial deposits (Fisher and others, 1970 \#1930; Isachsen and Fisher, $1970 \# 1933)$. Although these relations are shown at the small map scale of 1:250,000, they indicate a possibility of young reactivation of some lowland faults. In particular, Geraghty and Isachsen (1981 \#2033; summarized by Isachsen and others, 1983 \#2203) suggested Neogene reactivation of the north-striking McGregor-Saratoga-Ballston Lake fault system at the southern end of the lowlands, for the following four reasons. First, seismic refraction profiles and topographic maps at several localities along the fault system showed that the fault is exactly at the foot of a bedrock escarpment at each locality. Erosional retreat of the escarpment from the fault has been negligible, from which Geraghty and Isachsen (1981 \#2033) suggested Neogene reactivation of the fault. Second, at three places along the fault zone, possible sag ponds exist at the bases of escarpments adjacent to the fault zone. Geraghty and Isachsen (1981 \#2033) suggested that the ponds might indicate geologically young tilting of the hanging walls, and therefore geologically young slip on the fault. However, some of the lowland fault blocks are tilted into their bounding normal faults, as though the faults are listric in the subsurface (Quinn, 1933 \#1879; Isachsen and Fisher, 1970 \#1933). Such tilting, combined with differential solution or erosion of the uppermost exposed strata in the hanging walls, might produce topographic depressions atop the hanging-wall blocks adjacent to the faults. Third, a temporary seismograph network located two microearthquakes near the fault system with an epicentral resolution of approximately $1 \mathrm{~km}$ but unknown depths (Geraghty and Isachsen, 1981 \#2033; Mitronovas, 1981 \#1866). One of the epicenters is exactly on the trace of the fault. However, this is not conclusive evidence for seismic reactivation of the fault, because if the fault dips away from the vertical, the hypocenter would be in the footwall, not on the fault. In addition, the magnitude was 1.6, which indicates a rupture zone smaller than $50 \mathrm{~m}$ in diameter (Johnston, 1993 \#1840). The only hypocentral depth reported near the fault system was $5 \mathrm{~km}$ (Geraghty and Isachsen, 1981 \#2033). If the microearthquake had a similar depth, a rupture zone $50 \mathrm{~m}$ in diameter at a depth of $5 \mathrm{~km}$ could occur on a fault too small and deep to be detected. These considerations might explain why the second precisely located epicenter fell $17 \mathrm{~km}$ from the nearest mapped high-angle fault (figure 3 of Geraghty and Isachsen, 1981 \#2033)). Fourth, six of 14 highly carbonated springs in the area issue from the McGregor-Saratoga-Ballston Lake fault system, and such springs are characteristic of seismically active areas worldwide (Geraghty and Isachsen, 1981 \#2033). Thus, the negligible erosional retreat of escarpments and the highly carbonated springs might be evidence for Neogene reactivation of the McGregor-Saratoga-Ballston Lake fault system, and perhaps for other, similar lowland faults. However, Neogene reactivation would precede the Quaternary. Geraghty and Isachsen (1981 \#2033) state that they found "no direct evidence for Holocene movement on the faults" (p. 37). 
Isachsen and others (1983) used topographic, geomorphic, geodetic, and other evidence to suggest that the domal Adirondack Mountains underwent Neogene, and probably Pliocene, uplift that might continue today. Vertical uplift of the Adirondack Mountains might reactivate faults along its eastern border in the Champlain lowlands, even in the absence of the regional extension speculated by Burke (1977). The best studied candidate for such reactivation is the McGregor-Saratoga-Ballston Lake fault system (Geraghty and Isachsen, 1981; Isachsen and others, 1983). However, as argued in the preceding paragraph, the evidence for young motion in this fault system is intriguing but, ultimately, favors Neogene faulting more than Quaternary.

Accordingly, in the absence of paleoseismological study of trench exposures, such as those recommended by Geraghty and Isachsen (1981) and Isachsen and others (1983), the lowland faults are assigned to class $\mathrm{C}$.

Date of compilation 05/27/98; revised 01/28/00

Compiler and affiliation Russell L. Wheeler, U.S. Geological Survey

State New York; Vermont

County Clinton; Essex; Warren; Washington; Saratoga; Schenectady; Albany (New York State); Grand Isle; Chittenden; Addison; Rutland (Vermont)

$1^{\circ} \times 2^{\circ}$ sheet Lake Champlain; Glens Falls; Albany

Physiographic province St. Lawrence Valley; Valley and Ridge

\section{References}

\#1804 Burke, K., 1977, Are Lakes George and Champlain in Neogene graben reactivating early Paleozoic rifts?: Geological Society of America Abstracts with Programs, v. 9, p. 247248.

\#1930 Fisher, D.W., Isachsen, Y.W., and Rickard, L.V., 1970, Geologic map of New YorkHudson-Mohawk sheet: New York State Museum and Science Service Map and Chart Series 15, 1 sheet, scale 1:250,000.

\#2033 Geraghty, E.P., and Isachsen, Y.W., 1981, Investigation of the McGregor-SaratogaBallston Lake fault system, east central New York: U.S. Nuclear Regulatory Commission Report NUREG/CR-1866, 45 p., 1 pl.

\#2037 Hunt, A.S., 1989, Detailed investigations of several apparent faults beneath Lake Champlain, Vermont-New York, in Barosh, P.J., and Smith, P.V., eds., New England seismotectonic activities during fiscal year 1980: U.S. Nuclear Regulatory Commission Report NUREG/CR-3252, p. 68-73.

\#1832 Hutchinson, D.R., Ferrebee, W.M., Knebel, H.J., and Wold, R.J., 1981, The sedimentary framework of the southern basin of Lake George, New York: Quaternary Research, v. 15 , p. 44-61.

\#2038 Isachsen, Y.W., 1985, Structural and tectonic studies in New York State-Final report, July 1981-June 1982: U.S. Nuclear Regulatory Commission Report NUREG/CR-3178, $75 \mathrm{p}$. 
\#1933 Isachsen, Y.W., and Fisher, D.W., 1970, Geologic map of New York-Adirondack sheet: New York State Museum and Science Service Map and Chart Series 15, 1 sheet, scale $1: 250,000$.

\#2203 Isachsen, Y.W., Geraghty, E.P., and Wiener, R.W., 1983, Fracture domains associated with a neotectonic, basement-cored-dome-The Adirondack Mountains, New York, in Gabrielsen, R.H., Ramberg, I.B., Roberts, D., and Steinlein, O.A., eds., International Conference on Basement Tectonics: Salt Lake City, International Basement Tectonics Association, 4th Proceeding, Oslo, Norway, August 10-14, 1981, p. 287-305.

\#1934 Isachsen, Y.W., and McKendree, W.G., 1977, Preliminary brittle structures map of New York: New York State Museum Map and Chart Series 31 A-G, 7 sheets.

\#2039 Johnston, A.C., 1989, The seismicity of 'stable continental interiors', in Gregersen, S., and Basham, P.W., eds., Earthquakes at North Atlantic passive margins-Neotectonics and postglacial rebound: Dordrecht, The Netherlands, Kluwer Academic Publishers, p. 299-327.

\#1840 Johnston, A.C., 1993, Average stable continental earthquake source parameters based on constant stress drop scaling [abs.]: Seismological Research Letters, v. 64, p. 261.

\#2040 Johnston, A.C., 1994, Seismotectonic interpretations and conclusions from the stable continental region seismicity database, in Schneider, J.F., ed., The earthquakes of stable continental regions - v. 1, Assessment of large earthquake potential: Technical report to Electric Power Research Institute TR-102261-V1, Palo Alto, California, December 1994, p. 4-1-4-103.

\#1866 Mitronovas, W., 1981, Seismicity in the upper Hudson Valley [abs.]: Earthquake Notes, v. 52 , p. $21-22$.

\#1879 Quinn, A.W., 1933, Normal faults of the Lake Champlain region: Journal of Geology, v. 41, p. 113-143.

\#2060 Turner, P.J., 1977, Seismic reflection survey in Lake Champlain: Burlington, University of Vermont, unpublished M.S. thesis, 60 p., 11 pls.

\#1918 Wold, R.J., Isachsen, Y.W., Geraghty, E.P., and Hutchinson, D.R., 1977, Seismic-reflection profiles of Lake George, Adirondack Mountains, New York, as a guide to the neotectonic history of the region: Geological Society of America Abstracts with Programs, v. 9, no. 7, p. 1233.

\#1922 Zoback, M.L., and Zoback, M.D., 1989, Tectonic stress field of the continental United States, in Pakiser, L.C., and Mooney, W.D., eds., Geophysical framework of the continental United States: Geological Society of America Memoir 172, p. 523-539. 


\section{Clarendon-Linden fault zone (Class C)}

Structure Name Clarendon-Linden fault zone (Class C)

Comments: The fault zone was found and named in 1920, and since then it has been mapped geologically and characterized in the subsurface, by well logging, seismic-reflection profiling, and other methods that were part of exploration for petroleum and assessment of seismic hazards (Van Tyne, 1975 \#1979; Jacobi and Fountain, 1997 \#1838; Pomeroy and others, undated \#2051). The zone is best developed in the subsurface in and below Lower Silurian rocks (Van Tyne, 1975 \#1979). Its surface expression is subtle (Fakundiny and others, 1978 \#2012; Jacobi and Fountain, 1993 \#1837). The fault zone extends at least $94 \mathrm{~km}$ from near the shoreline of Lake Ontario in Orleans County, western New York State, south-southwestward at least into northern Allegany County (Fakundiny and others, 1978 \#2012; Jacobi and Fountain, 1993 \#1837). The fault zone comprises three main strands along most of its length as Van Tyne (1975 \#1979) mapped it from well data, and from a width of $6 \mathrm{~km}$ in the north, it widens southward to $17 \mathrm{~km}$ in the south. In addition, the zone might extend across Lake Ontario to its north shore (Fakundiny and others, 1978 \#2012; Hutchinson and others, 1979 \#1836; McFall, 1993 \#1859). Recent work has extended the zone southward into central Allegany County, near the Pennsylvania border, where the zone contains as many as 17 faults (Jacobi and Fountain, 1993 \#1837).

Reason for assignment to class C: This evaluation of Quaternary faulting is not a reliable guide to seismic hazard of the Clarendon-Linden fault zone. The most authoritative and reliable assessment of the seismic hazard in the area evaluated here is the national seismic hazard maps, which are published by the USGS (Open-File Report 97-131, 12 maps, scale 1:7,000,000; http://geohazards.cr.usgs.gov/eq/). In the Central and Eastern U.S. (CEUS) east of the Rocky Mountain Front, the distribution of historical earthquakes is a reasonable guide to seismic hazard. In the CEUS, the national seismic hazard maps rely mainly on the distribution of historical seismicity to calculate the hazard. In contrast to examining the area's historical seismicity, this discussion focuses on surficial evidence of large, prehistoric earthquakes. Where present, this surficial evidence will be integrated with the historical seismicity to improve future versions of the national hazard maps. In the CEUS, the most common types of surficial evidence of large, prehistoric earthquakes are liquefaction features and faults that offset young strata. However, in some areas the surficial record of large, prehistoric earthquakes is incomplete because of erosion, equivocal, or presently unrecognized. Nonetheless, the national hazard maps show that, for many parts of the CEUS, although convincing surficial evidence of large, prehistoric earthquakes is absent, these areas are NOT free of seismic hazard. The occurrence of significant historical earthquakes in the area described here demonstrates a notable level of seismic hazard.

Although seismological evidence indicates that the mapped fault zone is probably undergoing seismic reactivation in the present-day compressional stress field, there is no paleoseismological evidence for prehistoric Quaternary seismic reactivation. The Clarendon-Linden fault zone was assessed for three reasons.

The fault zone is a member of a family of Late Proterozoic-Cambrian normal faults that formed during the rifting episode that initiated the Iapetus Ocean (Wheeler, 1995 \#1914; Wheeler, 1996 \#1916; Jacobi and Fountain, 1997 \#1838; Jacobi and Fountain, 1998 \#1839; 
Pomeroy and others, undated \#2051). Other members of the fault family are inferred to be the sources of damaging earthquakes in Quebec, Virginia, and perhaps Tennessee (Wheeler, 1995 \#1914). Thus, the age and likely extensional origin of the Clarendon-Linden fault zone indicates a potential for seismic reactivation.

Three observations indicate that the fault zone might be close to failure. First, fluid injection induced small, shallow earthquakes on one or more of the fault strands (Fletcher and Sykes, 1977 \#1823). Second, epicenters of small earthquakes cluster between and near the strands of the fault zone (Fletcher and Sykes, 1977 \#1823; Seeber and Armbruster, 1993 \#1892). Third, at approximately the time of the 1988 Saguenay earthquake in Quebec, new gas seeps formed near the main strand of the fault zone, and were sufficiently energetic to spatter mud into nearby tree tops (Jacobi and Fountain, 1993 \#1837).

Medium-sized earthquakes are spatially associated with the fault zone. On August 12, 1929, a damaging shock occurred near Attica, near the trace of the fault zone, although the epicenter has a locational uncertainty of approximately $20 \mathrm{~km}$ (Metzger and Johnston, 1994 \#2064, p. NA-128). The intensity was MMI VIII (Stover and Coffman, 1993 \#1986) and the moment magnitude was Mw 4.9 (Johnston, 1994 \#2040). Two more recent earthquakes had epicentral uncertainties of approximately $5 \mathrm{~km}$, and their epicenters were inside the 14-km-wide fault zone (Herrmann, 1978 \#1830; Mw 4.2 on January 1, 1966 and Mw 4.1 on June 13, 1967 Johnston, 1994 \#2042; Metzger and Johnston, 1994 \#2064, p. NA-128). Each of these two earthquakes had a focal mechanism with a nodal plane striking approximately N. $20^{\circ}$ E. and dipping approximately $70^{\circ} \mathrm{SE}$, parallel to the surrounding strands of the fault zone (Herrmann, 1978 \#1830; Pomeroy and others, undated \#2051). P-axes indicated dextral reverse slip, consistent with the ambient east-northeast trend of the greatest horizontal compressional stress. Depths were 2-3 km (Herrmann, 1978 \#1830). Well logs and seismic reflection profiles allow the nearby fault strands to be traced nearly to the depths of the hypocenters (Van Tyne, 1975 \#1979; Fakundiny and others, 1978 \#2012; Pomeroy and others, undated \#2051). Johnston (1993 \#1840) estimated that earthquakes of this size in stable continental regions like western New York State might typically have rupture zones with diameters of 0.6 $\mathrm{km}$. Presumably rupture zones of this size would have occurred on faults at least several times larger, and the only large faults known in the area at the shallow depths of the hypocenters are the strands of the Clarendon-Linden fault zone. Thus, the locations, depths, rupture-zone sizes, and nodal-plane orientations of the 1966 and 1967 earthquakes are unusually good matches to the locations, depths, and orientations of the strands of the Clarendon-Linden fault zone.

However, there is no paleoseismological evidence that the fault zone has slipped during the Quaternary. Tuttle and others (1995 \#1909; 1995 \#2240; 1996 \#1910) searched for, but did not find, historic or prehistoric liquefaction features in the liquefiable deposits in the meizoseismal area of the 1929 Attica earthquake and south of Attica along the fault zone. Various soft-sediment structures were observed, but all could be more reasonably attributed to glacial, sedimentological, or mass wasting processes (Tuttle and others, 1995 \#1909; 1995 \#2240; 1996 \#1910; Young and Jacobi, 1998 \#1921). The lack of observed paleoliquefaction features may indicate that earthquakes of Mw larger than 6 have not occurred along the ClarendonLinden fault zone during the last 12,000 years (Tuttle and others, 1995 \#2240). However, smaller earthquakes could occur without leaving a detectable paleoliquefaction record, and the 
1929 earthquake demonstrated that smaller earthquakes can occur on or near the fault zone. Accordingly, the Clarendon-Linden fault zone is assigned to class $\mathrm{C}$ because of a lack of paleoseismological evidence for Quaternary faulting, although seismological evidence indicates that probably the zone was active during this century.

Date of compilation 04/24/98; revised 01/31/00

Compiler and affiliation Russell L. Wheeler, U.S. Geological Survey

State New York

County Genesee; Orleans, Wyoming, Allegany, Monroe

$1^{\circ} \times 2^{\circ}$ sheet Buffalo; Toronto

Physiographic province Central Lowland; Appalachian Plateaus

\section{References}

\#2012 Fakundiny, R.H., Myers, J.T., Pomeroy, P.W., Pferd, J.W., and Nowak, T.A., Jr., 1978, Structural instability features in the vicinity of the Clarendon-Linden fault system, western New York and Lake Ontario, in Thompson, J.C., ed., Advances in analysis of geotechnical instabilities: Waterloo, Ontario, Canada, University of Waterloo Press, Solid Mechanics Division Study 13, p. 121-178.

\#1823 Fletcher, J.B., and Sykes, L.R., 1977, Earthquakes related to hydraulic mining and natural seismic activity in western New York State: Journal of Geophysical Research, v. 82 , p. $3767-3780$.

\#1830 Herrmann, R.B., 1978, A seismological study of two Attica, New York earthquakes: Bulletin of the Seismological Society of America, v. 68, p. 641-651.

\#1836 Hutchinson, D.R., Pomeroy, P.W., Wold, R.J., and Halls, H.C., 1979, A geophysical investigation concerning the continuation of the Clarendon-Linden fault across Lake Ontario: Geology, v. 7, p. 206-210.

\#1837 Jacobi, R., and Fountain, J., 1993, The southern extension and reactivations of the Clarendon-Linden fault system: Géographie physique et Quaternaire, v. 47, p. 285-302.

\#1838 Jacobi, R., and Fountain, J., 1997, Discrimination of tectonic and nontectonic faults-A case study involving 11 integrated techniques [abs.]: Eos, Transactions of the American Geophysical Union, v. 78, no. 17, p. 316.

\#1839 Jacobi, R.D., and Fountain, J., 1998, Characteristics of the basement-controlled faults of the Clarendon-Linden fault system-Evidence from seismic reflection profiles for local multiple Phanerozoic reactivations during far-field orogenies: Geological Society of America Abstracts with Programs, v. 30, no. 1, p. 27.

\#1840 Johnston, A.C., 1993, Average stable continental earthquake source parameters based on constant stress drop scaling [abs.]: Seismological Research Letters, v. 64, p. 261.

\#2042 Johnston, A.C., 1994, Appendix C-Summary tables, SCR seismicity data base, in Schneider, J.F., ed., The earthquakes of stable continental regions-v. 2-Appendices A to E: Technical report to Electric Power Research Institute TR-102261-V2, Palo Alto, California, December 1994, p. C-1-C-46. 
\#2040 Johnston, A.C., 1994, Seismotectonic interpretations and conclusions from the stable continental region seismicity database, in Schneider, J.F., ed., The earthquakes of stable continental regions - v. 1, Assessment of large earthquake potential: Technical report to Electric Power Research Institute TR-102261-V1, Palo Alto, California, December 1994, p. 4-1-4-103.

\#1859 McFall, G.H., 1993, Structural elements and neotectonics of Prince Edward County, southern Ontario: Géographie physique et Quaternaire, v. 47, p. 303-312.

\#2064 Metzger, A.G., and Johnston, A.C., 1994, The stable continental region seismicity database, in Schneider, J.F., ed., The earthquakes of stable continental regions-v. 3 and 4, Appendix F, Seismicity data sheets: Technical report to Electric Power Research Institute TR-102261-V2 and V3, Palo Alto, California, December 1994, 1656 p.

\#2051 Pomeroy, P.W., Nowak, T.A., Jr., and Fakundiny, R.H., undated, Clarendon-Linden fault system of western New York-A Vibroseis ${ }^{\circledR}$ seismic study: New York State Geological Survey Open-File Report, 66 p.

\#1892 Seeber, L., and Armbruster, J.G., 1993, Natural and induced seismicity in the Lake ErieLake Ontario region-Reactivatioin of ancient faults with little neotectonic displacement: Géographie physique et Quaternaire, v. 47, p. 363-378.

\#1986 Stover, C.W., and Coffman, J.L., 1993, Seismicity of the United States, 1568-1989 (revised): U.S. Geological Survey Professional Paper 1527, 418 p.

\#1909 Tuttle, M.P., Dyer-Williams, K., and Barstow, N., 1995, Limits on the earthquake potential of the Clarendon-Linden fault system in western New York State: Geological Society of America Abstracts with Programs, v. 27, p. A-395.

\#1910 Tuttle, M.P., Dyer-Williams, K., and Barstow, N., 1996, Seismic hazard implications of a paleoliquefaction study along the Clarendon-Linden fault system in western New York State: Geological Society of America Abstracts with Programs, v. 28, no. 3, p. 106.

\#2240 Tuttle, M.P., Dyer-Williams, K., and Barstow, N.L., 1995, Paleoliquefaction study along the Clarendon-LInden fault system, in Jacobi, R., and Fountain, J., eds., Determination of the seismic potential of the Clarendon-Linden fault system in Allegany County: Final Report to New York State Energy Research and Development Agency, p. 2106, 31 pls.

\#1979 Van Tyne, A.M., 1975, Subsurface investigation of the Clarendon-Linden structure, western New York: New York State Geological Survey Open-File Report, 14 p., 5 pls., scale 1:62,500.

\#1914 Wheeler, R.L., 1995, Earthquakes and the cratonward limit of Iapetan faulting in eastern North America: Geology, v. 23, p. 105-108.

\#1916 Wheeler, R.L., 1996, Sources of seismic hazard near the eastern Great Lakes: Geological Society of America Abstracts with Programs, v. 28, no. 3, p. 110.

\#1921 Young, R.A., and Jacobi, R.D., 1998, Bedrock-till deformation structure along the Clarendon-Linden fault zone near Linden, NY-Tectonic or glacial origin?: Geological Society of America Abstracts with Programs, v. 30, no. 1, p. 85. 


\section{Cooke fault (Class C)}

Structure Name Cooke fault (Class C)

Comments: Seismic-reflection profiles in the meizoseismal area of the 1886 earthquake at Charleston, South Carolina, showed several subsurface faults. One, named the Cooke fault by Behrendt and others (1981 \#1794) and Hamilton and others (1983 \#1965), strikes approximately N. $65^{\circ} \mathrm{E}$. and dips $70^{\circ} \mathrm{NW}$ with a length of approximately $10 \mathrm{~km}$. The deepest reflector is disrupted by the fault and shallower reflectors are flexed over the disruption, with the hanging wall up. Offsets of individual reflectors increase downward from $20 \mathrm{~m}$ to $190 \mathrm{~m}$, indicating persistent reverse slip (Behrendt and others, 1981 \#1794; Hamilton and others, 1983 \#1965). At its northeast end, the Cooke fault enters a diffuse cluster of epicenters (Behrendt and others, 1981 \#1794; Hamilton and others, 1983 \#1965), but without a cross section showing precise hypocenter locations this map-view spatial association cannot be evaluated. Marple and Talwani (1993 \#1857) and Talwani and Marple (1997 \#2236) suggested that the Cooke fault might be part of a longer, more northerly striking fault, based on additional seismic-reflection profiles and reinterpretations of some results of Hamilton and others (1983 \#1965).

Reason for assignment to class C: A reflector at a depth of $150 \mathrm{~m}$, which corresponds to an Eocene unconformity, is flexed over the fault to produce $20 \mathrm{~m}$ of offset (Behrendt and others, 1981 \#1794; Hamilton and others, 1983 \#1965). This is the youngest reported deformation attributable to the Cooke fault. Therefore, the Cooke fault is assigned to class $\mathrm{C}$ for lack of evidence of faulting younger than Eocene.

Date of compilation 06/04/98; 01/28/00

Compiler and affiliation Russell L. Wheeler, U.S. Geological Survey

State South Carolina

County Dorchester

$1^{\circ} \times 2^{\circ}$ sheet Savannah

Physiographic province Coastal Plain

\section{References}

\#1794 Behrendt, J.C., Hamilton, R.M., Ackermann, H.D., and Henry, V.J., 1981, Cenozoic faulting in the vicinity of the Charleston, South Carolina, 1886 earthquake: Geology, v. 9 , p. 117-122.

\#1965 Hamilton, R.M., Behrendt, J.C., and Ackermann, H.D., 1983, Land multichannel seismic-reflection evidence for tectonic features near Charleston, South Carolina, in Gohn, G.S., ed., Studies related to the Charleston, South Carolina, earthquake of 1886-Tectonics and seismicity: U.S. Geological Survey Professional Paper 1313, p. I1-I18.

\#1857 Marple, R.T., and Talwani, P., 1993, Evidence of possible tectonic upwarping along the South Carolina coastal plain from an examination of river morphology and elevation data: Geology, v. 21, p. 651-654. 
\#2236 Talwani, P., and Marple, R.T., 1997, Evidence of neotectonic activity in the South Carolina Coastal Plain, in Hong, Y., ed. Contemporary lithospheric motion/seismic geology: Utrecht, The Netherlands, VSP, International Geological Congress, 30th, Beijing, China, August 4-14, 1996, v. 5, p. 49-61. 


\section{Cornwall-Massena earthquake (Class C)}

Structure Name Cornwall-Massena earthquake (Class C)

Comments: The damaging earthquake of September 5, 1944 had a moment magnitude of $\mathbf{M}$ 5.8 and caused damage of Modified Mercalli intensity VIII (Stover and Coffman, 1993 \#1986; Bent, 1996 \#2195). Tuttle (1996 \#2239) summarized a 1945 report by C.P. Berkey that documents ground fissures and sand vents attributed to the earthquake.

Reason for assignment to class C: This evaluation of Quaternary faulting is not a reliable guide to seismic hazard of the vicinity of the Cornwall-Massena earthquake. The most authoritative and reliable assessment of the seismic hazard in the area evaluated here is the national seismic hazard maps, which are published by the USGS (Open-File Report 97-131, 12 maps, scale 1:7,000,000; http://geohazards.cr.usgs.gov/eq/). In the Central and Eastern U.S. (CEUS) east of the Rocky Mountain Front, the distribution of historical earthquakes is a reasonable guide to seismic hazard. In the CEUS, the national seismic hazard maps rely mainly on the distribution of historical seismicity to calculate the hazard. In contrast to examining the area's historical seismicity, this discussion focuses on surficial evidence of large, prehistoric earthquakes. Where present, this surficial evidence will be integrated with the historical seismicity to improve future versions of the national hazard maps. In the CEUS, the most common types of surficial evidence of large, prehistoric earthquakes are liquefaction features and faults that offset young strata. However, in some areas the surficial record of large, prehistoric earthquakes is incomplete because of erosion, equivocal, or presently unrecognized. Nonetheless, the national hazard maps show that, for many parts of the CEUS, although convincing surficial evidence of large, prehistoric earthquakes is absent, these areas are NOT free of seismic hazard. The occurrence of significant historical earthquakes in the area described here demonstrates a notable level of seismic hazard.

The two reported searches for paleoseismological evidence of Quaternary faulting in the epicentral area found none. First, Coates (1975 \#3899) examined soft-sediment features, such as folded and contorted beds and load structures, and attempted to distinguish the numerous features of likely glacial origin from a possible few of seismic origin. The attempt was unsuccessful. Such features have been observed to form with and without seismic shaking, but there is still no reliable, widely recognized way to distinguish those of seismic and nonseismic origins (Obermeier, 1996 \#2256). Second, Tuttle (1996 \#2239) investigated two air photo linears corresponding to the locations and orientations of ground fissures that were noted in a 1945 report of C.P. Berkey. Tuttle (1996 \#2239) opened four trenches near and possibly across the linears. No unequivocal earthquake-induced liquefaction or paleoliquefaction features were found. Much of the study site had been disturbed by construction or other human activity. Sand diapirs and dewatering structures were observed in sediments exposed in two trenches. These features are indicative of liquefaction, but by themselves do not constitute evidence of ground shaking. Accordingly, the epicentral area of the Cornwall-Massena earthquake is assigned to class $\mathrm{C}$ in this compilation, because of the lack of paleoseismological evidence of prehistoric Quaternary seismic faulting.

Date of compilation $08 / 20 / 98$; revised $1 / 31 / 00$

Compiler and affiliation Russell L. Wheeler, U.S. Geological Survey

State New York; Ontario 
County St. Lawrence

$1^{\circ} \times 2^{\circ}$ sheet Ogdensburg

Physiographic province St. Lawrence Valley

\section{References}

\#2195 Bent, A.L., 1996, Source parameters of the damaging Cornwall-Massena earthquake of 1944 from regional waveforms: Bulletin of the Seismological Society of America, v. 86, p. 489-497.

\#3899 Coates, D.R., 1975, Identification of late Quaternary sediment deformation and its relation to seismicity in the St. Lawrence lowland, New York: Report to New York State Atomic and Space Development Authority, Contract agreement 17333, 268 p.

\#2256 Obermeier, S.F., 1996, Use of liquefaction-induced features for paleoseismic analysisAn overview of how seismic liquefaction features can be distinguished from other features and how their regional distribution and properties of source sediment can be used to infer the location and strength of Holocene paleo-earthquakes: Engineering Geology, v. 44, p. 1-76.

\#1986 Stover, C.W., and Coffman, J.L., 1993, Seismicity of the United States, 1568-1989 (revised): U.S. Geological Survey Professional Paper 1527, 418 p.

\#2239 Tuttle, M.P., 1996, Case study of liquefaction induced by the 1944 Massena, New YorkCornwall, Ontario earthquake: U.S. Nuclear Regulatory Commission NUREG/CR$6495,24 \mathrm{p}$. 


\section{Criner fault (Class C)}

Structure Name Criner fault (Class C)

Reason for assignment to Class C: Interest in possible Quaternary reactivation of the Criner fault developed shortly after paleoseismic studies confirmed the existence of Holocene movement on the Meers fault. The only detailed investigations to examine evidence of Quaternary reactivation of the fault have been done by Geomatrix Consultants, San Francisco, California, who conducted these studies under contract with the U.S. Nuclear Regulatory Commission (NRC). The most comprehensive description of these studies is a draft version of the final project report that was submitted to the NRC in July 1993 (Swan and others, written commun. 1993 \#675). Kelson and others (1990 \#683) published an abstract that contains some information about these studies, but the subsequent work described in Swan and others (written commun. 1993 \#675) raises questions about the validity of evidence of latest Pleistocene movement cited by Kelson and others. Subsequent investigations favor a landslide origin rather than a tectonic origin for the geomorphic features that are suggestive of Quaternary movement (Hanson and others, 1997 \#2639). Because conclusive evidence of Quaternary movement on the fault has yet to be discovered and documented, this feature is classified as a Class C feature.

The Criner fault is located at the southeastern end of the Meers-Duncan-Criner fault system (Swan and others, written commun. 1993 \#675) in south-central Oklahoma. At its northwestern end, the fault merges with the Duncan fault in the subsurface and, at its southeastern end, it terminates against the Ouachita fold and thrust belt (Swan and others, written commun. 1993 \#675). A 12-km-long section of the fault is exposed in the Criner Hills, which coincide with the Criner uplift. In the Criner Hills, the fault strikes N. $45^{\circ} \mathrm{W}$. and separates Lower Paleozoic carbonate rocks on the northeast from Pennsylvanian carbonate and clastic rock on the southwest. Stratigraphic studies show that the sense of vertical offset on the fault changes along strike; in the Criner Hills, the sense of vertical separation is down-to-the-southwest whereas subsurface data in the area northwest of the hills show a down-to-the-northeast separation. This change in throw direction along strike suggests a significant component of lateral slip on the fault. The stratigraphy of Paleozoic rocks in basins adjacent to the Criner uplift indicate that the uplift occurred between late Mississippian and late Pennsylvanian time. Permian rocks northwest and Cretaceous rocks southeast of the Criner Hills are not offset by the fault (Hart, 1974 \#679).

The fault is marked by a prominent vegetation and topographic lineament and a linear southwest-facing hill front (Swan and others, written commun. 1993 \#675). Evidence of possible Quaternary reactivation of the fault includes topographic scarps 0.3-1.0 m high along the hill front and across drainage gullies. Along the north-central part of the exposed fault, near-vertical, southwest-facing scarps are present in limestone bedrock. Swan and others (written commun. 1993 \#675) report the presence of one or more scarps on colluvium-covered hill slopes at several locations; it is not known if the scarps are formed on the colluvium or if they are formed on bedrock which is mantled with colluvium. The topographic scarps do not cross small Holocene alluvial fans. Other geomorphic features suggestive of reactivation include deflected drainages, springs, and stream knickpoints along the trace of the fault.

The scarp on bedrock has a down-to-the-southwest sense of vertical offset, but the extremely 
linear trace of the fault is similar to many strike-slip faults. This linear trace could be an artifact of the lateral slip that occurred in Late Paleozoic time. The stratigraphy of the Upper Paleozoic rocks in the Criner Hills show that rocks northeast of the fault are uplifted relative to those southwest of the fault (Tomlinson, 1952 \#685; Hart, 1974 \#679).

The only detailed examination of the relations between the fault and Quaternary deposits have been conducted in natural exposures along Hickory Creek. Preliminary studies at this site suggested middle to late Pleistocene movement on the fault (Kelson and others, 1990 \#683), but subsequent studies led to a preferred interpretation of the evidence of apparent Quaternary faulting as a Pleistocene landslide (Swan and others, written commun. 1993 \#675). This tentative conclusion was further substantiated by mapping of additional exposures that provide evidence supporting the landslide origin for the geomorphic features. Hanson and others (1997 \#2639) cite three lines of evidence that favor a landslide origin, but they cannot preclude a tectonic faulting origin. Because no compelling evidence of Quaternary faulting is available, the Criner fault is classified as a Class $\mathrm{C}$ feature in this compilation.

Date of compilation 03/15/94; updated 04/15/98

Compiler and affiliation Anthony J. Crone, U.S. Geological Survey

State Oklahoma

County Carter, Love

$1^{\circ} \times 2^{\circ}$ sheet Ardmore

Physiographic province Central Lowlands

\section{References}

\#2639 Hanson, K.L., Swan, F.H., Wesling, J.R., and Kelson, K.I., 1997, Quaternary deformation along the Criner Fault, Oklahoma-A case study for evaluating tectonic versus landslide faulting: Eos, Transactions of the American Geophysical Union, v. 78, no. 17, p. S317.

\#679 Hart, D.L., Jr., 1974, Reconnaissance of the water resources of the Ardmore and Sherman quadrangles, southern Oklahoma: Oklahoma Geological Survey Hydrologic Atlas 3, Map HA-3, 4 sheets, scale 1:250,000.

\#683 Kelson, K.I., Swan, F.H., and Coppersmith, K.J., 1990, Implications of late Quaternary faulting along the Meers and Criner faults to assessments of seismic hazards in the Central and Eastern U.S.: Geological Society of America Abstracts with Programs, v. 22, p. 10.

\#675 Swan, F.H., Wesling, J.R., Hanson, K.A., Kelson, K.I., and Perman, R.C., written commun. 1993, Draft report-Investigation of the Quaternary structural and tectonic character of the Meers fault (southwestern Oklahoma): Technical report to U.S. Nuclear Regulatory Commission, Washington, D.C., under Contract NRC-04-87-007, July 1993, 104 p., 3 pls.

\#685 Tomlinson, C.W., 1952, Odd geologic structures of southern Oklahoma: Bulletin of the American Association of Petroleum Geologists, v. 36, p. 1820-1840. 


\section{Dobbs Ferry fault zone (Class C)}

Structure Name Dobbs Ferry fault zone (Class C)

Comments: Seeber and Dawers (1989 \#1894) and Dawers and Seeber (1991 \#1809) applied the name to a zone of abundant fractures and joints, many of them bearing slickensides, of small faults no longer than approximately $1 \mathrm{~km}$ and mostly much shorter, and of topographic lineaments. The late L.M. Hall, in a report that remains unpublished, had previously recognized the fault zone as a zone of concentrated slickensided fractures, naming it the Dobbs Ferry fracture zone (Seeber and Dawers, 1989 \#1894; Dawers and Seeber, 1991 \#1809). The fault zone extends southeastward from the east bank of the Hudson River and crosses the Bronx River to Reservoir No. 1. The fault zone strikes northwest, and is 8-10 km long and $400 \mathrm{~m}$ wide at its widest point. Mapping by Seeber and Dawers (1989 \#1894) divided the fault zone into eight straight sections approximately 0.5 to $2 \mathrm{~km}$ long, which individually strike from north-northwest to west-northwest. The individual fractures, joints, faults, and lineaments are still more diverse in their individual strikes and trends, but they, like the eight sections of the fault, have a northwesterly preferred orientation. Most of the fractures, joints, and faults dip steeply, which indicates that the fault zone as a whole may also dip steeply. Superimposed, differently oriented slickensides indicate more than one episode of slip on the fault. Most slip sense indicators are sinistral, and sinistral slip on the fault zone as a whole would be consistent with the present-day, east-northeast, regional orientation of the greatest horizontal compressive stress. However, some indicators are older and dextral, including the $30 \mathrm{~m}$ upper limit of the largest offset of a geologic contact (Seeber and Armbruster, 1989 \#2227). Epidote, chlorite, and quartz mineralization on some fracture surfaces indicates that at least the older, dextral slip occurred at depths of several kilometers (Seeber and Dawers, 1989 \#1894). Seeber and Dawers (1989 \#1894) and Dawers and Seeber (1991 \#1809) suggested that the dextral slip may date from Mesozoic extension, whereas the sinistral slip is younger and perhaps continuing.

Reason for exclusion: This evaluation of Quaternary faulting is not a reliable guide to seismic hazard of the Dobbs Ferry fault zone. The most authoritative and reliable assessment of the seismic hazard in the area evaluated here is the national seismic hazard maps, which are published by the USGS (Open-File Report 97-131, 12 maps, scale 1:7,000,000; http://geohazards.cr.usgs.gov/eq/). In the Central and Eastern U.S. (CEUS) east of the Rocky Mountain Front, the distribution of historical earthquakes is a reasonable guide to seismic hazard. In the CEUS, the national seismic hazard maps rely mainly on the distribution of historical seismicity to calculate the hazard. In contrast to examining the area's historical seismicity, this discussion focuses on surficial evidence of large, prehistoric earthquakes. Where present, this surficial evidence will be integrated with the historical seismicity to improve future versions of the national hazard maps. In the CEUS, the most common types of surficial evidence of large, prehistoric earthquakes are liquefaction features and faults that offset young strata. However, in some areas the surficial record of large, prehistoric earthquakes is incomplete because of erosion, equivocal, or presently unrecognized. Nonetheless, the national hazard maps show that, for many parts of the CEUS, although convincing surficial evidence of large, prehistoric earthquakes is absent, these areas are NOT free of seismic hazard. The occurrence of significant historical earthquakes in the area described here demonstrates a notable level of seismic hazard. 
Although seismological evidence summarized later indicates that probably the Dobbs Ferry fault zone is undergoing seismic reactivation in the present-day compressional stress field, there is no paleoseismological evidence for prehistoric Quaternary seismic reactivation. The Dobbs Ferry fault zone was considered in this compilation for two reasons.

(1) A worldwide survey of damaging earthquakes in stable continental regions found that large earthquakes occur preferentially in passive margins and continental rifts, with the preference being strongest for areas that underwent Mesozoic or Cenozoic extension (Johnston, 1989 \#2039; Johnston, 1994 \#2040). Thus, the possibility that the Dobbs Ferry fault zone formed by dextral slip during the Mesozoic extensional initiation of the Atlantic continental margin indicates possibly elevated earthquake potential.

(2) The Ardsley earthquake of October 19, 1985, and its first six located aftershocks defined a vertical, northwest-striking rupture zone with a diameter of approximately three-quarters of a kilometer (Seeber, 1987 \#2053). The main shock had a magnitude of $m_{b}(\mathrm{Lg}) 4$, which is equivalent to a moment magnitude of $\mathbf{M} 4.1$ (Johnston, 1996 \#1841). A rupture zone of the size indicated by the hypocentral distribution of the aftershocks would be typical for rupture zones of M 4.0-4.5 earthquakes in stable continental regions worldwide (Johnston, 1993 \#1840). Single-earthquake focal mechanisms of the main shock and the largest aftershock have well-constrained nodal planes that strike northwest, dip vertically for the main shock and steeply northeast for the aftershock, and underwent sinistral slip. The disk-shaped zone of hypocenters is centered five kilometers directly beneath the center of the Dobbs Ferry fault zone. Before the 1985 Ardsley earthquake, the late L.M. Hall, in a report that remains unpublished, had recognized the fault zone as a zone of concentrated slickensided fractures (Seeber and Dawers, 1989 \#1894; Dawers and Seeber, 1991 \#1809). Accordingly, Seeber (1987 \#2053), Seeber and Dawers (1989 \#1894), and Dawers and Seeber (1991 \#1809) concluded that the earthquakes probably occurred on the fault zone.

However, the earthquakes occurred too deep to produce any recognized surface cracking or rupture along the trace of the fault zone, and Seeber (1987 \#2053), Seeber and Dawers (1989 \#1894), and Dawers and Seeber (1991 \#1809) reported no other paleoseismological evidence for prehistoric Quaternary seismic faulting along the Dobbs Ferry fault zone. Accordingly, the fault zone is assigned to class $\mathrm{C}$.

Date of compilation 04/27/98; revised 01/31/00

Compiler and affiliation Russell L. Wheeler, U.S. Geological Survey

State New York

County Westchester

$1^{\circ} \times 2^{\circ}$ sheet New York; Hartford

Physiographic province Piedmont

\section{References}

\#1809 Dawers, N.H., and Seeber, L., 1991, Intraplate faults revealed in crystalline bedrock in the 1983 Goodnow and 1985 Ardsley epicentral areas, New York: Tectonophysics, v. 186, p. 115-131. 
\#2039 Johnston, A.C., 1989, The seismicity of 'stable continental interiors', in Gregersen, S., and Basham, P.W., eds., Earthquakes at North Atlantic passive margins-Neotectonics and postglacial rebound: Dordrecht, The Netherlands, Kluwer Academic Publishers, p. 299-327.

\#1840 Johnston, A.C., 1993, Average stable continental earthquake source parameters based on constant stress drop scaling [abs.]: Seismological Research Letters, v. 64, p. 261.

\#2040 Johnston, A.C., 1994, Seismotectonic interpretations and conclusions from the stable continental region seismicity database, in Schneider, J.F., ed., The earthquakes of stable continental regions - v. 1, Assessment of large earthquake potential: Technical report to Electric Power Research Institute TR-102261-V1, Palo Alto, California, December 1994, p. 4-1-4-103.

\#1841 Johnston, A.C., 1996, Seismic moment assessment of earthquakes in stable continetal regions-I. Instrumental seismicity: Geophysical Journal International, v. 124, p. 381414.

\#2053 Seeber, L., 1987, Problems in intraplate seismogenesis and earthquake hazard, in Jacob, K.H., ed., Proceedings from the symposium on seismic hazards, ground motions, soilliquefaction and engineering practice in eastern North America: National Center for Earthquake Engineering Research Technical Report NCEER-87-0025, p. 143-162.

\#2227 Seeber, L., and Armbruster, J.G., 1989, Low-displacement seismogenic faults and nonstationary seismicity in the eastern United States, in Jacob, K.H., and Turkstra, C.J., eds., Earthquake hazards and the design of constructed facilities in the eastern United States: Annals of the New York Academy of Science, v. 558, p. 21-39.

\#1894 Seeber, L., and Dawers, N., 1989, Characterization of an intraplate seismogenic fault in the Manhattan prong, Westchester Co., N.Y.: Seismological Research Letters, v. 60, p. 71-78. 


\section{Everona fault - Mountain Run fault zone (Class C)}

\section{Structure Name Everona fault - Mountain Run fault zone (Class C)}

Comments: The Everona fault cuts a gravel deposit of possible Pleistocene age, and two possible fault-line scarps on the nearby Mountain Run fault zone are of Cenozoic age.

A small, brittle fault strikes northeast near Everona. Here named the Everona fault, it cuts a gravel deposit of possible Pleistocene age. Approximately $1 \mathrm{~km}$ to the east, the Mountain Run fault zone is a zone of Paleozoic mylonite that strikes northeast for at least $100-150 \mathrm{~km}$ in the central Appalachians of Virginia (Virginia Division of Mineral Resources, 1993 \#1952). Two possible fault-line scarps on the Mountain Run fault zone are of Cenozoic age. The Everona fault and the Mountain Run fault zone are treated together here because of their geographic closeness. A photograph of the faulted gravel deposit at Everona (Manspeizer and others, 1989 \#1992) and the descriptions and geologic map of Pavlides (1994 \#1973) allow the fault and the two fault-line (?) scarps to be located on the Unionville and Germanna Bridge 1:24,000-scale topographic maps. In addition, a geologic map of the Fredericksburg 30' by 60' quadrangle is in press for publication in the U.S. Geological Survey's I-map series. The fault and scarps may be locatable on the geologic map.

Four hundred meters southwest of Everona, the small, northwest-dipping Everona fault strikes N. $55^{\circ}$ E. and offsets the base of a late Cenozoic stream gravel and associated colluvium (Pavlides and others, 1983 \#1875; Pavlides, 1994 \#1973). Pavlides and others (1983 \#1875), Prowell (1988 \#1993), Manspeizer and others (1989 \#1992), and Pavlides (1994 \#1973) referred to the Everona fault as reverse. Vertical offset is $1.5 \mathrm{~m}$ (Pavlides and others, 1983 \#1875; Pavlides, 1994 \#1973). Pavlides and others (1983 \#1875) and Pavlides (1994 \#1973) gave the dip as $20^{\circ}$ and noted that the fault is one of two or more low-angle reverse faults that cut the basal stream gravel. In actuality, the fault dips steeply and flattens upward: dip is $55^{\circ}$ $\mathrm{NW}$ in saprolite, $33^{\circ}$ at the top of the saprolite, and $15^{\circ}$ in overlying alluvium and colluvium (D.C. Prowell, unpub. data). The Everona fault cuts a gravel layer that forms the base of a stream channel deposit. Pavlides and others (1983 \#1875) estimated the age of the gravel as "probable late Tertiary". Prowell (1988 \#1993) and Manspeizer and others (1989 \#1992) estimated the age as Pleistocene (?). Pavlides (1994 \#1973) estimated the age as late Cenozoic. The Everona fault and its offset have no geomorphic expression (Pavlides and others, 1983 \#1875; Manspeizer and others, 1989 \#1992).

Approximately $1 \mathrm{~km}$ east of the Everona fault, the Mountain Run fault zone strikes N. $40^{\circ}$ E. and separates metamorphic rocks of the Piedmont province on the southeast from those of the Blue Ridge province on the northwest (Virginia Division of Mineral Resources, 1993 \#1952; Pavlides, 1994 \#1973). The fault zone originated in the early Paleozoic and is inferred to have been reactivated during Mesozoic extension, so that part of the fault zone now forms part of the southeastern border of the Mesozoic Culpeper basin (Pavlides and others, 1983 \#1875; Pavlides, 1994 \#1973). The fault zone varies dramatically in width, from a few hundred meters or less to as wide as 4-5 km (Pavlides, 1994 \#1973). Two scarps align along the Mountain Run fault zone and face northwest. Near the northeastern end of the fault zone, the Kellys Ford scarp of Pavlides (1987 \#2017) is $2 \mathrm{~km}$ long and is interpreted as related to the southeastern border fault of the Mesozoic Culpeper basin (Pavlides, 1994 \#1973). Beginning approximately $16 \mathrm{~km}$ farther southwest along the Mountain Run fault zone, the Mountain Run 
scarp of Pavlides (1987 \#2017) extends along the fault zone for another $13 \mathrm{~km}$, including the vicinity of the Everona fault. Between the two scarps, the border fault of the Culpeper basin diverges westward from the Mountain Run fault zone, so that the border fault is several kilometers west of the Mountain Run scarp (Pavlides, 1994 \#1973). Pavlides (1994 \#1973) considered the Kellys Ford and Mountain Run scarps to be Cenozoic fault-line scarps formed by normal slip on northwest-dipping faults. Alternatively, the scarps could have formed as southeastward-migrating streams impinged against resistant mylonites of the Mountain Run fault zone.

If the Kellys Ford and Mountain Run scarps are fault-line scarps, the age of their faulted deposits is Cenozoic and possibly Pleistocene (Pavlides, 1994 \#1973). Topographic maps show that the Kellys Ford and Mountain Run scarps face northwest. If they are resequent fault-line scarps, their northwest sides dropped down. Probably the Kellys Ford scarp would be part of the southeast border fault of the Mesozoic Culpeper extensional basin, so probably the underlying fault would dip northwest and the Kellys Ford scarp would have formed by normal slip (Pavlides, 1994 \#1973). However, normal slip is possible but unlikely in the Cenozoic environment of compressive stress in which the scarp probably formed. Elsewhere, the Mountain Run fault zone probably dips southeast (Pavlides, 1994 \#1973). If the Mountain Run scarp formed by young slip along a southeast-dipping strand of the fault zone, then the scarp would have been uplifted in reverse slip, in contrast to a suggestion of normal faulting by Pavlides (1994 \#1973). The existence, magnitude, and sense of any strike slip components cannot be evaluated with present information. However, the easterly to northeasterly trend of present-day compressive stress in this part of Virginia (Zoback and Zoback, 1989 \#1922) would lead one to expect that any young strike slip components should be dextral.

The Kellys Ford scarp is formed in resistant Paleozoic phyllites, with Mesozoic strata and Quaternary alluvium underlying the lowlands to the northwest (Pavlides, 1994 \#1973). The Germanna Bridge 1:24,000-scale topographic map shows that the scarp is $2 \mathrm{~km}$ long and 80$120 \mathrm{ft}(24-37 \mathrm{~m})$ high. Sixteen $\mathrm{km}$ and more to the southwest, Paleozoic phyllites underlie the Mountain Run scarp and the uplands to its southeast, and Quaternary alluvium fills the narrow valley of Mountain Run at the northwest foot of the scarp. The Unionville 1:24,000-scale topographic map shows that the scarp is $13 \mathrm{~km}$ long and 60-120 ft (18-37 m) high. The northwest side of Mountain Run valley exposes Paleozoic phyllites, slates, siltstones, and argillites in hills that are gentler and approximately $50 \mathrm{ft}(15 \mathrm{~m})$ lower than the top of the Mountain Run scarp. If the Kellys Ford and Mountain Run scarps are fault-line scarps, as interpreted by Pavlides (1994 \#1973), then the lower elevations on their northwest sides would be consistent with their inferred formation by normal slip on northwest-dipping faults (Pavlides, 1994 \#1973). However, flights of terraces exist on the northwest side of Mountain Run valley. The terraces indicate uplift of the northwest side of the Mountain Run fault zone, inconsistently with the interpretation of Pavlides (1994 \#1973) but consistently with the northwest dip of the reverse Everona fault.

Reason for assignment to class $\mathbf{C}$ The faulting at Everona is likely to be of Quaternary age, but the likelihood has not been tested by detailed paleoseismological or other investigations. Prowell (1988 \#1993) and Manspeizer and others (1989 \#1992) estimated the age of the Everona fault as Pleistocene (?). The fault "extends into the solum" (Pavlides and others, 1983 $\# 1875)$. The $1.5 \mathrm{~m}$ offset may have formed during a single earthquake during or before the 
Quaternary. The fault flattens upward from saprolite into alluvium and colluvium. A deep, well-developed soil profile exists on both sides of the Everona fault, but the upper soil horizons have been eroded at the fault, which indicates that reverse slip on the upward-flattening fault domed the soil and led to its partial erosion (W.L. Newell, unpub. data). The heights of the Kellys Ford and Mountain Run scarps indicate that they might have formed in several faulting events, the last one or more of which may have been Quaternary. Pavlides (1994 \#1973) argued that the rugged topography of both scarps indicates relative youth. Thus, Quaternary reactivation of the Everona fault or some part of the Mountain Run fault zone is likely.

Slip rates are unknown because ages of faulted materials are poorly constrained. Vertical offset on the Everona fault is $1.5 \mathrm{~m}$ (Pavlides and others, 1983 \#1875). Fault dip is $55^{\circ}$. If the offset formed at 1.6 Ma, then the rate of Quaternary dip slip would be much less than 0.2 $\mathrm{mm} / \mathrm{yr}$.

Date of compilation 12/15/98; revised 01/28/00

Compiler and affiliation Russell L. Wheeler, Wayne L. Newell, and David C. Prowell, U.S. Geological Survey

State Virginia

County Orange; Culpeper; Fauquier

$1^{\circ} \times 2^{\circ}$ sheet Washington

Physiographic province Piedmont

\section{References}

\#1992 Manspeizer, W., DeBoer, J., Costain, J.K., Froelich, A.J., Çoruh, C., Olsen, P.E., McHone, G.J., Puffer, J.H., and Prowell, D.C., 1989, Post-Paleozoic activity, in Hatcher, R.D., Jr., Thomas, W.A., and Viele, G.W., eds., The Appalachian-Oachita Orogen in the United States: Boulder, Colorado, Geological Society of America, The Geology of North America, v. F-2, p. 319-374.

\#2017 Pavlides, L., 1987, Mountain Run fault zone of Virginia, in Jacobson, M.L., and Rodriguez, T.R., eds., National Earthquake Hazards Reduction Program summaries of technical reports, v. XXIII: U.S. Geological Survey Open-File Report 87-63, p. 93-94.

\#1973 Pavlides, L., 1994, Continental margin deposits and the Mountain Run fault zone of Virginia-Stratigraphy and tectonics, in Drake, A.A., and Pavlides, L., eds., Stratigraphic notes, 1993: U.S. Geological Survey Bulletin 2076, p. B1-B9.

\#1875 Pavlides, L., Bobyarchick, A.R., Newell, W.L., and Pavich, M.J., 1983, Late Cenozoic faulting along the Mountain Run fault zone, central Virginia Piedmont: Geological Society of America Abstracts with Programs, v. 15, no. 2, p. 55.

\#1993 Prowell, D.C., 1988, Cretaceous and Cenozic tectonism on the Atlantic coastal margin, in Sheridan, R.E., and Grow, J.A., eds., The Atlantic continental margin, U.S.: Boulder, Colorado, Geological Society of America, The Geology of North America, v. I-2, p. 557-564. 
\#1952 Virginia Division of Mineral Resources, 1993, Geologic map of Virginia: Virginia Division of Mineral Resources, 1 sheet, scale 1:500,000.

\#1922 Zoback, M.L., and Zoback, M.D., 1989, Tectonic stress field of the continental United States, in Pakiser, L.C., and Mooney, W.D., eds., Geophysical framework of the continental United States: Geological Society of America Memoir 172, p. 523-539. 


\section{Hares Crossroads fault (Class C)}

Structure Name Hares Crossroads fault (Class C)

Comments: A single reverse fault exposed in a road cut offsets the basal contact of Coastal Plain sediments of undetermined age. This is fault no. 46 of Prowell (1983 \#1951).

Daniels and others (1972 \#2067, figure 1) showed the location of the faulted exposure on their planimetric map of their field trip route, at a scale of approximately 1:1,000,000. However, their road log allowed Prowell (1983 \#1951) to locate the exposure at lat. $35^{\circ} 40^{\prime} \mathrm{W}$., long. $78^{\circ} 15^{\prime} \mathrm{W}$. Daniels and others (1972 \#2067) mentioned and sketched the fault as their field trip stop 7. Daniels and others (1972 \#2067) mentioned two more faults in the next 20 miles (36 $\mathrm{km}$ ) of their road log, but did not describe them. Prowell (1983 \#1951, fault no. 46) revisited the exposure of the fault at stop 7 and gave its location as "North side of State Rt. 42 about 0.05 mi. west of junction with State Rt. 39 at Hares Crossroads." Because no one has named the fault, I give it the name of the nearest named geographic feature.

The exposure is in the middle Coastal Plain, which is underlain by Paleozoic metamorphic rocks. Here and there, the deeply weathered Paleozoic rocks are exposed as saprolite. The Coastal Plain strata in the exposure are of undetermined age (Daniels and others, 1972 \#2067; Prowell, 1983 \#1951). Daniels and others (1972 \#2067) observed reverse displacement of saprolite over sediments, and gave the orientation of the fault as N. $7^{\circ}$ E. / $63^{\circ} \mathrm{SE}$. Prowell (1983 \#1951, sheet 1) noted that the "Geometry of ... unconformity on adjacent sides of fault plane suggests that significant lateral offset may have occurred on fault." The east to northeast trend of regional greatest horizontal compression (Zoback and Zoback, 1989 \#1922) implies that a dextral component is likely, but none has been reported. The geomorphic expression of the fault is negligible at most. The sketch of Daniels and others (1972 \#2067) shows a hill approximately $1 \mathrm{ft}(0.3 \mathrm{~m})$ tall above the hanging wall of the fault, but does not mention whether the hill is likely to be tectonic or erosional.

Reason for assignment to class $\mathbf{C}$ The faulting is not demonstrably of Quaternary age. No detailed studies are known to have been performed. More recently than 1972, field inspection of the hillside site indicated that the offset shown by Daniels and others (1972, \#2067) may be localized, which may suggest a landslide more than a tectonic fault (C.H. Gardner, oral commun., 2/25/00). A reconnaissance trench in a field atop the road cut exposed a stream lag deposit with approximately 10 feet $(3 \mathrm{~m})$ of dip separation; the fault trace was not visible (R.T. Marple, oral commun., 2/16/00). These observations are consistent with the field sketch of Daniels and others (1972, \#2067). Prowell (1983 \#1951) measured the dip slip as approximately $2.8 \mathrm{~m}(9 \mathrm{ft})$ vertically and at least $2 \mathrm{~m}(6 \mathrm{ft})$ horizontally. The components of dip slip imply $11 \mathrm{~m}$ of dip slip. If this slip occurred since approximately the beginning of the Quaternary, the slip rate would be much less than $0.2 \mathrm{~mm} / \mathrm{yr}$. Any component of dextral slip would increase the slip rate.

Date of compilation 12/15/98; revised 02/22/00

Compiler and affiliation Russell L. Wheeler, U.S. Geological Survey

State North Carolina

County Johnston 
$1^{\circ} \times 2^{\circ}$ sheet Raleigh

Physiographic province Coastal Plain

\section{References}

\#2067 Daniels, R.B., Gamble, E.E., Wheeler, W.H., and Holzhey, C.S., 1972, Field Trip Guidebook 13: Raleigh, Carolina Geological Society, Carolina Geological Society and Atlantic Coastal Plain Geological Association, Annual Meetings and Field Trip, October 7-8, 1972, Guidebook, 68 p.

\#1951 Prowell, D.C., 1983, Index of faults of Cretaceous and Cenozoic age in the Eastern United States: U.S. Geological Survey Miscellaneous Field Studies Map MF-1269, 2 sheets, scale 1:2,500,000.

\#1922 Zoback, M.L., and Zoback, M.D., 1989, Tectonic stress field of the continental United States, in Pakiser, L.C., and Mooney, W.D., eds., Geophysical framework of the continental United States: Geological Society of America Memoir 172, p. 523-539. 


\section{Helena Banks fault zone (Class C)}

Structure Name Helena Banks fault zone (Class C)

Comments: Marine seismic-reflection profiles offshore from the meizoseismal area of the 1886 earthquake at Charleston, South Carolina, showed several faults beneath the sea bottom. One, named the Helena Banks fault by Behrendt and others (1981 \#1794; 1983 \#1963) and renamed the Helena Banks fault zone by Behrendt and Yuan (1987 \#1795), trends subparallel to the shoreline 13-40 km offshore from the Charleston area. The fault zone strikes approximately N. $66^{\circ} \mathrm{E}$. and dips $70^{\circ} \mathrm{NW}$ with a length of approximately $110 \mathrm{~km}$. The zone comprises several 10-40 $\mathrm{km}$ sections that step left along the zone. The deeper reflectors are disrupted by the faults and shallower reflectors are flexed over them, with the hanging walls up. Offsets of individual reflectors increase downward, indicating persistent reverse slip (Behrendt and others, 1981 \#1794; Behrendt and others, 1983 \#1963; Behrendt and Yuan, 1987 \#1795).

Reason for assignment to class C: There is no reported evidence for slip younger than Miocene on the Helena Banks fault zone. "The strata represented by the shallowest observed deformed reflections are probably Miocene clay" (see p. J9 in Behrendt and others, 1983 \#1963). Overlying, apparently undeformed material may be younger, but it is acoustically transparent and any deformation that might be present in it would not be recognizable in seismic-reflection profiles (Behrendt and others, 1981 \#1794; Behrendt and others, 1983 \#1963; Behrendt and Yuan, 1987 \#1795). Quaternary deposits have been mapped (McCartan and others, 1990 \#1969) and dated (Szabo, 1985 \#1901) on the Coastal Plain opposite the fault zone. The deposits range from early Pleistocene to Holocene in age, and form at least six transgressive-regressive sequences that are dominated by unconsolidated sand. The Quaternary deposits are 5-25 m thick, and are underlain by unconsolidated to lithified Tertiary strata. Judging from outcrop photographs of McCartan and others (1990 \#1969), if similar Quaternary materials overlie the Helena Banks fault zone offshore, they are likely to take the form of loose sand, in which any deformation probably would not be recognizable.

Therefore, the youngest deformation could be as old as Miocene, depending on whether the deformed Miocene clay dates from the early or late Miocene. Behrendt and Yuan (see p. 591 in 1987 \#1795) speculated that the youngest deformation is "probably as young as Pleistocene", but provide no evidence. Accordingly, the Helena Banks fault zone is assigned to class $\mathrm{C}$ for lack of evidence of faulting younger than Miocene.

Date of compilation 06/05/98; revised 02/01/00

Compiler and affiliation Russell L. Wheeler, U.S. Geological Survey

State South Carolina (offshore)

County Charleston (offshore)

$1^{\circ} \times 2^{\circ}$ sheet James Island; Savannah

Physiographic province Coastal Plain (offshore)

\section{References}

\#1963 Behrendt, J.C., Hamilton, R.M., Ackerman, H.D., Henry, V.J., and Bayer, K.C., 1983, Marine multichannel seismic-reflection evidence for Cenozoic faulting and deep 
crustal structure near Charleston, South Carolina, in Gohn, G.S., ed., Studies related to the Charleston, South Carolina, earthquake of 1886-Tectonics and seismicity: U.S. Geological Survey Professional Paper 1313, p. J1-J29.

\#1794 Behrendt, J.C., Hamilton, R.M., Ackermann, H.D., and Henry, V.J., 1981, Cenozoic faulting in the vicinity of the Charleston, South Carolina, 1886 earthquake: Geology, v. 9, p. 117-122.

\#1795 Behrendt, J.C., and Yuan, A., 1987, The Helena Banks strike-slip(?) fault zone in the Charleston, South Carolina, earthquake area-Results from a marine, high-resolution, multichannel, seismic-reflection survey: Geological Society of America Bulletin, v. 98, p. 591-601.

\#1969 McCartan, L., Weems, R.E., and Lemon, E.M., Jr., 1990, Quaternary stratigraphy in the vicinity of Charleston, South Carolina, and its relationship to local seismicity and regional tectonism, in Studies related to the Charleston, South Carolina, earthquake of 1886 - Neogene and Quaternary lithostratigraphy and biostratigraphy: U.S.

Geological Survey Professional Paper 1367-A, p. 39.

\#1901 Szabo, B.J., 1985, Uranium-series dating of fossil corals from marine sediments of southeastern United States Atlantic Coastal Plain: Geological Society of America Bulletin, v. 96, p. 398-406. 


\section{Humboldt fault zone (Class C)}

Structure Name Humboldt fault zone (Class C)

Comments: The Humboldt fault zone is a north-northeasterly trending complex set of faults that bound the eastern margin of the Nemaha uplift (also known as the Nemaha Ridge) in Nebraska, Kansas, and Oklahoma. The fault zone and the adjacent uplift are known and mapped on the basis of drill-hole data throughout the region (Berendsen, 1997 \#3962). Stratigraphic relations determined from the drill-hole data indicate that recurrent uplift has occurred on the Nemaha uplift (and therefore presumably recurrent movement on faults in the Humboldt fault zone) at various times during the Paleozoic (Steeples and others, 1979 \#2831); rocks as young as Permian in age are deformed (Burchett and others, 1985 \#2827). Because the faults are only known from subsurface data, details of the fault slip and fault patterns are limited (see map in Burchett and others, 1985 \#2827; Berendsen, 1997 \#3962).

Reason for assignment to Class C: This evaluation of Quaternary faulting is not a reliable guide to seismic hazard of the Humboldt fault zone and Nemaha uplift. The most authoritative and reliable assessment of the seismic hazard in this area is the national seismic hazard maps, which are published by the USGS (Open-File Report 97-131, 12 maps, scale 1:7,000,000; http://geohazards.cr.usgs.gov/eq/). In the Central and Eastern U.S. (CEUS) east of the Rocky Mountain Front, the distribution of historical earthquakes is a reasonable guide to seismic hazard. In the CEUS, the national seismic hazard maps rely mainly on the distribution of historical seismicity to calculate the hazard. In contrast to examining the area's historical seismicity, this discussion focuses on surficial evidence of large, prehistoric earthquakes. Where present, this surficial evidence will be integrated with the historical seismicity to improve future versions of the national hazard maps. In the CEUS, the most common types of surficial evidence of large, prehistoric earthquakes are liquefaction features and faults that offset young strata. However, in some areas the surficial record of large, prehistoric earthquakes is incomplete because of erosion, equivocal, or presently unrecognized. Nonetheless, the national hazard maps show that, for many parts of the CEUS, although convincing surficial evidence of large, prehistoric earthquakes is absent, these areas are NOT free of seismic hazard. The occurrence of significant historical earthquakes in the area described here demonstrates a notable level of seismic hazard.

Felt historical earthquakes in eastern Nebraska and Kansas and microearthquakes recorded by a regional seismograph network have been directly associated with the Humboldt fault zone and the Nemaha uplift (Steeples and others, 1979 \#2831; Burchett and others, 1985 \#2827; Hildebrand and others, $1988 \# 2828 ; 1990 \# 2832$ ); these observations led to the conclusion that the structures are currently tectonically active. Based on the length of fault segments in the Humboldt fault zone, Steeples and others (Steeples and others, 1990 \#2832) suggest that infrequent magnitude 6 or greater earthquakes could occur.

These seismological studies stimulated interest concerning the possibility that earthquakes of larger magnitudes than the historical events might occur along the fault zone or uplift. To evaluate this possibility, Niemi and others (1998 \#2829) speculated that, if they had occurred, such large prehistoric earthquakes might have caused liquefaction and left a valuable geological record. To support this speculation, Niemi and others (1998 \#2829) note an historical account of a sand blow that reportedly formed during an M 5.2 earthquake in 1867 in eastern Kansas. 
To date, Niemi and others (1998 \#2829) have not found field evidence confirming this historical report nor have they found evidence of any prehistoric liquefaction features. Therefore, until convincing evidence of earthquake-induced strong ground motion is documented, the Humboldt fault zone and Nemaha uplift are categorized as Class $\mathrm{C}$ structures.

\section{Date of compilation $06 / 08 / 98$}

Compiler and affiliation Anthony J. Crone, U.S. Geological Survey

State Kansas, Oklahoma, Nebraska,

County Butler, Chase, Cowley, Jackson, Lyon, Marlon, Morris, Nemaha, Potawatomie, Sedgwick, Shawnee, Sumner, Wabaunsee (Kansas); Cleveland, Grant, Garfield, Kay, Logan, Noble, Oklahoma (Oklahoma); Cass, Johnson, Nemaha, Otoe, Pawnee, Richardson, Sarpy (Nebraska)

$\mathbf{1}^{\circ} \times \mathbf{2}^{\circ}$ sheet Nebraska City, Iowa, Missouri, Nebraska; Lincoln, Nebraska; Manhattan, Kansas; Hutchinson, Kansas; Wichita, Kansas; Enid, Oklahoma; Oklahoma City, Oklahoma.

Physiographic province Central Lowland

\section{References}

\#3962 Berendsen, P., 1997, Tectonic evolution of the midcontinent rift system in Kansas, in Ojakangas, R.W., Dickas, A.B., and Green, J.E., eds., Middle Proterozoic to Cambrian rifting, Central North America: Geological Society of America Special Paper 312, p. 235-241.

\#2827 Burchett, R.R., Luza, K.V., Van Eck, O.J., and Wilson, F.W., 1985, Seismicity and tectonic relationships of the Nemaha uplift and Midcontinent Gravity anomaly (Final project summary): Oklahoma Geological Survey Special Publication 85-2, 339 p., 2 pls.

\#2828 Hildebrand, G.M., Steeples, D.W., Knapp, R.W., Miller, R.D., and Bennett, B.C., 1988, Microearthquakes in Kansas and Nebraska 1977-1987: Seismological Research Letters, v. 59, no. 4, p. 159-163.

\#2829 Niemi, T.M., Abers, G.A., and Ferris, A.N., 1998, Paleoliquefaction and seismic potential along the Nemaha ridge and Humboldt fault, eastern Kansas-Preliminary results: Eos, Transactions of the American Geophysical Union, v. 79, no. 17, p. S340-S341.

\#2832 Steeples, D.W., Bennett, B.C., Park, C., Miller, R.D., and Knapp, R.W., 1990, Microearthquakes in Kansas and Nebraska 1977-1989: U.S. Nuclear Regulatory Commission NUREG/CR-5629 RA, 14 p.

\#2831 Steeples, D.W., DuBois, S.M., and Wilson, F.W., 1979, Seismicity, faulting, and geophysical anomalies in Nemaha County, Kansas-Relationship to regional structures: Geology, v. 7, p. 134-138. 


\section{Kingston fault (Class C)}

Structure Name Kingston fault (Class C)

Comments: Subsurface data indicate Pliocene-Pleistocene offset of the Kingston fault.

Harper (1984 \#2258) and Parker and Houghton (1990 \#2257) showed the northern part of the trace of the Kingston fault on 1:24,000-scale topographic bases, and Parker and Houghton reported the dip as $85^{\circ} \mathrm{SE}$. Owens and others (1995 \#2220) showed the entire trace on a 1:100,000-scale topographic base. The fault name was first used by Parker and Houghton (1990 \#2257). Stanford and others (1995 \#1897) first identified possible Quaternary movement on the fault.

The Kingston fault underwent extensional slip during the Mesozoic formation of the Newark Basin, in whose interior the fault lies (Lyttle and Epstein, 1987 \#1935; Stanford and others, 1995 \#1897). The fault strikes north-northeasterly for approximately $12 \mathrm{~km}$ (Owens and others, $1995 \# 2220$ ). The fault trace is in three contiguous sections, arranged to form an open Z. The southern section strikes N. $13^{\circ}$ E. for $4.6-5.9 \mathrm{~km}$, the central section strikes N. $33^{\circ}$ E. for $5.3 \mathrm{~km}$, and the northern section strikes N. $2^{\circ} \mathrm{W}$. for $1.6 \mathrm{~km}$. The middle of the southern section passes through the town of Kingston, where the fault is covered by post-Miocene gravels (Bascom and others, 1909 \#2103; Stanford and others, 1995 \#1897). At Kingston, 1.9 $\mathrm{km}$ of the fault is covered by fluvial sand to cobble gravel of the Pleistocene Pensauken Formation, and, adjacent to the south, another $1.5 \mathrm{~km}$ is covered by latest Pleistocene glaciofluvial sand and gravel of the Cape May Formation (Bascom and others, 1909 \#2103; Owens and others, 1995 \#2220). The two units are now thought to be of Pliocene (?) and late Pleistocene ages, respectively (Stanford and others, $1995 \# 1897$ ).

Pliocene (?) fluvial gravel thickens southeastward as much as $80 \mathrm{ft}(24 \mathrm{~m})$ across the Kingston fault, and is overlain without offset by late Pleistocene glaciofluvial gravel (Stanford and others, 1995). The geometry and sedimentological characteristics of the Pliocene (?) gravel favor a faulting rather than a fluvial origin for the thickening (Stanford and others, 1995 \#1897). The fault is essentially vertical at the surface, and only the dip slip component is reported (Stanford and others, 1995 \#1897). The only published report on the offset is that of Stanford and others (1995 \#1897), who summarized results from well, boring, and geophysical data. The southeast side of the fault moved down, as indicated by the Pliocene (?) gravel that thickens southeastward across the fault. The northeasterly trend of the regional greatest horizontal compression (Zoback and Zoback, 1989 \#1922) indicates that any strike slip component on the north-northeast-striking fault may be dextral. The fault has no geomorphic expression.

Reason for assigned to class $\mathbf{C}$ The faulting is not demonstrably of Quaternary age. No detailed paleoseismological studies have been performed. The Pliocene (?) gravel thickens across the Kingston fault, and is overlain by a late Pleistocene gravel that is not offset by the fault (Stanford and others, 1995 \#1897). Accordingly, Stanford and others (1995 \#1897) concluded that the Kingston fault probably moved during the Pliocene or early or middle Pleistocene. In addition, no paleoseismological study has yet determined whether the thickening of the Pliocene (?) gravel occurred gradually in aseismic creep, or in several episodes that were sudden enough to indicate seismic faulting. The slip rate is unknown. The $24 \mathrm{~m}$ of 
offset on the nearly vertical fault probably occurred after the beginning of the Pliocene at 5.3 Ma, because the Pliocene(?) gravel thickens across the fault, but before the beginning of the late Pleistocene at $130 \mathrm{ka}$, because the late Pleistocene gravel is not offset (Stanford and others, 1995 \#1897). If the offset occurred entirely by pure dip-slip faulting, then these values give slip rates less than or equal to $0.2 \mathrm{~mm} / \mathrm{yr}$. The estimated slip rate would be larger if the faulting had a component of strike slip.

Date of compilation 12/16/98; revised 01/28/00

Compiler and affiliation Russell L. Wheeler, U.S. Geological Survey; Scott D. Stanford, New Jersey Geological Survey

State New Jersey

County Somerset; Middlesex

$1^{\circ} \times 2^{\circ}$ sheet Newark

Physiographic province Piedmont

\section{References}

\#2103 Bascom, F., Darton, N.H., Kümmel, H.B., Clark, W.B., Miller, B.L., and Salisbury, R.D., 1909, Trenton folio, New Jersey-Pennsylvania: U.S.Geological Survey Geologic Atlas of the United States Folio 167, 24 p., 3 pls., scale 1:125,000.

\#2258 Harper, D.P., 1984, Geologic compilation map of the Monmouth Junction quadrangle, New Jersey: New Jersey Geological Survey Open File Map 1, 1 sheet, scale 1:24,000.

\#1935 Lyttle, P.T., and Epstein, J.B., 1987, Geologic map of the Newark $1^{\circ}$ x $2^{\circ}$ quadrangle, New Jersey, Pennsylvania, and New York: U.S. Geological Survey Miscellaneous Investigations Map I-1715, 1 sheet, scale 1:250,000.

\#2220 Owens, J.P., Sugarman, P.J., Sohl, N.F., Parker, R.A., Houghton, H.F., Volkert, R.A., Drake, A.A., Jr., and Orndorff, R.C., 1995, Geologic map of New Jersey-Central sheet: U.S. Geological Survey Open-File Report 95-0253, 60 p., 3 pls., scale $1: 100,000$.

\#2257 Parker, R.A., and Houghton, H.F., 1990, Bedrock geologic map of the Monmouth Junction quadrangle, New Jersey: U.S. Geological Survey Open-File Report 90-219, 1 pl., scale 1:24,000.

\#1897 Stanford, S.D., Jagel, D.L., and Hall, D.W., 1995, Possible Pliocene-Pleistocene movement on a reactivated Mesozoic fault in central New Jersey: Geological Society of America Abstracts with Programs, v. 27, no. 1, p. 83.

\#1922 Zoback, M.L., and Zoback, M.D., 1989, Tectonic stress field of the continental United States, in Pakiser, L.C., and Mooney, W.D., eds., Geophysical framework of the continental United States: Geological Society of America Memoir 172, p. 523-539. 


\section{Lancaster seismic zone (Class C)}

\section{Structure Name Lancaster seismic zone (Class C)}

Comments: Historical seismicity of southeastern Pennsylvania since 1752 is most abundant in an approximately circular area with a diameter of 50-60 km, and named the Lancaster seismic zone by Armbruster and Seeber (1987 \#1791). The seismic zone's largest known earthquake ( $\mathrm{m}_{\mathrm{bLg}} 4.6, \mathbf{M} 4.3$, MMI VI-VII) struck the northeastern edge of the zone on January 16, 1994 (Seeber and others, 1998 \#2228).

Reason for assignment to class C: This evaluation of Quaternary faulting is not a reliable guide to seismic hazard of the Lancaster seismic zone. The most authoritative and reliable assessment of the seismic hazard in the area evaluated here is the national seismic hazard maps, which are published by the USGS (Open-File Report 97-131, 12 maps, scale 1:7,000,000; http://geohazards.cr.usgs.gov/eq/). In the Central and Eastern U.S. (CEUS) east of the Rocky Mountain Front, the distribution of historical earthquakes is a reasonable guide to seismic hazard. In the CEUS, the national seismic hazard maps rely mainly on the distribution of historical seismicity to calculate the hazard. In contrast to examining the area's historical seismicity, this discussion focuses on surficial evidence of large, prehistoric earthquakes. Where present, this surficial evidence will be integrated with the historical seismicity to improve future versions of the national hazard maps. In the CEUS, the most common types of surficial evidence of large, prehistoric earthquakes are liquefaction features and faults that offset young strata. However, in some areas the surficial record of large, prehistoric earthquakes is incomplete because of erosion, equivocal, or presently unrecognized. Nonetheless, the national hazard maps show that, for many parts of the CEUS, although convincing surficial evidence of large, prehistoric earthquakes is absent, these areas are NOT free of seismic hazard. The occurrence of significant historical earthquakes in the area described here demonstrates a notable level of seismic hazard.

Seismological evidence summarized next indicates that at least two geologically unidentified faults in the Lancaster seismic zone are slipping seismically. However, as argued later, there is no reported evidence for Quaternary tectonic faulting beyond the earthquakes. Accordingly, the zone will be placed in class $\mathrm{C}$ for this compilation. First, however, it must be considered here for five reasons.

An earthquake in 1984 (mbLg 4.1, M 3.7, MMI VI Scharnberger and Howell, 1985 \#1889; Armbruster and Seeber, 1987 \#1791; Johnston, 1996 \#1841) and its aftershocks provided seismological evidence for an active fault in the upper crust. The main shock occurred $4.7 \mathrm{~km}$ deep (Stockar, 1989 \#2057). Aftershocks defined a vertical tabular zone that strikes north, and the seven aftershocks with depth uncertainties (ERZ) less than $1.0 \mathrm{~km}$ spanned $0.3 \mathrm{~km}$ vertically and $1.4 \mathrm{~km}$ north-south, with a median depth of $4.7 \mathrm{~km}$ (Armbruster and Seeber, 1987 \#1791). The few first arrivals from the main shock provide moderate constraint for a focal mechanism with a preferred nodal plane of N. $10^{\circ}$ E. $/ 60^{\circ} \mathrm{SE}$ (Armbruster and Seeber, 1987 \#1791).

The 1994 Cacoosing Valley earthquake and its aftershocks provided seismological evidence for a second active fault in the seismic zone, oriented N. $45^{\circ} \mathrm{W} . / 54^{\circ} \mathrm{SW}$ (Seeber and others, 1998 \#2228). The Cacoosing Valley sequence is described separately in this compilation. The 
1994 mainshock was larger and shallower than that of 1984, but, as in 1984, no geological evidence of surface rupture or liquefaction has been found.

Six instrumental epicenters from 1964 through 1997 form a north-trending alignment approximately $15 \mathrm{~km}$ wide, much narrower than the area of historical seismicity (Dewey and Gordon, 1984 \#1928; Armbruster and Seeber, 1987 \#1791). Thus, the Lancaster seismic zone itself might be much narrower than $30 \mathrm{~km}$, and is much longer than the 1984 rupture zone (Armbruster and Seeber, 1987 \#1791). This observation would be consistent with the existence of a buried fault or zone of faults that is undergoing compressional reactivation in the modern, east-northeast-trending, greatest horizontal compression (Armbruster and Seeber, 1987 \#1791; Zoback and Zoback, 1989 \#1922). However, any such narrow, north-trending fault or fault zone would probably not include the 1994 Cacoosing Valley earthquake, which occurred farther northeast.

Short, discontinuous, crudely north-striking faults are scattered throughout the Lancaster seismic zone (Berg and others, 1981 \#1937). They cut Triassic and Paleozoic rocks and all other types of faults, and are, therefore, the youngest faults mapped in the zone (Jonas and Stose, 1930 \#2066). They are of early Mesozoic age or younger, and perhaps formed as extensional faults during the early Mesozoic extension that initiated the Atlantic passive margin (Stose, 1924 \#2230). A worldwide survey of damaging earthquakes in stable continental regions found that large earthquakes occur preferentially in passive margins and continental rifts, with the preference being strongest for areas that underwent Mesozoic or Cenozoic extension (Johnston, 1989 \#2039; Johnston, 1994 \#2040). Thus, the likelihood of Mesozoic or younger extension on the north-striking faults indicates a possibility of elevated earthquake potential.

A seismically active fault or fault zone has been suggested in the Lancaster seismic zone, but not yet recognized structurally, stratigraphically, or paleoseismologically. The entire seismic zone lies in the south-dipping thrust and nappe complex of the Appalachian Piedmont, and the depth of the 1984 earthquake sequence places it well above the likely depth of the basal detachment fault of the complex (Berg and others, 1981 \#1937). The preferred nodal plane of the 1984 main shock projects upward to reach ground level $2 \mathrm{~km}$ west of the epicenter and 7 $\mathrm{km}$ south of, and on trend with, the north-striking Fruitville fault (Armbruster and Seeber, 1987 \#1791; Stockar, 1989 \#2057). Compared to its surroundings, the Lancaster seismic zone contains unusually many north-trending straight sections of streams, short faults that trend northeast to northwest and cut Triassic-Jurassic rocks, topographic and Landsat lineaments, north-trending gullies, soil-gas radon anomalies, springs that align north-south, and tufa deposits that might indicate recently active faults along which circulating ground water dissolves comminuted carbonate rock and carries it upward into streams (Parrish and others, 1988 \#2068; Parrish, 1989 \#1874; Alexander and others, 1989 \#2022; Stockar, 1989 \#2057; Thornton, 1989 \#2059; Alexander and Thornton, 1991 \#1785). Thus, there is abundant evidence of a high density of north-striking, near-surface fractures and fracture zones in the Lancaster seismic zone. Scharnberger and Howell (1985 \#1889), Armbruster and Seeber (1987 \#1791), Alexander and others (1989 \#2022), and Stockar (1989 \#2057) have noted the spatial association of the epicenters with the area of abundant, north-striking fractures, including the Fruitville fault; none has suggested that the association is causal. 
One of these north-striking structures is the Fruitville fault. The longer an exposed fault is, the more likely it is to penetrate to the $5-15 \mathrm{~km}$ depths at which many earthquakes nucleate east of the Rocky Mountains (Wheeler and Johnston, 1992 \#2243). No mapped structures in the Lancaster seismic zone are known to be seismically active, and we are unaware of any assignment of individual earthquakes to known faults. However, if the Fruitville fault is long, then the parallelism between the fault and the 1984 rupture zone, and the location of the 1984 epicenter on trend with and south of the exposed fault, together could support a speculation that the earthquake might have occurred on a subsurface, downdip extension of the fault (Scharnberger and Howell, 1985 \#1889). In this way a long Fruitville fault could constitute suggestive structural geologic evidence for historical faulting. In addition, several published reports show a long Fruitville fault, as described in the next paragraph. For these reasons the Fruitville fault must be evaluated here.

The length of the Fruitville fault is uncertain. The local structural grain is easterly, and most dips of Paleozoic structures are southerly (Berg and others, 1981 \#1937). Stose (1924 \#2230, p.474, fig. 6) mapped an east-trending, fault-bounded anticline, "the Fruitville faulted belt", in which Cambrian Antietam quartzite underlies a hill at Fruitville. A north-striking "cross fault at Fruitville" cuts the anticline and its bounding faults and offsets the quartzite hill dextrally "one-fourth mile" (0.4 km). Stose (1924 \#2230) mapped the fault as $2.6 \mathrm{~km}$ long. Jonas and Stose (1930 \#2066) drew on this and additional mapping during 1922-1926 to extend the north-striking fault to a length of $16 \mathrm{~km}$. This latter interpretation was incorporated into the next two state geologic maps (Stose and Ljungstedt, 1931 \#1945; Gray and others, 1960 \#1958). It is also the interpretation shown on the maps of Scharnberger and Howell (1985 \#1889), Armbruster and Seeber (1987 \#1791), Alexander and others (1989 \#2022), and Stockar (1989 \#2057). The area of the Fruitville fault was remapped by Meisler and Becher (1967 \#1971; 1968 \#1975; 1971 \#2015). On their map (1971) the Fruitville fault has largely vanished, being represented only by three short faults that are drawn as dotted lines to indicate that their existence is inferred. The southernmost short fault strikes N. $20^{\circ}$ E. and is 0.8 $\mathrm{km}$ long, the northernmost strikes N. $30^{\circ} \mathrm{W}$. for $1.0 \mathrm{~km}$, and the middle one curves through $70^{\circ}$ over its $1.2 \mathrm{~km}$ length. The three faults coincide with topographic offsets in two ridges that are underlain by resistant sandstones and quartzites. This representation of the vicinity of the Fruitville fault appears on the most recent Geologic Map of Pennsylvania (Berg and others, 1981 \#1937).

Stockar (1989 \#2057) correctly noted that the sparse outcrops in this heavily farmed area of low relief preclude a demonstration by geologic mapping of the true length of the Fruitville fault. Although one of us (CKS) has, in the past, expressed sympathy for the long-fault interpretation of Jonas and Stose (1930 \#2066), we must conclude that the short-fault interpretation of Meisler and Becher (1971 \#2015) is more likely to be correct, for three reasons. First, their mapping is more detailed in scale than that of Jonas and Stose (1930 \#2066). Second, Meisler and Becher (1971 \#2015) used a more finely divided stratigraphy, consisting of 14 map units instead of the eight of Jonas and Stose (1930 \#2066). The finer stratigraphy should have given Meisler and Becher (1971 \#2015) greater ability to detect fault offsets of geologic contacts. Third, the maps of Stose (1924 \#2230) and Jonas and Stose (1930 \#2066) show faults as straight, solid lines. On large-scale geologic maps, this convention can indicate a paucity of outcrop control and insufficient distinction between observation and inference. 
Sparse outcrops prevent showing the Fruitville fault to be short, but the interpretation of Meisler and Becher (1971 \#2015) and Berg (1981 \#1937) best fits the data. We have some reservations, however, about the 70 degree curvature of the fault at Fruitville as shown on Meisler and Becher's map.

In conclusion, the Fruitville fault is probably one or a few short faults of limited depth extent, and is unlikely to reach the depth of the 1984 earthquake or depths typical of the rest of central and eastern North America. We know of no other structural, stratigraphic, or paleoseismological evidence for Quaternary faulting in the Lancaster seismic zone, and the zone is assigned to class $\mathrm{C}$ in this compilation of such evidence.

Having said that, we must note two things. First, a few earthquakes in the Lancaster seismic zone occur at unusually shallow depths, as indicated by intensity data (C.K. Scharnberger, unpub. data) and as demonstrated by the 1994 Cacoosing Valley earthquake sequence (Seeber and others, 1998 \#2228). The shallow earthquakes suggest that even short, shallow faults might host earthquakes. Therefore, the Lancaster seismic zone remains a promising place in which to seek paleoseismological evidence for Quaternary faulting, both historic and prehistoric. Second, even if the short, shallow faults of the Lancaster seismic zone do not themselves slip seismically, the faults and earthquakes together might reflect some other, deeper geologic control on seismicity (for example, Wise and Faill, 1998 \#2244).

Date of compilation 01/12/99; revised 02/01/00

Compiler and affiliation Russell L. Wheeler, U.S. Geological Survey; Charles K. Scharnberger, Millersville University

State Pennsylvania

County Lancaster

$1^{\circ} \times 2^{\circ}$ sheet Baltimore; Harrisburg

Physiographic province Piedmont

\section{References}

\#2022 Alexander, S.S., Gold, D.P., Gardner, T.W., Slingerland, R.L., and Thornton, C.P., 1989, Near-surface neotectonic deformation associated with seismicity in the northeastern United States: U.S. Nuclear Regulatory Commission Report NUREG/CR-5418, 343 p.

\#1785 Alexander, S.S., and Thornton, C.P., 1991, Travertine as an indicator of geologicallyrecent earthquake activity in the eastern United States [abs.]: Eos, Transactions of the American Geophysical Union, v. 72, no. 17, p. 203.

\#1791 Armbruster, J.G., and Seeber, L., 1987, The 23 April 1984 Martic earthquake and the Lancaster seismic zone in eastern Pennsylvania: Bulletin of the Seismological Society of America, v. 77, p. 877-890.

\#1937 Berg, T.M., Edmunds, W.E., Geyer, A.R., Glover, A.D., Hoskins, D.M., MacLachlan, D.B., Root, S.I., Sevon, W.D., and Socolow, A.A., 1981, Geologic map of Pennsylvania: Pennsylvania Topographic and Geologic Survey Map 1, 3 sheets, scale 1:250,000.

\#1928 Dewey, J.W., and Gordon, D.W., 1984, Map showing recomputed hypocenters of earthquakes in the Eastern and Central United States and adjacent Canada, 1925-1980: U.S. 
Geological Survey Miscellaneous Field Studies Map MF-1699, 39 p. pamphlet, 1 sheet, scale $1: 2,500,000$.

\#1958 Gray, C., Shepps, V.C., Coulin, R.R., Lytle, W.S., Hoskins, D.M., Bergsten, J.M., Shaffuer, M.N., Miller, J.T., Socolow, A.A., Wood, G.H., Jr., McLaughlin, D.B., Arndt, H.H., Geyer, A.R., Kelin, T.M., Cale, A.S., and Van Olden, A.E., compilers, 1960, Geologic map of Pennsylvania: Pennsylvania Topographic and Geologic Survey, 2 sheets, scale 1:250,000.

\#2039 Johnston, A.C., 1989, The seismicity of 'stable continental interiors', in Gregersen, S., and Basham, P.W., eds., Earthquakes at North Atlantic passive margins-Neotectonics and postglacial rebound: Dordrecht, The Netherlands, Kluwer Academic Publishers, p. 299-327.

\#2040 Johnston, A.C., 1994, Seismotectonic interpretations and conclusions from the stable continental region seismicity database, in Schneider, J.F., ed., The earthquakes of stable continental regions - v. 1, Assessment of large earthquake potential: Technical report to Electric Power Research Institute TR-102261-V1, Palo Alto, California, December 1994, p. 4-1-4-103.

\#1841 Johnston, A.C., 1996, Seismic moment assessment of earthquakes in stable continental regions-I. Instrumental seismicity: Geophysical Journal International, v. 124, p. 381-414.

\#2066 Jonas, A.I., and Stose, G.W., 1930, Geology and mineral resources of the Lancaster quadrangle, Pennsylvania: Pennsylvania Geological Survey, Fourth Series, Topographic and Geologic Atlas of Pennsylvania 168, 106 p., 2 pls., scale 1:62,500.

\#1971 Meisler, H., and Becher, A.E., 1967, Hydrogeologic significance of calcium-magnesium ratios in ground water from carbonate rocks in the Lancaster quadrangle, southeastern Pennsylvania, in Geological Survey research 1967: U.S. Geological Survey Professional Paper 575, p. C232-C235.

\#1975 Meisler, H., and Becher, A.E., 1968, Carbonate rocks of Cambrian and Ordovician age in the Lancaster quadrangle, Pennsylvania, in Contributions to stratigraphy, 1967: U.S. Geological Survey Bulletin 1254-G, p. G1-G14.

\#2015 Meisler, H., and Becher, A.E., 1971, Hydrogeology of the carbonate rocks of the Lancaster 15-minute quadrangle, southeastern Pennsylvania: Pennsylvania Topographic and Geologic Survey, Fourth Series, Bulletin W26, 149 p., 2 pls., scale 1:24,000.

\#1874 Parrish, J., 1989, Mapping fractures in Lancaster County, PA, using magnetics, soil-gas radon and LANDSAT TM data: Geological Society of America Abstracts with Programs, v. 21, no. 6, p. A372.

\#2068 Parrish, J., Harding, T., and Etter, K., 1988, Remote sensing of the Lancaster Co., PA, fault zone [abs.], in Proceedings of the Sixth Thematic Conference on Remote Sensing for Exploration Geology, v. II: Ann Arbor, Environmental Research Institute of Michigan, p. 687.

\#1889 Scharnberger, C.K., and Howell, B.F., Jr., 1985, Intensities and structural setting of the earthquakes of 19 April and 23 April, 1984 Lancaster County, Pennsylvania: Earthquake Notes, v. 56, p. 43-46. 
\#2228 Seeber, L., Armbruster, J.G., Kim, W.-Y., Barstow, N., and Scharnberger, C., 1998, The 1994 Cacoosing Valley earthquakes near Reading, Pennsylvania-A shallow rupture triggered by quarry unloading: Journal of Geophysical Research, v. 103, no. B10, p. 24,505-24,521.

\#2057 Stockar, D.V., 1989, Contemporary tectonics of the Lancaster, Pennsylvania seismic zone, in Alexander, S.S., Gold, D.P., Gardner, T.W., Slingerland, R.L., and Thornton, C.P., eds., Near-surface neotectonic deformation associated with seismicity in the northeastern United States: U.S. Nuclear Regulatory Commission Report NUREG/CR-5418, p. A1 - A204.

\#2230 Stose, G.W., 1924, New type of structure in the Appalachians: Bulletin of the Geological Society of America, v. 35, p. 465-480.

\#1945 Stose, G.W., and Ljungstedt, O.A., eds., 1931, Geologic map of Pennsylvania: Pennsylvania Topographic and Geologic Survey, 1 sheet, scale 1:380,160.

\#2059 Thornton, C.P., 1989, Except from Professor C.P. Thornton's Ph.D. thesis describing fault-associated travertine deposits in Virginia, in Alexander, S.S., Gold, D.P., Gardner, T.W., Slingerland, R.L., and Thornton, C.P., eds., Near-surface neotectonic deformation associated with seismicity in the northeastern United States: U.S. Nuclear Regulatory Commission Report NUREG/CR-5418, p. B1-B9.

\#2243 Wheeler, R.L., and Johnston, A.C., 1992, Geologic implications of earthquake source parameters in central and eastern North America: Seismological Research Letters, v. 63, no. 4, p. 491-514.

\#2244 Wise, D.U., and Faill, R.T., 1998, Lancaster County seismic zone (Penna.)—Reactivation of a Taconic structural feature?: Geological Society of America Abstracts with Programs, v. 30, no. 7, p. A-320.

\#1922 Zoback, M.L., and Zoback, M.D., 1989, Tectonic stress field of the continental United States, in Pakiser, L.C., and Mooney, W.D., eds., Geophysical framework of the continental United States: Geological Society of America Memoir 172, p. 523-539. 


\section{Lebanon Church fault (Class C)}

Structure Name Lebanon Church fault (Class C)

Comments: A small reverse fault offsets Blue Ridge crystalline basement $1.5 \mathrm{~m}$ over gravels that may be Quaternary in age. This is fault number 37 of Prowell (1983).

The descriptions of Nelson (1962 \#2213, p. 50-51) and Prowell (1983 \#1951) locate the fault with respect to Lebanon Church and U.S. route 250. Both the church and the road appear on the 1:62,500-scale geologic map of Nelson (1962 \#2213) and on the 1:24,000-scale topographic map of the Waynesboro East 7.5 minute quadrangle. The fault is exposed in a road cut on the northwest side of U.S. Route 250, three miles $(5 \mathrm{~km})$ east of Afton, Virginia, directly in front of Lebanon Church (Nelson, 1962 \#2213, p. 50-51; Prowell, 1983 \#1951). The 1973 Waynesboro East 1:24,000-scale topographic map (photorevised 1987) shows the church approximately $4.7 \mathrm{mi}(7.5 \mathrm{~km})$ east along U.S. Route 250 from its underpass beneath Interstate 64 . We name the fault after the church.

Prowell (1983 \#1951) gives the location as lat $38^{\circ} 02^{\prime}$ N., long $78^{\circ} 47^{\prime} \mathrm{W}$. More detailed location information is given above. The underlying bedrock is granodiorites, hypersthene granodiorites, and granites of the Precambrian Virginia Blue Ridge complex (Nelson, 1962 \#2213). The less detailed geologic map of Virginia Division of Mineral Resources (1993 \#1952) shows the locality as underlain by layered pyroxene granulites of the early or preGrenville, Middle Proterozoic, Blue Ridge basement complex. An exposed reverse fault placed the crystalline bedrock $5 \mathrm{ft}(1.5 \mathrm{~m})$ above terrace gravels. Prowell (1983 \#1951) gave the orientation of the reverse fault as N. $20^{\circ}$ E. / $57^{\circ}$ SE, and Nelson (p. 511962 \#2213) showed a photograph of the faulted road cut. Neither Nelson (1962 \#2213) nor Prowell (1983 \#1951) mentioned any indication of a strike-slip component of the reverse slip. The fault has no geomorphic expression.

Nelson (1962 \#2213, p. 50-51) described the faulted deposits as Pleistocene terrace gravels. Prowell (1983 \#1951) referred to them as high-level fluvial gravels of Miocene to Pliocene age. The Waynesboro East 1:24,000-scale topographic map shows that the faulted gravel lies at an elevation of $780 \mathrm{ft}(238 \mathrm{~m})$, approximately $60 \mathrm{ft}(18 \mathrm{~m})$ above Stockton Creek, a permanent stream that flows southeastward and eastward. Stockton Creek passes approximately 400 $\mathrm{m}$ southwest of the faulted gravel. Four km northwest of the faulted gravel, the crest of the Blue Ridge is approximately 2,600 ft (790 m) above sea level. From the crest to Lebanon Church is all downhill, without intervening topographic lows. Only intermittent streams descend southeastward from the Blue Ridge to the vicinity of the Lebanon Church fault, and none pass between the ridge crest and the fault. The faulted gravel is at least $10 \mathrm{ft}(3 \mathrm{~m})$ thick at the fault.

This setting provides reasons to suspect that the faulted gravel is younger than Pliocene. The thickness of the faulted gravel makes it unlikely that the gravel is a fluvial deposit of the intermittent streams that flow from the nearby Blue Ridge crest. The faulted gravel might be a fluvial deposit of Stockton Creek, or a colluvial deposit derived from the slopes uphill from Lebanon Church. A fluvial deposit of Stockton Creek that is now $18 \mathrm{~m}$ above the present elevation of the creek may be older than Pleistocene. However, a colluvial deposit could have formed recently at any elevation above the creek, and, thus, could be of Quaternary age. 
Fluvial gravels in this part of the Appalachians are often composed mostly of pebbles or cobbles of quartz or quartzite, indicating substantial transport that destroyed the softer lithic fragments (Prowell, unpub. data). However, the faulted gravel at Lebanon Church contains many angular pebbles of diverse lithologies, including graywacke clasts, and a sticky clay matrix, indicating little transport (Prowell, unpub. data). Therefore, probably the faulted gravel is colluvium, and it may be of Quaternary age. This suggestion is supported by the regional observation of Prowell that fluvial gravels are abundant in the geologic record, but colluvium is scarce or absent. This observation could indicate that colluvium is ephemeral, which would imply that probably the faulted gravel is young. For these reasons, we suggest that the Lebanon Church fault might be of Quaternary age, although the suggestion cannot be confirmed with present evidence.

No individual slip events have been distinguished on the Lebanon Church fault, and indeed the offset of $5 \mathrm{ft}(1.5 \mathrm{~m})$ could have formed in a single earthquake. A recurrence interval cannot be calculated without at least two dated slip events. The slip rate is unknown. However, the fault dips $57^{\circ}$ and the vertical offset is $1.5 \mathrm{~m}$ (Prowell, 1983 \#1951). If the offset occurred entirely during the Holocene, the slip rate could exceed $0.2 \mathrm{~mm} / \mathrm{yr}$. If the slip occurred entirely during the Quaternary, the slip rate could be more than two orders of magnitude less. Thus, the slip rate is probably less than $0.2 \mathrm{~mm} / \mathrm{yr}$.

Reason for assignment to class $\mathbf{C}$ The faulting is not demonstrably of Quaternary age. No detailed paleoseismological studies have been performed to determine the age of the faulting.

Date of compilation 12/16/98; revised 01/28/00

Compiler and affiliation Russell L. Wheeler, David C. Prowell, U.S. Geological Survey

State Virginia

County Albemarle

$1^{\circ} \times 2^{\circ}$ sheet Charlottesville

Physiographic province Blue Ridge

\section{References}

\#2213 Nelson, W.A., 1962, Geology and mineral resources of Albermarle County: Virginia Division of Mineral Resources Bulletin 77, scale 1:62,500.

\#1951 Prowell, D.C., 1983, Index of faults of Cretaceous and Ceozoic age in the Eastern United States: U.S. Geological Survey Miscellaneous Field Studies Map MF-1269, 2 sheets, scale 1:2,500,000.

\#1952 Virginia Division of Mineral Resources, 1993, Geologic map of Virginia: Virginia Division of Mineral Resources, 1 sheet, scale 1:500,000. 


\section{Lexington fault system (Class C)}

\section{Structure Name Lexington fault system (Class C)}

Comments: Electrical resistivity profiling, augering, and streambed profiling indicate possible Quaternary slip at six locations along the Lexington fault system of east central Kentucky. However, no trenching has been performed to test these indications.

This part of the Lexington fault system (Noger, 1988 \#1938; McDowell and Schultz, 1990 \#1974) was previously called the West Hickman Creek fault zone (MacQuown, 1968 \#1936). Index maps (Carew, 1990 \#2024) at scales of approximately 1:1200 show six locations of possible Quaternary faulting, together with bedrock faults, geologic contacts, and stream shorelines, but without latitude or longitude marks. However, the linework of the index maps is taken from the 1:24,000-scale geologic map of MacQuown (1968 \#1936). Comparison of the faults, contacts, and shorelines between the index maps and the geologic map would identify the faulting locations on the 1:24,000-scale topographic base used by MacQuown (1968 \#1936), from which the faulting locations could be digitized.

The Lexington fault system trends north-northeast across east-central Kentucky for approximately $122 \mathrm{~km}$ (Noger, 1988 \#1938), and perhaps farther in the subsurface (Drahovzal and Noger, 1995 \#1929). Throughout its extent, the fault system is an east-facing normal fault, although some fault strands dip east and others dip west. In its center, the fault system forms the western boundary of the Rome trough, a large, east-northeast-trending graben of Cambrian age (Drahovzal and Noger, 1995 \#1929; Wheeler, 1995 \#1914). At the western end of the Rome trough, the fault system offsets the top of Precambrian basement approximately $600 \mathrm{~m}$ (Drahovzal and Noger, 1995 \#1929). In the study area, north of the intersection with the Rome trough, the Lexington fault system offsets basement less than $300 \mathrm{~m}$. At ground level in the study area, the fault system is made of anastomosing strands that form a network 0.3-3.6 km wide (Black, 1967 \#1926; MacQuown, 1968 \#1936). Rocks exposed on both sides of the fault system and between its strands are Ordovician limestones with some shales (MacQuown, 1968 \#1936). The study sites of Carew (1990 \#2024) are where MacQuown (1968 \#1936) mapped strands of the fault system as passing under Quaternary alluvium of West Hickman and Hickman Creeks.

Quaternary faulting has only been suggested, not demonstrated, by Carew (1990 \#2024). However, the Lexington fault system strikes north-northeast in the area of interest here (MacQuown, 1968 \#1936). The present-day orientation of greatest horizontal compressive stress is east-northeast (Zoback and Zoback, 1989 \#1922), from which reactivation is likely to be compressional, with dextral, reverse, or both components. MacQuown (1968 \#1936) shows faults dipping steeply east and west in a shallow cross section but gives no values. Sections of faults that MacQuown (1968 \#1936) showed as solid lines cross numerous streams, and the $10 \mathrm{ft}(3 \mathrm{~m})$ topographic contours would allow fault orientation to be calculated with three-point solutions. However, V-shaped traces where faults cross streams are subdued, so dips are likely to be moderate to steep. Carew (1990 \#2024) mentioned several places where faults are exposed for possible dip measurement.

Reason for assignment to class $\mathbf{C}$ The faulting is not demonstrably of Quaternary age. No trenches were excavated. However, a foundation for them has been laid. Carew (1990 \#2024) 
studied six sites at which MacQuown (1968 \#1936) had mapped exposed strands of the Lexington fault system as passing beneath Quaternary stream alluvium of West Hickman Creek and Hickman Creek. Carew (1990 \#2024) used electrical resistivity surveys to locate the approximate positions of the fault strands beneath the alluvium. In addition, geologic cross sections were drawn along each resistivity survey line; the sections were based on auger holes that were drilled and logged to bedrock. Most holes were spaced $15 \mathrm{~m}$ apart, with spacings of 3 or $6 \mathrm{~m}$ above some suspected faults. Finally, longitudinal stream bed profiles were measured across most of the studied fault strands. Carew (1990 \#2024) used the mapped senses of dip slip on the fault strands, and changes in electrical resistivity, bedrock depth, flood plain stratigraphy, surface topography, and stream bed elevation to infer the presence or absence of steps in the bedrock-alluvium contact at the likely locations of the faults beneath the alluvium. All six sites have some evidence for offset of the contact at the faults, which may indicate Quaternary faulting. The fault strands have little or no topographic expression. Some study sites of Carew (1990 \#2024) have slight depressions in alluvium above the suspected fault traces, perhaps attributable to solution of the underlying limestones (Carew, 1990 \#2024).

The slip rate is unknown. However, a Holocene slip rate of $0.2 \mathrm{~mm} / \mathrm{yr}$ would have produced sufficient offset that it would probably have been detected in the field if it were reverse, although perhaps not if it were strike slip. The same rate throughout the Quaternary would have produced $320 \mathrm{~m}$ of slip, which would probably have been detected in the field even if it were all strike slip. No offset was reported. As described above, Quaternary faulting has been suggested by subsurface studies but not demonstrated by trenching. Absent such a demonstration, and absent evidence that any faulting occurred suddenly instead of by aseismic creep, no recurrence interval can be calculated.

Date of compilation 12/16/98; revised 01/28/00

Compiler and affiliation Russell L. Wheeler, U.S. Geological Survey

State Kentucky

County Jessamine

$1^{\circ} \times 2^{\circ}$ sheet Winchester

Physiographic province Interior Low Plateaus

\section{References}

\#1926 Black, D.F.B., 1967, Geologic map of the Coletown quadrangle, east-central Kentucky: U.S. Geological Survey Geologic Quadrangle Map GQ-644, 1 sheet, scale 1:24,000.

\#2024 Carew, P.B., 1990, Investigation of Holocene movement along the Lexington fault system in Jessamine County, Kentucky: Richmond, Eastern Kentucky University, unpublished M.S. thesis, 57 p., 2 pl.

\#1929 Drahovzal, J.A., and Noger, M.C., 1995, Preliminary map of the structure of the Precambrian surface in eastern Kentucky: Kentucky Geological Survey Map and Chart Series 8, Seris XI, 9 p. pamphlet, 1 sheet, scale 1:500,000. 
\#1936 MacQuown, W.C., Jr., 1968, Geologic map of the Nicholasville quadrangle, Jessamine and Fayette Counties, Kentucky: U.S. Geological Survey Geologic Quadrangle Map GQ-767, 1 sheet, scale 1:24,000.

\#1974 McDowell, R.C., and Schultz, A.P., 1990, Structural and stratigraphic framework of the Giles County area, a part of the Appalachian Basin of Virginia and West Virginia, in Evolution of sedimentary basins-Appalachian Basin: U.S. Geological Survey Bulletin 1839, p. E1-E24, 1 pl., scale 1:125,000.

\#1938 Noger, M.C., compiler, 1988, Geologic map of Kentucky: U. S. Geological Survey and Kentucky Geological Survey, 1 sheet, scale 1:500,000.

\#1914 Wheeler, R.L., 1995, Earthquakes and the cratonward limit of Iapetan faulting in eastern North America: Geology, v. 23, p. 105-108.

\#1922 Zoback, M.L., and Zoback, M.D., 1989, Tectonic stress field of the continental United States, in Pakiser, L.C., and Mooney, W.D., eds., Geophysical framework of the continental United States: Geological Society of America Memoir 172, p. 523-539. 


\section{Lindside fault zone (Class c)}

Structure Name Lindside fault zone (Class C)

Comments: The fault zone was first described by Dennison (1994 \#1812) and named by Dennison (1996 \#2028). The most complete published summary to date is by Dennison and Stewart (1998 \#2029), who attributed most of the detailed descriptions and measurements to a thesis by A.M. Mehlhop (1996 \#2249). The Lindside fault zone extends for at least $50 \mathrm{~km}$ northeastward along the strike of overturned rocks that dip steeply southeast in the footwall of the St. Clair fault. The southeast-dipping St. Clair fault is the boundary between the Appalachian Plateaus and Valley and Ridge Provinces. The Lindside fault zone is recognized as a zone of steeply dipping, conjugate normal faults. The width of the zone varies between exposures but can be as great as approximately $2 \mathrm{~km}$ (Mehlhop and others, 1996 \#1861). The fault zone post-dates Appalachian folding and thrust faulting, and its normal slip has excised hundreds of meters of the steeply dipping Devonian and Mississippian strata. Dennison (1994 \#1812) calculated $800 \mathrm{~m}$ of dip slip at the type locality at Lindside, West Virginia. Dennison and Stewart (1998 \#2029) suggested that the normal faulting might have occurred during gravitational collapse of the orogenically-thickened Appalachian crust, presumably during latest Paleozoic or more recent time.

Reason for assignment to class $\mathbf{C}$ : The Lindside fault zone is assigned to class $\mathrm{C}$ because of a lack of evidence for Quaternary slip on the fault zone. It strikes approximately N. $65^{\circ}$ E., following the structural grain of the exposed parts of the thrust complex of the Appalachians. Nearby to the southeast, the Giles County seismic zone is defined by a steeply dipping, tabular zone of hypocenters that strikes N. 44 E. (Bollinger and Wheeler, 1983 \#1803; Bollinger and Wheeler, 1988 \#1968). The seismic zone is confined to structural basement beneath the Appalachian thrust complex, which is $3-5 \mathrm{~km}$ thick near the seismic zone and the Lindside fault zone. Therefore, the seismic zone and the Lindside fault zone are $3-5 \mathrm{~km}$ apart vertically and differ by approximately $20^{\circ}$ in orientation. Dennison and Stewart (1998 \#2029) speculated that the fault zone might represent ancient, post-Appalachian, reactivation of the Proterozoic to Cambrian, basement fault zone that Bollinger and Wheeler (1983 \#1803; 1988 \#1968) suggested is undergoing seismic reactivation today.

However, the local orientation of greatest horizontal compressive stress trends N. $64^{\circ} \mathrm{E}$. (Bollinger and Wheeler, 1988 \#1968), consistently with the regional east-northeast trend (Zoback and Zoback, 1989 \#1922). Thus, the Lindside fault zone is poorly oriented for reactivation in the present-day compressional stress field. In addition, no evidence has yet been reported of Quaternary slip on the faults of the fault zone.

Date of compilation 05/26/98; revised 01/28/00

Compiler and affiliation Russell L. Wheeler, U.S. Geological Survey

State West Virginia; Virginia

County Mercer; Monroe (West Virginia); Giles (Virginia)

$1^{\circ} \times 2^{\circ}$ sheet Bluefield

Physiographic province Appalachian Plateaus 


\section{References}

\#1803 Bollinger, G.A., and Wheeler, R.L., 1983, The Giles County, Virginia, seismic zone: Science, v. 219, p. 1063-1065.

\#1968 Bollinger, G.A., and Wheeler, R.L., 1988, The Giles County, Virginia, seismic zoneSeismological results and geologic interpretations: U.S. Geological Survey Professional Paper 1355, 85 p.

\#1812 Dennison, J.M., 1994, A newly discovered fault in West Virgina and Virginia related to the location of the Narrows of New River: Geological Society of America Abstracts with Programs, v. 26, no. 4, p. 10.

\#2028 Dennison, J.M., ed., 1996, Geologic field guide to Devonian hydrocarbon stratigraphy of southeastern West Virginia and adjacent Virginia: Charleston, West Virginia, Appalachian Geological Society, October 12-13, 1996, Guidebook, 160 p.

\#2029 Dennison, J.M., and Stewart, K.G., eds., 1998, Geologic field guide to extensional structures along the Allegheny Front in Virginia and West Virginia near the Giles County seismic zone: Southeastern Section, Geological Society of America, Charleston, West Virginia, March 28-29, 1998, Guidebook, 102 p.

\#2249 Mehlhop, A.M., 1996, Extensional structures along the Allegheny Front in Virginia and West Virginia near the Giles County seismic zone: University of North Carolina at Chapel Hill, unpublished M.S. thesis, $91 \mathrm{p}$.

\#1861 Mehlhop, A.M., Dennison, J.M., and Stewart, K.G., 1996, Extensional structures along the Allegheny Front in Virginia and West Virginia near the Giles County seismic zone: Geological Society of America Abstracts with Programs, v. 28, no. 7, p. A-239.

\#1922 Zoback, M.L., and Zoback, M.D., 1989, Tectonic stress field of the continental United States, in Pakiser, L.C., and Mooney, W.D., eds., Geophysical framework of the continental United States: Geological Society of America Memoir 172, p. 523-539. 


\section{Louisiana wrench faults (Class C)}

Structure Name Louisiana wrench faults (Class C)

Comments: Zimmerman and Sassen (1993 \#2247) and Zimmerman (1992 \#2245; 1994 \#2246; 1995 \#2248) inferred the existence of four large strike-slip faults in northern and central Louisiana, southeastern Arkansas, and central western Mississippi. Zimmerman inferred the existence of the faults from alignments and spatial associations of anomalies in eight kinds of geological and hydrological data, chiefly those encountered during analysis of subsurface data from more than 7,000 petroleum wells. Five of the eight kinds of data might reflect processes that operated as recently as the Holocene. This potential recency is the reason for evaluating the inferred faults here. Three of the inferred faults strike approximately N. $24^{\circ}$ E. through northern and central Louisiana and adjacent parts of Arkansas and Mississippi and are approximately $60 \mathrm{~km}$ apart. The fourth inferred fault strikes approximately N. $62^{\circ}$ W. through central western Mississippi, northeasternmost Louisiana, and southeastern Arkansas, and intersects the other three inferred faults. Meloy and Zimmerman (1997 \#2212) concluded that the northeast-striking inferred faults do not link northward with the Reelfoot rift, which hosts the New Madrid seismic zone, and therefore do not present a significant earthquake hazard.

Reason for assignment to class C: The inferred faults are assigned to class $\mathrm{C}$ in this compilation of evidence for Quaternary faulting for two reasons. (1) The reports cited above under "Structure name" do not present convincing evidence for the existence of the faults. The notion of a large, northwest-striking transform fault of Cambrian age at approximately the location and orientation suggested by Zimmerman is an old one (Thomas, 1976 \#2237; 1991 \#678). However, most of the examples figured by Zimmerman (1992 \#2245; 1994 \#2246; 1995 \#2248) to illustrate various indicators of faulting along northeast or northwest trends have alternative explanations that do not involve the inferred vertical faults. Also, two of the indicators, imagery lineaments and changes and straight reaches in river courses, are notoriously subjective and irreproducible, but no tests of reliability are mentioned. Finally, igneous intrusions are tentatively attributed to possible wrench faults. If the attribution is valid, the intrusions should align along the postulated faults; they do not. The same is the case for the locations of all eight indicators taken together. (2) Although five of the eight geological and hydrological indicators that were used to infer the faults are stated to record processes that operated as recently as the Holocene (table 1 of Zimmerman, 1992 \#2245; fig. 2 of

Zimmerman, 1994 \#2246; fig. 2 of Zimmerman, 1995 \#2248), no clear evidence is given for any Holocene activity. Potentially the clearest evidence might be straight reaches of streams, but the one cited example shows a reach of the Mississippi River that, to my eye, is curved.

Date of compilation $08 / 20 / 98$; revised $01 / 28 / 00$

Compiler and affiliation Russell L. Wheeler, U.S. Geological Survey

State Louisiana; Arkansas; Mississippi

County Beauregard; Caldwell; East Carroll; Grant; Jackson; La Salle; Lincoln; Natchitoches; Pointe Coupee; Rapides; Richland; Union; Vernon; West Carroll; Winn (Louisiana); Ashley; Bradley; Calhoun; Chicoi; Desha; Drew; Union (Arkansas); Issaquena; Sharkey; Washington; Yazoo (Mississippi) 
$1^{\circ} \times 2^{\circ}$ sheet Jackson; Alexandria; Shreveport; Natchez; El Dorado; Greenwood; Lake Charles Physiographic province Coastal Plain

\section{References}

\#2212 Meloy, D.U., and Zimmerman, R.K., 1997, Potential seismic risk associated with Louisiana wrench faulting: Louisiana Geological Survey Open-File Series No. 97-01, $38 \mathrm{p}$.

\#2237 Thomas, W.A., 1976, Evolution of Ouachita-Appalachian continental margin: Journal of Geology, v. 84, p. 323-342.

\#678 Thomas, W.A., 1991, The Appalachian-Ouachita rifted margin of southeastern North America: Geological Society of America Bulletin, v. 103, p. 415-431.

\#2245 Zimmerman, R.K., 1992, Fractured Smackover limestone in northeast LouisianaImplications for hydrocarbon exploitation: Transactions of the Gulf Coast Association of Geological Societies, v. 42, p. 401-412.

\#2246 Zimmerman, R.K., 1994, Evidence of wrench faulting in north and central Louisiana: Louisiana State University Energy and Environmental Resources Basin Research Institute Bulletin, v. 4, no. 1, p. 53-61.

\#2248 Zimmerman, R.K., 1995, Evidence and effects of wrench faulting, north central Gulf Coast region: Transactions of the Gulf Coast Association of Geological Societies, v. 45 , p. 629-635.

\#2247 Zimmerman, R.K., and Sassen, R., 1993, Hydrocarbon transfer pathways from Smackover source rocks to younger reservoir traps in the Monroe gas field, northeast Louisiana: Transactions of the Gulf Coast Association of Geological Societies, v. 43, p. 473-480. 


\section{Moodus seismic zone (Class c)}

Structure Name Moodus seismic zone (Class C)

Comments: Ebel (1987 \#2031) referred to the area as the central Connecticut seismic zone, but Moodus is used here because it is the more common usage.

Reason for assignment to class C: This evaluation of Quaternary faulting is not a reliable guide to seismic hazard of the Moodus seismic zone. The most authoritative and reliable assessment of the seismic hazard in the area evaluated here is the national seismic hazard maps, which are published by the USGS (Open-File Report 97-131, 12 maps, scale 1:7,000,000; http://geohazards.cr.usgs.gov/eq/). In the Central and Eastern U.S. (CEUS) east of the Rocky Mountain Front, the distribution of historical earthquakes is a reasonable guide to seismic hazard. In the CEUS, the national seismic hazard maps rely mainly on the distribution of historical seismicity to calculate the hazard. In contrast to examining the area's historical seismicity, this discussion focuses on surficial evidence of large, prehistoric earthquakes. Where present, this surficial evidence will be integrated with the historical seismicity to improve future versions of the national hazard maps. In the CEUS, the most common types of surficial evidence of large, prehistoric earthquakes are liquefaction features and faults that offset young strata. However, in some areas the surficial record of large, prehistoric earthquakes is incomplete because of erosion, equivocal, or presently unrecognized. Nonetheless, the national hazard maps show that, for many parts of the CEUS, although convincing surficial evidence of large, prehistoric earthquakes is absent, these areas are NOT free of seismic hazard. The occurrence of significant historical earthquakes in the area described here demonstrates a notable level of seismic hazard.

The Moodus seismic zone is considered in this compilation of evidence for Quaternary faulting for three reasons.

The zone has been seismically active since before the arrival of Europeans (Ebel and others, 1982 \#1821). Indeed, the town of Moodus takes its name from a longer Native American word that refers to the characteristic noises produced by frequent small tremors in the area (Ebel and others, 1982 \#1821). The largest historical earthquake caused MMI VI-VIII in 1791 (Ebel and others, 1982 \#1821; Stover and Coffman, 1993 \#1986 used standardized methods to assign a VII). Johnston (1994 \#2042) estimated the moment magnitude as M 4.2. Microearthquakes are common (Ebel, 1981 \#1816). The 1980's saw four swarms of shallow microearthquakes (Ebel and others, 1982 \#1821; Ebel, 1989 \#1817; Quittmeyer and others, 1989 \#1880).

The metamorphic rocks that underlie the area have been mapped in detail (see source list in Rodgers, 1985 \#1944) and were the subject of diverse studies to identify the seismic source (for example Koch and others, 1978 \#1848; Barosh and others, 1982 \#2023; London, 1988 \#1853; London, 1989 \#2014).

A borehole was drilled 1,450 $\mathrm{m}$ into or near the top of the source volume of some of the microearthquake swarms (Ebel, 1989 \#1817; London, 1989 \#2014). The hole was logged, sampled, and tested in numerous ways (for example Baumgärtner and Zoback, 1989 \#1793; deBoer, 1989 \#1810; London, 1989 \#2014; Quittmeyer and others, 1989 \#1880; Ambers and Wintsch, 1990 \#1991; Meglis and others, 1991 \#1860). 
However, despite the intense geological, seismological, and other geophysical study, the causes and causative faults of the earthquakes remain enigmatic (Ebel and Kafka, 1991 \#2008). In addition, reconnaissance of stream, swamp, and marsh exposures found no evidence for liquefaction or paleoliquefaction (Gelinas and others, 1993 \#1826). Accordingly, the seismic zone was assigned to class $\mathrm{C}$ in this compilation of structural, stratigraphic, and paleoseismological evidence for Quaternary faulting.

Date of compilation 05/27/98; revised 02/01/00

Compiler and affiliation Russell L. Wheeler, U.S. Geological Survey

State Connecticut

County Middlesex; New London

$1^{\circ} \times 2^{\circ}$ sheet Hartford

Physiographic province New England

\section{References}

\#1991 Ambers, C.P., and Wintsch, R.P., 1990, Subsurface identification of Merrimack, PutnamNashoba, and metavolcanic Avalon terrace rocks, and ductile to brittle fault rocks in the 1.45-kilometer-deep research hole, Moodus, Connecticut, in Socci, A.D., Skehan, J.W., and Smith, G.W., eds., Geology of the composite Avalon terrane of southern New England: Geological Society of America Special Paper 245, p. 171-186.

\#2023 Barosh, P.J., London, D., and de-Boer, J., 1982, Structural geology of the Moodus seismic area, south-central Connecticut, in Joesten, R., and Quarrier, S.S., eds., Guidebook for fieldtrips in Connecticut and south central Massachusetts: State Geological and Natural History Survey of Connecticut Guidebook 5, New England Intercollegiate Geological Conference, 74th annual meeting, Storrs, Connecticut, October 2-3, 1982, p. 419-451.

\#1793 Baumgärtner, J., and Zoback, M.D., 1989, Interpretation of hydraulic fracturing pressuretime records using interactive analysis methods: International Journal of Rock Mechanics and Mining Sciences and Geomechanical Abstracts, v. 26, p. 461-469.

\#1810 deBoer, J.Z., 1989, Neotectonic deformation of southern New England; new data on stress configuration and brittle failure: Geological Society of America Abstracts with Programs, v. 21, no. 2, p. 10.

\#1816 Ebel, J.E., 1981, Source parameters of some earthquakes near Moodus, Connecticut [abs.]: Eos, Transactions of the American Geophysical Union, v. 62, no. 45, p. 967.

\#2031 Ebel, J.E., 1987, The seismicity of the northeastern United States, in Jacob, K.H., ed., Proceedings from the symposium on seismic hazards, ground motions, soil-liquefaction and engineering practice in eastern North America: National Center for Earthquake Engineering Research Technical Report NCEER-87-0025, p. 178-188.

\#1817 Ebel, J.E., 1989, A comparison of the 1981, 1982, 1986, and 1987-1988 microearthquake swarms at Moodus, Connecticut: Seismological Research Letters, v. 60, p. 177-184.

\#2008 Ebel, J.E., and Kafka, A.L., 1991, Earthquake activity in the northeastern United States, in Slemmons, D.B., Engdahl, E.R., Zoback, M.D., and Blackwell, D.D., eds., 
Neotectonics of North America: Boulder, Colorado, Geological Society of America, Decade Map Volume 1, p. 277-290.

\#1821 Ebel, J.E., Vudler, V., and Celata, M., 1982, The 1981 microearthquake swarm near Moodus, Connecticut: Geophysical Research Letters, v. 9, p. 397-400.

\#1826 Gelinas, R.L., Kemppinen, H.M.A., and Amick, D.C., 1993, Evaluation of liquefactionsusceptible materials near moderate magnitude historical earthquakes in New England [abs.]: Seismological Research Letters, v. 64, p. 259-260.

\#2042 Johnston, A.C., 1994, Appendix C-Summary tables, SCR seismicity data base, in Schneider, J.F., ed., The earthquakes of stable continental regions-v. 2-Appendices A to E: Technical report to Electric Power Research Institute TR-102261-V2, Palo Alto, California, December 1994, p. C-1-C-46.

\#1848 Koch, B.F., Fahey, R.J., Quarrier, S.S., and Kick, J.F., 1978, Geology and geophysics of the Moodus seismic area, Connecticut: Geological Society of America Abstracts with Programs, v. 10, no. 2, p. 71.

\#1853 London, D., 1988, Characteristics and regional significance of the Cremation Hill ductile fault zone at the Bronson Hill-Merrimack boundary, south-central Connecticut: American Journal of Science, v. 288, p. 353-375.

\#2014 London, D., 1989, Bedrock geology of the Moodus seismic area, south-central Connecticut: State Geological and Natural History Survey of Connecticut Report of Investigations No. 11, 25 p., 1 pl., scale 1:12,000.

\#1860 Meglis, I.L., Engelder, T., and Graham, E.K., 1991, The effect of stress-relief on ambient microcrack porosity in core samples from the Kent Cliffs (New York) and Moodus (Connecticut) scientific research boreholes: Tectonophysics, v. 186, p. 163-173.

\#1880 Quittmeyer, R., Mrotek, K., Naumoff, P., and Statton, C.T., 1989, The 1987 earthquake swarm at Moodus, CT and its relation to the tectonic stress field measured by borehole testing: Geological Society of America Abstracts with Programs, v. 21, no. 2, p. 59.

\#1944 Rodgers, J., compiler, 1985, Bedrock geologic map of Connecticut: Connecticut Geological and Natural History Survey and U.S. Geological Survey, 2 sheets, scale $1: 125,000$.

\#1986 Stover, C.W., and Coffman, J.L., 1993, Seismicity of the United States, 1568-1989 (revised): U.S. Geological Survey Professional Paper 1527, 418 p. 


\section{Mosholu fault (Class C)}

\section{Structure Name Mosholu fault (Class C)}

Comments: The Mosholu fault is well mapped, and diversion of the Bronx River, which crosses it, is convincingly dated as post-glacial. However, the conclusion of post-glacial slip on the fault depends on interpreting a bedrock high across the former course of the river as a tectonic uplift caused by fault slip. The uplift would then have diverted the river. The interpretation of a tectonic uplift is reasonable but evidence is not conclusive.

Lobeck (1939 \#2046, p. 568) showed the fault on a sketch map, referring to it as the Van Cortlandt Park fault. Baskerville (1982 \#2007) mapped the fault and renamed it the Mosholu Parkway fault zone. Baskerville (1992 \#1924) shortened the name to the Mosholu fault. Baskerville (1992 \#1924) showed the curved fault extending $9.2 \mathrm{~km}$ from near West $261^{\text {st }}$ St. in northwesternmost Bronx Co., in the north, to East $172^{\text {nd }}$ St. approximately $1 \mathrm{~km}$ east of the Bronx River, in the south. The fault location is from the 1:24,000-scale bedrock geologic map of Baskerville (1992 \#1924, sheet 1), which shows topographic control with a 10-foot (3 $\mathrm{m})$ contour interval. The fault was located from geologic mapping and abundant subsurface data that were obtained from public agencies and corporations.

The bedrock is amphibolite-grade, Late Proterozoic to Ordovician, metamorphic rock of the Manhattan Prong (Fisher and others, 1970 \#1931; Baskerville, 1982 \#2007; Baskerville, 1992 \#1924). Map-scale folds trend northeast and plunge gently southwest. Differential erosion has produced a topographic grain parallel to the northeast structural grain (Merguerian and Sanders, 1997 \#1862). Most of the large streams, including the Bronx River, follow the topographic grain southwestward along strike valleys underlain by the Cambrian to Ordovician Inwood Marble.

The largest post-metamorphic faults strike northwest, dip steeply to moderately, and show dextral and sinistral strike- and oblique slip, with various senses of subsequent reactivation (Baskerville, 1982 \#2007; Merguerian and Sanders, 1996 \#2047; Merguerian and Sanders, 1997 \#1862). Dextral separation can be as large as $100-200 \mathrm{~m}$ but sinistral separation is typically measured in centimeters. The Mosholu fault is one of the largest northwest-striking faults in the New York City area. Its map-scale separation is approximately $35 \mathrm{~m}$ dextral within the Inwood Marble (Baskerville, 1992 \#1924). However, the strike-slip component of any modern reactivation would probably be sinistral in the present-day, northeast-trending, greatest horizontal compressive stress (Zoback and Zoback, 1989 \#1922).

Thirteen kilometers northeast along the strike of the structural grain lies an informative analog to the Mosholu fault (Merguerian and Sanders, 1997 \#1862). The northwest-striking Dobbs

Ferry fault zone is also in the Manhattan Prong, and appears to have undergone seismic reactivation in 1985 (Seeber and Dawers, 1989 \#1894). The Dobbs Ferry fault zone shows dextral separation as large as approximately $30 \mathrm{~m}$, and lesser sinistral separation. Seeber and Dawers (1989 \#1894) suggested that the dextral slip is the older, perhaps originating in the Mesozoic extension that formed the Atlantic passive margin, whereas the sinistral slip might be the younger, because its orientation and sense are consistent with the present-day stress field. The same faulting chronology might apply to the Mosholu fault. The best test of this hypothesis would be geochronological data from minerals whose grains form kinematic indicators in the fault rock. Alternatively, relative ages of dextral and sinistral slip might be determined, and 
their absolute ages constrained, from kinematic observations and petrographic and petrologic arguments like those of Ratcliffe and others (1990 \#1943).

Baskerville (1992 \#1924) shows dips at three places along the fault, all in the southeastern quarter of the trace. From the southeast, the values are $45^{\circ} \mathrm{NE}$, vertical, and $89^{\circ} \mathrm{NE}$. All measurements were taken in schists and gneisses of the Cambrian-Ordovician Hartland Formation.

I found no mention of faulting in materials younger than the Proterozoic to Ordovician metamorphic rocks. Geomorphic expression of the fault is not reported. The area around the fault is mantled by Pleistocene glacial till (Baskerville, 1992 \#1924). Bedrock outcrops vary from scarce to absent.

Sinistral slip is inferred for any Quaternary movement because it would be consistent with the present-day stress field. Thus, any such Quaternary strike slip on the Mosholu fault would reverse part of the presumably larger and older dextral slip that dominates the separation of the contact of the Inwood Marble. The shape of the trace of the Mosholu fault, as mapped by Baskerville (1992 \#1924), includes two right-stepping bends adjacent to the "East 204 ${ }^{\text {th }} \mathrm{St}$. bulge" of Merguerian and Sanders (1996 \#2047; 1997 \#1862) (see below). If the fault slipped sinistrally, the bends would be restraining or compressional and might have contributed to the formation of the bulge. Alternatively, the compressional nature of the stress field and the presence of the bulge also would be consistent with a component of reverse slip (Merguerian and Sanders, 1996 \#2047). The steep dip of the fault (see below) may make the first alternative more likely.

Reason for assignment to class $\mathbf{C}$ The faulting is not demonstrably of Quaternary age. No detailed paleoseismological studies have been performed to test the possibility of Quaternary faulting.

Merguerian and Sanders (1996 \#2047; 1997 \#1862) inferred the occurrence and age of the most recent faulting as follows. The Bronx River flows southwestward along a lowland underlain by the Inwood Marble, and the Mosholu fault strikes northwest across the lowland. From a diversion point approximately $0.7 \mathrm{~km}$ northeast of the fault, the lowland continues southwestward as the Webster Avenue lowland, to join the Harlem River after traversing another 5-6 km. However, the Webster Avenue lowland presently contains only a small stream. At the diversion point, the Bronx River now leaves the lowland and flows southward across an upland, through the narrow V-shaped Snuff Mill gorge of Merguerian and Sanders (1996 \#2047). The gorge is cut into resistant Proterozoic gneisses and schists (Baskerville, 1992 \#1924). Kemp (1896 \#1844; 1897 \#2065) reported that the gorge is 75 feet (23 m) deep and retains fresh potholes in its sides 25,55 , and 75 feet $(8,17$, and $23 \mathrm{~m})$ above the present elevation of the river. The potholes indicated to Kemp that the gorge was cut in glacial or post-glacial time. The diversion would have occurred at the start of the cutting. In addition, Merguerian and Sanders (1996 \#2047; 1997 \#1862) noted that the V-shaped cross section of the gorge and the lack of glacial striae on its fresh walls required the diversion and cutting to be younger than Pleistocene glaciation.

Merguerian and Sanders (1996 \#2047; 1997 \#1862) attributed the diversion of the Bronx River to an uplift. At the diversion point, the Webster Avenue lowland is blocked in the sub- 
surface by the southeastern nose of a buried, elongated, bedrock uplift that Merguerian and Sanders (1996 \#2047) named the East 204th St. bulge. The crest of the bulge is approximately $0.5 \mathrm{~km}$ northeast of the trace of the Mosholu fault, and maintains or slightly decreases this separation as the bulge and the fault trend northwestward together. The map of Baskerville (1992 \#1924, sheet 2) shows contours of the elevation of bedrock. The contours allow the bulge to be traced northwestward for $2 \mathrm{~km}$ from its nose. Farther northwest, the bedrock contours are lacking, but topographic contours and locations of bedrock outcrops indicate that the total length of the bulge is approximately $3 \mathrm{~km}$.

Immediately north of the diversion point, borehole data indicate the presence of clay that overlies glacial till in the valley through which the Bronx River flowed, and still flows, southwestward to the diversion point (Merguerian and Sanders, 1996 \#2047; Merguerian and Sanders, 1997 \#1862). No such clay was found south of the diversion point in the Webster Avenue lowland (Merguerian and Sanders, 1996 \#2047). Merguerian and Sanders (1996 \#2047; 1997 \#1862) concluded that a post-glacial uplift formed the East 204th St. bulge, thereby damming the Bronx River and forming a lake in which the clay settled. The river would then have diverted southward across the upland, cutting the Snuff Mill gorge and eventually draining the lake through the gorge.

The bulge is more likely to be of tectonic than erosional origin. The northwest-trending bulge is defined largely by a trough in bedrock along the southwest limb of the bulge. The Mosholu fault strikes approximately along the middle of the trough, and this map relation indicates the possibility that the trough formed by preferential erosion of fault-shattered rock or gouge. In such a case the bulge could be an artifact of erosion, and need have no tectonic significance. However, Baskerville (1982 \#2007; 1992 \#1924) cites a written communication from T.W. Fluhr that the Mosholu fault, where observed in city water tunnels, is narrow and shows little weathering or alteration. Thus, it appears unlikely that the bedrock trough formed mainly or entirely by stream or glacial erosion along the course of the fault. Perhaps more likely is that the bulge formed in a compressional bend during post-glacial sinistral slip on the Mosholu fault. Once formed, the topographic expression of the bulge might have been accentuated by post-glacial fluvial erosion.

The attribution of the uplift to post-glacial slip on the Mosholu fault is a reasonable inference, but is not demonstrated. In addition, Merguerian and Sanders (1997 \#1862) cautioned that they cannot prove that the uplift occurred seismically instead of by aseismic creep. However, the bedrock contours of Baskerville (1992 \#1924) show that the subsurface structural relief of the East $204^{\text {th }}$ St. bulge is 3-6 m. Perhaps one or more earthquakes are the most likely way to generate this much relief in exposed, multiply-folded, medium-grade metamorphic rocks during the short 12,000 years (Merguerian and Sanders, 1996 \#2047) of post-glacial time.

Neither is there evidence with which to determine whether the uplift, if seismic, occurred in one large earthquake or many smaller ones. However, even if post-glacial stream erosion has doubled or tripled the original relief of the uplift to reach the present 3-6 m, the rest of the relief would be large enough to indicate that it may have accumulated over several earthquakes. For example, original relief of 1-3 m, doubled or tripled, could equal the present relief. In stable continental regions worldwide, earthquakes of moment magnitude $\mathbf{M} 5.5$ typically may have rupture zones approximately $3 \mathrm{~km}$ long and slip of $0.5 \mathrm{~m}$ (Johnston, 1993 
\#1840). If the Mosholu fault dips $45^{\circ} \mathrm{NE}$ near the East $204^{\text {th }}$ St. bulge, pure dip slip could have produced the hypothetical original relief in perhaps 2-6 M 5.5 earthquakes. If the fault is vertical near the bulge, oblique slip along a rake of $30^{\circ}$ could have produced the relief in perhaps 4-12 M 5.5 earthquakes.

Date of compilation 12/16/98; revised 01/28/00

Compiler and affiliation Russell L. Wheeler, U.S. Geological Survey

State New York

County Bronx

$1^{\circ} \times 2^{\circ}$ sheet New York

Physiographic province New England

\section{References}

\#2007 Baskerville, C.A., 1982, The foundation geology of New York City, in Legget, R.F., ed., Geology under cities: Geological Society of America Reviews in Engineering Geology, v. 5, p. 95-117.

\#1924 Baskerville, C.A., 1992, Bedrock and engineering geologic maps of Bronx County and parts of New York and Queens Counties, New York: U.S. Geological Survey Miscellaneous Investigations Map I-2003, 2 sheets, scale 1:24,000.

\#1931 Fisher, D.W., Isachsen, Y.W., and Rickard, L.V., 1970, Geologic map of New YorkLower Hudson sheet: New York State Museum and Science Service Map and Chart Series 15, 1 sheet, scale 1:250,000.

\#1840 Johnston, A.C., 1993, Average stable continental earthquake source parameters based on constant stress drop scaling [abs.]: Seismological Research Letters, v. 64, p. 261.

\#1844 Kemp, J.F., 1896, Glacial or post-glacial diversion of the Bronx River: Science, v. 4, p. 696.

\#2065 Kemp, J.F., 1897, The glacial or post-glacial diversion of the Bronx River from its old channel: Transactions of the New York Academy of Science, v. 16, p. 18-24.

\#2046 Lobeck, A.K., 1939, Geomorphology-An introduction to the study of landscapes: New York, McGraw-Hill, 731 p.

\#2047 Merguerian, C., and Sanders, J.E., 1996, Diversion of the Bronx River in New York City; evidence for postglacial surface faulting?, in Geology of Long Island and metropolitan New York: Stony Brook, State University of New York at Stony Brook, Long Island Geologists, p. 131-145.

\#1862 Merguerian, C., and Sanders, J.E., 1997, Bronx River diversion-Neotectonic implications: International Journal of Rock Mechanics and Mining Sciences, v. 34, no. 3-4, paper no. 198.

\#1943 Ratcliffe, N.M., Burton, W.C., and Pavich, M.J., 1990, Orientation, movement history, and cataclastic rocks of Ramapo fault based on core drilling and trenching along the 
western margin of the Newark basin near Berndardsville, New Jersey: U.S. Geological Survey Miscellaneous Investigations Map I-1982, 1 sheet.

\#1894 Seeber, L., and Dawers, N., 1989, Characterization of an intraplate seismogenic fault in the Manhattan prong, Westchester Co., N.Y.: Seismological Research Letters, v. 60, p. 71-78.

\#1922 Zoback, M.L., and Zoback, M.D., 1989, Tectonic stress field of the continental United States, in Pakiser, L.C., and Mooney, W.D., eds., Geophysical framework of the continental United States: Geological Society of America Memoir 172, p. 523-539. 


\section{New York Bight fault (Class C)}

\section{Structure Name New York Bight fault (Class C)}

Comments: A fault, $50 \mathrm{~km}$ long, trends north-northeast in the Atlantic Ocean south of Long Island, New York, and east of northern New Jersey. Middle and late Quaternary sediments overlie the fault without offset larger than the 1-m limit of resolution. The fault was named by Hutchinson and Grow (1985 \#1833). Schwab and others (1997 \#2224; 1997 \#2226) referred to it as both the New York Bight fault and the New York Bight fault zone. Work in progress by the U.S. Geological Survey, in cooperation with the U.S. Army Corps of Engineers, images the fault with high-resolution marine seismic-reflection profiles (Schwab and others, 1997 \#2224; 1997 \#2225; 1997 \#2226). The profiles cross the fault every $250 \mathrm{~m}$ along approximately $40 \mathrm{~km}$ of its length; the fault trace is mapped at a scale of 1:75,000 (Lotto and others, 1997 \#2208, and L.L. Lotto, oral and written communs., 1998).

Triassic-Jurassic rifting produced early Mesozoic rift basins to initiate the Atlantic margin, including four basins on the Long Island Platform, south of Long Island and New England and east of New Jersey (Hutchinson and others, 1986 \#1835). The westernmost of these four basins is the New York Bight basin. As rifting gave way to drifting, a post-rift unconformity developed across the rifted basement and its sediment-filled rift basins. Deposition of conformable Coastal Plain strata began to bury the post-rift unconformity during the Late Jurassic offshore and the Early Cretaceous onshore. In Cretaceous time the post-rifting New York Bight fault formed at or near the western edge of the New York Bight basin (Hutchinson and Grow, 1985 \#1833; Hutchinson and others, 1985 \#1834). The western edge of the New York Bight basin has not been imaged clearly in published reports to date, and the structure of the basin is complex (Hutchinson and Grow, 1985 \#1833; Hutchinson and others, 1986 \#1835). Any connection between the New York Bight basin and the New York Bight fault is unclear at present.

The New York Bight fault strikes north-northeast for $50 \mathrm{~km}$ in the Atlantic Ocean on the Long Island Platform (Hutchinson and Grow, 1985 \#1833). Schwab and others (1997 \#2224; 1997 \#2226) remapped the northern $38 \mathrm{~km}$ of the fault. The fault dips nearly vertically and was traced on marine seismic-reflection profiles to within $8 \mathrm{~km}$ of the Long Island coast (Lotto and others, 1997 \#2208; Schwab and others, 1997 \#2224; Schwab and others, 1997 \#2226). The fault's closest approach to the New Jersey coast is $27 \mathrm{~km}$ at its southern end (Hutchinson and Grow, $1985 \# 1833$ ). The west side of the fault was dropped down as much as $109 \mathrm{~m}$ during and since the Late Cretaceous, with offsets decreasing upward to indicate growth faulting that continued at least until Eocene time (Hutchinson and Grow, 1985 \#1833). The west side of the fault is consistently down at all crossings along the north-northeast-striking fault (Hutchinson and Grow, 1985 \#1833; Lotto and others, 1997 \#2208). However, dips are steeply to the west at some crossings and steeply to the east at others. The possibility of a strike-slip component cannot be evaluated with information available to Hutchinson and Grow (1985 \#1833). The fault has no reported geomorphic expression.

Reason for assignment to class C The fault lacks documented Quaternary offset. Cretaceous to Eocene strata are offset (Hutchinson and Grow, 1985 \#1833; Lotto and others, 1997 \#2208). Eocene and Miocene strata are separated by an unconformity that has been dated elsewhere as middle Oligocene. The unconformity and overlying Miocene strata are not offset sufficiently to be detected with the profiles that were available to Hutchinson and Grow (1985 
\#1833). More recent seismic-reflection work in progress (see above) indicates that Cretaceous and Tertiary strata are overlain unconformably at the fault by middle and late Quaternary sediments (Lotto, 1997 \#2208; Schwab, 1997 \#2224; 1997 \#2226, and L.L. Lotto, oral and written communs., 1998). The middle and late Quaternary sediments lack offsets larger than the 1-m limit of resolution.

Therefore, the most recent offset is either smaller than $1 \mathrm{~m}$ or older than middle Quaternary. Individual faulting events have not been distinguished. In addition, discussion of recurrences would be premature unless the faulting events can be shown to have occurred seismically. Rates of dip slip can be estimated in two ways, both of which indicate that the rate is probably much less than $0.2 \mathrm{~mm} / \mathrm{yr}$. The estimates come from the marine seismic-reflection profiles of Hutchinson and Grow (1985 \#1833). Accordingly, only dip slip can be estimated and the possibility of strike slip cannot be evaluated. If the New York Bight fault were to slip in the present-day stress field, the east-northeast trend of local greatest horizontal compression (Zoback and Zoback, 1989 \#1922) implies that a dextral component might be likely. In such a case total slip would exceed dip slip. (1) Hutchinson and Grow (1985 \#1833) tabulated amounts and ages of offsets of several reflectors. The youngest offset reflectors on four profiles are offset 5-50 m and range in age from 37-58 m.y. to $67 \mathrm{~m} . \mathrm{y}$. (2) If dip slip occurred at a rate of $0.2 \mathrm{~mm} / \mathrm{yr}$, the $1.6 \mathrm{Ma}$ base of the Quaternary would be offset by $320 \mathrm{~m}$. Such a large offset would have been seen and it was not (Hutchinson and Grow, 1985 \#1833, fig 10; Lotto and others, 1997 \#2208; Schwab and others, 1997 \#2224; 1997 \#2226).

Date of compilation 12/16/98; revised 01/28/00

Compiler and affiliation Russell L. Wheeler, U.S. Geological Survey

State New York (offshore)

County Nassau (offshore)

$1^{\circ} \times 2^{\circ}$ sheet New York

Physiographic province Coastal Plain (offshore)

\section{References}

\#1833 Hutchinson, D.R., and Grow, J.A., 1985, New York Bight fault: Geological Society of America Bulletin, v. 96, p. 975-989.

\#1834 Hutchinson, D.R., Klitgord, K.D., and Detrick, R.S., 1985, Block Island fault-A Paleozoic crustal boundary on the Long Island platform: Geology, v. 13, p. 875-879.

\#1835 Hutchinson, D.R., Klitgord, K.D., and Detrick, R.S., 1986, Rift basins of the Long Island platform: Geological Society of America Bulletin, v. 97, p. 688-702.

\#2208 Lotto, L., Allison, M.A., Schwab, W.C., Butman, B., Foster, D., Denny, J., and Corso, W., 1997, Seismic stratigraphy of the New York Bight, NY/NJ continental shelf: Geological Society of America Abstracts with Programs, v. 29, no. 1, p. 62.

\#2224 Schwab, W.C., Allison, M.A., Corso, W., Lotto, L.L., Butman, B., Buchholtz ten Brink, M., Denny, J.F., Danforth, W.W., and Foster, D.S., 1997, Initial results of high-resolution sea-floor mapping offshore of the New York-New Jersey metropolitan area using sidescan sonar: Northeastern Geology and Environmental Sciences, v. 19, no. 4, p. 243-262. 
\#2225 Schwab, W.C., Butman, B., Denny, J.F., Buchholtz ten Brink, M., Corso, W., Lotto, L., and Allison, M.A., 1997, High-resolution sea-floor mapping of the New York Bight apex-Sedimentary framework: Geological Society of America Abstracts with Programs, v. 29, no. 1, p. 77.

\#2226 Schwab, W.C., Corso, W., Allison, M.A., Butman, B., Denny, J.F., Lotto, L.L., Danforth, W.W., Foster, D.S., O'Brien, T.F., Nichols, D.A., Irwin, B.J., and Parolski, K.F., 1997, Mapping the sea floor geology offshore of the New York-New Jersey metropolitan area using sidescan sonar-Preliminary report: U.S. Geological Survey Open-File Report 97-61, 3 sheets.

\#1922 Zoback, M.L., and Zoback, M.D., 1989, Tectonic stress field of the continental United States, in Pakiser, L.C., and Mooney, W.D., eds., Geophysical framework of the continental United States: Geological Society of America Memoir 172, p. 523-539. 


\section{Northeast Ohio seismic zone (Class C)}

\section{Structure Name Northeast Ohio seismic zone (Class C)}

Comments: The Northeast Ohio seismic zone was named by Seeber and Armbruster (1993 $\# 1892$ ). It is defined by the epicenters of 20 earthquakes dating back to 1836 (Hansen, 1993 \#1829). Seeber and Armbruster (1993 \#1892) excluded three other nearby earthquakes because (1) a 1928 earthquake in Lorain County is too far west, (2) a 1987 earthquake to the east in Ashtabula County was induced, and (3) an 1857 earthquake that was originally located in Ashtabula County has a recalculated location approximately $80 \mathrm{~km}$ to the northwest, in the middle of Lake Erie. The 20 epicenters of the seismic zone form a diffuse cluster that is approximately $80 \mathrm{~km}$ long in the northeast-southwest direction and approximately $40 \mathrm{~km}$ wide (Hansen, 1993 \#1829). The 11 largest epicenters are more tightly aligned along an approximately N. $30^{\circ}$ E. trend and lie along and northwest of the Akron Magnetic Lineament (Seeber and Armbruster, 1993 \#1892). One of the aligned earthquakes occurred on January 31,1986 , at a depth of 4-6 km, had a moment magnitude of $\mathbf{M} 4.6-4.9$, produced Modified Mercalli intensities up to VI-VII, and had almost pure dextral slip on a plane oriented N. $55^{\circ}$ E. $/ 73^{\circ} \mathrm{SE}$ (Nicholson and others, 1988 \#2214). Aftershocks aligned roughly parallel to this plane and spanned an area of approximately 6 square kilometers in the steeply dipping plane (Nicholson and others, 1988 \#2214). The area spanned by the aftershocks is similar to the 510 square kilometers that would be expected as the area of a typical rupture zone of this magnitude earthquake, in a stable continental region like northeastern Ohio (Johnston, 1993 \#1840).

Reason for assignment to class C: This evaluation of Quaternary faulting is not a reliable guide to seismic hazard of the Northeast Ohio seismic zone. The most authoritative and reliable assessment of the seismic hazard in the area evaluated here is the national seismic hazard maps, which are published by the USGS (Open-File Report 97-131, 12 maps, scale 1:7,000,000; http://geohazards.cr.usgs.gov/eq/). In the Central and Eastern U.S. (CEUS) east of the Rocky Mountain Front, the distribution of historical earthquakes is a reasonable guide to seismic hazard. In the CEUS, the national seismic hazard maps rely mainly on the distribution of historical seismicity to calculate the hazard. In contrast to examining the area's historical seismicity, this discussion focuses on surficial evidence of large, prehistoric earthquakes. Where present, this surficial evidence will be integrated with the historical seismicity to improve future versions of the national hazard maps. In the CEUS, the most common types of surficial evidence of large, prehistoric earthquakes are liquefaction features and faults that offset young strata. However, in some areas the surficial record of large, prehistoric earthquakes is incomplete because of erosion, equivocal, or presently unrecognized. Nonetheless, the national hazard maps show that, for many parts of the CEUS, although convincing surficial evidence of large, prehistoric earthquakes is absent, these areas are NOT free of seismic hazard. The occurrence of significant historical earthquakes in the area described here demonstrates a notable level of seismic hazard.

Obermeier examined selected stream banks in the Northeast Ohio seismic zone for prehistoric liquefaction features that might indicate the occurrence of prehistoric earthquakes of magnitudes 6 or larger (S. Obermeier, unpub. annual report accessed July 28, 1998 on the World 
Wide Web at URL http://erp-web.er.usgs.gov/reports/VOL37/CU/obermeir.htm, ASCII (text) format). The stream banks contain exposures of deposits of various Holocene ages. No liquefaction features were found, although the scarcity of suitable exposures precludes definitive statements about prehistoric earthquakes (S. Obermeier, unpublished memorandum to Andrew Murphy, U.S. Nuclear Regulatory Commission, dated May 23, 1996). More work would be needed for a complete survey. I know of no other geologic work that has been done on the seismic zone. Accordingly, the zone lacks paleoseismological evidence for Quaternary faulting, and is assigned to class $\mathrm{C}$.

Date of compilation 07/29/98; revised 02/01/00

Compiler and affiliation Russell L. Wheeler, U.S. Geological Survey

State Ohio

County Cuyahoga and offshore; Lake and offshore; Geauga; Summit; Portage

$1^{\circ} \times 2^{\circ}$ sheet Cleveland

Physiographic province Appalachian Plateaus; Central Lowland

\section{References}

\#1829 Hansen, M.C., 1993, Earthquakes and seismic risk in Ohio: Ohio Geology, summer issue, p. 1 and 3-6.

\#1840 Johnston, A.C., 1993, Average stable continental earthquake source parameters based on constant stress drop scaling [abs.]: Seismological Research Letters, v. 64, p. 261.

\#2214 Nicholson, C., Roeloffs, E., and Wesson, R.L., 1988, The northeastern Ohio earthquake of 31 January 1986 - Was it induced?: Bulletin of the Seismological Society of America, v. 78, p. 188-217.

\#1892 Seeber, L., and Armbruster, J.G., 1993, Natural and induced seismicity in the Lake ErieLake Ontario region-Reactivatioin of ancient faults with little neotectonic displacement: Géographie physique et Quaternaire, v. 47, p. 363-378. 


\section{Norumbega fault system (Class C)}

Structure Name Norumbega fault system (Class C)

Comments: Stewart and Wones (1974 \#2055) named the Norumbega fault (see also Wones and Stewart, 1976 \#1919; Wones and Thompson, 1979\#1920). It is now recognized as a multi-stranded fault system that stretches at least $400 \mathrm{~km}$ northeastward across southeastern Maine and southwestern New Brunswick, and perhaps far beyond in both directions (Ludman, 1998 \#1855). The state geologic map shows the fault system as a belt of discrete faults 2-15 $\mathrm{km}$ wide (Osberg and others, 1985 \#1940). However, more recent work indicates that the fault system consists of a belt of distributed strain up to several tens of kilometers wide, with higher strain concentrated in narrow zones one to a few kilometers wide (Swanson, 1992 \#2231; 1994 \#2233; Hubbard and others, 1995 \#1831; West and Hubbard, 1997 \#1912; Ludman, 1998 \#1855; Ludman and Gibbons, 1999 \#1989; Ludman and others, 1999 \#1990). In southwestern Maine, where midcrustal rocks are exposed, early strain was mostly ductile with brittle strain superimposed as erosion cut down toward present levels; whereas, in northeastern Maine, where upper crustal rocks are exposed because of less uplift and erosion, strain was mostly brittle.

Reason for assignment to class C No structural, stratigraphic, paleoseismological, or similar evidence is reported for Quaternary motion on the fault system. The Norumbega fault system was considered in this compilation of evidence for Quaternary faulting for four reasons.

(1) It has a long history of repeated, Devonian and later Paleozoic, right-lateral slip (Swanson, 1992 \#2231; 1993 \#2232; 1994 \#2233; Ludman and West, 1996 \#2041; West and Hubbard, 1997 \#1912; Ludman, 1998 \#1855; West, 1999 \#1988; Ludman and Gibbons, 1999 \#1989; Ludman and others, 1999 \#1990). Repeated reactivation of a fault is often used as evidence of an increased potential for additional slip, which might occur seismically.

(2) Thermochronologic and seismic-reflection data indicate that parts of the fault system underwent several kilometers of Mesozoic or younger normal slip (West and others, 1993 \#1913; Doll and others, 1996 \#1814; West, 1999 \#1988). A worldwide survey of damaging earthquakes in stable continental regions found that large earthquakes occur preferentially in passive margins and continental rifts, with the preference being strongest for areas that underwent Mesozoic or Cenozoic extension (Johnston, 1989 \#2039; 1994 \#2040). Thus, extensional reactivation of part of the Norumbega fault system during or since the Mesozoic initiation of the Atlantic passive continental margin indicates the likelihood of elevated earthquake potential.

(3) In six outcrops along $135 \mathrm{~km}$ of the fault system, small faults a few meters long offset glaciated pavements vertically by $1.5-30.0 \mathrm{~mm}$; one of the small faults offsets the bedrock-till contact (Thompson, $1979 \# 1905 ; 1981 \# 1978$ ). However, it is not known whether these small offsets occurred seismically, or even whether the small faults are tectonic. Koons (1989 \#1999) compiled locations of these and 50 other similarly faulted exposures throughout Maine. Koons observed that all the postglacial faults are in stratified rock, and that the faults parallel joints or local bedrock fabric instead of being oriented systematically with respect to the regional compressive stress. Koons attributed the small postglacial faults to frost heaving or glaciotectonic effects in strata that are decoupled from their substrates by sheeting joints. 
(4) Ebel and Spotila (1991 \#1819; 1992 \#1820) observed that several small earthquakes occurred along the Norumbega fault system since 1975, and that focal mechanisms of five of the earthquakes show reverse faulting on nodal planes that strike parallel to the fault system. Ebel and Spotila (1991 \#1819; 1992 \#1820) speculated that parts of the fault system might be slipping in the present-day compressional stress field. However, most recently Ebel and Spotila (1999 \#2011) noted that no strand of the Norumbega fault system has yet produced evidence of Holocene tectonic faulting, and that the aligned epicenters and few focal mechanisms are not strong evidence for seismic reactivation.

Accordingly, the Norumbega is assigned to class $\mathrm{C}$ in this compilation.

Date of compilation 04/22/98; revised 01/28/00

Compiler and affiliation Russell L. Wheeler, U.S. Geological Survey

State Maine

County York; Cumberland; Sagadahoc; Lincoln; Kennebec; Waldo; Penobscot; Hancock; Washington

$1^{\circ} \times 2^{\circ}$ sheet Portland; Bangor; Millinocket; Fredericton

Physiographic province New England

\section{References}

\#1814 Doll, W.E., Domoracki, W.J., Costain, J.K., Çoruh, C., Ludman, A., and Hopeck, J.T., 1996, Seismic reflection evidence for the evolution of a transcurrent fault system-The Norumbega fault zone, Maine: Geology, v. 24, p. 251-254.

\#1819 Ebel, J.E., and Spotila, J.A., 1991, Seismicity along the Norumbega fault in Maine [abs.]: Eos, Transactions of the American Geophysical Union, v. 72, no. 44 (supplement), p. 336.

\#1820 Ebel, J.E., and Spotila, J.A., 1992, Seismicity along the Norumbega fault in New England-Implications for seismic hazard in the northeast United States: Geological Society of America Abstracts with Programs, v. 24, no. 3, p. 17-18.

\#2011 Ebel, J.E., and Spotilla, J.A., 1999, Modern earthquake activity and the Norumbega fault zone, in Ludman, A., and West, D.P., Jr., eds., Norumbega fault system of the northern Appalachians: Geological Society of America Special Paper 331, p. 195-202.

\#1831 Hubbard, M.S., West, D.P., Jr., Ludman, A., Guidotti, C.V., and Lux, D.R., 1995, The Norumbega fault zone, Maine-A mid- to shallow-level crustal section within a transcurrent shear zone: Atlantic Geology, v. 31, p. 109-116.

\#2039 Johnston, A.C., 1989, The seismicity of 'stable continental interiors', in Gregersen, S., and Basham, P.W., eds., Earthquakes at North Atlantic passive margins-Neotectonics and postglacial rebound: Dordrecht, The Netherlands, Kluwer Academic Publishers, p. 299-327.

\#2040 Johnston, A.C., 1994, Seismotectonic interpretations and conclusions from the stable continental region seismicity database, in Schneider, J.F., ed., The earthquakes of stable 
continental regions - v. 1, Assessment of large earthquake potential: Technical report to Electric Power Research Institute TR-102261-V1, Palo Alto, California, December 1994, p. 4-1-4-103.

\#1999 Koons, D., 1989, Postglacial bedrock faulting in Maine, in Anderson, W.A., and Borns, H.W., Jr., eds., Neotectonics of Maine - Studies in seismicity, crustal warping, and sealevel change: Maine Geological Survey Bulletin 40, p. 149-155.

\#1855 Ludman, A., 1998, Evolution of transcurrent fault system in shallow crustal metasedimentary rocks - The Norumbega fault zone, eastern Maine: Journal of Structural Geology, v. 20, p. 93-107.

\#1989 Ludman, A., and Gibbons, S., 1999, Multistage shearing of the Deblois granite in the Kellyland fault zone, eastern Maine, in Ludman, A., and West, D.P., Jr., eds., Norumbega fault system of the northern Appalachians: Geological Society of America Special Paper 331, p. 41-57.

\#1990 Ludman, A., Lanzirotti, A., Lux, D., and Wang, C., 1999, Constraints on timing and displacement of multistage shearing in the Norumbega fault system, eastern Maine, in Ludman, A., and West, D.P., Jr., eds., Norumbega fault system of the northern Appalachians: Geological Society of America Special Paper 331, p. 179-194.

\#2041 Ludman, A., and West, D.P., Jr., 1996, "Cool", shallow crustal generation of mylonites: examples from the Norumbega fault zone, Maine: Geological Society of America Abstracts with Programs, v. 28, no. 3, p. 77.

\#1940 Osberg, P.H., Arthur, H.M., and Boone, G.M., eds., 1985, Bedrock geologic map of Maine: Maine Geological Survey, 1 pl., scale 1:500,000.

\#2055 Stewart, D.B., and Wones, D.R., 1974, Bedrock geology of northern Penobscot Bay area, in Osberg, P.H., ed., Geology of east-central and north-central Maine: New England Intercollegiate Geological Conference 64th guidebook, p. 223-239.

\#2231 Swanson, M.T., 1992, Late Acadian-Alleghenian transpressional deformation-Evidence from asymmetric bondinage in the Casco Bay area, coastal Maine: Journal of Structural Geology, v. 14, p. 323-341.

\#2232 Swanson, M.T., 1993, The Casco Bay restraining bend on the Norumbega fault zone-A model for regional deformation in coastal Maine: Geological Society of America Abstracts with Programs, v. 25, no. 6, p. A-478.

\#2233 Swanson, M.T., 1994, Minimum dextral shear strain estimates in the Casco Bay area of coastal Maine from vein reorientation and elongation: Geological Society of America Abstracts with Programs, v. 26, no. 3, p. 75.

\#1905 Thompson, W.B., 1979, Postglacial faulting along the Norumbega fault zone, eastern Maine: Geological Society of America Abstracts with Programs, v. 11, no. 1, p. 56.

\#1978 Thompson, W.B., 1981, Postglacial faulting in the vicinity of the Norumbega fault zone, eastern Maine: U.S. Geological Survey Open-File Report 90-1039, 19 p.

\#1988 West, D.P., Jr., 1999, Timing of displacements along the Norumbega fault system, southcentral and south-coastal Maine, in Ludman, A., and West, D.P., Jr., eds., Norumbega 
fault system of the northern Appalachians: Geological Society of America Special Paper 331, p. 167-178.

\#1912 West, D.P., Jr., and Hubbard, M.S., 1997, Progressive localization of deformation during exhumation of a major strike-slip shear zone-Norumbega fault zone, south-central Maine, USA: Tectonophysics, v. 273, p. 185-201.

\#1913 West, D.P., Jr., Lux, D.R., and Hussey, A.M., II, 1993, Contrasting thermal histories across the Flying Point fault, southwestern Maine - Evidence for Mesozoic displacement: Geological Society of America Bulletin, v. 105, p. 1478-1490.

\#1919 Wones, D.R., and Stewart, D.B., 1976, Middle Paleozoic regional right-lateral strike-slip faults in central coastal Maine: Geological Society of America Abstracts with Programs, v. 8 , no. 2 , p. 304.

\#1920 Wones, D.R., and Thompson, W., 1979, The Norumbega fault zone-A major regional structure in central eastern Maine: Geological Society of America Abstracts with Programs, v. 11, no. 1, p. 60. 


\section{Oak Bay fault (Class c)}

Structure Name Oak Bay fault (Class C)

Comments: The Oak Bay fault strikes north-northwest along the Maine-New Brunswick border, trending inland from the Atlantic coast for approximately $58 \mathrm{~km}$ (Osberg and others, 1985 \#1940; Gates, 1989 \#1997). The fault is mostly underwater in the St. Croix River and western Passamaquoddy Bay. Where the fault is exposed at its northwestern end, it is a fault zone a kilometer wide (Gates, 1989 \#1997). Gates (1989 \#1997) estimated that the vertical fault has slipped approximately $3 \mathrm{~km}$ in a sinistral oblique sense since its inception, with the northeast side down. The Oak Bay fault cuts northeast-striking strands of a regional Carboniferous fault system, is crossed by a probably unfaulted diabase dike of latest Early Jurassic age, and is considered to terminate underwater at its southeast end against the offshore, northeast-striking, border fault of the Fundy Basin of Triassic-Jurassic age (Gates, 1989 \#1997; Manspeizer, 1989 \#2063). Thus, the movement on the Oak Bay fault is of Carboniferous-Early Jurassic age.

Reason for assignment to class C: No evidence is reported for Quaternary slip. The Oak Bay fault is considered in this compilation of Quaternary faulting for four reasons.

(1) A worldwide survey of damaging earthquakes in stable continental regions found that large earthquakes occur preferentially in passive margins and continental rifts, with the preference being strongest for areas that underwent Mesozoic or Cenozoic extension (Johnston, 1989 \#2039; Johnston, 1994 \#2040). The possibility that the Oak Bay fault formed during the Mesozoic extensional development of the Atlantic passive continental margin indicates a possibility of elevated earthquake potential.

(2) Epicenters of six small earthquakes form a weak alignment along part of the Oak Bay fault (Lee and Diehl, 1989 \#2000). However, other epicenter maps that span longer periods of time, and which apparently use slightly different locations for some of the earthquakes, show no such alignment (Ebel, 1989 \#1996; Gates, 1989 \#1997).

(3) Kelley and others (1989 \#1998) collected marine seismic-reflection data along $1000 \mathrm{~km}$ of profiles in seven bays along the Maine coast, seeking evidence of Quaternary faulting. They found numerous scattered slumps and small gas deposits. One possible fault scarp was found in Oak Bay, but it is ambiguously resolved on a noisy record, and the possible scarp might result from current reworking of sediment (Kelley and others, 1989 \#1998). Newman (1979 \#1985) found no evidence of Quaternary slip on the Oak Bay fault on land.

(4) The Oak Bay fault is the longest, straightest, and youngest fault exposed in or near the seismically active Passamaquoddy Bay area (Osberg and others, 1985 \#1940; Gates, 1989 \#1997). However, the north-northwest-striking fault is nearly perpendicular to the regional greatest horizontal compressive stress (Ebel, $1989 \# 1996)$. This strike and the vertical dip that was inferred by Gates (1989 \#1997) make it unlikely that the fault would slip seismically. Accordingly, the Oak Bay fault is assigned to class C for lack of demonstrated Quaternary faulting.

Date of compilation 04/01/98; revised 01/28/00

Compiler and affiliation Russell L. Wheeler, U.S. Geological Survey

State Maine 
County Washington

$1^{\circ} \times 2^{\circ}$ sheet Fredericton; Eastport

Physiographic province New England

\section{References}

\#1996 Ebel, J.E., 1989, The seismicity of Maine, in Anderson, W.A., and Borns, H.W., Jr., eds., Neotectonics of Maine-Studies in seismicity, crustal warping, and sea-level change: Maine Geological Survey Bulletin 40, p. 219-228.

\#1997 Gates, O., 1989, The geology and geophysics of the Passamaquoddy Bay area, Maine and New Brunswick, and their bearing on local subsidence, in Anderson, W.A., and Borns, H.W., Jr., eds., Neotectonics of Maine-Studies in seismicity, crustal warping, and sea-level change: Maine Geological Survey Bulletin 40, p. 11-24.

\#2039 Johnston, A.C., 1989, The seismicity of 'stable continental interiors', in Gregersen, S., and Basham, P.W., eds., Earthquakes at North Atlantic passive margins-Neotectonics and postglacial rebound: Dordrecht, The Netherlands, Kluwer Academic Publishers, p. 299-327.

\#2040 Johnston, A.C., 1994, Seismotectonic interpretations and conclusions from the stable continental region seismicity database, in Schneider, J.F., ed., The earthquakes of stable continental regions - v. 1, Assessment of large earthquake potential: Technical report to Electric Power Research Institute TR-102261-V1, Palo Alto, California, December 1994, p. 4-1-4-103.

\#1998 Kelley, J.T., Belknap, D.F., Shipp, R.C., and Miller, S.B., 1989, An investigation of neotectonic activity in coastal Maine by seismic reflection methods, in Anderson, W.A., and Borns, H.W., Jr., eds., Neotectonics of Maine-Studies in seismicity, crustal warping, and sea-level change: Maine Geological Survey Bulletin 40, p. 157-204.

\#2000 Lee, F.T., and Diehl, S.F., 1989, Geomechanical aspects of subsidence in eastern Maine, in Anderson, W.A., and Borns, H.W., Jr., eds., Neotectonics of Maine-Studies in seismicity, crustal warping, and sea-level change: Maine Geological Survey Bulletin 40, p. 209-218.

\#2063 Manspeizer, W., compiler, 1989, Onshore and offshore Late Triassic-Early Jurassic basins, eastern United States and parts of Maritime Canada, in Hatcher, R.D., Jr., Thomas, W.A., and Viele, G.W., eds., The Appalachian-Ouachita Orogen in the United States: Boulder, Colorado, Geological Society of America, The Geology of North America, v. F-2, plate 5A, scale 1:5,000,000.

\#1985 Newman, W.A., 1979, The possibility of Pleistocene-Holocene movement along the Oak Bay fault on the Maine-New Brunswick border: Maine Geological Survey Open-File Report No. 79-20, 7 p.

\#1940 Osberg, P.H., Arthur, H.M., and Boone, G.M., eds., 1985, Bedrock geologic map of Maine: Maine Geological Survey, 1 pl., scale 1:500,000. 


\section{Offset glaciated surfaces (Class C)}

Structure Name Offset glaciated surfaces (Class C)

Comments: Glacially smoothed, polished, or striated rock surfaces are offset on small, steeply dipping faults at numerous localities in the northeastern U.S.. Offsets are typically in the millimeter to decimeter range although rare occurrences exceed $1 \mathrm{~m}$, and dip slip dominates. Strikes of the postglacial faults box the compass, without any dominant relationship to the east-northeast trend of present-day greatest horizontal compressive stress. Faults are found near artificial or blasted exposures, as well as in natural outcrops far from possible artificial triggers, and in both layered and massive rocks. I am unaware of anyone who has made a systematic literature or field search for such localities throughout the Northeast. However, Oliver and others (1970 \#2219) summarized 12 localities in the Hudson River Valley of eastern New York State and in New England, and another 17 in Quebec, Nova Scotia, and New Brunswick. Ratcliffe (1982 \#2221) analyzed three localities of Oliver and others (1970 \#2219) and seven new ones, all of them in the Hudson River Valley. Isachsen (1985 \#2038) reported on seven localities in the Adirondack Mountains of New York State, and Koons (1989 \#1999) reviewed 56 in Maine.

Reason for assignment to class $\mathbf{C}$ : The small fault offsets of glaciated surfaces are assigned to class $\mathrm{C}$ for this compilation of geological evidence of Quaternary faulting, because, as explained in the following paragraphs, their most likely origin is in frost heaving. The most likely causes include (1) expansion caused by hydration, (2) stress changes or rebound accompanying or closely following deglaciation, (3) present-day tectonic stresses, and (4) frost heaving (Oliver and others, 1970 \#2219; Isachsen, 1985 \#2038). The possibility that the small faults record continuing postglacial tectonic deformation, and the consequent implications for seismic hazard, form the impetus for the cited studies.

(1) Oliver and others (1970\#2219) elaborated on an earlier suggestion that the faults formed as a result of volume increase caused by hydration, presumably during chemical weathering. The argument of Oliver and others (1970 \#2219) applies to faults that form along well-developed cleavage in slates, but cannot explain the faults that Isachsen (1985 \#2038) and Koons (1989 \#1999) observed in massive rocks, chiefly high-grade gneisses.

(2) Dip-slip faulting produced a few large scarps in glaciated continental shields shortly after removal of the ice load (for example, Johnston, 1996 \#2205). In North America most of the glaciated shield is now virtually aseismic, at least in comparison to the Phanerozoic orogens and rifted terranes that rim the shield (Wesnousky and Scholz, $1980 \# 2242$; Wheeler and Johnston, 1992 \#2243). The large scarps have not been reported from the Northeast and adjacent Canada, where the small faults in glaciated surfaces have been reported by Oliver and others (1970 \#2219), Ratcliffe (1982 \#2221), Isachsen (1985 \#2038), and Koons (1989 \#1999). I do not know of sufficient evidence with which to test the hypothesis that the small offsets might have formed shortly after the removal of the ice load. However, if the small offsets did form then, the subsequent decay of the stresses caused by deglaciation indicates that the small offsets should no longer be forming, and should present no or negligible seismic hazard.

(3) Oliver and others (1970 \#2219) favored a tectonic origin over frost heaving because (a) the faults in their compilation are mostly in a narrow, strike-parallel belt of Paleozoic slates in the 
western Appalachians, and dip southeast to east, parallel to cleavage, (b) many offsets are uniform in size over horizontal distances of many meters, and (c) the small faults that they studied tend strongly to parallel the strike of cleavage instead of cross it. Oliver and others (1970 \#2219) considered the uniform offsets and parallelism to cleavage to be unlikely results of frost heaving, which they expected would break heaved blocks irregularly. However, subsequently Koons (1989 \#1999) reported instances of irregular breakage by small faults in Maine. In addition, present-day greatest horizontal compressive stresses trend east-northeast throughout the Northeast, whereas the small faults have now been found in all orientations (Isachsen, 1985 \#2038; Zoback and Zoback, 1989 \#1922; Koons, 1989 \#1999). Thus, a tectonic origin in the present-day stress field is unlikely.

(4) Koons (1989 \#1999) examined the largest group of faults, and observed that all formed in layered rocks, parallel to local rock strike or to joints. He suggested an origin in "frost heaving or glaciotectonic effects in rocks broken by bedding, schistosity, and sheeting" (Koons, $1989 \# 1999$, p. 155). The most thorough analysis was that of Ratcliffe (1982 \#2221), who studied the Paleozoic slates initially summarized by Oliver and others (1970 \#2219). Ratcliffe found downward-tapering voids bounded by slaty cleavage and joints or other small brittle faults, which indicate that frost heaving may have extracted the missing wedges of rock. In addition, folds in cleavage "form subhorizontal to gently dipping 'lift off' floors to probable ice wedge blocks in some exposures" (Ratcliffe, 1982 \#2221, p. 76). Ratcliffe's observations strongly favor frost heaving over recent tectonism as a probable cause of the small faults that he examined.

In summary, the evidence supports a frost-wedging origin more than any other likely origin. The diverse host lithologies and orientations of the small faults are evidence against an origin by hydration or present-day tectonism. An origin by glacial unloading is presently an untestable hypothesis. No evidence requires an origin other than in frost heaving.

In the unlikely event that the small faults are of tectonic origin, calculations demonstrate that they are still unlikely to affect hazard. First, the small faults are unlikely to penetrate more than a few tens to hundreds of meters downward. If they did penetrate much deeper, they would be the upper edges of faults with lengths and down-dip widths measured in kilometers, and the faults would be likely to vary greatly in size. It is highly unlikely that faults of such large and variable sizes would all chance to have their upper edges at ground level over five states. Thus, I assume that the small faults have lengths approximately equal to their downdip widths, with both measured in tens to hundreds of meters. Second, estimates of Johnston (1993 \#1840) show that a small fault with a $55 \mathrm{~m}$ trace and $1 \mathrm{~cm}$ of dip slip could host an earthquake moment magnitude $\mathbf{M} 2.0$. Ten $\mathrm{cm}$ of dip slip on a fault with a $232 \mathrm{~m}$ trace could produce M 3.5. These dimensions and dip slips are typical of the offset glaciated surfaces. An earthquake of M 3.5 would probably be felt, but it would present negligible hazard.

Accordingly, the small faults that offset glaciated surfaces are assigned to class $\mathrm{C}$ because, although they are Quaternary in age, they are unlikely to be related to seismic hazard.

Date of compilation 08/17/98; revised 02/01/00

Compiler and affiliation Russell L. Wheeler, U.S. Geological Survey

State Maine; New York; New Hampshire; Massachusetts; Vermont 
County Aroostook; Somerset; Piscataquis; Penobscot; Washington; Cumberland; Franklin; York; Sagadahoc; Waldo (Maine); Columbia; Dutchess; Hamilton; Putnam; Rensselaer; Essex; Warren (New York); Bristol (Massachusetts); Grafton (New Hampshire); Rutland (Vermont)

$1^{\circ} \times 2^{\circ}$ sheet Presque Isle; Millinocket; Edmundston; Fredericton; Bangor; Portland; Bath; Lewiston; Quebec; Albany; Hartford; Glens Falls; Utica; Lake Champlain; Lewiston; Glens Falls; Providence

Physiographic province New England; Valley and Ridge; Adirondack

\section{References}

\#2038 Isachsen, Y.W., 1985, Structural and tectonic studies in New York State-Final report, July 1981-June 1982: U.S. Nuclear Regulatory Commission Report NUREG/CR$3178,75 \mathrm{p}$.

\#1840 Johnston, A.C., 1993, Average stable continental earthquake source parameters based on constant stress drop scaling [abs.]: Seismological Research Letters, v. 64, p. 261.

\#2205 Johnston, A.C., 1996, A wave in the earth: Science, v. 274, p. 735.

\#1999 Koons, D., 1989, Postglacial bedrock faulting in Maine, in Anderson, W.A., and Borns, H.W., Jr., eds., Neotectonics of Maine-Studies in seismicity, crustal warping, and sea-level change: Maine Geological Survey Bulletin 40, p. 149-155.

\#2219 Oliver, J., Johnson, T., and Dorman, J., 1970, Postglacial faulting and seismicity in New York and Quebec: Canadian Journal of Earth Sciences, v. 7, p. 579-590.

\#2221 Ratcliffe, N.M., 1982, Tectonic versus frost-wedging origin of faulted glacially polished surfaces in the lower Hudson River Valley area: Geological Society of America Abstracts with Programs, v. 14, no. 1,2, p. 76.

\#2242 Wesnousky, S.G., and Scholz, C.H., 1980, The craton-Its effect on the distribution of seismicity and stress in North America: Earth and Planetary Science Letters, v. 48, p. 348-355.

\#2243 Wheeler, R.L., and Johnston, A.C., 1992, Geologic implications of earthquake source parameters in central and eastern North America: Seismological Research Letters, v. 63, no. 4, p. 491-514.

\#1922 Zoback, M.L., and Zoback, M.D., 1989, Tectonic stress field of the continental United States, in Pakiser, L.C., and Mooney, W.D., eds., Geophysical framework of the continental United States: Geological Society of America Memoir 172, p. 523-539. 


\section{Old Hickory faults (Class C)}

Structure Name Old Hickory faults (Class C)

Comments: The youngest sediments mined and involved in faulting at the Old Hickory Heavy Mineral Deposit are Pliocene clays, sand, and gravel of the Yorktown Formation (Berquist and Bailey, 1999 \#3879). The sediments are up to $12 \mathrm{~m}$ thick and overlie Paleozoic metamorphic and igneous rocks of the Appalachians. The Paleozoic rocks are widely exposed to the west, in the Piedmont physiographic province, whereas the Pliocene sediments are exposed to the east, in the Coastal Plain province. The Old Hickory deposit is in the Fall Zone, the irregular boundary between the two physiographic provinces. Topographic relief at and near the deposit is on the order of $50 \mathrm{ft}(15 \mathrm{~m})$. Accordingly, the sediments form most hills and the rocks are mainly exposed in drainages. Reverse and reverse-oblique slip on five small faults transported saprolite developed from the metamorphic and igneous rocks over the sediments. I informally name the faults after the heavy mineral deposit in which they occur. Beginning in 1997 the sediment was quarried for heavy minerals, and the quarrying first exposes and then destroys the faults. Throw is up to $6 \mathrm{~m}$. The faults strike northwest and west-northwest, dip 45 to 70 degrees to both northeast and southwest, indicate east-northeast shortening parallel to the modern greatest horizontal compressive stress, and have trace lengths of 100-150 m. Some of the faults extended to present-day ground level before they were removed by quarrying, but others were buried by muddy sand beds that contain pebbles and cobbles in the Yorktown Formation. Berquist and Bailey (1999 \#3879) interpreted the muddy sand beds as debris flows shed from upfaulted blocks. This interpretation, and the observation that some faults were buried by the muddy sand beds, together indicate that Yorktown deposition and faulting were coeval (Berquist and Bailey, 1999 \#3879). Berquist and Bailey (1999 \#3879) found no evidence of Holocene faulting.

Reason for assignment to class C: The faulting was probably of Pliocene age, representing possible reactivation of Paleozoic faults (Berquist and Bailey, 1999 \#3879).

Date of compilation 12/16/99; revised 2/28/00

Compiler and affiliation Russell L. Wheeler, U.S. Geological Survey

State Virginia

County Dinwiddie; Sussex

$1^{\circ} \times 2^{\circ}$ sheet Norfolk

Physiographic province Coastal Plain

\section{References}

\#3879 Berquist, C.R., Jr., and Bailey, C.M., 1999, Late Cenozoic reverse faulting in the fall zone, Southeastern Virginia: Journal of Geology, v. 107, p. 727-732. 


\section{Pen Branch fault (Class C)}

Structure Name Pen Branch fault (Class C)

Comments: The Pen Branch fault is nowhere exposed, but it is well characterized by dense subsurface control from wells, seismic-reflection profiles, and other geophysical data (Snipes and others, 1993 \#1896; Stieve and Stephenson, 1995 \#1900). The fault strikes N. 55 E. for at least $24 \mathrm{~km}$ across the Savannah River Site, a nuclear fuels processing plant. Triassic to Holocene Coastal Plain strata thicken southeastward across the 300 square mi. (780 square $\mathrm{km})$ site, from approximately $700 \mathrm{ft}(210 \mathrm{~m})$ in the northwest to $1400 \mathrm{ft}(430 \mathrm{~m})$ in the southeast (Fallaw and Price, 1995 \#1822). Only the Middle Eocene and younger units are exposed (Prowell, 1996 \#1939). The Coastal Plain strata are underlain by Paleozoic metamorphic rocks and, southeast of the Pen Branch fault, by Mesozoic sedimentary rocks that fill the extensional Dunbarton basin (Daniels and others, 1983 \#1962; Snipes and others, 1993 \#1896; Dennis and others, 1997 \#1811). The Pen Branch fault dips 50 SE in the Coastal Plain units and shallows at least to $40^{\circ} \mathrm{SE}$ in basement (Stieve and Stephenson, 1995 \#1900). Other, similarly oriented faults underlie other parts of the Savannah River site and its surroundings (Stieve and Stephenson, 1995 \#1900), but the Pen Branch fault is the best characterized.

Reason for assignment to class $\mathbf{C}$ : The Pen Branch fault is assigned to class $\mathrm{C}$ in this compilation of Quaternary faulting because of its lack of evidence for post-Eocene slip. However, the fault was considered for two reasons.

First, it is the upward continuation into Cenozoic strata of the northwestern border fault of the extensional Dunbarton basin of Mesozoic age (Snipes and others, 1993 \#1896; Stieve and Stephenson, 1995 \#1900). A worldwide survey of damaging earthquakes in stable continental regions found that large earthquakes occur preferentially in passive margins and continental rifts, with the preference being strongest for areas that underwent Mesozoic or Paleogene extension (Johnston, 1989 \#2039; Johnston, 1994 \#2040). Thus, Mesozoic extensional faults like those that bound the Dunbarton basin may be susceptible to modern compressional reactivation and thereby may have elevated earthquake potential. Indeed, post-extension, reverse offsets of Late Cretaceous and younger horizons on the Pen Branch fault decrease upward, indicating a prolonged compressional history as a growth fault (Snipes and others, 1993 \#1896). However, the youngest horizon that is known to be faulted is the top of the Dry Branch Formation of Late Eocene age (Snipes and others, 1993 \#1896). Prowell (1996 \#1939) mapped a fluvial unit of sand, gravel, and clay of possible Miocene age, the "upland unit". Structure contours on the base of the unit and field observations near the Pen Branch fault indicate that the upland unit has no abrupt irregularities at its base over the projected intersection of the fault with the land surface. Therefore, post-Miocene fault movement is unlikely (D.C. Prowell, written communs., 1998). In addition, a Quaternary soil horizon 3-6 m thick is exposed across the projected trend of the Pen Branch fault, and lacks discernable offset (Snipes and others, 1993 \#1896).

Second, the dip component of the most recent documented slip on the Pen Branch fault is reverse (Snipes and others, 1993 \#1896; Stieve and Stephenson, 1995 \#1900). Reverse or reverse-dextral slip on this northeast-striking, southeast-dipping fault is consistent with compressional reactivation in the east-northeast-trending, greatest horizontal compressive stress $\left(\mathrm{S}_{\mathrm{Hmax}}\right)$ that characterizes the Southeast generally (Zoback and Zoback, 1989 \#1922). In fact, 
on June 9, 1985 an earthquake of duration magnitude $\mathrm{M}_{\mathrm{D}} 2.6$ occurred inside the Savannah River Site at a depth of $0.96 \mathrm{~km}(E R Z=1.6 \mathrm{~km}$, Talwani and others, 1985 \#1903). The epicenter is well constrained $(\mathrm{ERH}=0.3 \mathrm{~km})$ and plots $3 \mathrm{~km}$ northwest of the trace of the Pen Branch fault. A single-earthquake focal mechanism indicates mostly sinistral strike slip and has one tightly constrained nodal plane oriented at N. $43^{\circ}$ E. $/ 46^{\circ}$ SE. Talwani and others (1985 \#1903) suggested that the earthquake occurred by dominantly sinistral reactivation of part of the Pen Branch fault. However, Zoback and others (1989 \#2062) determined the orientation of $\mathrm{S}_{\mathrm{Hmax}}$ in that part of the Savannah River Site to be N. $65^{\circ}$ E. at depths close to that of the shallow hypocenter. Snipes and others (1993 \#1896) noted that (1) a fault that strikes only $10^{\circ}$ away from the orientation of $\mathrm{S}_{\mathrm{Hmax}}$, as does the Pen Branch fault at N. $55^{\circ}$ E., may be an unlikely candidate for reactivation, and (2) the extensive drilling, coring, and seismic-reflection program at the site produced no indications of strike slip motion on the fault. In addition, a nodal plane that strikes N. $43^{\circ}$ E. should undergo dextral strike slip in the measured $\mathrm{S}_{\mathrm{Hmax}}$, not sinistral. Thus, the relation of the earthquake to the Pen Branch fault is questionable. Therefore, the Pen Branch fault is assigned to class $\mathrm{C}$ in this compilation of Quaternary faulting because evidence is lacking for slip more recently than the Eocene.

Date of compilation 08/19/98; revised 01/28/00

Compiler and affiliation Russell L. Wheeler, U.S. Geological Survey

State South Carolina

County Barnwell

$1^{\circ} \times 2^{\circ}$ sheet Augusta

Physiographic province Coastal Plain

\section{References}

\#1962 Daniels, D.L., Zietz, I., and Popenoe, P., 1983, Distribution of subsurface lower Mesozoic rocks in southeastern United States, as interpreted from regional aeromagnetic and gravity maps, in Gohn, G.S., ed., Studies related to the Charleston, South Carolina, earthquake of 1886-Tectonics and seismicity: U.S. Geological Survey Professional Paper 1313-K, p. K1-K24.

\#1811 Dennis, A.J., Wright, J.E., Maher, H.D., Mauldin, J.C., and Shervais, J.W., 1997, Repeated Phanerozoic reactivation of a southern Appalachian fault zone beneath the up-dip Coastal Plain of South Carolina: Geological Society of America Abstracts with Programs, v. 29, p. A-223-A-224.

\#1822 Fallaw, W.C., and Price, V., 1995, Stratigraphy of the Savannah River Site and vicinity: Southeastern Geology, v. 35, p. 21-58.

\#2039 Johnston, A.C., 1989, The seismicity of 'stable continental interiors', in Gregersen, S., and Basham, P.W., eds., Earthquakes at North Atlantic passive margins-Neotectonics and postglacial rebound: Dordrecht, The Netherlands, Kluwer Academic Publishers, p. 299-327.

\#2040 Johnston, A.C., 1994, Seismotectonic interpretations and conclusions from the stable continental region seismicity database, in Schneider, J.F., ed., The earthquakes of stable continental regions - v. 1, Assessment of large earthquake potential: Technical 
report to Electric Power Research Institute TR-102261-V1, Palo Alto, California, December 1994, p. 4-1-4-103.

\#1939 Prowell, D.C., 1996, Geologic map of the Savannah River Site, Aiken, Allendale, and Barnwell Counties, South Carolina: U.S. Geological Survey Miscellaneous Field Studies Map MF-2300, 7 p. pamphlet, 1 sheet, scale 1:48,000.

\#1896 Snipes, D.S., Fallaw, W.C., Price, V., Jr., and Cumbest, R.J., 1993, The Pen Branch fault-Documentation of late Cretaceous-Tertiary faulting in the Coastal Plain of South Carolina: Southeastern Geology, v. 33, p. 195-218.

\#1900 Stieve, A., and Stephenson, D., 1995, Geophysical evidence for post late Cretaceous reactivation of basement structures in the central Savannah River area: Southeastern Geology, v. 35, p. 1-20.

\#1903 Talwani, P., Rawlins, J., and Stephenson, D., 1985, The Savannah River Plant, South Carolina, earthquake of June 9, 1985 and its tectonic setting: Earthquake Notes, v. 56, p. 101-106.

\#2062 Zoback, M.D., Moos, D., and Stephenson, D.E., 1989, State of stress and the relation to tectonics in the central Savannah River area of South Carolina, in : 30th U.S. Symposium on Rock Mechanics, Morgantown, West Virginia, June 19-22, 1989, Proceedings, p. 553-560.

\#1922 Zoback, M.L., and Zoback, M.D., 1989, Tectonic stress field of the continental United States, in Pakiser, L.C., and Mooney, W.D., eds., Geophysical framework of the continental United States: Geological Society of America Memoir 172, p. 523-539. 


\section{Pierre, South Dakota faults (Class C)}

Structure Name Pierre, South Dakota faults (Class C)

Comments: The structures discussed here are a group of faults in the Upper Cretaceous Pierre Shale located about 16-32 km west of the city of Pierre, South Dakota.

Reason for assignment to Class $\mathbf{C}$ : The deformation associated with these faults was originally considered to possibly be tectonic, but subsequent studies failed to provide conclusive evidence that the surficial movements are directly related to deep-seated tectonic deformation. Therefore, they are categorized as Class $\mathrm{C}$ features.

Nichols and Collins (1987 \#2802) initially reported the evidence of possible active faulting in the area west of Pierre, South Dakota. They reported evidence of movement on faults in the Pierre Shale that had deformed colluvium, which was radiocarbon dated as less than $1,300 \mathrm{yr}$ old. They described geomorphic evidence of structural instability including marked changes in stream gradients, prominent knickpoints along streams, hanging valleys, and changes in stream drainage directions. They reported that movement on the faults has locally damaged highways and an abandoned highway bridge. They suggested that these damaging movements could be caused by swelling of freshly exposed clay gouge, gravity-driven movements on faults in the shale, or possibly active tectonic faulting.

Collins and others (1988 \#2801) and Nichols and others (1994 \#2803) list the characteristics of 24 prominent faults in a $2,000 \mathrm{~km}^{2}$ area; most faults have a normal sense of slip and a separation of between 1-35 $\mathrm{m}$. They also report that one fault has a 22-m-high scarp. In places where some of these faults cross highways, the deformation rates are so high, that the pavement requires frequent repair. Despite the high slip rates on the faults inferred from the frequent repairs, only four notable historical earthquakes have occurred in the region (largest event was M 4.2 in 1961).

As a result of their field investigations, seismic-reflection and refraction data, mineralogical analyses of clays in the Pierre Shale, examination of level-line data, and a geomorphic analysis of stream gradients, they conclude that the movement on the faults is not related to tectonic activity, but is probably the result of rebound-induced movement on the faults related to the removal of overburden and bedrock during highway construction. The movement is facilitated by the clayey fault gouge acting as a conduit for surface water and groundwater, which keeps the gouge moist and minimizes its frictional strength. These studies also concluded that the evidence is not definitive enough to determine if tectonic uplift is contributing to the shallow deformation. The non-tectonic origin for this deformation is strongly supported by the observation that, since construction was completed in 1962, movement on a fault in the Pierre Shale near the spillway of Oahe Dam (about $10 \mathrm{~km}$ north of the city of Pierre) has created a 1.5-m-high scarp. This scarp formed without any notable seismic events.

Date of compilation 11/24/97

Compiler and affiliation Anthony J. Crone, U.S. Geological Survey

State South Dakota

County Stanley 
$1^{\circ} \times 2^{\circ}$ sheet Pierre

Physiographic province Great Plains

\section{References}

\#2801 Collins, D.S., Swolfs, H.S., and Nichols, T.C., Jr., 1988, Highway damage related to faults near Pierre, South Dakota: U.S. Geological Survey Open-File Report 88-674, 34 p., 1 oversized pl.

\#2802 Nichols, T.C., Jr., and Collins, D.S., 1987, Recent faulting in the Pierre Shale near Pierre, South Dakota: Geological Society of America Abstracts with Programs, v. 19, no. 5, p. 323-324.

\#2803 Nichols, T.C., Jr., Collins, D.S., Jones-Cecil, M., and Swolfs, H.S., 1994, Faults and structure in the Pierre Shale, central South Dakota, in Shurr, G.W., Ludvigson, G.A., and Hammond, R.H., eds., Perspectives on the eastern margin of the Cretaceous western interior basin: Geological Society of America Special Paper 287, p. 211-235. 


\section{Plum River fault zone (Class C)}

Structure Name Plum River fault zone (Class C)

Comments: The Plum River fault zone was originally recognized as a narrow belt of eastwest trending faults in northwestern Illinois, but subsequent work in Iowa determined that it extends westward more than $80 \mathrm{~km}$ (50 miles) farther into east-central Iowa The sense of throw on the fault is down-to-the-north and vertical displacements are 52-70 $\mathrm{m}$ (Bunker and others, 1985 \#2804). The fault zone offsets Paleozoic rocks, but these rocks are poorly exposed and are generally buried beneath Pleistocene glacial, fluvial, and eolian deposits. In extreme eastern Iowa, the fault zone juxtaposes Silurian rocks against Ordovician rocks and westward, it juxtaposes Devonian strata against Silurian rocks. A seismic-reflection profile in Jones County, Iowa, helps characterize the width of the fault zone and the characteristics of the deformation (Bunker and others, $1985 \# 2804$, p. 69).

Reason for assignment to Class C: No unequivocal evidence of Quaternary movement. The Plum River fault zone is known from offsets in Paleozoic rocks, but the stratigraphic relations in these rocks are not known in sufficient detail to eliminate the possibility of as much as $9 \mathrm{~m}$ of post-Pennsylvanian vertical offset. There have not been any systematic investigations to examine the possibility of Quaternary offset on the fault, but one observation raises this possibility. Late Quaternary loess-covered terraces along the Goose Creek channel, an ancient channel of the Mississippi River, cross the Plum River fault zone in Jackson County, Iowa. Longitudinal profiles show that the terrace surface generally slopes to the south, which is the direction of the inferred relict stream gradient. However, at the northern end of the channel where the terraces cross the Plum River fault zone, the terrace surface slopes to the north. This change in slope direction could be evidence of late Quaternary deformation, or it could be related to erosional modification of the terrace and subsequent burial by loess (Bunker and others, $1985 \# 2804$, p. 103). This is the only evidence of possible Quaternary deformation, and it is not definitive.

The evidence of Quaternary movement on the Plum River fault zone is equivocal; in the absence of strong evidence of Quaternary faulting, the fault zone is assigned to Class C in this compilation.

Date of compilation 11/14/97

Compiler and affiliation Anthony J. Crone, U.S. Geological Survey

State Iowa, Illinois

County Clinton, Jackson, Jones, Linn (Iowa); Carroll, Ogle (Illinois)

$1^{\circ} \times 2^{\circ}$ sheet Rockford, Dubuque, Davenport

Physiographic province Central Lowland

\section{References}

\#2804 Bunker, B.J., Ludvigson, G.A., and Witzke, B.J., 1985, The Plum River fault zone and the structural and stratigraphic framework of eastern Iowa: Iowa Geological Survey Technical Information Series 13, 126 p. 


\section{Potter County fault (Class C)}

Structure Name Potter County fault (Class C)

Comments: One of the major faults that bounds the southeastern margin of the Amarillo uplift in the Texas Panhandle.

Reason for assignment to Class C: Ramelli and others (1987 \#668) postulated that the fault may have experienced movement during the Quaternary based on the presence of fault-related lineaments that were observed during aerial reconnaissance of the area. Subsequent, more detailed studies by Swan and others (written commun. 1993 \#675) indicate that the lineament is likely related to the ". . fortuitous alignment of several geomorphic features along the approximate location of the Potter County fault". Stratigraphic evidence indicates that the fault has not moved since deposition of the Miocene-age Potter Member of the Ogallala Formation. Based on this evidence, the fault is assigned to Class $\mathrm{C}$ for this compilation.

Date of compilation $03 / 08 / 94$

Compiler and affiliation Anthony J. Crone, U.S. Geological Survey

State Texas

County Potter

$1^{\circ} \times 2^{\circ}$ sheet Amarillo

Physiographic province Great Plains Province, High Plains

\section{References}

\#668 Ramelli, A.R., Slemmons, D.B., and Brocoum, S.J., 1987, The Meers fault-Tectonic activity in southwestern Oklahoma: U.S. Nuclear Regulatory Commission NUREG/CR-4852, $25 \mathrm{p}$.

\#675 Swan, F.H., Wesling, J.R., Hanson, K.A., Kelson, K.I., and Perman, R.C., written commun. 1993, Draft report-Investigation of the Quaternary structural and tectonic character of the Meers fault (southwestern Oklahoma): Technical report to U.S. Nuclear Regulatory Commission, Washington, D.C., under Contract NRC-04-87-007, July 1993, 104 p., 3 pls. 


\section{Ramapo fault system (Class C)}

Structure Name Ramapo fault system (Class C)

Comments: In northern New Jersey and southeastern New York State, as well as farther southwest, the Mesozoic Newark basin is bounded on the northwest by a wide system of northeast-striking, mostly steeply to moderately southeast-dipping, brittle normal faults of Mesozoic age (Fisher and others, 1970 \#1931; Ratcliffe, 1971 \#1883; Ratcliffe, 1980 \#2052; Lyttle and Epstein, 1987 \#1935; Drake and others, 1996 \#1957). Various faults of the system contain evidence of repeated slip in various directions since Proterozoic time, including Mesozoic extensional reactivation (Ratcliffe, 1971 \#1883; Ratcliffe, 1980 \#2052; Ratcliffe, 1992 \#1972). Sedimentary and igneous Mesozoic strata of the basin-fill dip generally northwesterly into the normal faults. At their northwestern edge, the Mesozoic rocks are in fault contact with the Proterozoic and Paleozoic metamorphic and igneous rocks of the Hudson Highlands, and the contact steps right or left along the fault system from one strand to another. Thus, at any given point along the contact between Mesozoic and older rocks, brittle normal faults are likely to cut Mesozoic rocks several kilometers southeast of the contact, and other brittle normal faults are likely to cut older, ductile structures or reactivate older ductile faults in the pre-Mesozoic rocks northwest of the contact.

In New Jersey, northeastward from the vicinity of Bernardsville, the contact between Mesozoic and older rocks follows a single strand of the normal fault system, the Ramapo fault (Ratcliffe, 1971 \#1883). Over much of the $56 \mathrm{~km}$ northeastward from the vicinity of Bernardsville to the New York State border and for several kilometers beyond, the Ramapo fault is the largest in this part of the normal fault system. I extend the usage of Ratcliffe (1971 \#1883) and follow a suggestion by N.M. Ratcliffe (written commun., 1998) in referring to the entire normal fault system as the Ramapo fault system. Thus, the Ramapo fault is but one strand of the Ramapo fault system.

Northeast of the Hudson River, Mesozoic rocks have not been mapped, and therefore large, continuous Mesozoic faults are not identified there (Ratcliffe, 1992 \#1972). However, the various strands of the Ramapo fault zone and its northeastward extensions are mapped within Proterozoic and Paleozoic metamorphic and igneous rocks for tens of kilometers northeastward from the Hudson River (Ratcliffe, 1992 \#1972). At many localities northeast of the river, one or another mapped fault strand contains structural and petrologic indicators of nearsurface, brittle extension that must be younger than deep, post-Appalachian erosional unroofing (Ratcliffe, 1980 \#2052; Ratcliffe, 1992 \#1972). The nature and wide distribution of these indicators is evidence that they formed as part of the widespread Mesozoic extension that initiated the rifting associated with the Atlantic passive margin (Ratcliffe, 1980 \#2052; Ratcliffe, 1992 \#1972), probably by reactivation of Paleozoic thrust faults (Ratcliffe and Burton, 1985 \#1976; Ratcliffe and others, 1986 \#2222).

Reason for assignment to class $\mathbf{C}$ : The Ramapo fault system is assigned to class $\mathrm{C}$ because of a lack of evidence for Quaternary slip on the fault. However, it was evaluated for this compilation of geologic evidence for Quaternary faulting for four reasons.

(1) It has a long history of repeated slip in various directions (Ratcliffe, 1971 \#1883; Ratcliffe, 1980 \#2052; Ratcliffe, 1992 \#1972). Repeated reactivation of a fault is often presumed to indicate an increased potential for additional slip, which might occur seismically. 
(2) A worldwide survey of damaging earthquakes in stable continental regions found that large earthquakes occur preferentially in passive margins and continental rifts, with the preference being strongest for areas that underwent Mesozoic or Paleogene extension (Johnston, 1989 \#2039; Johnston, 1994 \#2040). Kafka and Miller (1996 \#2206) showed that epicenter locations correlate significantly with the locations of the Newark and Hartford Mesozoic rift basins. Thus, Mesozoic extensional slip on the Ramapo fault system indicates the likelihood of elevated earthquake potential.

(3) Earthquake epicenters, hypocentral depths, and single-earthquake focal mechanisms were interpreted as being consistent with reverse slip on a surface that dips $60^{\circ}-65^{\circ}$ southeast from the trace of the Ramapo fault (Page and others, 1968 \#1873; Aggarwall and Sykes, 1978 \#1783). Scattered epicenters led Aggarwal and Sykes (1978 \#1783, p. 425) to incriminate the Ramapo fault system as a whole, by suggesting that "seismic activity ... is concentrated along several northeast-trending faults of which the Ramapo fault appears to be the most active." According to Aggarwal and Sykes (1978 \#1783), the dominantly reverse mechanisms imply east-southeast-directed greatest horizontal compressive stress $\mathrm{S}(\mathrm{Hmax})$. However, in four sets of later studies, most of these results have not been replicated. First, additional data show that $\mathrm{S}$ (Hmax) in the vicinity of the Ramapo fault system, and throughout most of the eastern United States, trends east-northeast (Zoback and Zoback, 1989 \#1922). One of the focal mechanisms of Aggarwal and Sykes was later found to be non-unique; the preferred solution is consistent with an $\mathrm{S}(\mathrm{Hmax})$ orientation of east-northeast, not east-southeast (Quittmeyer and others, $1985 \# 1881$ ). A three-dimensional velocity model shows a 10-15 percent velocity difference across the Ramapo fault in the upper $10 \mathrm{~km}$ of the crust (Thurber and Caruso, 1985 \#1908). The improved velocity model changed some epicenters and depths; in addition, it might have affected some of the focal mechanisms of Aggarwal and Sykes (1978 \#1783) if it had been available when they did their work. Second, Kafka and others (1985 \#1843) culled the earthquake catalog to insure uniform station locations, uniform instrumentation, and a uniform detection threshold. The culled catalog showed that approximately half the earthquakes, including the largest ones, occurred distant from the Ramapo fault, around the periphery of the Newark Basin. Although some of these earthquakes occurred away from the Ramapo fault, they occurred within the Ramapo fault system, as originally noted by Aggarwal and Sykes (1978 \#1783). The epicentral alignment along the Ramapo fault remains, but is much less striking than the one shown by Aggarwal and Sykes (1978 \#1783). Thus, the fault does not appear to dominate seismicity in its region - but the fault system still might do so. Third, structural and petrographic analyses of fault rock that was cored from the Ramapo and related basin-border faults at six localities in New York and New Jersey showed that the most recent slip was extensional at each locality (Ratcliffe, 1980 \#2052; Ratcliffe, 1982 \#1941; Burton and Ratcliffe, 1985 \#1927; Ratcliffe and others, 1990 \#1943). The last widespread extension in the area of the Ramapo fault was Mesozoic. Reactivation of the Ramapo or other border faults in the present-day compressional stress field would be inconsistent with the results of the core analyses (Ratcliffe and Burton, 1984 \#1884). Fourth, borehole cores at five localities and two seismic-reflection profiles along the part of the Ramapo fault that Aggarwal and Sykes (1978 \#1783) analyzed show that, except at its northeasternmost end, the fault dips $5^{\circ}$ $15^{\circ}$ more shallowly than was inferred from the results of Aggarwal and Sykes (1978 \#1783) (Ratcliffe and Burton, 1985 \#1976; Ratcliffe and others, 1986 \#2222). The implication is that most of the earthquakes that were attributed to present-day compressional reactivation of the 
Ramapo fault actually occurred in the Proterozoic rocks of its footwall. Ratcliffe and Costain (1985 \#2018) present an example of exactly that relation, from farther southwest along the Ramapo fault.

(4) Scattered, inconclusive reports hint at Quaternary deformation at or near the Ramapo fault. At Ladentown, New York, between the Hudson River and the New Jersey border, pollen data indicate possible Holocene downdropping of the southeast side of the Ramapo fault (Nelson, 1980 \#1869). Sea-level curves from nine tidal marshes along the Hudson River indicate at least two episodes of Holocene downdropping of areas southeast of individual strands of the Ramapo fault system (Newman and others, 1983 \#1870; Newman and others, 1987 \#2016). Cores from sediments of glacial Lake Passaic contain slump folds, breccias, and small normal and reverse faults, which Forsythe and Chisholm (1989 \#1824) speculated might be the result of strong ground motion. Kafka and others (1989 \#2043) interpreted terrace levels, offset streams, and shapes and locations of stream meanders as indicating possible right-lateral strike slip on the Ramapo fault in New York State and northernmost New Jersey. However, four arguments counter these hints. First, none of the cited reports provides evidence of sudden offset, which alone can distinguish prehistoric seismic slip from aseismic creep. Second, Stone and Ratcliffe (1984 \#1987) and Ratcliffe and others (1990 \#1943) trenched the updip projection of the Ramapo fault at two places. Neither trench revealed evidence of Quaternary tectonic faulting. Third, as mentioned earlier, kinematic indicators in cored faultrock show that the most recent slip on the Ramapo and related faults was normal, and presumably Mesozoic. Fourth, the present-day east-northeast orientation of S(Hmax) is inconsistent with possible downdropping of the southeast sides of the southeast-dipping strands of the Ramapo fault system.

None of the arguments and evidence presented here can preclude the possibility that the Ramapo fault or fault system slips to produce occasional small earthquakes, or rarer large ones whose geologic record has not been recognized. However, convincing evidence for Quaternary faulting in the Ramapo fault system has not yet been presented. Accordingly, the fault system is assigned to class $\mathrm{C}$ for this compilation.

Date of compilation 08/31/98; 01/28/00

Compiler and affiliation Russell L. Wheeler, U.S. Geological Survey

State New Jersey; New York

County Bergen; Essex; Hunterdon; Somerset; Mercer; Morris; Passaic; Warren (New Jersey); Rockland; Westchester; Putnam (New York)

$1^{\circ} \times 2^{\circ}$ sheet Newark; Scranton; Hartford

Physiographic province Piedmont; New England

\section{References}

\#1783 Aggarwall, Y.P., and Sykes, L.R., 1978, Earthquakes, faults, and nuclear power plants in southern New York and northern New Jersey: Science, v. 200, p. 425-429.

\#1927 Burton, W.C., and Ratcliffe, N.M., 1985, Attitude, movement history, and structure of cataclastic rocks of the Flemington fault-Results of core drilling near Oldwick, New Jersey: U.S. Geological Survey Miscellaneous Field Studies Map MF-1781, 1 sheet. 
\#1957 Drake, A.A., Jr., Volkert, R.A., Monteverde, D.H., Herman, G.C., Houghton, H.F., Parker, R.A., and Dalton, R.F., 1996, Bedrock geologic map of northern New Jersey: U.S. Geological Survey Miscellaneous Investigations Map I-2540-A, 6 p. pamphlet, 2 sheets, scale 1:100,000.

\#1931 Fisher, D.W., Isachsen, Y.W., and Rickard, L.V., 1970, Geologic map of New YorkLower Hudson sheet: New York State Museum and Science Service Map and Chart Series 15, 1 sheet, scale 1:250,000.

\#1824 Forsythe, R.D., and Chisholm, L., 1989, Are there earthquake-induced deformation structures in the Highlands/Lowlands border region of New Jersey?: Geological Society of America Abstracts with Programs, v. 21, no. 2, p. 15.

\#2039 Johnston, A.C., 1989, The seismicity of 'stable continental interiors', in Gregersen, S., and Basham, P.W., eds., Earthquakes at North Atlantic passive margins-Neotectonics and postglacial rebound: Dordrecht, The Netherlands, Kluwer Academic Publishers, p. 299-327.

\#2040 Johnston, A.C., 1994, Seismotectonic interpretations and conclusions from the stable continental region seismicity database, in Schneider, J.F., ed., The earthquakes of stable continental regions - v. 1, Assessment of large earthquake potential: Technical report to Electric Power Research Institute TR-102261-V1, Palo Alto, California, December 1994, p. 4-1-4-103.

\#2206 Kafka, A.L., and Miller, P.E., 1996, Seismicity in the area surrounding two Mesozoic rift basins in the northeastern United States: Seismological Research Letters, v. 67, p. 6986.

\#1843 Kafka, A.L., Schlesinger-Miller, E.A., and Barstow, N.L., 1985, Earthquake activity in the greater New York City area - Magnetudes, seismicity, and geologic structures: Bulletin of the Seismological Society of America, v. 75, p. 1285-1300.

\#2043 Kafka, A.L., Winslow, M.A., and Barstow, N.L., 1989, Earthquake activity in the greater New York City area-A faultfinder's guide, in Weiss, D., ed. Field trip guidebook: New York State Geological Association, 61st Annual Meeting, Middletown, New York, October 13-15, 1989, Guidebook, p. 177-203.

\#1935 Lyttle, P.T., and Epstein, J.B., 1987, Geologic map of the Newark $1^{\circ}$ x $2^{\circ}$ quadrangle, New Jersey, Pennsylvania, and New York: U.S. Geological Survey Miscellaneous Investigations Map I-1715, 1 sheet, scale 1:250,000.

\#1869 Nelson, S., 1980, Determination of Holocene fault movement along the Ramapo fault in southeastern New York using pollen stratigraphy: Geological Society of America Abstracts with Programs, v. 12, no. 2, p. 75.

\#1870 Newman, W.S., Cinquemani, L.J., Sperling, J.A., Marcus, L.F., and Pardi, R.R., 1983, Holocene neotectonics of the lower Hudson Valley: Geological Society of America Abstracts with Programs, v. 15, no. 3, p. 148.

\#2016 Newman, W.S., Cinquemani, L.J., Sperling, J.A., Marcus, L.F., and Pardi, R.R., 1987, Holocene neotectonics and the Ramapo fault zone sea-level anomaly-A study of varying marine transgression rates in the lower Hudson estuary, New York and New 
Jersey, in Nummedal, D., Pilkey, O.H., and Howard, J.D., eds., Sea-level fluctuation and coastal evolution: Society of Economic Paleontologists and Mineralogists Special Publication 41, p. 97-111.

\#1873 Page, R.A., Molnar, P.H., and Oliver, J., 1968, Seismicity in the vicinity of the Ramapo fault, New Jersey-New York: Bulletin of the Seismological Society of America, v. 58, p. 681-687.

\#1881 Quittmeyer, R.C., Statton, C.T., Mrotek, K.A., and Houlday, M., 1985, Possible implications of recent microearthquakes in southern New York State: Earthquake Notes, v. 56, p. 35-42.

\#1883 Ratcliffe, N.M., 1971, The Ramapo fault system in New York and adjacent northern New Jersey-A case of tectonic heredity: Geological Society of America Bulletin, v. 82, p. $125-142$.

\#2052 Ratcliffe, N.M., 1980, Brittle faults (Ramapo fault) and phyllonitic ductile shear zones in the basement rocks of the Ramapo seismic zones New York and New Jersey, and their relationship to current seismicity, in Manspeizer, W., ed. Field studies of New Jersey geology and guide to field trips: Newark, New Jersey, Rutgers University, Geology Department, New York State Geological Association, 52nd annual meeting, October 10, 1980, Guidebook, p. 278-312.

\#1941 Ratcliffe, N.M., 1982, Results of core drilling of the Ramapo fault at Sky Meadow Road, Rockland County, New York, and assessment of evidence for reactivation to produce current seismicity: U.S. Geological Survey Miscellaneous Investigations Map I-1401, 1 sheet.

\#1972 Ratcliffe, N.M., 1992, Bedrock geology and seismotectonics of the Oscawana Lake quadrangle, New York: U.S. Geological Survey Bulletin 1941, 38 p., 1 pl., scale $1: 24,000$.

\#1884 Ratcliffe, N.M., and Burton, W.C., 1984, Brittle fault fabrics, mineraology and geometry of border faults of the Newark basin, N.Y.-N.J., from drill-core information: Geological Society of America Abstracts with Programs, v. 16, no. 1, p. 57.

\#1976 Ratcliffe, N.M., and Burton, W.C., 1985, Fault reactivation models for origin of the Newark basin and studies related to Eastern U.S. seismicity, in Robinson, G.R., Jr., and Froelich, A.J., eds., Proceedings of the Second U.S. Geological Survey workshop on the early Mesozoic basins of the Eastern United States: U.S. Geological Survey Circular 946, p. 36-42.

\#2222 Ratcliffe, N.M., Burton, W.C., D'Angelo, R.M., and Costain, J.K., 1986, Low-angle extensional faulting, reactivated mylonites and seismic reflection geometry of the Newark basin in eastern Pennsylvania: Geology, v. 14, p. 766-770.

\#1943 Ratcliffe, N.M., Burton, W.C., and Pavich, M.J., 1990, Orientation, movement history, and cataclastic rocks of Ramapo fault based on core drilling and trenching along the western margin of the Newark basin near Berndardsville, New Jersey: U.S. Geological Survey Miscellaneous Investigations Map I-1982, 1 sheet. 
\#2018 Ratcliffe, N.M., and Costain, J.K., 1985, Northeastern seismicity and tectonics, in Jacobson, M.L., and Rodriguez, T.R., eds., National Earthquake Hazards Reduction Program summaries of technical reports, v. XX: U.S. Geological Survey Open-File Report 85-464, p. 54-58.

\#1987 Stone, B.M., and Ratcliffe, N.M., 1984, Faults in Pleistocene sediments at trace of Ramapo fault, in Geological Survey reserach, fiscal year 1981: U.S. Geological Survey Professional Paper 1375, p. 49.

\#1908 Thurber, C.H., and Caruso, T.C., 1985, Crustal structure along the Ramapo fault zone, New York State: Earthquake Notes, v. 56, p. 145-152.

\#1922 Zoback, M.L., and Zoback, M.D., 1989, Tectonic stress field of the continental United States, in Pakiser, L.C., and Mooney, W.D., eds., Geophysical framework of the continental United States: Geological Society of America Memoir 172, p. 523-539. 


\section{Rough Creek fault system (Class C)}

\section{Structure Name Rough Creek fault system (Class C)}

Comments: Electrical resistivity profiling and augering indicate possible Quaternary slip at five locations along the Rough Creek fault system of western Kentucky. However, no trenching has been performed to test these indications.

Five of the eight study sites of Stickney (1985 \#2056) and Chadwick (1989 \#2025) show evidence of possible Quaternary faulting. Wheeler and others (1997 \#1948) transferred the five site locations from large-scale site maps of Stickney (1985 \#2056) and Chadwick (1989 \#2025) onto 1:24,000 geologic and topographic maps, and then digitized the locations. The five locations are shown on the 1:250,000-scale map of Wheeler and others (1997 \#1948), and the digital locations may be downloaded by following instructions in Rhea (1997 \#1980).

This is the Rough Creek-Shawneetown fault system of Nelson (1995 \#1984). The fault system forms the northern border of the Rough Creek graben, which trends east-west in southeastern Illinois and western Kentucky. The name Shawneetown has been used for the Illinois part of the fault system, and Rough Creek for the Kentucky part. The study sites that concern us are in Kentucky, so I use the Kentucky name. The study sites are at locations S-SA1, S-SA2, CSS1(N), C-SS1(S), and C-SS3 of Wheeler and others (1997 \#1948). Respectively, the sites are study area 1 (drill line S-A) and study area 2 (drill line S-B) of Stickney (1985 \#2056); and study site 1 (drill line 2), a second site several tens of meters farther south along the same drill line at the same study site, and study site 3 (drill line 5) of Chadwick (1989 \#2025).

The Rough Creek graben trends east across western Kentucky and southern Illinois, and the Rough Creek fault system forms its northern border (Noger, 1988 \#1938; Nelson, 1995 \#1984). The fault system formed with the graben during Cambrian and possibly earlier continental rifting, was reactivated during late Paleozoic compression and Permian or Mesozoic extension, and dips steeply southward to depths that exceed $9 \mathrm{~km}$ (Nelson, 1995 \#1984; Wheeler, 1997 \#1915; Wheeler and others, 1997 \#1947 and numerous references cited in these three compilations). At the surface, the fault system is mapped as a zone of anastomosing fault strands as wide as 7-8 km (Noger, 1988 \#1938). The five study sites listed above are located where some of these fault strands are mapped as passing beneath Quaternary alluvium. If any Quaternary or Neogene deposits are faulted, they are of Pliocene(?) to Holocene age (Stickney, 1985 \#2056; Chadwick, 1989 \#2025).

No Quaternary faulting is reported from the Rough Creek fault system. However, nearby orientations of the greatest horizontal compressive stress trend approximately east-northeast, counterclockwise from the easterly trend of the fault system (Wheeler, 1997 \#1915). This angular relation would imply a likelihood of sinistral slip, perhaps with a reverse component, if the Rough Creek fault system were reactivated in the present-day compressional stress field. The fault strands have no clear geomorphic expression of young movement at the study sites.

Reason for assignment to class C No Quaternary faulting is reported from the Rough Creek fault system. No detailed paleoseismological studies have been performed. However, Stickney and others (1984 \#1899), Stickney (1985 \#2056), and Chadwick (1989 \#2025) studied eight locations at which strands of the Rough Creek fault system had been mapped at 1:24,000-scale as passing beneath Pliocene(?)-Holocene alluvium. Electrical resistivity and 
very low frequency electromagnetic profiles determined the most likely locations of the faults beneath the alluvium. Lines of auger holes produced logs from which bedrock steps could be recognized beneath the alluvium. Each line contained 6-8 holes spaced $15 \mathrm{~m}$ apart. Bedrock steps several meters high were found at five of the eight locations. Stickney and others (1984 \#1899) suggested that the bedrock steps may represent Pliocene(?)-Holocene reactivation of strands of the Rough Creek fault system. However, Stickney (1985 \#2056) and Chadwick (1989 \#2025) were careful to note that the presence or absence of Pliocene or Quaternary faulting can be demonstrated only by subsequent trenching studies, which have not yet been performed. Absent such studies, and absent evidence that any faulting occurred suddenly instead of by aseismic creep, no recurrence interval can be calculated. The slip rate is unknown. However, a Holocene slip rate of $0.2 \mathrm{~mm} / \mathrm{yr}$ would have produced sufficient offset that it would probably have been detected in the field if it were reverse, although perhaps not if it were strike slip. The same slip rate would have produced $320 \mathrm{~m}$ of Quaternary slip, which probably would have been detected even if it were all strike slip. None was reported.

Date of compilation 12/16/98; revised 01/28/00

Compiler and affiliation Russell L. Wheeler, U.S. Geological Survey

State Kentucky

County Webster; McLean; Daviess

$1^{\circ} \times 2^{\circ}$ sheet Evansville

Physiographic province Interior Low Plateaus

\section{References}

\#2025 Chadwick, D.L., 1989, Investigation of recent movement within the Rough Creek fault zone in McLean and Daviess Counties, Kentucky: Richmond, Eastern Kentucky University, unpublished M.S. thesis, 95 p., 5 pl., scale 1:150.

\#1984 Nelson, W.J., 1995, Structural features in Illinois: Illinois State Geological Survey Bulletin 100, 144 p., 2 pls.

\#1938 Noger, M.C., compiler, 1988, Geologic map of Kentucky: U. S. Geological Survey and Kentucky Geological Survey, 1 sheet, scale 1:500,000.

\#1980 Rhea, S., compiler, 1997, Seismotectonic maps in the vicinity of the lower Wabash Valley, Illinois, Indiana, and Kentucky—Digital spatial database: U.S. Geological Survey Open-File Report 97-681, 15 p.

\#2056 Stickney, J.F., 1985, Investigation of recent movement along the Rough Creek fault system in Webster and McLean Counties, Kentucky: Richmond, Eastern Kentucky University, unpublished M.S. thesis, 95 p., 5 pls., scale 1:150.

\#1899 Stickney, J.F., Chadwick, D.L., and VanArsdale, R.B., 1984, Investigation of recent movement along the Rough Creek fault system in portions of Daviess, McLean, and Webster Counties, Kentucky: Geological Society of America Abstracts with Programs, v. 16, no. 3, p. 199. 
\#1915 Wheeler, R.L., 1997, Boundary separating the seismically active Reelfoot Rift from the sparsely seismic Rough Creek graben, Kentucky and Illinois: Seismological Research Letters, v. 68, p. 586-598.

\#1947 Wheeler, R.L., Diehl, S.F., Rhea, S., Sargent, M.L., and Bear, G.W., 1997, Map showing selected wells and geophysical survey and modeling lines in the vicinity of the lower Wabash Valley, Illinois, Indiana, and Kentucky: U.S. Geological Survey Geologic Investigations Series I-2583-C, 16 p. pamphlet, 1 sheet, scale 1:250,000.

\#1948 Wheeler, R.L., Rhea, S., Diehl, S.F., Drahovzal, J.A., Bear, G.W., and Sargent, M.L., 1997, Seismotectonic map showing faults, igneous rocks, and geophysical and neotectonic features in the vicinity of the lower Wabash Valley, Illinois, Indiana, and Kentucky: U.S. Geological Survey Geologic Investigations Series I-2583-D, 19 p. pamphlet, 1 sheet, scale 1:250,000. 


\section{South Sebec seismic zone (Class c)}

Structure Name South Sebec seismic zone (Class C)

Comments: The South Sebec seismic zone and its surrounding area in central Maine have been seismically active at a low level since at least 1817, with one and perhaps two earthquakes having Modified Mercalli intensities of VI (Ebel, 1989 \#1996; Doll and others, 1992 \#1813). During 1989 and 1990 a portable array of seismographs located 28 microearthquakes, all of which were shallower than $3 \mathrm{~km}$ focal; depths of most of the microearthquakes were shallower than $1 \mathrm{~km}$ (Doll and others, 1992 \#1813). Twenty-one of the microearthquake epicenters define a northwest-trending alignment as much as $9 \mathrm{~km}$ long. One of these 21 aligned epicenters and three of the others form a second, N. $70^{\circ}$ E.-trending alignment that is $4 \mathrm{~km}$ long. This east-northeast alignment is parallel to, but $1 \mathrm{~km}$ northwest of, a straight and narrow valley that contains elongated ponds, bogs, and streams (the Harriman Pond lineament). Focal mechanisms of two larger earthquakes from 1986 and 1987 indicate east-west compression, and the focal mechanisms have nodal planes that strike approximately parallel to the northwest-trending alignment of the microearthquake epicenters (Ebel and Bouck, 1988 \#1818; Foster and others, 1992 \#1825).

Reason for assignment to class $\mathbf{C}$ : This evaluation of Quaternary faulting is not a reliable guide to seismic hazard of the South Sebec seismic zone. The most authoritative and reliable assessment of the seismic hazard in the area evaluated here is the national seismic hazard maps, which are published by the USGS (Open-File Report 97-131, 12 maps, scale 1:7,000,000; http://geohazards.cr.usgs.gov/eq/). In the Central and Eastern U.S. (CEUS) east of the Rocky Mountain Front, the distribution of historical earthquakes is a reasonable guide to seismic hazard. In the CEUS, the national seismic hazard maps rely mainly on the distribution of historical seismicity to calculate the hazard. In contrast to examining the area's historical seismicity, this discussion focuses on surficial evidence of large, prehistoric earthquakes. Where present, this surficial evidence will be integrated with the historical seismicity to improve future versions of the national hazard maps. In the CEUS, the most common types of surficial evidence of large, prehistoric earthquakes are liquefaction features and faults that offset young strata. However, in some areas the surficial record of large, prehistoric earthquakes is incomplete because of erosion, equivocal, or presently unrecognized evidence. Nonetheless, the national hazard maps show that, for many parts of the CEUS, although convincing surficial evidence of large, prehistoric earthquakes is absent, these areas are NOT free of seismic hazard. The occurrence of significant historical earthquakes in the area described here demonstrates a notable level of seismic hazard.

No structural, stratigraphic, geomorphic, or paleoseismological evidence is reported for Quaternary faulting. Marvinney (1991 \#1858) examined exposures of the Paleozoic metasedimentary bedrock along the Harriman Pond lineament. He found quartz veins, bed-parallel shears, and slickensides, indicating faulting that could be as old as Paleozoic. Foster and others (1992 \#1825) speculated that the shallow earthquakes might indicate modern sinistral reactivation of joints that were observed to strike northwest, or new faults forming parallel to the joints. Roy (1996 \#1888) explored Pleistocene and Holocene deposits in two nearby river valleys, one of which crosses the northwest-trending epicentral alignment. He found numerous glacial features but no evidence of prehistoric shaking-induced liquefaction. Accordingly, the South Sebec seismic zone is assigned to class $\mathrm{C}$ in this compilation. 
Date of compilation 04/02/98; revised 02/02/00

Compiler and affiliation Russell L. Wheeler, U.S. Geological Survey

State Maine

County Piscataquis

$1^{\circ} \times 2^{\circ}$ sheet Millinocket

Physiographic province New England

\section{References}

\#1813 Doll, W.E., Rea, C.D., Ebel, J.E., Craven, S.J., and Cipar, J.J., 1992, Analysis of shallow microearthquakes in the South Sebec seismic zone, Maine, 1989-1990: Seismological Research Letters, v. 63, p. 557-566.

\#1996 Ebel, J.E., 1989, The seismicity of Maine, in Anderson, W.A., and Borns, H.W., Jr., eds., Neotectonics of Maine-Studies in seismicity, crustal warping, and sea-level change: Maine Geological Survey Bulletin 40, p. 219-228.

\#1818 Ebel, J.E., and Bouck, B.R., 1988, New focal mechanisms for the New England regionConstraints on the regional stress regime: Seismological Research Letters, v. 59, p. 183-187.

\#1825 Foster, J.E., Roy, D.C., Ebel, J.E., and Tuttle, M.P., 1992, Faults, joints, liquefaction features, and earthquakes in the Dover-Foxcroft area, Maine: Geological Society of America Abstracts with Programs, v. 24, no. 3, p. 21.

\#1858 Marvinney, R.G., 1991, Preliminary structural investigation of a $25 \mathrm{~km}$ topographic lineament in central Maine: Geological Society of America Abstracts with Programs, v. 23, no. 1, p. 99.

\#1888 Roy, D.C., 1996, A paleoseismic investigation of the Dover-Foxcroft area, central Maine: Geological Society of America Abstracts with Programs, v. 28, no. 3, p. 95. 


\section{Stanleytown-Villa Heights faults (Class C)}

Structure Name Stanleytown-Villa Heights faults (Class C)

Comments: Conley and Toewe (1968 \#3878) mapped and described two small, north-striking, normal faults in the Piedmont province of southern Virginia. Martinsville is the seat of Henry County. One unnamed fault is approximately $8 \mathrm{~km}$ northwest of Martinsville and approximately $1.5 \mathrm{~km}$ south of Stanleytown; I informally name it the Stanleytown fault. A second unnamed fault is on the western edge of the community of Villa Heights, itself a northwestern suburb of Martinsville; I informally name the second fault the Villa Heights fault. No other faults appear on the map of Conley and Toewe (1968 \#3878).

The Stanleytown fault dips 62 degrees east and its trace is mapped as approximately $600 \mathrm{ft}$ (200 m) long; the text (Conley and Toewe, 1968 \#3878, p. 25) gives the length as approximately 300 yards $(274 \mathrm{~m})$. The fault juxtaposes Quaternary terrace deposits on the east against Paleozoic Rich Acres Norite (Rich Acres Formation of Cambrian age:

Virginia Division of Mineral Resources, 1993 \#1952) on the west. The terrace deposits have been dropped down 15-20 ft (5-6 m) on the fault. The fault trace cuts nearly perpendicularly across the east-plunging nose of a hill, and a small stream flows on its alluvium around the nose. At both its ends, the trace disappears under the alluvium. The trace rises and falls approximately $20 \mathrm{ft}(6 \mathrm{~m})$ as it crosses the nose of the hill. Conley and Toewe (1968 \#3878, p. 24) showed a photograph of the fault as it appeared in a cut bank of the small stream.

The Villa Heights fault is similar in size, strike, and style. It dips vertically and its trace is mapped as approximately $600 \mathrm{ft}(200 \mathrm{~m})$ long; the text (Conley and Toewe, 1968 \#3878, p. $25)$ gives the length as approximately $100 \mathrm{ft}(30 \mathrm{~m})$. The fault juxtaposes Quaternary colluvium on the east against biotite gneiss (Fork Mountain Formation of Cambrian age:

Virginia Division of Mineral Resources, 1993 \#1952) on the west. The colluvium has been dropped down at least $5 \mathrm{ft}(2 \mathrm{~m})$ on the fault. The trace extends down the north-northeastplunging nose of a hill, slightly east of the ridge line of the nose. This nose is several times higher than the one that underlies the Stanleytown fault, and accordingly the north end of the Villa Heights fault is approximately $150 \mathrm{ft}(48 \mathrm{~m})$ lower than its south end.

Reason for assignment to class $\mathbf{C}$ : Both faults appear as likely to be landslides as tectonic faults. From the evidence gleaned from the text and map of Conley and Toewe (1968 \#3878), neither origin can be favored. Both faults are short, both drop their east sides down in the downhill direction, and no other faults were mapped in the quadrangle. In addition, the bedrock in the footwalls of both faults is highly weathered and good outcrops of the norite and of the gneiss are rare in the vicinity (Conley and Toewe, $1968 \# 3878$, p. 8, 17). Indeed, the norite weathers to a saprolite. Thus, landslides might be expected on such hillsides.

Date of compilation 12/16/99; revised 01/28/00

Compiler and affiliation Russell L. Wheeler, U.S. Geological Survey

State Virginia

County Henry

$1^{\circ} \times 2^{\circ}$ sheet Greensboro

Physiographic province Piedmont 


\section{References}

\#3878 Conley, J.F., and Toewe, E.C., 1968, Geology of the Martinsville West quadrangle, Virginia: Virginia Division of Mineral Resources Report of Investigations 16, 44 p., 1 plate, scale 1:24,000.

\#1952 Virginia Division of Mineral Resources, 1993, Geologic map of Virginia: Virginia Division of Mineral Resources, 1 sheet, scale 1:500,000. 


\section{Upper Marlboro faults (Class C)}

Structure Name Upper Marlboro faults (Class C)

Comments: These faults make up entry number 18 of Prowell (1983 \#1951). Dryden (1932 \#1815) described but did not name these three small faults, which he observed in a road cut $3.3 \mathrm{mi}$. $(5.3 \mathrm{~km})$ from the town of Upper Marlboro. "At a curve on the Crain Highway 3.3 miles south of the southern railroad crossing at Upper Marlboro, Prince George's County, there is exposed a section of Eocene, Miocene, and Pleistocene beds" (see p. 471 in Dryden, 1932 \#1815).

Reason for assignment to class $\mathbf{C}$ : The faults are assigned to class $\mathrm{C}$ because probably they are surficial structures that do not extend to hypocentral depths. Dryden (1932 \#1815) included a sketch of the road cut, with no indication of its orientation. From left to right, the sketch shows two probable faults that dip to the right and one certain fault, of smaller slip, that dips to the left. Both right-dipping features are concave upward, and all three features $\operatorname{dip} 30^{\circ}-40^{\circ}$. Pleistocene sediments cap the road cut unconformably. The Pleistocene sediments are thin or eroded atop the two right-dipping features, but the sediments step downward to the right $4.7 \mathrm{~m}$ vertically across the left-dipping fault.

The two right-dipping features might or might not be faults. If they are faults, then they are listric and unlikely to penetrate deeply. In this case the left-dipping fault would be antithetic and probably would terminate against one of the larger, right-dipping faults. If the two rightdipping features are not faults, then they might be erosional features (Dryden, 1932 \#1815). In this case the left-dipping fault would be the only fault in the road cut, and it would have offset the base of the Pleistocene sediments by $4.7 \mathrm{~m}$ vertically in a reverse or reverse-oblique sense. However, Dryden (1932 \#1815) observed that erosional features resembling the two right-dipping features are not known elsewhere within deposits of the same age. Accordingly, the two right-dipping features are probably faults, and none of the three faults is likely to penetrate deeply into bedrock.

Prowell (1983 \#1951) noted that aspects of Dryden's sketch indicate strike-slip faulting. The faults dip toward each other, and the blocks between the faults have different stratigraphies. Both aspects are consistent with small dip-slip components of movement in a positive flower structure that formed in overall strike slip. Strike slip could indicate deeply rooted faulting.

However, the low dips of all three faults are more consistent with a surficial origin of the faults than with a flower structure. In addition, the different stratigraphies in the various fault blocks could result from differential erosion in hilly terrane. Dryden's sketch shows an unconformity in the block between the two right-dipping faults. The unconformity has a valley-like shape, the sides of the probable valley have similar dips as the faults, and the probable valley is filled with Miocene sands. The valley-shaped unconformity has not achieved its present synformal shape by folding because adjacent beds remain horizontal. Thus, the sketch provides evidence for hilly terrane during Miocene deposition. Accordingly, Dryden's description and sketch are best explained by surficial faulting.

Date of compilation 05/20/98; revised 01/28/00

Compiler and affiliation Russell L. Wheeler, U.S. Geological Survey

State Maryland 
County Prince Georges

$1^{\circ} \times 2^{\circ}$ sheet Washington

Physiographic province Coastal Plain

\section{References}

\#1815 Dryden, A.L., Jr., 1932, Faults and joints in the Coastal Plain of Maryland: Journal of the Washington Academy of Sciences, v. 22, p. 469-472.

\#1951 Prowell, D.C., 1983, Index of faults of Cretaceous and Ceozoic age in the Eastern United States: U.S. Geological Survey Miscellaneous Field Studies Map MF-1269, 2 sheets, scale $1: 2,500,000$. 


\section{Washita Valley fault (Class C)}

Structure Name Washita Valley fault (Class C)

Comments: The Washita Valley fault is a major fault in south-central Oklahoma that extends for about $80 \mathrm{~km}$ in the subsurface from its junction with the Frontal Wichita fault system (Harlton, 1951 \#670; 1963 \#667) on the northwest to the Ouachita Mountain thrust belt on the southeast (Tanner, 1967 \#680). The fault is mapped at the surface in Paleozoic rocks in the Arbuckle Mountains for a distance of about $55 \mathrm{~km}$ from near Hennepin, Oklahoma southeast to Ravia, Oklahoma (Hart, 1974 \#679).

Reason for assignment to Class C: This feature is classified as a Class $\mathrm{C}$ fault because detailed studies have failed to document any evidence of Quaternary faulting. Interest in possible Quaternary reactivation of the Washita Valley fault developed shortly after paleoseismic studies confirmed the existence of Holocene movement on the Meers fault, which is about 80 $\mathrm{km}$ to the northwest and is part of the same regional structural network of faults that extend from the Texas Panhandle southeasterly through southern Oklahoma. Quaternary movement on the fault remains uncertain; the studies conducted to date have yet to find unequivocal evidence of Quaternary displacement. The primary geological evidence that stimulated recent detailed studies is the geomorphic characteristics of several north-flowing streams that cross the fault.

The only studies designed to examine evidence of Quaternary movement on the fault are those of Cox and VanArsdale, (1988 \#677) and VanArsdale and others (1989 \#676).

VanArsdale and others (1989 \#676) describe detailed studies at 5 sites along and near the fault.

At a site near the northwestern end of the fault, unfaulted Holocene alluvium in the Wildhorse Creek Valley has been dated as $1910 \pm 80$ yr B.P. old. To the southeast in Squirrel and Garrison Creek Valleys, Quaternary alluvium appears to be ponded against a down-to-thesouth bedrock scarp, and auger-hole data of the alluvial fill in Squirrel Creek suggests the presence of a 5-m-high bedrock scarp beneath the alluvium. A longitudinal valley profile of Squirrel Creek suggests a possible displaced terrace across the trace of the fault. Adjacent to Squirrel Creek, VanArsdale and others (1989 \#676) excavated two trenches in Paleozoic rocks across a splay of the fault and exposed northeast-dipping reverse faults but no displacement in the thin overlying veneer of Quaternary colluvium.

At a site that is several kilometers north of the mapped trace of the fault, VanArsdale and others (1989 \#676) found no evidence of faulting in terrace deposits estimated to be 12,00015,000 yr old.

At a site where the Washita River crosses the fault, natural exposures along the river do not contain evidence of recent faulting (VanArsdale and others, (1989 \#676). An alluvial deposit dated as $1570 \pm 190 \mathrm{yr}$ B.P. old can be traced unbroken across the fault in discontinuous exposures.

Along the section of the fault along which Oil Creek flows, VanArsdale and others (1989 \#676) found no evidence of faulting in alluvial deposits that were dated as $1810 \pm 80 \mathrm{yr}$ B.P. At a site near the southeastern end of the exposed fault, VanArsdale and others (1989 \#676) examined natural exposures along creeks and excavated 7 trenches. In some of the exposures 
and trenches, Cretaceous rocks were displaced by as much as $2 \mathrm{~m}$, but there was no evidence of faulting in alluvial units.

In summary, the studies of VanArsdale and others (1989 \#676) determined that Holocene alluvium $(<2000$ years old) exposed in trenches and natural exposures is unfaulted along the Washita Valley fault. At two sites, latest Pleistocene alluvium (inferred to be Wisconsinan in age based on regional Quaternary stratigraphic studies) is also unfaulted. VanArsdale and others (1989 \#676) conclude that their study "reveals that, 1) no surface rupture has occurred along the southeastern portion of the WVF since the deposition of a Wisconsin age $(18,000$ $20,000 \mathrm{yr}$ ) terrace, 2) no fault movement has occurred along the WVF from Oil Creek to Wildhorse Creek within approximately the last $2000 \mathrm{yr}$, and 3) no fault movement has occurred along a N. $32^{\circ}$ W. subsidiary fault in northern Murray County within the last 12,000 yr.

On the basis of the information summarized above, this feature is classified as a Class $\mathrm{C}$ fault.

Date of compilation $03 / 11 / 94$

Compiler and affiliation Anthony J. Crone, U.S. Geological Survey

State Oklahoma

County Garvin; Murray; Carter; Johnston

$1^{\circ} \times 2^{\circ}$ sheet Ardmore

Physiographic province Central Lowland

\section{References}

\#677 Cox, R.T., and VanArsdale, R.B., 1988, Structure and chronology of the Washita Valley fault, southern Oklahoma aulacogen: Shale Shaker, v. 39, p. 2-13.

\#670 Harlton, B.H., 1951, Faults in sedimentary part of Wichita Mountains of Oklahoma: Bulletin of the American Association of Petroleum Geologists, v. 35, p. 988-999.

\#667 Harlton, B.H., 1963, Frontal Wichita fault system of southwestern Oklahoma: Bulletin of the American Association of Petroleum Geologists, v. 47, p. 1552-1580.

\#679 Hart, D.L., Jr., 1974, Reconnaissance of the water resources of the Ardmore and Sherman quadrangles, southern Oklahoma: Oklahoma Geological Survey Hydrologic Atlas 3, Map HA-3, 4 sheets, scale 1:250,000.

\#680 Tanner, J.H., III, 1967, Wrench fault movements along Washita Valley fault, Arbuckle Mountain area, Oklahoma: Bulletin of the American Association of Petroleum Geologists, v. 51, p. 126-141.

\#676 VanArsdale, R., Ward, C., and Cox, R., 1989, Post-Pennsylvanian reactivation along the Washita Valley fault, southern Oklahoma: U.S. Nuclear Regulatory Commission NUREG/CR-5375, 48 p. 


\section{Fowler fault (Class D)}

Structure Name Fowler fault (Class D)

Comments: The fault was first named by Kirkham and Rogers (1981 \#2707) although it was earlier reported as an inferred fault by Scott (1970 \#1141) and mapped as a fault by Scott and others (1978 \#2735). This fault was previously mapped as a potentially active Quaternary fault (fault \#172) by Kirkham and Rogers (1981 \#2707). This feature is categorized in Class $\mathrm{D}$ because recent studies have not shown that the feature is not a fault, but rather a geomorphic escarpment.

Reason for assignment to Class D: The Fowler fault is considered to be a non-tectonic feature because of the lack of compelling evidence that the prominent escarpment coincides with distinctive faults in the underlying bedrock.

This $\mathrm{N} 60^{\circ} \mathrm{W}$-trending topographic escarpment is located about $5 \mathrm{~km}$ northwest of the town of Fowler, Colorado, along the northeastern side of the Arkansas River Valley. The evidence originally reported by Scott (1970 \#1141) to infer the presence of a Quaternary fault was twofold: (1) mapping of Quaternary deposits suggested that early Pleistocene Rocky Flats Alluvium was vertically offset about $18 \mathrm{~m}$ along an abrupt, linear, 12-km-long trend; and (2) three closely spaced northward-dipping faults in Upper Cretaceous Pierre Shale were recognized in an arroyo that crosses the inferred fault line. The $18 \mathrm{~m}$ vertical offset does not occur across a topographically continuous surface, but rather the offset is inferred on the basis of correlating gravelly deposits of early Pleistocene Rocky Flats Alluvium that are spaced several tens to hundreds of meters apart but are at markedly different altitudes. The gravels and their associated soils are very similar, leading to the conclusion that these non-concordant deposits were originally contiguous and had been offset by Quaternary faulting.

In 1994, Crone and Machette (1994 \#2678) conducted a brief field reconnaissance specifically in search of demonstrable evidence of Quaternary faulting. To date, the results to these reconnaissance studies are only reported in a 1994 Final Technical Report to the U.S. Nuclear Regulatory Commission. The results of their investigation of the Fowler fault, as presented in their report, are summarized below.

Although the top of the Rocky Flats Alluvium appears to be offset about $18 \mathrm{~m}$, changes in the attitude and elevation of the basal contact of the alluvium across the scarp provide evidence for a more plausible, non-tectonic explanation for the apparent offset. On the northeast (upthrown) side of the scarp, the alluvium is typically 3-4 m thick and has a generally planar base, which is consistent with the gravelly alluvium being deposited as a thin sheet across a low-relief piedmont surface. In contrast, on the southwest (downthrown) side the thickness of the alluvium varies considerably over a short distance, from only about $1 \mathrm{~m}$ adjacent to the trace of the inferred fault to several (possibly 10) meters thick at a point a few hundred meters southwest of the inferred fault. The geometry of the base of the alluvium adjacent to (southwest of) the fault suggested that the alluvium has filled an ancient stream channel; the base of this channel sweeps upward in the direction of the scarp (toward the northeast). Southwest of the inferred fault, the basal channel fill is composed of calcium carbonate-cemented pebbly sandstone that is distinct compared to the typical Rocky Flats Alluvium. The relatively well- 
sorted character of the sandstone suggests that it was deposited in a fluvial channel. Along a 4-km-long section in the central part of the suspected fault, the base and the top of the Rocky Flats Alluvium show the same pattern of upward sweeping basal and upper contacts adjacent to the inferred fault. The nature of these contacts and the presence of the carbonate-cemented sand were interpreted by Crone and Machette (1994 \#2678) as evidence of a major fluvial channel that defines the boundary between two stages of Rocky Flats Alluvium, an older, higher deposit $\left(\mathrm{Qrf}_{1}\right)$ and a slightly younger inset deposit $\left(\mathrm{Qrf}_{2}\right)$. On the basis of their field observations, Crone and Machette (1994 \#2678) interpreted the escarpment not as a fault scarp, but rather as the boundary (i.e., terrace riser) between two slightly different age deposits of Rocky Flats Alluvium whose elevations are different because of downcutting along the ancient Arkansas River.

Scott's (1970 \#1141) second line of evidence favoring a fault interpretation was the presence of closely spaced northward-dipping faults in the Pierre Shale beneath the trace of the inferred fault. Crone and Machette (1994 \#2678) carefully searched the arroyo walls in the area where Scott reported these north-dipping faults but could not find evidence of significant fault displacement despite nearly continuous exposures along the arroyo walls. Furthermore, bedding in the shale could be traced almost continuously across the area where the trace of the fault would be present. The only features present in the shale were several north-dipping fractures that strike $055^{\circ}$ and dip $39^{\circ}$ to $44^{\circ} \mathrm{N}$ (similar to Scott's notations). The fractures consist of 1$\mathrm{cm}$-wide disruptions in the nearly horizontally bedded shale, but there is no evidence of significant offset across them. The small size of the fractures and the lack of disruption in the well-bedded shale suggest that it is unlikely that the fractures could be responsible for the inferred $18 \mathrm{~m}$ of Quaternary throw on the fault. On the basis of stratigraphic and structural evidence, Crone and Machette (1994 \#2678) concluded that the inferred "Fowler fault" is not a product of Quaternary tectonism, but rather an erosional escarpment associated with the early Quaternary history of the Arkansas River.

Jack Benjamin and Associates and Geomatrix Consultants (1996 \#2703) conducted field reconnaissance in two small drainages that cross this fault. They discovered relatively continuous bedding in the Pierre Shale across the inferred trace of the fault, and an alluvial surface remnant inset about $17 \mathrm{~m}$ below the upper Rocky Flats surface. This suggested the lower surface was a younger fluvial channel rather than a downdropped fault block of Rocky Flats Alluvium. Based on their observations, they concurred that the Fowler fault is an erosional escarpment rather than a Quaternary fault.

\section{Date of compilation 11/04/97}

Compiler and affiliation Anthony J. Crone, U.S. Geological Survey

State Colorado

County Pueblo, Crowley

$1^{\circ} \times 2^{\circ}$ sheet Pueblo

Physiographic province High Plains 


\section{References}

\#2678 Crone, A.J., and Machette, M.N., 1994, Reconnaissance investigations of Quaternary faulting in the stable interior of the west-central United States: FY 1994 Final Report to the Nuclear Regulatory Commission, $11 \mathrm{p}$.

\#2703 Jack Benjamin \& Associates and Geomatrix Consultants, 1996, Probabilistic seismic hazard assessment for the U.S. Army chemical disposal facility, Pueblo Depot Activity, Colorado: Technical report to Science Applications International Corporation, Maryland, under Contract JBA 148-130-PU-002.

\#2707 Kirkham, R.M., and Rogers, W.P., 1981, Earthquake potential in Colorado: Colorado Geological Survey Bulletin 43, 171 p.

\#1141 Scott, G.R., 1970, Quaternary faulting and potential earthquakes in east-central Colorado: U.S. Geological Survey Professional Paper 700-C, C11-C18 p.

\#2735 Scott, G.R., Taylor, R.B., Epis, R.C., and Wobus, R.A., 1978, Geologic map of the Pueblo $1^{\circ}$ x $2^{\circ}$ quadrangle, south-central Colorado: U.S. Geological Survey Miscellaneous Geologic Investigations I-1022. 


\section{Grossman's Hammock rock reef (Class D)}

Structure Name Grossman's Hammock rock reef (Class D)

Comments: South Florida contains northwest-southeast-trending ridges that have typical lengths of 1-20 km, typical widths of $100 \mathrm{~m}$ or less, and typical topographic reliefs of 0.5-1.5 m (Steinen and others, 1995 \#1898, T.D. Hickey, written commun., 1998). The ridges are locally referred to as rock reefs, and I use this local term to distinguish the ridges from topographic ridges in other parts of the country that are commonly higher and wider in comparison to their lengths. Exposed bedrock is the bryozoan facies of the Miami Limestone of late Pleistocene age (T.D. Hickey, written commun., 1998). The Miami Limestone forms the upper part of a sequence of mainly carbonate, marine and freshwater units separated by discontinuity surfaces that record subaerial exposure (Enos and Perkins, 1977 \#2198; Steinen and others, 1995 \#1898). Deeper in the subsurface is the southward-deepening South Florida Basin, filled with phosphatic and siliciclastic rocks and underlying carbonate rocks; basement beneath the basin is more than $4.5 \mathrm{~km}$ deep in the vicinity of Grossman's Hammock rock reef (DuBar, 1991 \#2255). Steinen and others (1995 \#1898) tentatively interpreted drill cores as indicating $1 \mathrm{~m}$ or more of late Pleistocene and possibly Holocene, vertical offset on a southwest-dipping normal fault that strikes along the rock reef.

There are several possible origins of such a fault. The suggested fault is within a few tens of kilometers of the coastline of southeasternmost Florida. Bathymetric maps show that the sea floor drops sharply eastward into the Straits of Florida, with water depths greater than $0.5 \mathrm{~km}$ within a few kilometers offshore. Southern Florida is a subsiding carbonate platform, with the subsidence perhaps attributable to solution of carbonate rock (DuBar, 1991 \#2255). Thus, near-surface normal faulting like that inferred for the Grossman Hammock rock reef might be caused by solution collapse, antithetic faulting above a thick sedimentary column that might be collapsing and spreading into the Straits of Florida, or seismic faulting.

Reason for assignment to class D: Since the tentative inference of Quaternary faulting by Steinen and others (1995 \#1898), additional data from more recent drilling and ground penetrating radar show no evidence of Quaternary faulting (T.D. Hickey, R. Steinen, oral and written communs., 1998). Bore holes drilled along a transect perpendicular to Grossman's Hammock rock reef reveal no displacement indicative of Quaternary faulting. Ground penetrating radar verifies the absence of displacement along a surface of stratigraphic discontinuity that indicates an interval of subaerial exposure, and which is consistently observed at a depth of $13 \mathrm{ft}(4 \mathrm{~m})$. Accordingly, the Grossman's Hammock rock reef is assigned to class D.

Date of compilation 07/27/98; revised 12/15/98

Compiler and affiliation Russell L. Wheeler, U.S. Geological Survey

State Florida

County Dade

$1^{\circ} \times 2^{\circ}$ sheet Miami

Physiographic province Coastal Plain 


\section{References}

\#2255 DuBar, J.R., 1991, Quaternary geology of the Gulf of Mexico Coastal Plain-Florida panhandle, in Morrison, R.B., ed., Quaternary nonglacial geology; conterminous U.S.: Boulder, Colorado, Geological Society of America, The Geology of North America, v. K-2, p. 595-610.

\#2198 Enos, P., and Perkins, R.D., 1977, Quaternary sedimentation in South Florida: Geological Society of America Memoir 147, 198 p., 19 pls.

\#1898 Steinen, R.P., Shinn, E.A., and Halley, R.B., 1995, Hypothesized fault origin for the rock reefs of south Florida: Geological Society of America Abstracts with Programs, v. 27, no. 6, p. A-229. 


\section{Hain Quarry fissures (CLass D)}

\section{Structure Name Hain Quarry fissures (Class D)}

Comments: Vertical, tabular, downward-tapering, filled fissures in southern New England and New Jersey have long been interpreted as ice-wedge casts. Thorson and others (1986 \#1907) and Thorson (1988 \#1906) examined several of the wedges that were exposed at the Hain Quarry, a gravel pit near Willimantic in east central Connecticut. They concluded that the fissures in the quarry most likely formed by liquefaction and incipient lateral spreading that were induced by prehistoric earthquake shaking.

Reason for assignment to class D: The Hain Quarry fissures are filled with sandy silt and other materials, overlain by eolian sandy silt, and underlain by lacustrine silt, clay, and sand (Thorson and others, 1986 \#1907; Stone and Ashley, 1992 \#2229). Numerous criteria can be used to distinguish earthquake-induced liquefaction features from the many similar features of other origins (Obermeier, $1996 \# 2256$ ). Often it is easier to disprove an earthquake origin for prehistoric features than to prove it. In the case of the Hain Quarry fissures, demonstration of an earthquake origin requires, at a minimum, demonstration that (1) the fissure fillings moved upward into the fissures, and (2) the fillings were emplaced suddenly and violently. Schafer and others (1987 \#1890) and Kemppinen and others (1992 \#1845; 1993 \#1846) observed that some fissure fillings contain ventifacts, determined that physical and textural properties of the fillings resemble those of the overlying eolian sediments more than those of the underlying lacustrine materials, and therefore discounted an earthquake origin of the fissures. In contrast, R. Thorson (oral commun., 1998) observed varved clay clasts atop some fissures, although the clasts need not have risen suddenly or violently from the lacustrine beds. Schafer and others (1987 \#1890) reported that delicate, steeply dipping to vertical bedding in the fissure fillings is preserved intact to a degree that is inconsistent with sudden, violent emplacement of the fillings. I found no reports of evidence for sudden, violent emplacement. Kemppinen and others (1993 \#1846) summarized other, less direct arguments against an earthquake origin. Accordingly, an earthquake origin of the fissure fillings in the Hain Quarry is ruled out, and the fissure fillings are assigned to class D because they are not evidence of tectonic faulting. Disagreement continues about whether the fillings are ice-wedge casts (Black, 1983 \#1796; Stone and Ashley, 1992 \#2229, and R. Thorson, oral commun., 1998). Perhaps the fissures are more complex than, or fundamentally different from features that have been recognized before. However, that question is not germane to this compilation of geologic evidence for Quaternary faulting.

Date of compilation 07/02/98; revised 02/01/00

Compiler and affiliation Russell L. Wheeler, U.S. Geological Survey

State Connecticut

County Windham

$1^{\circ} \times 2^{\circ}$ sheet Hartford

Physiographic province New England 


\section{References}

\#1796 Black, R.F., 1983, Pseudo-ice-wedge casts of Connecticut, northeastern United States: Quaternary Research, v. 20, p. 74-89.

\#1845 Kemppinen, H.M.A., Gelinas, R.L., and Amick, D.C., 1992, A comparison of seismically-induced liquefaction features in the southeastern U.S. versus postulated earthquake deformation features in central Connecticut: Geological Society of America Abstracts with Programs, v. 24, no. 2, p. 24.

\#1846 Kemppinen, H.M.A., Gelinas, R.L., and Amick, D.C., 1993, Evaluation of wedge-type pseudoliquefaction features in central Connecticut [abs.]: Seismological Research Letters, v. 64, p. 261.

\#2256 Obermeier, S.F., 1996, Use of liquefaction-induced features for paleoseismic analysisAn overview of how seismic liquefaction features can be distinguished from other features and how their regional distribution and properties of source sediment can be used to infer the location and strength of Holocene paleo-earthquakes: Engineering Geology, v. 44, p. 1-76.

\#1890 Schafer, J.P., Obermeier, S.F., and Stone, J.R., 1987, On the origin of wedge structures in southern New England: Geological Society of America Abstracts with Programs, v. 19 , no. 1, p. 55.

\#2229 Stone, J.R., and Ashley, G.M., 1992, Ice-wedge casts, pingo scars, and the drainage of glacial Lake Hitchcock, in Robinson, P., and Brady, J.B., eds., Guidebook for field trips in the Connecticut Valley region of Massachusetts and adjacent states, v. 2: Amherst, University of Massachusetts Department of Geology and Geography Contribution 66, New England Intercollegiate Geological Conference, 84th Annual Meeting, Amherst, Massachusetts, October 9-11, 1992, p. 305-331.

\#1906 Thorson, R.M., 1988, Pervasive ground deformation in the Hain Quarry, Connecticut-A status report: Geological Society of America Abstracts with Programs, v. 20, no. 1, p. 75 and 77.

\#1907 Thorson, R.M., Clayton, W.S., and Seeber, L., 1986, Geologic evidence for a large prehistoric earthquake in eastern Connecticut: Geology, v. 14, p. 463-467. 


\section{Harlan County fault (Class D)}

\section{Structure Name Harlan County fault (Class D)}

Comments: This feature is known from only one exposure in a wave-cut bluff along the western side of Bone Cove, which is a narrow bay on the southern shore of Harlan County Reservoir. The man-made reservoir was created in 1952 when the Army Corps of Engineers completed the Harlan County Dam across the Republican River. The exposure that revealed the suspected fault was created after the reservoir was filled and wave erosion undercut loesscovered hillslopes.

Reason for assignment to Class D: Lack of compelling evidence that the feature exposed in the bluff is a deeply seated tectonic fault. Detailed studies provide convincing evidence that the vertical offset in the loess exposed in the bluff is related to an ancient landslide (Crone and others, 1996 \#1163; Machette and others, 1998 \#2856). Therefore, the Harlan County fault is not a tectonic fault and thus is categorized as a Class D feature.

The Harlan County fault has no surface expression and is only exposed in a 7-m-high, wavecut bluff on the western shore of Bone Cove, on the southern shore of Harlan County Lake. This exposure was discovered by William C. Johnson (University of Kansas) in the late 1980's during his studies of the Quaternary stratigraphy of loesses in southern Nebraska and northern Kansas. Initial field studies suggested that the faulting could be less than 1000 years old, and that the faulting might be related to seismic activity on the eastern side of the ChadronCambridge arch (Johnson and others, 1995 \#2797). Subsequent studies have shown that the feature is not related to tectonic faulting.

Detailed mapping of the bluff at Bone Cove indicated at least $6 \mathrm{~m}$ of stratigraphic offset on the top of the late Pleistocene Gilman Canyon Formation, whose top is marked by three pronounced, dark paleosols (A and B horizons) in the immediate footwall of the fault. Elsewhere near Bone Cove in both walls of the fault, the three paleosols merge into one. The Gilman Canyon Formation is overlain by latest Pleistocene Peoria Loess, which extends to the top of the bluff exposure. The slip planes in the bluff have a down-to-the-south, normal sense of slip, form a sharp boundary between sediment in the hanging wall and footwall, and are typically less than $1 \mathrm{~cm}$ wide. The slip planes can be clearly traced upward into the Peoria Loess to within $30 \mathrm{~cm}$ of the modern ground surface, but the planes are not associated with any scarp at the surface.

Radiocarbon dating has documented the age of the deposits exposed in the bluff at the Bone Cove site. The paleosols at the top of the Gilman Canyon Formation have yielded radiocarbon ages of $26,260 \pm 680{ }^{14} \mathrm{C}$ yr B.P. and $25,555 \pm 500{ }^{14} \mathrm{C}$ yr B.P. for soil (Martin, 1993 \#2798), and charcoal fragments in a burn layer in the Peoria Loess yielded a radiocarbon age of $22.4 \mathrm{ka}$.

South-central Nebraska has not been seismically active during historical time, thus it seems plausible that the slip planes in the bluff could have a non-tectonic origin (Machette and others, 1998 \#2856). The most obvious non-tectonic explanation is that the slip planes are related to an ancient slope failure (landslide) associated with the paleotopography related to downcutting of the Republican River, the main channel of which lies to the north of the exposure. Initially, a landslide explanation seemed unlikely because the slip planes have a down- 
to-the-south throw whereas lowland topography of the modern Republican River Valley is north of the Bone Cove site. However, detailed study around the site provided evidence that an ancient tributary paleovalley probably existed south of the Bone Cove bluff, and that the slip planes in the bluff mark the headwall of an ancient slope failure that slid southward into the paleovalley.

Two key pieces of evidence support this interpretation (Machette and others, 1998 \#2856). First, extensive excavations at the base of the bluff show that the attitudes of the slip planes decrease rapidly with depth. In the upper part of the bluff, the slip planes have a dip of $65^{\circ}$ $70^{\circ}$, whereas, at a depth of about $8 \mathrm{~m}$, their dip decreases to about $35^{\circ}$. This rapidly decreasing dip at shallow depths is strong evidence supporting a landslide origin.

The second line of evidence for a non-tectonic origin is the fact that the net offset of the soil A horizon, at the top of the Gilman Canyon Formation, is only $0.5 \mathrm{~m}$. Within the bluff exposure, the A horizon are vertically offset about $6 \mathrm{~m}$, but about $300 \mathrm{~m}$ south of the bluff, the A horizon is exposed along the shoreline and the elevation of the A horizon there is only about $0.5 \mathrm{~m}$ lower than the elevation of the A horizon $100 \mathrm{~m}$ north of the bluff in the "footwall" of the suspected fault. Thus, the apparent $6 \mathrm{~m}$ of throw is a local characteristic, and the actual change in elevation of the A horizon is measured in tens of centimeters. This small variability in the elevation of the paleosol is likely related to natural topography and is not indicative of a tectonic offset.

The lack of significant vertical offset on the top of the Gilman Canyon Formation is consistent with the interpretation of high-resolution seismic-reflection data in the area adjacent to the bluff. These data were collected and interpreted by Richard Miller (Kansas Geological Survey) and Donald Steeples (University of Kansas). Their interpretation of the reflection data indicates that the Miocene Ogallala Formation is not vertically offset beneath the projection of the suspected fault.

Collectively, these observations indicate that the "Harlan County fault" is likely a non-tectonic feature. The slip planes exposed in the bluff are probably related to an ancient landslide that slid southward into a tributary valley of Bone Cove, and subsequent eolian deposition probably buried the headscarp (Machette and others, 1998 \#2856).

Date of compilation $11 / 05 / 97$

Compiler and affiliation Anthony J. Crone, U.S. Geological Survey

State Nebraska

County Harlan County

$1^{\circ} \times 2^{\circ}$ sheet Grand Island, Nebraska

Physiographic province Great Plains

\section{References}

\#1163 Crone, A.J., Machette, M.N., Haller, K.M., Stephenson, W.J., Williams, R.A., and Odum, J.K., 1996, Late Quaternary paleoearthquakes in central Nebraska?-New evidence favoring general tectonic stability: Geological Society of America Abstracts with Programs, v. 28, no. 7, p. A-55. 
\#2797 Johnson, W.C., Miller, R.D., and Steeples, D.W., 1995, Geomorphology, stratigraphy, and chronology of a late quaternary (Holocene) fault, Harlan County, Nebraska: Geological Society of America Abstracts with Programs, v. 27, no. 6, p. A-376.

\#2856 Machette, M.N., Crone, A.J., Haller, K.M., Bradley, L.A., Stephenson, W.J., Williams, R.A., and Souders, V.L., 1998, Field investigations of suspected late Quaternary faults in central Nebraska -Evidence of non-tectonic origins: U.S. Geological Survey Miscellaneous Investigations Map I-2649, 1 pl.

\#2798 Martin, C.W., 1993, Radiocarbon ages of late Pleistocene loess stratigraphy of Nebraska and Kansas, central Great Plains, U.S.A.: Quaternary Science Reviews, v. 12, p. 179188. 


\section{Fractures on Mount Toby (Class D)}

Structure Name Fractures on Mount Toby (Class D)

Comments: All place or geographic names used here appear on the Mount Toby and Greenfield 1:24,000-scale topographic maps. Loomis (1921 \#1854) described inferred postglacial faults on Mount Toby, Massachusetts. Mount Toby is a hill approximately $4 \mathrm{~km}$ wide east-west and $5 \mathrm{~km}$ long north-south, an erosional remnant of Triassic and Jurassic strata in the Mesozoic Deerfield basin (Zen and others, 1983 \#1960). The hill is bounded on the east by the eastern border fault of the basin, and the south and west sides of the hill slope toward the interior of the basin. Dips on Mount Toby are generally gently eastward with local westerly dips. In stratigraphic succession downward from the summit, Mount Toby is underlain by (1) pale red conglomerate and arkosic sandstone of the Lower Jurassic Mount Toby Formation, (2) brown and red arkosic sandstone and conglomerate and gray and black lacustrine beds of the Lower Jurassic Turner Falls Sandstone, (3) the well-jointed Lower Jurassic Deerfield Basalt, and (4) brown and red arkose and conglomerate and gray and black lacustrine sandstones, siltstones, and shales of the Lower Jurassic and Upper Triassic Sugarloaf Formation (Zen and others, 1983 \#1960; Robinson and Luttrell, 1985 \#2223).

Zen and others (1983 \#1960) showed the border fault of the Deerfield basin as striking northnorthwest along the eastern side of Mount Toby (the Mount Toby fault of Willard, 1952 \#1950), and also showed five short faults striking north to northeast along the southwestern flank of Mount Toby. The short faults are 0.4-0.8 km long, cut the Deerfield Basalt, and extend short distances into the sedimentary units above and below. Zen and others (1983 \#1960) labeled the five short faults as of Mesozoic age.

Willard (1951 \#1949; 1952 \#1950) mapped five Mesozoic faults on and near Mount Toby, in addition to the Mount Toby fault itself. Two west-facing normal faults at the northwestern base of Mount Toby were inferred from two patches of an "autochthonous breccia" (Willard, 1952 \#1950) near North Sunderland and on Taylor Hill. Willard (1952 \#1950) interpreted the breccia as overlying near-surface crystalline basement immediately east of thick Mesozoic strata and deeply buried basement. However, Robinson and Luttrell (1985) showed the breccias to be Jurassic landslide deposits, thereby removing the main evidence for the faults. In addition, Willard (1951 \#1949) suggested two northwest-facing normal faults near the summit of Mount Toby, but Zen and others (1983 \#1960) do not show them. Finally, Willard (1951 \#1949) suggested a fifth fault that coincides approximately with the southernmost of the five short Mesozoic faults shown by Zen and others (1983 \#1960). Thus, more recent mapping has discounted at least four of Willard's (1951 \#1949; 1952 \#1950) faults west of the Mount Toby fault itself.

Loomis (1921 \#1854) published two photographs of inferred fault escarpments, and both appear to show jointed Deerfield Basalt. Loomis (1921 \#1854) refers to more than 20 similar escarpments on the slopes of Mount Toby, with offsets of $1.5-18 \mathrm{~m}$ that he attributed to faulting. However, Loomis (1921 \#1854) located only three faults, by showing two on his topographic map and by implying the existence and location of a third. (1) Fault y-z strikes northeast parallel to the northwestern foot of Mount Toby and along the east side of the Connecticut River, at North Sunderland and Whitmore Pond. Figure 3 of Loomis (1921 \#1854) shows a photograph of the escarpment. (2) Fault x-y strikes northwest down the lower 
northwestern slope of Mount Toby, and crosses Falls Road south of Chard Pond. Figure 2 of Loomis (1921 \#1854) shows a photograph of the escarpment. (3) An unnamed fault is implied at Mohawk Brook near the southwestern foot of Mount Toby (point $f$ of Loomis, 1921 \#1854, figure 1). Loomis (1921 \#1854) reported the elevation of the shoreline of glacial Lake Hitchcock as $104 \mathrm{~m}$ southeast of Mohawk Brook and north of fault x-y, but as only 79 $\mathrm{m}$ in the intervening $5 \mathrm{~km}$. The change in shoreline elevation is the strongest part of the evidence for fault $\mathrm{x}-\mathrm{y}$. Loomis did not state the inferred presence of a fault at Mohawk Brook, but his line of argument points toward it. Loomis (1921 \#1854) suggested that all these faults have postglacial slip, and the suggestion is the reason for considering the Mount Toby area here.

Reason for assignment to class D: Loomis (1921 \#1854) offered three observations in arguing for a postglacial origin of the inferred faults that are described above under "Structure name". First, small deltas that formed along the shoreline of postglacial Lake Hitchcock ring the southern and western feet of Mount Toby. These deltas and the shoreline itself are $24 \mathrm{~m}$ lower along the southwestern side of the hill than farther southeast or north. The Comment above under "Structure name" provides more details. Second, the lips of the escarpments are sharp, unweathered, and scarcely notched by small streams that flow across them. Third, several of the escarpments each consist of two or more blocks that are bounded by vertical fractures that parallel the escarpment, and the blocks step down outward, away from the hill, to produce the total displacement of the inferred fault. The tops of the blocks are glacially smoothed, and the smoothed surfaces are offset by vertical slip on the fractures.

The first observation was refuted by surficial geologic mapping of Jahns (1951 \#2204), which showed that the Lake Hitchcock shoreline is not lower between Mohawk Brook and Chard Pond (point $f$ and fault $x-y$ of Loomis, 1921 \#1854, respectively). The shoreline maintains its regional elevation of 91-94 m along the south, southwest, west, and northwest sides of Mount Toby. At and south of Loomis's point f, outwash plain deposits of Lake Hitchcock form a large delta with shoreward lake-bottom deposits at its toe. The delta and bottom deposits extend northward without offset $0.7 \mathrm{~km}$ beyond Loomis's point $\mathrm{f}$, at which point he reported the shoreline dropped northward $24 \mathrm{~m}$. Farther north within the block reported as downdropped, a patch of Lake Hitchcock beach deposits is at the regional elevation of 91-94 m.

The second and third observations require a postglacial origin of the escarpments, the fractures that comprise them, and the offsets of glacially smoothed surfaces across the fractures. However, Loomis (1921 \#1854) also described some of the blocks between the fractures as tilting toward the hill, so that talus caves formed between the blocks at their bases and water collects on the inward-sloping tops of the blocks. Such inward tilting requires the bases of the tilted blocks to have moved outward, away from the hill. In contrast, other blocks are tilted away from the hill, so that the fractures gape at their tops. Such outward tilting requires any blocks farther out than the tilted blocks also to have moved outward, away from the hill. These observations are consistent with an hypothesis of (1) rapid postglacial weathering and erosion of the shaley lacustrine strata beneath the much more resistant Deerfield Basalt, (2) the jointed, resistant Deerfield Basalt breaking up along its outcrop as it loses support by removal of the underlying lacustrine strata, and (3) the joint blocks of basalt sinking down into the void left by the eroded lacustrine beds and sliding outward and downhill. 
The two photographs of Loomis (1921 \#1854) provide additional evidence that at least some of the inferred fault escarpments are probably the faces of joints that formed in extension, not faults that formed in shear. (1) Figure 2 shows an eastward view of the northwest-striking escarpment $x-y$. The photograph shows several structures that, together, are diagnostic of extension fractures, and which rule out an origin in shear (for example, Kulander and others, 1990 \#2207). First, large, irregular surfaces form most of the face of the escarpment, and dip steeply toward the valley, as is characteristic of valley-release joints. Second, these northwest-striking escarpment-parallel surfaces appear to terminate against more planar, vertical fractures that strike into the escarpment, in abutting relations that indicate that the escarpment-parallel surfaces formed second. Third, several of the escarpment-parallel surfaces step sharply inward or outward across nearly horizontal partings. In joints, such steps would indicate that the escarpment-parallel fractures nucleated and propagated after the horizontal partings opened, probably at shallow depths. Finally, some escarpment-parallel faces show sharp discontinuities that might be twist hackle steps. (2) Figure 3 shows a southeastward view of the northeast-striking escarpment y-z. The dark, blurred photograph appears to show horizontally layered rock whose exposed surface steps back farther in successively higher layers, as it would if a progression of sheeting or parting, valley-release jointing, and mass wastage had worked sideward and downward into a hillside. Neither photograph shows the comparatively smooth, locally striated or corrugated surface that one might expect of a young, postglacial fault.

Thus, postglacial faulting is less likely than a combination of jointing and the differential erosion that would be expected in the humid climate of postglacial Massachusetts. Loomis's (1921 \#1854) strongest argument for postglacial faulting, a down-dropped shoreline of Lake Hitchcock, was refuted by subsequent surficial mapping (Jahns, 1951 \#2204). Two generations of bedrock mapping found no faults younger than Mesozoic (Willard, 1951 \#1949; Willard, 1952 \#1950; Zen and others, 1983 \#1960). Postglacial faulting might still be hidden on Mount Toby, but such an hypothesis would require more and better evidence than is yet reported. Accordingly, the small "faults" on Mount Toby are assigned to category D.

Date of compilation 08/14/98; revised 01/28/00

Compiler and affiliation Russell L. Wheeler, U.S. Geological Survey

State Massachusetts

County Franklin

$1^{\circ} \times 2^{\circ}$ sheet Albany

Physiographic province New England

\section{References}

\#2204 Jahns, R.H., 1951, Surficial geology of the Mount Toby quadrangle, Massachusetts: U.S. Geological Survey Geologic Quadrangle map GQ-9, 1 sheet, scale 1:31,680.

\#2207 Kulander, B.R., Dean, S.L., and Ward, B.J., Jr., 1990, Fractured core analysisInterpretation, logging, and use of natural and induced fractures in core: American Association of Petroleum Geologists Methods in Exploration Series No. 8, 88 p. 
\#1854 Loomis, F.B., 1921, Postglacial faulting about Mount Toby, Massachusetts: Geological Society of America Bulletin, v. 32, p. 75-80.

\#2223 Robinson, P., and Luttrell, G.W., 1985, Revision of some stratigraphic names in central Massachusetts: U.S. Geological Survey Bulletin 1605-A, 78 p.

\#1949 Willard, M.E., 1951, Bedrock geology of the Mount Toby quadrangle, Massachusetts: U.S. Geological Survey Geologic Quadrangle Map GQ-8, 1 sheet, scale 1:31,680.

\#1950 Willard, M.E., 1952, Bedrock geology of the Greenfield quadrangle, Massachusetts: U.S. Geological Survey Geologic Quadrangle Map GQ-20, 1 sheet, scale 1:31,680.

\#1960 Zen, E.-a., ed., Goldsmith, R., Ratcliffe, N.M., Robinson, P., Stanley, R.S., compilers, Hatch, N.L., Jr., Shride, A.F., Weed, E.G.A., and Wones, D.R., 1983, Bedrock geologic map of Massachusetts: U.S. Geologic Survey in cooperation with The Commonwealth of Massachusetts Department of Public Works, 3 sheets, scale 1:250,000. 


\section{Ord escarpment (Class D)}

\section{Structure Name Ord Escarpment (Class D)}

Comments: The name Ord escarpment is an informal name given to a prominent N. $42^{\circ} \mathrm{W}$.trending, linear escarpment in east-central Nebraska (Machette and others, 1998 \#2856). This escarpment and several similarly oriented linear valley margins throughout the Loup River drainage basin were suggested as possible Quaternary fault scarps by Dort and others (1993 \#2799; 1995 \#2800). In this area, many of the various forks and tributaries of the Loup River are confined to unusually narrow, linear valleys, and the drainage network has a very strong northwest-trending grain. The Ord escarpment is one of the most prominent escarpments in the region, is continuous for as much as $32 \mathrm{~km}$, and has as much as $60 \mathrm{~m}$ of surface relief.

In the Loup River drainage system, Dort and others (1993 \#2799) described broad, flat-floored valleys that have anomalously blunt heads and noted that surface scarps coincide with gradients in geophysical data, which suggested significant offsets in subjacent bedrock. Dort and others (1993 \#2799) also reported that Tertiary bedrock has been locally uplifted enough to be exposed at the surface, but generally, the landscape is formed on the latest Pleistocene Peoria Loess, the deposition of which ceased about $12 \mathrm{ka}$. Thus, they speculated that more than $60 \mathrm{~m}$ of uplift has occurred since deposition of the loess.

Reason for assignment to Class D: Geomorphic evidence and historical seismicity are inconsistent with the high slip rates inferred from the stratigraphic relations reported by Dort and others (1993 \#2799; 1995 \#2800). Furthermore, high-resolution seismic-reflection studies show no stratigraphic offset in the shallow subsurface that corresponds to the inferred fault at the surface (Machette and others, 1998 \#2856). Therefore, the escarpment is not associated with a tectonic fault and is assigned to Class D in this compilation.

The Ord escarpment is as much as $47 \mathrm{~m}$ high where it was profiled (Machette and others, 1998 \#2856), and it separates a highly dissected, loess-capped plateau to the southwest from a relatively low-relief, sand-filled Cedar Creek Valley to the northeast. The eolian sand in the valley is an eastward extension of the Nebraska Sand Hills. At a regional scale (1:250,000scale topographic maps), the escarpment appears to be abrupt, linear, and composed of en echelon sections; however, at a local scale, the escarpment front is dissected, embayed, and less well-defined. If the relief across the escarpment is truly the product of post-Peoria Loess faulting, then the inferred fault beneath the escarpment has a latest Pleistocene vertical slip rate on the order of 4-6 mm/yr. Active faults that have comparable latest Pleistocene slip rates are typically marked by abrupt, linear escarpments, even at local scales. Thus, indirect geomorphic evidence argues against the escarpment being associated with a highly active latest Pleistocene fault. Furthermore, these inferred stratigraphic relations suggest extremely high slip rates (ca. $5 \mathrm{~mm} / \mathrm{yr}$ ) on largely unknown and seismically quiescent tectonic features.

As part of a continuing effort to identify and document Quaternary faults in the central U.S., Crone and others (1996 \#1163) and Machette and others (1998 \#2856) collected $1.95 \mathrm{~km}$ of high-resolution seismic-reflection data at three sites along the escarpment to determine if subsurface strata are offset comparable amounts to the inferred offset at the surface. The reflection data were collected at sites where the escarpment is prominent and near its maximum height. All of the profiles show a similar strong, multi-cycle reflection that correlates with the 
top of the Miocene Ogallala Formation, which is present at depths generally between 50 and $85 \mathrm{~m}$. Crone and others (1996 \#1163) and Machette and others (1998 \#2856) used subsurface data to correlate reflections on the profiles with the Ogallala Formation. A prominent reflection on all of the profiles is clearly continuous and is not vertically offset by faults having tens of meters of throw. The lack of faults in the subsurface beneath the escarpment is convincing evidence that the escarpment is not a tectonic feature. Crone and others (1996 \#1163) and Machette and others (1998 \#2856) conclude that the escarpment is a fluvial feature.

Date of compilation 11/13/97; revised 12/22/98

Compiler and affiliation Anthony J. Crone, U.S. Geological Survey

State Nebraska

County Garfield, Valley, Greeley

$1^{\circ} \times 2^{\circ}$ sheet Broken Bow, Nebraska

Physiographic province Great Plains

\section{References}

\#1163 Crone, A.J., Machette, M.N., Haller, K.M., Stephenson, W.J., Williams, R.A., and Odum, J.K., 1996, Late Quaternary paleoearthquakes in central Nebraska?-New evidence favoring general tectonic stability: Geological Society of America Abstracts with Programs, v. 28, no. 7, p. A-55.

\#2799 Dort, W., Jr., Zeller, E.J., and Martin, L.D., 1993, Extensive late Quaternary faulting in the Mid-continent Great Plains: Geological Society of America Abstracts with Programs, v. 25, no. 6, p. A-70.

\#2800 Dort, W., Jr., Zeller, E.J., and Martin, L.D., 1995, Development of early to mid-Holocene fault-block topography in central and south-central Nebraska: Geological Society of America Abstracts with Programs, v. 27, no. 3, p. 47.

\#2856 Machette, M.N., Crone, A.J., Haller, K.M., Bradley, L.A., Stephenson, W.J., Williams, R.A., and Souders, V.L., 1998, Field investigations of suspected late Quaternary faults in central Nebraska-Evidence of non-tectonic origins: U.S. Geological Survey Miscellaneous Investigations Map I-2649, 1 pl. 


\section{Cumulative Reference List}

\#1961 Ackermann, H.D., 1983, Seismic-refraction study in the area of the Charleston, South Carolina, 1886 earthquake, in Gohn, G.S., ed., Studies related to the Charleston, South Carolina, earthquake of 1886-Tectonics and seismicity: U.S. Geological Survey Professional Paper 1313-F, p. 1-20.

\#1783 Aggarwall, Y.P., and Sykes, L.R., 1978, Earthquakes, faults, and nuclear power plants in southern New York and northern New Jersey: Science, v. 200, p. 425-429.

\#1785 Alexander, S.S., and Thornton, C.P., 1991, Travertine as an indicator of geologicallyrecent earthquake activity in the eastern United States [abs.]: Eos, Transactions of the American Geophysical Union, v. 72, no. 17, p. 203.

\#2022 Alexander, S.S., Gold, D.P., Gardner, T.W., Slingerland, R.L., and Thornton, C.P., 1989, Near-surface neotectonic deformation associated with seismicity in the northeastern United States: U.S. Nuclear Regulatory Commission Report NUREG/CR-5418, 343 p.

\#1991 Ambers, C.P., and Wintsch, R.P., 1990, Subsurface identification of Merrimack, PutnamNashoba, and metavolcanic Avalon terrace rocks, and ductile to brittle fault rocks in the 1.45-kilometer-deep research hole, Moodus, Connecticut, in Socci, A.D., Skehan, J.W., and Smith, G.W., eds., Geology of the composite Avalon terrane of southern New England: Geological Society of America Special Paper 245, p. 171-186.

\#1787 Amick, D., and Gelinas, R., 1991, The search for evidence of large prehistoric earthquakes along the Atlantic seaboard: Science, v. 251, p. 655-658.

\#1788 Amick, D., Maurath, G., and Gelinas, R., 1990, Characteristics of seismically induced liquefaction sites and features located in the vicinity of the 1886 Charleston, South Carolina earthquake: Seismological Research Letters, v. 61, p. 117-130.

\#1789 Ammon, C.J., Herrmann, R.B., Langston, C.A., and Benz, H., 1998, Faulting parameters of the January 16, 1994 Wyomissing Hills, Pennsylvania earthquakes: Seismological Research Letters, v. 69, p. 261-269.

\#3880 Amos, D.H., 1967, Geologic map of part of the Smithland quadrangle, Livingston County, Kentucky: U.S. Geological Survey Geologic Quadrangle Map GQ-657, 1 sheet, scale 1:24,000.

\#3881 Amos, D.H., 1974, Geologic map of the Burna quadrangle, Livingston County, Kentucky: U.S. Geological Survey Geologic Quadrangle Map GQ-1150, 1 sheet, scale $1: 24,000$.

\#3882 Amos, D.H., and Wolfe, E.W., 1966, Geologic map of the Little Cypress quadrangle, Kentucky-Illinois: U.S. Geological Survey Geologic Quadrangle Map GQ-554, 1 sheet, scale $1: 24,000$.

\#1790 Armbruster, J.G., and Seeber, L., 1984, Low seismicity in South Carolina prior to the 1886 earthquake [abs.]: Eos, Transactions of the American Geophysical Union, v. 65, p. 241.

\#1791 Armbruster, J.G., and Seeber, L., 1987, The 23 April 1984 Martic earthquake and the Lancaster seismic zone in eastern Pennsylvania: Bulletin of the Seismological Society of America, v. 77, p. 877-890.

\#1792 Armbruster, J.G., Seeber, L., Barstow, N., Kim, W.Y., Horton, S., and Scharnberger, C.K., 1994, The Jan. 1994 Wyomissing Hills earthquakes (Mblg=4.0 \& 4.6) in south- 
eastern Pennsylvania-A $2 \mathrm{~km}$-long northwest-striking fault illuminated by aftershocks [abs.]: Eos, Transactions of the American Geophysical Union, v. 75, no. 16 (supplement), p. 237.

\#3703 Barnes, V.E., supervisor, 1992, Geologic map of Texas: Bureau of Economic Geology, The University of Texas at Austin, 4 sheets, scale 1:500,000.

\#2023 Barosh, P.J., London, D., and de-Boer, J., 1982, Structural geology of the Moodus seismic area, south-central Connecticut, in Joesten, R., and Quarrier, S.S., eds., Guidebook for fieldtrips in Connecticut and south central Massachusetts: State Geological and Natural History Survey of Connecticut Guidebook 5, New England Intercollegiate Geological Conference, 74th annual meeting, Storrs, Connecticut, October 2-3, 1982, p. 419-451.

\#2103 Bascom, F., Darton, N.H., Kümmel, H.B., Clark, W.B., Miller, B.L., and Salisbury, R.D., 1909, Trenton folio, New Jersey-Pennsylvania: U.S.Geological Survey Geologic Atlas of the United States Folio 167, 24 p., 3 pls., scale 1:125,000.

\#2007 Baskerville, C.A., 1982, The foundation geology of New York City, in Legget, R.F., ed., Geology under cities: Geological Society of America Reviews in Engineering Geology, v. 5, p. 95-117.

\#1924 Baskerville, C.A., 1992, Bedrock and engineering geologic maps of Bronx County and parts of New York and Queens Counties, New York: U.S. Geological Survey Miscellaneous Investigations Map I-2003, 2 sheets, scale 1:24,000.

\#1793 Baumgärtner, J., and Zoback, M.D., 1989, Interpretation of hydraulic fracturing pressuretime records using interactive analysis methods: International Journal of Rock Mechanics and Mining Sciences and Geomechanical Abstracts, v. 26, p. 461-469.

\#3883 Baxter, J.W., Desborough, G.A., and Shaw, C.W., 1967, Areal geology of the Illinois Fluorspar District-Part 3-Herod and Shetlerville quadrangles: Illinois State Geological Survey Circular 413, 41 p., 1 plate, scale 1:24,000.

\#2833 Bear, G.W., Rupp, J.A., and Rudman, A.J., 1997, Seismic interpretation of the deep structure of the Wabash Valley fault system: Seismological Research Letters, v. 68, no. 4, p. 624-640.

\#1795 Behrendt, J.C., and Yuan, A., 1987, The Helena Banks strike-slip(?) fault zone in the Charleston, South Carolina, earthquake area-Results from a marine, high-resolution, multichannel, seismic-reflection survey: Geological Society of America Bulletin, v. 98, p. 591-601.

\#1963 Behrendt, J.C., Hamilton, R.M., Ackerman, H.D., Henry, V.J., and Bayer, K.C., 1983, Marine multichannel seismic-reflection evidence for Cenozoic faulting and deep crustal structure near Charleston, South Carolina, in Gohn, G.S., ed., Studies related to the Charleston, South Carolina, earthquake of 1886-Tectonics and seismicity: U.S. Geological Survey Professional Paper 1313, p. J1-J29.

\#1794 Behrendt, J.C., Hamilton, R.M., Ackermann, H.D., and Henry, V.J., 1981, Cenozoic faulting in the vicinity of the Charleston, South Carolina, 1886 earthquake: Geology, v. 9, p. 117-122.

\#2195 Bent, A.L., 1996, Source parameters of the damaging Cornwall-Massena earthquake of 1944 from regional waveforms: Bulletin of the Seismological Society of America, v. 86, p. $489-497$. 
\#3962 Berendsen, P., 1997, Tectonic evolution of the midcontinent rift system in Kansas, in Ojakangas, R.W., Dickas, A.B., and Green, J.E., eds., Middle Proterozoic to Cambrian rifting, Central North America: Geological Society of America Special Paper 312, p. 235-241.

\#1937 Berg, T.M., Edmunds, W.E., Geyer, A.R., Glover, A.D., Hoskins, D.M., MacLachlan, D.B., Root, S.I., Sevon, W.D., and Socolow, A.A., 1981, Geologic map of Pennsylvania: Pennsylvania Topographic and Geologic Survey Map 1, 3 sheets, scale 1:250,000.

\#3879 Berquist, C.R., Jr., and Bailey, C.M., 1999, Late Cenozoic reverse faulting in the fall zone, Southeastern Virginia: Journal of Geology, v. 107, p. 727-732.

\#3648 Berryhill, H.L., and Trippet, A.R., 1980, Map showing post-Wisconsin sedimentation patterns and faulting in the Port Isabel $1^{\circ}$ x $2^{\circ}$ Quadrangle, Texas: U.S. Geological Survey Miscellaneous Investigations Map I-1254-D, 1 sheet, scale 1:250,000.

\#3884 Bertagne, A.J., and Leising, T.C., 1991, Interpretation of seismic data from the Rough Creek Graben of Western Kentucky and Southern Illinois, in Leighton, M.W., Kolata, D.R., Oltz, D.F., and Eidel, J.J., eds., Interior cratonic basins: Tulsa, Oklahoma, The American Association of Petroleum Geologists, Memoir 51, p. 199-208.

\#1925 Bicker, A.R., Jr., compiler, 1969, Geologic map of Mississippi: Mississippi Geological Survey, 1 sheet, scale 1:500,000.

\#3649 Biewick, L.R.H., Hardie, J.K., Williamson, C., and Arndt, H.H., 1990, Evaluation of coal resources in the Eastern part of the Fort Peck Indian Reservation, Montana: U.S. Geological Survey Bulletin 1869, 136 p.

\#1926 Black, D.F.B., 1967, Geologic map of the Coletown quadrangle, east-central Kentucky: U.S. Geological Survey Geologic Quadrangle Map GQ-644, 1 sheet, scale 1:24,000.

\#1796 Black, R.F., 1983, Pseudo-ice-wedge casts of Connecticut, northeastern United States: Quaternary Research, v. 20, p. 74-89.

\#3927 Blackwelder, B.W., 1981, Late Cenozoic marine deposition in the United States Atlantic Coastal Plain related to tectonism and global climate: Paleogeography, Paleoclimatology, Paleoecology, v. 34, p. 87-114.

\#1797 Bollinger, G.A., 1973, Seismicity and crustal uplift in the southeastern United States: American Journal of Science, v. 273-A, p. 396-408.

\#1798 Bollinger, G.A., 1973, Seismicity of the southeastern United States: Bulletin of the Seismological Society of America, v. 63, p. 1785-1808.

\#1966 Bollinger, G.A., 1977, Reinterpretation of the intensity data for the 1886 Charleston, South Carolina, earthquake, in Rankin, D.W., ed., Studies related to the Charleston, South Carolina, earthquake of 1886-A Preliminary Report: U.S. Geological Survey Professional Paper 1028-B, p. 17-32.

\#2196 Bollinger, G.A., 1987, Seimotectonics of the Virginia and eastern Tennesse seismic zones, in Jacob, K.H., ed., Symposium on seismic hazards, ground motions, soil-liquefaction and engineering practice in eastern North America: Proceedings-National Center for Earthquake Engineering Reserach Technical Report NCEER-87-0025, p. 202-216.

\#1799 Bollinger, G.A., and Hopper, M.G., 1971, Virginia's two largest earthquakes-December 22, 1875 and May 31, 1897: Bulletin of the Seismological Society of America, v. 61, p. 1033-1039.

\#1801 Bollinger, G.A., and Sibol, M.S., 1985, Seismicity, seismic reflection studies, gravity and geology of the central Virginia seismic zone-Part I. Seismicity: Geological Society of America Bulletin, v. 96, p. 49-57. 
\#1967 Bollinger, G.A., and Visvanathan, T.R., 1977, The seismicity of South Carolina prior to 1886, in Rankin, D.W., ed., Studies related to the Charleston, South Carolina, earthquake of 1886-A preliminary report: U.S. Geological Survey Professional Paper 1028C, p. 33-41.

\#1802 Bollinger, G.A., and Wheeler, R.L., 1980, The Giles County, Virginia, seismogenic zone: Geological Society of America Abstracts with Programs, v. 12, no. 7, p. 389.

\#1803 Bollinger, G.A., and Wheeler, R.L., 1983, The Giles County, Virginia, seismic zone: Science, v. 219, p. 1063-1065.

\#1968 Bollinger, G.A., and Wheeler, R.L., 1988, The Giles County, Virginia, seismic zoneSeismological results and geologic interpretations: U.S. Geological Survey Professional Paper 1355, $85 \mathrm{p}$.

\#2005 Bollinger, G.A., Johnston, A.C., Talwani, P., Long, L.T., Shedlock, K.M., Sibol, M.S., and Chapman, M.C., 1991, Seismicity of the southeastern United States; 1698 to 1986, in Slemmons, D.B., Engdahl, E.R., Zoback, M.D., and Blackwell, D.D., eds., Neotectonics of North America: Boulder, Colorado, Geological Society of America, Decade Map Volume 1, p. 291-308.

\#1800 Bollinger, G.A., Law, R.D., Pope, M.C., Wirgart, R.H., and Whitmarsh, R.S., 1992, Geologically recent near-surface faulting in the Valley and Ridge province-New exposures of extensional faults in alluvial deposits, Giles County, SW Virginia: Geological Society of America Abstracts with Programs, v. 24, no. 1, p. A152.

\#3916 Boyd, K.F., and Schumm, S.A., 1995, Geomorphic evidence of deformation in the northern part of the New Madrid seismic zone: U.S. Geological Survey Professional Paper 1538-R, $35 \mathrm{p}$.

\#702 Braile, L.W., Keller, G.R., Hinze, W.J., and Lidiak, E.G., 1982, An ancient rift complex and its relation to contemporary seismicity in the New Madrid seismic zone: Tectonics, v. 1, p. 225-237.

\#2197 Bramlett, K.W., Secor, D.T., Jr., and Prowell, D.C., 1982, The Belair fault-A Cenozoic reactivation structure in the eastern Piedmont: Geological Society of America Bulletin, v. 93, p. 1109-1117.

\#703 Bristol, H.M., and Treworgy, J.D., 1979, The Wabash Valley fault system in southeastern Illinois: Illinois State Geological Survey Circular 509, 19 p.

\#3928 Brown, L.D., 1978, Recent vertical crustal movement along the east coast of the United States: Tectonophysics, v. 44, p. 205-231.

\#3929 Brown, L.D., and Oliver, J.E., 1976, Vertical crustal movements from leveling data and their relation to geologic structure in the Eastern United States: Reviews of Geophysics and Space Physics, v. 14, no. 1, p. 13-35.

\#2818 Brown, L.D., and Oliver, J.E., 1976, Vertical crustal movements from leveling data and their relation to geologic structure in the eastern United States: Reviews of Geophysics and Space Physics, v. 14, no. 1, p. 13-35.

\#2804 Bunker, B.J., Ludvigson, G.A., and Witzke, B.J., 1985, The Plum River fault zone and the structural and stratigraphic framework of eastern Iowa: Iowa Geological Survey Technical Information Series 13, $126 \mathrm{p}$.

\#2827 Burchett, R.R., Luza, K.V., Van Eck, O.J., and Wilson, F.W., 1985, Seismicity and tectonic relationships of the Nemaha uplift and Midcontinent Gravity anomaly (Final project summary): Oklahoma Geological Survey Special Publication 85-2, 339 p., 2 pls. 
\#1804 Burke, K., 1977, Are Lakes George and Champlain in Neogene graben reactivating early Paleozoic rifts?: Geological Society of America Abstracts with Programs, v. 9, p. 247248.

\#2815 Burnett, A.W., and Schumm, S.A., 1983, Alluvial-river response to neotectonic deformation in Louisiana and Mississippi: Science, v. 222, p. 49-50.

\#1927 Burton, W.C., and Ratcliffe, N.M., 1985, Attitude, movement history, and structure of cataclastic rocks of the Flemington fault-Results of core drilling near Oldwick, New Jersey: U.S. Geological Survey Miscellaneous Field Studies Map MF-1781, 1 sheet.

\#2819 Cagle, J.W., and Kahn, M.A., 1983, Smackover-Norphlet stratigraphy, south Wiggins arch, Mississippi and Alabama: Transactions of the Gulf Coast Association of Geological Societies, v. 33, p. 23-29.

\#1805 Callis, J.G., and Williams, R.T., 1997, Geophysical images and geologic models for Quaternary faults near Pembroke, Virginia, using seismic reflection and ground penetrating radar [abs.]: Seismological Research Letters, v. 68, p. 815.

\#2024 Carew, P.B., 1990, Investigation of Holocene movement along the Lexington fault system in Jessamine County, Kentucky: Richmond, Eastern Kentucky University, unpublished M.S. thesis, 57 p., 2 pl.

\#658 Cetin, H., 1990, The northwest continuation of the Meers fault and its tectonic activity in southwestern Oklahoma: Geological Society of America Abstracts with Programs, v. 22, p. 3.

\#674 Cetin, H., 1992, The northwest extension of the Meers fault in southwestern Oklahoma, in Sharma, S., ed. Proceedings of the 28th symposium on engineering geology and geotechnical engineering: 28th Symposium on Engineering Geology and Geotechnical Engineering, Boise, Idaho, April 1-3, 1992, Proceedings, p. 43-58.

\#2025 Chadwick, D.L., 1989, Investigation of recent movement within the Rough Creek fault zone in McLean and Daviess Counties, Kentucky: Richmond, Eastern Kentucky University, unpublished M.S. thesis, 95 p., 5 pl., scale 1:150.

\#1806 Chang, T.M., Ammon, C.J., and Herrmann, R.B., 1998, Faulting parameters of the October 24, 1997 southern Alabama earthquake [abs.]: Seismological Research Letters, v. 69 , p. 175-176.

\#730 Chiu, J.M., Johnston, A.C., and Yang, Y.T., 1992, Imaging the active faults of the central New Madrid seismic zone using PANDA array data, in Johnston, A.C., Shedlock, K.M., Herrmann, R.B., and Hopper, M.G., eds., New Madrid special issue: Seismological Research Letters, v. 63, p. 375-393.

\#3650 Clanton, U.S., 1979, Faults offsetting land surfaces in southeastern Houston metropolitan area, Texas: Bulletin of the American Association of Petroleum Geologists, v. 63, no. 3, p. 432.

\#3899 Coates, D.R., 1975, Identification of late Quaternary sediment deformation and its relation to seismicity in the St. Lawrence lowland, New York: Report to New York State Atomic and Space Development Authority, Contract agreement 17333, 268 p.

\#3651 Collier, A.J., and Knechtel, M.M., 1939, The coal resources of McCone County, Montana: U.S. Geological Survey Bulletin 905, 80 p., 1 pl., scale 1:250,000.

\#2801 Collins, D.S., Swolfs, H.S., and Nichols, T.C., Jr., 1988, Highway damage related to faults near Pierre, South Dakota: U.S. Geological Survey Open-File Report 88-674, 34 p., 1 oversized pl. 
\#3653 Colton, R.B., 1963, Geologic map of the Brockton Quadrangle, Roosevelt and Richland Counties, Montana: U.S. Geological Survey Miscellaneous Geologic Investigations I362, 1 sheet, scale 1:62,500.

\#3654 Colton, R.B., 1963, Geologic map of the Poplar Quadrangle, Roosevelt, Richland and McCone Counties, Montana: U.S. Geological Survey Miscellaneous Geologic Investigations I-367, 1 sheet, scale 1:62,500.

\#3655 Colton, R.B., and Bateman, F.A., Jr., 1956, Brockton-Froid fault zone in Northeastern Montana: Geological Society of America Bulletin, v. 67, no. 12, p. 1792.

\#3656 Colton, R.B., and Bateman, F.A., Jr., 1956, Geologic and structure contour map of the Fort Peck Indian Reservation and vicinity, Montana: U.S. Geological Survey Miscellaneous Geologic Investigations I-225, 1 sheet, scale 1:125,000.

\#3878 Conley, J.F., and Toewe, E.C., 1968, Geology of the Martinsville West quadrangle, Virginia: Virginia Division of Mineral Resources Report of Investigations 16, 44 p., 1 plate, scale 1:24,000.

\#1807 Çoruh, C., Bollinger, G.A., and Costain, J.K., 1988, Seismogenic structures in the central Virginia seismic zone: Geology, v. 16, p. 748-751.

\#2805 Cox, R.T., and Van Arsdale, R.B., 1997, Investigation of surface faulting in the southern Mississippi embayment: Technical report to U.S. Geological Survey, under Contract 1434-HQ-97-GR-03014, 30 p.

\#677 Cox, R.T., and VanArsdale, R.B., 1988, Structure and chronology of the Washita Valley fault, southern Oklahoma aulacogen: Shale Shaker, v. 39, p. 2-13.

\#2806 Cox, R.T., Van Arsdale, R.B., and Harris, J.B., 1998, Quaternary faulting in the southern Mississippi embayment: Eos, Transactions of the American Geophysical Union, v. 79, no. 17, p. S341.

\#706 Crone, A.J., 1992, Structural relations and earthquake hazards of the Crittenden County fault zone, northeastern Arkansas, in Johnston, A.C., Shedlock, K.M., Herrmann, R.B., and Hopper, M.G., eds., New Madrid special issue: Seismological Research Letters, v. 63, p. 249-262.

\#661 Crone, A.J., and Luza, K.V., 1990, Style and timing of Holocene surface faulting on the Meers fault, southwestern Oklahoma: Geological Society of America Bulletin, v. 102, p. $1-17$.

\#2678 Crone, A.J., and Machette, M.N., 1994, Reconnaissance investigations of Quaternary faulting in the stable interior of the west-central United States: FY 1994 Final Report to the Nuclear Regulatory Commission, $11 \mathrm{p}$.

\#2679 Crone, A.J., and Machette, M.N., 1995, Holocene movement on the Cheraw fault, SE Colorado-Another hazardous late Quaternary fault in the stable continental interior: Eos, Transactions of the American Geophysical Union, v. 76, no. 46, November 7, 1995 supplement, p. F362.

\#883 Crone, A.J., Giardino, M., and Schweig, E.S., III, 1995, Paleoseismic studies of the Bootheel lineament, southeastern Missouri, and the Crittenden County fault zone, northeastern Arkansas, New Madrid seismic zone, central United States: U.S. Geological Survey Miscellaneous Field Studies Map MF-2279, 21 p. pamphlet, 1 sheet,.

\#2680 Crone, A.J., Machette, M.N., Bradley, L.-A., and Mahan, S.A., 1997, Late Quaternary surface faulting on the Cheraw fault, southeastern Colorado: U.S. Geological Survey Miscellaneous Geologic Investigations I-2591, 7 p. pamphlet, 1 oversize pl. 
\#1163 Crone, A.J., Machette, M.N., Haller, K.M., Stephenson, W.J., Williams, R.A., and Odum, J.K., 1996, Late Quaternary paleoearthquakes in central Nebraska?-New evidence favoring general tectonic stability: Geological Society of America Abstracts with Programs, v. 28, no. 7, p. A-55.

\#728 Crone, A.J., McKeown, F.A., Harding, S.T., Hamilton, R.M., Russ, D.P., and Zoback, M.D., 1985, Structure of the New Madrid seismic source zone in southeastern Missouri and northeastern Arkansas: Geology, v. 13, p. 547-550.

\#2682 Curtis, B.F., 1988, Sedimentary rocks in the Denver basin, in Baars, D.L., and 15 others, eds., Basins of the Rocky Mountain region-Decade of North American geology:

Boulder, Colorado, Geological Society of America, The Geology of North America, v. D-2, p. 109-221.

\#3930 Dall, W.H., 1892, Correlation papers-Neocene: U.S. Geological Survey Bulletin 84, $349 \mathrm{p}$.

\#1962 Daniels, D.L., Zietz, I., and Popenoe, P., 1983, Distribution of subsurface lower Mesozoic rocks in southeastern United States, as interpreted from regional aeromagnetic and gravity maps, in Gohn, G.S., ed., Studies related to the Charleston, South Carolina, earthquake of 1886-Tectonics and seismicity: U.S. Geological Survey Professional Paper 1313-K, p. K1-K24.

\#2067 Daniels, R.B., Gamble, E.E., Wheeler, W.H., and Holzhey, C.S., 1972, Field Trip Guidebook 13: Raleigh, Carolina Geological Society, Carolina Geological Society and Atlantic Coastal Plain Geological Association, Annual Meetings and Field Trip, October 7-8, 1972, Guidebook, 68 p.

\#2027 Davison, F.C., Jr., 1988, Stress tensor estimates derived from focal mechanism solutions of sparse data sets-Applications to seismic zones in Virginia and eastern Tennessee: Blacksburg, Virginia Polytechnic Institute and State University, unpublished Ph.D. dissertation, $189 \mathrm{p}$.

\#1809 Dawers, N.H., and Seeber, L., 1991, Intraplate faults revealed in crystalline bedrock in the 1983 Goodnow and 1985 Ardsley epicentral areas, New York: Tectonophysics, v. 186, p. $115-131$.

\#1810 deBoer, J.Z., 1989, Neotectonic deformation of southern New England; new data on stress configuration and brittle failure: Geological Society of America Abstracts with Programs, v. 21, no. 2, p. 10.

\#1811 Dennis, A.J., Wright, J.E., Maher, H.D., Mauldin, J.C., and Shervais, J.W., 1997, Repeated Phanerozoic reactivation of a southern Appalachian fault zone beneath the updip Coastal Plain of South Carolina: Geological Society of America Abstracts with Programs, v. 29, p. A-223-A-224.

\#1812 Dennison, J.M., 1994, A newly discovered fault in West Virgina and Virginia related to the location of the Narrows of New River: Geological Society of America Abstracts with Programs, v. 26, no. 4, p. 10.

\#2029 Dennison, J.M., and Stewart, K.G., eds., 1998, Geologic field guide to extensional structures along the Allegheny Front in Virginia and West Virginia near the Giles County seismic zone: Southeastern Section, Geological Society of America, Charleston, West Virginia, March 28-29, 1998, Guidebook, 102 p.

\#2028 Dennison, J.M., ed., 1996, Geologic field guide to Devonian hydrocarbon stratigraphy of southeastern West Virginia and adjacent Virginia: Charleston, West Virginia, Appalachian Geological Society, October 12-13, 1996, Guidebook, 160 p. 
\#2030 Dewey, J.W., 1985, A review of recent research on the seismotectonics of the southeastern seaboard and an evaluation of hypotheses on the source of the 1886 Charleston, South Carolina, earthquake: U.S. Nuclear Regulatory Commission Report NUREG/CR4339, $44 \mathrm{p}$.

\#1928 Dewey, J.W., and Gordon, D.W., 1984, Map showing recomputed hypocenters of earthquakes in the Eastern and Central United States and adjacent Canada, 1925-1980: U.S. Geological Survey Miscellaneous Field Studies Map MF-1699, 39 p. pamphlet, 1 sheet, scale $1: 2,500,000$.

\#1814 Doll, W.E., Domoracki, W.J., Costain, J.K., Çoruh, C., Ludman, A., and Hopeck, J.T., 1996, Seismic reflection evidence for the evolution of a transcurrent fault system-The Norumbega fault zone, Maine: Geology, v. 24, p. 251-254.

\#1813 Doll, W.E., Rea, C.D., Ebel, J.E., Craven, S.J., and Cipar, J.J., 1992, Analysis of shallow microearthquakes in the South Sebec seismic zone, Maine, 1989-1990: Seismological Research Letters, v. 63, p. 557-566.

\#2799 Dort, W., Jr., Zeller, E.J., and Martin, L.D., 1993, Extensive late Quaternary faulting in the Mid-continent Great Plains: Geological Society of America Abstracts with Programs, v. 25, no. 6, p. A-70.

\#2800 Dort, W., Jr., Zeller, E.J., and Martin, L.D., 1995, Development of early to mid-Holocene fault-block topography in central and south-central Nebraska: Geological Society of America Abstracts with Programs, v. 27, no. 3, p. 47.

\#1929 Drahovzal, J.A., and Noger, M.C., 1995, Preliminary map of the structure of the Precambrian surface in eastern Kentucky: Kentucky Geological Survey Map and Chart Series 8, Series XI, 9 p. pamphlet, 1 sheet, scale 1:500,000.

\#1957 Drake, A.A., Jr., Volkert, R.A., Monteverde, D.H., Herman, G.C., Houghton, H.F., Parker, R.A., and Dalton, R.F., 1996, Bedrock geologic map of northern New Jersey: U.S. Geological Survey Miscellaneous Investigations Map I-2540-A, 6 p. pamphlet, 2 sheets, scale 1:100,000.

\#2255 DuBar, J.R., 1991, Quaternary geology of the Gulf of Mexico Coastal Plain-Florida panhandle, in Morrison, R.B., ed., Quaternary nonglacial geology; conterminous U.S.: Boulder, Colorado, Geological Society of America, The Geology of North America, v. K-2, p. 595-610.

\#2010 DuBar, J.R., Ewing, T.E., Lundelius, E.L., Jr., Otvos, E.G., and Winker, C.D., 1991, Quaternary geology of the Gulf of Mexico Coastal Plain, in Morrison, R.B., ed., Quaternary nonglacial geology; conterminous U.S.: Boulder, Colorado, Geological Society of America, The Geology of North America, v. K-2, p. 583-610.

\#3829 Durham, C.O., Jr., and Peeples, E.M., III, 1956, Pleistocene fault zone in southeastern Louisiana, in Rogers, J.K., ed. Transactions of the Gulf Coast Association of Geological Societies: Gulf Coast Section of the Society of Economic Paleontologists and Mineralogists, Annual meeting, San Antonio, Texas, October 31-November 2, 1956, v. 6, p. 65-66.

\#1816 Ebel, J.E., 1981, Source parameters of some earthquakes near Moodus, Connecticut [abs.]: Eos, Transactions of the American Geophysical Union, v. 62, no. 45, p. 967. \#2031 Ebel, J.E., 1987, The seismicity of the northeastern United States, in Jacob, K.H., ed., Proceedings from the symposium on seismic hazards, ground motions, soil-liquefaction 
and engineering practice in eastern North America: National Center for Earthquake Engineering Research Technical Report NCEER-87-0025, p. 178-188.

\#1817 Ebel, J.E., 1989, A comparison of the 1981, 1982, 1986, and 1987-1988 microearthquake swarms at Moodus, Connecticut: Seismological Research Letters, v. 60, p. 177-184.

\#1996 Ebel, J.E., 1989, The seismicity of Maine, in Anderson, W.A., and Borns, H.W., Jr., eds., Neotectonics of Maine-Studies in seismicity, crustal warping, and sea-level change: Maine Geological Survey Bulletin 40, p. 219-228.

\#1818 Ebel, J.E., and Bouck, B.R., 1988, New focal mechanisms for the New England regionConstraints on the regional stress regime: Seismological Research Letters, v. 59, p. 183187.

\#2008 Ebel, J.E., and Kafka, A.L., 1991, Earthquake activity in the northeastern United States, in Slemmons, D.B., Engdahl, E.R., Zoback, M.D., and Blackwell, D.D., eds., Neotectonics of North America: Boulder, Colorado, Geological Society of America, Decade Map Volume 1, p. 277-290.

\#1819 Ebel, J.E., and Spotila, J.A., 1991, Seismicity along the Norumbega fault in Maine [abs.]: Eos, Transactions of the American Geophysical Union, v. 72, no. 44 (supplement), p. 336.

\#1820 Ebel, J.E., and Spotila, J.A., 1992, Seismicity along the Norumbega fault in New England-Implications for seismic hazard in the northeast United States: Geological Society of America Abstracts with Programs, v. 24, no. 3, p. 17-18.

\#2011 Ebel, J.E., and Spotilla, J.A., 1999, Modern earthquake activity and the Norumbega fault zone, in Ludman, A., and West, D.P., Jr., eds., Norumbega fault system of the northern Appalachians: Geological Society of America Special Paper 331, p. 195-202.

\#1821 Ebel, J.E., Vudler, V., and Celata, M., 1982, The 1981 microearthquake swarm near Moodus, Connecticut: Geophysical Research Letters, v. 9, p. 397-400.

\#3658 Edmisten, N., and Foster, N.H., 1985, Weldon Field, in Tonnsen, J.J., ed., Montana oil and gas fields symposium 1985, v. 2: Billings, Montana, Montana Geological Society, p. 1163-1166.

\#1959 Engdahl, E.R., compiler, 1988, Seismicity map of North America: Boulder, Colorado, Geological Society of America Continent-Scale Map 004, 4 sheets, scale 1:5,000,000.

\#2198 Enos, P., and Perkins, R.D., 1977, Quaternary sedimentation in South Florida: Geological Society of America Memoir 147, 198 p., 19 pls.

\#735 Ervin, C.P., and McGinnis, L.D., 1975, Reelfoot rift-Reactivated precursor to the Mississippi embayment: Geological Society of America Bulletin, v. 86, p. 1287-1295.

\#3659 Ewing, T.E., 1990, Tectonic map of Texas: Bureau of Economic Geology, The University of Texas at Austin, 4 sheets, scale 1:750,000.

\#1994 Ewing, T.E., 1991, Structural framework, in Salvador, A., ed., The Gulf of Mexico basin: Boulder, Colorado, Geological Society of America, The Geology of North America, v. J, p. 31-52.

\#2032 Ewing, T.E., and Lopez, R.F., 1991, Principal structural features, Gulf of Mexico basin, in Salvador, A., ed., The Gulf of Mexico basin: Boulder, Colorado, Geological Society of America, The Geology of North America, v. J, plate 2, scale 1:2,500,000.

\#2012 Fakundiny, R.H., Myers, J.T., Pomeroy, P.W., Pferd, J.W., and Nowak, T.A., Jr., 1978, Structural instability features in the vicinity of the Clarendon-Linden fault system, western New York and Lake Ontario, in Thompson, J.C., ed., Advances in analysis of 
geotechnical instabilities: Waterloo, Ontario, Canada, University of Waterloo Press, Solid Mechanics Division Study 13, p. 121-178.

\#1822 Fallaw, W.C., and Price, V., 1995, Stratigraphy of the Savannah River Site and vicinity: Southeastern Geology, v. 35, p. 21-58.

\#3660 Feltis, R.D., 1981, Glendive $1^{\circ}$ x $2^{\circ}$ Quadrangle, northeastern Montana: Montana Bureau of Mines and Geology Geologic Map 15, 1 sheet, scale 1:250,000.

\#3661 Feltis, R.D., 1981, Jordan $1^{\circ}$ x $2^{\circ}$ Quadrangle, northeastern Montana: Montana Bureau of Mines and Geology Geologic Map 16, 1 sheet, scale 1:250,000.

\#3662 Feltis, R.D., 1981, Wolf Point $1^{\circ}$ x $2^{\circ}$ Quadrangle, northeastern Montana: Montana Bureau of Mines and Geology Geologic Map 17, 1 sheet, scale 1:250,000.

\#1930 Fisher, D.W., Isachsen, Y.W., and Rickard, L.V., 1970, Geologic map of New YorkHudson-Mohawk sheet: New York State Museum and Science Service Map and Chart Series 15, 1 sheet, scale 1:250,000.

\#1931 Fisher, D.W., Isachsen, Y.W., and Rickard, L.V., 1970, Geologic map of New York-Lower Hudson sheet: New York State Museum and Science Service Map and Chart Series 15, 1 sheet, scale 1:250,000.

\#1823 Fletcher, J.B., and Sykes, L.R., 1977, Earthquakes related to hydraulic mining and natural seismic activity in western New York State: Journal of Geophysical Research, v. 82, p. 3767-3780.

\#3663 Flint, R., Colton, R.B., Goldthwait, R.P., and Williams, H.B., 1959, Glacial map of the United States east of the Rocky Mountains: .

\#1824 Forsythe, R.D., and Chisholm, L., 1989, Are there earthquake-induced deformation structures in the Highlands/Lowlands border region of New Jersey?: Geological Society of America Abstracts with Programs, v. 21, no. 2, p. 15.

\#1825 Foster, J.E., Roy, D.C., Ebel, J.E., and Tuttle, M.P., 1992, Faults, joints, liquefaction features, and earthquakes in the Dover-Foxcroft area, Maine: Geological Society of America Abstracts with Programs, v. 24, no. 3, p. 21.

\#2809 Frye, J.C., 1942, Geology and ground-water resources of Meade County, Kansas: Bulletin of the University of Kansas, State Geological Survey of Kansas 45, 152 p.

\#2810 Frye, J.C., and Hibbard, C.W., 1941, Pliocene and Pleistocene stratigraphy and paleontology of the Meade basin, southwestern Kansas: State Geological Survey of Kansas Bulletin 38, 390-424 p.

\#723 Fuller, M.L., 1912, The New Madrid earthquake: U.S. Geological Survey Bulletin 494, 119 p., 1 plate.

\#1997 Gates, O., 1989, The geology and geophysics of the Passamaquoddy Bay area, Maine and New Brunswick, and their bearing on local subsidence, in Anderson, W.A., and Borns, H.W., Jr., eds., Neotectonics of Maine-Studies in seismicity, crustal warping, and sea-level change: Maine Geological Survey Bulletin 40, p. 11-24.

\#1826 Gelinas, R.L., Kemppinen, H.M.A., and Amick, D.C., 1993, Evaluation of liquefactionsusceptible materials near moderate magnitude historical earthquakes in New England [abs.]: Seismological Research Letters, v. 64, p. 259-260.

\#2033 Geraghty, E.P., and Isachsen, Y.W., 1981, Investigation of the McGregor-SaratogaBallston Lake fault system, east central New York: U.S. Nuclear Regulatory Commission Report NUREG/CR-1866, 45 p., 1 pl. 
\#672 Gilbert, M.C., 1983, The Meers fault of southwestern Oklahoma-Evidence for possible strong Quaternary seismicity in the midcontinent [abs.]: Eos, Transactions of the American Geophysical Union, v. 64, p. 313.

\#671 Gilbert, M.C., 1983, The Meers fault-Unusual aspects and possible tectonic consequences: Geological Society of America Abstracts with Programs, v. 18, p. 1.

\#2034 Glover, L., III, Evans, N.H., Patterson, J.G., Brown, W.R., Wehr, F., and Mose, D., 1989, Tectonics of the Virginia Blue Ridge and Piedmont: Washington, D.C., American Geophysical Union, 28th International Geological Congress Field Trip Guidebook T363, $59 \mathrm{p}$.

\#1827 Glover, L., III, Speer, J.A., Russell, G.S., and Farrar, S.S., 1983, Ages of regional metamorphism and ductile deformation in the central and southern Appalachians: Lithos, v. 16, p. 223-245.

\#1964 Gohn, G.S., ed., 1983, Studies related to the Charleston, South Carolina, earthquake of 1886-Tectonics and seismicity: U.S. Geological Survey Professional Paper 1313, 423 p., 8 pls.

\#3440 Gomberg, J., and Wolf, L., 1999, Possible cause for an improbable earthquake-The 1997 Mw 4.9 southern Alabama earthquake and hydrocarbon recovery: Geology, v. 27, p. 367-370.

\#1828 Gomberg, J., Wolf, L., Raymond, D., Raymond, R., Barnes, A., Carver, D., Bice, T., Cranswick, E., Meremonte, M., Frankel, A., Overturf, D., Hopper, M., Rhea, S., and Eckhoff, O., 1998, A noteworthy earthquake in an unlikely place [abs.]: Seismological Research Letters, v. 69, p. 175.

\#3701 Gott, G.B., Witkind, I.J., Hansen, W.R., Lindvall, R.M., Prouty, C.E., Smith, J.H., Basile, R.E., and Kaye, C.A., 1959, Geologic map of the Smoke Creek-Medicine Lake-Grenora area, Montana and South Dakota, in Witkind, I.J., ed., Quaternary geology of the Smoke Creek-Medicine Lake-Grenora Area, Montana and South Dakota: U.S. Geological Survey Bulletin 1073, p. 80, 2 sheets, scale 1:62,500.

\#2199 Granger, D.E., Kirchner, J.W., and Finkel, R.C., 1997, Quaternary downcutting rate of the New River, Virginia, measured from differential decay of cosmogenic ${ }^{26} \mathrm{Al}$ and ${ }^{10} \mathrm{Be}$ in cave-deposited alluvium: Geology, no. 25, p. 107-110.

\#1958 Gray, C., Shepps, V.C., Coulin, R.R., Lytle, W.S., Hoskins, D.M., Bergsten, J.M., Shaffuer, M.N., Miller, J.T., Socolow, A.A., Wood, G.H., Jr., McLaughlin, D.B., Arndt, H.H., Geyer, A.R., Kelin, T.M., Cale, A.S., and Van Olden, A.E., compilers, 1960, Geologic map of Pennsylvania: Pennsylvania Topographic and Geologic Survey, 2 sheets, scale 1:250,000.

\#3665 Groat, C.G., 1973, Holocene faulting and subsidence in the Texas coastal zone: Geological Society of America Abstracts with Programs, v. 5, no. 7, p. 645.

\#737 Guccione, M.J., and Hehr, L.H., 1991, Origin of the "sunklands" in the new Madrid seismic zone-Tectonic or alluvial drowning? [abs.]: Seismological Research Letters, v. 62, p. 171-172.

\#739 Guccione, M.J., Miller, J.Q., and VanArsdale, R.B., 1994, Amount and timing of deformation near the St. Francis "sunklands", northeastern Arkansas: Geological Society of America Abstracts with Programs, v. 26, p. 7.

\#3809 Guccione, M.J., Prior, W.L., and Rutledge, E.M., 1988, Crowley's Ridge, Arkansas, in Hayward, O.T., ed., South-central section: Geological Society of America Centennial Field Guide, v. 4, p. 225-230. 
\#2811 Gutentag, E.D., Lobmeyer, D.H., and Slagle, S.E., 1981, Geohydrology of southwestern Kansas: Kansas Geological Survey Irrigation Series 7, 73 p., 3 oversized pls.

\#2834 Hajic, E.R., Wiant, M.D., and Oliver, J.J., 1995, Distribution and dating of prehistoric earthquake liquefaction in southeastern Illinois, Central U. S.: Final Report to the U.S. Geological Survey, 33 p.

\#1932 Haley, B.R., Glick, E.E., Bush, W.V., Clardy, B.F., Stone, C.G., Woodward, M.B., and Zachry, D.L., 1993, Geologic map of Arkansas: Arkansas Geological Commission and U. S. Geological Survey, 1 sheet, scale 1:500,000.

\#718 Haller, K.M., and Crone, A.J., 1986, Log of an exploratory trench in the New Madrid seismic zone near Blytheville, Arkansas: U.S. Geological Survey Miscellaneous Field Studies Map MF-1858, 1 sheet.

\#2035 Hamilton, R.M., 1981, Geologic origin of Eastern U.S. seismicity, in Beavers, J.E., ed., Earthquakes and earthquake engineering-The Eastern United States: Ann Arbor, Michigan, Ann Arbor Science, p. 3-23.

\#1965 Hamilton, R.M., Behrendt, J.C., and Ackermann, H.D., 1983, Land multichannel seismic-reflection evidence for tectonic features near Charleston, South Carolina, in Gohn, G.S., ed., Studies related to the Charleston, South Carolina, earthquake of 1886Tectonics and seismicity: U.S. Geological Survey Professional Paper 1313, p. I1-I18.

\#2200 Hanor, J.S., 1982, Reactivation of fault movement, Tepetate fault zone, south central Louisiana: Transactions of the Gulf Coast Association of Geological Societies, v. 32, p. 237-245.

\#3666 Hansen, A.R., 1966, Reef trends of Mississippian Ratcliffe Zone, northeast Montana and northwest North Dakota: Bulletin of the American Association of Petroleum Geologists, v. 50 , no. 10 , p. 2260.

\#1829 Hansen, M.C., 1993, Earthquakes and seismic risk in Ohio: Ohio Geology, summer issue, p. 1 and 3-6.

\#2639 Hanson, K.L., Swan, F.H., Wesling, J.R., and Kelson, K.I., 1997, Quaternary deformation along the Criner Fault, Oklahoma-A case study for evaluating tectonic versus landslide faulting: Eos, Transactions of the American Geophysical Union, v. 78, no. 17, p. S317.

\#3667 Hardie, J.K., and Arndt, H.H., 1988, Geology, structure, and coal beds of the Fort Union Formation in the eastern part of the Fort Peck Indian Reservation, Daniels, Roosevelt, and Sheridan Counties, Montana: U.S. Geological Survey Coal Investigations Map C122-A, 1 sheet, scale 1:100,000.

\#3668 Hardie, J.K., and Arndt, H.H., 1989, Stratigraphy of the Fort Union Formation in the eastern part of the Fort Peck Indian Reservation, Daniels, Roosevelt, and Sheridan Counties, Montana: U.S. Geological Survey Coal Investigations Map C-122-B, 1 sheet, scale $1: 100,000$.

\#3669 Hardie, J.K., and Arndt, H.H., 1990, Stratigraphic framework of coal beds in the Fort Union Formation, eastern part of the Fort Peck Indian Reservation, Daniels, Roosevelt, and Sheridan Counties, Montana: U.S. Geological Survey Coal Investigations Map C122-C, 1 sheet, scale 1:100,000.

\#3670 Hardie, J.K., and Van Gosen, B.S., 1986, Stratigraphic framework of coal beds underlying the northeast part of the Fort Peck Indian Reservation, Montana: U.S. Geological Survey Miscellaneous Field Studies Map MF-1775, 1 sheet, scale 1:125,000. 
\#670 Harlton, B.H., 1951, Faults in sedimentary part of Wichita Mountains of Oklahoma: Bulletin of the American Association of Petroleum Geologists, v. 35, p. 988-999.

\#667 Harlton, B.H., 1963, Frontal Wichita fault system of southwestern Oklahoma: Bulletin of the American Association of Petroleum Geologists, v. 47, p. 1552-1580.

\#666 Harlton, B.H., 1972, Faulted fold belts of southern Anadarko basin adjacent to Frontal Wichitas: Bulletin of the American Association of Petroleum Geologists, v. 56, p. 15441551.

\#2258 Harper, D.P., 1984, Geologic compilation map of the Monmouth Junction quadrangle, New Jersey: New Jersey Geological Survey Open File Map 1, 1 sheet, scale 1:24,000.

\#3931 Harris, W.B., 1996, An overview of the marine Tertiary and Quaternary deposits between Cape Fear and Cape Lookout, North Carolina, in Cleary, W.J., ed., Environmental coastal geology-Cape Lookout to Cape Fear, North Carolina: Carolina Geological Society Fieldtrip Guidebook, p. 1-10.

\#3932 Harris, W.B., Zullo, V.A., and Baum, G.R., 1979, Tectonic effects on Cretaceous, Paleogene, and early Neogene sedimentation, North Carolina, in Baum, G.R., Harris, W.B., and Zullo, V.A., eds., Structural and stratigraphic framework for the coastal plain of North Carolina: Carolina Geological Society and Atlantic Coastal Plain Geological Association, p. 17-29.

\#679 Hart, D.L., Jr., 1974, Reconnaissance of the water resources of the Ardmore and Sherman quadrangles, southern Oklahoma: Oklahoma Geological Survey Hydrologic Atlas 3, Map HA-3, 4 sheets, scale 1:250,000.

\#2036 Hatcher, R.D., Jr., Osberg, P.H., Drake, A.A., Jr., Robinson, P., and Thomas, W.A., 1989, Tectonic map of the U.S. Appalachians, in Hatcher, R.D., Jr., Thomas, W.A., and Viele, G.W., eds., The Appalachian-Ouachita orogen in the United States: Boulder, Colorado, Geological Society of America, The Geology of North America, v. F-2, plate 1.

\#2814 Haworth, E., 1896, Local deformation of strata in Meade County, Kansas and adjoining territory (preliminary): American Journal of Science, v. 2, p. 368-373.

\#2201 Heinrich, P.V., 1988, Tectonic origin of Montgomery terrace scarp of southwestern Louisiana [abs]: Transactions of the Gulf Coast Association of Geological Societies, v. 38, p. 582.

\#2202 Heinrich, P.V., 1997, Pleistocene fault-line scarps and neotectonics in southwest Louisiana: Geological Society of America Abstracts with Programs, v. 29, no. 3, p. 23.

\#1830 Herrmann, R.B., 1978, A seismological study of two Attica, New York earthquakes: Bulletin of the Seismological Society of America, v. 68, p. 641-651.

\#733 Herrmann, R.B., 1979, Surface wave focal mechanisms for eastern North American earthquakes with tectonic implications: Journal of Geophysical Research, v. 84, no. B7, p. 3543-3552.

\#732 Herrmann, R.B., and Canas, J.-A., 1978, Focal mechanism studies in the New Madrid seismic zone: Bulletin of the Seismological Society of America, v. 68, p. 1095-1102.

\#2828 Hildebrand, G.M., Steeples, D.W., Knapp, R.W., Miller, R.D., and Bennett, B.C., 1988, Microearthquakes in Kansas and Nebraska 1977-1987: Seismological Research Letters, v. 59, no. 4, p. 159-163.

\#736 Hildenbrand, T.G., 1985, Rift structure of the northern Mississippi embayment from the analysis of gravity and magnetic data: Journal of Geophysical Research, v. 90, no. B14, p. $12,607-12,622$. 
\#2835 Hildenbrand, T.G., and Ravat, D., 1997, Geophysical setting of the Wabash Valley fault system: Seismological Research Letters, v. 68, no. 4, p. 567-585.

\#721 Hildenbrand, T.G., Kane, M.F., and Hendricks, J.D., 1982, Magnetic basement in the upper Mississippi embayment region-A preliminary report, in McKeown, F.A., and Pakiser, L.C., eds., Investigations of the New Madrid, Missouri, earthquake region: U.S. Geological Survey Professional Paper 1236, p. 39-53.

\#3674 Holzer, T., Gabrysch, R.K., and Verbeek, E.R., 1983, Faulting arrested by control of ground-water withdrawal in Houston, Texas: Earthquake Information Bulletin, v. 15, no. 6, p. 204-209.

\#3672 Holzer, T.L., 1980, Land subsidence and ground failure induced by fluid withdrawal in urban areas: Geological Society of America Abstracts with Programs, v. 12, no. 7, p. 449.

\#3673 Holzer, T.L., and Gabrysch, R.K., 1982, Historical surface faulting in part of the Houston-Galveston, Texas, subsidence bowl arrested by partial water-level recoveries: Geological Society of America Abstracts with Programs, v. 14, no. 7, p. 517.

\#3675 Holzer, T.L., and Verbeek, E.R., 1980, Modern surface faulting in the Goose Creek Oil Field (Baytown, Texas)-A reexamination: Geological Society of America Abstracts with Programs, v. 12, no. 7, p. 449.

\#3885 Hook, J.W., 1974, Structure of the fault systems in the Illinois-Kentucky Fluorspar District, in Hutcheson, D.W., ed., A symposium of the geology of Fluorspar: Kentucky Geological Survey Special Publication 22, p. 77-86.

\#3671 Horner, R.B., and Hasegawa, H.S., 1978, The seismotectonics of southern Saskatchewan: Canadian Journal of Earth Science, v. 15, p. 1341-1355.

\#1831 Hubbard, M.S., West, D.P., Jr., Ludman, A., Guidotti, C.V., and Lux, D.R., 1995, The Norumbega fault zone, Maine-A mid- to shallow-level crustal section within a transcurrent shear zone: Atlantic Geology, v. 31, p. 109-116.

\#2037 Hunt, A.S., 1989, Detailed investigations of several apparent faults beneath Lake Champlain, Vermont-New York, in Barosh, P.J., and Smith, P.V., eds., New England seismotectonic activities during fiscal year 1980: U.S. Nuclear Regulatory Commission Report NUREG/CR-3252, p. 68-73.

\#1833 Hutchinson, D.R., and Grow, J.A., 1985, New York Bight fault: Geological Society of America Bulletin, v. 96, p. 975-989.

\#1832 Hutchinson, D.R., Ferrebee, W.M., Knebel, H.J., and Wold, R.J., 1981, The sedimentary framework of the southern basin of Lake George, New York: Quaternary Research, v. 15, p. 44-61.

\#1834 Hutchinson, D.R., Klitgord, K.D., and Detrick, R.S., 1985, Block Island fault-A Paleozoic crustal boundary on the Long Island platform: Geology, v. 13, p. 875-879.

\#1835 Hutchinson, D.R., Klitgord, K.D., and Detrick, R.S., 1986, Rift basins of the Long Island platform: Geological Society of America Bulletin, v. 97, p. 688-702.

\#1836 Hutchinson, D.R., Pomeroy, P.W., Wold, R.J., and Halls, H.C., 1979, A geophysical investigation concerning the continuation of the Clarendon-Linden fault across Lake Ontario: Geology, v. 7, p. 206-210.

\#2038 Isachsen, Y.W., 1985, Structural and tectonic studies in New York State-Final report, July 1981-June 1982: U.S. Nuclear Regulatory Commission Report NUREG/CR-3178, 75 p. 
\#1933 Isachsen, Y.W., and Fisher, D.W., 1970, Geologic map of New York-Adirondack sheet: New York State Museum and Science Service Map and Chart Series 15, 1 sheet, scale 1:250,000.

\#1934 Isachsen, Y.W., and McKendree, W.G., 1977, Preliminary brittle structures map of New York: New York State Museum Map and Chart Series 31 A-G, 7 sheets.

\#2203 Isachsen, Y.W., Geraghty, E.P., and Wiener, R.W., 1983, Fracture domains associated with a neotectonic, basement-cored-dome-The Adirondack Mountains, New York, in Gabrielsen, R.H., Ramberg, I.B., Roberts, D., and Steinlein, O.A., eds., International Conference on Basement Tectonics: Salt Lake City, International Basement Tectonics Association, 4th Proceeding, Oslo, Norway, August 10-14, 1981, p. 287-305.

\#2812 Izett, G.A., and Honey, J.G., 1995, Geologic map of the Irish Flats NE quadrangle, Meade County, Kansas: U.S. Geological Survey Miscellaneous Investigations Map I2498, scale 1:24,000.

\#2703 Jack Benjamin \& Associates and Geomatrix Consultants, 1996, Probabilistic seismic hazard assessment for the U.S. Army chemical disposal facility, Pueblo Depot Activity, Colorado: Technical report to Science Applications International Corporation, Maryland, under Contract JBA 148-130-PU-002.

\#1837 Jacobi, R., and Fountain, J., 1993, The southern extension and reactivations of the Clarendon-Linden fault system: Géographie physique et Quaternaire, v. 47, p. 285-302.

\#1838 Jacobi, R., and Fountain, J., 1997, Discrimination of tectonic and nontectonic faults-A case study involving 11 integrated techniques [abs.]: Eos, Transactions of the American Geophysical Union, v. 78, no. 17, p. 316.

\#1839 Jacobi, R.D., and Fountain, J., 1998, Characteristics of the basement-controlled faults of the Clarendon-Linden fault system-Evidence from seismic reflection profiles for local multiple Phanerozoic reactivations during far-field orogenies: Geological Society of America Abstracts with Programs, v. 30, no. 1, p. 27.

\#2204 Jahns, R.H., 1951, Surficial geology of the Mount Toby quadrangle, Massachusetts: U.S. Geological Survey Geologic Quadrangle map GQ-9, 1 sheet, scale 1:31,680.

\#715 Jibson, R.W., and Keefer, D.K., 1988, Landslides triggered by earthquakes in the central Mississippi Valley, Tennessee and Kentucky, in Russ, D.P., and Crone, A.J., eds., The New Madrid, Missouri, earthquake region-Geological, seismological, and geotechnical studies: U.S. Geological Survey Professional Paper 1336-C, p. C1-C24.

\#714 Jibson, R.W., and Keefer, D.K., 1992, Analysis of the seismic origin of a landslide in the New Madrid seismic zone, in Johnston, A.C., Shedlock, K.M., Herrmann, R.B., and Hopper, M.G., eds., New Madrid special issue: Seismological Research Letters, v. 63, p. $427-437$.

\#259 Johns, W.M., Straw, W.T., Bergantino, R.N., Dresser, H.W., Hendrix, T.E., McClernan, H.G., Palmquist, J.C., and Schmidt, C.J., 1982, Neotectonic features of southern Montana east of $112^{\circ} 30^{\prime}$ west longitude: Montana Bureau of Mines and Geology OpenFile Report 91, 79 p., 2 sheets.

\#2816 Johnson, O.H., Jr., 1958, The Monroe uplift: Transactions of the Gulf Coast Association of Geological Societies, v. 8, p. 24-32.

\#2797 Johnson, W.C., Miller, R.D., and Steeples, D.W., 1995, Geomorphology, stratigraphy, and chronology of a late quaternary (Holocene) fault, Harlan County, Nebraska: Geological Society of America Abstracts with Programs, v. 27, no. 6, p. A-376. 
\#3676 Johnston, A.C., 1989, The effect of large ice sheets on earthquake genesis, in Gregersen, S., and Basham, P.W., eds., Earthquakes at North-Atlantic passive margins; neotectonics and postglacial rebound, v. 266: D. Reidel Publishing Company, p. 581-599.

\#2039 Johnston, A.C., 1989, The seismicity of 'stable continental interiors', in Gregersen, S., and Basham, P.W., eds., Earthquakes at North Atlantic passive margins-Neotectonics and postglacial rebound: Dordrecht, The Netherlands, Kluwer Academic Publishers, p. 299327.

\#1840 Johnston, A.C., 1993, Average stable continental earthquake source parameters based on constant stress drop scaling [abs.]: Seismological Research Letters, v. 64, p. 261.

\#2042 Johnston, A.C., 1994, Appendix C-Summary tables, SCR seismicity data base, in Schneider, J.F., ed., The earthquakes of stable continental regions-v. 2-Appendices A to E: Technical report to Electric Power Research Institute TR-102261-V2, Palo Alto, California, December 1994, p. C-1-C-46.

\#2040 Johnston, A.C., 1994, Seismotectonic interpretations and conclusions from the stable continental region seismicity database, in Schneider, J.F., ed., The earthquakes of stable continental regions-v. 1, Assessment of large earthquake potential: Technical report to Electric Power Research Institute TR-102261-V1, Palo Alto, California, December 1994, p. 4-1-4-103.

\#2205 Johnston, A.C., 1996, A wave in the earth: Science, v. 274, p. 735.

\#1842 Johnston, A.C., 1996, Seismic moment assessment of earthquakes in stable continental regions-III. New Madrid 1811-1812, Charleston 1886 and Lisbon 1755: Geophysical Journal International, v. 126, p. 314-344.

\#1841 Johnston, A.C., 1996, Seismic moment assessment of earthquakes in stable continental regions-I. Instrumental seismicity: Geophysical Journal International, v. 124, p. 381414.

\#3810 Johnston, A.C., and Schweig, E.S., III, 1996, The enigma of the New Madrid earthquakes of 1811-1812: Annual Review of Earth and Planetary Sciences, v. 24, p. 339384.

\#2066 Jonas, A.I., and Stose, G.W., 1930, Geology and mineral resources of the Lancaster quadrangle, Pennsylvania: Pennsylvania Geological Survey, Fourth Series, Topographic and Geologic Atlas of Pennsylvania 168, 106 p., 2 pls., scale 1:62,500.

\#663 Jones-Cecil, M., and Crone, A.J., 1989, Constraints on the Anadarko basin-Wichita uplift boundary interpreted from aeromagnetic data, in Johnson, K.S., ed., Anadarko basin symposium, 1988: Oklahoma Geological Survey Circular 90, p. 228-232.

\#673 Jones-Cecil, M., 1995, Total-field aeromagnetic and derivative maps of the Lawton area, southwestern Oklahoma: U.S. Geological Survey Geophysical Investigations Series Map GP-998-A, 2 sheets, scale 1:100,000.

\#2206 Kafka, A.L., and Miller, P.E., 1996, Seismicity in the area surrounding two Mesozoic rift basins in the northeastern United States: Seismological Research Letters, v. 67, p. 6986.

\#1843 Kafka, A.L., Schlesinger-Miller, E.A., and Barstow, N.L., 1985, Earthquake activity in the greater New York City area-Magnetudes, seismicity, and geologic structures: Bulletin of the Seismological Society of America, v. 75, p. 1285-1300. 
\#2043 Kafka, A.L., Winslow, M.A., and Barstow, N.L., 1989, Earthquake activity in the greater New York City area-A faultfinder's guide, in Weiss, D., ed. Field trip guidebook: New York State Geological Association, 61st Annual Meeting, Middletown, New York, October 13-15, 1989, Guidebook, p. 177-203.

\#1998 Kelley, J.T., Belknap, D.F., Shipp, R.C., and Miller, S.B., 1989, An investigation of neotectonic activity in coastal Maine by seismic reflection methods, in Anderson, W.A., and Borns, H.W., Jr., eds., Neotectonics of Maine-Studies in seismicity, crustal warping, and sea-level change: Maine Geological Survey Bulletin 40, p. 157-204.

\#659 Kelson, K.I., and Swan, F.H., 1990, Paleoseismic history of the Meers fault, southwestern Oklahoma, and implications for evaluations of earthquake hazards in the Central and Eastern United States, in Weiss, A.J., ed., Seventeenth water reactor safety information meeting: Proceedings of the U.S. Nuclear Regulatory Commission NUREG/CP-0105, v. 2, p. 341-365.

\#3811 Kelson, K.I., Simpson, G.D., Van Arsdale, R.B., Harris, J.B., Haraden, C.C., and Lettis, W.R., 1996, Multiple Holocene earthquakes along the Reelfoot fault, central New Madrid seismic zone: Journal of Geophysical Research, v. 101, p. 6151-6170.

\#683 Kelson, K.I., Swan, F.H., and Coppersmith, K.J., 1990, Implications of late Quaternary faulting along the Meers and Criner faults to assessments of seismic hazards in the Central and Eastern US: Geological Society of America Abstracts with Programs, v. 22, p. 10.

\#729 Kelson, K.I., VanArsdale, R.B., Simpson, G.D., and Lettis, W.R., 1992, Assessment of the style and timing of surficial deformation along the central Reelfoot scarp, Lake County, Tennessee, in Johnston, A.C., Shedlock, K.M., Herrmann, R.B., and Hopper, M.G., eds., New Madrid special issue: Seismological Research Letters, v. 63, p. 349-356.

\#1844 Kemp, J.F., 1896, Glacial or post-glacial diversion of the Bronx River: Science, v. 4, p. 696.

\#2065 Kemp, J.F., 1897, The glacial or post-glacial diversion of the Bronx River from its old channel: Transactions of the New York Academy of Science, v. 16, p. 18-24.

\#1845 Kemppinen, H.M.A., Gelinas, R.L., and Amick, D.C., 1992, A comparison of seismically-induced liquefaction features in the southeastern U.S. versus postulated earthquake deformation features in central Connecticut: Geological Society of America Abstracts with Programs, v. 24, no. 2, p. 24.

\#1846 Kemppinen, H.M.A., Gelinas, R.L., and Amick, D.C., 1993, Evaluation of wedge-type pseudoliquefaction features in central Connecticut [abs.]: Seismological Research Letters, v. 64, p. 261.

\#1847 Kim, W.-Y., Gao, L., Horton, S., Such, R., Johnson, D., and Lerner-Lam, A., 1994, Analysis of digital records from Wyomissing Hills, PA. earthquakes of Jan. 16, 1994 [abs.]: Eos, Transactions of the American Geophysical Union, v. 75, no. 16 (supplement), p. 237.

\#792 Kirkham, R.M., and Rogers, W.P., 1981, Earthquake potential in Colorado-A preliminary evaluation: Colorado Geological Survey Bulletin 43, 171 p., 3 pls.

\#2707 Kirkham, R.M., and Rogers, W.P., 1981, Earthquake potential in Colorado: Colorado Geological Survey Bulletin 43, $171 \mathrm{p}$.

\#1848 Koch, B.F., Fahey, R.J., Quarrier, S.S., and Kick, J.F., 1978, Geology and geophysics of the Moodus seismic area, Connecticut: Geological Society of America Abstracts with Programs, v. 10, no. 2, p. 71. 
\#3886 Kolata, D.R., Treworgy, J.D., and Masters, J.M., 1981, Structural framework of the Mississippi embayment of southern Illinois: Illinois Institute of Natural Resources State Geological Survey Division Circular 516, $30 \mathrm{p}$.

\#1999 Koons, D., 1989, Postglacial bedrock faulting in Maine, in Anderson, W.A., and Borns, H.W., Jr., eds., Neotectonics of Maine-Studies in seismicity, crustal warping, and sealevel change: Maine Geological Survey Bulletin 40, p. 149-155.

\#2207 Kulander, B.R., Dean, S.L., and Ward, B.J., Jr., 1990, Fractured core analysisInterpretation, logging, and use of natural and induced fractures in core: American Association of Petroleum Geologists Methods in Exploration Series No. 8, 88 p.

\#1849 LaForge, R., and Ruff, L.J., 1991, Seismicity and crustal structure in the Anna, Ohio region [abs.]: Eos, Transactions of the American Geophysical Union, v. 72, no. 17, p. 196.

\#3917 Langenheim, V.E., and Hildenbrand, T.G., 1997, Commerce geophysical lineament-Its source, geometry, and relation to the Reelfoot rift and New Madrid seismic zone: Geological Society of America Bulletin, v. 109, no. 5, p. 580-595.

\#700 Langer, C.J., and Bollinger, G.A., 1991, The southeastern Illinois earthquake of 10 June 1987-The later aftershocks: Bulletin of the Seismological Society of America, v. 81, p. 423-445.

\#3678 Larson, B.S., 1985, Geology associated with lineaments in the Weldon-Richfield Area, Williston Basin, Montana, in Aldrich, M.J., Jr., and Laughlin, A.W., eds., Proceedings of the sixth international conference on basement tectonics: Salt Lake City, Utah, International Basement Tectonics Association, p. 200.

\#1850 Law, R.D., Pope, M.C., Wirgart, R.H., Bollinger, G.A., and Whitmarsh, R.S., 1992, Geologically recent near-surface folding and faulting in the Valley and Ridge provinceNew exposures of extensional faults in alluvial sediments, Giles County, SW Virgina [abs.]: Seismological Research Letters, v. 63, p. 609-610.

\#1851 Law, R.D., Pope, M.C., Wirgart, R.H., Eriksson, K.A., Carpenter, D., Robinson, E.S., and Bollinger, G.A., 1993, Geologically recent near-surface folding and faulting in the Valley and Ridge province-New exposures of extensional faults in alluvial sediments, Giles County, SW Virginia [abs.]: Eos, Transactions of the American Geophysical Union, v. 74, p. 282.

\#2044 Law, R.D., Pope, M.C., Wirgart, R.H., Eriksson, K.A., Robinson, E.S., Sayer, S., Phinney, E.J., and Bollinger, G.A., 1994, Geologically recent near-surface folding and faulting in Giles County, southwest Virginia-New exposures of extensional and apparent reverse faults in alluvial sediments between Pembroke and Pearisburg, in Proceedings of the U.S. Nuclear Regulatory Commission, Twenty-First Water Reactor Safety Information Meeting: U.S. Nuclear Regulatory Commission Report NUREG/CP-0133, v. 3, p. 415-432.

\#1852 Law, R.D., Robinson, E.S., Cyrnak, J.S., Sayer, S., Williams, R.T., Callis, J., and Pope, M., 1997, Geologically-recent faulting and folding of alluvial sediments near Pearisburg, Giles County, Virginia-Tectonic faulting or karst subsidence in origin? [abs.]: Eos, Transactions of the American Geophysical Union, v. 78, no. 17 (supplement), p. S316. \#2045 Law, R.D., Robinson, E.S., Sayer, S., Cyrnak, J.S., Williams, R.T., Callis, J., and Pope, M., 1998, Geologically-recent faulting and folding of alluvial sediments near Pearisburg, 
Giles County, Virginia-Tectonic faulting or karst subsidence in origin?, in Dennison, J.M., and Stewart, K.G., eds., Geologic field guide to extensional structures along the Allegheny Front in Virginia and West Virginia near the Giles County seismic zone:

Southeastern Section, Geological Society of America, Charleston, West Virginia, March 28-29, 1998, Guidebook, p. 95-101.

\#2000 Lee, F.T., and Diehl, S.F., 1989, Geomechanical aspects of subsidence in eastern Maine, in Anderson, W.A., and Borns, H.W., Jr., eds., Neotectonics of Maine-Studies in seismicity, crustal warping, and sea-level change: Maine Geological Survey Bulletin 40, p. 209-218.

\#708 Liu, L., Zoback, M.D., and Segall, P., 1992, Rapid intraplate strain accumulation in the New Madrid seismic zone: Science, v. 257, p. 1666-1669.

\#2046 Lobeck, A.K., 1939, Geomorphology-An introduction to the study of landscapes: New York, McGraw-Hill, 731 p.

\#1853 London, D., 1988, Characteristics and regional significance of the Cremation Hill ductile fault zone at the Bronson Hill-Merrimack boundary, south-central Connecticut: American Journal of Science, v. 288, p. 353-375.

\#2014 London, D., 1989, Bedrock geology of the Moodus seismic area, south-central Connecticut: State Geological and Natural History Survey of Connecticut Report of Investigations No. 11, 25 p., 1 pl., scale 1:12,000.

\#1854 Loomis, F.B., 1921, Postglacial faulting about Mount Toby, Massachusetts: Geological Society of America Bulletin, v. 32, p. 75-80.

\#2208 Lotto, L., Allison, M.A., Schwab, W.C., Butman, B., Foster, D., Denny, J., and Corso, W., 1997, Seismic stratigraphy of the New York Bight, NY/NJ continental shelf: Geological Society of America Abstracts with Programs, v. 29, no. 1, p. 62.

\#1855 Ludman, A., 1998, Evolution of transcurrent fault system in shallow crustal metasedimentary rocks-The Norumbega fault zone, eastern Maine: Journal of Structural Geology, v. 20, p. 93-107.

\#1989 Ludman, A., and Gibbons, S., 1999, Multistage shearing of the Deblois granite in the Kellyland fault zone, eastern Maine, in Ludman, A., and West, D.P., Jr., eds., Norumbega fault system of the northern Appalachians: Geological Society of America Special Paper 331, p. 41-57.

\#2041 Ludman, A., and West, D.P., Jr., 1996, "Cool", shallow crustal generation of mylonites: Examples from the Norumbega fault zone, Maine: Geological Society of America Abstracts with Programs, v. 28, no. 3, p. 77.

\#1990 Ludman, A., Lanzirotti, A., Lux, D., and Wang, C., 1999, Constraints on timing and displacement of multistage shearing in the Norumbega fault system, eastern Maine, in Ludman, A., and West, D.P., Jr., eds., Norumbega fault system of the northern Appalachians: Geological Society of America Special Paper 331, p. 179-194.

\#669 Luza, K.V., Madole, R.F., and Crone, A.J., 1987, Investigation of the Meers fault in southwestern Oklahoma: U.S. Nuclear Regulatory Commission NUREG/CR-4937, 53 p., 2 pls.

\#544 Luza, K.V., Madole, R.F., and Crone, A.J., 1987, Investigation of the Meers fault, southwestern Oklahoma: Oklahoma Geological Survey Special Publication 87-1, 75 p., 2 pls.

\#705 Luzietti, E.A., Kanter, L.R., Schweig, E.S., Shedlock, K.M., and VanArsdale, R.B., 1992, Shallow deformation along the Crittenden County fault zone near the southeastern boundary of the Reelfoot rift, northeast Arkansas, in Johnston, A.C., Shedlock, K.M., 
Herrmann, R.B., and Hopper, M.G., eds., New Madrid special issue: Seismological Research Letters, v. 63, p. 263-275.

\#1935 Lyttle, P.T., and Epstein, J.B., 1987, Geologic map of the Newark $1^{\circ}$ x $2^{\circ}$ quadrangle, New Jersey, Pennsylvania, and New York: U.S. Geological Survey Miscellaneous Investigations Map I-1715, 1 sheet, scale 1:250,000.

\#2856 Machette, M.N., Crone, A.J., Haller, K.M., Bradley, L.A., Stephenson, W.J., Williams, R.A., and Souders, V.L., 1998, Field investigations of suspected late Quaternary faults in central Nebraska-Evidence of non-tectonic origins: U.S. Geological Survey Miscellaneous Investigations Map I-2649, 1 pl.

\#1936 MacQuown, W.C., Jr., 1968, Geologic map of the Nicholasville quadrangle, Jessamine and Fayette Counties, Kentucky: U.S. Geological Survey Geologic Quadrangle Map GQ-767, 1 sheet, scale 1:24,000.

\#662 Madole, R.F., 1988, Stratigraphic evidence of Holocene faulting in the mid-continent-The Meers fault, southwestern Oklahoma: Geological Society of America Bulletin, v. 100, p. 392-401.

\#2209 Maher, H.D., Jr., 1987, Kinematic history of mylonitic rocks from the Augusta fault zone, South Carolina and Georgia: American Journal of Science, v. 287, p. 795-816.

\#2063 Manspeizer, W., compiler, 1989, Onshore and offshore Late Triassic-Early Jurassic basins, eastern United States and parts of Maritime Canada, in Hatcher, R.D., Jr., Thomas, W.A., and Viele, G.W., eds., The Appalachian-Ouachita Orogen in the United States: Boulder, Colorado, Geological Society of America, The Geology of North America, v. F-2, plate 5A, scale 1:5,000,000.

\#1992 Manspeizer, W., DeBoer, J., Costain, J.K., Froelich, A.J., Çoruh, C., Olsen, P.E., McHone, G.J., Puffer, J.H., and Prowell, D.C., 1989, Post-Paleozoic activity, in Hatcher, R.D., Jr., Thomas, W.A., and Viele, G.W., eds., The Appalachian-Oachita Orogen in the United States: Boulder, Colorado, Geological Society of America, The Geology of North America, v. F-2, p. 319-374.

\#3933 Markewich, H.W., 1985, Geomorphic evidence for Pliocene-Pleistocene uplift in the area of the Cape Fear Arch, North Carolina, in Morisawa, M., and Hack, J.T., eds., Tectonic geomorphology: Boston, Allen \& Unwin, p. 279-297.

\#1856 Marone, C., and Scholz, C.H., 1988, The depth of seismic faulting and the upper transition from stable to unstable slip regimes: Geophysical Research Letters, v. 15, p. 621624.

\#1857 Marple, R.T., and Talwani, P., 1993, Evidence of possible tectonic upwarping along the South Carolina coastal plain from an examination of river morphology and elevation data: Geology, v. 21, p. 651-654.

\#2798 Martin, C.W., 1993, Radiocarbon ages of late Pleistocene loess stratigraphy of Nebraska and Kansas, central Great Plains, U.S.A.: Quaternary Science Reviews, v. 12, p. 179188.

\#1858 Marvinney, R.G., 1991, Preliminary structural investigation of a $25 \mathrm{~km}$ topographic lineament in central Maine: Geological Society of America Abstracts with Programs, v. 23, no. 1, p. 99.

\#3680 Mastroianni, J.J., and Norman, C.E., 1992, A study of active fault movement, Houston, Texas and vicinity: Geological Society of America Abstracts with Programs, v. 24, no. 1, p. 18. 
\#2836 McBride, J.H., Sargent, M.L., and Potter, C.J., 1996, Investigating possible earthquakerelated structure beneath the southern Illinois basin from seismic reflection: Seismological Research Letters, v. 67, no. 4, p. 641-649.

\#1969 McCartan, L., Weems, R.E., and Lemon, E.M., Jr., 1990, Quaternary stratigraphy in the vicinity of Charleston, South Carolina, and its relationship to local seismicity and regional tectonism, in Studies related to the Charleston, South Carolina, earthquake of 1886-Neogene and Quaternary lithostratigraphy and biostratigraphy: U.S. Geological Survey Professional Paper 1367-A, p. 39.

\#660 McConnell, D.A., 1989, Determination of offset across the northern margin of the Wichita uplift, southwest Oklahoma: Geological Society of America Bulletin, v. 101, p. 13171332.

\#2210 McCulloh, R.P., 1991, Surface faults in East Baton Rouge Parish: Louisiana Geological Survey Open-File Series No. 96-01, 25 p., 5 plates, scale 1:24,000.

\#2211 McCulloh, R.P., 1996, Topographic criteria bearing on the interpreted placement of the traces of faults of the Baton Rouge system in relation to their fault-line scarps: Louisiana Geological Survey Open-File Series No. 96-01, 13 p.

\#2253 McCulloh, R.P., and Autin, W.J., 1991, Revised mapping of surface faults, East Baton Rouge Parish, Louisiana: Transactions of the Gulf Coast Association of Geological Societies, v. 41, p. 473-474.

\#1974 McDowell, R.C., and Schultz, A.P., 1990, Structural and stratigraphic framework of the Giles County area, a part of the Appalachian Basin of Virginia and West Virginia, in Evolution of sedimentary basins-Appalachian Basin: U.S. Geological Survey Bulletin 1839, p. E1-E24, 1 pl., scale 1:125,000.

\#693 McDowell, R.C., Grabowski, G.J., Jr., and Moore, S.L., 1981, Geologic map of Kentucky: U.S. Geological Survey in cooperation with The Eleventh Kentucky Geological Survey, 4 sheets, scale 1:250,000.

\#1859 McFall, G.H., 1993, Structural elements and neotectonics of Prince Edward County, southern Ontario: Géographie physique et Quaternaire, v. 47, p. 303-312.

\#709 McKeown, F.A., 1982, Overview and discussion, in McKeown, F.A., and Pakiser, L.C., eds., Investigations of the New Madrid, Missouri, earthquake region: U.S. Geological Survey Professional Paper 1236, p. 1-14.

\#3900 McNulty, W.E., and Obermeier, S.F., 1997, Liquefaction evidence for Holocene paleoearthquakes in central and southwestern Illinois: Eos, Transactions of the American Geophysical Union, v. 78, no. 17, p. S316.

\#3901 McNulty, W.E., and Obermeier, S.F., 1997, Liquefaction evidence for two Holocene paleo-earthquakes in central and southwestern Illinois: U.S. Geological Survey OpenFile Report 97-435, 22 p.

\#3906 McNulty, W.E., and Obermeier, S.F., 1999, Liquefaction evidence for at least two strong Holocene paleo-earthquakes in central and southwestern Illinois, USA: Environmental \& Engineering Geoscience, v. 5, no. 2, p. 133-146.

\#1860 Meglis, I.L., Engelder, T., and Graham, E.K., 1991, The effect of stress-relief on ambient microcrack porosity in core samples from the Kent Cliffs (New York) and Moodus (Connecticut) scientific research boreholes: Tectonophysics, v. 186, p. 163-173. 
\#2249 Mehlhop, A.M., 1996, Extensional structures along the Allegheny Front in Virginia and West Virginia near the Giles County seismic zone: University of North Carolina at Chapel Hill, unpublished M.S. thesis, 91 p.

\#1861 Mehlhop, A.M., Dennison, J.M., and Stewart, K.G., 1996, Extensional structures along the Allegheny Front in Virginia and West Virginia near the Giles County seismic zone: Geological Society of America Abstracts with Programs, v. 28, no. 7, p. A-239.

\#1971 Meisler, H., and Becher, A.E., 1967, Hydrogeologic significance of calcium-magnesium ratios in ground water from carbonate rocks in the Lancaster quadrangle, southeastern Pennsylvania, in Geological Survey research 1967: U.S. Geological Survey Professional Paper 575, p. C232-C235.

\#1975 Meisler, H., and Becher, A.E., 1968, Carbonate rocks of Cambrian and Ordovician age in the Lancaster quadrangle, Pennsylvania, in Contributions to stratigraphy, 1967: U.S. Geological Survey Bulletin 1254-G, p. G1-G14.

\#2015 Meisler, H., and Becher, A.E., 1971, Hydrogeology of the carbonate rocks of the Lancaster 15-minute quadrangle, southeastern Pennsylvania: Pennsylvania Topographic and Geologic Survey, Fourth Series, Bulletin W26, 149 p., 2 pls., scale 1:24,000.

\#2212 Meloy, D.U., and Zimmerman, R.K., 1997, Potential seismic risk associated with Louisiana wrench faulting: Louisiana Geological Survey Open-File Series No. 97-01, $38 \mathrm{p}$.

\#2047 Merguerian, C., and Sanders, J.E., 1996, Diversion of the Bronx River in New York City; evidence for postglacial surface faulting?, in Geology of Long Island and metropolitan New York: Stony Brook, State University of New York at Stony Brook, Long Island Geologists, p. 131-145.

\#1862 Merguerian, C., and Sanders, J.E., 1997, Bronx River diversion-Neotectonic implications: International Journal of Rock Mechanics and Mining Sciences, v. 34, no. 3-4, paper no. 198.

\#2064 Metzger, A.G., and Johnston, A.C., 1994, The stable continental region seismicity database, in Schneider, J.F., ed., The earthquakes of stable continental regions-V. 3 and 4, Appendix F, Seismicity data sheets: Technical report to Electric Power Research Institute TR-102261-V2 and V3, Palo Alto, California, December 1994, 1656 p.

\#664 Miller, R.D., Steeples, D.W., and Myers, P.B., 1990, Shallow seismic reflection survey across the Meers fault, Oklahoma: Geological Society of America Bulletin, v. 102, p. $18-25$.

\#1981 Mills, H.H., 1985, Descriptions of backhoe trenches dug on New River terraces between Radford and Pearisburg, Virginia, June, 1981: U.S. Geological Survey Open-File Report $85-474,63 \mathrm{p}$.

\#1863 Mills, H.H., 1986, Possible differential uplift of New River terraces in southwestern Virginia: Neotectonics, v. 1, p. 75-86.

\#1864 Mills, H.H., 1994, Distribution of high-level gravels along the course of the New River in southwestern Virginia-Implications for neotectonics: Geological Society of America Abstracts with Programs, v. 26, no. 4, p. 56.

\#1865 Mills, H.H., and Bartholomew, M.J., 1986, Evolution of the course of the New River in southwest Virginia-Some interpretations based on distribution of high-level gravels in Giles, Montgomery, Pulaski, and Floyd Counties: Geological Society of America Abstracts with Programs, v. 18, no. 3, p. 255. 
\#1866 Mitronovas, W., 1981, Seismicity in the upper Hudson Valley [abs.]: Earthquake Notes, v. 52, p. 21-22.

\#3963 Mueller, K., Champion, J., Guccione, M., and Kelson, K., 1999, Fault slip rates in the modern New Madrid seismic zone: Science, v. 286, p. 1135-1138.

\#1867 Munsey, J.W., and Bollinger, G.A., 1985, Focal mechanism analyses for Virginia earthquakes (1978-1984): Bulletin of the Seismological Society of America, v. 75, p. 16131636.

\#2838 Munson, P.J., and Munson, C.A., 1996, Paleoliquefaction evidence for recurrent strong earthquakes since 20,000 yr BP in the Wabash Valley area of Indiana: U.S. Geological Survey Final Report, 137 p.

\#697 Munson, P.J., Munson, C.A., Bleuer, N.K., and Labitzke, M.D., 1992, Distribution and dating of prehistoric earthquake liquefaction in the Wabash Valley of the Central U.S., in Johnston, A.C., Shedlock, K.M., Herrmann, R.B., and Hopper, M.G., eds., New Madrid special issue: Seismological Research Letters, v. 63, p. 337-342.

\#2839 Munson, P.J., Obermeier, S.F., Munson, C.A., and Hajic, E.R., 1997, Liquefaction evidence for Holocene and latest Pleistocene seismicity in the southern halves of Indiana and Illinois-A preliminary overview: Seismological Research Letters, v. 68, no. 4, p. 521-536.

\#1868 Nábelek, J., and Suárez, G., 1989, The 1983 Goodnow earthquake in the central Adirondacks, New York-Rupture of a simple, circular crack: Bulletin of the Seismological Society of America, v. 79, p. 1762-1777.

\#1995 Nelson, R.H., 1991, Salt tectonics and listric-normal faulting, in Salvador, A., ed., The Gulf of Mexico basin: Boulder, Colorado, Geological Society of America, The Geology of North America, v. J, p. 73-89.

\#1869 Nelson, S., 1980, Determination of Holocene fault movement along the Ramapo fault in southeastern New York using pollen stratigraphy: Geological Society of America Abstracts with Programs, v. 12, no. 2, p. 75.

\#2213 Nelson, W.A., 1962, Geology and mineral resources of Albermarle County: Virginia Division of Mineral Resources Bulletin 77, scale 1:62,500.

\#3887 Nelson, W.J., 1991, Structural styles of the Illinois Basin, in Leighton, M.W., Kolata, D.R., Oltz, D.F., and Eidel, J.J., eds., Interior cratonic basins: Tulsa, Oklahoma, The American Association of Petroleum Geologists, Memoir 51, p. 209-243.

\#1984 Nelson, W.J., 1995, Structural features in Illinois: Illinois State Geological Survey Bulletin 100, 144 p., 2 pls.

\#3898 Nelson, W.J., 1996, Geologic map of the Reevesville quadrangle, Illinois: Illinois Geologic Quadrangle Map IGQ-18, 1 sheet, scale 1:24,000.

\#2837 Nelson, W.J., 1996, Late Tertiary/Quaternary tectonism in southernmost Illinois [abs]: Seismological Research Letters, v. 67, no. 2, p. 48.

\#3889 Nelson, W.J., Denny, B.F., Follmer, L.R., and Masters, J.M., 1999, Quaternary grabens in southernmost Illinois-Deformation near an active intraplate seismic zone: Tectonophysics, v. 305, p. 381-397.

\#3888 Nelson, W.J., Denny, F.B., Devera, J.A., Follmer, L.R., and Masters, J.M., 1997, Tertiary and Quaternary tectonic faulting in southernmost Illinois: Engineering Geology, v. 46, p. 235-258.

\#3890 Nelson, W.J., Harrison, R.W., and Hoffman, D., 1999, Neotectonics of the northern Mississippi embayment: Illinois State Geological Survey Guidebook 30, 34 p. 
\#3964 Newman, A., Stein, S., Weber, J., Engeln, J., Mao, A., and Dixon, T., 1999, Slow deformation and lower seismic hazard at the New Madrid seismic zone: Science, v. 284, p. 619-621.

\#1985 Newman, W.A., 1979, The possibility of Pleistocene-Holocene movement along the Oak Bay fault on the Maine-New Brunswick border: Maine Geological Survey Open-File Report No. 79-20, 7 p.

\#1870 Newman, W.S., Cinquemani, L.J., Sperling, J.A., Marcus, L.F., and Pardi, R.R., 1983, Holocene neotectonics of the lower Hudson Valley: Geological Society of America Abstracts with Programs, v. 15, no. 3, p. 148.

\#2016 Newman, W.S., Cinquemani, L.J., Sperling, J.A., Marcus, L.F., and Pardi, R.R., 1987, Holocene neotectonics and the Ramapo fault zone sea-level anomaly-A study of varying marine transgression rates in the lower Hudson estuary, New York and New Jersey, in Nummedal, D., Pilkey, O.H., and Howard, J.D., eds., Sea-level fluctuation and coastal evolution: Society of Economic Paleontologists and Mineralogists Special Publication 41, p. 97-111.

\#2802 Nichols, T.C., Jr., and Collins, D.S., 1987, Recent faulting in the Pierre Shale near Pierre, South Dakota: Geological Society of America Abstracts with Programs, v. 19, no. 5, p. 323-324.

\#2803 Nichols, T.C., Jr., Collins, D.S., Jones-Cecil, M., and Swolfs, H.S., 1994, Faults and structure in the Pierre Shale, central South Dakota, in Shurr, G.W., Ludvigson, G.A., and Hammond, R.H., eds., Perspectives on the eastern margin of the Cretaceous western interior basin: Geological Society of America Special Paper 287, p. 211-235.

\#2214 Nicholson, C., Roeloffs, E., and Wesson, R.L., 1988, The northeastern Ohio earthquake of 31 January 1986-Was it induced?: Bulletin of the Seismological Society of America, v. 78 , p. $188-217$.

\#2829 Niemi, T.M., Abers, G.A., and Ferris, A.N., 1998, Paleoliquefaction and seismic potential along the Nemaha ridge and Humboldt fault, eastern Kansas-Preliminary results: Eos, Transactions of the American Geophysical Union, v. 79, no. 17, p. S340-S341.

\#1938 Noger, M.C., compiler, 1988, Geologic map of Kentucky: U. S. Geological Survey and Kentucky Geological Survey, 1 sheet, scale 1:500,000.

\#2215 Nunn, J.A., 1985, State of stress in the northern Gulf Coast: Geology, v. 13, p. 429-432.

\#756 Nuttli, O.W., 1979, Seismicity of the Central United States, in Hatheway, A.W., and McClure, C.R., Jr., eds., Geology in the siting of nuclear power plants: Geological Society of America Reviews in Engineering Geology, v. 4, p. 67-93.

\#2216 Oaks, S.D., and Bollinger, G.A., 1986, The epicenter of the $\mathrm{m}_{\mathrm{b}}$, December 22, 1875 Virginia earthquake-New finds from documentary sources: Earthquake Notes, v. 57, no. 3, p. 65-75.

\#1983 Obermeier, S., 1995, Paleoseismic liquefaction studies-Central U.S. and Pacific northwestern U.S., in Jacobson, M.L., ed., National earthquake hazards reduction program annual project summaries-XXXVI, v.2: U.S. Geological Survey Open-File Report 95210, p. 606-609.

\#3813 Obermeier, S.F., 1988, Liquefaction potential in the central Mississippi Valley: U.S. Geological Survey Bulletin 1832, p. 21.

\#3903 Obermeier, S.F., 1996, Seismically induced paleoliquefaction features in southern half of Illinois: Seismological Research Letters, v. 67, no. 2, p. 49. 
\#2256 Obermeier, S.F., 1996, Use of liquefaction-induced features for paleoseismic analysis-An overview of how seismic liquefaction features can be distinguished from other features and how their regional distribution and properties of source sediment can be used to infer the location and strength of Holocene paleo-earthquakes: Engineering Geology, v. 44, p. 1-76.

\#2048 Obermeier, S.F., 1996, Using liquefaction-induced features for paleoseismic analysis, in McCalpin, J.P., ed., Paleoseismology: San Diego, Academic Press, p. 331-396.

\#2840 Obermeier, S.F., 1997, Overview of liquefaction evidence for strong earthquakes of Holocene and latest Pleistocene ages in southern Indiana and Illinois: U.S. Geological Survey Open-File Report 96-724, 39 p.

\#3902 Obermeier, S.F., 1998, Liquefaction evidence for strong earthquakes of Holocene and latest Pleistocene ages in the states of Indiana and Illinois, USA: Engineering Geology, v. 50, p. 227-254.

\#1872 Obermeier, S.F., and McNulty, W.E., 1998, Paleoliquefaction evidence for seismic quiescence in central Virginia during late and middle Holocene time [abs.]: Eos, Transactions of the American Geophysical Union, v. 79, no. 17, p. S342.

\#601 Obermeier, S.F., Bleuer, N.R., Munson, C.A., Munson, P.J., Martin, W.S., McWilliams, K.M., Tabaczynski, D.A., Odum, J.K., Rubin, M., and Eggert, D.L., 1991, Evidence of strong earthquake shaking in the lower Wabash Valley from prehistoric liquefaction features: Science, v. 251, p. 1061-1063.

\#1871 Obermeier, S.F., Gohn, G.S., Weems, R.E., Gelinas, R.L., and Rubin, M., 1985, Geologic evidence for recurrent moderate to large earthquakes near Charleston, South Carolina: Science, v. 227, p. 408-411.

\#717 Obermeier, S.F., Jacobson, R.B., Smoot, J.P., Weems, R.E., Gohn, G.S., Monroe, J.E., and Powars, D.S., 1990, Earthquake-induced liquefaction features in the coastal setting of South Carolina and in the fluvial setting of the New Madrid seismic zone: U.S. Geological Survey Professional Paper 1504, 44 p., 1 plate.

\#704 Obermeier, S.F., Martin, J.R., Frankel, A.D., Youd, T.L., Munson, P.J., Munson, C.A., and Pond, E.C., 1993, Liquefaction evidence for one or more strong Holocene earthquakes in the Wabash Valley of southern Indiana and Illinois, with a preliminary estimate of magnitude: U.S. Geological Survey Professional Paper 1536, 27 p.

\#2841 Obermeier, S.F., Martin, J.R., Frankel, T.L., Munson, P.J., Munson, C.A., and Pond, E.C., 1993, Liquefaction evidence for one or more strong Holocene earthquakes in the Wabash Valley of southern Indiana and Illinois-U.S. estimated magnitudes and accelerations associated with prehistoric earthquakes in the Wabash Valley region of the Central United States: Seismological Research Letters, v. 68, no. 4, p. 611-623.

\#698 Obermeier, S.F., Munson, P.J., Munson, C.A., Martin, J.R., Frankel, A.D., Youd, T.L., and Pond, E.C., 1992, Liquefaction evidence for strong Holocene earthquake(s) in the Wabash Valley of Indiana-Illinois, in Johnston, A.C., Shedlock, K.M., Herrmann, R.B., and Hopper, M.G., eds., New Madrid special issue: Seismological Research Letters, v. 63, p. 321-335.

\#2050 Obermeier, S.F., Weems, B.E., and Jacobson, R.B., 1987, Earthquake-induced liquefaction features in the coastal South Carolina region, in Jacob, K.H., ed., Proceedings from the symposium on seismic hazards, ground motions, soil-liquefaction and engineering practice in eastern North America: National Center for Earthquake Engineering Research Technical Report NCEER-87-0025, p. 480-493. 
\#2218 Obermeier, S.F., Weems, R.E., Jacobson, R.B., and Gohn, G.S., 1989, Liquefaction evidence for repeated Holocene earthquakes in the coastal region of South Carolina, in Jacob, K.H., and Turkstra, C.J., eds., Earthquake hazards and the design of constructed facilities in the eastern United States: Annals of the New York Academy of Sciences, v. 558, p. 183-195.

\#2219 Oliver, J., Johnson, T., and Dorman, J., 1970, Postglacial faulting and seismicity in New York and Quebec: Canadian Journal of Earth Sciences, v. 7, p. 579-590.

\#3681 O'Neil, M.W., and Van Siclen, D.C., 1984, Activation of Gulf Coast faults by depressuring of aquifers and an engineering approach to siting structures along their traces: Bulletin of the Association of Engineering Geologists, v. 21, no. 1, p. 73-87.

\#1940 Osberg, P.H., Arthur, H.M., and Boone, G.M., eds., 1985, Bedrock geologic map of Maine: Maine Geological Survey, 1 pl., scale 1:500,000.

\#3934 Owens, J.P., 1970, Post-Triassic tectonic movements in the central and southern Appalachians as recorded by sediments of the Atlantic Coastal Plain, in Fisher, G.W., Pettijohn, F.J., Reed, J.C., Jr., and Weaver, K.N., eds., Studies of Appalachian geologyCentral and southern: New York, John Wiley and Sons, p. 417-427.

\#3935 Owens, J.P., 1989, Geologic map of the Cape Fear region, Florence $1^{\circ} \times 2^{\circ}$ quadrangle and northern half of the Georgetown $1^{\circ} \times 2^{\circ}$ quadrangle, North Carolina and South Carolina: U.S. Geological Survey Miscellaneous Investigations Map I-1948-A, 2 sheets, scale 1:250,000.

\#2220 Owens, J.P., Sugarman, P.J., Sohl, N.F., Parker, R.A., Houghton, H.F., Volkert, R.A., Drake, A.A., Jr., and Orndorff, R.C., 1995, Geologic map of New Jersey-Central sheet: U.S. Geological Survey Open-File Report 95-0253, 60 p., 3 pls., scale 1:100,000.

\#1873 Page, R.A., Molnar, P.H., and Oliver, J., 1968, Seismicity in the vicinity of the Ramapo fault, New Jersey-New York: Bulletin of the Seismological Society of America, v. 58, p. 681-687.

\#2257 Parker, R.A., and Houghton, H.F., 1990, Bedrock geologic map of the Monmouth Junction quadrangle, New Jersey: U.S. Geological Survey Open-File Report 90-219, 1 pl., scale 1:24,000.

\#1874 Parrish, J., 1989, Mapping fractures in Lancaster County, PA, using magnetics, soil-gas radon and LANDSAT TM data: Geological Society of America Abstracts with Programs, v. 21, no. 6, p. A372.

\#2068 Parrish, J., Harding, T., and Etter, K., 1988, Remote sensing of the Lancaster Co., PA, fault zone [abs.], in Proceedings of the Sixth Thematic Conference on Remote Sensing for Exploration Geology, v. II: Ann Arbor, Environmental Research Institute of Michigan, p. 687.

\#2017 Pavlides, L., 1987, Mountain Run fault zone of Virginia, in Jacobson, M.L., and Rodriguez, T.R., eds., National Earthquake Hazards Reduction Program summaries of technical reports, v. XXIII: U.S. Geological Survey Open-File Report 87-63, p. 93-94.

\#1973 Pavlides, L., 1994, Continental margin deposits and the Mountain Run fault zone of Virginia-Stratigraphy and tectonics, in Drake, A.A., and Pavlides, L., eds., Stratigraphic notes, 1993: U.S. Geological Survey Bulletin 2076, p. B1-B9.

\#1875 Pavlides, L., Bobyarchick, A.R., Newell, W.L., and Pavich, M.J., 1983, Late Cenozoic faulting along the Mountain Run fault zone, central Virginia Piedmont: Geological Society of America Abstracts with Programs, v. 15, no. 2, p. 55. 
\#1878 Peavy, S.T., and Sayer, S., 1998, Analysis of a possible neotectonic feature in SW Virginia using potential field attributes (PFA): Geological Society of America Abstracts with Programs, v. 30, no. 1, p. 66.

\#1876 Pennington, W.D., Davis, S.D., Carlson, S.M., DuPree, J., and Ewing, T.E., 1986, The evolution of seismic barriers and asperities caused by the depressuring of fault planes in oil and gas fields of south Texas: Bulletin of the Seismological Society of America, v. 76, p. 939-948.

\#2051 Pomeroy, P.W., Nowak, T.A., Jr., and Fakundiny, R.H., undated, Clarendon-Linden fault system of western New York-A Vibroseis(r) seismic study: New York State Geological Survey Open-File Report, 66 p.

\#1363 Pond, E.C., and Martin, J.R., 1997, Estimated magnitudes and accelerations associated with prehistoric earthquakes in the Wabash Valley region of the Central United States: Seismological Research Letters, v. 68, p. 611-623.

\#3892 Potter, C.J., Goldhaber, M.B., and Heigold, P.C., 1995, Structure of the Reelfoot-Rough Creek Rift System, Fluorspar Area Fault Complex, and Hicks Dome, southern Illinois and western Kentucky-New constraints from regional seismic reflection data, in Shedlock, K.M., and Johnston, A.C., eds., Investigations of the New Madrid Seismic Zone: U.S. Geological Survey Professional Paper 1539-Q, p. 19, 1 plate.

\#3682 Pratt, W.E., and Johnson, D.W., 1926, Local subsidence of the Goose Creek Oil Field: Journal of Geology, v. 34, no. 7, p. 577-590.

\#1951 Prowell, D.C., 1983, Index of faults of Cretaceous and Cenozoic age in the Eastern United States: U.S. Geological Survey Miscellaneous Field Studies Map MF-1269, 2 sheets, scale 1:2,500,000.

\#1993 Prowell, D.C., 1988, Cretaceous and Cenozoic tectonism on the Atlantic coastal margin, in Sheridan, R.E., and Grow, J.A., eds., The Atlantic continental margin, U.S.: Boulder, Colorado, Geological Society of America, The Geology of North America, v. I-2, p. 557-564.

\#1939 Prowell, D.C., 1996, Geologic map of the Savannah River Site, Aiken, Allendale, and Barnwell Counties, South Carolina: U.S. Geological Survey Miscellaneous Field Studies Map MF-2300, 7 p. pamphlet, 1 sheet, scale 1:48,000.

\#3936 Prowell, D.C., and Obermeier, S.F., 1991, Evidence of Cenozoic tectonism, in Horton, J.W., Jr., and Zullo, V.A., eds., The geology of the Carolinas: Knoxville, Tennessee, University of Tennessee Press, p. 309-318.

\#1877 Prowell, D.C., and O'Connor, B.J., 1978, Belair fault zone-Evidence of Tertiary fault displacement in eastern Georgia: Geology, v. 6, p. 681-684.

\#2251 Prowell, D.C., O'Connor, B.J., and Rubin, M., 1975, Preliminary evidence for Holocene movement along the Belair fault zone near Augusta, Georgia: U.S. Geological Survey Open-File Report 75-680, 20 p.

\#3793 Pujol, J., Herrmann, R., Chiu, S.-C., and Chiu, J.-M., 1998, Constrained joint location of New Madrid seismic zone earthquakes: Seismological Research Letters, v. 69, p. 56-68.

\#1879 Quinn, A.W., 1933, Normal faults of the Lake Champlain region: Journal of Geology, v. 41, p. 113-143.

\#1880 Quittmeyer, R., Mrotek, K., Naumoff, P., and Statton, C.T., 1989, The 1987 earthquake swarm at Moodus, CT and its relation to the tectonic stress field measured by borehole testing: Geological Society of America Abstracts with Programs, v. 21, no. 2, p. 59. 
\#1881 Quittmeyer, R.C., Statton, C.T., Mrotek, K.A., and Houlday, M., 1985, Possible implications of recent microearthquakes in southern New York State: Earthquake Notes, v. 56, p. $35-42$.

\#1882 Rajendran, C.P., and Talwani, P., 1993, Paleoseismic indicators near Bluffton, South Carolina-An appraisal of their tectonic implications: Geology, v. 21, p. 987-990.

\#665 Ramelli, A.R., and Slemmons, D.B., 1990, Implications of the Meers fault on seismic potential in the Central United States, in Krinitzsky, E.L., and Slemmons, D.B., eds., Neotectonics in earthquake evaluation: Geological Society of America Reviews in Engineering Geology, v. 8, p. 59-75.

\#668 Ramelli, A.R., Slemmons, D.B., and Brocoum, S.J., 1987, The Meers fault-Tectonic activity in southwestern Oklahoma: U.S. Nuclear Regulatory Commission NUREG/CR4852, 25 p.

\#1970 Rankin, D.W., ed., 1977, Studies related to the Charleston, South Carolina, earthquake of 1886-A preliminary report: U.S. Geological Survey Professional Paper 1028, 204 p.

\#1883 Ratcliffe, N.M., 1971, The Ramapo fault system in New York and adjacent northern New Jersey-A case of tectonic heredity: Geological Society of America Bulletin, v. 82, p. 125-142.

\#2052 Ratcliffe, N.M., 1980, Brittle faults (Ramapo fault) and phyllonitic ductile shear zones in the basement rocks of the Ramapo seismic zones New York and New Jersey, and their relationship to current seismicity, in Manspeizer, W., ed. Field studies of New Jersey geology and guide to field trips: Newark, New Jersey, Rutgers University, Geology Department, New York State Geological Association, 52nd annual meeting, October 10, 1980, Guidebook, p. 278-312.

\#1941 Ratcliffe, N.M., 1982, Results of core drilling of the Ramapo fault at Sky Meadow Road, Rockland County, New York, and assessment of evidence for reactivation to produce current seismicity: U.S. Geological Survey Miscellaneous Investigations Map I-1401, 1 sheet.

\#2221 Ratcliffe, N.M., 1982, Tectonic versus frost-wedging origin of faulted glacially polished surfaces in the lower Hudson River Valley area: Geological Society of America Abstracts with Programs, v. 14, no. 1,2, p. 76.

\#1972 Ratcliffe, N.M., 1992, Bedrock geology and seismotectonics of the Oscawana Lake quadrangle, New York: U.S. Geological Survey Bulletin 1941, 38 p., 1 pl., scale $1: 24,000$.

\#1884 Ratcliffe, N.M., and Burton, W.C., 1984, Brittle fault fabrics, mineraology and geometry of border faults of the Newark basin, N.Y.-N.J., from drill-core information: Geological Society of America Abstracts with Programs, v. 16, no. 1, p. 57.

\#1976 Ratcliffe, N.M., and Burton, W.C., 1985, Fault reactivation models for origin of the Newark basin and studies related to Eastern U.S. seismicity, in Robinson, G.R., Jr., and Froelich, A.J., eds., Proceedings of the Second U.S. Geological Survey workshop on the early Mesozoic basins of the Eastern United States: U.S. Geological Survey Circular 946, p. 36-42.

\#2018 Ratcliffe, N.M., and Costain, J.K., 1985, Northeastern seismicity and tectonics, in Jacobson, M.L., and Rodriguez, T.R., eds., National Earthquake Hazards Reduction Program summaries of technical reports, v. XX: U.S. Geological Survey Open-File Report 85-464, p. 54-58. 
\#1943 Ratcliffe, N.M., Burton, W.C., and Pavich, M.J., 1990, Orientation, movement history, and cataclastic rocks of Ramapo fault based on core drilling and trenching along the western margin of the Newark basin near Berndardsville, New Jersey: U.S. Geological Survey Miscellaneous Investigations Map I-1982, 1 sheet.

\#2222 Ratcliffe, N.M., Burton, W.C., D'Angelo, R.M., and Costain, J.K., 1986, Low-angle extensional faulting, reactivated mylonites and seismic reflection geometry of the Newark basin in eastern Pennsylvania: Geology, v. 14, p. 766-770.

\#1886 Rhea, S., 1989, Evidence of uplift near Charleston, South Carolina: Geology, v. 17, p. 311-315.

\#3919 Rhea, S., and Wheeler, R.L., 1994, Map showing large structures interpreted from geophysical data in the vicinity of New Madrid, Missouri: U.S. Geological Survey Miscellaneous Field Studies Map MF-2264-B, 1 sheet, scale 1:250,000.

\#1980 Rhea, S., compiler, 1997, Seismotectonic maps in the vicinity of the lower Wabash Valley, Illinois, Indiana, and Kentucky-Digital spatial database: U.S. Geological Survey Open-File Report 97-681, 15 p.

\#3814 Rhea, S.B., Wheeler, R.L., and Tarr, A.C., 1994, Map showing seismicity and sandblows in the vicinity of New Madrid, Missouri: U.S. Geological Survey Miscellaneous Field Studies Map MF-2264-A, scale 1:250,000.

\#1887 Robinson, E.S., Sayer, S., Phinney, E.J., and Law, R.D., 1994, A geophysical survey of faulted alluvial 'terrace' deposits near Pembroke, Virginia: Geological Society of America Abstracts with Programs, v. 26, no. 4, p. 59-60.

\#2223 Robinson, P., and Luttrell, G.W., 1985, Revision of some stratigraphic names in central Massachusetts: U.S. Geological Survey Bulletin 1605-A, 78 p.

\#716 Rodbell, D.T., and Schweig, E.S., III, 1993, The record of seismically induced liquefaction on late Quaternary terraces in northwestern Tennessee: Bulletin of the Seismological Society of America, v. 83, p. 269-278.

\#1944 Rodgers, J., compiler, 1985, Bedrock geologic map of Connecticut: Connecticut Geological and Natural History Survey and U.S. Geological Survey, 2 sheets, scale $1: 125,000$.

\#3893 Ross, C.A., 1963, Structural framework of southernmost Illinois: Illinois State Geological Survey Circular 351, 28 p.

\#3894 Ross, C.A., 1964, Geology of the Paducah and Smithland quadrangles in Illinois: Illinois State Geological Survey Circular 360, 32 p., 1 plate, scale 1:62,500.

\#1888 Roy, D.C., 1996, A paleoseismic investigation of the Dover-Foxcroft area, central Maine: Geological Society of America Abstracts with Programs, v. 28, no. 3, p. 95.

\#3684 Ruhl, J.H., and Norman, C.E., 1992, Identification, geometry, and movement history of active surface faults in Fort Bend County, Texas: Geological Society of America Abstracts with Programs, v. 24, no. 1, p. 44.

\#753 Russ, D.P., 1979, Late Holocene faulting and earthquake recurrence in the Reelfoot Lake area, northwest Tennessee: Geological Society of America Bulletin, v. 90, p. 10131018.

\#722 Russ, D.P., 1982, Style and significance of surface deformation in the vicinity of New Madrid, Missouri, in McKeown, F.A., and Pakiser, L.C., eds., Investigations of the New Madrid, Missouri, earthquake region: U.S. Geological Survey Professional Paper 1236H, p. 95-114. 
\#1815 Ryden, A.L., Jr., 1932, Faults and joints in the Coastal Plain of Maryland: Journal of the Washington Academy of Sciences, v. 22, p. 469-472.

\#2807 Salvador, A., 1991, Origin and development of the Gulf of Mexico basin, in Salvador, A., ed., The Gulf of Mexico basin: Geological Society of America, The Geology of North America, v. J, p. 389-444.

\#2019 Salvador, A., compiler, 1991, Cross sections of the Gulf of Mexico basin, in Salvador, A., ed., The Gulf of Mexico basin: Boulder, Colorado, Geological Society of America, The Geology of North America, v. J, plate 6.

\#2020 Salvador, A., compiler, 1991, Structure at the base and subcrop below Mesozoic marine section, Gulf of Mexico basin, in Salvador, A., ed., The Gulf of Mexico basin: Boulder, Colorado, Geological Society of America, The Geology of North America, v. J, plate 3, scale 1:2,500,000.

\#711 Saucier, R.T., 1991, Geoarchaeological evidence of strong prehistoric earthquakes in the New Madrid (Missouri) seismic zone: Geology, v. 19, p. 296-298.

\#2021 Saucier, R.T., and Snead, J.I., 1991, Quaternary geology of the Lower Mississippi Valley, in Morrison, R.B., ed., Quaternary nonglacial geology; conterminous U.S.: Boulder, Colorado, Geological Society of America, The Geology of North America, v. K-2, plate 6 , scale $1: 1,000,000$.

\#3685 Sawyer, D.S., Buffler, R.T., and Pilger, R.H., Jr., 1991, The crust under the Gulf of Mexico basin, in Salvador, A., ed., The Gulf of Mexico Basin: Boulder, Colorado, Geological Society of America, The Geology of North America, v. J, p. 53-72.

\#1890 Schafer, J.P., Obermeier, S.F., and Stone, J.R., 1987, On the origin of wedge structures in southern New England: Geological Society of America Abstracts with Programs, v. 19, no. 1, p. 55.

\#1889 Scharnberger, C.K., and Howell, B.F., Jr., 1985, Intensities and structural setting of the earthquakes of 19 April and 23 April, 1984 Lancaster County, Pennsylvania: Earthquake Notes, v. 56, p. 43-46.

\#2817 Schumm, S.A., 1986, Alluvial river response to active tectonics, in Active tectonics: Washington, D. C., National Academy Press, p. 80-94.

\#2224 Schwab, W.C., Allison, M.A., Corso, W., Lotto, L.L., Butman, B., Buchholtz ten Brink, M., Denny, J.F., Danforth, W.W., and Foster, D.S., 1997, Initial results of high-resolution sea-floor mapping offshore of the New York-New Jersey metropolitan area using sidescan sonar: Northeastern Geology and Environmental Sciences, v. 19, no. 4, p. 243262.

\#2225 Schwab, W.C., Butman, B., Denny, J.F., Buchholtz ten Brink, M., Corso, W., Lotto, L., and Allison, M.A., 1997, High-resolution sea-floor mapping of the New York Bight apex-Sedimentary framework: Geological Society of America Abstracts with Programs, v. 29, no. 1, p. 77.

\#2226 Schwab, W.C., Corso, W., Allison, M.A., Butman, B., Denny, J.F., Lotto, L.L., Danforth, W.W., Foster, D.S., O'Brien, T.F., Nichols, D.A., Irwin, B.J., and Parolski, K.F., 1997, Mapping the sea floor geology offshore of the New York-New Jersey metropolitan area using sidescan sonar-Preliminary report: U.S. Geological Survey Open-File Report 9761,3 sheets.

\#1891 Schwartz, S.Y., and Christensen, D.H., 1988, The 12 July 1986 St. Marys, Ohio earthquake and recent seismicity in the Anna, Ohio seismogenic zone: Seismological Research Letters, v. 59, p. 57-62. 
\#725 Schweig, E.S., III, and Marple, R.T., 1991, Bootheel lineament-A possible coseismic fault of the great New Madrid earthquakes: Geology, v. 19, p. 1025-1028.

\#726 Schweig, E.S., III, Marple, R.T., and Li, Y., 1992, An update of studies of the Bootheel lineament in the New Madrid seismic zone, southeastern Missouri and northeastern Arkansas, in Johnston, A.C., Shedlock, K.M., Herrmann, R.B., and Hopper, M.G., eds., New Madrid special issue: Seismological Research Letters, v. 63, p. 277-284.

\#1141 Scott, G.R., 1970, Quaternary faulting and potential earthquakes in east-central Colorado: U.S. Geological Survey Professional Paper 700-C, C11-C18 p.

\#2735 Scott, G.R., Taylor, R.B., Epis, R.C., and Wobus, R.A., 1978, Geologic map of the Pueblo $1^{\circ}$ x $2^{\circ}$ quadrangle, south-central Colorado: U.S. Geological Survey Miscellaneous Geologic Investigations I-1022, 1:250,000.

\#2053 Seeber, L., 1987, Problems in intraplate seismogenesis and earthquake hazard, in Jacob, K.H., ed., Proceedings from the symposium on seismic hazards, ground motions, soilliquefaction and engineering practice in eastern North America: National Center for Earthquake Engineering Research Technical Report NCEER-87-0025, p. 143-162.

\#2054 Seeber, L., and Armbruster, J.G., 1986, A study of earthquake hazards in New York State and adjacent areas-Final report covering the period 1982-1985: U.S. Nuclear Regulatory Commission Report NUREG/CR-4750, 99 p.

\#2227 Seeber, L., and Armbruster, J.G., 1989, Low-displacement seismogenic faults and nonstationary seismicity in the eastern United States, in Jacob, K.H., and Turkstra, C.J., eds., Earthquake hazards and the design of constructed facilities in the eastern United States: Annals of the New York Academy of Science, v. 558, p. 21-39.

\#1892 Seeber, L., and Armbruster, J.G., 1993, Natural and induced seismicity in the Lake ErieLake Ontario region-Reactivatioin of ancient faults with little neotectonic displacement: Géographie physique et Quaternaire, v. 47, p. 363-378.

\#1894 Seeber, L., and Dawers, N., 1989, Characterization of an intraplate seismogenic fault in the Manhattan prong, Westchester Co., N.Y.: Seismological Research Letters, v. 60, p. 71-78.

\#1893 Seeber, L., Armbruster, J.G., and Kim, W.-Y., 1998, A quarry as the straw and stable continental crust as the camel's back-The Mblg4.6, 1994 Cacoosing earthquake in southeastern PA [abs.]: Eos, Transactions of the American Geophysical Union, v. 79, no. 17 (supplement), p. S339-340.

\#2228 Seeber, L., Armbruster, J.G., Kim, W.-Y., Barstow, N., and Scharnberger, C., 1998, The 1994 Cacoosing Valley earthquakes near Reading, Pennsylvania-A shallow rupture triggered by quarry unloading: Journal of Geophysical Research, v. 103, no. B10, p. 24,505-24,521.

\#2741 Sharps, J.A., 1976, Geologic map of the Lamar quadrangle, Colorado and Kansas: U.S. Geological Survey Miscellaneous Geologic Investigations I-944, scale 1:250,000.

\#1982 Shedlock, K.M., 1987, Earthquakes recorded by the South Carolina seismic network (1974-1986): U.S. Geological Survey Open-File Report 87-437, 92 p.

\#3686 Sheets, M.M., 1979, Oil fields and their relation to subsidence and active surface faulting in the Houston area: Houston, Texas, Houston Geological Society, 20 p.

\#3920 Shoemaker, M., Anderson, N., Vaughn, J.D., Hoffman, D., and Palmer, J.R., 1997, Dudley Ridge-Late Wisconsinan terrace of fault scarp?, in Palmer, J., Hoffman, D., Vaughn, J.D., and Harrison, R.W., eds., Late Quaternary faulting and earthquake lique- 
faction features in southeast Missouri-The identification of new earthquake hazards: Missouri Division of Geology and Land Survey Open File Report OFR-97-96-GS, Association of Missouri Geologist 43rd annual meeting and field trip, Cape Girardeau, Missouri, September 20-21, 1996, p. 13-22.

\#3955 Shoemaker, M., Vaughn, J.D., Anderson, N.L., Hoffman, D., and Palmer, J.R., 1998, A shallow high-resolution seismic reflection study of Dudley Ridge, south-east Missouri: Computers \& Geosciences, v. 23, no. 10, p. 1113-1120.

\#2813 Smith, H.T.U., 1940, Geological studies in southwestern Kansas: Bulletin of the University of Kansas, State Geological Survey of Kansas 34, 212 p.

\#1896 Snipes, D.S., Fallaw, W.C., Price, V., Jr., and Cumbest, R.J., 1993, The Pen Branch faultDocumentation of late Cretaceous-Tertiary faulting in the Coastal Plain of South Carolina: Southeastern Geology, v. 33, p. 195-218.

\#3938 Soller, D.R., 1987, Late Cenozoic tectonism of the Cape Fear Arch, central Atlantic Coastal Plain: Geological Society of America Abstracts with Programs, v. 19, no. 2, p. 130.

\#3937 Soller, D.R., 1988, Geology and tectonic history of the lower Cape Fear River Valley, southeastern North Carolina: U.S. Geological Survey Professional Paper 1466-A, 60 p., 1 plate, scale 1:250,000.

\#1897 Stanford, S.D., Jagel, D.L., and Hall, D.W., 1995, Possible Pliocene-Pleistocene movement on a reactivated Mesozoic fault in central New Jersey: Geological Society of America Abstracts with Programs, v. 27, no. 1, p. 83.

\#2832 Steeples, D.W., Bennett, B.C., Park, C., Miller, R.D., and Knapp, R.W., 1990, Microearthquakes in Kansas and Nebraska 1977-1989: U.S. Nuclear Regulatory Commission NUREG/CR-5629 RA, 14 p.

\#2831 Steeples, D.W., DuBois, S.M., and Wilson, F.W., 1979, Seismicity, faulting, and geophysical anomalies in Nemaha County, Kansas-Relationship to regional structures: Geology, v. 7, p. 134-138.

\#1898 Steinen, R.P., Shinn, E.A., and Halley, R.B., 1995, Hypothesized fault origin for the rock reefs of south Florida: Geological Society of America Abstracts with Programs, v. 27, no. 6 , p. A-229.

\#3954 Stephenson, W.J., Odum, J.K., Williams, R.A., Pratt, T.L., Harrison, R.W., and Hoffman, D., 1999, Deformation and Quaternary faulting in southeast Missouri across the Commerce geophysical lineament: Bulletin of the Seismological Society of America, v. 89 , no. 1, p. 140-155.

\#2055 Stewart, D.B., and Wones, D.R., 1974, Bedrock geology of northern Penobscot Bay area, in Osberg, P.H., ed., Geology of east-central and north-central Maine: New England Intercollegiate Geological Conference 64th guidebook, p. 223-239.

\#2056 Stickney, J.F., 1985, Investigation of recent movement along the Rough Creek fault system in Webster and McLean Counties, Kentucky: Richmond, Eastern Kentucky University, unpublished M.S. thesis, 95 p., 5 pls., scale 1:150.

\#1899 Stickney, J.F., Chadwick, D.L., and VanArsdale, R.B., 1984, Investigation of recent movement along the Rough Creek fault system in portions of Daviess, McLean, and Webster Counties, Kentucky: Geological Society of America Abstracts with Programs, v. 16, no. 3, p. 199. 
\#1900 Stieve, A., and Stephenson, D., 1995, Geophysical evidence for post late Cretaceous reactivation of basement structures in the central Savannah River area: Southeastern Geology, v. 35, p. 1-20.

\#2057 Stockar, D.V., 1989, Contemporary tectonics of the Lancaster, Pennsylvania seismic zone, in Alexander, S.S., Gold, D.P., Gardner, T.W., Slingerland, R.L., and Thornton, C.P., eds., Near-surface neotectonic deformation associated with seismicity in the northeastern United States: U.S. Nuclear Regulatory Commission Report NUREG/CR-5418, p. A1 - A204.

\#1987 Stone, B.M., and Ratcliffe, N.M., 1984, Faults in Pleistocene sediments at trace of Ramapo fault, in Geological Survey Research, fiscal year 1981: U.S. Geological Survey Professional Paper 1375, p. 49.

\#2229 Stone, J.R., and Ashley, G.M., 1992, Ice-wedge casts, pingo scars, and the drainage of glacial Lake Hitchcock, in Robinson, P., and Brady, J.B., eds., Guidebook for field trips in the Connecticut Valley region of Massachusetts and adjacent states, v. 2: Amherst, University of Massachusetts Department of Geology and Geography Contribution 66, New England Intercollegiate Geological Conference, 84th Annual Meeting, Amherst, Massachusetts, October 9-11, 1992, p. 305-331.

\#2230 Stose, G.W., 1924, New type of structure in the Appalachians: Bulletin of the Geological Society of America, v. 35, p. 465-480.

\#1945 Stose, G.W., and Ljungstedt, O.A., eds., 1931, Geologic map of Pennsylvania: Pennsylvania Topographic and Geologic Survey, 1 sheet, scale 1:380,160.

\#1986 Stover, C.W., and Coffman, J.L., 1993, Seismicity of the United States, 1568-1989 (revised): U.S. Geological Survey Professional Paper 1527, 418 p.

\#675 Swan, F.H., Wesling, J.R., Hanson, K.A., Kelson, K.I., and Perman, R.C., written commun. 1993, Draft report-Investigation of the Quaternary structural and tectonic character of the Meers fault (southwestern Oklahoma): Technical report to U.S. Nuclear Regulatory Commission, Washington, D.C., under Contract NRC-04-87-007, July 1993, 104 p., 3 pls.

\#2231 Swanson, M.T., 1992, Late Acadian-Alleghenian transpressional deformation-Evidence from asymmetric bondinage in the Casco Bay area, coastal Maine: Journal of Structural Geology, v. 14, p. 323-341.

\#2232 Swanson, M.T., 1993, The Casco Bay restraining bend on the Norumbega fault zone-A model for regional deformation in coastal Maine: Geological Society of America Abstracts with Programs, v. 25, no. 6, p. A-478.

\#2233 Swanson, M.T., 1994, Minimum dextral shear strain estimates in the Casco Bay area of coastal Maine from vein reorientation and elongation: Geological Society of America Abstracts with Programs, v. 26, no. 3, p. 75.

\#1901 Szabo, B.J., 1985, Uranium-series dating of fossil corals from marine sediments of southeastern United States Atlantic Coastal Plain: Geological Society of America Bulletin, v. 96, p. 398-406.

\#1946 Szabo, M.W., and Copeland, C.W., Jr., 1988, Geologic map of Alabama, southwest sheet: Geological Survey of Alabama Special Map 220, 1 sheet, scale 1:250,000.

\#2013 Talwani, P., 1990, Neotectonics in the southeastern United States with emphasis on the Charleston, South Carolina, area, in Krinitzsky, E.L., and Slemmons, D.B., eds., 
Neotectonics in earthquake evaluation: Geological Society of America Reviews in Engineering Geology, v. 8, p. 59-75.

\#1977 Talwani, P., 1994, Paleoseismological studies in South Carolina, in Prentice, C.S., Schwartz, D.P., and Yeats, R.S., eds., Proceedings of the workshop on paleoseismology, September 18-22, 1994, Marshall, California: U.S. Geological Survey Open-File Report 94-568, p. 180-181.

\#2234 Talwani, P., 1996, Prehistoric earthquakes in the South Carolina Coastal Plain: Geological Society of America Abstracts with Programs, v. 28, no. 7, p. A-283.

\#2235 Talwani, P., 1999, Fault geometry and earthquakes in continental interiors: Tectonophysics, v. 305, p. 371-379.

\#1902 Talwani, P., and Cox, J., 1985, Paleoseismic evidence for recurrence of earthquakes near Charleston, South Carolina: Science, v. 229, p. 379-381.

\#2236 Talwani, P., and Marple, R.T., 1997, Evidence of neotectonic activity in the South Carolina Coastal Plain, in Hong, Y., ed. Contemporary lithospheric motion/seismic geology: Utrecht, The Netherlands, VSP, International Geological Congress, 30th, Beijing, China, August 4-14, 1996, Proceedings, v. 5, p. 49-61.

\#2058 Talwani, P., Kellogg, J.N., and Trenkamp, R., 1997, Validation of tectonic models for an intraplate seismic zone, Charleston, South Carolina, with GPS geodetic data: U.S. Nuclear Regulatory Commission Report NUREG/CR-6529, 41 p.

\#1903 Talwani, P., Rawlins, J., and Stephenson, D., 1985, The Savannah River Plant, South Carolina, earthquake of June 9, 1985 and its tectonic setting: Earthquake Notes, v. 56, p. 101-106.

\#680 Tanner, J.H., III, 1967, Wrench fault movements along Washita Valley fault, Arbuckle Mountain area, Oklahoma: Bulletin of the American Association of Petroleum Geologists, v. 51, p. 126-141.

\#699 Taylor, K.B., Herrmann, R.B., Hamburger, M.W., Pavlis, G.L., Johnston, A., Langer, C., and Lam, C., 1989, The southeastern Illinois earthquake of 10 June 1987: Seismological Research Letters, v. 60, p. 101-110.

\#3688 Thomas, G.E., 1974, Lineament-block tectonics-Williston-Blood Creek Basin: Bulletin of the American Association of Petroleum Geologists, v. 58, no. 7, p. 1305-1322.

\#2237 Thomas, W.A., 1976, Evolution of Ouachita-Appalachian continental margin: Journal of Geology, v. 84, p. 323-342.

\#2808 Thomas, W.A., 1989, The Appalachian-Ouachita orogen beneath the Gulf Coastal Plain between the outcrops in the Appalachian and Ouachita Mountains, in Hatcher, R.D., Thomas, W.A., and Viele, G.W., eds., The Appalachian-Ouachita orogen in the United States: Geological Society of America, The Geology of North America, v. F-2, p. 537553.

\#678 Thomas, W.A., 1991, The Appalachian-Ouachita rifted margin of southeastern North America: Geological Society of America Bulletin, v. 103, p. 415-431.

\#1904 Thompson, S.N., Peck, J.H., Patterson, A.R., and Willis, D.E., 1976, Faulting and seismicity in the Anna Ohio region: Geological Society of America Abstracts with Programs, v. 8, no. 6, p. 1139.

\#1905 Thompson, W.B., 1979, Postglacial faulting along the Norumbega fault zone, eastern Maine: Geological Society of America Abstracts with Programs, v. 11, no. 1, p. 56. \#1978 Thompson, W.B., 1981, Postglacial faulting in the vicinity of the Norumbega fault zone, eastern Maine: U.S. Geological Survey Open-File Report 90-1039, 19 p. 
\#2059 Thornton, C.P., 1989, Exerpt from Professor C.P. Thornton's Ph.D. thesis describing fault-associated travertine deposits in Virginia, in Alexander, S.S., Gold, D.P., Gardner, T.W., Slingerland, R.L., and Thornton, C.P., eds., Near-surface neotectonic deformation associated with seismicity in the northeastern United States: U.S. Nuclear Regulatory Commission Report NUREG/CR-5418, p. B1-B9.

\#1906 Thorson, R.M., 1988, Pervasive ground deformation in the Hain Quarry, Connecticut-A status report: Geological Society of America Abstracts with Programs, v. 20, no. 1, p. 75 and 77.

\#3689 Thorson, R.M., 1996, Earthquake recurrence and glacial loading in western Washington: Geological Society of America Bulletin, v. 108, no. 9, p. 1182-1191.

\#1907 Thorson, R.M., Clayton, W.S., and Seeber, L., 1986, Geologic evidence for a large prehistoric earthquake in eastern Connecticut: Geology, v. 14, p. 463-467.

\#1908 Thurber, C.H., and Caruso, T.C., 1985, Crustal structure along the Ramapo fault zone, New York State: Earthquake Notes, v. 56, p. 145-152.

\#685 Tomlinson, C.W., 1952, Odd geologic structures of southern Oklahoma: Bulletin of the American Association of Petroleum Geologists, v. 36, p. 1820-1840.

\#3895 Trace, R.D., and Amos, D.H., 1984, Stratigraphy and structure of the western Kentucky Fluorspar District: U.S. Geological Survey Professional Paper 1151-D, 41 p., 1 plate, scale $1: 48,000$.

\#2060 Turner, P.J., 1977, Seismic reflection survey in Lake Champlain: Burlington, University of Vermont, unpublished M.S. thesis, 60 p., 11 pls.

\#3815 Tuttle, M., and Barstow, N., 1996, Liquefaction-related ground failure: A case study in the New Madrid seismic zone, Central United States: Bulletin of the Seismological Society of America, v. 86, p. 636-645.

\#1911 Tuttle, M., and Seeber, L., 1991, Historic and prehistoric earthquake-induced liquefaction in Newbury, Massachusetts: Geology, v. 19, p. 594-597.

\#3904 Tuttle, M., Chester, J., Lafferty, R., Dyer-Williams, K., and Cande, R., 1999, Paleoseismology study northwest of the New Madrid seismic zone: U.S. Nuclear Regulatory Commission Report NUREG/CR-5730, xi + 155 p.

\#3957 Tuttle, M., Chester, J., Lafferty, R., Dyer-Williams, K., Haynes, M., Cande, R., and Sierzchula, M., 1998, Liquefaction features in southwestern Illinois and southeastern Missouri and thier implications for paleoseismicity: Eos, Transactions of the American Geophysical Union, v. 79, no. 17, p. S342.

\#2239 Tuttle, M.P., 1996, Case study of liquefaction induced by the 1944 Massena, New YorkCornwall, Ontario earthquake: U.S. Nuclear Regulatory Commission NUREG/CR6495, $24 \mathrm{p}$.

\#3921 Tuttle, M.P., 1999, Late Holocene earthquakes and their implications for earthquake potential of the New Madrid seismic zone, central United States: University of Maryland, unpublished Ph.D dissertation, $250 \mathrm{p}$.

\#3818 Tuttle, M.P., and Schweig, E.S., 1995, Archeological and pedological evidence for large prehistoric earthquakes in the New Madrid seismic zone, Central United States: Geology, v. 23, p. 253-256.

\#3819 Tuttle, M.P., and Schweig, E.S., 1996, Recognizing and dating prehistoric liquefaction features: Lessons learned in the New Madrid seismic zone, Central United States: Journal of Geophysical Research, v. 101, p. 6177-6178. 
\#1909 Tuttle, M.P., Dyer-Williams, K., and Barstow, N., 1995, Limits on the earthquake potential of the Clarendon-Linden fault system in western New York State: Geological Society of America Abstracts with Programs, v. 27, p. A-395.

\#1910 Tuttle, M.P., Dyer-Williams, K., and Barstow, N., 1996, Seismic hazard implications of a paleoliquefaction study along the Clarendon-Linden fault system in western New York State: Geological Society of America Abstracts with Programs, v. 28, no. 3, p. 106.

\#2240 Tuttle, M.P., Dyer-Williams, K., and Barstow, N.L., 1995, Paleoliquefaction study along the Clarendon-LInden fault system, in Jacobi, R., and Fountain, J., eds., Determination of the seismic potential of the Clarendon-Linden fault system in Allegany County: Final Report to New York State Energy Research and Development Agency, p. 2106, 31 pls.

\#3956 Tuttle, M.P., Lafferty, R.H., Cande, R.F., Chester, J.S., and Haynes, M., 1996, Evidence of earthquake-induced liquefaction north of the New Madrid seismic zone, Central United States: Seismological Research Letters, v. 67, no. 2, p. 58.

\#3817 Tuttle, M.P., Lafferty, R.H., III, and Schweig, E.S., III, 1998, Dating of liquefaction in the New Madrid seismic zone and implications for seismic hazard: U.S. Nuclear Regulatory Commission NUREG/CR-0017, $77 \mathrm{p}$.

\#3816 Tuttle, M.P., Lafferty, R.H., III, Guccione, M.J., Schwig, E.S., III, Lopinot, N., Cande, R.F., Dyer-Williams, K., and Haynes, M., 1996, Use of archaeology to date liquefaction features and seismic events in the New Madrid seismic zone, Central United States: Geoarchaeology, v. 11, p. 451-480.

\#2061 Tuttle, M.P., Seeber, L., and Bradley, L., 1987, Liquefaction of glaciomarine sediments during the 1727 earthquake in Newburyport, Massachusetts, in Jacob, K.H., ed., Proceedings from the symposium on seismic hazards, ground motions, soil-liquefaction and engineering practice in eastern North America: National Center for Earthquake Engineering Research Technical Report NCEER-87-0025, p. 467-479.

\#2252 U.S. Geological Survey, 1977, Preliminary report on Belair exploratory trench \#10-76 near Augusta, Georgia: U.S. Geological Survey Open-File Report 77-411, 20 p., 2 pls.

\#684 Van Arsdale, R.B., 1986, Quaternary displacement on faults within the Kentucky River fault system of east-central Kentucky: Geological Society of America Bulletin, v. 97, p. 1382-1392.

\#3968 Van Arsdale, R.B., 2000, Displacement history and slip rate on the Reelfoot fault of the New Madrid seismic zone: Engineering Geology, v. 55, p. 219-226.

\#3967 Van Arsdale, R.B., Cox, R.T., Johnston, A.C., Stephenson, W.J., and Odurn, J.K., 1999, Southeastern extension of the Reelfoot fault: Seismological Research Letters, v. 70, no. 3, p. 348-359.

\#3965 Van Arsdale, R.B., Kelson, K.I., and Lurnsden, C.H., 1995, Northern extension of the Tennessee Reelfoot scarp into Kentucky and Missouri: Seismological Research Letters, v. 66 , no. 5 , p. $57-62$.

\#3966 Van Arsdale, R.B., Stahle, D.W., Cleaveland, M.K., and Guccione, M.J., 1998, Earthquake signals in tree-ring data from the New Madrid seismic zone and implications for paleoseismicity: Geology, v. 26, no. 6, p. 515-518.

\#676 Van Arsdale, R., Ward, C., and Cox, R., 1989, Post-Pennsylvanian reactivation along the Washita Valley fault, southern Oklahoma: U.S. Nuclear Regulatory Commission NUREG/CR-5375, 48 p. 
\#1979 Van Tyne, A.M., 1975, Subsurface investigation of the Clarendon-Linden structure, western New York: New York State Geological Survey Open-File Report, 14 p., 5 pls., scale 1:62,500.

\#3922 Vaughn, J.D., 1991, Active tectonics in the Western Lowlands of southeast Missouri-An initial assessment, in Louis Unfer Jr. conference on the geology of the Mid-Mississippi Valley, Cape Girardeau Missouri, extended abstracts: Missouri Division of Geology and Land Survey Special Publication 8, p. 54-59.

\#3924 Vaughn, J.D., 1994, Paleoseismological studies in the western lowlands of southeast Missouri: Technical report to U.S. Geological Survey, Rolla, Missouri, under Contract 14-08-0001-G1931, $27 \mathrm{p}$.

\#3923 Vaughn, J.D., Hoffman, D., and Palmer, J.R., 1993, A Late-Holocene surficial sandblow in the western lowlands of southeast Missouri-A paleoseismic milestone: Geological Society of America Abstracts with Programs, v. 25, no. 3, p. 87.

\#3925 Vaughn, J.D., Palmer, J.R., and Hoffman, D., 1996, Dudley Main Ditch-Multiple late Quaternary earthquake induced liquefaction events, in Palmer, J., Hoffman, D., Vaughn, J.D., and Harrison, R.W., eds., Late Quaternary faulting and earthquake liquefaction features in southeast Missouri-The identification of new earthquake hazards: Missouri Division of Geology and Land Survey Open-File Report OFR-97-96-GS, Association of Missouri Geologist 43rd annual meeting and field trip, Cape Girardeau, Missouri, September 20-21, 1996, p. 1-12.

\#3691 Verbeek, E.R., 1979, Quaternary fault activity in Texas Gulf Coast: Bulletin of the American Association of Petroleum Geologists, v. 63, no. 3, p. 545.

\#3692 Verbeek, E.R., 1979, Surface faults in the Gulf Coastal Plain between Victoria and Beaumont, Texas: Tectonophysics, v. 52, p. 373-375.

\#3693 Verbeek, E.R., and Clanton, U.S., 1978, Map showing surface faults in the southeastern Houston metropolitan area, Texas: U.S. Geological Survey Open-File Report 78-797, 20 p., 1 pl., scale 1:24,000.

\#3694 Verbeek, E.R., and Clanton, U.S., 1979, Clodine Fault, southwestern Houston metropolitan area, Texas: U.S. Geological Survey Open-File Report 79-947, 25 p., 1 pl., scale $1: 24,000$.

\#3695 Verbeek, E.R., Ratzlaff, K.W., and Clanton, U.S., 1979, Faults in parts of north-central and western Houston metropolitan areas, Texas: U.S. Geological Survey Miscellaneous Field Studies Map MF-1136, 1 sheet, scale 1:24,000.

\#1952 Virginia Division of Mineral Resources, 1993, Geologic map of Virginia: Virginia Division of Mineral Resources, 1 sheet, scale 1:500,000.

\#2241 Weems, R.E., and Obermeier, S.F., 1989, The 1886 Charleston earthquake-An overview of geological studies, in Proceedings of the U.S. Nuclear Regulatory CommissionSeventeenth Water Reactor Safety Meeting: U.S. Nuclear Regulatory Commission NUREG/CP-0105, v. 2, p. 289-313.

\#3896 Weibel, C.P., Nelson, W.J., Oliver, L.B., and Esling, S.P., 1993, Geology of the Waltersburg quadrangle Pope County, Illinois: Illinois State Geological Survey Bulletin 98, $41 \mathrm{p}$.

\#713 Wesnousky, S.G., and Leffler, L.M., 1992, The repeat time of the 1811 and 1812 New Madrid earthquakes-A geological perspective: Bulletin of the Seismological Society of America, v. 82, p. 1756-1785. 
\#2242 Wesnousky, S.G., and Scholz, C.H., 1980, The craton-Its effect on the distribution of seismicity and stress in North America: Earth and Planetary Science Letters, v. 48, p. 348-355.

\#1988 West, D.P., Jr., 1999, Timing of displacements along the Norumbega fault system, southcentral and south-coastal Maine, in Ludman, A., and West, D.P., Jr., eds., Norumbega fault system of the northern Appalachians: Geological Society of America Special Paper 331, p. $167-178$.

\#1912 West, D.P., Jr., and Hubbard, M.S., 1997, Progressive localization of deformation during exhumation of a major strike-slip shear zone-Norumbega fault zone, south-central Maine, USA: Tectonophysics, v. 273, p. 185-201.

\#1913 West, D.P., Jr., Lux, D.R., and Hussey, A.M., II, 1993, Contrasting thermal histories across the Flying Point fault, southwestern Maine-Evidence for Mesozoic displacement: Geological Society of America Bulletin, v. 105, p. 1478-1490.

\#1914 Wheeler, R.L., 1995, Earthquakes and the cratonward limit of Iapetan faulting in eastern North America: Geology, v. 23, p. 105-108.

\#1916 Wheeler, R.L., 1996, Sources of seismic hazard near the eastern Great Lakes: Geological Society of America Abstracts with Programs, v. 28, no. 3, p. 110.

\#1915 Wheeler, R.L., 1997, Boundary separating the seismically active Reelfoot Rift from the sparsely seismic Rough Creek graben, Kentucky and Illinois: Seismological Research Letters, v. 68, p. 586-598.

\#2243 Wheeler, R.L., and Johnston, A.C., 1992, Geologic implications of earthquake source parameters in central and eastern North America: Seismological Research Letters, v. 63, no. 4, p. 491-514.

\#754 Wheeler, R.L., and Rhea, S., 1994, Map showing surficial and hydrologic features in the vicinity of New Madrid, Missouri: U.S. Geological Survey Miscellaneous Field Studies Map MF-2264-E, 1 sheet, scale 1:250,000.

\#1947 Wheeler, R.L., Diehl, S.F., Rhea, S., Sargent, M.L., and Bear, G.W., 1997, Map showing selected wells and geophysical survey and modeling lines in the vicinity of the lower Wabash Valley, Illinois, Indiana, and Kentucky: U.S. Geological Survey Geologic Investigations Series I-2583-C, 16 p. pamphlet, 1 sheet, scale 1:250,000.

\#1948 Wheeler, R.L., Rhea, S., Diehl, S.F., Drahovzal, J.A., Bear, G.W., and Sargent, M.L., 1997, Seismotectonic map showing faults, igneous rocks, and geophysical and neotectonic features in the vicinity of the lower Wabash Valley, Illinois, Indiana, and Kentucky: U.S. Geological Survey Geologic Investigations Series I-2583-D, 19 p. pamphlet, 1 sheet, scale 1:250,000.

\#3697 White, W.A., and Morton, R.A., 1997, Wetland losses related to fault movement and hydrocarbon production, southeastern Texas coast: Journal of Coastal Research, v. 13, no. 4, p. 1305-1320.

\#1949 Willard, M.E., 1951, Bedrock geology of the Mount Toby quadrangle, Massachusetts: U.S. Geological Survey Geologic Quadrangle Map GQ-8, 1 sheet, scale 1:31,680.

\#1950 Willard, M.E., 1952, Bedrock geology of the Greenfield quadrangle, Massachusetts: U.S. Geological Survey Geologic Quadrangle Map GQ-20, 1 sheet, scale 1:31,680.

\#3820 Williams, R.A., Luzietti, E.A., and Carver, D.L., 1995, High-resolution seismic imaging of Quaternary faulting in the Crittenden County fault zone, New Madrid seismic zone, northeastern Arkansas: Seismological Research Letters, v. 66, p. $42-57$. 
\#1917 Williams, R.T., and Callis, J.G., 1996, Collocated seismic reflection and radar profiles over Quaternary normal faults in southwestern Virginia [abs.]: Eos, Transactions of the American Geophysical Union, v. 77, no. 46 (supplement), p. F497-F498.

\#3698 Winker, C.D., 1990, Quaternary geology, northwestern Gulf Coast, in Morrison, R.B., ed., Quaternary nonglacial geology; conterminous U.S.: Boulder, Colorado, Geological Society of America, The Geology of North America, v. K-2, 1 pl., scale 1:2,000,000.

\#3939 Winker, C.D., and Howard, J.D., 1977, Correlation of tectonically deformed shorelines on the southern Atlantic Coastal Plain: Geology, v. 5, p. 123-127.

\#2244 Wise, D.U., and Faill, R.T., 1998, Lancaster County seismic zone (Penna.)-Reactivation of a Taconic structural feature?: Geological Society of America Abstracts with Programs, v. 30, no. 7, p. A-320.

\#3702 Witkind, I.J., 1959, Quaternary geology of the Smoke Creek-Medicine Lake-Grenora area, Montana and South Dakota: U.S. Geological Survey Bulletin 1073, 80 p., 5 plates.

\#1918 Wold, R.J., Isachsen, Y.W., Geraghty, E.P., and Hutchinson, D.R., 1977, Seismic-reflection profiles of Lake George, Adirondack Mountains, New York, as a guide to the neotectonic history of the region: Geological Society of America Abstracts with Programs, v. 9 , no. 7, p. 1233.

\#1919 Wones, D.R., and Stewart, D.B., 1976, Middle Paleozoic regional right-lateral strike-slip faults in central coastal Maine: Geological Society of America Abstracts with Programs, v. 8, no. 2, p. 304.

\#1920 Wones, D.R., and Thompson, W., 1979, The Norumbega fault zone-A major regional structure in central eastern Maine: Geological Society of America Abstracts with Programs, v. 11, no. 1, p. 60.

\#3700 Yerkes, R.F., and Castle, R.O., 1976, Seismicity and faulting attributable to fluid extraction: Engineering Geology, v. 10, p. 151-167.

\#1921 Young, R.A., and Jacobi, R.D., 1998, Bedrock-till deformation structure along the Clarendon-Linden fault zone near Linden, NY-Tectonic or glacial origin?: Geological Society of America Abstracts with Programs, v. 30, no. 1, p. 85.

\#1960 Zen, E.-A., ed., Goldsmith, R., Ratcliffe, N.M., Robinson, P., Stanley, R.S., compilers, Hatch, N.L., Jr., Shride, A.F., Weed, E.G.A., and Wones, D.R., 1983, Bedrock geologic map of Massachusetts: U.S. Geologic Survey in cooperation with The Commonwealth of Massachusetts Department of Public Works, 3 sheets, scale 1:250,000.

\#2245 Zimmerman, R.K., 1992, Fractured Smackover limestone in northeast LouisianaImplications for hydrocarbon exploitation: Transactions of the Gulf Coast Association of Geological Societies, v. 42, p. 401-412.

\#2246 Zimmerman, R.K., 1994, Evidence of wrench faulting in north and central Louisiana: Louisiana State University Energy and Environmental Resources Basin Research Institute Bulletin, v. 4, no. 1, p. 53-61.

\#2248 Zimmerman, R.K., 1995, Evidence and effects of wrench faulting, north central Gulf Coast region: Transactions of the Gulf Coast Association of Geological Societies, v. 45, p. 629-635.

\#2247 Zimmerman, R.K., and Sassen, R., 1993, Hydrocarbon transfer pathways from Smackover source rocks to younger reservoir traps in the Monroe gas field, northeast Louisiana: Transactions of the Gulf Coast Association of Geological Societies, v. 43, p. $473-480$. 
\#731 Zoback, M.D., 1979, Recurrent faulting in the vicinity of Reelfoot Lake, northwestern Tennessee: Geological Society of America Bulletin, v. 90, p. 1019-1024.

\#2006 Zoback, M.D., and Zoback, M.L., 1991, Tectonic stress field of North America and relative plate motions, in Slemmons, D.B., Engdahl, E.R., Zoback, M.D., and Blackwell, D.D., eds., Neotectonics of North America: Boulder, Colorado, Geological Society of America, Decade Map Volume 1, p. 339-366.

\#2062 Zoback, M.D., Moos, D., and Stephenson, D.E., 1989, State of stress and the relation to tectonics in the central Savannah River area of South Carolina, in 30th U.S. Symposium on Rock Mechanics, Morgantown, West Virginia, June 19-22, 1989, Proceedings, p. 553-560.

\#1922 Zoback, M.L., and Zoback, M.D., 1989, Tectonic stress field of the continental United States, in Pakiser, L.C., and Mooney, W.D., eds., Geophysical framework of the continental United States: Geological Society of America Memoir 172, p. 523-539.

\#1923 Zoback, M.L., Zoback, M.D., Adams, J., Assumpcão, M., Bell, S., Bergman, E.A., Blümling, P., Brereton, N.R., Denham, D., Ding, J., Fuchs, K., Gay, N., Gergersen, S., Gupta, H.K., Gvishiani, A., Jacob, K., Klein, R., Knoll, P., Magee, M., Mercier, J.L., Müller, B.C., Paquin, C., Rajendran, K., Stephansson, O., Suarez, G., Suter, M., Udias, A., Xu, Z.H., and Zhizhin, M., 1989, Global patterns of tectonic stress: Nature, v. 341, no. 6240, p. 291-298.

\#3940 Zullo, V.A., and Harris, B.W., 1979, Plio-Pleistocene crustal warping in the outer coastal plain of North Carolina, in Baum, G.R., Harris, B.W., and Zullo, V.A., eds., Structural and stratigraphic framework for the Coastal Plain of North Carolina: Carolina Geological Society and Atlantic Coastal Plain Geological Assoication, Raleigh, North Carolina, October 19-21, 1979, Guidebook, p. 31-40. 